\title{
Ontwerp en implementatie van de masteropleiding Special Educational Needs via e-learning
}

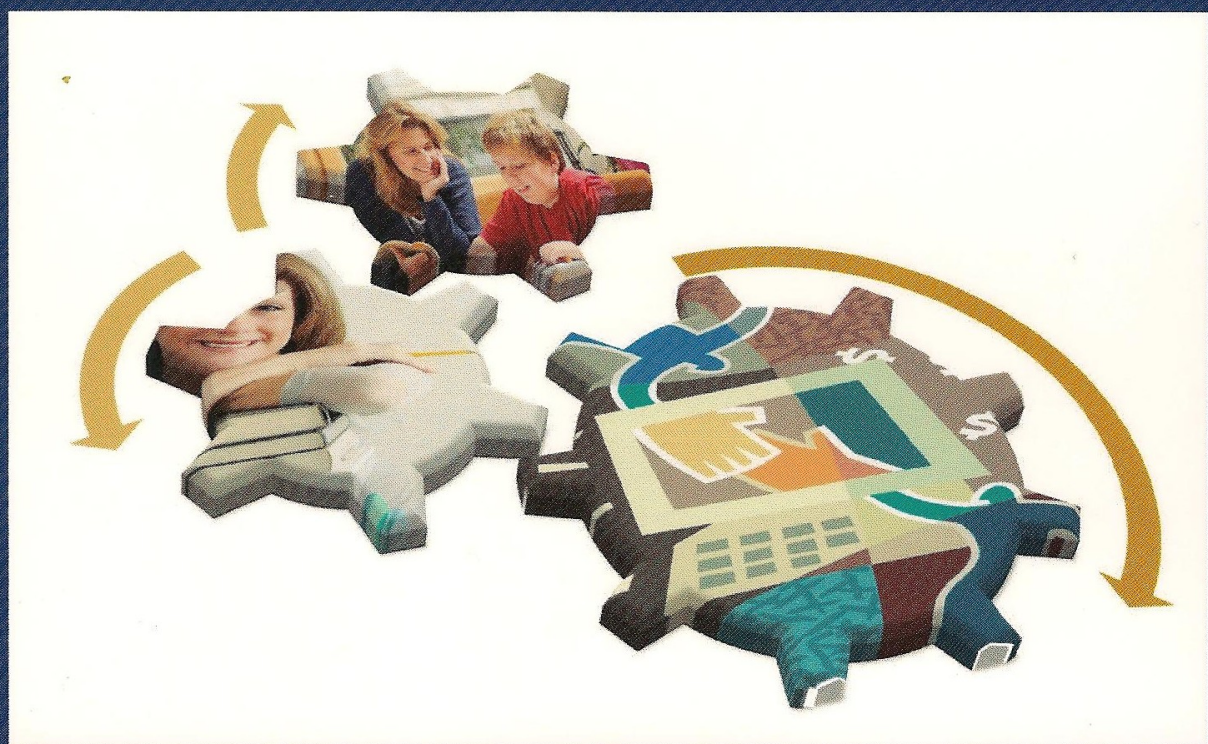

Anneke Smits 
ONTWERP EN IMPLEMENTATIE VAN DE MASTEROPLEIDING SPECIAL EDUCATIONAL NEEDS VIA E-LEARNING

Anneke Smits 
PROMOTIECOMMISSIE

Voorzitter

Promotor

Assistent promotor

Leden
Prof. Dr. K. I. van Oudenhoven-van der Zee - University of Twente

Prof. Dr. J. J. H. van den Akker - University of Twente

Dr. J. M. Voogt - University of Twente

Dr. F. J. H. Harinck - Windesheim University

Prof. Dr. J. M. Pieters - University of Twente

Prof. Dr. A. J. M. de Jong - University of Twente

Prof. Dr. A. J. J. M. Ruijssenaars - University of Groningen

Dr. H. Wentink - Edith Stein University for Teacher Education

Dr. E. van den Berg - University of Twente

Smits, A.E.H.

Ontwerp en implementatie van de masteropleiding Special Educational Needs via e-learning

Proefschrift University of Twente, Enschede.

ISBN 978-90-365-3350-8

DOI $10.3990 / 1.9789036533508$

Kaftontwerp: Anjette van de Ven en Anneke Smits

Layout: Sandra Schele

Drukker: Ipskamp Drukkers B.V. Enschede

(C) Copyright, 2012, A.E.H. Smits 
ONTWERP EN IMPLEMENTATIE VAN DE MASTEROPLEIDING SPECIAL

EdUCATIONAL NEEDS VIA E-LEARNING

\title{
PROEFSCHRIFT
}

\author{
ter verkrijging van \\ de graad van doctor aan de Universiteit Twente, \\ op gezag van de rector magnificus, \\ prof. dr. H. Brinksma, \\ volgens besluit van het College voor Promoties \\ in het openbaar te verdedigen \\ op vrijdag 25 mei 2012 om 14.45 uur
}

door

Anna Elizabeth Helena Smits

geboren op 3 juli 1961

te Leende 
Promotor

Assistent promotoren
Prof. Dr. J. J. H. van den Akker

Dr. J. M. Voogt

Dr. F. J. H. Harinck

De promotor en de assistent promotoren hebben het proefschrift goedgekeurd. 


\section{INHOUD}

1. INLEIDING 1

$\begin{array}{ll}1.1 \text { Begripsafbakening } & 1\end{array}$

1.2 De praktische aanleiding voor het onderzoek 2

1.2.1 Instellingsbeleid en schoolbeleid 3

1.2.2 De bestaande afstandsleer-praktijk binnen de Windesheim School of Education

1.2.3 Het e-learning projectplan en het e-learning projectteam van Windesheim OSO 4

1.3 Centrale probleemstelling en onderzoeksopzet 5

1.3.1 Centrale probleemstelling 5

$\begin{array}{ll}\text { 1.3.2 Ontwerponderzoek } & 7\end{array}$

$\begin{array}{ll}1.4 \text { Overzicht van de volgende hoofdstukken } & 8\end{array}$

2. ONDERZOEKSMETHODOLOGIE 9

2.1 Ontwerponderzoek 9

2.1.1 Doelen van ontwerponderzoek 9

2.1.2 Fasering, dataverzameling en dilemma's van
ontwerponderzoek

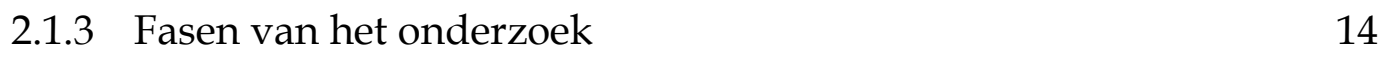


2.2 Onderzoeksopzet fase 1: Analyse en eerste ontwerp 15

$\begin{array}{ll}\text { 2.2.1 Vragen en deelvragen over validiteit } & 15\end{array}$

2.2.2 Deelnemers aan het onderzoek over validiteit 16

2.2.3 Methodes, instrumenten en data-analyse 16

$\begin{array}{ll}2.3 \text { Onderzoeksopzet fase 2: Pilotfase } & 18\end{array}$

$\begin{array}{lll}\text { 2.3.1 Deelvragen over bruikbaarheid } & 18\end{array}$

2.3.2 Deelnemers aan het onderzoek in de pilotfase 19

2.3.3 Methodes, instrumenten en data-analyse in de pilotfase $\quad 19$

2.4 Onderzoeksopzet fase 3: De implementatiefase 22

2.4.1 Vragen en deelvragen over bruikbaarheid, waardering en $\begin{array}{ll}\text { effectiviteit } & 23\end{array}$

2.4.2 Deelnemers aan het onderzoek in de implementatiefase 24

2.4.3 Methodes, instrumenten en data-analyse 25

3. HET ONTWERP VAN DE E-LEARNING OPLEIDINGEN 39

3.1 Doelen en randvoorwaarden ten aanzien van het ontwerp 40

3.1.1 Het opleidingsconcept 42

3.1.2 De uitwerking van het onderwijsconcept in de reguliere modules 43

3.2 Het ruwe ontwerp: ontstaanswijze 44

3.3 Het e-learning ontwerp: vier clusters van ontwerpelementen 48

3.3.1 Interactie tussen studenten: definities, argumenten en procedures 48

3.3.2 E-learning structuur: definities, argumenten en procedures $\quad 56$

$\begin{array}{ll}\text { 3.3.3 Docentrol: definities, argumenten en procedures } & 61\end{array}$

3.3.4 Leermaterialen: definities, argumenten en procedures $\quad 75$

$\begin{array}{ll}3.4 \text { Samenvattend beeld van het ontwerp } & 78\end{array}$

$\begin{array}{ll}3.5 \text { Expert raadpleging } & 79\end{array}$

3.5.1 Algemene raadgevingen $\quad 80$

3.5.2 Expert meningen over ontwerpkenmerken $\quad 81$

4. Resultaten VAN DE PILOTFASE 89

4.1 De opzet van het onderzoek in de pilotfase 89

4.2 De bruikbaarheid van de verschillende ontwerpkenmerken in de pilotfase $\quad 91$

4.3 Aantrekkelijkheid voor studenten 96

$\begin{array}{ll}4.4 \text { Conclusies en gevolgen voor het ontwerp } & 100\end{array}$ 


\section{RESULTATEN IMPLEMENTATIEFASE: INTERACTIE TUSSEN}

STUDENTEN

5.1 Bruikbaarheid 106

5.1.1 Aantallen berichten in de leeromgeving 106

5.1.2 De zin van asynchrone discussies voor het leerproces 109

5.1.3 Bruikbaarheid van het kenmerk van 'sociale interactie' 119

5.1.4 Gesignaleerde knelpunten in de interactie tussen studenten 123

$\begin{array}{ll}\text { 5.1.5 Samenvatting bruikbaarheid } & 128\end{array}$

5.2. Waardering voor de samenwerking 129

5.2.1 Waardering voor de samenwerking met medestudenten 130

5.2.2 Verbanden met het cijfer voor de waardering voor de samenwerking 131

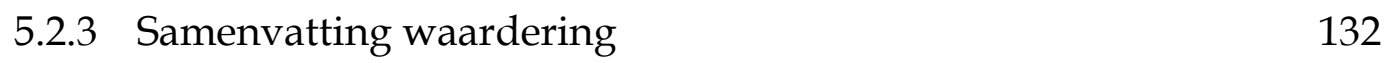

5.3 Aanpassingen aan het ontwerp 132

5.3.1 Aanpassingen tijdens/na moduleperiode $1 \quad 132$

5.3.2 Alsnog door te voeren aanpassingen 134

6. RESULTATEN IMPLEMENTATIEFASE: E-LEARNING STRUCTUUR 137

6.1 Bruikbaarheid van de structuur kenmerken 138

6.1.1 De ondersteunende rol van strakke planning 138

6.1.2 Strakke planning in relatie tot samenwerking 140

6.1.3 Spreiding van de studielast en ervaren werkdruk 142

6.1.4 Duidelijkheid van leerdoelen en verwachtingen 148

6.1.5 Ervaren chaos en organisatielast voor studenten 151

6.1.6 Samenvatting bruikbaarheid $\quad 155$

6.2 Waardering voor de organisatie 156

6.2.1 Waardering voor de organisatie van de e-learning 156

6.2.2 Verbanden met het cijfer voor de waardering van de organisatie 157

6.2.3 Samenvatting waardering 158

6.3 Aanpassingen aan het ontwerp 159

7. RESULTATEN IMPLEMENTATIEFASE: DOCENTROL 161

7.1 Bruikbaarheid van uitgangspunten van de docentrol 162

7.1.1 Zichtbare aanwezigheid, reactiesnelheid en tijd 162

$\begin{array}{lll}7.1 .2 & \text { Moderatie } & 172\end{array}$

$\begin{array}{lll}7.1 .3 & \text { Feedback } & 176\end{array}$ 
$\begin{array}{lll}\text { 7.1.4 Organisatorische ondersteuning } & 181\end{array}$

$\begin{array}{lll}7.1 .5 & \text { Vraagsturing en flexibiliteit } & 183\end{array}$

$\begin{array}{ll}\text { 7.1.6 Controle en activering } & 185\end{array}$

$\begin{array}{lll}\text { 7.1.7 Sociale aanwezigheid } & 186\end{array}$

$\begin{array}{ll}\text { 7.1.8 Scholing voor e-learning docenten } & 190\end{array}$

7.1.9 Samenvatting bruikbaarheid uitgangspunten docentrol 191

$\begin{array}{ll}7.2 \text { Waardering } & 194\end{array}$

7.2.1 Waardering voor de docentrol 194

7.2.2 Verbanden met het cijfer voor de docent 195

$\begin{array}{ll}\text { 7.2.3 Samenvatting waardering } & 197\end{array}$

$\begin{array}{ll}\text { 7.3 Aanpassingen aan het ontwerp } & 197\end{array}$

$\begin{array}{lll}\text { 7.3.1 Doorgevoerde aanpassingen } & 197\end{array}$

7.3.2 Alsnog door te voeren aanpassingen 199

8. RESULTATEN IMPLEMENTATIEFASE: LEERMATERIALEN 201

8.1 Bruikbaarheid van uitgangspunten van de leermaterialen 202

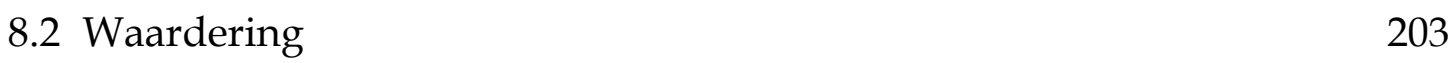

8.2.1 Leerzaamheid van de verschillende soorten leerobjecten 203

8.2.2 Waardering voor de leerzaamheid van de module 204

8.2.3 Verbanden met de ervaren leerzaamheid van de module 205

8.3 Samenvatting bruikbaarheid en waardering rijke leeromgeving 206

8.4 Aanpassingen aan het ontwerp 206

9. RESUlTATEN IMPLEMENTATIEFASE: DE EFFECTEN VAN DE OSO ELEARNING OPLEIDINGEN 209

9.1 Tevredenheid van studenten over de modules 210

9.2 Uitval en studierendement 220

9.3 Samenvatting resultaten: effecten van de leeromgeving 223

9.4 Aanpassingen aan het ontwerp 226

10. CONCLUSIES EN DISCUSSIE

10.1 Reflectie op de bruikbaarheid en de effectiviteit van de $\begin{array}{ll}\text { ontwerpkenmerken } & 228\end{array}$

10.1.1 Centrale ontwerpclusters en onderzoeksvragen 228

10.1.2 Interactie tussen studenten 229

$\begin{array}{lll}\text { 10.1.3 E-learning structuur } & 231\end{array}$ 
10.1.4 Docentrol 233

10.1.5 Leermaterialen 235

10.1.6 De effecten van de leeromgeving 236

$\begin{array}{ll}10.2 \text { Methodologische aspecten } & 237\end{array}$

10.3 Aanpassingen aan het ontwerp: Leren online leren 243

10.4 Leren online doceren 249

10.5 Is het de moeite waard? 255

10.6 Opbrengsten van het onderzoek en vervolgvragen 264

$\begin{array}{lr}\text { REFERENTIES } & 267\end{array}$

$\begin{array}{ll}\text { ENGELSE SAMENVATTING } & 285\end{array}$

$\begin{array}{lr}\text { BIJLAGEN } & 299\end{array}$ 


\section{LIJST VAN FIGUREN EN TABELLEN}

\section{FIGUREN}

1.1 De onderzoeksvragen in de drie onderzoeksfases

5.1 Aantallen berichten per student per moduleperiode van 8 weken

\section{TABELLEN}

2.1 Codeerschema voor digitale berichten van studenten 21

2.2 Aantal deelnemers per cohort, per moduleperiode 24

2.3 Soorten organisatorische berichten 27

2.4 Origine en aard van de gehanteerde vragenlijsten 29

2.5 Afnametijdstippen vragenlijsten 30

2.6 Betrouwbaarheid van de gebruikte schalen 31

2.7 Samenhang tussen schalen in moduleperiodes 1-7 32

3.1 Doelen en randvoorwaarden voor e-learning 42

3.2 Uitgangsprincipes voor het ruwe ontwerp 44

3.3 Kernargumenten voor de opname van specifieke ontwerpkenmerken 48

3.4 Interactie tussen studenten: kenmerken en kernargumenten 56

3.5 E-learning structuur: kenmerken en kernargumenten 61

3.6 Docentrol: kenmerken en kernargumenten 75

3.7 Leermaterialen: kenmerken en kernargumenten 78

4.1 Aantallen berichten $\quad 91$

5.1 Gemiddelde aantallen berichten per student per moduleperiode $\quad 107$

5.2 Aantallen asynchrone berichten in andere opleidingen 108

5.3 Cohort 1: verschillen tussen aantallen berichten in opeenvolgende $\begin{array}{ll}\text { moduleperiodes } & 109\end{array}$ 
5.4 Leerzaamheid van de asynchrone discussies en samenwerkingsopdrachten 110

5.5 De invloed van asynchrone discussie op begrip van de literatuur 111

5.6 Steun van medestudenten voor het leerproces 112

5.7 Cohort 1: verschillen in ervaren steun voor het leerproces 113

5.8 Inhoud van de berichten in periode 1 en 7: aantallen toegekende codes

5.9 Omvang van de verschillende soorten tekstsegmenten: aantallen woorden

$\begin{array}{ll}5.10 \text { Verbondenheid per moduleperiode } & 119\end{array}$

5.11 Cohort 1: verschillen in verbondenheid tussen moduleperiodes $\quad 120$

5.12 Woord en ervaring: sociaal 121

5.13 Inhoud van de berichten in periode 1 en 7: aantallen toegekende codes 122

5.14 Tevredenheid over de samenwerking met medestudenten 130

5.15 Cohort 1: verschillen in tevredenheid over de samenwerking 130

5.16 Verbanden met de waardering voor de samenwerking 131

5.17 Aanpassingen door het e-learning team in en buiten Blackboard 133

6.1 Gemiddeldes en standaarddeviaties voor 'ondersteuning door planning' 139

6.2 Tijdig inleveren van de eindopdracht van de module 139

6.3 Deelname aan discussieopdrachten 141

6.4 Gerealiseerde deadlines voor de overige opdrachten in de module 142

6.5 Evenwichtige spreiding van de studielast 143

6.6 Werkdruk en begrip 144

6.7 Cohort 1: verschillen in werkdruk tussen moduleperiodes 144

6.8 Schaal tijdsdruk en stress van de vragenlijst Woord en Ervaring 145

6.9 Uitzonderingen op rooster/deadlines 146

6.10 Duidelijkheid 149

6.11 Duidelijkheid van de e-learning opdrachten 149

6.12 Ervaren chaos 152

6.13 Inhoud van de berichten in periode 1 en $7 \quad 153$

6.14 Soorten organisatorische berichten 154

6.15 Soorten organisatorische codes 154

6.16 Rapportcijfer voor organisatie 157

6.17 Verband tussen rapportcijfers voor de organisatie en voor de docent 157

6.18 Verbanden met de waardering voor de organisatie 158 
6.19 Aanpassingen door het e-learning team in en buiten Blackboard

$\begin{array}{lll}7.1 & \text { Aantal docentbijdrages per groepje } & 163\end{array}$

7.2 Aantal docentbijdrages in algemene discussielijn 164

$\begin{array}{lll}7.3 & \text { Regelmatige mededelingen plaatsen over planning } & 164\end{array}$

7.4 De snelheid waarmee de docent reageert op vragen 165

7.5 Tevredenheid over reactiesnelheid van docent 166

7.6 De snelheid waarmee de docent feedback geeft 167

$\begin{array}{lll}7.7 & \text { Feedback snelheid, middelste waardes } & 168\end{array}$

7.8 Tevredenheid over de snelheid waarmee de docent feedback geeft $\quad 169$

$\begin{array}{ll}7.9 \text { Moderatie door docenten } & 172\end{array}$

7.10 Leerzaamheid van de discussiebijdragen van docenten 173

7.11 Moderatiekwaliteit en inhoudelijke ervarenheid van docenten $\quad 174$

7.12 Verschillen tussen inhoudelijk ervaren en - onervaren docenten $\quad 174$

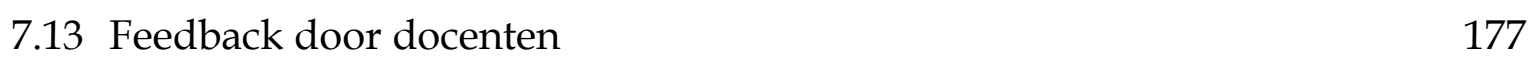

$\begin{array}{ll}7.14 & \text { Leerzaamheid van feedback van docenten } \\ 7.15\end{array}$

$\begin{array}{ll}7.15 & \text { Adequate antwoorden van docenten } \\ 7.16\end{array}$

$\begin{array}{ll}7.16 \text { Vraagsturing } & 184\end{array}$

7.17 Herinneren om bijdrages te leveren 185

$\begin{array}{ll}7.18 \text { Docentcommunicatie } & 186\end{array}$

$\begin{array}{ll}7.19 \text { Persoonlijke communicatie } & 187\end{array}$

7.20 Rapportcijfer voor docent begeleiding 194

7.21 E-learning ervaring 195

7.22 Verbanden met de waardering voor de docent 196

7.23 Aanpassingen door het e-learning team in en buiten Blackboard 198

8.1 Leerzaamheid van soorten leerobjecten 204

8.2 Rapportcijfer voor leerzaamheid van de modules 205

8.3 Verband met cijfer voor leerzaamheid van de module 205

8.4 Aanpassingen door het e-learning team in Blackboard 207

9.1 Rapportciffers voor modules 211

9.2 Verbanden met het rapportcijfer voor de module 212

$\begin{array}{lll}9.3 & \text { Aansluiting bij leerwensen } & 214\end{array}$

9.4 Verbanden met leerwensen van studenten 215

$\begin{array}{lll}9.5 & \text { Engagement } 216\end{array}$

9.6 Computerattitude van e-learning studenten 217

9.7 Verbanden tussen tevredenheid en computerattitude 218

$\begin{array}{ll}9.8 \text { Angst bij e-learning studenten } & 219\end{array}$

9.9 Verbanden tussen angst en tevredenheid 219 
9.10 Aantallen uitvallers

9.11 Verbanden met al dan niet uitvallen van studenten 221

9.12 Afgestudeerden 223

9.13 Aanpassingen door het e-learning team in en buiten Blackboard 226 


\section{VOORWOORD}

Dit boek vertelt het verhaal van het ontwerp en de implementatie van een complexe kleinschalige onderwijsvernieuwing binnen een grote $\mathrm{HBO}$ instelling; hogeschool Windesheim. De uitdaging bestond erin om de tweejarige master Special Educational Needs opleiding om te vormen tot een opleiding via elearning. Onderwijs zonder mensen in het klaslokaal; onderwijs via internet met de computer als tussenpersoon. Mensen die elkaar ontmoeten en met elkaar samenwerken en leren via de digitale snelweg. Kan dat? Is dat nog steeds onderwijs? Heeft dat misschien naast nadelen ten opzichte van de klassensituatie, ook voordelen?

Ik ben bepaald geen 'digital native'. Toen de eerste computers vele jaren geleden hun intrede deden op de school voor speciaal onderwijs waar ik werkte verklaarde ik samen met een collega manhaftig dat wij daar 'niet aan gingen beginnen'. Standvastig zijn is niet altijd zinvol in dit leven, dus dat 'niet beginnen' duurde niet lang. Mijn nieuwsgierigheid overwon mijn angst. Zou het mogelijk zijn om dyslectische leerlingen nog beter te helpen met behulp van de computer? Met Andi Sanderson onderzocht ik of dyslectische leerlingen in Nederland en in Engeland baat hadden bij het gebruik van compenserende software. Verder implementeerden we op school met goede resultaten software om spelling te oefenen.

Waar we aanvankelijk met kasten vol materialen werkten om dyslectische leerlingen te leren lezen en spellen, hadden we uiteindelijk nog maar 2 dingen nodig: een excellent boekenaanbod en een computer. Steeds meer mensen raakten geïnteresseerd in onze werkwijzen. Uiteindelijk besloot ik om op een hogeschool te gaan werken om anderen te kunnen leren hoe zij lees- en spellingproblemen konden voorkomen en remediëren. Door deze stap naar de hogeschool kwamen weer nieuwe mogelijkheden van de computer naar voren. Hoe kon internet gebruikt worden om het leerproces van studenten te verstevigen en te 
vergemakkelijken? Was er niet meer mogelijk met Blackboard dan alleen maar het opslaan van stukken?

Mijn leidinggevende Erica de Bruïne stelde me in 2005 twee dingen voor: maak een e-learning opleiding en ga promoveren. Al gauw was de synergie tussen beide opdrachten gevonden. Onderzoek kon de nodige richting geven in dit in Nederland relatief onontgonnen digitale onderwijsgebied, en onderzoek kon de kwaliteit van de implementatie verbeteren. Jan Jurriëns begeleidde me enthousiast bij mijn eerste wankele schreden in de richting van het promotie onderzoek. Dankzij zijn vertrouwen durfde ik verder te gaan op dit pad.

Het implementeren van een e-learning opleiding doe je niet alleen. Ik dank in het bijzonder mijn e-learning collega Miriam Limpens voor haar rol in de implementatie en het in stand houden van de opleiding. Haar organisatietalent, durf en doortastendheid speelden een belangrijke rol in de wording van onze elearning opleiding. Ik dank ook alle andere e-learning docenten voor hun inzet in deze nieuwe vorm van onderwijs. De intense collegialiteit onder de e-learning docenten van het eerste uur zal me altijd bijblijven. Uiteraard gaat mijn dank ook uit naar de e-learning studenten die meewerkten in mijn onderzoek. Een nieuwe vorm van onderwijs, hard werken en dan ook nog vragenlijsten invullen. Dat vergt veel van mensen.

Vele mensen hebben mij ondersteund tijdens het promotietraject. Natuurlijk gaat in de eerste plaats mijn dank uit naar mijn promotores. Joke Voogt, Frits Harinck en Jan van den Akker, jullie vormden het perfecte begeleidingsteam. Jullie feedback was altijd zeer zinvol en zeer congruent. Jullie hielpen me met de dilemma's die ik tegenkwam. Jullie enthousiasme hielp me om de moed er in te houden. In de laatste fase van het proefschrift kreeg ik veel praktische ondersteuning van Sandra Schele. Het is heerlijk als de zaken rondom de lay-out en publicatie zo professioneel geregeld zijn.

Binnen en buiten Windesheim waren er velen die me bemoedigden met hun warme belangstelling. Het leven moet toch een heel klein beetje anders worden straks, als niemand meer vraagt 'hoe gaat het met je promotie?' Gelukkig had ik meerdere promovendi om mij heen met wie ik ervaringen kon delen. Erna van Koeven en mijn zus Heleen verdienen in dit opzicht een speciaal woordje, we deelden vele ervaringen en jullie hielpen me met goede raad. We gaven elkaar 
nieuwe moed als dat nodig was. Jullie hebben het hele proces leuker en begrijpelijker gemaakt! Ook mijn collega's van de HU speelden een belangrijke rol in dit opzicht. Al vele jaren werk ik heel prettig samen met Thoni Houtveen. Haar wetenschappelijke gedrevenheid is mij tot voorbeeld en inspiratie. Van haar en van de promovendi die zij begeleidt heb ik veel geleerd en hoop ik nog veel te leren.

Tot slot dank ik mijn familie en mijn vrienden. Mijn lieve vader maakt het einde van dit proces niet meer mee. Hij was gelukkig wel bij het begin. Mijn moeder was en is mij altijd tot steun en dat is van onschatbare waarde. Mijn vijf jongens, mijn vrienden en mijn (schoon) familie hielden me bij de les in het leven. Zij zorgden er gelukkig voor dat er steeds oneindig veel meer was dan promoveren alleen. Johan gaf me steeds liefdevol de ruimte die ik nodig had om dit boek te kunnen schrijven en bemoedigde me altijd weer vanuit zijn zonnige kijk op het leven. 


\section{HoOfDSTUK 1 Inleiding}

Het is een uitdaging om een volledige tweejarige opleiding te vertalen naar een vorm van e-learning waarbij interactie tussen studenten een belangrijk kenmerk is. Het onderzoek rondom e-learning is relatief jong en wordt gekenmerkt door een grote diversiteit in aanpak en terminologie. Verschillende auteurs geven aan dat onderzoek nog onvoldoende evidentie heeft opgeleverd om tot heldere en effectieve ontwerprichtlijnen te komen voor de interactie tussen studenten bij elearning. Deze dissertatie wil hieraan een bijdrage leveren en kiest daarbij voor de ingang van ontwerponderzoek. Dit type onderzoek streeft naar het verhelderen van ontwerpkenmerken via het testen en verbeteren van prototypes, in dit geval de e-learning modules binnen een e-learning opleiding.

De eerste paragraaf (1.1) verheldert het onderwerp van deze dissertatie en bakent dit af. Paragraaf 1.2 schetst de praktische aanleiding voor het onderzoek. Deze paragraaf geeft trapsgewijs het beleid van Windesheim weer dat leidde tot het elearning project en tot het daaraan gekoppelde onderzoek. In de derde paragraaf (1.3) komen de onderzoeksvragen en de aard van het onderzoek aan de orde. Dit hoofdstuk zal eindigen met een overzicht van de hoofdstukken die volgen (1.4).

\subsection{BEGRIPSAFBAKENING}

E-learning is een begrip met vele betekenissen. Sommigen spreken van e-learning als zij de inzet van de computer voor instructiedoeleinden bedoelen; dit kan niet alleen via internet maar ook via software en CD ROM (Clark \& Mayer, 2008). Anderen doelen louter op het leren via internet (Garrison \& Anderson, 2003; Kirschner \& Paas, 2001; Rosenberg, 2006). Vaak wordt met e-learning afstands- 
onderwijs bedoeld, soms ook vormen van instructie via computers binnen de schoolse setting. Clark en Mayer (2008) voorzien in een nadere uitwerking van het begrip e-learning. In hun definitie noemen zij een aantal kenmerken die aanwezig moeten zijn om van e-learning te kunnen spreken. Zij noemen leerdoelen, relevante digitale materialen en instructietechnieken. Met behulp van deze elementen wordt nieuwe kennis opgebouwd en worden vaardigheden getraind.

In deze dissertatie wordt e-learning opgevat als afstandsleren via internet. De leerdoelen, de materialen, de instructietechnieken, de begeleiding door docenten en de organisatie van het leren krijgen gestalte via een internetplatform (in dit geval Blackboard). Het type e-learning dat hier beschreven wordt stelt asynchrone interactie met medestudenten centraal en past als zodanig bij de officiële definitie van het 'Asynchronous Learning Network' (ALN) zoals weergegeven in Hiltz en Goldman (2005, p. 5). 'ALN's are peoples networks for anytime and anywhere learning. ALN combines self-study with substantial, rapid interactivity with others. In ALN learners use computer and communications technologies to work with remote learning resources, including coaches and other learners, but without the requirement to be online at the same time. The most common ALN communication tool is the World Wide Web.' Het ALN onderzoeksgebied maakt deel uit van het bredere onderzoeksgebied van Computer Supported Collaborative Learning (CSCL). In dat onderzoeksgebied staat samenwerkend leren met behulp van de computer centraal (Stahl, Koschmann, \& Suthers, 2006).

\subsection{DE PRAKTISCHE AANLEIDING VOOR HET ONDERZOEK}

In het schooljaar 2005-2006 gaf de leiding van de Windesheim Opleidingen Speciale Onderwijszorg (OSO) de opdracht tot het ombouwen van vier reguliere leerroutes van de master Special Educational Needs (SEN) naar e-learning. Dit verzoek kwam voort uit het e-learning beleid van de hogeschool en uit de wens om de markt voor de OSO opleidingen uit te breiden. Binnen Windesheim bestonden al afstandsopleidingen. Mede naar aanleiding van de ervaringen met deze opleidingen kreeg het projectplan e-learning OSO gestalte. Met dit projectplan als uitgangspunt startte het OSO e-learning projectteam met de ontwikkeling van de e-learning opleidingen. De ontwikkeling van de producten van dit projectteam vormde de aanleiding tot het huidige onderzoek. 


\subsubsection{Instellingsbeleid en schoolbeleid}

In het instellingsplan van hogeschool Windesheim (2003) werd e-learning benoemd als speerpunt. De nadere uitwerking hiervan werd overgelaten aan de verschillende Schools binnen Windesheim. Eén van die Schools is de School of Education. Deze bestaat uit twee initiële lerarenopleidingen en één postinitiële opleiding. Dit zijn respectievelijk de opleiding tot leraar basisonderwijs, de opleiding tot leraar voortgezet onderwijs en de Opleidingen Speciale Onderwijszorg (OSO). OSO leidt op voor de professionele master Special Educational Needs (SEN).

Naar aanleiding van het e-learning speerpunt van de hogeschool formuleerde de School of Education specifieke doelen ten aanzien van de implementatie van elearning (Bolhuis, Schoot, Smits, \& Valstar, 2003, p. 5). Deze doelen luidden als volgt:

- 'De curricula van de initiële opleiding zodanig vormgeven dat de studenten worden toegerust, dat zij in de (nabije) toekomst het eigen onderwijs elearning rijk (..) kunnen vormgeven (e-learning als doel);

- In het onderwijs van de initiële- en (vooral ook) de postinitiële opleidingen wordt e-learning ingezet om tijd- en plaatsonafhankelijk kennis tussen medewerkers en studenten binnen de instelling en in (inter)nationaal verband uit te wisselen; wordt e-learning gebruikt om samenwerkings- en communicatieprocessen te faciliteren en het onderwijsproces vraaggestuurd vorm te geven (e-learning als middel).'

Als opbrengsten van de implementatie van e-learning benoemden de auteurs de mogelijkheid tot flexibilisering en individualisering in het aanbod van leerarrangementen, het effectiever en efficiënter kunnen behalen van onderwijsdoelen, het vergroten van de mogelijkheden voor levenslang leren en het bevorderen van de e-learning bekwaamheid van aankomende leraren.

\subsubsection{De bestaande afstandsleer-praktijk binnen de Windesheim School of Education}

De initiële lerarenopleiding van Windesheim biedt sinds 2001 afstandsonderwijs aan in samenwerking met de Leidse Onderwijs Instellingen (LOI). Deze samenwerking zal overigens in 2012 tot een einde komen. Studenten werken in de LOI/Windesheim opleiding in hun eigen tempo zelfstandig aan de leerstof. Het onderwijsconcept is individueel en instructivistisch van aard. Dit wil zeggen dat 
het onderwijs sterk gericht is op de overdracht van kennis aan de individuele student. Er zijn een aantal contactzaterdagen per jaar en de studenten lopen fysieke stages in het kader van de opleiding.

De docentrol is beperkt. Deze bestaat uit stagebegeleiding, nakijken van ingeleverd werk en uit het verzorgen van onderwijs op de contactzaterdagen. In 2005 waren er overwegend schriftelijke leermiddelen. Deze kwamen grotendeels overeen met de leermiddelen van de reguliere opleiding. De leermiddelen waren niet speciaal ontworpen voor afstandsleren, ze waren wel in beperkte mate daarvoor aangepast. Het onderwijs was niet competentiegericht.

De hoge uitvalscijfers en het geringe afstudeerrendement van deze vorm van afstandsleren vormden een al langer bestaande klacht binnen de hogeschool. Het afstandsonderwijs van de lerarenopleiding kende te hoge uitvalscijfers en het afstudeerrendement lag duidelijk lager dan in de reguliere opleiding. In 2008 werd dit bevestigd in het onderzoek van Mebus et al.. Deze problemen waren aanleiding om in de e-learning opleiding te streven naar rendementen die minstens vergelijkbaar waren met de reguliere opleiding.

\subsubsection{Het e-learning projectplan en het e-learning projectteam van Windesheim OSO}

In aansluiting op het Raamplan e-learning van de School stelde de leiding van Windesheim OSO in juni 2005 concrete doelen op in het projectplan 'Deelproject digitalisering en e-learning 2005 -2006'. Deze doelen luidden als volgt:

- 'Ontwikkelen van visie, begroting en een marktplan voor afstandsleren.

- Voor vier leerroutes uit het uitstroomprofiel Leerproblemen (dyslexie en remediëren) wordt het curriculum zodanig aangepast dat het e-learning mogelijk maakt voor Nederlandstalige studenten in binnen- en buitenland.'

In het projectplan werd verder duidelijk dat het MT van OSO dit voorstel wilde laten aansluiten bij het e-learning beleid van de School of Education en ook bij het recent ontworpen master beleid voor OSO.

Om de genoemde doelen met betrekking tot e-learning te kunnen bereiken, werd een klein projectteam in het leven geroepen. Dit team bestond uit een projectleider en drie leden. Eén van de projectleden kreeg als taak om een visie op e-learning te ontwerpen op basis van een beperkte literatuurstudie. De overige twee leden zouden vervolgens de bestaande Blackboard modules omzetten naar 
e-learning op basis van deze visie. In december 2005 werd de visie op e-learning opgeleverd (Smits, 2005). Dit document bevatte een veelheid aan ontwerpelementen voor de elektronische leeromgeving. Deze elementen werden geclusterd in vier onderwerpen: interactie, structuur, docentrol en leermaterialen. Centraal in het oorspronkelijke ontwerp staat het samenwerkend leren via asynchrone discussies. De docent modereert de discussies inhoudelijk. Een duidelijk tijdpad met opdrachten vormt de basis van waaruit interactie kan plaatsvinden. Deze structuur is ook bedoeld als bescherming tegen studievertraging en uitval. De meeste kennisoverdracht vindt plaats op basis van een rijke elektronische leeromgeving. Het ontwerp was fundamenteel anders dan het elders binnen de School gebruikte LOI concept waarbij de student zelfstandig studeert en zijn eigen tijdpad bepaalt.

Binnen OSO ontstonden naar aanleiding van het ruwe ontwerp een aantal vragen rondom het e-learning project. Zo vroegen de leidinggevenden van OSO zich bijvoorbeeld af of het ontwerp voldoende studenten zou trekken. Ook vroeg men zich af of het toepassen van de voorgestelde didactiek de docent niet meer tijd zou kosten dan voorzien. De vragen die op dat moment ontstonden, lieten zich clusteren als vragen naar de relevantie, de bruikbaarheid en de effectiviteit van het ruwe ontwerp. Het huidige onderzoeksproject startte in januari 2006 en werd opgezet om het ruwe ontwerp aan te scherpen, de implementatie te ondersteunen, te evalueren en waar nodig te kunnen bijsturen. Het onderzoek betreft de ontwikkeling van vier OSO e-learning leerroutes voor master SEN vanaf het eerste ruwe ontwerp (december 2005) tot en met de evaluatie van het tweede uitvoeringsjaar (2008-2009).

\subsection{CENTRALE PROBLEEMSTELLING EN ONDERZOEKSOPZET}

\subsubsection{Centrale probleemstelling}

De centrale probleemstelling voor dit onderzoek komt voort uit de vragen die binnen OSO ontstonden naar aanleiding van het ruwe ontwerp. Daaraan toegevoegd is de vraag naar de validiteit van dit ontwerp. Dit leidde tot de volgende centrale probleemstelling:

Welke kenmerken heeft een valide, bruikbaar en effectief e-learning ontwerp voor de opleiding tot master SEN? 
Onder 'valide' verstaan we dat het e-learning ontwerp mede gebaseerd is op recente wetenschappelijke inzichten en op de kennis en ervaring van experts in het vakgebied. 'Bruikbaar' betekent dat de ontwerpkenmerken uitvoerbaar en zinvol zijn voor studenten en docenten (zie Doyle \& Ponder, 1977). Om 'effectief' te zijn is het belangrijk dat e-learning geen verhoogde dropout genereert ten opzichte van de reguliere opleiding, dat e-learning de studenten in staat stelt om binnen 2-3 jaar de beoogde competenties te behalen op het niveau van de master SEN en dat e-learning een studenttevredenheid genereert die minstens vergelijkbaar is met de reguliere opleiding.

Deze centrale probleemstelling wordt verder vertaald in drie onderzoeksvragen:

1. Wat is een veelbelovend ontwerp voor de e-learning leerroutes?

In de eerste fase van het onderzoek (analysefase) wordt getracht op basis van onderzoeksliteratuur een valide ontwerp voor de e-learning leerroutes te beschrijven. Het eerste ontwerp en een eerste prototype van een module worden ter beoordeling voorgelegd aan een drietal experts op het vlak van elearning. Waar nodig vinden aanpassingen plaats op basis van de uitkomsten van de expertraadpleging.

2. Is het ontwerp bruikbaar in de e-learning leerroute master SEN?

Om een antwoord te kunnen geven op deze onderzoeksvraag worden in de tweede fase van het onderzoek twee modules uitgeprobeerd met één docent en een beperkt aantal studenten (pilot fase). Op basis van de bevindingen wordt het ontwerp waar nodig aangepast. De vraag naar de bruikbaarheid komt nogmaals aan de orde als de hele opleiding integraal wordt uitgevoerd met een normale studentengroep en een groter aantal e-learning docenten (de implementatiefase van het onderzoek). Waar nodig kan dit wederom leiden tot aanpassingen.

3. Leidt het ontwerp tot een effectieve masteropleiding?

Tijdens en na het uitvoeren van de gehele opleiding (implementatiefase) wordt de effectiviteit gemeten in termen van tevredenheid, drop out en afstuderen. Waar nodig kan dit leiden tot aanpassingen.

Het verband tussen de onderzoeksvragen en de onderzoeksfasen wordt hieronder weergegeven in figuur 1.1. Tijdens en tussen de verschillende fasen vinden aanpassingen plaats in het ontwerp indien dit nodig is. 


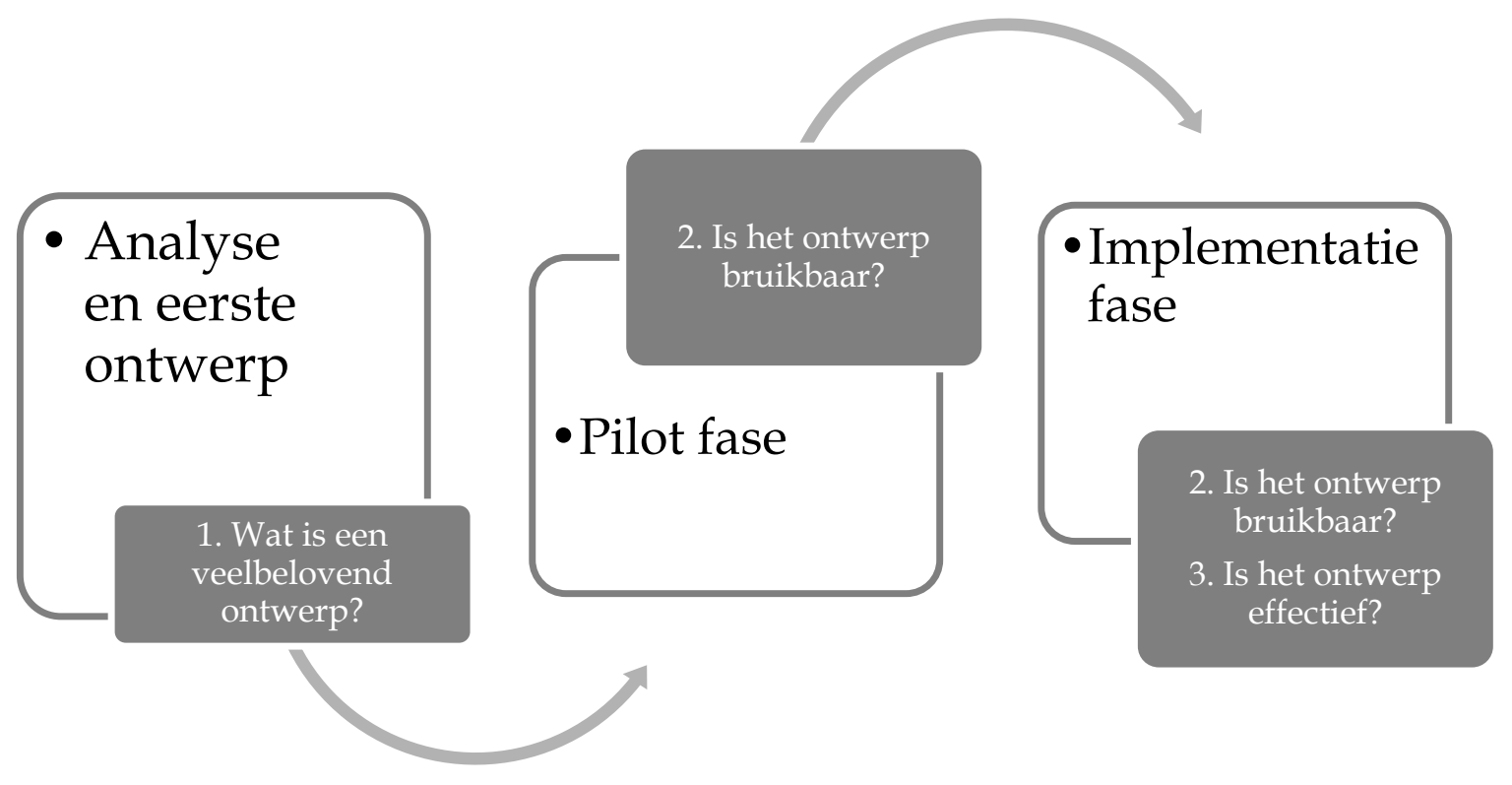

Figuur 1.1 De onderzoeksvragen in de drie onderzoeksfases

\subsubsection{Ontwerponderzoek}

Het onderzoek is opgezet volgens de principes van ontwerponderzoek zoals beschreven door van den Akker (1999) en door Nieveen (2009). Ontwerponderzoek is bedoeld om antwoord te geven op het type vragen dat opkwam naar aanleiding van het eerste e-learning ontwerp. Dit type onderzoek kent een nauwe verwevenheid tussen theorie en praktijk en een cyclische interactie tussen ontwerp, implementatie en evaluatie. Onderzoek leidt tot verbeteringen in de onderwijspraktijk. Naast kennis levert dit type onderzoek concrete producten op en professionele ontwikkeling van de betrokkenen.

Het primaire doel van dit type onderzoek is het produceren van kennis in de vorm van ontwerpkenmerken voor toepassing in de onderwijspraktijk. Deze kennis komt tot stand door het ontwerp, en door de evaluatie en implementatie van prototypes. Tijdens de implementatie vindt formatieve evaluatie plaats. In opeenvolgende cycli van ontwerpen, implementeren en evalueren worden waar nodig verbeteringen aangebracht in de prototypes.

Het onderzoek heeft een cyclisch karakter waarbij onderzoek aanleiding geeft tot verbetering van de implementatie van e-learning. Zowel in de pilotfase als tijdens de implementatiefase worden verbeteracties geformuleerd in interactie tussen 
theorie en praktijk. In het OSO e-learning onderzoek kunnen ook de modules in de implementatiefase worden opgevat als prototypes die nog steeds verder doorontwikkeld worden.

\subsection{OVERZICHT VAN DE VOLGENDE HOOFDSTUKKEN}

In hoofdstuk twee wordt de onderzoeksmethodologie toegelicht. Hoofdstuk drie beschrijft het oorspronkelijke e-learning ontwerp op basis van de literatuur, alsmede de resultaten van de expertraadpleging. De bevindingen met betrekking tot de twee pilotmodules komen aan de orde in hoofdstuk vier. De hoofdstukken 5, 6, 7 en 8 gaan over de bruikbaarheid van de vier ontwerpclusters binnen de setting van de volledige tweejarige Windesheim OSO opleiding. In hoofdstuk 9 wordt de effectiviteit van het curriculum geëvalueerd in termen van studenttevredenheid, docenttevredenheid en studierendement. In het laatste hoofdstuk (hoofdstuk 10) volgen de conclusies van het onderzoek. Het hoofdstuk eindigt met een discussie waarin gereflecteerd wordt op de gehanteerde methodologie en op de uitkomsten van het onderzoek. Ook worden richtingen voor toekomstig onderzoek aangegeven. In de bijlages zijn instrumenten uit het onderzoek en enkele voorbeelden van de leeromgeving opgenomen. 


\section{HOOFDSTUK 2 \\ Onderzoeksmethodologie}

\section{INLEIDING}

De centrale probleemstelling van dit onderzoek betreft het ontwerp en de implementatie van een e-learning omgeving voor een masteropleiding. Dit is een complex probleem waarvoor in de Nederlandse situatie geen kant en klare oplossingen beschikbaar zijn. Als onderzoeksbenadering is gekozen voor ontwerponderzoek. Dit type onderzoek heeft als doel om oplossingen te genereren voor complexe problemen in de dynamische praktijk van het onderwijs. Daarbij wordt kennis geproduceerd over wat werkt binnen een specifieke context en waarom.

In paragraaf 2.1 van dit hoofdstuk worden de karakteristieken van ontwerponderzoek beschreven in relatie tot het huidige onderzoek. In paragraaf 2.2 wordt de opzet van het onderzoek naar de validiteit van het ontwerp beschreven. Vervolgens wordt in paragraaf 2.3 de onderzoeksopzet van de pilotfase beschreven. De onderzoeksopzet van de implementatiefase komt in paragraaf 2.4 aan de orde.

\subsection{ONTWERPONDERZOEK}

\subsubsection{Doelen van ontwerponderzoek}

Ontwerponderzoek wordt vaak gedefinieerd in termen van de doelen van dit type onderzoek (van den Akker, 1999). In de literatuur worden de volgende doelen genoemd (Nieveen, 1999; Plomp, 2009; Richey \& Klein, 2007; van den Akker, 1999; van den Akker, Gravemeijer, McKenney \& Nieveen, 2006; Wang \& Hannafin, 2005): 
- Het ondersteunen van de ontwikkeling van concrete oplossingen voor complexe problemen in de onderwijspraktijk (onder 'oplossingen' kan men onder meer verstaan: programma's, didactische aanwijzingen en materialen)

- Het produceren van kennis over de kenmerken van bruikbare en effectieve oplossingen in de praktijk van het onderwijs

- Het produceren van kennis over het proces van ontwerp en implementatie van deze oplossingen

- Het produceren van methodologische kennis omtrent de formatieve en summatieve evaluatie van oplossingen in het onderwijs

Het huidige onderzoek is opgezet vanuit de eerste twee hierboven genoemde doelen. Er was sprake van een complex probleem in de onderwijspraktijk: er moest een bruikbare en effectieve e-learning omgeving ontwikkeld worden binnen de dynamische context van een bestaande master SEN opleiding. Uitkomsten van eerder onderzoek gaven wel goede algemene principes voor het ontwerp, maar onvoldoende aanwijzingen voor een concrete en effectieve vertaling naar de leeromgeving. Zo komt bijvoorbeeld uit de literatuur naar voren dat interactie tussen studenten kan bijdragen aan het leerproces en aan de studenttevredenheid (o.m. Garrison, Anderson \& Archer, 2001; Gunawardena \& Zittle, 1997; Harasim, 1990; Jonassen, Davidson, Collins, Campbell, \& Haag, 1995; Picciano, 2002; Richardson \& Swan, 2003; Schellens \& Valcke, 2005) maar werd het niet duidelijk hoe deze interactie binnen de context van Windesheim OSO precies vorm zou moeten krijgen om tot goede resultaten te leiden. Om die reden ontstond de behoefte aan onderzoeksmatige ondersteuning van dit ontwikkelproces.

In ontwerponderzoek wordt groot belang gehecht aan de onderwijscontext. Leren, cognitie en de onderwijscontext worden opgevat als onderling afhankelijke entiteiten. Ecologische validiteit vormt dan ook een essentieel aspect van het onderzoek (Barab \& Squire, 2004; Gravemeijer \& Cobb, 2006). In dit licht kan de vraag gesteld worden welke reikwijdte de conclusies van ontwerponderzoek kunnen hebben. De kennis die het onderzoek oplevert is immers in de eerste plaats contextspecifiek. Twee aspecten van ontwerponderzoek kunnen de generaliseerbaarheid naar andere onderwijssituaties vergroten. In de eerste plaats betreft dit het gebruik van de wetenschappelijke literatuur als basis van het onderzoek, maar ook als toetssteen tijdens en na de iteratieve cycli. Hierdoor kan het ontstaan van een geïsoleerde, te sterk door de context bepaalde theorie voorkomen worden. Het tweede aspect waardoor de generaliseerbaarheid van 
ontwerponderzoek vergroot kan worden is de zogenaamde 'rijke' beschrijving van de resultaten. Op basis van een rijke en transparante beschrijving van de context, de interventie en het onderzoek kunnen belanghebbenden beslissen of de bevindingen en de gemaakte aanpassingen bruikbaar zijn in hun eigen context (van den Akker, 1999). Dit type generalisatie werd door Stake (1995) 'petite generalization' genoemd, daarin wordt gefocust op de toepassing in de eigen context en in vergelijkbare contexten. Herhaalde cycli waarbij interventies worden toegepast in verschillende contexten kunnen uiteindelijk resulteren in de vorming en/of de verfijning van theorie en daardoor in meer algemene generaliseerbaarheid.

\subsubsection{Fasering, dataverzameling en dilemma's van ontwerponderzoek}

Ontwerponderzoek kent verschillende fases die herhaaldelijk worden doorlopen. Er wordt gestart met contextanalyse en literatuuronderzoek. Op basis daarvan wordt een ontwerp beschreven dat wordt voorgelegd aan deskundigen (van den Akker, 1999). Vervolgens wordt het ontwerp beproefd in een context die doorgaans evolueert van minder natuurlijk tot volledig natuurlijk (Nieveen, 2009). In het huidige onderzoek is dit ook het geval. De tweede fase van het onderzoek (de pilot) speelt zich af in een beperkte context, waar de derde fase van het onderzoek (implementatie) in de volledige en rijke context van de opleiding plaatsvindt.

Een rijkdom aan dataverzameling is typerend voor ontwerponderzoek (van den Akker, 1999; Richey \& Klein, 2007). Daarbij worden veel verschillende onderzoekswijzen gehanteerd, zowel kwantitatief als kwalitatief (Plomp, 2009; Shavelson, Philips, Towne \& Feuer, 2003). Binnen de verschillende fases van het onderzoek worden doorgaans meerdere onderzoeksmethoden gebruikt om tot triangulatie van de bevindingen te komen. Op basis van de rijke documentatie vindt reflectie en retrospectieve analyse plaats over de validiteit, de bruikbaarheid en de effecten van het ontwerp; zodanig dat het ontwerp waar nodig bijgesteld kan worden. In het huidige onderzoek is gebruik gemaakt van de volgende onderzoekswijzen: literatuurstudie, semi-gestructureerde interviews, vragenlijsten, onderzoekerslogboek (veldnotities), documentanalyse en kwantitatieve- en kwalitatieve analyse van bijdragen in Blackboard.

Het systematisch verwerken van een dergelijke veelheid en veelzijdigheid aan (veelal kwalitatieve) gegevens vormt een centrale uitdaging van ontwerponderzoek (Cobb, Confrey, diSessa, Lehrer, \& Schauble, 2003). Vaak worden er in dit soort onderzoek veel meer data verzameld dan er verwerkt 
kunnen worden (Dede, 2004). Het niet verwerken van grote hoeveelheden gegevens kan de betrouwbaarheid van de conclusies in gevaar brengen (Wang \& Hannafin, 2005). In de literatuur vinden we twee aanbevelingen in verband met dit probleem. Ten eerste is het van belang om overmatig methodologie gebruik te voorkomen door uitgebreide literatuurstudie en conceptualisatie bij de start (Dede, 2004). Ten tweede is het van groot belang nauwkeurig te beschrijven welke conclusies voortkomen uit welke data (Cobb et al., 2003). Deze aanbevelingen worden opgevolgd in het huidige onderzoek. Ontwerponderzoek kent daarnaast nog andere uitdagingen. Deze uitdagingen hangen samen met het werken binnen de natuurlijke onderwijscontext. McKenney, Nieveen en van den Akker (2006) beschrijven de volgende dilemma's die hieronder nader toegelicht zullen worden in de context van het huidige onderzoek:

- de driedubbele rol van de ontwerper/onderzoeker/direct betrokkene in de implementatie

- adaptiviteit van het ontwerp, de wijze van onderzoeken en de rollen in het project

\section{Driedubbele rol}

In het huidige onderzoek heeft de onderzoeker een driedubbele rol: onderzoeker, ontwerper en direct betrokkene in de implementatie. Deze driedubbele rol kent zowel voordelen als valkuilen. Een eerste voordeel is dat gemakkelijk rijke data verzameld kunnen worden (Easton, 2003). Een tweede voordeel is dat op basis van de formatieve evaluatie gemakkelijk aanpassingen doorgevoerd kunnen worden. McKenney et al. (2006) benoemen daarnaast ook valkuilen van ontwerpend en participerend onderzoeken. Enthousiasme over het eigen ontwerp kan blinde vlekken veroorzaken in het onderzoek. De ontwerper is vanuit dit enthousiasme in sommige gevallen verminderd toegankelijk voor kritiek op het ontwerp. Een ander met deze dubbelrol verbonden probleem is het effect dat een dergelijke (drie)dubbelrol kan hebben op de deelnemers aan het onderzoek. Deelnemers kunnen zich 'speciaal' voelen door de aandacht van de onderzoeker en zich daardoor anders gaan gedragen. Ze kunnen daarin zo ver gaan dat ze proberen te raden wat de onderzoeker graag zou willen vinden in het onderzoek, en zich daarnaar gaan gedragen.

Door de veelzijdige betrokkenheid heeft de onderzoeker een persoonlijke invloed in de implementatie. Dit lijkt zeker te gelden als de onderzoeker een insider is in de organisatie zoals in het huidige onderzoek het geval is. Van den Akker (2004) 
benadrukt het belang van een communicatief relationele stijl voor de kwaliteit van de implementatie. Een insider heeft een persoonlijke historie in de organisatie die mede bepalend is voor de kwaliteit van de communicatie en de samenwerking en daarmee voor de implementatie van het ontwerp. Een nadeel is dat dit soort invloeden soms ongrijpbaar zijn (Wang \& Hannafin, 2005). Dit kan de conclusies kleuren en de transfer naar andere situaties bemoeilijken.

Belangrijke beschermende factoren tegen de genoemde nadelen zijn triangulatie, een onderzoeker die in de loop van het proces meer afstand neemt van het proces op de werkvloer (fading), onderzoeksinstrumenten met wat meer afstand tot de participanten (vragenlijsten versus interviews), kritische bevraging door onderzoekers van buiten het project, het realiseren van een zeer natuurlijke setting en een scherp bewustzijn van de problematiek (McKenney et al., 2006; Miles \& Huberman, 1999; Plomp, 2009). Al deze beschermende factoren zijn aanwezig in het huidige onderzoek.

De verschuiving van de rol van de onderzoeker vond als volgt plaats: bij de start had de onderzoeker de rol van ontwerper en vervolgens participeerde de onderzoeker als docent in de twee pilot modules. Toen het onderzoek in de implementatiefase kwam nam de onderzoeker meer afstand door niet meer als elearning docent te participeren. De afstand was niet volledig omdat de onderzoeker nog wel participeerde in de projectgroep e-learning. Deze projectgroep had een ondersteunende functie voor docenten en bracht waar nodig aanpassingen aan in de e-learning opleidingen. De besluitvorming over implementatievraagstukken geschiedde na de start van de opleiding zoveel mogelijk met alle projectgroepleden en met meerdere e-learning docenten zodat steeds meer docenten zich mede-eigenaar konden voelen van de opleiding. Hierdoor kon de invloed van de onderzoeker beperkt worden.

\section{Adaptiviteit}

In ontwerponderzoek vinden er niet alleen cyclisch veranderingen plaats in het ontwerp, het kan op basis van die veranderingen ook nodig zijn om de onderzoeksopzet te veranderen. Zo kunnen bijvoorbeeld vragenlijsten evolueren op grond van de bevindingen van het onderzoek. Aspecten die eerder niet belangrijk leken, kunnen zo toch meegenomen worden in het onderzoek op basis van bevindingen uit eerdere cycli. Een te sterk evoluerend design heeft uiteraard ook nadelen. Bevindingen uit verschillende fases van het onderzoek kunnen niet 
meer gemakkelijk vergeleken worden. In het huidige onderzoek heeft adaptiviteit van de onderzoeksopzet vooral gespeeld met betrekking tot de toevoeging van een vragenlijst die van te voren niet voorzien was; dit betrof de vragenlijst Woord en Ervaring. Deze toevoeging vond in een vroeg stadium van het onderzoek plaats, waardoor de lijst toch meerdere keren gebruikt kon worden. Verder bleek tijdens het onderzoek dat de werkdruk van de studenten niet toeliet om steeds veel vragenlijsten in te vullen. Het aantal in te vullen vragenlijsten per moduleperiode werd beperkt en de tijdsduur van het onderzoek werd uitgebreid, zodat uiteindelijk toch alle vragenlijsten meermaals konden worden afgenomen.

De literatuurstudie bij de start van het onderzoek vormde een belangrijke bescherming tegen een al te sterk evoluerende onderzoeksopzet. Deze literatuurstudie bracht een rijkdom van aspecten van e-learning aan het licht die meegenomen werden bij de constructie van de instrumenten. Dit voorkwam dat bepaalde issues pas te laat aan het licht kwamen.

\subsubsection{Fasen van het onderzoek}

Ontwerponderzoek behelst een iteratief proces waarbij de gewenste oplossing progressief benaderd wordt (Van den Akker, 1999). In dit proces zijn verschillende fases te onderkennen, deze fases worden hieronder beschreven voor het huidige onderzoek.

\section{Fase 1: Analyse en eerste ontwerp}

Het startpunt van het huidige onderzoek werd gevormd door een fase van analyse en eerste ontwerp. In deze fase werd gefocust op de validiteit van het eerste ontwerp. Deze fase bestond uit een contextanalyse, een literatuurstudie, het ontwerp van een prototype en een expert raadpleging. Over deze fase van het onderzoek wordt gerapporteerd in hoofdstuk 3.

\section{Fase 2: Pilotfase}

In de pilotfase werden twee e-learning pilot modules uitgevoerd met een klein aantal studenten. De nadruk lag in deze periode op het onderzoek naar de bruikbaarheid. Formatieve evaluatie en reflectie leidden tot opeenvolgende verbeterslagen zodat het ontwerp steeds bruikbaarder werd. 


\section{Fase 3: De implementatiefase}

$\mathrm{Na}$ de pilot fase volgde de implementatiefase. Dit is de fase waarin de opleiding officieel van start ging met de daarvoor ingeschreven studenten. Zowel de bruikbaarheid als de effectiviteit vormden de onderzoeksfocus in deze fase. Er vond formatieve evaluatie, reflectie en verbetering plaats. Daarna werd de elearning opleiding geëvalueerd naar aanleiding van de vooraf vastgestelde doelen.

\subsection{ONDERZOEKSOPZET FASE 1: ANALYSE EN EERSTE ONTWERP}

De start van het onderzoek werd gevormd door een analyse van de opleidingscontext. Dit was nodig omdat de te ontwerpen e-learning leerroutes zeer nauw moesten aansluiten bij de bestaande reguliere leerroutes. De analyse leidde tot een beschrijving van doelen en randvoorwaarden voor het ontwerp. Vervolgens vond literatuurstudie plaats. Het oorspronkelijke e-learning ontwerp van de projectgroep e-learning was gebaseerd op een beperkte literatuurstudie. In het kader van het huidige onderzoek werd een uitgebreidere literatuurstudie ondernomen.

Op basis van deze uitgangspunten en kenmerken werden twee prototypes gebouwd. Prototype 1 kwam nog niet voldoende overeen met de beschreven ontwerpkenmerken ten gevolge van onervarenheid met het bouwen van elearningmodules. Prototype 2 sloot beter aan bij de beschreven ontwerpkenmerken. $\mathrm{Na}$ het bouwen van prototype 2 vond een expertraadpleging plaats. Drie experts gaven daarin hun mening over de validiteit van de uitgangspunten.

\subsubsection{Vragen en deelvragen over validiteit}

Onder de validiteit van het ontwerp verstaan we dat de ontwerpkenmerken gebaseerd zijn op een contextanalyse, op recente wetenschappelijke inzichten en op de kennis en ervaring van experts in het vakgebied.

Met betrekking tot de validiteit zijn de volgende deelvragen geformuleerd die beantwoord zullen worden in hoofdstuk 3:

- In welke context moet het ontwerp functioneren?

- Welke doelen en randvoorwaarden vanuit de bestaande opleiding zijn van belang voor het ontwerp? 
- Wat zijn veelbelovende ontwerpkenmerken binnen deze context?

- Kunnen de kenmerken van het oorspronkelijke ruwe ontwerp bevestigd, aangescherpt of verworpen worden vanuit recente wetenschappelijke inzichten?

- Kunnen de kenmerken van het ontwerp bevestigd, aangescherpt of verworpen worden vanuit de kennis en ervaring van experts in het vakgebied?

\subsubsection{Deelnemers aan het onderzoek over validiteit}

In het kader van de context analyse zijn drie semigestructureerde interviews uitgevoerd met betrokkenen bij het afstandsleren van de Windesheim lerarenopleiding. Deze vorm van afstandsleren bestond op dat moment uit een combinatie van schriftelijke bronnen en zaterdagonderwijs. De projectleden spraken met de decaan, de leidinggevende en met de coördinator van het ICT Ondersteuningsteam (ICTO) van de School of Education.

Buiten Windesheim zijn drie experts geïnterviewd. Deze experts zijn onderwijskundigen uit Nederland en Vlaanderen met veel onderzoekservaring op het vlak van de implementatie van elektronische leeromgevingen. Twee van de geïnterviewden waren betrokken bij de ontwikkeling en implementatie van een elektronische leeromgeving in het wetenschappelijk onderwijs. Zij ondersteunden docenten om een dergelijke omgeving te leren inrichten voor hun studenten. Eén van deze twee geïnterviewden heeft ook ervaring als docent in een elektronische leeromgeving. De derde geïnterviewde heeft veel ervaring met blended learning en afstandsleren met grote groepen studenten.

\subsubsection{Methodes, instrumenten en data-analyse}

\section{Documentanalyse}

De basisdocumenten van de OSO master SEN werden verzameld en ook alle opleidingsdocumenten die verband hielden met e-learning. De verzamelde documenten werden geanalyseerd met betrekking tot de vraag naar doelen en randvoorwaarden voor het ontwerp. Deze doelen en randvoorwaarden werden vervolgens bediscussieerd en vastgesteld in de projectgroep e-learning. 
Semigestructureerde interviews met betrokkenen bij afstandsleren (hogeschool Windesheim)

De interviews dienden om zicht te krijgen op do's en don'ts van afstandsleren binnen de context van hogeschool Windesheim. Het interview met de decaan had de belangen van de toekomstige e-learning student als voornaamste focus. Van deze interviews werden samenvattende verslagen gemaakt.

\section{Literatuurstudie}

Het doel van de literatuurstudie was om de ontwerpkenmerken van het oorspronkelijke ruwe ontwerp te valideren, aan te scherpen of te verwerpen. Voor de literatuurstudie is gebruik gemaakt van elektronische databases en catalogi van de Universiteit Twente en van de hogeschool Windesheim. De volgende zoekmachines werden gebruikt: Scopus, Web of Science, ERIC, PiCarta, de UT catalogus, Academic Search Elite en de catalogus van het mediacentrum van Hogeschool Windesheim. In de loop van het onderzoek verbeterde de toegankelijkheid van de databases doordat er sneller door de hele collectie gezocht kan worden met respectievelijk FindUT en SeekQ. Daarnaast werd gebruik gemaakt van Google Scholar waarmee in toenemende mate full text artikelen vindbaar en doorzoekbaar zijn en waarin doorverwezen wordt naar de databases van de Universiteit Twente en Windesheim.

Om informatie te vinden zijn verschillende zoekstrategieën gebruikt. Ten eerste is gebruik gemaakt van de volgende algemene zoektermen die in combinaties gebruikt zijn met specifieke zoektermen per kenmerk van het ontwerp: "elearning", "online learning", "teacher training". "higher education", "postgraduate", "satisfaction", "persistence", "retention", "attrition" en "drop out". Vanuit bruikbaar bevonden artikelen werd vervolgens op twee manieren doorgezocht naar andere artikelen en boeken. Ten eerste werd er gezocht in de literatuurlijst van de gevonden artikelen. Daarnaast werd via de databases gezocht in nieuwere artikelen die refereren aan eerder gevonden artikelen. Andere zoekstrategieën waren het zoeken op namen van vaak geciteerde wetenschappers in het vakgebied en het doorzoeken van jaargangen van invloedrijke tijdschriften in het vakgebied. Om een inschatting te maken van de mate van invloed van de peer reviewed tijdschriften is een lijst aangelegd van de peer reviewed tijdschriften in het vakgebied met impactfactor en Scopus trendline en, in een latere fase, hun waarde voor online onderwijs zoals in kaart gebracht door Elbeck en Mandernach (2009). 
De bruikbaarheid van de artikelen werd op meerdere manieren ingeschat. Een eerste oordeel over de bruikbaarheid van de gevonden referenties is gevormd op grond van titels en abstracts. Op basis daarvan is geselecteerd welke artikelen voor bestudering in aanmerking kwamen. Er is voornamelijk gekozen voor onderzoek dat zich afspeelde in verschillende vormen van hoger onderwijs. Bij het bestuderen van de literatuur is gestart met reviews en met artikelen die vaak geciteerd waren door anderen en daardoor als invloedrijk beschouwd konden worden. Daarna werden de overige beschikbare artikelen over het betreffende onderwerp bestudeerd.

\section{Semi-gestructureerde interviews en walk-through met experts}

In december 2006 vond een expert raadpleging plaats over het ontwerp en het prototype van een e-learning module. Aan drie wetenschappers werd in afzonderlijke sessies het oorspronkelijke ruwe ontwerp voorgelegd alsmede een prototype van een module. In semi- gestructureerde interviews gaven zij hun mening over het ontwerp. De interviews werden opgenomen, uitgewerkt en samengevat. Als de deskundigen elkaar tegenspraken met betrekking tot de ontwerpkenmerken dan kregen uitspraken een grotere invloed het ontwerp naar mate de betreffende expert meer praktische- en onderzoekservaring had met betrekking tot de implementatie van het specifieke kenmerk.

\subsection{ONDERZOEKSOPZET FASE 2: PILOTFASE}

Er werden twee pilotmodules gebouwd naar aanleiding van de resultaten van het onderzoek in fase 1. Het betrof de module "aanvankelijk lezen en spellen" en de module "voortgezet lezen en spellen" die vorm kregen in Blackboard (versie 7).

Deze twee modules zijn uitgeprobeerd in een pilot waarin gewerkt is met twee, respectievelijk drie studenten. De onderzoeker participeerde als e-learning docent. De pilot vond plaats tussen januari en juni 2007. De onderzoeksfocus lag op de bruikbaarheid van het ontwerp. De resultaten van de pilotfase worden beschreven in hoofdstuk 4 .

\subsubsection{Deelvragen over bruikbaarheid}

Onder bruikbaarheid wordt in de pilotfase verstaan dat de verschillende ontwerpkenmerken voor studenten zowel praktisch uitvoerbaar zijn als 
aantrekkelijk. De vragen over de uitvoerbaarheid voor docenten waren in de pilot fase van het onderzoek nog niet aan de orde omdat de onderzoeker hier zelf nog een grote rol in speelde. Met betrekking tot de bruikbaarheid van het ontwerp vormden in deze fase de volgende deelvragen het uitgangspunt:

- Zijn de verschillende ontwerpkenmerken realiseerbaar in de praktijk met studenten?

- Zijn de verschillende kenmerken van het ontwerp aantrekkelijk voor studenten?

\subsubsection{Deelnemers aan het onderzoek in de pilotfase}

Het bleek moeilijk om studenten te interesseren voor deelname aan een pilot elearning module. Deelnemers werden geworven uit reguliere studentengroepen in Zwolle die dezelfde modules op het rooster hadden staan in dezelfde periode. Eén deelnemer meldde zich spontaan aan vanuit het buitenland. Van zeven studenten die aanvankelijk belangstelling toonden, deden uiteindelijk alleen twee vrouwelijke studenten mee met de eerste pilotmodule. De tweede pilotmodule draaide met deze zelfde twee deelnemers en één nieuwe vrouwelijke deelnemer. Twee van de drie deelnemers hadden veel werkervaring in het basisonderwijs. Eén student was kortgeleden afgestudeerd van de PABO en had nog geen werkervaring in het onderwijs. De deelnemers gaven toestemming voor de analyse van hun digitale berichten.

\subsubsection{Methodes, instrumenten en data-analyse in de pilotfase}

Digitale berichten van studenten

Dit betreft de registratie, het tellen en de inhoudelijke analyse van alle berichten van studenten in de discussieruimtes van de twee modules in de pilotfase. Daarenboven zijn de e-mails van studenten aan de docent-onderzoeker in deze periode verzameld. Er werd een selectie van deze e-mails gemaakt. Alleen e-mails die feedback bevatten met betrekking tot kenmerken van het ontwerp werden geanalyseerd. E-mails die alleen vragen en opmerkingen bevatten met betrekking tot inhoudelijke zaken werden niet geanalyseerd. Ruwe inspectie van de berichten in de discussieruimte toonde dat deze berichten in de volgende twee categorieën onderverdeeld kunnen worden, waarbij indeling in beide categorieën mogelijk was om geen informatie te verliezen: 
Berichten in het kader van het leerproces binnen de module

Hier worden berichten bedoeld die normaal deel uitmaken van het leerproces binnen de module. Dit zijn berichten van studenten met cognitieve inhoud, met sociale inhoud, en berichten met organisatorische inhoud in verband met de planning, de opdrachten, de samenwerking en de techniek.

Berichten die directe feedback geven over kenmerken van het ontwerp

Dit zijn berichten waarin aan de onderzoeker gevraagd of ongevraagd feedback gegeven wordt op kenmerken van het ontwerp; bijvoorbeeld op docentgedrag en op de organisatorische (structuur) kenmerken van de module. In de twee pilotmodules is er specifiek op aangestuurd om dit soort berichten te krijgen via de volgende tekst in het discussieforum: 'Wat vind je van deze module? We zijn erg benieuwd naar je mening.' Studenten konden er op ieder moment tijdens de looptijd van de module voor kiezen om hun mening te geven, dit kon zo vaak als zij wilden.

Na deze indeling vonden de volgende analyses plaats:

- Tellen van alle bijdrages in de discussieruimtes van Blackboard per student, per module en per discussie.

- Vergelijking van de data waarop de studenten (eind) opdrachten uitvoerden met de voorgeschreven data in het rooster. Hiertoe werden berichten gecodeerd als binnen de tijd / buiten de tijd op basis van het rooster.

- Codering van de berichten en e-mails die feedback bevatten; toekenning aan de volgende categorieën: feedback algemeen, feedback interactie studenten, feedback structuur, feedback docentrol en feedback leermaterialen. De berichten in deze categorieën werden samengevat per ontwerpkenmerk.

- Codering van de studentberichten die deel uit maken van het leerproces binnen de module. De berichten van studenten werden in aansluiting op de belangrijkste clusters van ontwerpkenmerken gecodeerd met de codes sociaal, cognitief en/of organisatorisch. Het codeerschema is een aangepaste en vereenvoudigde versie van het oorspronkelijke schema van Garrison, Cleveland-Innes, Koole en Kappelman (2006). Het codeerschema is aangepast om het beter aan te laten sluiten bij de beschreven ontwerpkenmerken. Alleen de hoofdcategorieën in dit codeerschema worden gescoord: sociaal, cognitief en organisatorisch. Iedere code kon per bericht maximaal één keer toegekend worden. Het was mogelijk om verschillende codes toe te kennen aan één bericht. De door Garrison et al. (2006) aangebrachte indicatoren worden niet 
gescoord, maar slechts gebruikt als indicatoren voor de hoofdcategorieën. De berichten die gecategoriseerd werden als organisatorisch werden in de pilotfase in beperkte mate nader geanalyseerd. Er werd nagegaan hoeveel van deze berichten in verband stonden met de organisatie van de samenwerking en hoeveel van deze berichten te maken hadden met onduidelijkheden in de (eind)opdrachten.

Voor de codering van de discussieberichten is gebruik gemaakt van een tweede beoordelaar die $10 \%$ van de berichten codeerde. $\mathrm{Na}$ een oefenfase en onderhandeling werd een goede overeenstemming bereikt; Scott's pi voor de drie categorieën Sociaal, Cognitief en Organisatorisch: 0,82. In tabel 2.1 wordt het codeerschema weergegeven.

Tabel 2.1 Codeerschema voor digitale berichten van studenten

\begin{tabular}{ll}
\hline Categorieën studenten & Indicatoren \\
\hline Sociaal & Emoties uitdrukken \\
& Persoonlijke ervaringen delen \\
& Sociale ondersteuning \\
\hline Cognitief & Inhoudelijke aspecten van het leerproces: \\
& Informatie geven \\
& Exploratie van het onderwerp \\
& Cognitieve verwarring / cognitieve tegenstellingen \\
& Verbinden van ideeën \\
& Onderbouwen van ideeën \\
& Toepassen van (nieuwe) ideeën \\
& Feedback geven aan medestudenten \\
& Uitleg vragen over inhoudelijke feedback \\
& Technische opmerkingen, vragen en problemen \\
& Onduidelijkheid (eind) opdracht \\
& Onduidelijkheid rooster \\
& Onderhandeling (eind) opdracht \\
& Onderhandeling over rooster \\
& Bedanken voor samenwerking, ondersteuning, feedback \\
& Organisatie van de samenwerking (inclusief \\
& explicitering/verduidelijking van de eigen activiteit) \\
& Medestudent(en) vragen om peer feedback \\
& Docent vragen om feedback \\
\hline Organisatorisch & \\
&
\end{tabular}

Semi-gestructureerde interviews met de deelnemende studenten

In de pilotfase zijn de drie participerende studenten geïnterviewd na afloop van de twee modules. Voor dit interview is een interview leiddraad ontworpen 
rondom de vier clusters van ontwerp elementen. De interviews worden letterlijk uitgeschreven en er vindt open codering plaats. Aan de hand daarvan volgt reflectie en betekenisvolle reconstructie en samenvatting van de bevindingen.

\section{Vragenlijsten}

In deze fase is een aantal vragenlijsten uitgeprobeerd die in het vervolg van het onderzoek gebruikt zouden gaan worden. Vragen die door de pilot studenten als onduidelijk ervaren werden, werden verwijderd of veranderd. De resultaten van deze vragenlijsten zijn in zeer beperkte mate gebruikt voor het onderzoek in de pilotfase. Er is alleen gebruik gemaakt van toegekende rapportciffers voor de modules.

De volgende vragenlijsten worden gebruikt in de pilotfase:

- Docentrol: Begeleiding door de docent

- Interactie tussen studenten: Samenwerking met medestudenten (naderhand vervangen door een vertaalde versie van de Classroom Community Scale, Rovai, 2002a)

- Leermaterialen: Leerzaamheid van de materialen in de e-learning module

- Structuur: Organisatie van de e-learning

\subsection{ONDERZOEKSOPZET FASE 3: DE IMPLEMENTATIEFASE}

Vanaf het schooljaar 2007-2008 werden de e-learning leerroutes volledig geïmplementeerd. Het eerste cohort startte in september 2007 met 39 ingeschreven studenten. Een jaar later (september 2008) startte het tweede cohort met 38 studenten. Vanaf september 2007 werden gegevens verzameld gedurende 7 moduleperiodes; een periode van bijna 2 jaar. Er werd gewerkt in 11 verschillende elearning modules en er waren 15 e-learning docenten betrokken bij het onderzoek.

De focus van het onderzoek lag zowel op bruikbaarheid als op effectiviteit. In hoofdstuk vijf tot en met acht worden de resultaten met betrekking tot de bruikbaarheid beschreven. In hoofdstuk negen is de effectiviteit van het ontwerp aan de orde. 


\subsubsection{Vragen en deelvragen over bruikbaarheid, waardering en effectiviteit}

Bruikbaarheid wordt hier opgevat als de uitvoerbaarheid en de zin van de verschillende ontwerpkenmerken voor studenten en docenten. Daarnaast wordt de waardering van studenten nagegaan voor de onderscheiden clusters van ontwerpkenmerken. Om 'effectief' te zijn is het belangrijk dat e-learning geen verhoogde dropout genereert ten opzichte van de reguliere opleiding, en dat elearning de studenten in staat stelt om binnen 2-3 jaar de beoogde competenties te behalen op het niveau van de master SEN. Daarnaast dienen de OSO e-learning modules een studenttevredenheid te genereren die vergelijkbaar is met of beter dan de reguliere opleiding, dit is bij de start van het project door de leiding van OSO geoperationaliseerd als een rapportcijfer $\geq 7$.

Voor de implementatiefase van het onderzoek zijn de volgende deelvragen geformuleerd:

1. Bruikbaarheid

a. Zijn de verschillende ontwerpkenmerken realiseerbaar voor studenten en docenten?

b. Zijn de verschillende ontwerpkenmerken zinvol in het kader van de opleiding?

2. Waardering - tevredenheid over het ontwerpcluster

a. Hoe waarderen de studenten de clusters van ontwerpkenmerken?

b. Met welke ontwerpkenmerken hangt deze waardering samen?

3. Effectiviteit: waardering - tevredenheid over modules

a. Hoe is de studenttevredenheid over de modules?

b. Haalt de studenttevredenheid over de modules de norm die door het management team is gesteld?

c. Welke factoren hangen samen met studenttevredenheid in e-learning?

4. Effectiviteit: dropout en afstuderen

a. Hoe groot is de dropout na het eerste, tweede en derde studiejaar?

b. Hoe verhoudt deze dropout zich tot de dropout in de reguliere opleiding?

c. Welke factoren hangen samen met dropout?

d. Zijn de e-learning modules geschikt om competenties te verwerven op het niveau van de master SEN? 
e. Hoeveel procent van de studenten studeert af als master SEN binnen de termijn van twee jaar? Hoeveel procent van de studenten studeert af als master SEN binnen drie en vier jaar? Hoe verhoudt dit zich tot de studenten in de reguliere leerroutes?

De onderzoeksvragen over bruikbaarheid en waardering voor de ontwerpclusters (onder de punten 1 en 2) worden per ontwerpcluster in een apart hoofdstuk besproken (zie de hoofdstukken 5 tot en met 8). De onderzoeksvragen met betrekking tot effectiviteit (punten 3 en 4) worden beantwoord in hoofdstuk 9 .

\subsubsection{Deelnemers aan het onderzoek in de implementatiefase}

De deelnemers aan het onderzoek selecteerden zichzelf door zich in te schrijven voor e-learning (studenten) of door te kiezen om één of meer e-learning modules te geven (docenten). Dit betekent dat deze deelnemers fundamenteel zouden kunnen verschillen van de reguliere OSO studenten. In het eerste jaar namen 3 mannen deel en 36 vrouwen. In het tweede jaar startten 2 mannen en 36 vrouwen. Deze scheve verdeling heeft te maken met de onderwerpen van de studie. Ook in de reguliere leerroutes Remediëren en Dyslexie schrijven zich zeer weinig mannen in. Alle studenten hadden minimaal een $\mathrm{HBO}$ opleiding afgerond en werkten naast de studie, in de meeste gevallen in het onderwijs, soms in een eigen praktijk. De gemiddelde leeftijd van de OSO e-learning studenten ligt rond de 40 jaar, met een standaarddeviatie van bijna 9 jaar.

In tabel 2.2 wordt per moduleperiode zichtbaar gemaakt aan hoeveel studenten vragenlijsten zijn toegezonden. De vragenlijsten zijn toegezonden aan alle studenten die actief deelnamen aan de module. In cohort 1 zijn vragenlijsten ook toegezonden als de betreffende student tijdens de moduleperiode uitviel. Dit is niet meer gedaan in cohort 2 omdat het een grote belasting betekende voor de studenten in kwestie.

Tabel 2.2 Aantal deelnemers per cohort, per moduleperiode

\begin{tabular}{lcccccccc}
\hline $\begin{array}{l}\text { Periode } \\
\text { Cohort }\end{array}$ & Start & $\mathbf{1}$ & $\mathbf{2}$ & $\mathbf{3}$ & $\mathbf{4}$ & $\mathbf{5}$ & $\mathbf{6}$ & $\mathbf{7}$ \\
\hline 1 & 39 & 39 & 30 & 31 & 26 & 24 & 22 & 20 \\
2 & 38 & 0 & 0 & 0 & 0 & 30 & 27 & 25 \\
\hline
\end{tabular}


Voor een paar aspecten in het onderzoek is een beperkte gegevensverzameling gedaan bij een vergelijkingsgroep. Hiervoor zijn studenten benaderd uit de vier overeenkomstige reguliere leerroutes van het uitstroomprofiel Leerproblemen, cohort 2007-2008. Twee vragenlijsten werden bovendien uitgezet bij alle eerste- en tweede jaars OSO studenten in het schooljaar 2007-2008.

De wisselende getallen in de verschillende moduleperiodes worden veroorzaakt door uitval, tijdelijke uitval (ziekte en dergelijke) en vrijstellingen. Heel soms kwam het voor dat studenten twee modules tegelijkertijd volgden. Ook afstuderen speelt mee; er waren twee afstudeerders in de loop van het tweede jaar. Versneld afstuderen is mogelijk als studenten vrijstellingen hebben gekregen van de examencommissie van de opleiding.

De 15 deelnemende e-learning docenten hadden nooit eerder als e-learning docent gefunctioneerd. Zij combineerden het e-learning docentschap met docenttaken in reguliere modules. Alle docenten hadden een dienstverband met Windesheim, in de meeste gevallen was dat een aanstelling tussen de 60 en 100\%. De e-learning docenten waren overwegend vrouwen; van de 15 was er maar één man. Op één na alle docenten waren ervaren Blackboard gebruikers (versie 7). Zij maakten ook in de reguliere opleiding gebruik van Blackboard. Eén docent werkte nog maar kort voor Windesheim en had daardoor minder ervaring met Blackboard.

Bij de start van de e-learning pilot modules en de opleiding werden de studenten van het eerste cohort geïnformeerd over het onderzoek en verzocht om deelname daaraan. 31 studenten van het eerste cohort (2007-2008) gaven toestemming om hun elektronische berichten te analyseren voor het onderzoek. Berichten van de studenten die geen toestemming gaven, zijn niet inhoudelijk geanalyseerd. Volledig geanonimiseerde rapportage over de onderzoeksbevindingen werd gegarandeerd. De docenten waren al langer op de hoogte van het onderzoek, evaluatie van hun functioneren door studenten hoort tot hun normale taakuitoefening.

\subsubsection{Methodes, instrumenten en data-analyse}

Berichten van studenten in Blackboard

Alle berichten van de studenten in Blackboard werden geteld. Per moduleperiode werden gemiddelde aantallen berichten berekend. Uit de 31 studenten in het eerste cohort die toestemming hebben gegeven voor de kwalitatieve analyse van hun 
berichten zijn random vijf studenten gekozen. Van deze vijf studenten zijn de berichten in de discussieruimtes van Blackboard in de eerste en in de laatste moduleperiode inhoudelijk geanalyseerd, zowel aan het begin van de studie waar de studenten nog moesten wennen als aan het eind van de studie waar de studenten ervaren e-learners waren geworden en waar de interactie patronen waarschijnlijk een gestabiliseerde vorm hadden bereikt. Eén van de vijf geselecteerde studenten studeerde vervroegd af op basis van vrijstellingen. Hierdoor konden geen berichten van deze student worden geanalyseerd in periode 7 .

De berichten werden gecodeerd met de codes sociaal, cognitief of organisatorisch. Als berichten directe feedback bevatten op het ontwerp dan werd als code 'feedback' gegeven zodat dit later makkelijk terug te vinden was. Het gebruikte codeerschema ten aanzien van de drie soorten interactie is weergegeven in tabel 2.1.

Om de betrouwbaarheid van het codeerproces te bewaken is gebruik gemaakt van een tweede beoordelaar die 10 \% van de berichten codeerde. Daarna vond waar nodig onderhandeling plaats. Een goede overeenstemming werd bereikt; Scott's pi voor de drie categorieën Sociaal, Cognitief en Organisatorisch: 0,87.

In de berichten van de vijf studenten werden daarnaast de volgende zaken geïnventariseerd en samengevat vanuit de berichten met een sociale en / of organisatorische code:

- Knelpunten ten aanzien van de interactie tussen studenten

- Knelpunten ten aanzien van de studiebelasting

- Knelpunten ten aanzien van de duidelijkheid van de opdrachten

Op de berichten die vielen in de organisatorische categorie is een nadere analyse toegepast. Hiertoe zijn in eerste instantie de indicatoren uit tabel 2.1 gebruikt als codes. Daaraan zijn op grond van de inspectie van het materiaal enkele codes toegevoegd. De codes werden geclusterd tot vijf soorten organisatorische onderwerpen: samenwerking, onduidelijkheden, onderhandelen, techniek en ondersteunen van medestudenten. De componenten van deze clusters worden weergegeven in tabel 2.3. Iedere code kon per bericht maximaal 1 keer toegekend worden. Per bericht konden meerdere verschillende codes toegekend worden. 
Tabel 2.3 Soorten organisatorische berichten

\begin{tabular}{ll}
\hline Clusters & Codes \\
\hline Samenwerking & $\begin{array}{l}\text { Organiseren van de samenwerking: hoe, wie, wat, wanneer + } \\
\text { expliciteren en verduidelijken van de eigen (in)activiteit } \\
\text { Vragen om peer feedback } \\
\text { Bedanken voor peer feedback en voor aspecten van de } \\
\text { samenwerking }\end{array}$ \\
& $\begin{array}{l}\text { Onduidelijkheden in het rooster } \\
\text { Onduidelijkheden beoordeling }\end{array}$ \\
& Onduidelijkheden in de (eind)opdrachten \\
Onduidelijkheden & Onderhandelen over het rooster \\
& Onderhandelen over de inhoud van de (eind)opdracht \\
Onderhandelen & Technische vragen, opmerkingen en problemen \\
Techniek & Onduidelijkheid enrollment \\
& Helpen met techniek \\
Praktisch ondersteunen & Aanbevelen studiematerialen \\
van medestudenten & Helpen met vindplaats in Blackboard/ op internet \\
& Helpen met het begrijpen van de (eind)opdracht \\
\hline
\end{tabular}

Analyse van inleverdata ten opzichte van het rooster

Voor alle studenten werd in alle moduleperiodes nagegaan of zij hun eindopdracht in Blackboard al dan niet binnen de daarvoor gestelde tijd inleverden. Voor de vijf random geselecteerde studenten werd nagegaan of zij in moduleperiodes 1 en 7, hun discussiebijdrages en overige e-learning opdrachten al dan niet binnen de door het rooster gestelde tijd uitvoerden. Hiertoe werden berichten gecodeerd als binnen de tijd/buiten de tijd op basis van het rooster.

\section{Onderzoekerslogboek (veldnotities)}

De onderzoeker participeerde in moduleperiode 1-4 in de projectgroep e-learning en hield een uitvoerig logboek bij met veldnotities en reflecties. Dit logboek werd online bijgehouden met behulp van Google kladblok. In het onderzoekerslogboek werden ook e-mails van studenten en docenten aan de onderzoeker opgenomen die feedback bevatten op de e-learning opleiding. Het logboek is verwerkt met behulp van open codering, reflectie en samenvatting van de bevindingen.

\section{Berichten van docenten in Blackboard}

In alle moduleperiodes werd geteld hoeveel berichten de docenten hadden geplaatst in de verschillende studentgroepjes. Ook werd geteld hoeveel berichten de docenten in totaal hadden bijgedragen in de algemene discussielijn en hoeveel docenten deelnamen aan deze discussielijn. 
Semi-gestructureerde interviews met docenten

In het eerste jaar van de implementatiefase van het onderzoek zijn zes van de zeven docenten van de eerste vier modules geïnterviewd nadat zij een module hadden gegeven. De interviews zijn op band opgenomen en woordelijk schriftelijk uitgewerkt. Daarna vond open codering plaats, reflectie en samenvatting van de bevindingen.

\section{Documentanalyse: drop-out en afstuderen}

Er is gebruik gemaakt van een overzicht dat op basis van gegevens in de studentenadministratie geproduceerd is in het kader van de visitatie van de opleiding in 2011. Op basis van dit document werden voor 3 jaren percentages uitvallers en afstudeerders berekend, zowel voor e-learning als voor de overeenkomstige reguliere leerroutes. Voor de e-learners werden de cijfers gecontroleerd vanuit het onderzoekerslogboek en met behulp van deelname statistieken van Blackboard. Waar nog onduidelijkheden waren, werd navraag gedaan bij de e-learning docenten.

\section{Vragenlijsten voor studenten}

In het onderzoek is gebruik gemaakt van acht vragenlijsten (zie bijlages A-H) . Deze vragenlijsten zijn onder te verdelen in twee groepen. De eerste groep vragenlijsten betreft algemene aspecten van e-learning en de tweede groep richt zich op de vier centrale ontwerpclusters uit dit onderzoek.

De constructie van een goed bruikbare, valide en betrouwbare vragenlijst vergt veel. Verschillende auteurs (Arbaugh \& Hiltz, 2005; Fink, 2008; Sudman \& Bradburn, 1982) adviseren dan ook om daarbij, waar mogelijk, gebruik te maken van vragenlijsten die door anderen uitvoerig getest en gevalideerd zijn, en waarover al betrouwbaarheidsgegevens bestaan. Arbaugh en Hiltz (ib.) adviseren om deze lijsten zorgvuldig aan te passen naar de eigen vraagstelling, waarbij wel risico's ontstaan ten aanzien van betrouwbaarheid en validiteit.

In dit onderzoek zijn twee bestaande en reeds gevalideerde vragenlijsten gebruikt (TAC en Classroom Community Scale). Verder is er een vragenlijst gebruikt die standaard binnen alle master SEN leerroutes van Windesheim ingezet wordt. De overige vragenlijsten zijn geheel of gedeeltelijk zelf ontworpen in nauwe aansluiting op het e-learning ontwerp en op de literatuurstudie die in verband daarmee plaatsvond. Waar mogelijk zijn items uit bestaande vragenlijsten gebruikt. 
In tabel 2.4 wordt weergegeven welke vragenlijsten zijn vertaald en aangepast, welke vragenlijst standaard wordt afgenomen binnen de Windesheim master SEN leerroutes en welke vragenlijsten zelf zijn ontwikkeld (al dan niet met gebruik van vertaalde items uit andere lijsten). Bovendien wordt in de linkerkolom weergegeven welke vragenlijsten een algemene focus hebben en welke vragenlijsten gaan over de vier ontwerpclusters van het e-learning ontwerp.

Tabel 2.4 Origine en aard van de gehanteerde vragenlijsten

\begin{tabular}{ll}
\hline $\begin{array}{l}\text { Vertaalde en aangepaste vragenlijsten } \\
\text { Gehanteerde naam in dit onderzoek }\end{array}$ & $\begin{array}{l}\text { Oorspronkelijke naam/ omschrijving van } \\
\text { de gebruikte vragenlijst }\end{array}$ \\
\hline TAC (algemeen) & $\begin{array}{l}\text { Teacher Attitudes towards Computers } \\
\text { (Knezek, Christensen, \& Miyashita, 2000; } \\
\text { Moonen, 2001) }\end{array}$ \\
$\begin{array}{l}\text { Samenwerking met medestudenten } \\
\text { (ontwerpcluster) }\end{array}$ & $\begin{array}{l}\text { Classroom Community Scale } \\
\text { (Rovai, 2002a) }\end{array}$ \\
\hline Standaard vragenlijst Windesheim OSO & Oorspronkelijke naam / omschrijving van \\
master SEN & de gebruikte vragenlijst \\
\hline OSO evaluatie (algemeen) & idem \\
\hline Eigen vragenlijsten & Met vertaalde items uit: oorspronkelijke \\
& naam / omschrijving \\
\hline Woord en Ervaring (algemeen) & n.v.t. \\
Vraagsturing & n.v.t. \\
Begeleiding door de docent (ontwerpcluster) & $\begin{array}{l}\text { The Online Learning Environment Survey } \\
\text { (OLES) (Pearson \& Trinidad, 2006) }\end{array}$ \\
& Web-based Course Evaluation \\
& (Stewart, Hong, \& Strudler, 2004) \\
Leerzaamheid van onderdelen in de e- & e-Learning Experience Questionnaire \\
learning (ontwerpcluster) & (Ginns \& Ellis, 2007) \\
Organisatie van de e-learning & Web-based Course Evaluation \\
(ontwerpcluster) & (Stewart et al., 2004) \\
& e-Learning Experience Questionnaire \\
& (Ginns \& Ellis, 2007) \\
\hline
\end{tabular}

Noot: *http://www.monochrome.com.au/oles/survey.htm

Bij het maken van nieuwe vragen is gelet op het inferentieniveau van de items (zie ook Stewart, Hong, \& Strudler, 2004). Items met een hoog inferentieniveau vergen veel interpretatie op basis van de kennis van de invuller. De betekenisgeving aan dit soort items kan zeer verschillend zijn en is oncontroleerbaar. Items met een laag inferentieniveau zijn feitelijke vragen die te beantwoorden zijn vanuit observatie en zonder ingewikkelde inferenties.

De vragenlijsten zijn voorgelegd aan één neerlandicus en twee onderzoekers om de formulering en de validiteit te beoordelen. Dit leidde in een aantal gevallen tot verbeteringen. Vervolgens zijn een aantal vragenlijsten uitgeprobeerd in de 
pilotfase om de geschiktheid van de vraagstelling voor studenten te kunnen beoordelen. Waar nodig zijn aanpassingen gemaakt na de pilotfase.

In de implementatiefase van het onderzoek werden de vragenlijsten verschillende keren afgenomen. In tabel 2.5 worden de tijdstippen van afname weergegeven in termen van moduleperiodes (MP) 1 tot en met 7. De afname geschiedde digitaal via Formdesk. De studenten werden daartoe via e-mail benaderd. In de e-mail werd duidelijk gemaakt dat de vragenlijsten afgenomen werden in het kader van het huidige onderzoek. Anonieme verwerking werd gegarandeerd. Er werd per periode maar een gedeelte van de vragenlijsten afgenomen om de belasting voor de studenten te beperken en daarmee de kans op respons te verhogen.

Tabel 2.5 Afnametijdstippen vragenlijsten

\begin{tabular}{|c|c|c|c|c|c|c|c|c|c|}
\hline Vragenlijsten & $\begin{array}{c}\text { Tijdens } \\
\text { MP1 }\end{array}$ & $\begin{array}{l}\text { Na } \\
\text { MP1 }\end{array}$ & $\begin{array}{c}\mathrm{Na} \\
\mathrm{MP2}\end{array}$ & $\begin{array}{l}\mathrm{Na} \\
\mathrm{MP3}\end{array}$ & $\begin{array}{l}\mathrm{Na} \\
\mathrm{MP4}\end{array}$ & $\begin{array}{l}\text { Tijdens } \\
\text { MP5 }\end{array}$ & $\begin{array}{c}\text { Na } \\
\text { MP5 }\end{array}$ & $\begin{array}{c}\mathrm{Na} \\
\mathrm{MP6}\end{array}$ & $\begin{array}{c}\text { Na } \\
\text { MP7 }\end{array}$ \\
\hline TAC & $x$ & & & & & $x$ & & & \\
\hline OSO evaluatie & & $x$ & $x$ & $x$ & $x$ & & & $x$ & $x$ \\
\hline Woord en ervaring & & $x$ & & & $x$ & & $x$ & & \\
\hline Vraagsturing & & $x$ & $x$ & $x$ & $x$ & & & & \\
\hline $\begin{array}{l}\text { Organisatie van de } \\
\text { e-learning }\end{array}$ & & & $x$ & & & & & $x$ & $x$ \\
\hline $\begin{array}{l}\text { Leerzaamheid van } \\
\text { onderdelen }\end{array}$ & & & $x$ & & & & & $x$ & $x$ \\
\hline $\begin{array}{l}\text { Begeleiding door de } \\
\text { docent }\end{array}$ & & $x$ & $x$ & $\mathrm{x}$ & $x$ & & & $x$ & $x$ \\
\hline $\begin{array}{l}\text { Samenwerking met } \\
\text { andere studenten }\end{array}$ & & $x$ & $x$ & $\mathrm{x}$ & $x$ & & & $x$ & $x$ \\
\hline
\end{tabular}

Bij de statistische verwerking werden negatief geformuleerde items omgecodeerd. De betrouwbaarheid van de schalen is getest met Cronbach's alpha. De grens voor gebruik van de schaal is 0,7, waarbij 0,70-0,79 wordt gezien als betrouwbaar, 0,80-0,90 wordt gezien als in hoge mate betrouwbaar en $>0,90$ als in zeer hoge mate betrouwbaar (Cohen, Manion \& Morrison, 2007, p. 506). In tabel 2.6 is per (sub)schaal het aantal items in het huidige onderzoek weergegeven en Cronbach's alpha. In sommige gevallen werden er in het oorspronkelijke onderzoek meer items gebruikt dan in het huidige onderzoek, dit is aangegeven naast de oorspronkelijke Cronbach's alpha. Items vielen soms weg omdat ze niet goed te vertalen waren, soms omdat ze verouderd waren (dit betrof de TAC) en soms omdat ze tot een minder betrouwbare schaal leidden. De gebruikte instrumenten bleken ruimschoots betrouwbaar. 
Tabel 2.6 Betrouwbaarheid van de gebruikte schalen

\begin{tabular}{|c|c|c|c|}
\hline Gebruikte (sub)schalen & $\begin{array}{l}\text { Aantal items } \\
\text { in huidige } \\
\text { onderzoek }\end{array}$ & $\begin{array}{l}\text { Cronbach's } \\
\text { alpha in het } \\
\text { oorspronkelijke } \\
\text { onderzoek }\end{array}$ & $\begin{array}{l}\text { Cronbach's } \\
\text { alpha } \\
\text { huidige } \\
\text { onderzoek }\end{array}$ \\
\hline \multicolumn{4}{|l|}{ ALGEMEEN E-LEARNING } \\
\hline \multicolumn{4}{|l|}{ TAC1 } \\
\hline 1. Plezier (Enjoyment) & 15 & 0,95 & 0,80 \\
\hline 2. Angst (Anxiety) & 15 & 0,96 & 0,93 \\
\hline 3. Vermijding (Avoidance) & 12 & 0,90 (13 items) & 0,73 \\
\hline $\begin{array}{l}\text { 4. Negatieve impact op de maatschap- } \\
\text { pij (Negative impact) }\end{array}$ & 11 & 0,85 & 0,80 \\
\hline 5. Productiviteit (Productivity) & 15 & 0,93 & 0,89 \\
\hline OSO Evaluatie (rapportcijfer module) & 1 & n.v.t. & n.v.t. \\
\hline \multicolumn{4}{|l|}{ Woord en Ervaring } \\
\hline 1. Engagement & 5 & n.v.t. & 0,90 \\
\hline 2. Sociaal & 5 & n.v.t. & 0,81 \\
\hline 3. Tijdsdruk en stress & 4 & n.v.t. & 0,78 \\
\hline 4. Chaos & 4 & n.v.t. & 0,80 \\
\hline 5. Angst & 4 & n.v.t. & 0,80 \\
\hline \multicolumn{4}{|l|}{$\begin{array}{l}\text { PEDAGOGISCH DIDACTISCHE } \\
\text { ASPECTEN }\end{array}$} \\
\hline Vraagsturing & 3 & n.v.t. & 0,73 \\
\hline \multicolumn{4}{|l|}{ Samenwerking met medestudenten ${ }^{2}$} \\
\hline 1. Verbondenheid & 4 & 0,92 (10 items) & 0,86 \\
\hline 2. Steun voor het leerproces & 3 & 0,87 (10 items) & 0,71 \\
\hline 3. Aansluiting bij leerwensen & 4 & 0,87 (10 items) & 0,74 \\
\hline \multicolumn{4}{|l|}{ Begeleiding door de docent } \\
\hline 1. Moderatie & 4 & n.v.t. & 0,85 \\
\hline 2. Feedback & 3 & n.v.t. & 0,79 \\
\hline 3. Docentcommunicatie & 4 & n.v.t. & 0,81 \\
\hline $\begin{array}{l}\text { Leerzaamheid van onderdelen van de } \\
\text { module }\end{array}$ & 14 & n.v.t. & n.v.t. \\
\hline \multicolumn{4}{|l|}{ Organisatie van de e-learning } \\
\hline 1. Ondersteuning door planning & 3 & n.v.t. & 0,80 \\
\hline 2. Duidelijkheid & 4 & n.v.t. & 0,83 \\
\hline 3. Werkdruk en begrip & 4 & n.v.t. & 0,81 \\
\hline
\end{tabular}

\section{Convergente validiteit voor nieuw geconstrueerde schalen}

Omdat met veel nieuw geconstrueerde schalen is gewerkt, is in de loop van het onderzoek waar mogelijk de convergente validiteit nagegaan door Pearson's $r$ te berekenen met conceptueel samenhangende schalen/maten. Dit is weergegeven in onderstaande tabel. De berekening is uitgevoerd voor alle moduleperiodes waarin

Knezek, Christensen, \& Miyashita (2000)

Rovai (2002a) 
beide instrumenten zijn afgenomen. In tabel 2.7 is voor alle moduleperiodes waarin beide instrumenten zijn afgenomen, weergegeven of de correlatie significant dan wel niet significant was. Per periode is met sterretjes het niveau van significantie weergegeven, ${ }^{*} p<0,05,{ }^{* *} p<0,01,{ }^{* * *} p<0,001$. Er zijn geen correlaties ingevuld als er geen conceptueel verwante meting beschikbaar was.

Tabel 2.7 Samenhang tussen schalen in moduleperiodes 1-7

\begin{tabular}{|c|c|c|c|}
\hline \multirow{2}{*}{$\begin{array}{l}\text { Gebruikte (sub)schalen } \\
\text { en maten } \\
\text { ALGEMEEN E- } \\
\text { LEARNING }\end{array}$} & \multirow[t]{2}{*}{ Met schaal / maat } & \multicolumn{2}{|c|}{$\begin{array}{l}\text { Significantie } \\
\text { in moduleperiodes 1-7 }\end{array}$} \\
\hline & & Significant & $\begin{array}{l}\text { Niet } \\
\text { significant }\end{array}$ \\
\hline \multicolumn{4}{|l|}{ Woord en Ervaring } \\
\hline Engagement & $\begin{array}{l}\text { Aansluiting bij } \\
\text { leerwensen }\end{array}$ & $1^{* * *}, 4^{* *}$ & - \\
\hline $\begin{array}{l}\text { Sociaal } \\
\text { Tijdsdruk en stress } \\
\text { Chaos } \\
\text { Angst }\end{array}$ & Verbondenheid & $1^{* *}, 4^{* * *}$ & - \\
\hline \multicolumn{4}{|l|}{$\begin{array}{l}\text { PEDAGOGISCH DIDAC- } \\
\text { TISCHE ASPECTEN }\end{array}$} \\
\hline Vraagsturing & $\begin{array}{l}\text { Aansluiting bij } \\
\text { leerwensen }\end{array}$ & $1^{* *}, 2^{*}, 4^{* *}$ & 3 \\
\hline \multicolumn{4}{|l|}{$\begin{array}{l}\text { Samenwerking met } \\
\text { medestudenten }\end{array}$} \\
\hline Verbondenheid & Cijfer voor samenwerking & $\begin{array}{l}1^{* * *}, 2^{* * *}, 3^{* * *} \\
4^{* * *}, 6^{* * *}, 7^{* *}\end{array}$ & - \\
\hline Steun voor het leerproces & Cijfer voor samenwerking & $\begin{array}{l}1^{* *}, 2^{* *}, 3^{* * *}, 4^{* * *} \\
6^{* * *}, 7^{*}\end{array}$ & - \\
\hline Aansluiting bij leerwensen & Cijfer voor de module & $\begin{array}{l}1^{* * *}, 2^{* *}, 4^{*}, 6^{* * *} \\
7^{* * *}\end{array}$ & 3 \\
\hline \multicolumn{4}{|l|}{$\begin{array}{l}\text { Begeleiding door de } \\
\text { docent }\end{array}$} \\
\hline Moderatie & $\begin{array}{l}\text { Cijfer voor } \\
\text { docentbegeleiding }\end{array}$ & $\begin{array}{l}1^{* * *}, 2^{* * *}, 3^{*}, 4^{*} \\
6^{* * *}, 7^{* * *}\end{array}$ & \\
\hline Feedback & $\begin{array}{l}\text { Cijfer voor } \\
\text { docentbegeleiding }\end{array}$ & $1^{* * *}, 2^{* * *}, 3^{*}, 7^{* * *}$ & 4,6 \\
\hline Docentcommunicatie & $\begin{array}{l}\text { Cijfer voor } \\
\text { docentbegeleiding }\end{array}$ & $1^{* *}, 2^{* * *}, 6^{* *}, 7^{* * *}$ & 3,4 \\
\hline \multicolumn{4}{|l|}{$\begin{array}{l}\text { Organisatie van de e- } \\
\text { learning }\end{array}$} \\
\hline $\begin{array}{l}\text { Ondersteuning door } \\
\text { planning }\end{array}$ & Cijfer voor organisatie & $6^{* \star *}, 7^{* *}$ & \\
\hline Duidelijkheid & Cijfer voor organisatie & $6^{* * *}, 7^{* *}$ & \\
\hline Werkdruk en begrip & Cijfer voor organisatie & $6^{* * *}, 7^{*}$ & \\
\hline
\end{tabular}

Noot: ${ }^{*} p<0,05,{ }^{* *} p<0,01,{ }^{* * *} p<0,001$. 
De meeste schalen laten (vrijwel) systematisch een verband zien met conceptueel verbonden maten. Voor de schalen Tijdsdruk en stress, Chaos en angst waren geen conceptueel verbonden maten beschikbaar, omdat de schalen met betrekking tot de organisatie van de e-learning niet in dezelfde moduleperiodes zijn afgenomen.

\section{Toelichting op de afzonderlijke vragenlijsten}

Teacher Attitude Scale (TAC), (Knezek et al., 2000; Moonen, 2001)

De TAC is een valide en betrouwbaar instrument, dat dient om de attitudes van leraren ten opzichte van computergebruik te meten. Er wordt in dit onderzoek gewerkt met versie 3.2B. Er bestaan modernere versies, maar er is in dit geval voor gekozen met deze versie omdat deze al eerder is vertaald en gebruikt in Nederland (Moonen, 2001). Er is voor gekozen om inmiddels verouderd geraakte items te verwijderen.

In het huidige onderzoek wordt gewerkt met de volgende 5 schalen:

1. Plezier (in het gebruik van computers)

2. Angst (voor het gebruiken van en praten over computers)

3. Vermijding (van het leren over en gebruiken van computers)

4. Negatieve impact (van computers op de maatschappij)

5. Productiviteit (invloed van computers op de productiviteit)

De schaal 'e-mail' uit de oorspronkelijke TAC wordt niet gebruikt omdat e-mail inmiddels zeer sterk is ingeburgerd in de maatschappij. De vragen in de schaal zijn daardoor minder relevant geworden. Evenals in de oorspronkelijke TAC wordt gebruik gemaakt van een 5-punts Likert schaal: helemaal oneens - oneens neutraal - eens - helemaal eens. Voorafgaand aan de statistische bewerking zijn negatief geformuleerde items omgecodeerd. Per schaal is een score berekend.

\section{OSO Evaluatie vragenlijst}

In de OSO evaluatie vragenlijst wordt studenten gevraagd om een rapportcijfer toe te kennen aan de module. Verder worden er negen vragen gesteld over verschillende aspecten van de studie. Sommige van deze vragen zijn multiinterpretabel voor studenten door het hoge inferentie gehalte. Zo wordt bijvoorbeeld de volgende vraag gesteld: 'De docent ondersteunde mij bij het ontwikkelen van een onderzoekende houding'. De student moet hiervoor een duidelijk beeld hebben van de betekenis van een 'onderzoekende houding' en een 
beeld van hiermee in verband staand stimulerend docent gedrag. Er is dan ook gekozen om alleen de rapportcijfers voor de module mee te nemen in het onderzoek en niet de overige vragen.

\section{Woord en Ervaring}

In de eerste moduleperiode werden in digitale berichten veel negatieve gevoelens beschreven door studenten. Om deze reden is besloten een vragenlijst te ontwerpen om deze gevoelens te meten. Hiertoe is in de discussiebijdragen en in e-mails gezocht welke emoties studenten en docenten benoemden. Voorts is literatuurstudie gedaan om in kaart te brengen welke gevoelens vaak benoemd worden door e-learners. Een aantal items voor de vragenlijst werden ontleend aan het onderzoek van O'Regan (2003).

Er is gekozen voor een simpele opzet: 40 vaak genoemde emoties worden weergegeven in 1-3 woorden en gescoord op een 5-punts Likert schaal: nee! - nee - soms - ja - ja!. Op deze wijze geven studenten en docenten aan of zij de betreffende woorden vinden passen bij hun ervaringen in een bepaalde e-learning module. Via explorerende factor analyse en de berekening van Cronbach's alpha kon het aantal items uiteindelijk teruggebracht worden tot 24, onderverdeeld in vijf factoren. Om een beeld te krijgen of de resultaten specifiek waren voor elearners of meer passend bij OSO studenten in het algemeen is dit instrument ook afgenomen bij reguliere OSO studenten.

\section{Samenwerking met medestudenten}

Het instrument 'samenwerking met medestudenten' is een vertaling van de 'Classroom Community Scale' van Rovai (2002a). Het betreft een betrouwbaar en gevalideerd instrument dat in meerdere onderzoeken gebruikt is (o.m. Dawson, 2006; Dawson, 2008; Rovai, 2002b; Rovai \& Jordan, 2004; Shea, Sau Li \& Picket, 2006). Het oorspronkelijke instrument heeft twee subschalen: verbondenheid en leren. De verbondenheids schaal gaat over zaken als vertrouwen, samenwerking en persoonlijke contacten. De schaal over leren vraagt naar durf om dingen te vragen en uit te spreken in het groepje, feedback en samen leren. Omdat de items vertaald zijn moest opnieuw onderzoek gedaan worden naar de betrouwbaarheid van de schalen. Dit onderzoek en beoordeling van de inhoud van de items leidde ertoe dat er uiteindelijk drie inhoudelijk verschillende schalen werden samengesteld uit de twee oorspronkelijke schalen, waaraan twee nieuwe items waren toegevoegd. Deze nieuwe items maken deel uit van de schaal 'Aansluiting bij leerwensen'. 
De oorspronkelijke vragenlijst werkte met een 5-puntsschaal. Dit is in het huidige onderzoek teruggebracht tot een 3-puntsschaal die gemakkelijker is in te vullen. Dit was belangrijk omdat de studenten veel vragenlijsten te verwerken kregen. De 3-puntsschaal zag er als volgt uit: nee- gaat wel - ja. Aan het einde van de vragenlijst is een vraag toegevoegd waarin de studenten werd verzocht een rapportcijfer toe te kennen aan hun tevredenheid met de samenwerking met medestudenten.

\section{Begeleiding door de docent}

Het instrument 'Begeleiding door de docent' is gedeeltelijk gebaseerd op 'The online learning environment survey' (OLES) door Pearson en Trinidad (2006). Ook zijn er items opgenomen uit de 'web-based course evaluation' van Stewart, Hong en Strudler (2004).

Het huidige instrument bestaat uit schalen en items die passen bij de belangrijkste taken van de e-learning docent zoals die in het ontwerp zijn weergegeven: planning, communicatie, moderatie en feedback. Deze worden gemeten met een 3-puntsschaal: nee- gaat wel - ja, met uitzondering van de items die gaan over de termijn van reageren door de docent. Aan het einde van de vragenlijst wordt gevraagd om in een cijfer de algemene tevredenheid over het gedrag van de online docent weer te geven.

\section{Vraagsturing}

Dit instrument betreft een zelfgeconstrueerde schaal met drie items. Deze worden gemeten met een 3-puntsschaal: nee- gaat wel - ja. Met behulp van de items wordt nagegaan of de studenten de inhoud van de modules en de eindopdrachten kunnen beïnvloeden op basis van hun individuele leerwensen.

\section{Leerzaamheid van de onderdelen van de e-learning module}

In deze vragenlijst zijn de verschillende elementen van Blackboard modules opgenomen die geconstrueerd zijn om kennisoverdracht en kennisconstructie te bewerkstellingen bij e-learning studenten. Voorbeelden hiervan zijn: gesproken powerpoints, filmpjes en discussies. De studenten wordt gevraagd deze items te beoordelen met een rapportcijfer voor de mate van leerzaamheid. Onder 'leerzaamheid' wordt verstaan: de mate waarin de student meent dat hij of zij leert van een bepaald moduleaspect. Ook wordt de algehele leerzaamheid van de Blackboard module beoordeeld met een rapportcijfer. 


\section{Organisatie van de e-learning}

In deze vragenlijst worden vragen gesteld over de organisatorische kenmerken van de Blackboard modules. De vragenlijst bevat items en schalen. Drie items zijn vertaald uit de 'e-Learning Experience Questionnaire'(Ginns \& Ellis, 2007). Eén item is afgeleid van het E-learning Maturity Model (Marshall, 2006). In het laatste item van de vragenlijst kennen de studenten een rapportcijfer toe aan de organisatie van de e-learning.

\section{Data-analyse vragenlijsten}

Alle analyses hebben altijd plaatsgevonden per moduleperiode om te voorkomen dat dezelfde personen meerdere keren voorkwamen in één dataset. In de meeste gevallen wordt er ook afzonderlijk geanalyseerd per cohort.

Per moduleperiode en per cohort zijn gemiddeldes en standaarddeviaties berekend. Als er tussen de moduleperiodes van één van de cohorten verschillen zichtbaar waren, is met variantie analyse voor herhaalde metingen nagegaan of deze significant waren. Er is gecorrigeerd met de conservatieve GreenhouseGeisser correctie of met MANOVA als Mauchly's test significant bleek. Mauchly's test is echter niet robuust bij een kleine N (Field, 2009, p. 460). Om die reden is ook de waarde van epsilon betrokken bij de beslissing om al dan niet te corrigeren. Als deze waarde laag was (dichter bij de lower bound dan bij 1) werd toch gecorrigeerd ondanks een niet significante test van Mauchly. Daar waar significante verschillen werden gevonden tussen de moduleperiodes werd post hoc analyse toegepast. Daarbij werden alleen de verschillen tussen de opeenvolgende moduleperiodes bekeken om het aantal analyses niet te groot te maken. Verschillen tussen de twee cohorten werden geanalyseerd met behulp van de $t$-toets voor onafhankelijke metingen.

Waar significante verschillen gevonden in de post hoc tests werden zijn effectgroottes $r$ of $\eta_{p}{ }^{2}$ berekend. Om de relevantie van een gevonden significant verschil te beoordelen, werd gebruik gemaakt van de volgende criteria (Field, 2009, p.57):

- $\quad$ een klein effect, $r=0,10, \eta_{p}^{2}=0,01$ (1\% verklaarde variantie)

- $\quad$ een middelmatig effect, $r=0,30, \eta_{p}^{2}=0,09$ (9\% verklaarde variantie)

- $\quad$ een groot effect $r=0,50, \eta_{p}^{2}=0,25$ (25\% verklaarde variantie)

In het onderzoek zijn twee items gebruikt op ordinaal niveau, voor deze items is gebruik gemaakt van non-parametrische toetsing om na te gaan of er verschillen waren tussen de verschillende moduleperiodes. 
Om verbanden na te gaan werden Pearson correlaties berekend voor interval variabelen. Voor ordinale variabelen werd Kendall's tau berekend. Daar waar sprake was van verbanden met een dichotome variabele zonder onderliggend continuüm is gebruik gemaakt van punt biseriële correlaties. 


\section{HoOFDSTUK 3 \\ Het ontwerp van de e-learning opleidingen}

\section{INLEIDING}

Eind 2005 produceerde het kleine e-learning projectteam een ruw ontwerp als basis voor vier inhoudelijk verwante e-learning leerroutes. Dit eerste ontwerp werd gemaakt naar aanleiding van een beperkte literatuurstudie, ervaringen met asynchrone discussies en gesprekken met collega's van afstandsleren bij de lerarenopleiding van Windesheim. Het oorspronkelijke ontwerp wordt aangemerkt als 'ruw' omdat een formele literatuurstudie ontbrak.

Uitgangspunten voor het ruwe ontwerp waren een aantal randvoorwaarden en doelen vanuit de context van de OSO opleidingen. In paragraaf 3.1 wordt deze context beschreven op basis van de onderzoeksvraag: 'welke doelen en randvoorwaarden vanuit de bestaande opleiding zijn van belang voor het ontwerp?' In Paragraaf 3.2 is aan de orde hoe het ruwe ontwerp tot stand gekomen is. Het ruwe ontwerp behelst vier clusters van ontwerpelementen specifiek voor e-learning: interactie tussen studenten, e-learning structuur, docentrol en leermaterialen. Deze clusters worden beschreven in paragraaf 3.3. waarin het ontwerp ook gevalideerd wordt op grond van de literatuur. De volgende onderzoeksvraag staat daar centraal: 'kunnen de kenmerken van het oorspronkelijke ruwe ontwerp bevestigd, aangescherpt of verworpen worden vanuit recente wetenschappelijke inzichten?' In paragraaf 3.4 wordt op basis van de beschreven kenmerken een samenvattend beeld geschetst van het ontwerp.

Het omzetten van het ruwe ontwerp naar een eerste complete pilot module bleek niet eenvoudig. In juni 2006 werd een eerste incomplete module opgeleverd. In december 2006 volgde de tweede module, deze werd compleet opgeleverd. Om een beeld te krijgen van de geschiktheid en bruikbaarheid van het ruwe ontwerp en om verbeteradviezen te krijgen voorafgaand aan een pilot met studenten 
volgde eind 2006 een expert raadpleging. Hierbij werden het ruwe ontwerp en de eerste complete module voorgelegd aan twee experts uit Nederland en één uit België. De onderzoeksvraag luidde 'Kunnen de kenmerken van het ontwerp bevestigd, aangescherpt of verworpen worden vanuit de kennis en ervaring van experts in het vakgebied?' De resultaten van deze expert raadpleging worden beschreven in paragraaf 3.5.

\subsection{DOELEN EN RANDVOORWAARDEN TEN AANZIEN VAN HET ONTWERP}

Windesheim OSO is een geaccrediteerde opleiding tot professionele master Special Educational Needs. Deze professionele masteropleiding is een competentiegerichte deeltijdopleiding van twee jaar met een studiebelasting van twintig uur per week. De opleiding kent zeventien verschillende leerroutes, waaronder de leerroute 'Dyslexie' en de leerroute 'Remediëren' die worden omgezet naar e-learning. Van ieder van deze twee leerroutes bestaan twee varianten: één voor primair onderwijs en één voor voortgezet onderwijs. Voor beide leerroutes zullen beide varianten worden omgezet naar e-learning.

In de leerroutes Dyslexie en Remediëren zijn de meeste modules gericht op orthodidactische competenties. Zo zijn er bijvoorbeeld modules met betrekking tot de orthodidactiek van aanvankelijk lezen, - voortgezet lezen, - aanvankelijk rekenen en - voortgezet rekenen. De vier leerroutes Dyslexie PO en VO, Remediëren $\mathrm{PO}$ en $\mathrm{VO}$ hebben een onderscheiden programma maar kennen ook een aanzienlijke overlap in modules.

Een HBO diploma is voorwaarde voor toelating tot de leerroutes. De meeste studenten zijn werkzaam in het onderwijs. Hun motivatie om te starten met een leerroute komt vaak voort uit de wens om effectiever te gaan werken met leerlingen met leer- en / of gedragsproblemen. Ook carrière overwegingen en de behoefte het eigen handelen beter te funderen spelen bij de opleidingskeuze.

De leerroutes Dyslexie en Remediëren worden aangeboden in de vier lesplaatsen van OSO Windesheim: Zwolle, Hoofddorp, Utrecht en Leeuwarden. De leerroutes hebben een landelijke aantrekkingskracht die niet afdoende gedekt wordt door de huidige vier lesplaatsen. Reistijden blijken vaak een belangrijk criterium te vormen voor de keuze van een opleiding. De studenten zijn vaak mensen voor 
wie de balans tussen gezin, werk, activiteiten en studie een voortdurende uitdaging is. Een forse reistijd kan die balans in gevaar brengen. De opleiding wilde haar aantrekkelijkheid voor deze studenten verhogen door te starten met een e-learning variant. De leiding van OSO formuleerde doelen en randvoorwaarden in het projectplan 'Deelproject digitalisering en e-learning 2005 -2006' (OSO Windesheim, juni 2005).

De doelen op korte termijn luiden als volgt:

- uitbreiding van studenten aantallen: voor het studiejaar 2006-2007 schrijven zich 30 e-learning studenten in

- studierendement: de studieresultaten zijn vergelijkbaar met reguliere O.S.O. opleidingen en de uitval is niet hoger dan in de reguliere O.S.O. opleidingen

- tevredenheid: de studenten waarderen de e-learning modules met een rapportcijfer $\geq 7$

Op langere termijn:

- er ontstaat mogelijkheid tot flexibilisering en individualisering in het aanbod van leerarrangementen

In het projectplan waren een aantal randvoorwaarden gesteld. Zo moest het ontwerp voldoen aan de uitgangspunten zoals gesteld in het opleidings- en toetskader van OSO Windesheim. Dit betekende dat het moest aansluiten bij het bestaande onderwijsconcept. Voorts moest een aantrekkelijke en studeerbare leeromgeving tot stand komen waarin voldaan wordt aan de leerwensen van studenten. De inhoud en de kwaliteit van het onderwijs in het e-learning platform moesten aansluiten bij de inhoud en de kwaliteit van de bestaande opleiding en mochten de bestaande accreditatie niet in gevaar brengen. Er moest draagvlak zijn voor de onderwijskundige visie ten aanzien van e-learning bij het management team, de regio coördinatoren, de veldadviesraad en de medewerkers. De uitvoering van het ontwerp moest betaalbaar en organiseerbaar zijn.

Het was de bedoeling om de bestaande reguliere modules van de leerroutes Dyslexie en Remediëren aan te passen voor e-learning. De module inhouden en de ( eind) opdrachten zouden hetzelfde blijven als in de reguliere modules. Waar nodig zouden aanpassingen gemaakt worden om e-learning mogelijk te maken. De doelen en randvoorwaarden die gesteld werden voor e-learning bij de start van de projectgroep in 2005 worden schematisch weergegeven in tabel 3.1. 
Tabel 3.1 Doelen en randvoorwaarden voor e-learning

\begin{tabular}{|c|c|c|c|}
\hline & Voor studenten & Voor docenten & Voor de opleiding/het MT \\
\hline ORGANISATIE & Studeerbaar & $\begin{array}{l}\text { Zij zijn op de hoogte } \\
\text { van hun taken }\end{array}$ & $\begin{array}{l}\text { Betaalbaar } \\
\text { Organiseerbaar }\end{array}$ \\
\hline LEEROMGEVING & $\begin{array}{l}\text { Aantrekkelijk } \\
\text { Voldoet aan } \\
\text { leerwensen } \\
\text { Langere } \\
\text { termijn: } \\
\text { flexibilisering } \\
\text { leerroutes }\end{array}$ & $\begin{array}{l}\text { Zij staan achter de } \\
\text { onderwijskundige visie } \\
\text { ten aanzien van e- } \\
\text { learning }\end{array}$ & $\begin{array}{l}\text { Aansluiting bij het } \\
\text { bestaande } \\
\text { onderwijsconcept } \\
\text { Aansluiten bij de reguliere } \\
\text { modules } \\
\text { Inhoud en kwaliteit } \\
\text { gelijkwaardig aan } \\
\text { reguliere opleiding } \\
\text { (accrediteerbaar) } \\
\text { De onderwijskundige visie } \\
\text { ten aanzien van e-learning } \\
\text { wordt OSO-breed } \\
\text { gedragen }\end{array}$ \\
\hline RENDEMENT & $\begin{array}{l}\text { Studie } \\
\text { resultaten en } \\
\text { studietempo } \\
\text { vergelijkbaar } \\
\text { met reguliere } \\
\text { leerroutes }\end{array}$ & & $\begin{array}{l}\text { Uitbreiding studenten } \\
\text { aantallen } \\
\text { Percentage afstudeerders } \\
\text { vergelijkbaar met reguliere } \\
\text { leerroutes }\end{array}$ \\
\hline
\end{tabular}

Bij beschouwing van dit schematische overzicht valt op dat er anvankelijk relatief weinig doelen en randvoorwaarden gesteld werden met betrekking tot de docenten die e-learning moesten gaan uitvoeren. Een belangrijke randvoorwaarde voor de e-learning leeromgeving was de aansluiting op het bestaande onderwijsconcept en op de reguliere modules. In de hierna volgende paragrafen worden de consequenties hiervan toegelicht.

\subsubsection{Het opleidingsconcept}

Centraal uitgangspunt voor het ontwerp van de e-learning leerroutes Remediëren en Dyslexie vormt het opleidingsconcept zoals beschreven in het Opleidings- en toetskader (Harinck, Smits, \& van der Bruggen, 2005). Dit opleidings- en toetskader is het uitgangsdocument voor alle leerroutes die vallen onder de OSO master Special Educational Needs. De volgende principes spelen hierin een belangrijke rol: sociaal-constructivisme, competentie-ontwikkeling, authentiek leren, autonoom leren, vraagsturing en het masterniveau. Centraal staat een sociaal constructivistische benadering om tot competentie-ontwikkeling te komen. Sociaal-constructivisme kent zijn grondvesten in het werk van Piaget (zie Piaget 
en Inhelder, 1969, 2000), Vygotsky (1978), Bruner (1990) en duidt op het actief en betekenisvol leren van studenten die binnen een rijke leeromgeving gezamenlijk kennis construeren en koppelen aan bestaande kennisbestanden (Schunk, 2008). Met 'competentie-ontwikkeling' wordt bedoeld dat het niet alleen gaat om de constructie van kennis, maar om een geïntegreerd geheel van kennis, vaardigheden en attitudes met behulp waarvan de professional adequaat kan functioneren in de beroepspraktijk (Cluitmans, Dekkers, \& van Oeffelt, 2002; WOSO, 2004). Authentiek leren duidt op het gebruik van authentieke beroepstaken binnen de opleiding, zowel in verband met kennisconstructie als op het moment van toetsing. Autonoom leren en vraagsturing betekenen dat de student ten dele richting kan geven aan zijn eigen leerproces, dit in aansluiting op zijn praktijkervaring en zijn leerwensen. In de opleidingsstructuur wordt expliciet aandacht geschonken aan de persoonlijke professionele ontwikkeling van de student. Dit is uitgewerkt in de 'Handleiding begeleiding' van de opleiding. Deze handleiding zal ook binnen e-learning gevolgd worden. OSO Windesheim is medio 2006 geaccrediteerd op grond van de Dublin descriptoren (NVAO, 2003). Dit betekent onder meer dat er eisen zijn met betrekking tot het theoretisch niveau van de opleiding, het centraal stellen van praktijkonderzoek en de internationale oriëntatie binnen de opleiding.

\subsubsection{De uitwerking van het onderwijsconcept in de reguliere modules}

Een tweede belangrijk uitgangspunt voor het e-learning ontwerp wordt gevormd door de bestaande modules. Deze zijn ontworpen op basis van het beschreven opleidingsconcept. Ze zijn geschreven binnen een daartoe vastgesteld format. De e-learning modules zullen deze bestaande modules en het bestaande format volgen waar dat mogelijk is. In ieder geval worden de leerdoelen, de onderwerpen, de literatuur en de eindopdracht gehandhaafd.

Bij een nadere beschouwing van de modules die de concrete uitwerking vormen van de OSO Windesheim onderwijsconcepten valt op dat er in de aanpak sprake is van een balans tussen verschillende onderwijsvisies. In de bestaande OSO modules speelt kennisoverdracht een duidelijke rol, zij het dat de overgedragen kennis via interactieve werkvormen snel gekoppeld wordt aan authentieke beroepssituaties. Ook training van vaardigheden speelt een rol, waarna deze vaardigheden worden toegepast in de eigen praktijksituatie. Een aantal van deze vaardigheden zijn al van te voren gedefinieerd en worden dus eerder gereconstrueerd door de student, dan (sociaal) geconstrueerd. Deze constatering 
over de didactiek in reguliere OSO modules betekent voor de e-learning modules dat er eveneens gezocht zal worden naar een balans tussen kennisoverdracht en reconstructie, gezamenlijke kennisconstructie en training.

\subsection{HET RUWE ONTWERP: ONTSTAANSWIJZE}

In het projectplan e-learning waren de uren en de termijn om het ruwe ontwerp tot stand te brengen krap begroot. Het aantal uren dat voor het ontwerp beschikbaar was bedroeg ongeveer 40. De termijn waarbinnen het tot stand moest komen was twee maanden. In september 2005 werd een start gemaakt met het ruwe ontwerp door de projectgroep e-learning die op dat moment uit twee leden bestond. Zij formuleerden een aantal uitgangsprincipes voor het ruwe ontwerp (Smits \& Logtenberg, 2005). Deze uitgangsprincipes worden weergegeven in tabel 3.2.

\section{Tabel 3.2 Uitgangsprincipes voor het ruwe ontwerp}

Het opleidingsconcept is hetzelfde als in het Opleidings en Toetskader (Harinck et al., 2005):

- Sociaal-constructivisme; dit is sterker te verwerkelijken binnen de elektronische leeromgeving (discussionboard en chat) waar meer gelijkheid ontstaat in de inbreng van docenten en studenten.

- Praktijknabij; studenten worden beoordeeld op authentieke beroepstaken

- Vraagsturing; dit wordt vooral verwezenlijkt door studenten hun eigen richting te laten bepalen binnen de module en de eindopdracht. Zo kunnen zij in aansluiting op hun eigen praktijkervaring een leerproces vormgeven dat hen daadwerkelijk een stap verder helpt in hun functioneren.

- Competentiegericht; het gaat in de opleiding niet om louter kennisoverdracht óf om louter vaardigheidstraining, maar om de integratie van kennisoverdracht, kennisconstructie en competentiegroei.

- Zelfverantwoordelijk leren; dit is sterker het uitgangspunt dan in de meer traditionele leeromgeving.

\section{Specifiek voor het afstandsleren via Blackboard ligt er bovendien nadruk op:}

- Samenwerken aan (discussie) opdrachten en elkaar binnen opdrachten ondersteunen en feedback geven staan centraal. Samenwerking en behulpzaamheid worden positief beoordeeld (maken deel uit van het beoordelingssysteem met betrekking tot discussies).

- Een gemeenschappelijke start, alleen dan is het groepsproces en de verdiepende communicatie in asynchrone en synchrone discussies mogelijk.

- 'Keep them going': studeerbaarheid en betrokkenheid. De leeromgeving maakt de student tot een betrokken leerder met duidelijke voortgang en mijlpalen in zijn leerproces. Er wordt een duidelijke planning gemaakt in de tijd om te zorgen dat de student blijft doorstuderen ondanks het feit dat hij niet de druk van wekelijkse colleges ondervindt. 
Deze uitgangsprincipes waren gestoeld op de projectopdracht, maar werden ook bepaald door eerdere ervaringen en aanwezige kennis van de projectleden. De projectleden werkten beiden al langere tijd voor Windesheim OSO en waren eerder als een projectteam betrokken geweest bij de implementatie van Blackboard in de afdeling. De praktische ervaring van de projectgroepleden lag bij aanvang van het project op het vlak van Blackboard inrichting, implementatieprocessen en moderatie van online discussies. De kennisontwikkeling van de projectgroep op het vlak van e-learning werd bij aanvang van het project vooral bepaald door de inhoud van vier boeken. Bij de keus van deze boeken speelden eerdere ervaringen met online discussies een rol. Het betrof de volgende titels:

- 'Facilitating online learning. Effective strategies for moderators.' (Collison, Elbaum, Haavind, \& Tinker, 2000)

- 'Discussion based online teaching to enhance student learning. Theory, practice and assessment.' (Bender, 2003)

- 'Learner centered theory and practice in distance education. Cases from higher education.' (Duffy \& Kirkley, 2004b)

- 'Learning together online. Research on asynchronous learning networks.' (Hiltz \& Goldman, 2005a)

Het boek van Collison et al. (2000) bevat een gedetailleerde beschrijving van de concrete aspecten van docentgedrag met betrekking tot moderatie. De docent wordt gepositioneerd als 'guide on the side' met een arsenaal aan interventies die studentdiscussies kunnen verrijken en verdiepen. Studenten construeren gezamenlijk betekenis, de docent heeft daarbij een decentrale rol. In het schooljaar 2004-2005 deden de projectgroepleden ervaring op met deze werkwijze. Op grond van deze ervaringen zagen zij goede mogelijkheden om deze werkvorm in te zetten bij e-learning, hoewel het niet altijd eenvoudig bleek te zijn om zowel studenten als docenten actief bij discussies te betrekken.

De boeken van Bender (2003) en Duffy en Kirkley (2004b) hielpen om een concreter beeld te krijgen van e-learning. Beide boeken vormen een neerslag van ervaringen met bestaande e-learning opleidingen. Bender (2003) formuleert concrete handvatten voor docenten. Duffy en Kirkley (2004b) zijn vooral georiënteerd op de relatie tussen onderwijsconcepten, onderwijsontwerp en de concrete uitwerking en effecten daarvan in de e-learning praktijk in het hoger onderwijs. In verschillende bijdrages wordt niet geschuwd naast successen ook 
praktische problemen en mislukkingen te beschrijven. Dit maakte dat de projectgroep in een aantal gevallen tot veiliger keuzes kon komen ten aanzien van ontwerpkenmerken. Hiltz en Goldman (2005a) beschrijven effectonderzoek naar verschillende aspecten van e-learning opleidingen die interactie tussen studenten als centraal uitgangspunt hebben.

Nadat de uitgangsprincipes van OSO e-learning geformuleerd waren, volgde het literatuuronderzoek dat deel uit maakt van het huidige onderzoek. Hiervan wordt verslag gedaan in paragraaf 3.3. Daarnaast interviewden de twee projectleden drie betrokkenen bij het afstandsleren van de Windesheim lerarenopleiding. Deze vorm van afstandsleren bestond op dat moment uit een combinatie van schriftelijke bronnen en zaterdagonderwijs. De projectleden spraken met de decaan, de leidinggevende en met de coördinator van het ICT Ondersteuningsteam (ICTO) van de School of Education. Het resultaat van de gesprekken werd schriftelijk vastgelegd zodat de leidinggevenden van OSO dit konden gebruiken bij de besluitvorming over het ontwerp van de projectgroep.

Doel van de interviews was om gebruik te maken van de ervaringen van Windesheim collega's met afstandsleren. De gesprekken dienden om het ontwerp te toetsen, om mogelijke risico's in het ontwerp te identificeren en om advies te verkrijgen over een aantal deelaspecten. Het gesprek met de decaan had de belangen van de toekomstige e-learning studenten als voornaamste onderwerp. Uit de gesprekken kwamen de volgende aandachtspunten:

\section{Betaalbaarheid}

- houd zoveel mogelijk aspecten van e-learning in eigen hand: laat eigen docenten ontwikkelen, regel zelf de public relations en gebruik een e-learning platform dat Windesheim zelf op de server heeft (Blackboard)

\section{Organiseerbaarheid}

- bij voorkeur één opstartmoment per jaar, maximaal twee. Zowel de administratieve systemen als de financieringssystematiek van de hogeschool zijn niet ingesteld op meerdere inschrijfmomenten per jaar

- groei niet te snel, begin klein: een start met twee groepen van niet meer 15 studenten is verstandig. De wijze van 'selecteren' dient goed gecommuniceerd te worden naar de doelgroep 


\section{Studeerbaarheid}

- zorg dat de opleiding studeerbaar is

- maak strakke afspraken met studenten over studievoortgang en gebruik een goed systeem voor de monitoring van deze afspraken

\section{Studentbegeleiding}

- doe een goede intake waarin extra voorwaarden (bijvoorbeeld op het vlak van ict) voor toelating helder aan de orde komen

- de noodzaak voor een evenwichtige verhouding tussen de inzet van docentformatie voor e-learning enerzijds en regulier onderwijs anderzijds: afstandsleerders hebben recht op dezelfde hoeveelheid begeleiding als reguliere studenten

- goede communicatie met studenten op afstand is essentieel, doe dit zowel via internet als via een wekelijks telefonisch spreekuur

- de taak van de studiecoach lijkt belangrijker dan in de reguliere opleiding; studenten op afstand hebben meer begeleiding nodig

- zwakke communicatie leidt tot veel werk op het vlak van klachtafhandeling

- geef vlotte feedback op opdrachten, doe dit sneller dan in de reguliere opleiding

- het Onderwijs Examen Reglement moet aangepast zijn aan e-learning en helder gecommuniceerd worden

\section{Onderwijsconcept}

- hanteer specifieke didactische concepten voor e-learning; alle gesprekspartners reageren positief op de plannen om online discussies en samenwerkingsopdrachten tot centrale werkvormen te maken

- maak vraagsturing mogelijk

Na deze gesprekken kreeg het ruwe ontwerp zijn definitieve vorm (Smits, 2005). In de loop van dit proces werden vier clusters van ontwerpelementen geïdentificeerd specifiek voor de e-learning opleidingen van Windesheim OSO. Deze zullen hieronder nader uitgewerkt en gevalideerd worden.

In de literatuur die geraadpleegd werd bij de start van het ontwerpproces, was achteraf gezien sprake van een oververtegenwoordiging van één van de ontwerpclusters te weten 'interactie tussen studenten'. De andere clusters kwamen beduidend minder aan de orde. Het cluster 'leermaterialen' kreeg duidelijk het minste aandacht. 


\subsection{HET E-LEARNING ONTWERP: VIER CLUSTERS VAN ONTWERPELEMENTEN}

In het oorspronkelijke ruwe ontwerp werden vier aan elkaar gerelateerde clusters van ontwerpkenmerken onderscheiden die kenmerkend zijn voor de e-learning omgeving: interactie tussen studenten, structuur, docentrol en leermaterialen. Hieronder wordt het oorspronkelijke ruwe ontwerp kritisch belicht op basis van literatuurstudie. De centrale vraag is: 'kunnen de kenmerken van het oorspronkelijke ruwe ontwerp bevestigd, aangescherpt of verworpen worden vanuit recente wetenschappelijke inzichten?' Per ontwerpcluster worden de afzonderlijke kenmerken gedefinieerd. Per kenmerk worden voordelen en nadelen beschreven zoals deze blijken uit de literatuur. Aan de hand daarvan worden de keuzes in het OSO e-learning ontwerp onderbouwd. Daarna worden procedures beschreven met betrekking tot de praktische uitvoering van het ontwerp. Tot slot worden de kernargumenten voor de opname van de betreffende kenmerken in het ontwerp schematisch samengevat. Hiertoe wordt gewerkt met vijf kernargumenten die aansluiten op de hierboven beschreven doelen en randvoorwaarden en ook op de aandachtspunten van de collega's van afstandsleren. Deze kernargumenten hebben ook een directe relatie met de onderzoeksvragen in dit onderzoek. De kernargumenten worden weergegeven in tabel 3.3.

Tabel 3.3 Kernargumenten voor de opname van specifieke ontwerpkenmerken

\begin{tabular}{|c|c|c|c|c|}
\hline $\begin{array}{l}\text { A } \\
\text { Meerwaarde } \\
\text { voor het } \\
\text { leerproces }\end{array}$ & $\begin{array}{l}\text { B } \\
\text { Aansluiting bij } \\
\text { bestaand onder- } \\
\text { wijs concept }\end{array}$ & $\begin{array}{l}\text { C } \\
\text { Aantrekkelijk voor } \\
\text { studenten; draagt bij } \\
\text { aan tevredenheid }\end{array}$ & $\begin{array}{l}\text { D } \\
\text { Beschermt } \\
\text { tegen uitval }\end{array}$ & $\begin{array}{l}\text { E } \\
\text { Voorwaarde voor } \\
\text { samenwerkend } \\
\text { leren }\end{array}$ \\
\hline
\end{tabular}

\subsubsection{Interactie tussen studenten: definities, argumenten en procedures}

\section{Kenmerk 1: Samenwerkend leren via asynchrone schriftelijke discussies}

De definities van samenwerkend leren in de literatuur kennen dezelfde grote lijn, maar verschillen op detailniveau (Cohen, 1994; Dillenbourg, 1999; Gokhale, 1995; Lockhorst, 2004). Op grond van de hier aangehaalde definities wordt in het kader van het huidige onderzoek uitgegaan van de volgende definitie: Samenwerkend leren is het leren dat plaatsvindt wanneer studenten in groepjes of in tweetallen werken aan complexe leertaken die zo geformuleerd zijn dat de studenten elkaars unieke inbreng nodig hebben om een oplossing te kunnen construeren. Samenwerkend leren betekent hier niet taakverdelend leren en ook niet alleen maar het uitleggen van stof aan studenten met minder kennis, maar juist het samenwerken aan één probleemstelling waarbij het geheel (de oplossing) groter wordt dan de som van de delen. 
Samenwerkend leren via asynchrone schriftelijke discussies valt onder het onderzoeksgebied van de Asynchronous Learning Networks, en onder het overkoepelende gebied van Computer Supported Collaborative Learning (CSCL). Op basis van Hiltz en Goldman (2005b, p. 5-6) kan de asynchrone discussie als volgt gedefinieerd worden. Het is een online discussie die in de tijd niet synchroon verloopt. Participanten werken op de plek van hun keuze en hoeven niet tegelijkertijd online te zijn. Ze dragen wel bij binnen een bepaalde tijdsspanne. Hun bijdrages zijn schriftelijk en worden geleverd in een discussieruimte op een internet platform. De bijdrages blijven zichtbaar voor anderen gedurende de looptijd van de discussie. Asynchrone discussies zijn zowel een vorm van samenwerkend leren als een communicatie middel om andere soorten samenwerkingsopdrachten vorm te kunnen geven, zoals bijvoorbeeld groepsprojecten en peer feedback.

Het belangrijkste voordeel van samenwerkend leren ten opzichte van individueel leren is dat het leidt tot langere retentie van het geleerde en tot meer diepgang in denkprocessen en kritisch denken (o.m. Gokhale, 1995). Asynchrone discussie kan positief bijdragen aan leerprocessen omdat het dialoog en online samenwerking mogelijk maakt. In een asynchrone discussie vindt groepsgewijze exploratie, betekenisonderhandeling en reflectie plaats, met kennisconstructie als resultaat. Studenten hebben een actieve rol in het leerproces en leren niet alleen van de docent maar juist ook van elkaar (Coppola, Hiltz, \& Rotter, 2002; Harasim, 1990; Jonassen, Davidson, Collins, Campbell, \& Haag, 1995). Deze werkwijze is bij uitstek geschikt voor volwassen professionals die met elkaar oplossingen ontwerpen en bediscussiëren voor complexe praktijkproblemen (Brower, 2003).

De asynchroniciteit en het schriftelijk karakter van de communicatie hebben in theorie voor het leerproces bijzondere voordelen in vergelijking met face-to-face discussies. De asynchroniciteit leidt ertoe dat studenten langer na kunnen denken over hun bijdrages dan tijdens reguliere discussies (Hiltz \& Goldman, 2005b; Meyer, 2003). Zij kunnen bijdrages heroverwegen en reviseren hetgeen een positief effect kan hebben op de kwaliteit van de bijdrages. Deze bedenktijd kan ook voordelen hebben voor introverte studenten, die in de snelle communicatie in het gewone klaslokaal vaak te weinig aan bod komen (Harasim, 1990; Oblinger \& Maruyama, 1996; Pallof \& Pratt, 1999). Een bijzonder kenmerk van asynchrone discussies is ook dat de bijdrages zichtbaar blijven en dat er in een later stadium op teruggekomen kan worden. De online discussieruimtes hebben daarbij het voordeel dat er mogelijkheden zijn om discussies te organiseren en te doorzoeken 
(Polin, 2004). Voor een opleiding heeft geschreven taal het voordeel dat het bewuster wordt geproduceerd dan gesproken taal omdat het vergt dat de schrijver zijn eigen gedachten bewust expliciteert (Vygotsky, 1961). Schrijfactiviteiten leiden dan ook tot meer diepgang in het leerproces dan alleen lezen en bestuderen (Langer \& Applebee, 1987). Het gebruik van geschreven taal lijkt dan ook een voordeel voor hogere-orde denkprocessen (Garrison, Anderson, \& Archer, 2000).

Verschillende onderzoekers vroegen zich af of er werkelijk verschillen aan te tonen zijn tussen online- en face-to-face (f2f) discussies. Jonassen en Kwon (2001) vergeleken deze twee soorten discussies voor het oplossen van slecht gestructureerde praktijkproblemen. Asynchrone discussies leken in dit opzicht voordelen te hebben ten opzichte van f2f discussies omdat de inhoud van de berichten meer taakgericht en reflectief was. De sequentie van de berichten sloot bovendien goed aan bij het proces van probleem oplossen: probleem definitie, oriëntatie en het ontwikkelen van een oplossing. Heckman en Annabi (2005) vergeleken eveneens online discussies met $\mathrm{f} 2 \mathrm{f}$ discussies en kwamen op grond van inhoudsanalyses tot de conclusie dat er in de online discussies meer interactie plaatsvond tussen studenten onderling en dat er sprake was van meer hogereorde cognitieve activiteit. De gewone f2f discussies in dit onderzoek bevatten overwegend lagere-orde cognitieve activiteit, en bijna alle studentbijdragen in de gewone discussies waren antwoorden op een vraag van de docent. Interactie tussen studenten onderling kwam vrijwel niet voor. De metareview van Bernard et al. (2004) sloot aan bij deze bevindingen. De uitkomsten van afstandsleren via asynchrone communicatie bleken gemiddeld iets beter te zijn dan van regulier onderwijs, waarbij wel sprake bleek van een grote variabiliteit.

Analyses die alleen het geschreven materiaal van asynchrone discussies betroffen, bevestigen dat asynchrone discussies hogere-orde denkprocessen bevatten (Aviv, Erlich, Ravid, \& Geva, 2003; Gunawardena, Lowe, \& Anderson, 1997; Meyer, 2003; Schellens \& Valcke, 2005).

Verder kan asynchrone discussie ook aantrekkelijk zijn voor studenten met een druk bezet werk- en privé leven. Zij kunnen zelf bepalen wanneer een bijdrage geleverd wordt. Zij hoeven geen lessen te volgen op vaststaande tijdstippen en plaatsen (Hiltz \& Goldman, 2005b). Daarnaast zijn asynchrone discussies aantrekkelijk voor studenten omdat zij ervaren dat zij er veel van leren (Jonassen \& Kwon, 2001). Swan (2001) concludeert dat de tevredenheid van studenten toeneemt naarmate er meer asynchrone interactie plaatsvindt. Studenten ervaren 
positieve leereffecten van asynchroon samenwerkend leren (Marks, Sibley, \& Arbaugh, 2005; Rovai, 2002b). Daarnaast is het een voordeel dat dit type interactie het isolement kan verminderen dat online leerders kunnen ervaren (Arbaugh \& Benbunan-Fich, 2006; Moore, 1993). Dit zou kunnen leiden tot een vermindering van de uitval. Positief is ook de bevinding dat asynchrone interactie tussen studenten leidt tot studenttevredenheid (Swan, 2001).

Online samenwerkend leren kent echter ook problemen. De leeruitkomsten zijn niet altijd positief (Lou, Abrami, \& d'Appolonia, 2001) en de interactie leidt niet altijd tot hogere orde denk-processen (Oliver \& Omari, 2001). Ook vindt een gedeelte van de online studenten samenwerkend leren niet prettig (Bishop, 2002; Easton, 2003; Hawisher \& Pemberton, 1997; Swan, 2002). Het blijkt moeilijker om studenten tot samenwerking te laten komen in groepsprojecten, dan hen een leerzame asynchrone discussie te laten voeren (Haavind, 2006; Swan, 2002). Asynchrone discussies als werkvorm voor samenwerkend leren leidden in het onderzoek van Swan (2002) dan ook tot een betere leerervaring dan complexe groepsprojecten.

Asynchrone schriftelijke discussies kennen ook nadelen. In asynchrone discussies ontbreken non-verbale cues (Garrison, et al., 2000), waardoor onduidelijkheden kunnen ontstaan. Daarnaast kan de tijdsspanne die er zit tussen het leveren van een bijdrage en het krijgen van een reactie, gewenning vergen (Hiltz en Goldman, $2005 b)$. Een ernstig probleem dat meermaals beschreven wordt in de literatuur is het probleem van non- of onderparticipatie. Het is niet altijd eenvoudig gebleken om studenten met voldoende frequentie actief te laten deelnemen aan asynchrone discussies (Barab, Kling \& Gray, 2004; Islas, 2004; Polin, 2004; Voogt, Almekinders, van den Akker \& Moonen, 2005). De discussie bloedt dood als er niet voldoende frequente bijdrages zijn. Leereffecten kunnen dan niet of nauwelijks verwacht worden. Een ander probleem is dat cognitieve diepgang niet vanzelf ontstaat in discussies. Het lijkt nodig dat de docent hier een actieve rol in speelt (Garrison \& Cleveland-Innes, 2005). Samenwerkend leren, al dan niet online, komt niet vanzelfsprekend tot stand. Het is afhankelijk van de kwaliteit van een aantal factoren die de interactie structureren (o.m. Cohen, 1994; Dillenbourg, 1999). Zo noemt Cohen (1994) de volgende factoren: de aard van de taak, de taakinstructie, de voorbereiding van studenten op samenwerkend leren en de rol van de docent. Bij de start van een e-learning opleiding speelt de vraag naar de concrete uitwerking van dit soort factoren. Bij Dillenbourg (1999) treffen we een lijst met praktische vragen van docenten aan. Hij waarschuwt echter dat er geen eenduidige antwoorden op deze vragen zijn en dat complexe interacties 
tussen de verschillende uitwerkingen bepalend zijn voor het resultaat. De belangrijkste vragen bij de start van OSO e-learning waren de volgende: wat is de optimale groepsgrootte, welke soorten taken zijn geschikt en hoe kunnen studenten daarop voorbereid worden en hoe wordt de aansprakelijkheid geregeld; individueel of per groep?

Over de optimale groepsgrootte voor asynchrone discussies is de literatuur niet eenduidig. Aspecten die in deze discussie een rol spelen, zijn de mate van interactiviteit en leren, het risico van cognitieve overbelasting en de werkdruk van docenten (Burke, 2005). Vrasidas en McIsaac (1999) vonden in één module dat een groep van vier studenten te klein was om productief asynchroon te discussiëren. Schellens en Valcke (2006) vonden dat groepen van 8-10 studenten taakgerichter waren dan grotere groepen. Bovendien bereikten deze kleinere groepen vaker de hogere fases van kennisconstructie. Zij stellen dat cognitieve overbelasting ontstaat als groepen groter zijn dan 12 studenten. Swan et al. (2000) daarentegen noemen een optimale groepsgrootte van 11-20 studenten. Voor het huidige ontwerp betekenen deze bevindingen dat een groep groot genoeg $(>4)$ moet zijn om voldoende discussiebijdrages te genereren, en klein genoeg $(<13)$ om cognitieve overbelasting te vermijden.

Cohen (1994) concludeert in haar review dat slecht gestructureerde complexe problemen met meerdere mogelijke uitkomsten bij uitstek geschikt zijn voor samenwerkend leren omdat de groepsleden elkaar nodig hebben om tot een antwoord te komen. Dit betekent dat authentieke en complexe praktijkproblemen geschikt materiaal zijn voor samenwerkend leren (zie o.m. Kirschner, Strijbos, Kreijns, \& Beers, 2004; Schellens \& Valcke, 2005). Er bestaat een veelheid van werkvormen die gehanteerd kunnen worden om samen te werken aan dit soort problemen. In het kader van online leren is verreweg het meeste onderzoek gedaan naar de asynchrone discussie als werkvorm. Naar de effectiviteit van andere werkvormen is veel minder onderzoek gedaan (Jonassen, Lee, Yang, \& Laffey, 2005). Voorbeelden van andere werkvormen zijn: seminars met presentatie en discussie, peer feedback, debat, simulaties, rollenspel en projecten waarin gezamenlijk een product gecreëerd wordt. Zo kunnen studenten gezamenlijk werken aan een casusbeschrijving, aan een onderzoeksinstrument, of samen tentamenvragen formuleren (Benbunan-Fich \& Hiltz, 2003). Andere auteurs noemen in dit verband ook gaming (Cronjé, Adendorff, Meyer, \& van Ryneveld, 2006). Interactie en ruimte voor onderhandeling zijn in al deze werkvormen 
essentieel om tot samenwerkend leren te komen (zie Dillenbourg, 1999). Dit betekent dat discussie altijd deel zal uitmaken van dergelijke werkvormen. Voor het OSO e-learning ontwerp is besloten om de asynchrone discussie centraal te stellen als samenwerkingsvorm, maar om ook ter afwisseling in beperkte mate andere werkvormen voor samenwerkend leren in te zetten: gezamenlijk werken aan een product, peer feedback en rollenspel. Daarnaast zal er een speciale discussieruimte geopend worden voor intervisie bij werkproblemen en peer consultancy. Deze werkvorm is ontleend aan Polin (2004).

Uit de literatuur blijkt dat het van belang is om studenten goed voor te bereiden op samenwerkend leren en hen ook te begeleiden daarbij (o.m. Cohen, 1994; Kreijns, 2004). Het is van belang om duidelijk te maken wat er van de discussie en van het eventuele product verwacht wordt en om dit te monitoren en waar nodig bij te sturen. Dit betekent voor het huidige ontwerp dat de kwaliteit van de samenwerking afhankelijk is van elementen uit de ontwerpclusters 'structuur' en 'docentrol'. Om studenten te motiveren om deel te nemen aan de groepsdiscussie is het daarnaast van belang om niet alleen de groepsfeedback te geven maar om ook het individu aansprakelijk te maken (Slavin, 1994; Kreijns, Kirschner, \& Jochems, 2003). In het huidige ontwerp is er op grond hiervan voor gekozen om per module de adequate deelname aan discussies tot voorwaarde te maken om het individuele eindwerkstuk te mogen inleveren. Wat onder adequate deelname wordt verstaan is omschreven met behulp van rubrics op basis van Pallof en Pratt (2003).

Samenvattend kan gezegd worden dat asynchroon samenwerkend leren zowel voor- als nadelen kent. De voordelen ten aanzien van het leerproces en ten aanzien van de aantrekkelijkheid voor studenten hebben geleid tot het opnemen van asynchrone samenwerking als een belangrijk kenmerk van het OSO elearning ontwerp. Om waar mogelijk te compenseren voor de genoemde nadelen zullen een aantal andere ontwerpkenmerken worden ingezet, deze worden later in dit hoofdstuk nader uitgewerkt. Ontwerpkenmerken uit het cluster 'structuur' worden ingezet om de participatie te stimuleren. Het stimuleren van hogere-orde cognitieve processen wordt besproken bij het ontwerpcluster 'docentrol' onder de noemer 'moderatie'.

\section{Kenmerk 2: Sociale interactie}

Garrison, Anderson en Archer presenteerden in 2000 hun invloedrijke model voor online hoger onderwijs: de 'Community of Inquiry', dit begrip zal hier verder 
vertaald worden als 'leergemeenschap'. In dit model is de basisaanname dat leren tot stand komt door de interactie van drie elementen: cognitieve aanwezigheid, sociale aanwezigheid en onderwijzende aanwezigheid. Waar in de literatuur over asynchrone netwerken en samenwerkend leren al uitgebreide aandacht was voor de cognitieve- en docerende aanwezigheid, onderscheidde dit model zich door het expliciet benoemen van de sociale aanwezigheid als één van de drie essentiële elementen van het online leren. Eerder was over het belang online sociale aanwezigheid al gepubliceerd door Gunawardena en Zittle (1997). Zij relateerden de sociale aanwezigheid aan de mate van online 'echtheid' van de persoon en aan de concepten van intimiteit en nabijheid. Zij maakten duidelijk dat sociale aanwezigheid online minder makkelijk te bereiken was door het ontbreken van non-verbale aspecten in de communicatie. Garrison, Anderson en Archer (2000) definieerden de sociale aanwezigheid als volgt: 'de vaardigheid om van de deelnemers om zichzelf sociaal en emotioneel in de leergemeenschap te projecteren waardoor zij zichzelf naar de andere deelnemers presenteren als 'echte mensen'. Opvallend is het gebrek aan normering in deze en andere definities van sociale aanwezigheid (Wise, Chang, Duffy, \& del Valle, 2004). Niet iedere vorm van online sociale 'echtheid' is bevorderlijk voor de leergemeenschap. Daarnaast gaat het in deze definitie eerder om presentatie dan om interactie. Om die reden is er voor gekozen om in dit onderzoek te werken met het begrip 'sociale interactie' en om de definitie van sociale interactie in het huidige onderzoek dichter te laten aansluiten bij het begrip 'directheid' (immediacy) van Wiener en Mehrabian (1968) waarnaar al langer uitgebreid onderzoek wordt gedaan. De in het huidige onderzoek gehanteerde definitie van sociale interactie is gebaseerd op definities van sociale aanwezigheid, interactie en directheid (Anderson, 2003; Garrison, Anderson, \& Archer, 2000; Gunawardena \& Zittle, 1997; Yacci, 2000) en luidt als volgt: sociale interactie is het wederkerig gebruik van sociale en emotionele uitingen die er op gericht zijn om de psychologische afstand tussen de deelnemers te verminderen, het gevoel van onderlinge veiligheid te vergroten en de verbondenheid tussen de deelnemers te versterken. In de literatuur worden vele voorbeelden genoemd van het gebruik van sociale en emotionele uitingen tussen online studenten (Beuchot \& Bullen, 2005; Conaway, Easton, \& Schmidt, 2005; Garrison et al., 2000; Gokhale, 1995; Jeong, 2006; O'Sullivan, Hunt, \& Lipert, 2004; Rourke, Anderson, Garrison, \& Archer, 2001): het uitdrukken van emoties, al dan niet met behulp van emoticons en acroniemen, het gebruik van humor, het geven van persoonlijke informatie, het gebruik van informele taal, het gebruik van namen en persoonlijke voornaamwoorden, het erkennen en waarderen van de bijdrages van anderen, het uitdrukken van begrip 
voor de problemen van anderen, het bieden van ondersteuning en het complimenteren en aanmoedigen van anderen.

Sociale interactie heeft zowel cognitieve als affectieve doelen (Garrison et al., 2000). Sociale interactie faciliteert het proces van gezamenlijk kritisch denken (Jeong, 2006) en wordt gezien als een essentiële component van samenwerkend leren (Gunawardena, Lowe, \& Anderson, 1997; Kreijns, Kirschner, \& Jochems, 2002). Sociale interactie hangt positief samen met de ervaring van studenten dat zij leren (Richardson \& Swan, 2003; Rovai, 2002b), hoewel er geen duidelijke samenhang met feitelijke leerresultaten wordt gevonden (Picciano, 2002; Hostetter \& Busch, 2006). Daarnaast vonden verschillende onderzoeken een positief verband van sociale interactie met studenttevredenheid (Gunawardena \& Zittle, 1997; Hostetter \& Busch, 2006; Richardson \& Swan, 2003; Russo \& Benson, 2005). Solidariteit en sociale ondersteuning kunnen een belangrijke rol kunnen spelen bij de preventie van uitval (Duffy \& Kirkley, 2004a; Rovai, 2002b; Tinto, 1997). Muilenburg en Berge (2005) vonden hiervoor enige bevestiging in hun onderzoek met vragenlijsten. Studenten die tevreden waren over de online sociale interactie spraken significant vaker de intentie uit om door te gaan met e-learning dan studenten die niet tevreden waren op dit punt.

Er kunnen ook problemen ontstaan binnen de online sociale interactie. Het ontbreken van non-verbale communicatiemiddelen betekent dat de communicatie minder beveiligd is. Er zijn geen non-verbale en contextuele cues om een rem te zetten op impulsieve uitingen van boosheid (Collins, 1992; Kiesler, Siegel, \& McGuire, 1984; Sproull \& Kiesler, 1986). Studenten kunnen ook gezamenlijk dit soort uitbarstingen genereren hetgeen bedreigend kan zijn voor docenten (Hiltz \& Wellman, 1997). Online boosheid is in principe blijvend zichtbaar voor iedereen waardoor er een extra bedreiging van uit gaat. In kleine groepen die gedurende langere tijd samenwerken komt het minder voor dan in grotere groepen die minder samenhang vertonen (Hiltz \& Wellman, 1997).

Sociale interactie in online leeromgevingen komt niet vanzelfsprekend tot stand (Kreijns et al., 2003), maar er moeten bewust maatregelen genomen worden om de sociale interactie tussen studenten te bevorderen. Kreijns et al. (2003) noemen de waarde van de niet taak gebonden context om de sociale interactie te bevorderen. $\mathrm{Tu}$ en McIsaac (2002) bevestigen dat het belangrijk is om de informele relaties tussen studenten te bevorderen. In het OSO e-learning ontwerp zijn hiertoe 
verschillende maatregelen genomen. Binnen dit e-learning ontwerp is gekozen voor een gemeenschappelijke startdag waarbij de studenten op de hogeschool fysiek met elkaar kennismaken als startpunt voor groepsvorming (Brower, 2003; Haythornthwaite, Kazmer, Robins, \& Shoemaker, 2000; Polin, 2004, Tisdell et al., 2004). Daarnaast worden er digitale kennismakingsactiviteiten gebruikt (Bender, 2003, p. 47-52, Salmon, 2004) en een discussieruimte die speciaal bedoeld is voor sociale uitwisseling (naar het model van de 'Water Cooler' van Collison et al., 2000 en de 'Virtual Lounge' van Bender, 2003). Daarnaast heeft de docent een belangrijke functie in het stimuleren van online sociaal gedrag (Aragon, 2003; Kreijns et al., 2003).

\section{Samenvattend: Interactie tussen studenten}

Tabel 3.4 geeft een samenvatting van de kenmerken en de kernargumenten met betrekking tot het cluster Interactie tussen studenten.

Tabel 3.4 Interactie tussen studenten: Kenmerken en kernargumenten

\begin{tabular}{|c|c|c|c|c|c|}
\hline \multirow[b]{2}{*}{ Kenmerken } & \multicolumn{5}{|c|}{ Kernargumenten } \\
\hline & $\begin{array}{c}\text { A } \\
\text { Meerwaarde } \\
\text { voor het } \\
\text { leerproces }\end{array}$ & $\begin{array}{c}\text { B } \\
\text { Aansluiting bij } \\
\text { bestaand } \\
\text { onderwijs } \\
\text { concept }\end{array}$ & $\begin{array}{c}\text { C } \\
\text { Aantrekkelijk } \\
\text { voor studenten; } \\
\text { draagt bij aan } \\
\text { tevredenheid }\end{array}$ & $\begin{array}{c}\text { D } \\
\text { Beschermt } \\
\text { tegen uitval }\end{array}$ & $\begin{array}{c}\text { E } \\
\text { Voorwaarde } \\
\text { voor samen- } \\
\text { werkend leren }\end{array}$ \\
\hline $\begin{array}{ll}\text { Samenwer- } \\
\text { kend leren via } \\
\text { asynchrone } \\
\text { discussies }\end{array}$ & $\mathbf{x}$ & $\mathbf{x}$ & $\mathbf{x}$ & $\mathbf{x}$ & \\
\hline 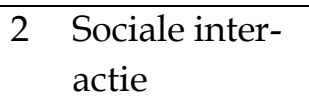 & $\mathbf{x}$ & & $\mathbf{x}$ & $\mathbf{x}$ & $\mathbf{x}$ \\
\hline
\end{tabular}

\subsubsection{E-learning structuur: definities, argumenten en procedures}

Kenmerk 3: Strakke planning

Strakke planning betekent in het huidige onderzoek het hanteren van een rooster met verplichte samenwerkingsopdrachten en deadlines, waardoor de activiteiten van de groepjes voor de hele moduleperiode naar tijdpad en inhoud gestructureerd worden rondom opdrachten tot samenwerkend leren en asynchrone discussie. Moore (1993) postuleerde in zijn theorie over transactionele afstand dat een sterke vastliggende structuur de transactionele afstand vergroot, terwijl interactie de transactionele afstand verkleint. In de literatuur over samenwerkend leren wordt echter duidelijk dat een heldere taakformulering en planning voorwaarden zijn om de 
gewenste hoeveelheid interactie en samenwerkend leren te genereren (Cohen, 1994; Dillenbourg, 1999). Ook in het model van de leergemeenschap van Garrison et al. (2000) wordt de nadruk gelegd op de organiserende rol, die als één van de drie hoofd aspecten van de docentrol gezien wordt. Bij het bouwen van online modules moeten proces, structuur, evaluatie en interactie helder geëxpliciteerd worden omdat in online modules niet gesteund kan worden op de aangeleerde verwachtingspatronen uit het reguliere klassikale onderwijs (Anderson, Rourke, Garrison, \& Archer, 2001), zo is er bijvoorbeeld geen klok in online klassen (Cohen \& Ellis, 2004). Een duidelijke structuur met verplichtingen, deadlines en beoordeling verhoogt de interactie en daarmee de samenwerking en het engagement (Aragon, 2003; Brower, 2003; Haavind, 2006; Vrasidas \& McIsaac, 1999). Uit het onderzoek van Dennen (2005) bleek dat het gebruik van deadlines niet alleen een duidelijk effect had op de mate van deelname aan de discussie maar ook op de inhoudelijke kwaliteit ervan. Hoe meer participatie, hoe kleiner de kans op uitval (Morris, Finnegan, \& Wu, 2005). Johnson en Howel (2005) vergeleken de tevredenheid en het gebruik van leermaterialen bij studenten met en zonder verplichting tot discussiëren. De verplichting tot discussiëren bleek te leiden tot een grotere tevredenheid en tot frequenter gebruik van leermaterialen.

Daarnaast bleek een strakke en duidelijke planning belangrijk om chaos en de daarbij behorende angst bij studenten en docenten te voorkomen (Easton, 2003). De beginnende studenten in het onderzoek van Conrad (2002) waardeerden dan ook de duidelijke tijdslijn die in de module geïmplementeerd was. De docenten in het onderzoek van Coppola, Hiltz en Rotter (2002) benadrukten dat het nodig is om online modules veel strakker te organiseren en te plannen dan gewone klassikale modules. Een strak rooster kan ook het time management van studenten ondersteunen en daardoor mogelijk de uitval van studenten beperken. Time management is in online leren immers een belangrijke succesfactor (Ludwig-Hardman, 2003; Song, Singleton, Hill, \& Koh, 2004).

In de literatuur worden ook nadelen van een te veel aan planning genoemd. Een voorbeeld daarvan is het te gedetailleerd voorschrijven van rollen in discussies waardoor de deelname aan de discussie verarmt door overmatige focus op de voorgeschreven rol (Cohen, 1994; Dillenbourg, 1999). Ook kunnen studenten te sterk gaan focussen op de 'beloning' en van daaruit niet meer doen dan strict noodzakelijk (Oliver \& Shaw, 2003). Een ander belangrijk nadeel kan zijn dat de planning te strak wordt aangehouden. Er bestaat dan te weinig flexibiliteit om 
aanpassingen te maken op grond van de leerwensen van de studenten. Een dergelijke opzet bevordert niet de autonomie en de motivatie van studenten (Reeve \& Jang, 2006). Het is dit type inflexibiliteit waar Moore (1993) op doelde. Als structuur in een opleiding te rigide wordt, kan de transactionele afstand toe nemen. Om aan deze nadelen tegemoet te komen zijn er in het OSO e-learning ontwerp verschillende maatregelen genomen. Er is besloten om niet te werken met voorgeschreven rollen in de discussie, hoewel daar in sommige gevallen ook een positieve invloed van kan uitgaan. Voorts is het advies van Cohen (1994) opgevolgd om de beloning voor deelname niet te 'sterk' te maken. Studenten discussiëren niet direct voor een cijfer, maar hun adequate deelname aan discussies en andere samenwerkingsopdrachten is voorwaarde voor het mogen inleveren van de eindopdracht van de module. Om te zorgen voor voldoende flexibiliteit is in het huidig ontwerp in de docentrol het kenmerk 'vraagsturing en flexibiliteit' voorzien. Onderhandeling tussen studenten en docenten maakt aanpassing aan de wensen van studenten mogelijk (Garrison, 2006; Polin, 2004). Daarnaast is er ook binnen de geformuleerde opdrachten ruimte om verschillende richtingen te kiezen naar gelang de behoeften van de studenten.

\section{Kenmerk 4: Spreiding studielast}

Onder spreiding van de studielast wordt verstaan dat er in alle modules gestreefd zal worden naar een evenwichtige spreiding van de studiebelastingsuren (168 uur per module) over de acht weken looptijd van de module. Garrison (2006) benadrukt het belang van evenwichtig spreiden van de studiebelasting ten aanzien van succesvol samenwerkend leren. Samenwerkend leren vergt interactie en reflectie. Een te hoge studiebelasting belemmert deze processen die essentieel zijn voor samenwerkend leren en leidt ertoe dat studenten in een soort overlevingsmodus raken. De curriculum inhoud moet dan ook zodanig beperkt worden dat er werkelijk tijd is voor diepgang in dialoog en reflectie. Als dit niet gebeurt, bestaat het risico dat studenten oppervlakkig gaan leren (Bullen, 1998; Gunn, 2006). Hammond (2005) benadrukt dat het nodig is om de studiebelasting zodanig aan te passen dat er werkelijk tijd is voor discussie. In het onderzoek van Delfino en Manca (2007) zijn de negatieve effecten van te hoge studiebelasting zichtbaar. Op een moment dat de studenten moe waren door een te hoge werkdruk nam de hoeveelheid bijdrages aan de discussie af.

Daarnaast geven verschillende auteurs aan dat een te hoge studiebelasting leidt tot een verminderde tevredenheid over het online onderwijs (Fenby, 2006; Ginns \& 
Ellis, 2007). Ook kan een onverwacht hoge werkdruk leiden tot het afhaken van studenten (Tweddell Levinsen, 2006). Het lijkt in online opleidingen die gebaseerd zijn op samenwerkend leren niet gemakkelijk om een evenwichtige en niet te hoge studiebelasting te realiseren. Meerdere auteurs rapporteren een te hoge studiebelasting van e-learners (Bishop, 2002; Cronjé et al., 2006; Nulden, 1999; Vrasidas \& McIsaac, 1999). Spreiding van de studielast wordt in de OSO e-learning modules gerealiseerd door de eindopdracht zo evenwichtig mogelijk uit te smeren over de hele module. Dit vormt een contrast met de reguliere opleiding waar de eindopdracht een piekbelasting vormt aan het einde van de module. Voorts wordt van de studenten gevraagd om hun verplichte discussiebijdrages (drie per discussie) evenwichtig te verdelen over de beschikbare tijd en niet te wachten tot de deadlines. Uit het onderzoek van Bullen (1998) blijkt dat dit niet altijd een vanzelfsprekendheid is, studenten zijn soms geneigd om dicht bij de deadline hun bijdrages te leveren. Het lukt dan niet om werkelijk een discussie te voeren. Uit het onderzoek van Hwang en Wang (2004) blijkt dan ook dat vroegtijdig en verspreid bijdragen leidt tot betere leeruitkomsten. Verder is het kenmerk 'vraagsturing en flexibiliteit' in de docentrol van belang om aanpassingen aan de taken te maken waar dat echt nodig lijkt op basis van de studiebelasting. De daadwerkelijke studielast is niet altijd van te voren goed in te schatten.

\section{Kenmerk 5: Helder geformuleerde leerdoelen en verwachtingen}

Onder helder geformuleerde leerdoelen en verwachtingen wordt in het OSO elearning ontwerp verstaan dat de leerdoelen en de verwachtingen van de opleiding helder en eenduidig worden beschreven, waarbij de beschrijvingen van de verwachtingen waar nodig worden aangevuld met gedetailleerde instructies op het vlak van de gewenste kwantiteit en/of kwaliteit. Om gezamenlijk tot hogere-orde denkprocessen te komen is het belangrijk dat studenten expliciete informatie krijgen over de verwachtingen met betrekking tot de kwaliteit, de frequentie en de lengte van discussiebijdrages (Conaway, Easton, \& Schmidt, 2005, Garrison, Anderson, \& Archer, 2001; Garrison \& Cleveland-Innes, 2005; Garrison, 2006; Pawan, Paulus, Yalcin, \& Chang, 2003). Meer dan bij reguliere studenten, dient er bij online studenten aandacht besteed te worden aan details in deze informatie (Coppola, Hiltz, \& Rotter, 2002). Online studenten zijn immers niet in de gelegenheid om snel even iets te vragen tijdens de les. Het belang van de gedetailleerde formulering van verwachtingen bleek in het onderzoek van Dennen (2005) naar negen verschillende online klassen. De studenten in dit onderzoek bleken meer geneigd tot deelname aan de discussies als de verwachtingen helder 
geformuleerd waren. Heldere instructies voor het discussiëren met duidelijk geformuleerde verwachtingen over kwantiteit en kwaliteit bleken de studenten te enthousiasmeren om deel te nemen aan de discussies. Bij onduidelijk geformuleerde verwachtingen daarentegen ontstond stress en kwam er nauwelijks een inhoudelijke discussie op gang. In overeenstemming met deze bevindingen toonden Shea, Frederickson, Pickett, Pelz, en Swan (2001) positieve verbanden aan tussen het percipiëren van duidelijke verwachtingen enerzijds en de tevredenheid en de leerervaring van studenten anderzijds.

Voor beginnende e-elearners lijkt deze duidelijkheid extra belangrijk. De beginnende e-learners in het onderzoek van Conrad (2002) waardeerden het zeer om een goed georganiseerde module aan te treffen met helder geformuleerde verwachtingen. Uit het onderzoek van Muilenburg en Berge (2005) blijkt dat helder geformuleerde verwachtingen de kans verhogen dat studenten ervoor kiezen om door te gaan met e-learning. Ook voor docenten kan het belangrijk zijn dat de verwachtingen van de opleiding voor studenten uitvoerig en eenduidig geëxpliciteerd zijn. Dit maakt beoordeling gemakkelijker (Dennen, 2005) en het voorkomt een lawine van vragen aan de docent bij het begin van de module (Berger, 1999). Ook is het belangrijk om op deze manier onnodige misverstanden ten aanzien van eindopdrachten en toetsen te voorkomen (Berger, 1999).

Uit de literatuur blijkt dat docenten en studenten niet altijd dezelfde opvattingen hebben over heldere formulering. Waar de docent meent heldere uitleg opgeschreven te hebben blijft het voor studenten soms toch onduidelijk wat de verwachtingen nu precies zijn (Blignaut \& Trollip, 2003; Bullen, 1998). Effectieve manieren om duidelijke verwachtingen te communiceren zijn het geven van voorbeelden van good practice (Bangert, 2004) en het formuleren van rubrics (Conaway, Easton, \& Schmidt, 2005). Voor beide mogelijkheden is gekozen in het OSO e-learning ontwerp. Het geven van goede voorbeelden is evenwel niet altijd mogelijk omdat eindopdrachten regelmatig veranderen waardoor er in een aantal gevallen nog geen goede voorbeelden bestaan.

\section{Samenvattend: E-learningstructuur}

Tabel 3.5 visualiseert de kenmerken en kernargumenten in het cluster Elearningstructuur. Er wordt zichtbaar dat de sterkste nadruk in de argumentatie ligt op de kwaliteit van het leerproces en het studierendement. De aantrekkelijkheid voor studenten kan een risico vormen. Studenten in 
afstandsleren hechten vaak sterk aan het aspect van tijdonafhankelijkheid. Het elearningstructuur cluster doet dit aspect enig geweld aan ten gunste van het studierendement en de kwaliteit van het leerproces.

Tabel 3.5 Elearning structuur: Kenmerken en kernargumenten

\begin{tabular}{|c|c|c|c|c|c|}
\hline \multirow[b]{2}{*}{ Kenmerken } & \multicolumn{5}{|c|}{ Kernargumenten } \\
\hline & $\begin{array}{c}\text { A } \\
\text { Meerwaarde } \\
\text { voor het } \\
\text { leerproces }\end{array}$ & $\begin{array}{c}\text { B } \\
\text { Aansluiting bij } \\
\text { bestaand } \\
\text { onderwijs } \\
\text { concept }\end{array}$ & $\begin{array}{c}\text { C } \\
\text { Aantrekkelijk } \\
\text { voor studenten; } \\
\text { draagt bij aan } \\
\text { tevredenheid }\end{array}$ & $\begin{array}{c}\text { D } \\
\text { Beschermt } \\
\text { tegen uitval }\end{array}$ & $\begin{array}{c}\text { E } \\
\text { Voorwaarde } \\
\text { voor samen- } \\
\text { werkend leren }\end{array}$ \\
\hline $\begin{array}{ll} & \begin{array}{l}\text { Strakke } \\
\text { planning }\end{array}\end{array}$ & & & & $\mathbf{x}$ & $\mathbf{x}$ \\
\hline $\begin{array}{ll} & \text { Spreiding } \\
& \text { studielast }\end{array}$ & & & $\mathbf{x}$ & $\mathbf{x}$ & $\mathbf{x}$ \\
\hline $\begin{array}{ll}5 & \begin{array}{l}\text { Helder gefor- } \\
\text { muleerde leer- }\end{array} \\
\text { doelen en ver- } \\
\text { wachtingen }\end{array}$ & $\mathbf{x}$ & & $\mathbf{x}$ & $\mathbf{x}$ & $\mathbf{x}$ \\
\hline
\end{tabular}

\subsubsection{Docentrol: definities, argumenten en procedures}

De rol van e-learning docent is gecompliceerd en kent veel verschillende aspecten (Anderson et al., 2001; Coppola et al., 2002). Het vinden van een goede balans tussen deze rollen is van groot belang voor docenten en voor hun studenten (Morris, Xu, \& Finnegan, 2005). In dit ontwerpcluster is het docentgedrag zo veel mogelijk uiteengerafeld in een poging maximale duidelijkheid te scheppen voor startende e-learning docenten.

\section{Kenmerk 6: Zichtbare aanwezigheid, reactiesnelheid en tijd}

Onder zichtbare aanwezigheid wordt in het OSO e-learning ontwerp verstaan dat docenten door middel van hun geschreven bijdrages tijdens modules vijf keer per week voor studenten zichtbaar aanwezig zijn in Blackboard. Met reactiesnelheid wordt bedoeld dat docenten snel reageren op vragen en verzoeken om feedback. Tijd betekent hier de tijd die docenten toegewezen kregen voor hun docentrol in de online module: zij kregen hiervoor even veel tijd als voor het onderwijzen van een reguliere module. Concreet betekende dit ongeveer 5 uur per moduleweek, en 1,5 uur nakijktijd per student.

Zichtbare aanwezigheid van de docent vormt de basis voor een bevredigende student-docent interactie (Dennen, 2005; Moore, 1989) en voor het tot stand komen van sociale aanwezigheid en leergemeenschap (Conrad, 2005; Morris, $\mathrm{Xu}$, et al., 
2005). In reguliere klassen is zichtbaarheid van docenten een vanzelfsprekendheid in online klassen geldt dat echter niet (Mandernach, Gonzalez, \& Garret, 2006; Savery, 2005). Online aanwezigheid wordt alleen zichtbaar als docenten berichten achterlaten. Als zij dit niet doen worden zij als onzichtbaar of absent ervaren door studenten. In een opleiding die volledig online plaatsvindt is zichtbare aanwezigheid essentieel, het maakt zichtbaar dat studenten er op kunnen vertrouwen dat zij niet aan hun lot worden overgelaten. Als de docent in dit opzicht passief is kan deze daarmee ongewild de boodschap uitstralen het leerproces onbelangrijk te vinden. Dit kan resulteren in passiviteit van studenten (Hewitt, 2005; Savery, 2005). Docenten verschillen sterk in de mate waarin zij een zichtbare rol aannemen in de online leeromgeving (Morris, Xu, et al., 2005). Het onderzoek van Mazzolini en Maddison (2003) laat zien dat studenten een grotere waardering hebben voor docenten die vaker bijdragen, zij worden ervaren als enthousiast en kundig. Ook uit het onderzoek van Conrad (2005) blijkt dat studenten grote waarde hechten aan de zichtbare aanwezigheid van docenten. Zij beschrijven dat ervaren studenten vanuit de kracht van hun leergemeenschap tijdelijk konden compenseren voor een afwezige docent, maar dat deze afwezigheid wel negatieve gevolgen had voor hun doelgerichtheid en motivatie. Het is om deze redenen dat in het OSO e-learning ontwerp is gekozen voor dagelijkse zichtbare aanwezigheid van docenten. Dit betekent zichtbaarheid in de vorm van vijf discussiebijdrages per week, het geregeld schrijven van mededelingen op Blackboard en het waar nodig contact houden via e-mail of telefoon.

Ook snel reageren versterkt de sociale aanwezigheid van docenten. Tijdige feedback en snelle reacties op vragen zijn van groot belang voor online leerders (Anderson et al., 2001; Tallent-Runnels et al., 2006; Vonderwell, 2003). Door snel te reageren kan de docent compenseren voor de problemen die ontstaan op grond van de fysieke afstand en een gevoel van isolement en onzekerheid voorkomen (Aragon, 2003; Bender, 2003; Cohen \& Ellis, 2004). Het tijdig antwoorden op vragen vergroot bovendien de kans dat docenten als echte en ondersteunende personen beschouwd worden door studenten. Niet tijdig antwoorden daarentegen vergroot de sociale afstand en verlaagt de motivatie (Baker, 2004; Blignaut \& Trollip, 2003). Tijdige en constructieve feedback leidt bovendien tot een betere kwaliteit van de online discussies en studenten hechten er veel waarde aan (Dennen, 2005; Rossman 1999). Het is van belang dat docenten tijdig misconcepties corrigeren en dat zij helpen om discussies zinvol te houden (Carr-Chelman \& Duchastel, 2000; Leidner \& Jarvenpaa 1995). Niet tijdige feedback is een bron van 
ontevredenheid voor studenten (Fenby, 2006) en kan leiden tot voortijdig afhaken (King, 2002). De literatuur geeft niet veel concrete handreikingen over de effectieve reactietermijn. Ten aanzien van feedback op discussies lijkt een hoge snelheid (binnen 24 uur) gewenst om discussies te kunnen bijsturen, dit zelfde geldt voor het beantwoorden van vragen (Aragon, 2003).

De keerzijde van zichtbare aanwezigheid en snelle feedback en reacties is de werkdruk van de docent. Uit de literatuur blijkt dat e-learning docenten veelvuldig een hoge werkdruk rapporteren. E-learning vergt tijd en continue aandacht van de docent (Coppola et al., 2002; Conrad, 2004; Carr-Chelman \& Duchastel, 2000; Dunlap, 2005; Hartman, Dziuban, \& Moskal, 2001; Kosak et al., 2004). Binnen de context van Windesheim OSO bleek het niet haalbaar om meer tijd te begroten voor e-learning dan voor regulier onderwijs. Maximaal haalbaar was om voor e-learning net zo veel docenttijd te begroten als voor het regulier onderwijs.

\section{Kenmerk 7: Moderatie}

Moderatie betekent in het OSO e-learning ontwerp dat de docent vanuit inhoudelijke expertise actief en regelmatig bijdraagt aan de discussie van de studenten met als doel een maximaal leerzame discussie te realiseren. Anderson et al. (2001) noemen dit aspect van de docentrol 'directe instructie'. Zij concretiseren dit als: het bevestigen van begrip via feedback, het identificeren van misvattingen, het noemen van extra bronnen, het presenteren van kennis en het samenvatten, het focussen van de discussie en het stimuleren van hogere-orde denkprocessen (Anderson et al., 2001; Garrison et al., 2001). Meerdere auteurs leggen de nadruk op het gebruik van de techniek van Socratisch bevragen (Bender, 2003; Coppola, Hiltz, \& Rotter, 2002; Parkinson \& Ekachai, 2002). Arbaugh (2001) waarschuwt dat het gebruik van deze techniek alleen niet genoeg is om leerzame discussies tot stand te brengen.

In de literatuur is een discussie gaande over de vraag hoe actief docenten nu werkelijk moeten zijn in discussies. Voor sommigen geldt het 'zwijgen is goud' principe, waarbij de docent de discussie bewaakt maar er zelf niet of nauwelijks bijdrages aan levert om studenten zoveel mogelijk de kans te geven de discussie zelf vorm te geven (Brower, 2003). Een actievere variant is het optreden als een soort bemoedigende coach ('guide on the side') aan de zijlijn van de discussie waarbij niet extreem veel gevraagd wordt van de inhoudelijke expertise van de docent (Salmon, 2004). Een nog actievere variant wordt eveneens 'guide on the side' genoemd, maar dit laat zich gezien de inhoud ervan eerder vertalen als 
gids dan als coach, waarbij het woord gids gebruikt wordt om aan te geven dat de docent inhoudelijk richting geeft aan de discussie. Deze variant is uitvoerig beschreven door Collison et al. (2000) en vormde een belangrijke inspiratiebron voor het ruwe ontwerp van de OSO e-learning opleidingen. Deze variant vormt in feite een gedetailleerde uitwerking van de docentrol zoals beschreven door Anderson et al. (2001). De uitwerking van Collison et al. (2000) bevat niet alleen het directe instructie aspect, maar ook de organisatorische en sociale aspecten van de docentrol die Anderson et al. benoemen. De meest actieve variant van moderatie komt naar voren in het onderzoek van Morris, Xu, et al. (2005). Eén van de docenten in dat onderzoek geeft daar directe instructie zoals hij dat ook in de reguliere les zou doen. Deze docent draagt extreem veel bij en domineert de discussie.

Binnen de OSO e-learning is gekozen voor een actieve, maar niet overactieve rol van de docent. Dit sluit dicht aan bij het concept directe instructie van Anderson et al. (2001) en bij de uitwerkingen van Collison et al. (2000). Het lijkt echter niet vanzelfsprekend om alle docenten hierin mee te krijgen. Uit onderzoeken waarin docentbijdragen zijn geanalyseerd blijkt dat docenten, onafhankelijk van hun onderwijsinstituut, heel verschillende plekken innemen op het continuüm van inactieve tot extreem actieve moderator (Morris, Xu, et al., 2005). Deze plekken bleken bovendien af te lezen aan de ratio van de docentbijdrages ten opzichte van de studentbijdrages (van laag naar hoog). Daarnaast bleek dat beginnende online docenten geneigd waren hun directe instructie rol te laten vervallen ten gunste van het oplossen van organisatorische problemen van studenten (Morris, $\mathrm{Xu}$, et al., 2005). In het OSO e-learning ontwerp is om deze reden voorzien dat docenten scholing krijgen voorafgaand aan hun taak als online docent, op deze wijze kunnen grote verschillen in taakuitoefening wellicht voorkomen worden.

Het belangrijkste voordeel van een actieve modererende rol is het stimuleren van hogere-orde denkprocessen. Discussies die niet actief gemodereerd worden blijven eerder oppervlakkig (Garrison \& Cleveland-Innes, 2005; Pawan, Paulus, Yalcin, \& Chang, 2003). Discussies waarin de docentrol wel actief vorm krijgt genereren meer hogere-orde denkprocessen. De interactie met docenten stimuleert het leren van studenten (Marks, Sibley, \& Arbaugh, 2005, Mazzolini en Maddison, 2003; Mullen \& Tallent-Runnels, 2006; Zhang, 2004). Studenten waarderen cognitieve uitdaging (Wen,Tsai, Lin, \& Chuang, 2004) en interactie met de docent (Oliver \& Shaw, 2003; Shea, Fredericksen, Pickett, Pelz, \& Swan, 2001). 
Het belangrijkste nadeel van een actieve modererende rol van de docent lijkt te zijn dat het een negatief effect kan hebben op de aantallen berichten die studenten genereren (Mazzolini en Maddison, 2003; Dennen, 2005). Een te veel aan moderatie met te veel directe instructie lijkt daar een rol in te kunnen spelen (Morris, Xu, et al., 2005). Er lijkt een bepaalde drempelwaarde te zijn waarboven de activiteit van de docent contraproductief wordt (Dennen, 2005). Mazzolini en Maddison (2003) waarschuwen overigens wel dat aantallen berichten van studenten geen gevoelige indicatoren zijn voor de kwaliteit van online discussies en dat gezocht moet worden naar betere indicatoren. In het OSO e-learning ontwerp wordt een eventueel negatief effect van docentactiviteit op berichten aantallen vermeden door te streven naar een uitgebalanceerde activiteit van de docent waardoor veel ruimte overblijft voor student initiatief. Voor de studenten wordt bovendien een minimum aantal berichten per discussie verplicht gesteld.

\section{Kenmerk 8: Feedback}

Het kenmerk feedback in het OSO e-learning ontwerp betreft snelle, concrete en bemoedigende feedback van docenten voor studenten (Bangert, 2004; Bender, 2003). In concrete feedback staat niet de waardering centraal, maar juist de beschrijving van de concrete aanleiding daarvoor (Faber \& Mazlish, 1996; Ginott, Ginott, \& Goddard, 1965, 2003). Docenten geven feedback op discussies, op samenwerkingsopdrachten en op delen van de eindopdracht. Dit gebeurt aan de hand van criteria die vooraf bekend gemaakt worden aan de studenten. Bemoedigende feedback vertrekt vanuit de positieve aspecten van het werk van de student. Pas daarna komen punten ter verbetering aan de orde.

De belangrijkste functie van feedback in iedere leeromgeving betreft het optimaliseren van het leerproces (Chickering \& Gamson, 1987; Graham, Cagiltay, Lim, Craner, \& Duffy, 2000; Locke \& Latham, 2002). Voor het leerproces is het onontbeerlijk om inzicht te krijgen in de grenzen van het eigen kennen en kunnen en in de eigen prestaties ten aanzien van de gestelde doelen (Chickering \& Gamson, 1987; Locke \& Latham, 2002). Feedback kan daarnaast invloed hebben op het geloof in eigen kunnen (self-efficacy) van de leerder en op de motivatie voor en het doorzettingsvermogen in het leerproces (Bangert, 2004; Zimmerman, 2000). Feedback heeft daarnaast nog twee speciale functies in het online leren. Ten eerste is feedback belangrijk om de onzekerheid van online studenten weg te nemen die ontstaat door de fysieke en psychologische afstand tot de docent (Hara \& Kling, 2000). Online studenten hebben door deze afstand meer behoefte aan 
feedback dan reguliere studenten (Phipps \& Merisotis, 2000). In verband met het compenseren voor de afstand benadrukken Graham et al. (2000) het belang van erkennende feedback. Door middel van erkennende feedback bevestigt de docent dat hij gebeurtenissen en uitingen hoort en ziet. In regulier onderwijs gebeurt dit veelal non-verbaal. In online onderwijs kan een gebrek aan erkennende feedback ertoe leiden dat studenten zich genegeerd voelen. Hoewel dit soort feedback in online omgevingen uiterst belangrijk is bleek het in onderzoeksdata van Graham et al. (2000) vrijwel niet voor te komen. Ten tweede is feedback van belang voor het leren van de specifieke vaardigheden die studenten nodig hebben voor online leren (Haavind, 2006). Voor het OSO e-learning ontwerp betekent dit dat het belangrijk is om docenten en studenten expliciet op het belang hiervan te wijzen.

Een nadeel van het geven van online feedback is dat non-verbale cues ontbreken, dit verhoogt de kans op misverstanden (Bender, 2003). Dit is een belangrijk argument om aandacht te hebben voor bemoediging in de formulering van de feedback. Een ander nadeel van het snel en vaak moeten leveren van digitale feedback is dat dit voor docenten intensief werk is dat een grote aandacht vraagt. Daardoor brengt het een grote werkdruk voor docenten met zich mee (CarrChelman \& Duchastel, 2000; Collis, de Boer, \& Slotman, 2001). Deze werkdruk leidde er in het onderzoek van Graham et al. (2001) toe dat online docenten in de loop van een semester steeds minder en ook steeds minder snel feedback gingen geven. Soms kwam er feedback die al niet meer relevant was omdat de betreffende discussie al afgelopen was. Graham et al. (2001) suggereren dat het onder tijdsdruk nog steeds mogelijk is om snelle feedback te geven op discussies door zoveel mogelijk feedback te geven aan de groep als geheel. Om de feedback druk voor docenten te verlichten kan ook gewerkt worden met peer feedback opdrachten (Hacker \& Niederhauser, 2000). Voor beginnende online docenten bleek het geven van feedback een groot probleem, in het onderzoek van Morris, $\mathrm{Xu}$, et al. (2005) bleken zij helemaal geen feedback te geven. Dit onderstreept de noodzaak van de scholing voor beginnende docenten die onderdeel is van het OSO e-learning ontwerp.

\section{Kenmerk 9: Organisatorische ondersteuning}

In het OSO e-learning ontwerp wordt onder ondersteuning door de docent het volgende verstaan: Het verduidelijken van organisatorische aangelegenheden in de module, zoals bijwoorbeeld de opdrachten, de verwachtingen, de beoordeling en de techniek. Het beantwoorden van vragen gebeurt via mail, via de discussieruimtes en via 
een wekelijks synchroon spreekuur via Breeze. Dit kenmerk is sterk gerelateerd aan de kenmerken 5 (helder geformuleerde leerdoelen en verwachtingen) en 6 (zichtbare aanwezigheid, reactiesnelheid en tijd). De argumenten die hierboven genoemd zijn voor deze kenmerken zijn ook hier geldig: positieve effecten voor het leerproces, het verminderen van stress en onzekerheid, het voorkomen van onnodige problemen en het vergroten van de tevredenheid van studenten.

Opvallend is dat in het oorspronkelijke model van Garrison et al. (2000) de organiserende rol gerealiseerd wordt door structuur en richtlijnen aan te brengen in de online module. De organiserende rol krijgt dan alleen vorm in statische module materialen, zoals hierboven geformuleerd naar aanleiding van het ontwerpcluster structuur. In het codeerschema dat Anderson et al. (2001) introduceren voor organisatorisch docentgedrag wordt duidelijk dat zij bovendien van de docent verwachten dat deze gedurende de discussies de studenten herinnert aan de tijdslijn en de richtlijnen in de module. In hun onderzoek wordt duidelijk dat dit een substantieel aandeel in het docentgedrag vertegenwoordigde: tussen 22 en $38 \%$ van de docentberichten.

De formulering van de organisatorische docentrol door Garrison et al. (2000; Anderson et al., 2001) veronderstelt dat het mogelijk is om door middel van zaken als roosters, syllabi en opdrachtenlijsten en criteria voldoende duidelijkheid te scheppen voor online studenten. In de praktijk van het afstandsleren blijkt dit echter niet het geval (Blignaut \& Trollip, 2003; Bullen, 1998). Hoewel duidelijke formulering van de module structuur het aantal vragen van studenten kan terugbrengen (Collis \& Gervedink Nijhuis, 2000) moet toch geconcludeerd worden dat het beantwoorden van vragen over organisatorische kwesties in de module een significant en tijdrovend onderdeel vormt van de online docenttaak (Bernard \& Lundgren-Cayrol, 2001; Coppola et al., 2002). Uit het onderzoek van Morris, Xu et al. (2005) blijkt zelfs dat in het werk van sommige, zowel onervaren als ervaren, docenten de organisatorisch ondersteunende taak de overhand had boven de cognitieve en sociale taken. Conrad (2002) concludeerde dat bij de aanvang van een module de organisatorisch ondersteunende werkzaamheden in sterkere mate de waardering voor de docent bepaalden dan de cognitieve kanten van de taakuitvoering. Studenten hadden de organisatorische ondersteuning bij de aanvang van de module hard nodig om hun angst te verminderen.

Voor het OSO e-learning ontwerp is van belang dat docenten tijdens de scholing goed worden ingelicht over het belang van het hier beschreven docentgedrag. 


\section{Kenmerk 10: Vraagsturing en flexibiliteit}

Dit kenmerk van het ontwerp is complementair aan de kenmerken 3 (strakke planning) en 5 (helder geformuleerde leerdoelen en verwachtingen). Een zeer statische structuur kan leiden tot een grote psychologische afstand tussen student en opleiding (Moore, 1993). Zoals eerder opgemerkt komt een dergelijke inflexibiliteit de motivatie van studenten niet ten goede. Om te kunnen afstemmen op de leerwensen en de privé en werksituatie van de student is flexibiliteit van de docent nodig. Dit betekent in het OSO e-learning ontwerp dat de docent in een discussie, via de mail of telefonisch gesprek samen met student(en) zoekt naar aanpassingen die zinvol zijn in het kader van leerwensen en privé- of werksituatie. Dit kan uitmonden in bijstellingen in de inhoud van de module, in de planning en in de opdrachten. Deze aanpassingen mogen niet strijdig zijn met het opleidingsen toetskader van OSO Windesheim. In een aantal gevallen moeten voorgestelde aanpassingen op grond van dit document door de student officieel worden aangevraagd bij de examencommissie.

Dit type onderhandeling sluit nauw aan bij het concept van vraagsturing. Het kan de studie aantrekkelijker maken en de kans op uitval verkleinen (zie Polin, 2004; Tisdell et al. 2004). Collis en Gervedink Nijhuis (2000) benadrukken de noodzaak van dit soort communicatie als onderdeel van de organisatorische rol van de docent. Zij stellen dat het met regelmaat nodig is om aanpassingen te maken in verband met privé situaties van studenten.

\section{Kenmerk 11: Controle en activering}

In de OSO e-learning opleidingen wordt hiermee bedoeld dat docenten zich er meermaals per week van vergewissen of de studenten in de groepjes die zij begeleiden actief deelnemen aan de discussies en samenwerkingsopdrachten. De docenten communiceren met studenten die onvoldoende deelnemen om na te gaan wat de oorzaak hiervan is, zoeken naar oplossingen en moedigen studenten aan om deel te nemen.

Controle en activering zijn om meerdere redenen belangrijk. Ten eerste kan daardoor onnodig afhaken van studenten voorkomen worden (Bouhnik \& Marcus, 2006). Sommige studenten dragen niet bij door technische- of andere problemen en vragen daarbij geen hulp. In de online omgeving merkt de docent hooguit dat de student niet bijdraagt, maar er zijn geen cues voorhanden om te signaleren dat er problemen zijn. Een dergelijke student zou kunnen afhaken als hulp uitblijft, terwijl de docent niet eens weet dat er problemen zijn. Om deze 
reden vonden de meeste docenten in het onderzoek van Easton (2003) het nodig om heel proactief te zijn naar studenten die even niet deelnamen. Ze wilden niet onnodig studenten verliezen. Ten tweede is controle en activering nodig om voldoende en gelijkwaardige deelname van de studenten aan het samenwerkingsproces te ondersteunen (Bangert, 2004). Dit is nodig omdat de discussies en het leerproces van alle studenten in het groepje stagneren als te veel studenten inactief zijn.

Online leren vergt meer controle en activering dan regulier onderwijs (Coppola et al., 2002). Het controleproces is niet eenvoudig als de docent met meerdere groepjes werkt en als discussies goed lopen en veel tekst bevatten. Het lukt dan ook niet altijd om problemen bijtijds te signaleren (Collis \& Gervedink Nijhuis, 2000). Het controleproces kan ondersteund worden door technische applicaties (Brace-Govan, 2003; Collis \& Gervedink Nijhuis, 2000). In Blackboard zijn er wel voorzieningen op dit vlak (prestatieoverzicht en modulestatistieken) maar die lijken het controleproces nauwelijks te versnellen. Daarom controleert de docent in het huidige ontwerp handmatig de bijdrages in de discussieruimtes.

\section{Kenmerk 12: Synchrone spreekuren}

In dit ontwerp wordt het volgende verstaan onder synchrone spreekuren: Wekelijks vindt op een vast tijdstip een spreekuur plaats waarbij de docent via Voice over Internet Protocol (VoIP) met de studenten communiceert. De studenten zijn in de gelegenheid om vragen te stellen over organisatorische of inhoudelijke zaken aangaande de module. Zij kunnen kiezen of ze daarvoor gebruik maken van tekst chat of VoIP, beide zijn mogelijk in het gebruikte platform (Breeze). Deelname aan de spreekuren is vrijwillig.

Ten aanzien van de effectiviteit van synchrone communicatie voor opleidingen is niet veel onderzoek beschikbaar. Het beschikbare onderzoek is bovendien eenzijdig van opzet, het betreft alleen gevalsstudies (Johnson, 2006). Het onderzoek betreft bovendien meestal tekst chat en geen VOIP. In chat sessies blijkt het mogelijk om cognitief georiënteerde discussies te voeren, hetgeen overigens afhankelijk is van de docentvaardigheden op dit vlak (Burnett, 2003). Docenten die zich autoritair en centraal opstellen, blokkeerden de discussies (Duemer et al., 2002). DavidsonShivers, Muilenburg en Tanner (2001) vergeleken asynchrone en synchrone communicatie door studenten random toe te wijzen aan één van de twee condities. Vervolgens discussieerden de studenten een week in de toegewezen conditie en de tweede week discussieerden zij weer, maar dan in de andere conditie. Davidson- 
Shivers et al. concludeerden dat de chat sessies meer inhoudsgerelateerde berichten bevatten dan de asynchrone discussies. De studenten toonden zich tevreden ten aanzien van beide communicatievormen. Specifieke voordelen van chat ten opzichte van asynchrone communicatie lijken te zijn: een gevoel van communicatieve directheid en nabijheid (Carr- Chelman \& Duchastel, 2000; Clouse \& Evans, 2003; Finlay, de Smet, \& Evans, 2004; Murphy \& Collins, 1997), een positieve invloed op teambuilding (Carr-Chelman \& Duchastel, 2000), snelle antwoorden op vragen (Carr-Chelman \& Duchastel, 2000) en snelle feedback (Clouse \& Evans, 2003; Finlay, de Smet, \& Evans, 2004). Aragon (2003) beschrijft modules waarin de mogelijkheden van chat conversaties heel expliciet ingezet wordt om de sociale interactie te stimuleren. Iedere wekelijkse chatsessie wordt iets voor de afgesproken tijd gestart met gesprekken over ieders welzijn en dagelijkse ervaringen. Het expliciete doel daarvan is om elkaar beter te leren kennen.

Chat kent ook nadelen. Chats vinden plaats op afgesproken tijdstippen en verminderen daardoor de tijdsonafhankelijkheid van de module (Brower, 2003; Carr-Chelman \& Duchastel, 2000; Milstead, 1998). De snelheid van chat kan sommige onervaren deelnemers intimideren of uitsluiten en er ontstaan vaak meerdere deelconversaties tussen participanten (McLinden, McCall, Hinton, \& Weston, 2006). Studenten kunnen tegelijkertijd bijdragen waardoor het gesprek snel en ongeorganiseerd verloopt. De samenhang wordt daardoor onduidelijk en belangrijke opmerkingen dreigen onder te sneeuwen (Milstead, 1998; Clouse \& Evans, 2003). Hierdoor is de chat soms moeilijk te volgen (Davidson-Shivers et al., 2001). Het onderzoek van Clouse en Evans (2003) roept twijfels op over het leerrendement van chat sessies. De combinatie van chat en asynchrone discussie leverde zwakkere tentamenresultaten op dan de combinatie van $\mathrm{f} 2 \mathrm{f}$ en asynchrone discussie. Een nadeel van chat voor docenten wordt gevormd door de toename in de belasting. De andere organisatorische en inhoudelijke taken nemen al veel tijd en de tijd die gepland wordt voor de chatsessie komt daar nog bij (DePaolo \& Sherwood, 2006).

Bij meerdere auteurs vinden we de gedachte terug van een virtueel synchroon spreekuur (Baker, 2004; King, 2002; Su, Bonk, Magjuka, Liu, \& Lee, 2005; Volery \& Lord, 2000), dit duurt meestal één tot anderhalf uur, en het is niet verplicht. Dit type spreekuur verhoogt de beschikbaarheid van docenten voor online studenten door directe interactiemogelijkheden te vergroten. Voor deze chats worden de volgende functies genoemd: organisatorische ondersteuning, interactie rondom vragen over de inhouden van de module en het versterken van de sociale 
interactie. Om goed gebruik te kunnen maken van chat lijkt voor onervaren studenten een fase van gewenning nodig voordat er inhoudelijk lastige onderwerpen besproken worden (Mariola \& Manley, 2002). Dit zal zonder twijfel ook gelden voor de OSO e-learning populatie die gemiddeld over weinig chat ervaring beschikt.

Ondanks alle nadelen genoemde nadelen van het gebruik van chat is er voor gekozen om binnen het OSO e-learning ontwerp gebruik te gaan maken van synchrone spreekuren. Deze keuze is vooral gemaakt vanuit de mogelijkheid om snel vragen te beantwoorden en feedback te geven, ook op aspecten van kennisconstructie bij studenten. Ook speelden bij deze keuze de sociaal samenbindende mogelijkheden van chat een rol.

\section{Kenmerk 13: Sociale aanwezigheid}

Sociale aanwezigheid is één van de drie hoofd componenten in het model van Garrison et al. (2000). De sociale aanwezigheid van de docent is in dit model echter ondergebracht binnen de directe instructie die een onderdeel vormt van de onderwijzende aanwezigheid. Vanwege de sterke relatie met kenmerk 2 (interactie tussen studenten) uit het huidige ontwerp wordt voor docenten vrijwel dezelfde definitie gebruikt als voor studenten. Er zijn wel enige nuances in aangebracht. Onder sociale aanwezigheid van docenten wordt in het OSO elearning ontwerp verstaan dat docenten sociale en emotionele communicatieve gedragingen stellen die er op gericht zijn om de psychologische afstand tussen de deelnemers en henzelf en de deelnemers onderling te verminderen, het gevoel van onderlinge veiligheid te vergroten en de onderlinge verbondenheid te versterken. De nuances die zijn aangebracht betreffen het dubbele doel van het sociale gedrag en de mogelijke eenzijdigheid van het gedrag. Coppola et al. (2002) benadrukken voor online leren de dubbele gerichtheid van de affectieve gedragingen van de docent. Deze zijn zowel gericht op de relatie van de docent met de studenten als op de relaties tussen de studenten onderling. De docent kan door middel van affectieve voorbeeld gedragingen de toon zetten voor de sfeer in de groep (Arbaugh, 2001). Het gedrag wat de docent stelt is dan ook soms eenzijdig, de docent geeft sociaal voorbeeld gedrag op het moment dat de groep nog niet zo ver is, entameert sociaal gedrag en blijft ook sociaal reageren op momenten dat iedere vorm van wederkerigheid (nog) ontbreekt. Uiteraard heeft de docent ook een rol om negatief gedrag in de groepjes te voorkomen en te reguleren. 
De doelen van de sociale aanwezigheid van de docent zijn zowel cognitief als affectief: het creëren van een vruchtbare en plezierige bodem voor hogere-orde denkprocessen die engagement oproept en tot intrinsieke motivatie en volharding leidt (Rourke et al., 2001). De sociale aanwezigheid van de docent sluit nauw aan bij het concept van 'immediacy (directheid)' zoals voor het regulier onderwijs onder meer beschreven door Christophel (1990). Christophel (1990) gebruikt in haar onderzoek de definitie van Mehrabian uit 1967 voor directheid: 'de mate waarin fysieke en/of psychologische nabijheid wordt ervaren'. Zowel nonverbale als verbale docent gedragingen hebben invloed op de directheid van de docent. Zij concludeert uit haar onderzoek dat de directheid van de docent een positieve invloed heeft op de motivatie van studenten en daarmee op de leerresultaten. Bovendien bleek de directheid van de docent een direct verband te vertonen met het besluit van studenten om bij dezelfde docent nogmaals een module te gaan volgen. In het kader van e-learning sluit het concept 'sociale aanwezigheid' aan bij de affectieve rol van de docent zoals beschreven door Coppola et al. (2002). Ondanks het ontbreken van non-verbale cues en verminderde mogelijkheden op het vlak van humor geven de online docenten in het onderzoek van Coppola et al. (2002) aan dat zij tot diepgang in de relatie met de studenten kwamen, meer dan in regulier onderwijs. Zij ervoeren dit als motiverend. De studenten in het onderzoek van Blignaut en Trollip (2003) benadrukken het belang dat zij er aan hechten om als persoon erkend en gevalideerd te worden door de docent. Dit lijkt verband te houden met de menselijke basisbehoeften relatie en competentie. Positieve ervaringen op deze vlakken hebben een belangrijke invloed op het welzijn van mensen (Reis, Sheldon, Gable, Roscoe, \& Ryan, 2000). Correlationeel onderzoek bevestigt positieve verbanden tussen affectief docentgedrag en ervaren leren (Arbaugh, 2001; Baker, 2004; Russo \& Benson, 2005), tussen affectief docentgedrag en tevredenheid over modules (Arbaugh, 2001; O'Sullivan et al., 2004) en tussen affectief docentgedrag en tevredenheid over de docent (O'Sullivan et al., 2004).

Docenten die online gaan werken vinden nieuwe manieren om emoties uit te drukken (Coppola et al., 2001), daarnaast gebruiken zij ook verbale strategieën uit het reguliere onderwijs (O'Sullivan et al., 2004). Dit betekent dat die docenten online in het voordeel zouden kunnen zijn die vanuit hun reguliere onderwijservaringen over een breed arsenaal sociale gedragingen beschikken (Arbaugh, 2001). In de literatuur zijn meerdere uitvoerige beschrijvingen van dit arsenaal aan docent gedragingen te vinden (Rourke et al., 2001; Aragon, 2003). 
Een voorbeeld hiervan is de beschrijving van O'Sullivan et al. (2004). Zij onderscheiden daarin als twee grote categorieën: benaderbaarheid en respect. Benaderbaarheid verwijst naar gedragingen die aangeven dat de docent als persoon benaderbaar is. Voorbeelden hiervan zijn: openheid over persoonlijke aangelegenheden, expressiviteit en informeel taalgebruik. Aanzien gaat over het benaderen van de ander. Voorbeelden van deze categorie zijn een persoonlijke benadering en attent reageren. Opvallend is dat docenten in niet spreken over werkdruk in relatie tot hun sociale aanwezigheid en sociale interactie met studenten. Het lijkt er op dat docenten dit kenmerk als motivator zien in online doceren (Coppola et al., 2001).

\section{Kenmerk 14: Scholing}

Onder scholing wordt in het OSO e-learning ontwerp een informele scholing verstaan waarin docenten voorafgaand aan het online lesgeven informatie, voorbeelden en oefening krijgen met betrekking tot de docenttaken en dat zij tijdens het uitvoeren van hun eerste module ondersteuning en feedback krijgen van meer ervaren online docenten.De veelheid van de hierboven genoemde kenmerken met betrekking tot de docentrol illustreert de complexiteit ervan. Er zijn veel 'how to' boeken geschreven over online lesgeven (o.m. Bender, 2003; Collison et al., 2000; Busch \& Mayer, 2002; Salmon, 2004; Pallof \& Pratt, 2003) maar er is relatief weinig geschreven over de concrete weg er naar toe. Mogelijk wordt verwacht dat docenten een boek lezen over online docentschap en dan les kunnen geven. In het licht van de complexe antwoorden op de vraag hoe leerkrachten moeten worden opgeleid voor f2f onderwijs lijkt het succes daarvan niet evident. De raadgevingen in de genoemde 'how to' boeken zijn bovendien complex en moeilijk meteen in de praktijk uitvoerbaar. In de literatuur wordt duidelijk dat de eerste stappen van docenten op het online pad wankel zijn, en dat er sprake is van een steile leercurve (Berger, 1999; Conrad, 2004; Hall, 2006; Harasim, 2000; Morris, $\mathrm{Xu}$, \& Finnegan, 2005). Mensen verschillen bovendien sterk in hun acceptatie van vernieuwingen (Rogers, 1995). Leren online doceren veroorzaakt cognitieve dissonantie, onzekerheid en de noodzaak tot aanpassingen en leren (Easton, 2003), niet iedereen gaat daar even gemakkelijk mee om. Dit bevestigt de noodzaak van middelen om docenten te ondersteunen bij deze eerste stappen op het pad van het online docentschap. Het doel hiervan is om docenten met voldoende aanvangscompetenties te laten starten met online doceren zodat er geen al te steile leercurve nodig is. Dit lijkt in het belang van zowel de docenten als de studenten. 
In de literatuur vinden de aanbeveling dat docenten een online module volgen als voorbereiding op het online docentschap (Gibbons \& Wentworth, 2001; Wilson \& Stacey, 2003;). In Nederland beschikt de hogeschool InHolland over een dergelijke module: de Happ-e-tutor. Docenten die zelf online leren ervaren begrijpen daardoor beter wat e-learning studenten meemaken en nodig hebben (Gibbons \& Wentworth, 2001). Wilson en Stacey (2003) geven daarnaast aan dat het voordelen heeft om gebruik te maken van formeel geaccrediteerde modules. In dergelijke modules moeten docenten hun competenties aantonen, maar kan ook zelfselectie plaatsvinden door reflectie op een aantal kernaspecten van het online docentschap (Gibbons \& Wentworth, 2001). Instituten kunnen het behalen van een dergelijke module als voorwaarde stellen voor aanstelling. In veel instellingen voor hoger onderwijs zijn workshops over aspecten van online leren vrijwillig en worden ze bevolkt door voorlopers ten aanzien van vernieuwingen (Conrad, 2004). Dit terwijl voor online leren juist een focus op de gemiddelde docent noodzakelijk is, die immers de meerderheid van de instelling vormt (Wilson \& Stacey, 2003). Aan de andere kant hebben meer informele en locaal georganiseerde trainingen het voordeel dat ze beter kunnen aansluiten op specifieke werkwijzen en afdelingsculturen (Wilson \& Stacey, 2003) . Op beperkte schaal is onderzoek beschikbaar dat de tevredenheid van docenten bevestigt over trainingen voor online docentschap (Kosak et al., 2004). Er is geen effectonderzoek beschikbaar naar deze trainingen.

Naast mogelijkheden als modules en workshops noemen een aantal auteurs ook de mogelijkheden van ondersteuning 'on the job', het observeren van ervaren collega's en het uitwisselen van ervaringen met collega's om tot samenwerkend leren te komen (Muirhead, \& Betz, 2002; Schweber, Kelley, \& Orr, 1998; Wilson \& Stacey, 2003). Uiteraard leren docenten ook van de feedback die zij van online studenten krijgen (Muirhead, \& Betz, 2002), maar het is veel te riskant om het leerproces alleen daarvan te laten afhangen (Gibbons \& Wentworth, 2001). Binnen OSO Windesheim is er voor gekozen om voor de, niet formeel geaccrediteerde, training eigen materialen te ontwikkelen die nauw aansluiten bij het beschreven ontwerp. Dit betreft zowel een handleiding voor docenten als een uitgebreide workshop. Daarnaast worden docenten 'on the job' begeleid.

\section{Samenvattend: Docentrol}

In tabel 3.6 zijn de kenmerken van de docentrol weergegeven met de bijbehorende kernargumenten. Opvallend is de hoeveelheid kenmerken en de 
verdeling van de argumentatie. Vier van de vijf argumenten spelen een belangrijke rol in dit ontwerp cluster. Dit maakt het grote belang van docent rol duidelijk voor het ontwerp. Tegelijkertijd wordt duidelijk dat de organiseerbaarheid van dit alles een risico vormt.

Tabel 3.6 Docentrol: Kenmerken en kernargumenten

\begin{tabular}{|c|c|c|c|c|c|}
\hline \multirow[b]{2}{*}{ Kenmerken } & \multicolumn{5}{|c|}{ Kernargumenten } \\
\hline & $\begin{array}{c}\text { A } \\
\text { Meerwaarde } \\
\text { voor het } \\
\text { leerproces }\end{array}$ & $\begin{array}{c}\text { B } \\
\text { Aansluiting bij } \\
\text { bestaand } \\
\text { onderwijs } \\
\text { concept }\end{array}$ & $\begin{array}{c}\text { C } \\
\text { Aantrekkelijk } \\
\text { voor studenten; } \\
\text { draagt bij aan } \\
\text { tevredenheid }\end{array}$ & $\begin{array}{c}\text { D } \\
\text { Beschermt } \\
\text { tegen uitval }\end{array}$ & $\begin{array}{c}\text { E } \\
\text { Voorwaarde } \\
\text { voor samen- } \\
\text { werkend leren }\end{array}$ \\
\hline $\begin{array}{ll}6 & \text { Tijd en aanwe- } \\
\text { zigheidsritme }\end{array}$ & & & $\mathbf{x}$ & $x$ & \\
\hline Moderatie & $x$ & $x$ & $\mathbf{x}$ & & $x$ \\
\hline Feedback & $x$ & & & & $x$ \\
\hline $\begin{array}{l}\text { Ondersteuning } \\
\text { en advisering }\end{array}$ & & $\mathbf{x}$ & $\mathbf{x}$ & $\mathbf{x}$ & \\
\hline $\begin{array}{l}10 \text { Vraagsturing en } \\
\text { flexibiliteit }\end{array}$ & $\mathbf{x}$ & $\mathbf{x}$ & $\mathbf{x}$ & $\mathbf{x}$ & \\
\hline $\begin{array}{l}11 \text { Controle en } \\
\text { activering }\end{array}$ & $\mathbf{x}$ & & & $\mathbf{x}$ & $\mathbf{x}$ \\
\hline $12 \begin{array}{l}\text { Synchrone } \\
\text { spreekuren }\end{array}$ & $x$ & $x$ & $x$ & & \\
\hline $\begin{array}{l}13 \text { Sociale aan- } \\
\text { wezigheid }\end{array}$ & & & $\mathbf{x}$ & $x$ & \\
\hline 14 Scholing & $\mathbf{x}$ & & & & \\
\hline
\end{tabular}

\subsubsection{Leermaterialen: definities, argumenten en procedures}

Moore (1989) noemt drie essentiële vormen van interactie voor een online opleiding: student-student, student-docent en student-inhoud. Het is deze laatste vorm van interactie die centraal staat in het ontwerpcluster 'leermaterialen'. In de OSO e-learning opleiding wordt de theoretische en methodische inhoud van de modules primair via de leermaterialen geïntroduceerd bij de studenten. Bender, Wood, en Vredevoogd (2004) zien dit als een voordeel: de technologie bevrijdt de docent van het overdragen van de stof en geeft de docent de kans om studenten te betrekken bij diepgaande discussies.

Deze werkwijze vormt een tegenstelling met de reguliere OSO opleiding waar een gedeelte van de inhoudelijke introductie nog tot de functie van de docent behoort. Uiteraard is het ook in de reguliere opleiding de bedoeling dat studenten actief 
omgaan met de leermaterialen, maar dat blijkt niet altijd gemakkelijk te realiseren (zie ook Anderson, 2003). Brost en Bradley (2006) beschrijven de vicieuze cirkel waarin opleiders en studenten kunnen raken als studenten onvoldoende lezen ter voorbereiding van de les. In reactie daarop gaan opleiders de inhoud van de te lezen literatuur tijdens de les bespreken en vinden studenten het vervolgens niet meer nodig om de literatuur te lezen. Een dergelijke vicieuze cirkel is niet gemakkelijk voorstelbaar als de student-docent interactie gelimiteerd is tot asynchrone schriftelijke discussies. In het onderzoek van Swan et al. (2000) wordt hiervoor enige bevestiging gevonden. De studenten in een online asynchrone leeromgeving ervoeren dat zij intensiever gebruik maakten van de leermaterialen dan tijdens eerdere reguliere opleidingen.

\section{Kenmerk 15 : Rijke leeromgeving}

Een rijke leeromgeving betekent in het huidige ontwerp dat de leeromgeving het volgende bevat:

- Een rijke thematisch georganiseerde verzameling artikelen

- De verplichting om de beschikking te hebben over specifieke boeken

- Een rijke thematisch georganiseerde verzameling multimediale leerobjecten

- Verwijzingen naar databases en zoekmachines waaruit nog meer informatie verkregen dient te worden.

Met het woord 'leerobject' wordt verwezen naar een kleine afgebakende hoeveelheid instructie. Multimediaal betekent in essentie dat er gebruik gemaakt wordt van zowel het auditieve als het visuele kanaal voor informatie verwerking (Mayer \& Moreno, 2003). Via internet zijn er zeer vele mogelijkheden om visueel en verbaal materiaal te presenteren (Mayer, 2001). Zo wordt er in het huidige ontwerp gebruik gemaakt van videofragmenten, audiofragmenten, schriftelijke uitleg, mindmaps en gesproken powerpoints. De OSO e-learning modules worden gebouwd door docenten, niet door mediaspecialisten, waardoor het eindproduct niet extreem 'glanzend' is in termen van multimedia. Het gebruiken van artikelen en boeken staat hier niet ter discussie omdat het ontwerp daarmee de lijn volgt van de reguliere opleiding. Ditzelfde geldt voor de verwijzingen naar databases en zoekmachines. De rijke multimediale verzameling leerobjecten is wel een specifiek kenmerk van de e-learning modules. Multimedia versterken het leren doordat er niet alleen gewerkt wordt met woorden, maar ook met visuele input (Mayer, 2001; Marks et al., 2005). Mayer (2001) onderbouwt dit vanuit modellen van het menselijk werkgeheugen (Baddeley, 1999). Dit geheugen kent 
minstens twee kanalen: het visuele en het auditieve. De kanalen zijn ieder afzonderlijk beperkt in capaciteit, maar gezamenlijk gebruik vergroot de totale verwerkingsmogelijkheid en vergroot daarmee de kans op leren. Multimedia gebruik kan dan ook, mits correct ingezet, leiden tot een optimaal gebruik van het menselijk werkgeheugen. Hiervoor bestaat experimentele evidentie (o.m. Mayer, 1989; Mayer, Bove, Bryman, Mars, \& Tapangco, 1996). In de betreffende experimenten is gewerkt met studenten die weinig tot niets afwisten van het vakgebied waarmee ze geconfronteerd werden en met onderwerpen waarbij visualisatie een sterke meerwaarde had. In andere onderzoeken die plaatsvonden in meer natuurlijke onderwijscontexten werd geen verband aangetoond tussen het inzetten van multi-media enerzijds en leren anderzijds, meestal tot verbazing van de onderzoekers (Marks et al., 2005; Martens, Bastiaens, \& Gulikers, 2002). Ook bleek uit deze onderzoeken geen verband tussen multi-media gebruik en tevredenheid. Bernard et al. (2004) vonden in hun metareview wel verbanden tussen het gebruik van video en televisie enerzijds en tevredenheid en leren anderzijds. Zij concluderen dat media gebruik kan leiden tot een engagerend leerproces bij studenten mits het gecombineerd wordt met het uitvoeren van authentieke opdrachten. Arbaugh (2005) vond eveneens een positief verband tussen multi-media gebruik en de leerervaring van studenten. Hij vond echter geen verband met tevredenheid.

Voor docenten kan het een voordeel zijn dat een gedeelte van de student-docent interactie vervangen wordt door student-inhoud interactie, dit kan de werkbelasting van docenten verminderen en uitbreiding naar grotere studenten aantallen mogelijk maken (Anderson, 2003). De rijke multi-mediale omgeving genereert niet in alle gevallen leren en student tevredenheid, kan cognitieve overbelasting veroorzaken (Mayer \& Moreno, 2003) en kan bovendien een flinke kostenpost zijn voor een opleiding, vooral als mediaspecialisten worden ingeschakeld. In de literatuur (Anderson, 2003; Wallace, 2003) wordt benadrukt dat de materialen zo moeten worden ontwikkeld dat zij zo veel mogelijk actief leren uitlokken en dat er aansluiting is met het samenwerkend leren in de leeromgeving. Dit betekent dat verzamelingen van leerobjecten nooit alleen maar gericht mogen zijn op het presenteren van materiaal, maar dat er ook gelegenheid moet zijn tot oefenen met feedback. Het onderzoek van Mayer et al. (1996) maant tot voorzichtigheid op het vlak van cognitieve overbelasting door tekstgebruik; korte overzichtelijke tekstfragmenten leiden tot beter leren dan lange stukken tekst. In het OSO e-learning ontwerp is gekozen om multimedia in te zetten waar 
dat werkelijk functioneel is, bijvoorbeeld door video fragmenten in te zetten in het kader van de training van vaardigheden. De leerobjecten worden nauwkeurig aangesloten op de interactieve opdrachten en er wordt op beperkte schaal gebruik gemaakt van interactieve oefeningen met feedback. Tekstfragmenten in de leerobjecten worden zodanig kort gehouden dat zij gemakkelijk in één scherm passen zodat scrollen niet nodig is. Bovendien worden zij voorzien van een overzichtelijke lay out waarin belangrijke elementen geaccentueerd worden.

\section{Samenvattend: Leermaterialen}

Tabel 3.7 geeft de kenmerken en de kernargumenten weer met betrekking tot de leermaterialen. In de argumentatie ligt de nadruk op de kwaliteit van het leerproces en op de aantrekkelijkheid voor studenten.

Tabel 3.7 Leermaterialen: kenmerken en kernargumenten

\begin{tabular}{|c|c|c|c|c|c|}
\hline \multirow[b]{2}{*}{ Kenmerken } & \multicolumn{5}{|c|}{ Kernargumenten } \\
\hline & $\begin{array}{c}\text { A } \\
\text { Meerwaarde } \\
\text { voor het } \\
\text { leerproces }\end{array}$ & $\begin{array}{c}\text { B } \\
\text { Aansluiting bij } \\
\text { bestaand } \\
\text { onderwijs } \\
\text { concept }\end{array}$ & $\begin{array}{c}\text { C } \\
\text { Aantrekkelijk } \\
\text { voor studenten; } \\
\text { draagt bij aan } \\
\text { tevredenheid }\end{array}$ & $\begin{array}{c}\text { D } \\
\text { Beschermt } \\
\text { tegen uitval }\end{array}$ & $\begin{array}{c}\mathbf{E} \\
\text { Voorwaarde } \\
\text { voor samen- } \\
\text { werkend leren }\end{array}$ \\
\hline $\begin{array}{l}15 \begin{array}{l}\text { Rijke leerom- } \\
\text { geving }\end{array}\end{array}$ & $\mathbf{x}$ & & $\mathbf{x}$ & & $\mathbf{x}$ \\
\hline
\end{tabular}

\subsection{SAMENVATTEND BEELD VAN HET ONTWERP}

In het OSO e-learning ontwerp worden alle in paragraaf 3.3 genoemde kenmerken toegepast. Om een beeld te krijgen van de wijze waarop de opleiding concreet vorm krijgt zijn de kenmerken hieronder kort samengevat en met elkaar in verband gebracht. In de bijlagen zijn screenshots en voorbeelden van discussieopdrachten opgenomen om een nog concreter beeld te krijgen.

OSO geeft het e-learning onderwijs groepsgewijs en volgens een strak rooster vorm via speciaal daartoe ingerichte Blackboardmodules. Deze modules zijn op een vaste manier ingericht om duidelijkheid en herkenbaarheid te bevorderen. Er zijn vier moduleperiodes van ieder 8 weken per jaar. Per moduleperiode wordt één module aangeboden met begeleiding van een docent. In deze modules worden per week thema's uit het vakgebied aangeboden door middel van literatuur en door middel van multimediale leerobjecten. 
De interactie tussen de studenten is binnen de Blackboard modules zowel cognitief als sociaal van aard. De cognitieve interactie wordt gestuurd door duidelijk geformuleerde samenwerkings- en discussieopdrachten die volgens een strak rooster plaatsvinden in de groepsdiscussieruimtes van Blackboard. Deze opdrachten zijn verplicht en dienen om kennis te oefenen, toe te passen en / of te construeren. De sociale interactie vormt een voorwaarde voor de samenwerking en leidt tot wederzijdse ondersteuning waardoor de studie makkelijker vol te houden is. De sociale interactie wordt geïnitieerd en gestimuleerd op de fysieke startdag en krijgt verder vorm via een online kennismakingsactiviteit en binnen speciaal daartoe bestemde discussieruimtes.

De docent begeleidt met een afgesproken frequentie de cognitieve discussies in Blackboard op basis van vakinhoudelijke expertise en moderatievaardigheden. De docent communiceert op persoonlijke wijze en geeft stimulerende en concrete feedback. Daarnaast controleert de docent de Blackboard activiteiten van studenten en treedt waar nodig activerend op. De docent reageert tijdig (binnen 2 werkdagen) op vragen van studenten en regelt waar nodig uitzonderingen voor studenten. Wekelijks organiseren de docenten een synchroon spreekuur via Breeze. De docenten worden ingeroosterd voor het online onderwijs en krijgen voor online modules even veel begeleidingstijd toegekend als voor reguliere modules. De docenten worden via een handleiding en via workshops geschoold en zij krijgen begeleiding 'on the job'.

\subsection{EXPERT RAADPLEGING}

In december 2006 vond een expert raadpleging plaats over het oorspronkelijke ruwe ontwerp. Doel van de expert raadpleging was om voor- en nadelen van het ontwerp in kaart te brengen en om adviezen te krijgen met betrekking tot de concrete procedures. Deze adviezen konden meegenomen worden in de eerste pilot die vanaf januari 2007 zou draaien.

De drie geraadpleegde experts zijn onderwijskundigen uit Nederland en Vlaanderen met veel onderzoekservaring op het vlak van elektronische onderwijsmaterialen en implementatie van e-learning platforms en -onderwijs. Aan de drie wetenschappers werd het oorspronkelijke ruwe ontwerp voorgelegd alsmede een concreet uitgewerkte digitale module. In semi- gestructureerde interviews gaven zij hun mening over het ontwerp. 
Hieronder (3.5.1) worden eerst de algemene raadgevingen van de deskundigen weergegeven. In 3.5.2. zijn de reacties van de deskundigen samengevat per ontwerpcluster.

\subsubsection{Algemene raadgevingen}

Deskundige A:

Deskundige A ziet eenvoud als een belangrijk uitgangspunt voor het ontwerpen van e-learning. Dit betekent voor hem dat de werkwijze voor e-learning niet te ver moet afwijken van de normale werkwijze van docenten. Onder verwijzing naar Betty Collis ('gewin, gemak en genot') geeft hij aan dat het van belang is voor de implementatie dat docenten zich prettig voelen bij de werkwijze en er voordeel van ondervinden. In het kader van de eenvoud van het ontwerp ziet hij het voorts als onverstandig om veel verschillende online systemen te gebruiken. Het gebruik van verschillende systemen is in zijn ogen gebruiksonvriendelijk doordat steeds weer op een andere manier ingelogd moet worden. Hij benadrukt tot slot het belang van de beschikbaarheid van technische ondersteuning voor studenten.

\section{Deskundige B:}

Deskundige B geeft aan dat het OSO e-learning ontwerp de drie componenten bevat die essentieel zijn voor een hedendaagse elektronische leeromgeving: een set bronnen, een set communicatietools en een set opdrachten met een tijdslijn. Hij benadrukt dat al deze componenten een goede concrete invulling moeten krijgen om het ontwerp werkbaar te maken voor docenten. Hij heeft twee grote zorgen op het vlak van de doorontwikkeling en de implementatie van elektronische leeromgevingen in Nederland. Zijn ene zorg behelst de motivatie en de vaardigheden van docenten. Het feit dat een docent aanvullende vaardigheden nodig heeft om te kunnen werken in een elektronische leeromgeving ziet hij als een belemmering voor de implementatie. Hij vraagt zich af hoe leraren te motiveren zijn voor dit soort werk. Als tweede zorg geeft hij aan dat er in Nederland onvoldoende geïnvesteerd wordt in het maken van concrete invullingen voor elektronische leeromgevingen. Concrete invulling gebeurt zijns inziens alleen op plekken waar de implementatie van e-learning wordt geflankeerd door onderzoek. Het onderzoek vormt dan de prikkel tot concrete invulling.

\section{Deskundige C:}

Deskundige $C$ ziet binnen zijn eigen onderwijsinstelling een groot voordeel van online leren. Zijn onderwijsinstelling heeft meer ingeschreven studenten dan 
mogelijk is gegeven de beschikbare ruimte. Dit wordt opgelost met behulp van blended learning en e-learning. Belangrijke voorwaarden voor deze werkwijze zijn een grote technische betrouwbaarheid van het e-learning platform en de beschikbaarheid van $7 \times 24$ uur technische ondersteuning per week. Studenten haken volgens hem zeer snel af als het systeem onbetrouwbaar blijkt. Qua systeem gaat zijn voorkeur uit naar open source. Het geld dat normaliter besteed wordt aan licenties kan dan besteed worden aan het aanpassen van het systeem aan de eisen die het onderwijskundig ontwerp stelt. Deze deskundige vindt het belangrijk om één geïntegreerd systeem te gebruiken zodat studenten maar één keer hoeven in te loggen voor alles wat ze willen doen. Naar zijn mening zijn binnen dit systeem een herkenbare structuur en huisstijl van belang.

Met betrekking tot de onderwijskundige uitgangspunten van het OSO e-learning ontwerp maant hij tot voorzichtigheid met betrekking tot het begrip 'sociaalconstructivisme' omdat dit meer een epistemologische positie betreft dan een feitelijk instructie- en leerpsychologisch mechanisme. Voor het aanbieden van een complex en omvattend kennisgebied gaat zijn voorkeur uit naar een cognitivistische benadering in combinatie met sterk gestructureerde samenwerkingsopdrachten. Sturing en structurering vindt hij uiterst belangrijk omdat het voor veel studenten te moeilijk blijkt om de inhouden zelfstandig te verwerken.

Samenwerkend leren is naar zijn mening een belangrijke werkvorm binnen een opleiding voor pedagogische competenties als coaching, begeleiding en tutoring. Implementatie van samenwerkend leren verloopt volgens hem bij voorkeur onderzoeksmatig. Er ontstaat dan synergie tussen onderzoek en onderwijs. Zo kunnen studenten bijvoorbeeld bijdrages beoordelen en deze beoordelingen tegelijkertijd gebruiken voor hun onderzoek. Vaardigheden trainen en beoordelen kan volgens hem gedeeltelijk via video-opnames, maar samenwerking met het werkveld en observatie ter plaatse blijven ook nodig. 'Je moet elkaar kunnen zien, anders gaat er veel te veel tijd verloren.'

\subsubsection{Expert meningen over ontwerpkenmerken}

Hieronder zijn de uitkomsten van de expert interviews samengevat per cluster van ontwerpelementen. Binnen het semigestructureerde interview kwamen niet altijd alle kenmerken aan de orde. Sommige kenmerken kwamen in de interviews alleen in samenhang met andere kenmerken aan de orde. 


\section{Interactie tussen studenten.}

Ten aanzien van samenwerkend leren via asynchrone discussie (kenmerk 1) zijn twee experts positief tot zeer positief, één van hen heeft zeer veel ervaring op dit vlak. Eén van de experts geeft een negatieve reactie op deze kenmerken. Er worden door de twee voorstanders verschillende voordelen genoemd. De discussies vormen een manier om actief om te gaan met kennis waardoor studenten zich de kennis makkelijker eigen maken. Asynchrone discussie is trager en daardoor reflectiever dan synchrone discussie. Het leidt tot kennisconstructie en het wordt door studenten gewaardeerd. Na een tijd ervaring met deze werkwijze worden studenten bovendien gedeeltelijk zelfsturend.

Alle drie de respondenten zien evenwel ook nadelen aan asynchrone discussies en samenwerkingsopdrachten. Twee experts geven aan dat het vaak niet lukt om mensen actief mee te laten doen. De derde, zeer ervaren, expert ziet geen problemen op het vlak van de deelname maar geeft aan dat deze werkwijze een hoge studiedruk voor studenten genereert. Studenten zijn met veel processen tegelijk bezig: samenwerken, cognitieve verwerking en metacognitieve processen. Sommige studenten hebben bij aanvang nog onvoldoende beheersing van deze processen. De expert die negatief reageert op asynchroon samenwerkend leren doet dat zowel vanuit het perspectief van studenten als van docenten. Voor studenten vindt hij het onaantrekkelijk omdat naar zijn mening de betreffende (deeltijd) studenten liever in hun eigen tempo werken. Afhankelijkheid van anderen genereert problemen en studievertraging. Zo is het lastig om mensen op afstand aan elkaar te koppelen voor peer feedback omdat dat een erg tijdafhankelijke taak is. Feedback moet snel. Het online samenwerken brengt bovendien het gevaar van liften met zich mee. Voor docenten is deze werkwijze in zijn ogen zwaar omdat zij belast worden met de samenwerkingsproblemen van studenten en omdat zij onvoldoende tijd hebben om asynchrone discussies goed in te richten en te begeleiden. Daarnaast kan deze werkvorm tot handelingsverlegenheid leiden bij docenten omdat er onvoldoende concrete richtlijnen bestaan voor docenten met betrekking tot de invulling en de beoordeling. Een dergelijke werkwijze heeft in zijn ogen alleen kans als het in het kader van een onderzoek vorm krijgt. Samenwerking is in zijn ogen bovendien niet voor alle onderwijskundige vakken van belang, hetgeen naar zijn mening in het algemeen het belang van deze werkvorm vermindert. 
De experts geven op een aantal punten raad over samenwerkend leren en asynchrone discussies. Sturing en structurering zijn heel belangrijk om alle studenten de verschillende benodigde processen voor samenwerking en kennisconstructie aan te leren. Daarbij dient ook aandacht geschonken te worden aan het leren geven van peer feedback. Het is van belang dat de discussieonderwerpen werkelijk interessant en daardoor intrinsiek motiverend zijn voor studenten. Er moet voor gewaakt worden dat de opdrachten voldoende diepgang hebben. Er moeten gemeenschappelijke onderwerpen en doelen zijn in de opdrachten en de begeleider kiest de casus. Het is belangrijk om studenten in discussies niet te laten werken vanuit hun eigen casuïstiek. Er ontstaat dan te weinig diepgang. Het is juist nodig om met opdrachten op een gestructureerde manier een nieuwe ervaringsbasis uit te lokken bij studenten. Het is van belang om voorzichtig te zijn met het voortbouwen op individuele ervaring. De ervaringsbasis kan de perceptie van studenten remmen als ze geneigd zijn om interpretaties te maken in termen van wat ze al kennen. In dit kader is het van groot belang om studenten te vragen om hun argumentatie te onderbouwen met externe bronnen.

Om de discussies overzichtelijk te maken is het van belang om studenten te leren werken met koppen en nieuwe discussielijnen. Het is voor de controle belangrijk om gemakkelijk te kunnen natrekken wie wat geschreven heeft. Om goed samen te werken is het van belang om binnen of buiten Blackboard een werkplek voor de studenten in te richten, eventueel kunnen studenten onderling ook op eigen verantwoordelijkheid de mail of skype gebruiken.

Alle drie de experts reageren positief op de individuele aansprakelijkheid van studenten voor wat betreft de eindopdracht van de module. De motivatie hiervoor komt voort uit het feit dat de opleiding aan de maatschappij moet kunnen verantwoorden dat het individu goed is voorbereid op zijn taak. Een voordeel van individuele aansprakelijkheid is dat het de taakgerichtheid van studenten tijdens discussieopdrachten verhoogt en voorkomt dat er te veel voor het leerproces irrelevante berichten worden geplaatst. Twee van de drie experts betwijfelen of beoordeling van discussiebijdrages nodig en mogelijk is. Er zijn in hun ogen onvoldoende concrete richtlijnen voor de beoordeling van discussies. Eén van deze twee experts geeft aan dat het beter is om de discussiebijdrages als voorwaarde te stellen voor het behalen van het betreffende vak. De ander is van mening dat het dubbel werk is voor studenten als er naast een discussie ook nog een werkstuk geschreven moet worden om tot beoordeling te kunnen komen. De 
derde expert is van mening dat discussies wel beoordeeld moeten worden. Er moet daarbij streng omgegaan worden met kwalitatieve en kwantitatieve standaarden rondom discussies. Om studenten te helpen met het leren discussiëren volgens de normen moeten concrete voorbeelden gegeven worden van wat er verwacht wordt.

De experts zijn het onderling niet eens hoe groot de groepjes moeten zijn waarin samengewerkt wordt. Twee experts zien de groepjes graag klein: respectievelijk 23 of 2-4 personen. De derde expert heeft onderzoek gedaan naar dit onderwerp en stelt dat groepjes van 8-12 studenten werkbaar zijn. Er is dan sprake van meerdere perspectieven en de discussie is nog goed te volgen. Deze expert adviseert om te werken met de toekenning van specifieke rollen in de discussie en met verrassingseffecten (nieuwe informatie, nieuwe rollen). Daarnaast wordt geadviseerd de groepssamenstelling stabiel te houden gedurende de opleiding.

Met betrekking tot kenmerk 2; sociale interactie reageren twee experts positief, de derde expert heeft niet gereageerd op dit kenmerk. Het advies luidt om een fysieke kennismaking te organiseren bij de start zodat studenten elkaar leren kennen en al vast afspraken kunnen maken over de samenwerking. Ook een tussentijdse bijeenkomst en een gezamenlijke afsluiting worden aanbevolen. Er wordt bovendien geadviseerd om studenten duidelijk te maken dat MSN gebruik tussen studenten onderling een keuze is. MSN gebruik tussen docenten en studenten wordt niet verstandig geacht.

\section{Structuur}

De drie experts reageren positief tot zeer positief op het ontwerpcluster structuur. Een strakke structuur (kenmerk 3) vormt volgens hen een prettige manier van werken voor studenten. Studenten weten hierdoor duidelijk waar ze aan toe zijn en hebben op deze manier een helder beeld van de studielast. Een dergelijk rooster bestaat uit een tabel met taken en deadlines. Alle drie de experts adviseren om daarin een strakke indeling in studieweken te maken. Een goed rooster moet bovendien de samenhang tussen inhoud en opdrachten duidelijk maken. Het verplicht stellen van opdrachten en discussies zorgt ervoor dat studenten actief meedoen aan de discussies. Een strak rooster met deadlines en verplichtingen zorgt er voor dat studenten hun activiteiten inplannen, het voorkomt uitstelgedrag en maakt dat studenten zich vanaf het begin verantwoordelijk voelen voor hun onderwijs. Een strak rooster maakt bovendien parallel lopen met het contactonderwijs mogelijk. 
Twee van de drie experts reageerden op het onderwerp 'spreiding van de studielast' (kenmerk 4). Beiden waren positief. Zij vinden het belangrijk om de studiebelasting zeer goed te bewaken. Deze twee experts reageerden ook op kenmerk 5: helder geformuleerde leerdoelen en verwachtingen. Beide reacties waren zeer positief. Op afstand ontstaan snel onduidelijkheden. Duidelijkheid in het e-learning platform voorkomt heel veel e-mail verkeer. Het is essentieel om verwachtingen die de opleiding heeft van studenten zowel kwantitatief als kwalitatief te concretiseren.

\section{Docentrol}

De meest ervaren expert reageert positief op kenmerk 6, tijd en aanwezigheidsritme. Hij is van mening dat dit een belangrijk kenmerk is. Als studenten hun docent online te weinig zien, dan leveren ze daar veel kritiek op. Bij grote aantallen studenten kost het echter veel tijd om dit kenmerk adequaat te realiseren. Het is nodig om realistisch uit te rekenen hoeveel tijd dit kost en voldoende menskracht in te plannen. Het is belangrijk om naar studenten toe duidelijk te zijn over wat zij in dit opzicht van docenten kunnen verwachten.

Twee experts reageren op het onderwerp moderatie (kenmerk 7). Eén van hen reageert twijfelend en stelt dat docenten er wel gevoel voor moeten hebben. De ander (met het meeste ervaring) reageert positief en geeft aan dat het model van Gilly Salmon goed bevalt als richtlijn voor docenten.

De meest ervaren expert reageert op het kenmerk 'feedback' (kenmerk 8). Feedback is belangrijk omdat studenten het nodig hebben om te weten dat ze het goed doen. Het is van belang om studenten garanties te geven over reactietijden. De snelheid van de feedback lijdt onder de werkdruk van de docent. Het is dan ook van belang dat de docent niet met te veel studenten werkt zodat hij snel feedback kan geven. Ook kan de werkdruk verlicht worden door te werken met tutoren (student- assistenten).

Het kenmerk ondersteuning en advisering is in geen enkele van de interviews aan de orde geweest. Twee experts reageerden op het kenmerk vraagsturing en flexibiliteit (kenmerk 10), door aan te geven dat inspraak een belangrijk uitgangspunt is bij dit type modules. Het is volgens één van de experts goed om de module bij de start maar half vol aan te leveren. De studenten maken dan de verdere inhoud door actief literatuur te zoeken en daar iets bij te vertellen. Discussies kunnen dan spontaan ontstaan vanuit deze bijdrages. Flexibiliteit is ook belangrijk 
met betrekking tot de organisatie, op die manier kan beter worden aangesloten bij individuele behoeftes. Naast een strakke structuur is het nodig om te voorzien in enige flexibiliteit. Zo is het van belang om te zorgen dat alles klaar staat zodat de studenten vooruit kunnen werken als ze dat willen. Ook is het van belang om andere afspraken te kunnen maken met studenten als dat nodig mocht zijn.

Het kenmerk controle en activering (kenmerk 11) is aan de orde geweest in twee van de interviews. Éen van de experts geeft aan dat het is soms moeilijk te traceren wie wat bijgedragen heeft. De ander stelt dat het traceren en bijhouden van discussiebijdrages van belang is voor de beoordeling, maar dat het bijna alleen uitvoerbaar is in het kader van onderzoek.

Alle drie de experts reageren met enige twijfel op de synchrone spreekuren (kenmerk 12). Synchrone communicatie wordt als handig gezien bij buitenlandse stages en als een uitstekend middel om feedback te geven op uitgewerkte opdrachten. Het scheelt reistijd, en de combinatie van elkaar zien, opschrijven en zaken tonen in Breeze wordt als positief gezien. Een nadeel is dat het gecompliceerd is om een Breeze sessie op te zetten. Telefonische communicatie werkt gemakkelijker. Het is ook maar de vraag of studenten genoeg vragen hebben om zo'n spreekuur te vullen. Er bestaat het risico op meeliften door studenten die niets vragen maar wel meeluisteren. Als te veel studenten dat doen is er niets te bespreken. Onderwijskundig ziet één van de experts geen redenen voor de invoering van zo'n spreekuur. Hij ziet het bovendien als nadelig dat er geen documentatie is van wat er afgesproken wordt. De experts geven drie tips. De eerste tip is dat het ook mogelijk is om een wekelijks spreekuur te houden via skype of MSN, de vele mogelijkheden van Breeze worden meestal toch onvoldoende benut. Ten tweede moet er een concrete invulling zijn voor het spreekuur, en ten derde is het van belang om tijdens het spreekuur aantekeningen te maken en die te e-mailen naar de studenten.

Eén van de experts heeft specifiek gereageerd op het kenmerk sociale aanwezigheid van docenten (kenmerk 13). Hij vindt dat belangrijk en geeft aan dat docenten zich digitaal moeten voorstellen aan hun studenten. Hij vindt het van belang dat docenten communiceren via e-mail en telefoon, maar niet via MSN.

Twee experts hebben gereageerd op kenmerk 14: scholing van docenten. Beide reacties zijn positief. Scholing is in twee opzichten belangrijk in hun ogen. Enerzijds om de vaardigheid van (soms digibete) docenten op peil te brengen met 
betrekking tot de elektronische leeromgeving. Anderzijds om docenten te ondersteunen bij hun rol in de discussieruimtes. De scholing moet aansluiten bij de eerdere ervaringen van docenten. De experts bevelen daarnaast zowel ondersteuning on-the-job aan als intervisie gesprekken. De intervisie gesprekken dienen vooral om de online coachings-vaardigheden te optimaliseren.

\section{Leermaterialen}

De drie experts reageren unaniem positief op de rijke leeromgeving (kenmerk 15) en bevestigen dat de pilot module van oso e-learning inderdaad een rijke leeromgeving vertegenwoordigt. Zij bevestigen een goede samenhang tussen leermaterialen, discussieopdrachten en overige opdrachten. $\mathrm{Zij}$ geven aan dat het belangrijk is om de inhoud sterk te structureren en syllabi en artikelen digitaal aan te leveren. De meeste tips gaan over het werken met video's. Eén van de experts geeft aan dat het werken met streaming video omslachtig is. Het is belangrijk om filmpjes te comprimeren en dan pas te plaatsen. Hiervoor kan Moviemaker gebruikt worden. Het kan voor het plaatsen van video's zinvol zijn om Youtube of Surfmedia te gebruiken naast Blackboard. Video-materiaal moet niet vrijblijvend geplaatst worden maar moet altijd verankerd worden in een opdracht.

\section{Conclusie met betrekking tot de expert interviews}

De reacties van de experts bevestigen de grote lijn van de ontwerpclusters, hoewel één van de experts negatief reageerde op de asynchrone discussies en het samenwerkend leren. De sterke bevestiging van de overige twee experts (waarvan één zeer ervaren) was nodig om de leiding van OSO Windesheim te overtuigen van de haalbaarheid en de zin van het huidige ontwerp. Op een aantal fronten brengen de experts nuanceringen aan. Dit betekent vooral dat waakzaamheid geboden is met betrekking tot de belasting en de mogelijke handelingsverlegenheid van docenten. Het minst positief waren de reacties op de Breeze spreekuren. In de pilot modules zullen deze uitgeprobeerd worden om daarna een besluit te nemen over toepassing in de reguliere opleiding. Daarnaast hebben de interviews enige specifieke richtlijnen gegenereerd voor het formuleren van leerzame en motiverende opdrachten voor studenten. 


\section{HOOFDSTUK 4 \\ Resultaten van de pilotfase}

INLEIDING

De pilotfase nam een half schooljaar in beslag. Daarin werden twee volledige elearning modules uitgevoerd met elk een duur van acht weken. In dit hoofdstuk worden de onderzoeksresultaten uit de pilotfase besproken aan de hand van de hoofdvraag in deze fase: is het ontwerp bruikbaar in de e-learning leerroute master SEN? In deze fase van het onderzoek viel deze onderzoeksvraag uiteen in de volgende twee deelvragen: (1) zijn de verschillende ontwerpkenmerken realiseerbaar in de praktijk met studenten? (2) zijn de verschillende kenmerken van het ontwerp aantrekkelijk voor studenten? Op basis van de bevindingen zijn een aantal veranderingen in het ontwerp doorgevoerd die aan het eind van dit hoofdstuk besproken worden.

In paragraaf 4.1 wordt een kort overzicht gegeven van de opzet van het onderzoek in deze fase (zie voor een uitgebreidere bespreking paragraaf 2.3) . In paragraaf 4.2 worden de resultaten van het onderzoek met betrekking tot de bruikbaarheid per kenmerk besproken. In paragraaf 4.3 wordt de vraag beantwoord of de kenmerken aantrekkelijk bleken voor de pilotstudenten. In paragraaf 4.4 volgen per ontwerpcluster de conclusies en de consequenties voor het ontwerp.

\subsection{DE OPZET VAN HET ONDERZOEK IN DE PILOTFASE}

Op basis van de resultaten van het onderzoek in fase 1 (zie hoofdstuk 3) werden in Blackboard twee pilotmodules volledig uitgewerkt. Het betrof de modules 
“aanvankelijk lezen en spellen" en "voortgezet lezen en spellen" . Deze twee modules zijn uitgeprobeerd in twee achtereenvolgende moduleperiodes waarin gewerkt is met twee, respectievelijk drie studenten. Het was oorspronkelijk de bedoeling om de pilot te draaien met meer studenten, maar het bleek niet haalbaar om hiervoor meer vrijwilligers te werven uit de reguliere studentengroepen. De onderzoeker participeerde als e-learning docent. De onderzoeksfocus lag op de bruikbaarheid van het ontwerp.

Om de in de inleiding van dit hoofdstuk genoemde onderzoeksvragen te kunnen beantwoorden werden in het onderzoek de volgende stappen gezet:

- Verzamelen van alle studentbijdrages uit Blackboard en van student e-mails met feedback op de module.

- Onderverdelen van de Blackboard bijdrages van studenten in twee soorten: berichten die feedback bevatten en berichten in het kader van het leerproces

- Tellen van alle bijdrages uit de discussieruimtes van Blackboard per student, per module en per discussie.

- Vergelijken van de data waarop de studenten (eind) opdrachten uitvoerden met de voorgeschreven data in het rooster.

- Coderen van de berichten en e-mails die feedback bevatten (zie paragraaf 2.3).

- Coderen van de studentberichten die deel uit maken van het leerproces binnen de module. De berichten van studenten werden in aansluiting op de belangrijkste clusters van ontwerpkenmerken gecodeerd met de codes sociaal, cognitief en/of organisatorisch (zie het codeerschema in paragraaf 2.3).

- Afnemen van semi-gestructureerde interviews met de drie deelnemende studenten.

- Afnemen van vier vragenlijsten.

De realisatie van de docentrol (kenmerken 6-11 en 13,14) vormde in de pilotfase geen onderwerp van het onderzoek omdat de onderzoeker zelf als docent fungeerde. De ervaringen van de onderzoeker als e-learning docent vergemakkelijkten wel het schrijven van een praktische handleiding voor aanstaande e-learning docenten. In het onderzoek is de realisatie van kenmerk 12 wel meegenomen omdat de synchrone spreekuren afhankelijk waren van de deelname van studenten. 


\subsection{DE BRUIKBAARHEID VAN DE VERSCHILLENDE ONTWERPKENMERKEN IN DE PILOTFASE}

Kenmerk 1: Samenwerkend leren via asynchrone schriftelijke discussies

Uit de literatuur bleek dat studenten niet altijd gemakkelijk komen tot het leveren van bijdrages in asynchrone discussieruimtes. In het ontwerp zijn om die reden verschillende maatregelen opgenomen om er voor te zorgen dat studenten tot actieve deelname komen. Bij de aanvang van de pilot waren belangrijke vragen (1) of de studenten voldoende bijdrages zouden leveren en (2) of deze bijdrages taakgericht zouden zijn. Om deze vragen te kunnen beantwoorden zijn alle bijdrages van de studenten in Blackboard geteld. Daarna zijn de berichten geanalyseerd waarbij werd nagegaan of ze cognitief, sociaal of organisatorisch van aard waren. In tabel 4.1 wordt per student en per module aangegeven hoeveel berichten geplaatst werden en hoeveel van deze berichten cognitief van aard waren. Deze berichten werden gezien als taakgericht ten aanzien van het leerproces.

Tabel 4.1 Aantallen berichten

\begin{tabular}{lccccccc}
\hline & \multicolumn{2}{c}{ Student A } & \multicolumn{2}{c}{ Student B } & \multicolumn{2}{c}{ Student C } \\
& totaal & cognitief & totaal & cognitief & totaal & cognitief \\
\cline { 1 - 5 } Aanvankelijk lezen & 113 & 78 & 113 & 60 & - & - \\
Voortgezet lezen & 95 & 74 & 63 & 48 & 65 & 48 \\
\hline
\end{tabular}

In beide modules kwamen de studenten tot substantiële aantallen bijdrages, gemiddeld minimaal 8 en maximaal 16 per week. In de eerste module schreven de deelnemers 8 tot 10 cognitieve bijdrages per persoon per week. In de tweede module was dat tussen 6 en 9 cognitieve bijdrages per persoon per week. De vraag of studenten tot actieve deelname aan de discussieruimtes kunnen komen, is daarmee positief beantwoord. Ook de vraag of de studenten tot voldoende taakgerichte bijdrages kunnen komen, kan positief beantwoord worden. Wel blijkt dat in de tweede module het totaal aantal berichten per student sterk daalde ten opzichte van de eerste module. Positief is dat het aantal cognitieve bijdrages relatief minder sterk daalde.

In beide modules is geteld hoeveel bijdrages de studenten leverden per discussie. In de module Aanvankelijk lezen werden in totaal zes discussies gevoerd. Per discussie dienden de studenten drie bijdrages te leveren. Dit lukte in drie van de zes discussieopdrachten ruim en in de andere helft van de discussieopdrachten 
niet. Beide studenten droegen wel bij in alle discussies. De eerste discussieopdracht in deze module ging niet gemakkelijk van start. Binnen de voorgeschreven tijd kwam er per student één uitgebreide en volledig uitgewerkte reactie op de opdracht. Uit hun bijdrages in Blackboard bleek dat de studenten een opdracht wilden aanleveren die meteen helemaal goed was. Zij hadden niet begrepen dat het de bedoeling was om samen via een discussie tot een antwoord te komen. Dit bleek verholpen na een toelichting van de docent. Twee andere zaken ten aanzien van asynchrone discussies waaraan de studenten in deze eerste modules moesten wennen, waren de asynchroniciteit en het zoeken van berichten. De studenten begrepen niet meteen het principe van de asynchroniciteit. $\mathrm{Zij}$ voelden zich geroepen om meteen te reageren op ieder bericht zodat er in feite een vorm van synchrone communicatie ontstond. Beide studenten in de eerste module hadden moeite met het terugvinden van bijdrages die ze eerder gelezen hadden. Zij waren niet op de hoogte van de zoekmachine die hiervoor in Blackboard beschikbaar is.

In de module Voortgezet lezen werden in totaal vijf discussies gevoerd. Alle bijdrages kwamen binnen de daarvoor gestelde tijd. In drie discussies waren er voldoende bijdrages. In twee discussies was dat niet het geval, maar waren er wel meerdere bijdrages.

Beschouwing van de discussieopdrachten in beide modules leerden dat opdrachten die te open, te weinig concreet en te eenvoudig waren weinig uitnodigden tot discussie. Moeilijke opdrachten met concrete richtinggevende vragen leverden wel veel respons op. Het aansluiten op de actualiteit in de beroepspraktijk bleek eveneens stimulerend te werken.

Opdrachten tot samenwerkend leren die anders waren dan discussieopdrachten bleken veel organisatie te vergen van studenten. Een vrij groot aantal bijdrages van studenten bevatte dan ook organisatorische elementen die gericht waren op het organiseren van de samenwerking. In de module Aanvankelijk lezen waren dit rond de 25 bijdrages per persoon. In de module Voortgezet lezen waren dit rond de 15 bijdrages per persoon. Dit getalsmatige verschil tussen de twee modules kan gedeeltelijk verklaard worden vanuit het feit dat er in de module voortgezet lezen minder discussie- en samenwerkingsopdrachten waren. 


\section{Kenmerk 2: Sociale interactie}

De sociale interactie in de pilot module bleef beperkt. In de module Aanvankelijk lezen waarin twee studenten deelnamen, waren er in totaal 24 bijdrages die als 'sociaal' geclassificeerd werden. In totaal betrof dit 6\% van de bijdrages. In de tweede module (Voortgezet lezen) werden nog minder sociale bijdrages geleverd. Verdeeld over drie studenten betrof dit slechts 12 bijdrages (5\% van alle bijdrages). Het ontwerp kon niet volledig uitgevoerd worden in de pilot modules. Er was geen sprake van een fysieke kennismaking voorafgaand aan de modules en de studenten studeerden niet voor langere tijd samen in een cohort. Dit kan een verklaring vormen voor de kleine percentages sociale berichten in deze twee modules.

\section{Kenmerk 3: Strakke planning}

In de modules was sprake van een rooster met deadlines. In dit rooster waren alle discussieopdrachten, alle samenwerkingsopdrachten en de eindopdracht gepland. Uit analyse van de data waarop de bijdrages geleverd waren, bleek dat de studenten zich goed hielden aan deze planning. Alleen de eerste twee discussies in de eerste module gingen over de deadline heen. De studenten hadden nog niet goed begrepen wat er van hen verwacht werd ten aanzien van de discussiebijdrages. De overige discussies werden binnen de aangegeven tijd gevoerd. Alle overige samenwerkingsopdrachten werden ook binnen de tijd uitgevoerd. Alle drie de studenten slaagden er bovendien in om met behulp van de e-learning opdrachten het werk voor de eindopdracht te verspreiden over de moduleperiode, waarna zij hun eindopdracht(en) ruim op tijd inleverden. Uit de bijdrages in Blackboard en uit de e-mails van studenten kwam naar voren dat het de studenten in de beginfase soms moeite kostte om goed gebruik te maken van de verschillende planningsdocumenten. Naast de lijst met opdrachten per week hadden zij ook het rooster met de daar aan gekoppelde data nodig. Dit was niet alle studenten meteen duidelijk. Hierdoor ontstond rondom een vakantie wat verwarring over de deadlines.

\section{Kenmerk 4: Spreiding studielast}

Uit de interviews, de bijdrages van studenten op Blackboard en de e-mails komt naar voren dat de studielast van de module aanvankelijk lezen te hoog was en ongelijk verdeeld over de weken. In deze module werden week 1 en week 4 als erg druk ervaren. In week 1 werd dit volgens de studenten veroorzaakt door de combinatie van het moeten wennen aan e-learning en het behandelen van een 
moeilijk onderwerp. De studenten gaven aan dat de problemen in week 4 ontstonden door het samenvallen van verschillende deadlines van opdrachten die een hoge technische moeilijkheidsgraad hadden. Zo moest er onder meer een gemonteerd filmpje aangeleverd worden aan het einde van week 4 . De studenten hadden hier geen enkele ervaring mee waardoor dit veel tijd en moeite kostte. Daarnaast gaven de studenten aan dat ze zich in deze module vaak genoodzaakt voelden om direct te reageren als er een bijdrage verscheen, hetgeen bijdroeg aan de ervaren studielast.

In de tweede module profiteerden de studenten van hun gewenning aan elearning. Zij maakten een betere inschatting van de hoeveelheid werk en werden minder overvallen door de opdrachten. De studielast van de tweede module was ook beter uitgelijnd. Er waren minder discussie- en samenwerkingsopdrachten in opgenomen. De studenten hadden in deze module ook afgeleerd om meteen te reageren op nieuwe bijdrages. Hierdoor verminderde de ervaren studielast ten opzichte van de eerste module.

Ik heb het minder belastend gevonden de tweede module. ...... je weet ongeveer hoe het gaat en hoe het werkt. Je kunt een beetje inschatten van waar wat meer tijd naar uitgaat. Je plant het iets makkelijker, soms zelfs naar voren, dat je denkt dat doe ik alvast maar. Je wordt iets vrijer in het omgaan met de planning die je aangereikt krijgt en met alles eigenlijk.

Uit de interviews blijkt dat de studenten de studiebelasting in beide modules ervoeren als een continu aanwezige druk. Het goed inplannen van de eigen studietijd bleek noodzakelijk maar vergde gewenning. Zij planden vanwege de continue druk die uitging van deze wijze van studeren, zowel tijd in om te studeren, als tijd waarin de computer niet aan ging.

\section{Kenmerk 5: Helder geformuleerde leerdoelen en verwachtingen}

Bij het produceren van de module werd veel aandacht besteed aan het helder formuleren van de leerdoelen, de opdrachten en de verwachtingen met betrekking tot de uitvoering van de opdrachten. Toch werd in de Blackboard bijdrages aan de module aanvankelijk lezen nog 10 maal een vraag gesteld over de opdrachtformuleringen. In de module voortgezet lezen gebeurde dit 12 maal. Nadere bestudering van deze vragen leerde dat dit vooral vragen waren over de eisen die gesteld werden aan de eindopdracht. Een gedeelte van de vragen kwam voort uit de onbekendheid van één van de studenten met het document over de eindopdracht in de eerste module. Andere vragen kwamen voort uit een 
onduidelijke opdrachtformulering. Ook onzekerheid van de studenten speelde een rol. Zij wilden heel graag weten of zij het wel helemaal goed deden.

\section{Kenmerk 12: Synchrone spreekuren via Breeze}

Tijdens de twee pilotmodules werd wekelijks een synchroon spreekuur georganiseerd via Breeze. Rondom de synchrone spreekuren traden drie problemen op. Het eerste probleem was dat de student die vanuit Azië studeerde niet deelnam aan de spreekuren. Het afstemmen van de tijd was moeilijk door het tijdsverschil en bovendien had zij in eerdere situaties de vervelende ervaring opgedaan dat de communicatie zeer vertraagd verliep tussen Europa en Azië. Een tweede probleem werd veroorzaakt door het werken met VoIP. Het duurde meerdere spreekuren voordat de studenten zowel geluid hoorden als konden produceren tijdens het spreekuur. Eén van de studenten had tijdens dit proces erg veel moeite om de geluidsinstellingen op de eigen computer goed in te stellen. Een derde probleem was dat het moeilijk was om een tijdstip te vinden waarop zowel de docent als de studenten in Nederland tegelijkertijd online konden zijn. De meeste spreekuren werden maar door één van de studenten en de docent bijgewoond.

\section{Kenmerk 15: Rijke leeromgeving}

In de leeromgeving werd de uitleg van de docent ten dele overbodig gemaakt door een thematisch georganiseerde verzameling multimediale leerobjecten. Alle drie de studenten gaven in de interviews aan dat zij deze leerobjecten bestudeerd hadden. Een uitzondering daarop wordt gevormd door de gesproken powerpoints. Twee studenten gaven aan deze powerpoints niet gebruikt te hebben. De derde student werkte er wel mee.

Voor een ingewikkeld onderwerp uit week 1 van aanvankelijk lezen was alleen een powerpoint met geschreven en gesproken uitleg beschikbaar. Dit bleek voor beide studenten niet voldoende om tot begrip te komen van het betreffende onderwerp. Voor één van de studenten bracht een mondelinge uitleg via het synchrone Breeze spreekuur (zie kenmerk 12) uitkomst. Daarna is er voor gekozen om ter verheldering een duidelijke samenvatting op Blackboard te zetten met een interactief item waarin studenten kunnen testen of ze het goed begrepen hebben. Dit bracht uitkomst voor de student die van uit Azië werkte en niet deelnam aan het synchrone Breeze spreekuur. 


\subsection{AANTREKKELIJKHEID VOOR STUDENTEN}

Op basis van inhoudsanalyse van de semi-gestructureerde interviews en de feedback in Blackboard is nagegaan wat studenten als aantrekkelijk benoemden aan het studeren in deze leeromgeving, en wat zij minder aantrekkelijk vonden. Als kenmerken hieronder niet genoemd worden dan komt dit doordat de studenten deze niet expliciet aan de orde hebben gesteld in de interviews.

\section{Algemeen: leerzaamheid en tevredenheid}

In de interviews en in de feedback die via Blackboard werd gegeven kwam als omvattend thema naar voren dat de studenten de e-learning modules aantrekkelijk vonden vanwege de grote ervaren leeropbrengst. Alle drie de studenten oordeelden dat de online leeromgeving leerzamer was dan de gewone klassikale leeromgeving. Ze ervoeren dat de leeromgeving zeer uitnodigde tot een actief en autonoom leerproces en tot het participeren in elkaars leerprocessen.

Ik vind een heel belangrijk verschil dat je in de e-learning module veel meer bezig bent met wat jij wilt leren en wat jij belangrijk vindt. Je krijgt makkelijker antwoorden op je eigen vragen ook. Je wordt heel erg uitgenodigd om na te denken over waar andere mensen mee bezig zijn. Dat vind ik een heel groot voordeel ervan. Waardoor het ook veel meer diepgang krijgt volgens mij. Je zoekt dingen uit, je leest eens wat en dat heb je natuurlijk als je hier in Zwolle bent niet. Ik vind dat toch iets meer consumeren.

Enige ambivalentie omtrent het actieve leerproces kwam ook naar voren uit de interviews. Een actief en autonoom leerproces vergt veel zelfstandig werken en dat kost tijd. Door alle studenten werd deze manier van studeren als tijdrovender ervaren dan de gewone manier van studeren. Daar stond tegenover dat ze ervoeren dat ze meer leerden.

Het is meer werk, het kost meer tijd, maar je krijgt er ook meer voor terug.

De studenten gaven aan het einde van iedere module hun tevredenheid aan middels een rapportcijfer, beide modules kregen in alle gevallen het cijfer 8 of hoger. Hiermee gaven de studenten aan zeer tevreden te zijn over de e-learning pilot modules.

\section{Kenmerk 1: Samenwerkend leren via asynchrone schriftelijke discussies}

Het onderwerp waar de studenten het meest over spraken in de interviews was de asynchrone interactie in Blackboard. Alle drie de studenten gaven aan dat ze 
veel geleerd hadden van elkaar en dat de discussieopdrachten daarin de belangrijkste rol gespeeld hadden. Nadat zij geleerd hadden met dit soort opdrachten om te gaan werden deze als het meest leerzaam ervaren. De studenten waren het er mee eens dat de discussies verplicht waren omdat zij van mening waren dat anders niet iedereen gelijkwaardig en tijdig mee zou doen. Juist deze gelijkwaardige en tijdige deelname maakte de discussies voor hen zo waardevol.

De studenten waren enthousiast over de afwisseling in de opdrachten. Zij vonden ook de samenwerkings- en de peer feedback opdrachten zinvol en te behouden. Zij zagen wel dat daar, gemakkelijker dan bij de discussieopdrachten, een ongelijke inbreng kon ontstaan bijvoorbeeld op basis van verschillen in werkervaring. De studenten waren positief over de peer feedback opdrachten alhoewel zij het formuleren van peer feedback aanvankelijk niet gemakkelijk vonden. Het kunnen zien van elkaars video opnames werd als zeer positief ervaren. Eén van de studenten gaf ook aan dat het zien en horen van elkaar bijdroeg aan het ontstaan van groepsvorming.

De studenten zagen voor het leerproces grote voordelen aan de asynchroniciteit van de communicatie. Ze vonden het van belang om veel interactie te hebben en de vaart in de discussie te houden, zonder tot synchrone communicatie te vervallen. De asynchrone communicatie leidde ertoe dat de studenten kennisbronnen konden raadplegen en konden nadenken voordat zij reageerden. Hierdoor ontstond volgens de studenten meer diepgang dan in de reguliere les. Zij vonden het ook prettig om de reactie van alle studenten te kunnen zien, zodat zij ook mee konden profiteren van de leerprocessen van de anderen. Eén van de studenten gaf aan dat ze het fijn vond dat 'fouten maken mag' in de discussies, en dat ze het waardevol vond dat er openheid was voor kritiek binnen de discussies. Eén van de andere studenten gaf aan dat zij door deze wijze van communiceren, met communicatieruimte voor iedereen, meer tot haar recht kwam dan in de gewone les.

De studenten in de module aanvankelijk lezen waren enthousiast over het werken in hun groepje van twee personen. Eén van de studenten had bij een eerdere elearning ervaring gediscussieerd in groepen van achttien. Zij ervoer dit als onpersoonlijk en het werkte voor haar niet goed omdat ze te veel reacties moest lezen. Beide studenten vonden het ook beter voor de onderlinge band om in kleine groepjes te werken van maximaal vier personen. 


\section{Kenmerk 2: Sociale interactie}

Sociale interactie gaf aanleiding tot wisselende reacties in de interviews. Eén van de studenten gaf aan dat zij het zowel een voordeel als een nadeel vond dat elearning onpersoonlijker is. Als voordeel zag zij dat het neutraler is. Gevoelens jegens anderen spelen minder een rol waardoor meer gelijkwaardigheid ontstaat in de communicatie. Als nadeel zag zij dat e-learning ongezelliger is dan het volgen van een gewone opleiding. Eén van de andere studenten was aanvankelijk bang dat zij de groep zou gaan missen bij de e-learning. In de beginfase van de eerste module voelde zij dit ook inderdaad zo. De synchrone communicatie met de docent via Breeze compenseerde dit verlies aan sociale interactie enigszins. Later in de eerste module ervoer zij toch dat groepsvorming tot stand kwam, en dat deze compensatie niet meer nodig was.

vind ik een groep wel belangrijk. Maar hier was eigenlijk net zo goed een groep. Alleen anders. Je krijgt een verlangen dingen van elkaar te weten. In het begin is dat vooral je werksituatie. Dan daarna komen er wat persoonlijke dingen bij... Je ziet elkaar op video's...Je hoort elkaars stem. Er ontstaat toch wel een soort groepsgevoel, tenminste dat vond ik wel.

De derde student ervoer geen groepsgevoel. Zij schreef dit zelf toe aan het feit dat zij jonger was, minder werkervaring had en haar medestudenten niet kende. Zij dacht wel dat het groepsgevoel zou verbeteren als het groepje langer bij elkaar zou zijn.

\section{Kenmerk 3: Strakke planning}

De studenten ervoeren de leeromgeving als overzichtelijk en logisch opgebouwd. Ze waardeerden de lijst van opdrachten als belangrijk uitgangspunt voor het leren in de module. Deze opdrachten en de bijbehorende deadlines brachten structuur in het leren. Het bleek belangrijk voor de studenten dat de eindopdracht middels deze lijst in deelopdrachten was opgesplitst. Dit maakte het voor hen gemakkelijker om de eindopdracht op tijd af te krijgen. De studenten vertoonden echter wel ambivalentie op dit vlak. Zij ervoeren de continuïteit waarmee aan de samenwerkings- en discussieopdrachten moest worden gewerkt als een belasting en één van de studenten gaf aan dat zij de deadlines als stressvol ervoer, hoewel zij ook voelde dat ze de deadlines nodig had om de module te kunnen afronden.

\section{Kenmerken 6- 11 en 13,14: Docentrol}

De studenten noemden in de interviews vier kenmerken van de docentrol die zij aantrekkelijk en belangrijk vonden. De volgende twee kenmerken van het docentgedrag werden het vaakst genoemd: kenmerk 8: leerzame feedback en kenmerk 6: snelle feedback en reacties van de docent op vragen. Alle drie de 
studenten vonden dit belangrijk voor hun leerproces. De studenten vonden het bovendien belangrijk dat de docent inhoudelijk richting gaf in discussies (kenmerk 7: moderatie). Zij gaven aan dat dit leidde tot een verbetering van de kwaliteit van de discussies en van het leerproces. Daarnaast werd flexibiliteit (kenmerk 10) gewaardeerd. De vaste opdrachten en deadlines waren van belang om de eindstreep van de module te kunnen halen, maar de studenten waardeerden dat er (in overleg met de docent) flexibiliteit was qua inhoud en planning als zij dat nodig hadden. Eén van de studenten benadrukte de rol van de docent tijdens de fase van gewenning aan e-learning. Zij gaf aan dat het in deze fase belangrijk is dat de docent de studenten stimuleert tot het leveren van bijdrages. Zij benoemde daartoe twee manieren: het direct aansporen van studenten tot het leveren van bijdrages (kenmerk 11: controle en aanmoediging) en het reageren op bijdrages van studenten op een manier die laat zien dat hun bijdrages er toe doen (een aspect van kenmerk 7). Ook gaf zij aan het belangrijk te vinden dat de docent bij de aanvang van de elearning alert was op mogelijke gevoelens van eenzaamheid van de studenten. Dit zou een functie kunnen zijn van kenmerk 13: de sociale aanwezigheid van de docent. Eén kenmerk werd in de interviews niet genoemd: de organisatorische ondersteuning door de docent. De studenten bleken deze ondersteuning wel nodig te hebben blijkens de vragen die zij stelden over de planning en de eindopdrachten. Zij waardeerden de snelle reactie van de docent op deze vragen.

\section{Kenmerk 12: Synchrone spreekuren}

De synchrone communicatie werd niet als aantrekkelijk ervaren. Er was slechts één student heel trouw in de aanwezigheid tijdens alle synchrone spreekuren. In het interview gaf zij aan dat ook zij na de beginfase van de e-learning er de meerwaarde er niet meer zo van zag. Er was bij twee van de drie studenten sprake van weerstand om vaste tijdstippen te plannen voor Breeze. Het plannen van tijdstippen verhield zich voor hen niet goed tot het principe van tijdonafhankelijk studeren.

\section{Kenmerk 15: Rijke leeromgeving}

De studenten waarderen het uitdagende niveau van de aangeboden stof en de bruikbaarheid voor de beroepspraktijk. De twee studenten die eerder reguliere modules volgden bij Windesheim OSO gaven beide aan dat zij tijdens de elearning modules veel meer artikelen gelezen hadden dan in de reguliere modules. Zij suggereerden dat er in de reguliere colleges door de docent zo veel informatie wordt overgedragen dat veel minder eigen leeswerk nodig is. De traditionele collegestructuur lijkt in hun ogen het actief leren te belemmeren, waar de wijze van leren binnen e-learning het actief leren lijkt te bevorderen. 
In een bijeenkomst heb je een beetje meer dat consumerende gevoel van ik ga zitten en zeg het maar. Dat is heel onbewust. Je komt naar zo'n middag wel om weer wat te horen, weer wat te leren. Dat is binnen e-learning heel anders. Daar gebeurt van alles, allerlei verschillende dingen door elkaar en je leert er ook een heleboel van maar je hebt niet het gevoel dat dat de hoofdzaak is op dat moment. Dat gebeurt gewoon.

En als je hier (in Zwolle) bent, denk ik dat je meer dat gevoel hebt. Ik kom naar de klas en ik wil wat horen waardoor ik de volgende week er weer mee verder kan. Je moet er wel weer een week mee door. Als ik het vandaag niet op BB te weten kom, dan morgen wel. Dus die tijd die ertussen zit is veel korter, dus het hoeft niet allemaal. De (fysieke) schoolomgeving nodigt ook uit tot dat (consumerende) gevoel.

Toch miste één van de studenten de colleges ook. Zij gaf aan dat zij vooral de voorbeelden miste die gegeven worden en dat zij het prettig vindt om in colleges te horen wat de docent belangrijk vindt in de stof.

De leerobjecten die gebouwd zijn voor kennisoverdracht binnen de e-learning modules blijken het mogelijk te maken voor studenten om aan te sluiten bij hun leervoorkeuren. Alle drie de studenten waren heel enthousiast over het gebruik van de interactieve items en over de filmpjes.

Ja die (interactieve items) vind ik heel erg leuk om te doen. Daar ben ik helemaal gek op. Het heeft het effect van een computerspelletje. En je kan even kijken, o wat is wel goed. Ja ik vond het een heel goed punt!

Er was één student met een duidelijk auditieve leervoorkeur. Zij was enthousiast over de gesproken powerpoints. De twee andere studenten hebben deze niet gebruikt. Zij gebruikten in plaats daarvan gewone powerpoints met een geschreven script. Eén van deze studenten gaf het commentaar dat ze powerpoints oppervlakkig vindt en liever werkte met geschreven samenvattingen. Er waren een aantal van deze samenvattingen beschikbaar in de leeromgeving.

\subsection{CONCLUSIES EN GEVOLGEN VOOR HET ONTWERP}

Hieronder worden per cluster van ontwerpelementen de conclusies van het onderzoek in de pilotfase beschreven, alsmede de consequenties voor het ontwerp.

\section{Interactie (ontwerpkenmerken 1 en 2)}

De pilot modules maakten duidelijk dat het met een klein aantal studenten mogelijk is om asynchroon samenwerkend leren (kenmerk 1) binnen een strakke planning (kenmerk 3) te realiseren. De studenten toonden zich enthousiast over 
de asynchrone discussies. Deze werden als zeer leerzaam ervaren. Uit de vergelijking met de andere soorten samenwerkingsopdrachten bleek dat de discussies van de studenten het minste organisatie vergden, vaker leidden tot gelijkwaardige deelname en bovendien als het meest leerzaam beschouwd werden. Deze resultaten bevestigen de bevindingen van Haavind (2006) en Swan (2002) dat het moeilijker is om studenten online aan groepsprojecten te laten werken dan hen een asynchrone discussie te laten voeren, en dat voor studenten de asynchrone discussie tot een betere leerervaring leidt dan complexe groepsprojecten. Op grond hiervan werd besloten dat in de e-learning opleiding sterker de nadruk zou komen te liggen op discussieopdrachten. Er werd echter niet besloten om exclusief met discussieopdrachten te werken vanwege de waardering van de studenten voor de diversiteit in de opdrachten.

Het leren online discussiëren bleek voor studenten moeilijker dan verwacht. De deelnemende studenten waren aanvankelijk meer geneigd om hele opdrachten aan te leveren in plaats van bijdragen in een discussie. Op grond van deze beperkte ervaringen werd besloten om in de e-learning opleiding hier expliciet aandacht aan te besteden in de eerste module en bij de f2f uitleg bij de gezamenlijke start.

Uit de pilot bleek dat niet iedere discussieopdracht even aantrekkelijk was. Uit de expert interviews kwam het belang van aantrekkelijke discussieopdrachten al naar voren. Er werd door de experts aangegeven dat de onderwerpen werkelijk interessant dienden te zijn en intrinsiek motiverend voor studenten. In de literatuur wordt meermaals gesteld dat asynchrone discussies en samenwerkend leren bij voorkeur plaatsvinden rondom complexe authentieke praktijkproblemen (Brower, 2003; Cohen, 1994; Kirschner, Strijbos, Kreijns, \& Beers, 2004; Schellens \& Valcke, 2005). In de pilot modules bleek dat het niet altijd eenvoudig was om aan deze criteria te voldoen. Sommige opdrachten waren te open, te weinig concreet en te eenvoudig en daardoor niet intrinsiek motiverend. De kwaliteit van de discussieopdrachten vormde een aandachtspunt voor de modules van de elearning opleiding.

Noch de literatuur, noch de experts leverden eenduidige richtlijnen met betrekking tot de optimale groepsgrootte voor e-learning. Het werken in zeer kleine groepjes (2-3) personen bleek in de pilot modules goed tot zeer goed te bevallen. De studenten adviseerden in de interviews om de groepjes klein te houden. Om deze 
reden is er op basis van de pilot gekozen om in de eerste e-learning module van de volledige opleiding te werken met groepjes van $4-5$ studenten.

Ten aanzien van de sociale interactie (kenmerk 2) konden geen conclusies getrokken worden uit de pilot module. Aan een aantal randvoorwaarden voor sociale interactie kon binnen deze setting niet worden voldaan: de studenten studeerden niet voorlangere tijd samen en er was geen f2f kennismakingsbijeenkomst. De hoeveelheid sociale interactie bleef laag hoewel éen van de studenten toch meer sociale interactie ervoer dan zij verwacht had binnen deze opzet.

\section{Structuur (ontwerpkenmerken 3, 4, 5)}

$\mathrm{Na}$ enige gewenning hielden de studenten zich goed aan de voorgeschreven structuur (kenmerk 3) hoewel er soms problemen optraden doordat de studenten niet alle documenten gelezen hadden. Op grond hiervan werd besloten om in de eerste module van de e-learning opleiding de studenten expliciet te verzoeken om het rooster en de opdrachtenlijst uit te printen en naast hun computer te houden.

De spreiding van de studielast (kenmerk 4) werd in de eerste module minder goed gerealiseerd dan in de tweede. De studenten ondervonden hier hinder van in de eerste module. De duidelijkheid (kenmerk 5) van de eindopdrachten liet soms nog te wensen over. De studenten compenseerden dit door vragen te stellen aan de docent. Het zou problemen kunnen opleveren voor de werkdruk van docenten in de e-learning opleiding als veel meer studenten dergelijke vragen zouden gaan stellen. Zowel de spreiding van de studielast als de duidelijkheid van de opdrachten bleven dan ook aandachtspunten voor de volledige e-learning opleiding.

\section{Docentrol (ontwerpkenmerken 6-14)}

Het belang van op één na alle kenmerken van de docentrol werd bevestigd in de pilot. Het belang van de kenmerken 6 (reactiesnelheid), 7 (feedback) en 8 (moderatie) werd het vaakst genoemd. De synchrone Breeze spreekuren (kenmerk 12) riepen veel technische problemen op bij studenten en waren moeilijk te plannen. Zelfs de student die alle keren deelnam zag er de meerwaarde uiteindelijk niet meer van. Deze bevindingen sluiten aan bij de twijfels die door de experts geuit werden omtrent de opbrengst van dergelijke spreekuren en omtrent de technische complexiteit er van. In de literatuur werd ook duidelijk dat het plannen van tijdstippen voor synchrone communicatie de tijdonafhankelijkheid van e-learning doorbreekt (Brower, 2003; Carr-Chellman \& Duchastell, 2000; Milstead \& Nelson, 1998). Voor twee van de drie studenten in de 
pilot bleek dit een probleem. Op grond van deze bevindingen is besloten om de synchrone spreekuren te laten vervallen. De technische complexiteit met twee studenten was zo hoog dat een verveelvoudiging van deze problemen verwacht werd met een grotere groep. Daarnaast speelde ook een rol dat de tijdsafhankelijkheid niet aantrekkelijk was voor studenten en dat de inhoudelijke meerwaarde uiteindelijk als gering werd ingeschat.

\section{Leermaterialen (kenmerk 15)}

De studenten maakten actief gebruik van de leeromgeving. Zij waardeerden vooral de interactieve items en de filmpjes. De gesproken powerpoints werden door twee van de drie studenten niet gewaardeerd. Op grond hiervan werd besloten om voor de nieuwe e-learning modules meer interactieve items aan te maken. Het gebruik van filmpjes sprak vanzelf omdat deze ook in de reguliere opleiding vaak gebruikt worden. Nader onderzoek was nodig ten aanzien van de waarde van de gesproken powerpoints. Het maken van gesproken powerpoints is arbeidsintensief. Op basis van twee studenten was het echter nog niet duidelijk of de inspanningen op dit vlak beperkt konden worden. Wel was duidelijk dat het belangrijk was voor studenten om powerpoints met begeleidende geschreven tekst (script) ter beschikking te stellen naast de gesproken powerpoints. 


\section{HoOFDSTUK 5 \\ Resultaten implementatiefase: Interactie tussen studenten}

\section{INLEIDING}

De implementatiefase van het onderzoek besloeg 7 moduleperiodes van 8 weken, verspreid over twee schooljaren. Het onderzoek werd uitgevoerd bij de studenten uit de eerste twee cohorten van de opleiding (cohort 2007 met 39 studenten en cohort 2008 met 38 studenten). In dit hoofdstuk worden de resultaten van deze implementatie beschreven voor wat betreft het eerste ontwerpcluster: interactie tussen studenten. Deze interactie kende de volgende twee ontwerpkenmerken (zie ook hoofdstuk 3):

- Samenwerkend leren via asynchrone schriftelijke discussies (kenmerk 1).

- Sociale interactie (kenmerk 2).

In de pilot (zie hoofdstuk 4) bleek dat studenten even moesten wennen aan asynchrone discussies als centrale werkvorm, maar dat deze werkvorm daarna goed gerealiseerd werd en dat de studenten enthousiast waren over de mate waarin zij er van leerden. De sociale interactie werd in de pilot niet gerealiseerd zoals bedoeld was. De situatie met een grotere groep die over langere termijn samenwerkt zoals in de volledige opleiding het geval is, zou misschien een betere context voor dit ontwerpkenmerk kunnen bieden. In dit hoofdstuk wordt gerapporteerd over bruikbaarheid en waardering van deze twee ontwerpkenmerken binnen de volledige e-learning opleiding. De centrale onderzoeksvragen voor dit hoofdstuk zijn:

- Zijn de ontwerpkenmerken met betrekking tot de interactie bruikbaar binnen de opleiding?

- Hoe waarderen de studenten de onderlinge samenwerking?

- Met welke kenmerken hangt deze waardering samen? 
Voor het onderzoeksontwerp en de instrumenten wordt verwezen naar hoofdstuk 2 (paragraaf 2.4). In paragraaf 5.1 wordt gerapporteerd over de bruikbaarheid van de twee ontwerpkenmerken. Daartoe worden de resultaten van de verschillende onderzoeksinstrumenten afzonderlijk weergegeven. Als voor een onderwerp zowel kwantitatieve als kwalitatieve gegevens beschikbaar waren, zijn de kwantitatieve gegevens als eerste weergegeven. Aan het eind van de paragraaf volgt een samenvatting van de meer algemene tendensen. In paragraaf $5.2 \mathrm{wordt}$ de waardering besproken voor het ontwerpcluster 'interactie tussen studenten'. In paragraaf 5.3 wordt weergegeven welke aanpassingen met betrekking tot deze ontwerpkenmerken gedaan werden in het eerste implementatiejaar en welke aanpassingen nog zinvol lijken voor de toekomst.

\subsection{BRUIKBAARHEID}

Onder de bruikbaarheid van de ontwerpkenmerken wordt verstaan of de ontwerpkenmerken realiseerbaar en zinvol zijn binnen de opleiding. In de rapportage over de bruikbaarheid wordt ingegaan op vier onderwerpen:

- De hoeveelheid asynchrone berichten van studenten (kenmerk 1; paragraaf 5.1.1).

- De zin van asynchrone discussies voor het leerproces (kenmerk 1; paragraaf 5.1.2).

- De bruikbaarheid van de uitgangspunten omtrent sociale interactie (kenmerk 2; paragraaf 5.1.3).

- De knelpunten in de studentinteractie (kenmerken 1 en 2; paragraaf 5.1.4).

\subsubsection{Aantallen berichten in de leeromgeving}

De e-learning studenten werkten in kleine groepjes asynchroon aan discussie- en samenwerkingsopdrachten. Deze groepjes hadden in het eerste jaar (periode 1 tot en met 4) een omvang van vier tot acht studenten. In het tweede jaar (periode 5 tot en met 7) hadden de groepjes een omvang van vier tot tien studenten. Binnen de groepjes werden sommige opdrachten (met name peer feedback opdrachten) in twee- of drietallen uitgevoerd.

Een eerste manier om na te gaan of het gelukt is om voldoende interactie tussen studenten tot stand te brengen is het tellen van het aantal asynchrone berichten dat door studenten geschreven werd. Hiertoe zijn alle berichten (24.772) van de studenten uit cohort 1 en 2 geteld gedurende de looptijd van het onderzoek 
(zeven moduleperiodes). In tabel 5.1 worden gemiddeldes en standaarddeviaties weergegeven per student en per periode. De studenten van cohort 2 zijn een jaar later begonnen met hun studie dan de studenten van cohort 1 , daardoor ontbreken hun gegevens in de eerste vier moduleperiodes. Alle moduleperiodes duurden acht weken.

Tabel 5.1 Gemiddelde aantallen berichten per student per moduleperiode (acht weken)

\begin{tabular}{lcccccc}
\hline & \multicolumn{3}{c}{ Cohort 1 e-learning } & \multicolumn{3}{c}{ Cohort 2 e-learning } \\
Periode & $N$ & $X$ & $S D$ & $N$ & $X$ & $S D$ \\
\hline & & & & & & \\
2 & 39 & 126,1 & 67,61 & & & \\
3 & 30 & 100,3 & 44,35 & & & \\
4 & 31 & 100,6 & 54,91 & & & \\
5 & 26 & 63,0 & 31,10 & & 67,9 & 37,71 \\
6 & 24 & 79,4 & 41,79 & 38 & 78,6 & 26,75 \\
7 & 22 & 93,7 & 71,79 & 27 & 81,4 & 31,80 \\
\hline
\end{tabular}

Opvallend in tabel 5.1 zijn de hoge gemiddelde aantallen berichten. Om tot de kwalificatie "hoog" te komen zijn cijfers over aantallen asynchrone berichten in de discussiefora van andere opleidingen verzameld uit de literatuur. Deze cijfers zijn weergegeven in tabel 5.2. In de betreffende artikelen worden deze cijfers doorgaans genoemd in het kader van steekproeven voor kwalitatieve analyse. Niet altijd wordt het aantal betrokkenen exact vermeld. De contexten van de onderzoeken verschillen ook op een aantal vlakken: het onderwerp van studie, de rol van afstand (blended learning of volledig afstandsleren), de (in)activiteit van docenten, sociale activiteiten, de formulering van de opdracht en de leeftijd en het geslacht van de participanten. Dit bemoeilijkt de vergelijkbaarheid van de cijfers. Toch wordt uit de tabel wel duidelijk dat in de OSO e-learning omgeving gedurende een lange looptijd hoge aantallen berichten per student gerealiseerd zijn. 


\begin{tabular}{|c|c|c|c|c|c|c|}
\hline Bron & $\begin{array}{c}\text { Aantal } \\
\text { betrokken } \\
\text { studenten }\end{array}$ & $\begin{array}{c}\text { Totaal } \\
\text { aantal } \\
\text { berichten }\end{array}$ & $\begin{array}{c}\text { Gesteld } \\
\text { minimum } \\
\text { aantal } \\
\text { bijdrages } \\
\text { per } \\
\text { discussie }\end{array}$ & $\begin{array}{l}\text { Looptijd } \\
\text { per } \\
\text { discussie }\end{array}$ & $\begin{array}{c}\text { Effectieve } \\
\text { looptijd } \\
\text { onderzoek }\end{array}$ & $\begin{array}{c}\text { Gemiddeld } \\
\text { aantal } \\
\text { berichten } \\
\text { per student } \\
\text { per week }\end{array}$ \\
\hline $\begin{array}{l}\text { Huidig } \\
\text { onderzoek }\end{array}$ & 77 & 24.772 & 3 & $\begin{array}{c}1-1,5 \\
\text { week }\end{array}$ & $\begin{array}{l}14 \text { maan- } \\
\text { den }\end{array}$ & 10,7 \\
\hline $\begin{array}{l}\text { Ho \& Swan, } \\
2007\end{array}$ & 15 & 512 & 2 & 2 weken & 2,5 maand & 3,4 \\
\hline Jeong, 2006 & 32 & 786 & 4 & 1 week & $\begin{array}{l}2 \text { maan- } \\
\text { den }^{* * *}\end{array}$ & 6,2 \\
\hline $\begin{array}{l}\text { Schellens \& } \\
\text { Valcke, } 2005\end{array}$ & $80^{*}$ & $1428^{* *}$ & 2 & 3 weken & $\begin{array}{c}3 \text { maan- } \\
\text { den }\end{array}$ & 1,5 \\
\hline Jeong, 2003 & $8^{*}$ & 208 & 8 & 4 weken & 1 maand & 6,5 \\
\hline
\end{tabular}

Noot: * Het totale cohort was groter, dit zijn de participanten waarvan de berichten werden geteld. Het betreft een schatting van het aantal studenten op basis van de verstrekte gegevens; ** Het totaal aantal berichten lag in werkelijkheid lager omdat sommige berichten door de onderzoekers voor inhoudsanalyse werden gesplitst in meerdere berichten; ${ }^{* * *}$ Gemiddeld aantal discussies per student: 3,94.

Gemiddeld haalden de e-learning studenten in het huidige onderzoek ruimschoots het minimale aantal van drie bijdrages per discussie. In sommige periodes waren de standaarddeviaties in cohort 1 echter zeer hoog. Sommige studenten namen zeer frequent deel en anderen hebben de minimumnorm niet gehaald.

Voor beide cohorten is met variantie analyse voor herhaalde metingen nagegaan of de verschillen tussen de opeenvolgende moduleperiodes significant waren. Voor cohort 1 werd de Greenhouse-Geisser correctie toegepast omdat Mauchly's test significant bleek te zijn $(p<0,001, \varepsilon=0,38)$. De gecorrigeerde analyse maakte duidelijk dat de verschillen in aantallen berichten tussen de moduleperiodes significant waren, $F(2,28 ; 43,36)=9,70, p<0,001, \eta_{p}{ }^{2}=0,34$.

Met behulp van toetsing van contrasten is er een vergelijking gemaakt tussen de aantallen berichten in opeenvolgende moduleperiodes. In drie gevallen bleken er significante verschillen tussen de aantallen bijdrages te bestaan. In de overige gevallen waren de verschillen $\eta_{p}^{2}$ net niet significant. In tabel 5.3 worden $F$ waardes, $p$ waardes en effectgroottes $\eta_{p}^{2}$ weergegeven voor de verschillen tussen de opeenvolgende moduleperiodes. 
Tabel 5.3 Cohort 1: verschillen tussen aantallen berichten in opeenvolgende moduleperiodes

\begin{tabular}{lccc}
\hline $\begin{array}{l}\text { Vergeleken } \\
\text { moduleperiodes }\end{array}$ & $\boldsymbol{F}$ & $\boldsymbol{p}$ & $\begin{array}{c}\text { Effectgrootte } \\
\boldsymbol{\eta}^{2}\end{array}$ \\
\hline 1 versus 2 & 9,85 &, $005^{* *}$ & 0,34 \\
2 versus 3 & 1,34 &, 261 & 0,07 \\
3 versus 4 & 24,83 &, $000^{* * *}$ & 0,57 \\
4 versus 5 & 3,56 &, 074 & 0,16 \\
5 versus 6 & 3,45 &, 079 & 0,15 \\
6 versus 7 & 5,57 &, $029^{*}$ & 0,23 \\
\hline
\end{tabular}

Noot: $\quad{ }^{*} p<0,05,{ }^{* *} p<0,01,{ }^{* * *} p<0,001$.

Uit de tabellen 5.1 en 5.3 blijkt dat de mate van deelname aan de asynchrone communicatie in cohort 1 instabiel was. Dit wordt zichtbaar door de grote standaarddeviaties (zie tabel 5.1) en door de effectgroottes van de verschillen tussen respectievelijk periodes 1 en 2 , periodes 3 en 4 en periodes 6 en 7 . In alle gevallen traden dalingen op van de aantallen berichten.

Voor de variantie analyse voor herhaalde metingen in cohort 2 bleek geen correctie nodig. Er was voldaan aan de voorwaarde van sphericiteit $(\varepsilon=0,94)$. Uit de variantie analyse bleek dat er geen significante verschillen waren in aantallen berichten tussen de verschillende moduleperiodes.

De aantallen bijdrages van cohort 2 bleken over hun eerste drie moduleperiodes veel stabieler dan de aantallen bijdrages van cohort 1 . Dit bleek zowel uit de grootte van de standaarddeviaties als uit de toetsen voor sphericiteit en de variantie analyses. Met de $t$-toets voor onafhankelijke steekproeven is nagegaan of er significante verschillen waren tussen cohort 1 en 2 in moduleperiodes 5, 6 en 7. Dit bleek niet het geval. De conclusie lijkt gerechtvaardigd dat de studenten in cohort 2 meteen vanaf de aanvang van hun studie (in moduleperiode 5) op een stabiele manier normale aantallen bijdrages leverden aan de discussies waar de hoge aantallen bij de start van cohort 1 beginperikelen van dit cohort lijken te reflecteren.

\subsubsection{De zin van asynchrone discussies voor het leerproces}

Verschillende instrumenten zijn gebruikt om na te gaan of de samenwerking via asynchrone discussies zin had voor het leerproces. De studenten beoordeelden de leerzaamheid van de discussies en de samenwerkingsopdrachten. Daarnaast werd gevraagd in hoeverre hun begrip van de literatuur verbeterde door de asynchrone discussies. Ook werd nagegaan of de studenten steun van elkaar ondervonden voor hun leerproces. Via kwalitatieve analyse werd bepaald welk 
percentage van de berichten van de vijf random geselecteerde studenten direct verband hield met het leerproces. In de interviews gaven de docenten hun mening over de zin van deze werkwijze voor het leerproces van de studenten.

\section{Leerzaamheid van de asynchrone discussies en de samenwerkingsopdrachten}

Nagegaan is in hoeverre de studenten van mening waren dat de asynchrone discussies en samenwerkingsopdrachten een positieve bijdrage leverden aan hun leerproces. Hiertoe is in de vragenlijst naar de leerzaamheid van de onderdelen van de e-learning modules gevraagd om de leerzaamheid van de asynchrone werkvormen met een rapportciffer te waarderen. Onder 'leerzaamheid' wordt verstaan: de mate waarin de student meent dat hij / zij leert van de discussie. Hieronder (tabel 5.4) wordt per moduleperiode en per cohort weergegeven met welk rapportcijfer (1-10) de studenten de leerzaamheid van deze samenwerkingsaspecten gemiddeld waardeerden.

Tabel 5.4 Leerzaamheid van de asynchrone discussies en samenwerkingsopdrachten

\begin{tabular}{|c|c|c|c|c|c|c|c|c|c|c|}
\hline \multirow{4}{*}{$\begin{array}{l}\text { Cohort } \\
N\end{array}$} & \multirow{2}{*}{\multicolumn{2}{|c|}{$\begin{array}{c}\text { Periode } 2 \\
1\end{array}$}} & \multicolumn{4}{|c|}{ Periode 6} & \multicolumn{4}{|c|}{ Periode 7} \\
\hline & & & \multirow{2}{*}{\multicolumn{2}{|c|}{$\begin{array}{c}1 \\
19\end{array}$}} & \multirow{2}{*}{\multicolumn{2}{|c|}{$\begin{array}{c}2 \\
23\end{array}$}} & \multirow{2}{*}{\multicolumn{2}{|c|}{$\begin{array}{c}1 \\
13\end{array}$}} & \multirow{2}{*}{\multicolumn{2}{|c|}{$\begin{array}{c}2 \\
11\end{array}$}} \\
\hline & & & & & & & & & & \\
\hline & $X$ & $S D$ & $X$ & $S D$ & $X$ & $S D$ & $X$ & $S D$ & $X$ & $S D$ \\
\hline $\begin{array}{l}\text { 1. De discussies binnen je } \\
\text { groepje }\end{array}$ & 7,6 & 1,50 & 7,6 & 1,39 & 7,6 & 1,24 & 7,7 & 0,63 & 7,7 & 0,79 \\
\hline $\begin{array}{l}\text { 2. De discussiebijdragen van } \\
\text { de medestudenten in je } \\
\text { groepje }\end{array}$ & 7,6 & 1,20 & 7,6 & 1,50 & 7,5 & 1,44 & -* $^{*}$ & & -* & \\
\hline $\begin{array}{l}\text { 3. De samenwerkingsopdrach- } \\
\text { ten binnen je groepje }\end{array}$ & 7,5 & 0,99 & 7,7 & 1,20 & 7,5 & 1,00 & 6,9 & 0,99 & 7,3 & 1,06 \\
\hline
\end{tabular}

Noot: $\quad$ *In periode 7 werd de vragenlijst ingekort, deze vraag werd toen niet gesteld.

In tabel 5.4 wordt zichtbaar dat de studenten de asynchrone discussies en de asynchrone samenwerkingsopdrachten gemiddeld als zeer leerzaam beschouwden. In periodes 2 en 6 zijn de standaarddeviaties met betrekking tot de leerzaamheid van de discussiebijdragen hoog. Dit betekent dat de studenten sterk van mening verschilden op dit punt. Dit is niet het geval in periode 7. In periode 7 scoorden de samenwerkingsopdrachten wat lager dan de discussieopdrachten. Dit was het duidelijkst in cohort 1.

Met behulp van variantie analyse voor herhaalde metingen is nagegaan of er significante verschillen waren tussen de cijfers voor de samenwerkingsopdrachten (item 3 in tabel 5.4) tussen de opeenvolgende moduleperiodes. 
Correctie voor sphericiteit bleek niet nodig. Voor cohort 1 zijn de verschillen tussen de moduleperiodes significant, $F(2 ; 16)=5,0, p<0,05, \eta_{p}{ }^{2}=0,38$. Uit de toetsing van contrasten tussen de achtereenvolgende moduleperiodes blijken geen significante verschillen tussen periodes 2 en 6 . Het verschil tussen de periodes 6 en 7 is wel significant $(p<0,05)$ en de effectgrootte is groot, $\eta_{p}^{2}=0,42$. Voor cohort 2 blijkt het verschil tussen moduleperiode 6 en 7 niet significant.

Uit de $t$-toets voor onafhankelijke steekproeven blijkt dat de rapportcijfers voor de leerzaamheid van samenwerkingsopdrachten van cohort 1 en 2 niet significant van elkaar verschillen. Omdat er voor de eerste twee items in tabel 5.4 niet of nauwelijks verschillen zijn geconstateerd tussen de periodes en de cohorten zijn er verder geen variantie analyses en $t$-toetsen uitgevoerd.

Asynchrone discussies en begrip van de literatuur

In de vragenlijst 'Samenwerking met medestudenten' kwam een item voor dat studenten vroeg naar de leerzaamheid van de verplichte discussies. Het item luidde als volgt: 'Door mee te doen aan de verplichte discussies is mijn begrip van de gelezen literatuur verdiept'. Dit item werd gescoord op een 3-puntsschaal (1=nee, 2=gaat wel, 3=ja). In tabel 5.5 zijn de gemiddelde scores en standaarddeviaties weergegeven per moduleperiode.

Tabel 5.5 De invloed van asynchrone discussie op begrip van de literatuur

\begin{tabular}{|c|c|c|c|c|c|c|c|c|c|c|c|c|c|c|c|}
\hline \multirow{2}{*}{\multicolumn{2}{|c|}{$\begin{array}{c}\text { Periode } 1 \\
\text { Cohort } 1 \\
N=22\end{array}$}} & \multirow{2}{*}{\multicolumn{2}{|c|}{$\begin{array}{c}\text { Periode } 2 \\
\text { Cohort } 1 \\
N=26\end{array}$}} & \multirow{2}{*}{\multicolumn{2}{|c|}{$\begin{array}{c}\text { Periode } 3 \\
\text { Cohort } 1 \\
N=22\end{array}$}} & \multirow{2}{*}{\multicolumn{2}{|c|}{$\begin{array}{c}\text { Periode } 4 \\
\text { Cohort } 1 \\
N=16\end{array}$}} & \multicolumn{4}{|c|}{ Periode 6} & \multicolumn{4}{|c|}{ Periode 7} \\
\hline & & & & & & & & \multicolumn{2}{|c|}{$\begin{array}{c}\text { Cohort } 1 \\
N=19\end{array}$} & \multicolumn{2}{|c|}{$\begin{array}{c}\text { Cohort } 2 \\
N=23\end{array}$} & \multicolumn{2}{|c|}{$\begin{array}{c}\text { Cohort } 1 \\
N=13\end{array}$} & \multicolumn{2}{|c|}{$\begin{array}{c}\text { Cohort } 2 \\
N=11\end{array}$} \\
\hline$X$ & $S D$ & $X$ & $S D$ & $X$ & $S D$ & $X$ & $S D$ & $X$ & $S D$ & $X$ & & $X$ & & $X$ & $S D$ \\
\hline 2,7 & & & & & & & & 2,9 & 0,32 & 3,0 & & & 0,3 & 2,9 & 0,0 \\
\hline
\end{tabular}

Uit deze tabel blijkt dat de gemiddelde score in alle gevallen ruim boven de 2,5 ligt. Dit betekent dat de studenten aangeven dat hun begrip van de literatuur door de discussies is verbeterd. Dit geeft nadere invulling aan het begrip 'leerzaamheid van discussies'. Uiteraard kunnen in de leerzaamheid van discussies ook nog andere aspecten een rol spelen zoals bijvoorbeeld de integratie van theorie en praktijk. Omdat er nauwelijks verschillen zijn tussen de periodes en de twee cohorten zijn geen nadere analyses uitgevoerd. 


\section{Onderlinge steun voor het leerproces}

Om na te gaan of de studenten steun van elkaar ondervonden bij het leerproces werd de schaal 'steun voor het leerproces' afgenomen. De drie items in deze schaal werden gescoord op een 3 - puntsschaal ( $1=$ nee, $2=$ gaat wel, $3=j a)$. In tabel 5.6 zijn per moduleperiode de gemiddeldes en standaarddeviaties weergegeven voor de verschillende cohorten. Het reguliere cohort is opgenomen ter vergelijking. Het leek in verband met de afstand en de potentiële eenzaamheid van e-learners gewenst dat zij even goed of beter zouden scoren dan reguliere studenten met betrekking tot de onderling ervaren steun voor het leerproces.

Tabel 5.6 Steun van medestudenten voor het leerproces

\begin{tabular}{lccccccccc}
\hline & \multicolumn{3}{c}{ Cohort 1 e-learning } & \multicolumn{3}{c}{ Cohort 1 regulier } & \multicolumn{3}{c}{ Cohort 2 e-learning } \\
periode & $N$ & $X$ & $S D$ & $N$ & $X$ & $S D$ & $N$ & $X$ & $S D$ \\
\hline & & & & & & & & & \\
1 & 22 & 2,7 & 0,36 & & & & & & \\
2 & 26 & 2,9 & 0,18 & 20 & 2,7 & 0,46 & & & \\
3 & 22 & 2,6 & 0,67 & 7 & 2,4 & 0,59 & & & \\
4 & 16 & 2,2 & 0,60 & 16 & 2,6 & 0,41 & & & \\
6 & 19 & 2,7 & 0,53 & & & & 23 & 2,7 & 0,40 \\
7 & 13 & 2,8 & 0,32 & & & & 11 & 2,8 & 0,31 \\
\hline
\end{tabular}

In de meeste gevallen lag de gemiddelde score boven de 2,5. Dit geeft aan dat reguliere- en e-learning studenten bevestigden dat zij steun ondervonden van medestudenten voor hun leerproces. In periode 4 ondervonden de e-learners minder steun voor hun leerproces van elkaar. De gemiddelde score lag dicht bij 2: 'gaat wel'.

Middels variantie analyse voor herhaalde metingen is nagegaan of de verschillen tussen de periodes significant waren voor e-learning cohort 1. De GreenhouseGeisser correctie is gebruikt vanwege de lage $\varepsilon(=0,37)$. Het resultaat laat zien dat de verschillen tussen de moduleperiodes inderdaad significant zijn, $F(1,9$; $9,4)=4,5, \quad p<0,05, \eta_{p}^{2}=0,47$. In tabel 5.7 worden $F$ waardes, $p$ waardes en effectgroottes weergegeven voor de verschillen tussen de opeenvolgende moduleperiodes. 
Tabel 5.7 Cohort 1: verschillen in ervaren steun voor het leerproces

\begin{tabular}{lccc}
\hline $\begin{array}{l}\text { Vergeleken } \\
\text { moduleperiodes }\end{array}$ & $\boldsymbol{F}$ & $\boldsymbol{p}$ & $\begin{array}{c}\text { Effectgrootte } \\
{ }^{2}{ }^{2}\end{array}$ \\
\hline 1 versus 2 & 0,63 & 0,47 & 0,11 \\
2 versus 3*** & - & - & - \\
3 versus 4 & 13,91 & $0,01^{*}$ & 0,74 \\
4 versus 6 & 4,41 & 0,09 & 0,47 \\
6 versus 7 & 1,00 & 0,36 & 0,17 \\
\hline
\end{tabular}

Noot: $\quad{ }^{*} p<0,05,{ }^{* *} p<0,01,{ }^{* * *} p<0,001$; ${ }^{* * * *}$ Sum of squares $=0$.

Alleen het verschil tussen de periodes 3 en 4 van cohort 1 bleek significant. In periodes 2 en 3 hadden de e-learners in cohort 1 gemiddeld een hogere score dan de reguliere studenten. In periode 2 was dit verschil significant $t(23 ; 55)=2,25$, $p<0,05, r=0,42$. In periode 3 was dit verschil niet significant. In periode 4 scoorden de reguliere studenten hoger dan de e-learning studenten. Dit verschil was significant $t(30)=2,31, p<0,05, r=0,39$. In de periodes 6 en 7 scoorden de e-learners stabiel hoog. Er werden met de $t$-toets voor onafhankelijke steekproeven geen significante verschillen gevonden tussen cohort 1 en 2 e-learning.

\section{Cognitieve berichten in de leeromgeving}

Het primaire doel van de asynchrone discussies was om een bijdrage te leveren aan het leerproces van de studenten. Dit betekende dat er een overwicht aan cognitief georiënteerde bijdrages zou moeten zijn in Blackboard. Om een beeld te krijgen van de aard van de berichten is een inhoudsanalyse uitgevoerd. Het was vanwege de grote aantallen berichten niet haalbaar om alle berichten te analyseren. Er is voor gekozen om van vijf random geselecteerde studenten uit cohort 1 alle berichten te analyseren in moduleperiode 1. In moduleperiode 7 studeerden vier van deze vijf studenten nog en zijn de berichten van deze vier studenten geanalyseerd. Op deze wijze ontstond een beeld van de aard van de berichten bij de start en aan het eind van de studie.

In totaal zijn 1158 berichten geanalyseerd: alle 895 berichten van de vijf studenten in de eerste moduleperiode en alle 263 berichten van de vier studenten in de laatste moduleperiode. In figuur 5.1 is per student en per periode weergegeven hoeveel berichten werden geschreven in de Blackboard discussieruimtes. 


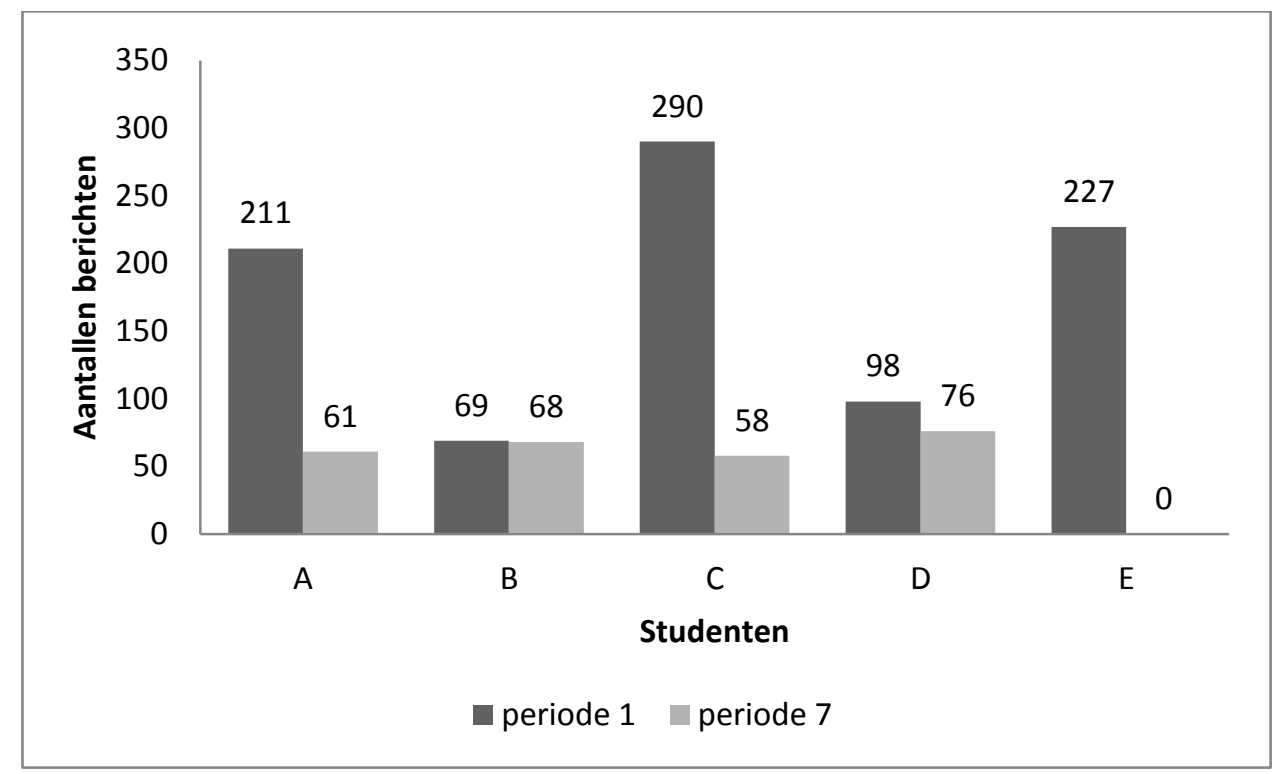

Figuur 5.1 Aantallen berichten per student (A,B,C,D en E) per moduleperiode van 8 weken

De inhoud van de berichten werd geanalyseerd door te coderen in drie categorieën: cognitief, sociaal en organisatorisch. Ieder van de drie codes kon per bericht maximaal één keer worden toegekend. Per bericht konden maximaal drie verschillende codes toegekend worden. In tabel 5.8 is per moduleperiode en per student het aantal cognitieve codes weergegeven. Per periode is op basis van het aantal opdrachten in de betreffende module uitgerekend hoeveel cognitieve bijdrages er minimaal hadden moeten zijn. Op deze manier kan nagegaan worden of voor deze vijf studenten de werkwijze voldoende cognitieve interactie genereerde. In de tabel is bovendien het gemiddeld aantal cognitieve bijdrages per week weergegeven. Hiertoe werd het totaal aantal cognitieve codes per module gedeeld door 8 omdat alle moduleperiodes 8 weken in beslag nemen.

Tabel 5.8 Inhoud van de berichten in periode 1 en 7: aantallen toegekende codes

\begin{tabular}{lcccc}
\hline Periode & Student & $\begin{array}{c}\text { Aantal } \\
\text { berichten }\end{array}$ & $\begin{array}{c}\text { Aantal } \\
\text { cognitieve codes }\end{array}$ & $\begin{array}{c}\text { Gemiddeld } \\
\text { cognitief per week }\end{array}$ \\
\hline Periode 1 & $\mathrm{A}$ & 211 & 74 & 9,3 \\
Minimaal 33 & $\mathrm{B}$ & 69 & 37 & 4,6 \\
bijdrages & $\mathrm{C}$ & 290 & 138 & 17,3 \\
& $\mathrm{D}$ & 98 & 53 & 6,6 \\
& $\mathrm{E}$ & 227 & 63 & 7,9 \\
\hline Periode 7 & $\mathrm{A}$ & 61 & 25 & 3,1 \\
Minimaal 22 & $\mathrm{B}$ & 68 & 42 & 5,3 \\
bijdrages & $\mathrm{C}$ & 58 & 49 & 6,1 \\
& $\mathrm{D}$ & 76 & 34 & 4,3 \\
\hline
\end{tabular}


Alle studenten haalden in beide modules het minimale aantal cognitieve bijdrages dat geleverd moest worden. Dit wijst op de bruikbaarheid van de interactiekenmerken voor de opleiding. In moduleperiode 1 waren er zeer grote verschillen tussen studenten en werden er in totaal zeer veel cognitieve bijdrages geleverd. Eén student (B) haalde net het voorgeschreven aantal bijdrages terwijl student $C$, die de meeste bijdrages leverde, 8,8 keer zoveel bijdrages schreef als minimaal vereist was. In moduleperiode 7 waren deze verschillen veel minder groot. Student A overschreed nauwelijks het minimum aantal cognitieve bijdrages. De student met de meeste bijdrages leverde 2,2 keer het minimum aantal bijdrages.

Naast het aantal berichten is ook gekeken naar de omvang van de tekstsegmenten die gecodeerd werden met de code cognitief. In tabel 5.9 is voor de studenten waarvan in moduleperiodes 1 en 7 de bijdrages kwalitatief geanalyseerd zijn, weergegeven hoeveel procent van de woorden gecodeerd werden met de code 'cognitief'.

Tabel 5.9 Omvang van de verschillende soorten tekstsegmenten: aantallen woorden

\begin{tabular}{llll}
\hline Periode & $\boldsymbol{N}$ & Aantal woorden & Cognitief \\
\hline Periode 1 & 5 & 117.045 & $71 \%$ \\
Periode 7 & 4 & 30.382 & $80 \%$ \\
\hline
\end{tabular}

Uit de tellingen van woorden blijkt dat de cognitieve uitwisseling een groot percentage besloeg van de interactie. Dit is in overeenstemming met het ontwerp van de leeromgeving. Opvallend is het zeer grote aantal woorden dat door de vijf studenten is bijgedragen in periode 1 . Uitgaande van 400 woorden per A4, is dit het equivalent van ruim 292 pagina's A4. Daarbij zijn de bladzijdes van de ingeleverde werkstukken niet meegeteld.

\section{De zin van online samenwerkend leren in de ogen van docenten}

In het eerste implementatiejaar werden zeven e-learning docenten geïnterviewd nadat zij voor het eerst een e-learning module hadden gegeven. In het onderstaande wordt samengevat wat zij gezegd hebben over de vraag of de discussies, de samenwerkingsopdrachten en de peer feedback opdrachten leidden tot leerprocessen bij studenten. Per uitspraak wordt weergegeven hoeveel docenten de betreffende mening waren toegedaan. 
Alle zeven docenten gaven aan dat e-learning leidde tot leerprocessen op masterniveau bij de studenten. Zes docenten waren van mening dat het voor de meeste studenten binnen de e-learning leeromgeving mogelijk is om de master SEN competenties te behalen. De zevende docent gaf aan dat zij dit alleen haalbaar achtte voor bovengemiddeld intelligente studenten die goed zelfstandig kunnen werken. De leerprocessen van studenten werden in de interviews besproken in relatie tot de volgende thema's: discussies, leren van elkaar, samenwerkingsopdrachten, peer feedback, de koppeling tussen theorie en praktijk en de kwaliteit van de opdrachten. Deze thema's worden hieronder uitgewerkt.

Alle geïnterviewde docenten waren enthousiast over het leereffect van de asynchrone discussies. Er vond duidelijk kennisconstructie plaats tijdens de discussies (6x). De discussies waren van hoog niveau en de reacties van studenten waren beter doordacht dan in de reguliere lessen $(3 x)$. De studenten konden zich niet onttrekken aan het leerproces in de module. Vanaf de eerste dag van de module moesten zij tot actieve productie komen in de discussies. Dit in tegenstelling tot de reguliere lessen waarin sommige studenten passief meeliften tijdens de lessen en pas tot activiteit komen als het eindwerkstuk gemaakt moet worden (2x). Eén docent gaf ook aan dat hele actieve studenten binnen e-learning niet geremd worden in hun activiteit terwijl dit in de reguliere lessen wel kan gebeuren. Belangrijke factoren met betrekking tot het niveau van de discussies waren de factor tijd en de eisen die gesteld werden aan de inhoud van de bijdrages. De studenten hadden de tijd om na te denken waardoor het niveau van de discussies hoger werd dan het niveau van de discussies in de reguliere lessen, waar de bijdrages vaak een meer impulsief karakter hebben $(3 x)$. Ook werd het door deze bedenktijd mogelijk voor secundair reagerende studenten om volwaardig mee te doen $(1 x)$. In de e-learning werden eisen gesteld aan de kwaliteit van de discussiebijdrages van studenten. Een belangrijke eis was het onderbouwen van meningen vanuit de literatuur. Deze nadruk op onderbouwen werd door vijf van de zeven docenten als heel positief gezien, de overige twee docenten noemden dit aspect niet. De docenten waren enthousiast over het feit dat onderbouwen vanuit de literatuur binnen de e-learning discussies verplicht is en dat studenten daar niet aan kunnen ontsnappen $(4 \mathrm{x})$. Twee docenten gaven aan dat e-learning studenten meer literatuur lazen dan reguliere studenten en beter nadachten over het gelezene. Eén maal werd gezegd dat de spreiding van de keuzeliteratuur over verschillende studenten er toe leidde dat de studenten in discussies in staat waren te nuanceren en het onderwerp langs meerdere kanten te 
belichten. Ook leerden de studenten de schriftelijke uitdrukkingsvaardigheden die horen bij argumenteren en verantwoorden op basis van literatuur(2x). Twee docenten gaven ook aan dat zij dit terugzagen in de werkstukken. Drie docenten gaven aan dat de e-learning resultaten invloed hadden op de reguliere lessen die zij gaven. Zij drongen tijdens discussies in reguliere lessen meer aan op onderbouwing vanuit de literatuur.

Zes docenten gaven aan dat zij als voordeel van e-learning zagen dat de studenten veel leren van elkaar, met name door de uitwisseling over hun eigen praktijksituaties (4x). Eén docent stelde dat studenten veel kennis hebben en ook inbrengen op bepaalde vlakken. In een aantal gevallen had deze inbreng van studenten meer invloed dan de inbreng van de docent. Dit betrof vooral situaties waarin weerstand bestond tegen het implementeren van nieuwe werkvormen. Als een medestudent daar in de eigen schoolpraktijk goede ervaringen mee opgedaan had, dan had dat meer invloed dan de meer theoretische inbreng van de docent (1). E-learning studenten waren voor hun leerproces minder afhankelijk van de docent doordat zij meer ondersteuning van elkaar ondervonden dan reguliere studenten $(1 \mathrm{x})$.

In de e-learning modules waren minder samenwerkingsopdrachten dan discussieopdrachten. De samenwerkingsopdrachten betroffen het gezamenlijk opleveren van een product. Dat kon bijvoorbeeld een mindmap zijn of een schaal om een aspect van het lezen te meten. Drie docenten gaven aan dat de studenten een goede inbreng leverden bij deze opdrachten en dat het hielp als zij al gewend waren aan dit type opdrachten vanuit eerdere modules. Eén docent gaf aan dat sommige samenwerkingsopdrachten de studenten dwongen tot het stellen van kritische vragen, hetgeen een voordeel was voor het leerproces op master niveau.

Het onderwerp 'peer feedback' is niet in alle interviews aan de orde gekomen. Met betrekking tot peer feedback maakten de studenten een ontwikkeling door tussen de eerste en de vierde moduleperiode. De peer feedback was in de eerste moduleperiode van wisselende kwaliteit. Sommige feedback was heel goed: constructief en kritisch. Andere feedback was te positief en te oppervlakkig (2x). Eén docent gaf over de peer feedback in moduleperiode 4 aan dat deze een hele goede kwaliteit had en dat zij die zelf niet beter had kunnen schrijven. 
In een masteropleiding voor leraren is het van belang dat de studenten tot integratie komen van theorie en praktijk. Het is de bedoeling dat zij vanuit theoretische inzichten werktheorieën construeren die zij gaan toetsen en toepassen in hun dagelijkse beroepspraktijk. Twee docenten noemden als voordeel van e-learning dat er een sterke koppeling ontstond tussen theorie en praktijk. Zij vonden dat de modules hier sterk op gericht waren. Eén docent gaf aan dat het voor een aantal studenten in de reguliere masteropleiding niet makkelijk is om deze koppeling te maken. Dit wordt volgens haar veroorzaakt door gewoontes die in de werksituatie van studenten bestaan. Dergelijke gewoontes interfereren met anders over dingen gaan denken en dat ook naar buiten brengen. Deze docent stelde dat e-learning dit proces vergemakkelijkt omdat het binnen de asynchrone discussies mogelijk is om dichter bij de overtuigingen van studenten te komen. De medestudenten spelen hierin een belangrijke rol door te vragen om explicitering en onderbouwing. Op die manier worden studenten gedwongen om zich bewust te worden van hun overtuigingen en deze te formuleren. Twee docenten gaven aan dat de theorie-praktijk integratie gestimuleerd werd doordat er binnen de discussieopdrachten ruimte was voor studenten om met hun eigen vragen uit de praktijk komen, dit leidde tot onverwachte en interessante uitkomsten. Twee andere docenten waren juist van mening dat de opdrachten erg vastlagen en weinig ruimte lieten voor vraagsturing. Deze tegenstelling zou veroorzaakt kunnen worden door de wijze waarop docenten zelf met de discussieopdrachten zijn omgegaan.

In de interviews is gesproken over aspecten van de kwaliteit van de discussie- en samenwerkingsopdrachten in de e-learning modules. Met betrekking tot de samenwerkingsopdrachten is tweemaal aangegeven dat deze zeer duidelijk moeten zijn. Er moet precies aangegeven worden wat er van studenten verwacht wordt en wanneer de opdracht ten einde is. Voor discussies lijken stellingen niet altijd de meest geschikte werkvorm. Stellingen kunnen moeilijk zijn omdat studenten naar aanleiding van een stelling meteen hun mening moeten verwoorden, veel studenten durven dat niet goed $(1 \mathrm{x})$. Stellingen die als open deur beschouwd kunnen worden, waar iedereen het mee eens is, leiden onvoldoende tot discussie (1x). Stellingen die strijdig zijn met de opleidingsvisie leiden tot verwarring bij studenten (1x). Als de opleiding een stelling presenteert dan lijken zij er a priori van uit te gaan dat deze strookt met de opleidingsvisie(1x). 
De docenten zijn van mening dat een discussieopdracht breed moet zijn. Het moet vanuit de literatuur mogelijk zijn om meerdere visies in te brengen (1x). De opdracht mag best bedrieglijk eenvoudig zijn maar moet zich lenen voor verdieping door de docent als de discussie gestart is $(1 \mathrm{x})$. In de beginfase van de studie is het moeilijk voor studenten om commentaar te geven op een casus waarin alleen subtiele problemen zichtbaar zijn. Het lijkt in deze fase beter om studenten om commentaar te vragen op casussen waarin aperte fouten gemaakt worden (1x). Hoe spannend een discussie wordt verschilt per onderwerp, hot items uit de pers en meningen die loodrecht tegenover elkaar staan lokken veel discussie uit $(1 \mathrm{x})$.

\subsubsection{Bruikbaarheid van het kenmerk van 'sociale interactie'}

\section{Verbondenheid tussen studenten}

Kenmerk 2 van het ontwerp was sociale interactie tussen studenten. Dit werd belangrijk geacht omdat hierdoor solidariteit, ondersteuning, wederkerigheid, vertrouwen en veiligheid zou kunnen ontstaan in de groep. De vraag was of een dergelijke verbondenheid tussen studenten zou kunnen ontstaan in de e-learning groepen. De veronderstelling was dat dit moeilijker zou kunnen zijn dan in reguliere groepen. Om te meten in hoeverre dit soort gevoelens ontstonden werd gebruik gemaakt van de schaal 'Verbondenheid'. De items werden gescoord op een 3-puntsschaal: nee - gaat wel - ja. In tabel 5.10 zijn per moduleperiode de gemiddeldes en standaarddeviaties weergegeven voor de verschillende cohorten.

Tabel 5.10 Verbondenheid per moduleperiode

\begin{tabular}{lccccccccc}
\hline & \multicolumn{3}{c}{ Cohort 1 e-learning } & \multicolumn{3}{c}{ Cohort 1 regulier } & \multicolumn{3}{c}{ Cohort 2 e-learning } \\
Periode & $N$ & $X$ & $S D$ & $N$ & $X$ & $S D$ & $N$ & $X$ & $S D$ \\
\hline 1 & 22 & 2,3 & 0,48 & & & & & & \\
2 & 26 & 2,6 & 0,43 & 20 & 2,8 & 0,33 & & & \\
3 & 22 & 2,3 & 0,66 & 7 & 2,4 & 0,53 & & & \\
4 & 16 & 1,6 & 0,63 & 16 & 2,5 & 0,58 & & & \\
6 & 19 & 2,4 & 0,63 & & & & 23 & 2,5 & 0,53 \\
7 & 13 & 2,5 & 0,58 & & & & 11 & 2,6 & 0,45 \\
\hline
\end{tabular}

In cohort 1 e-learning is opvallend dat het gemiddelde in veel gevallen beneden de 2,5 ligt. Dit betekent dat verbondenheid niet overtuigend gerealiseerd werd in cohort 1 . Opvallend in de tabel is de zeer lage score van cohort 1 in periode 4 .

Middels variantie analyse voor herhaalde metingen is nagegaan of de verschillen tussen de periodes significant waren voor e-learning cohort 1. De Greenhouse- 
Geisser correctie is gebruikt vanwege de lage $\varepsilon(=0,45)$. Het resultaat laat zien dat de verschillen tussen de moduleperiodes inderdaad significant waren, $F(2,3$; $11,3)=10,6, p<0,01, \eta_{p}{ }^{2}=0,68$. In tabel 5.11 worden $F$ waardes, $p$ waardes en effectgroottes weergegeven voor de verschillen tussen de opeenvolgende moduleperiodes.

Tabel 5.11 Cohort 1: verschillen in verbondenheid tussen moduleperiodes

\begin{tabular}{lccc}
\hline $\begin{array}{l}\text { Vergeleken } \\
\text { moduleperiodes }\end{array}$ & $\boldsymbol{F}$ & $\boldsymbol{p}$ & Effectgrootte $\boldsymbol{\eta}_{\boldsymbol{p}}{ }^{2}$ \\
\hline 1 versus 2 & 1 & 0,36 & 0,17 \\
2 versus 3 & 1 & 0,36 & 0,17 \\
3 versus 4 & 18,05 & $0,008^{* *}$ & 0,78 \\
4 versus 6 & 12,73 & $0,016^{*}$ & 0,72 \\
6 versus 7 & 0,13 & 0,73 & 0,03 \\
\hline
\end{tabular}

Noot: $\quad{ }^{*} p<0,05,{ }^{* *} p<0,01,{ }^{* * *} p<0,001$.

Tussen de periodes 3 en 4 was er sprake van een sterke daling van de verbondenheid tussen de studenten van cohort 1 . De verbondenheid in dit cohort herstelde zich tussen periode 4 en 6 . Variantie analyse voor herhaalde metingen liet geen significante verschillen zien tussen de twee meetmomenten (6 en 7) van Cohort 2. De verbondenheid in dit cohort was voldoende gerealiseerd en was stabiel tussen deze twee moduleperiodes.

De veronderstelling was dat e-learners moeilijker tot onderlinge verbondenheid zouden kunnen komen dan reguliere studenten. Dit is nagegaan met behulp van de $t$-toets voor onafhankelijke steekproeven. In de periodes 2 en 3 werd deze veronderstelling niet bevestigd. De verschillen tussen e-learners en reguliere studenten waren niet significant. In periode 4 was het verschil wel significant $t(21)=3,2, p<0,01, r=0,57$. Dit hing samen met de scherpe daling van de verbondenheid bij e-learning in periode 4 . In de periodes 6 en 7 scoorden de elearners in cohort 1 en 2 dicht rond de 2,5. Er waren geen significante verschillen tussen cohort 1 en 2 e-learning. In deze laatste periodes was de verbondenheid tussen e-learners in beide cohorten in voldoende mate gerealiseerd.

\section{Sociale interactie tussen studenten}

Een andere manier om de bruikbaarheid van het principe van sociale interactie binnen e-learning na te gaan was middels de subschaal 'sociaal' van de schaal Woord en Ervaring. Deze 5-puntsschaal ( $1=\mathrm{Nee}$, $2=\mathrm{Nee}, 3=\mathrm{Soms}, 4=\mathrm{Ja}, 5=\mathrm{Ja}$ !) is na periode 1 en na periode 4 afgenomen bij cohort 1 . Na periode 1 werd de schaal 
eveneens afgenomen bij de reguliere studenten van het profiel Leerproblemen. $\mathrm{Na}$ periode 5 is de schaal afgenomen bij cohort 1 en 2 e-learning en bij alle reguliere studenten van Windesheim OSO. De gemiddeldes en standaarddeviaties per periode en per cohort zijn zichtbaar in tabel 5.12.

Tabel 5.12 Woord en ervaring: sociaal

\begin{tabular}{llllllllll}
\hline & \multicolumn{3}{c}{ Cohort 1 e-learning } & \multicolumn{4}{c}{ Reguliere studenten } & \multicolumn{3}{c}{ Cohort 2 e-learning } \\
Periode & $\boldsymbol{N}$ & $\boldsymbol{X}$ & $\mathrm{SD}$ & $\boldsymbol{N}$ & $\boldsymbol{X}$ & $\mathrm{SD}$ & $\boldsymbol{N}$ & $\boldsymbol{X}$ & $\mathrm{SD}$ \\
\hline 1 & 36 & 3,5 & 0,62 & 33 & 3,7 & 0,56 & & & \\
4 & 23 & 2,8 & 0,80 & & & & & & \\
5 & 22 & 3,3 & 0,91 & 231 & 3,9 & 0,55 & 29 & 3,8 & 0,55 \\
\hline
\end{tabular}

Uit de tabel blijkt dat e-learners en reguliere studenten in de meeste gevallen bevestigden (gemiddelde score $\geq 3,5$ ) dat zij hun studie als sociaal ervaren. De studenten reageerden vaker met 'ja' dan met 'soms' op woorden als gezelligheid, sociaal en persoonlijk. Met de $t$-toets voor onafhankelijke steekproeven is nagegaan of er in periode 1 significante verschillen waren tussen cohort 1 elearning en de reguliere studenten. De verschillen bleken niet significant. Elearners en reguliere studenten verschilden niet in hun reacties ten aanzien van de sociale interactie met medestudenten.

In periode 4 valt de lage score op van het eerste cohort e-learning. Middels variantie analyse voor herhaalde metingen is nagegaan of de verschillen tussen de periodes significant waren voor e-learning cohort 1 . De Greenhouse-Geisser correctie is gebruikt vanwege significantie van Mauchly's $W(p<0,01 ; \varepsilon=0,70)$. Het resultaat laat zien dat de verschillen tussen de moduleperiodes inderdaad significant zijn, $F(1,4 ; 26,7)=7,0, p<0,01, \eta_{p}^{2}=0,27$. Het contrast tussen periodes 1 en 4 was significant $(p<0,01), \eta_{p}{ }^{2}=0,51$. Cohort 1 e-learning beleefde het studeren in periode 4 als minder sociaal dan het studeren in periode 1. Er leek wel herstel op te treden tussen periodes 4 en 5 . Het contrast tussen de periodes 4 en 5 bleek echter niet significant $(p=0,08)$. De effectgrootte was middelmatig, $\eta_{p}{ }^{2}=0,15$.

Middels variantie analyse is nagegaan of de verschillen tussen de groepen in periode 5 significant waren. De groepen vertoonden significante verschillen in variantie, $F(2,278)=6,0, p<0,01$. Daarom is gebruik gemaakt van de robuuste test (Welch), deze toonde aan dat de verschillen significant waren, $S(2 ; 35,42)=3,97, p$ $<0,05$. Voor de post-hoc tests is de Games-Howell procedure gebruikt. Op grond van deze procedure bleken alleen de verschillen tussen cohort 1 e-learning en de reguliere studenten significant, gemiddeld verschil $=0,52, p<0,05, r=0,37$. De e- 
learners in cohort 1 ervoeren in periode 4 hun wijze van studeren als minder sociaal dan de reguliere studenten. De e-learners uit cohort 2 ervoeren hun wijze van studeren als net zo sociaal als de reguliere studenten.

\section{Sociale berichten in de leeromgeving}

Om het leren te ondersteunen, werd actief aangestuurd op sociale interactie. Hieruit volgt dat bij de vijf random geselecteerde studenten een substantieel aantal sociale berichten verwacht werd (zie ook 5.1.2). De inhoud van de berichten werd geanalyseerd door te coderen in drie categorieën: cognitief, sociaal (kenmerk 2) en organisatorisch. In tabel 5.13 is per moduleperiode en per student het aantal sociale codes weergegeven. In de tabel is bovendien aangegeven het gemiddeld aantal sociale bijdrages per week (uitgaande van moduleperiodes van acht weken). Ter vergelijking zijn de aantallen cognitieve codes weergegeven (zie ook tabel 5.8).

Tabel 5.13 Inhoud van de berichten in periode 1 en 7: Aantallen toegekende codes

\begin{tabular}{lcccccc}
\hline Periode & Student & $\begin{array}{c}\text { Aantal } \\
\text { berichten }\end{array}$ & $\begin{array}{c}\text { Aantal } \\
\text { sociale } \\
\text { codes }\end{array}$ & $\begin{array}{c}\text { Aantal } \\
\text { cognitieve } \\
\text { codes }\end{array}$ & $\begin{array}{c}\text { Gemiddeld } \\
\text { sociaal per } \\
\text { week }\end{array}$ & $\begin{array}{c}\text { Gemiddeld } \\
\text { cognitief } \\
\text { per week }\end{array}$ \\
\hline Periode 1 & $\mathrm{A}$ & 211 & 43 & 74 & 5,4 & 9,3 \\
Minimaal 33 & $\mathrm{B}$ & 69 & 8 & 37 & 1 & 4,6 \\
bijdrages & $\mathrm{C}$ & 290 & 48 & 138 & 6 & 17,3 \\
& $\mathrm{D}$ & 98 & 11 & 53 & 1,4 & 6,6 \\
& $\mathrm{E}$ & 227 & 77 & 63 & 9,6 & 7,9 \\
\hline Periode 7 & $\mathrm{A}$ & 61 & 9 & 25 & 1,1 & 3,1 \\
Minimaal 22 & $\mathrm{B}$ & 68 & 4 & 42 & 0,5 & 5,3 \\
bijdrages & $\mathrm{C}$ & 58 & 6 & 49 & 0,8 & 6,1 \\
& $\mathrm{D}$ & 76 & 11 & 34 & 1,4 & 4,3 \\
\hline
\end{tabular}

Uit de tabel wordt duidelijk dat deze vijf studenten in moduleperiode 1 sterk verschilden in de hoeveelheid sociaal gedrag die zij in de discussieruimtes vertoonden. Studenten B en D schreven weinig berichten met sociale elementen. De overige drie studenten schreven er veel, student E produceerde zelfs meer sociale dan cognitieve berichten. In periode 7 werden zeer weinig sociale codes toegekend terwijl de studenten wel verbondenheid ervoeren (zie tabel 5.10). Het is mogelijk dat de studenten inmiddels andere dan asynchrone communicatiemiddelen gebruikten voor sociale uitwisseling (bijvoorbeeld: chat, mail, telefoon).

\section{Meningen van docenten over de sociale interactie tussen studenten}

In de interviews met docenten is niet specifiek gevraagd naar de bruikbaarheid van het kenmerk 'sociale interactie tussen studenten'. Vier docenten hebben daar wel commentaar op gegeven. Al deze vier docenten hechtten belang aan het sociale 
contact tussen de studenten onderling. Ze zijn van mening dat studenten behoefte hebben aan persoonlijke uitwisseling ( $4 \mathrm{x})$, bemoediging en steun van elkaar (2x) en dat het belangrijk is dat er een speciale plek in Blackboard is waar dit gebeurt en waar docenten niet altijd hoeven mee te lezen (2x). Eén van de docenten geeft aan dat het haar verbaasd heeft hoe sterk het groepsgevoel en de bonding was die al ontstond in de eerste moduleperiode. $\mathrm{Zij}$ gaf aan dat dit groepsgevoel ontstond zonder dat zij het gevoel had er veel aan te doen. Het leek haar dat ook de startdag, waar de studenten fysiek bijeen kwamen, hier niet veel aan bijgedragen had. Een andere docent gaf aan dat de mate van bonding die ontstaat sterk afhankelijk is van of het klikt tussen de mensen die toevallig in een groepje komen. In dit opzicht verschilde e-learning volgens haar niet van de reguliere studie.

Uit het logboek blijkt dat de studenten erg behulpzaam waren naar elkaar als er vragen waren op het vlak van software en studie. Voorts blijkt dat studenten via mail en telefoon aangaven dat de onderlinge sociale interactie in e-learning belangrijker was dan ze aanvankelijk gedacht hadden. Eén student gaf aan dat het contact met studiegenoten binnen e-learning intensiever was dan binnen de reguliere Windesheim OSO studie waarmee zij ook ervaring had. De docenten vroegen zich af hoe zij groepjes zo konden samenstellen dat het leidde tot hechte samenwerking. Er was in hun ogen verschil tussen hechte en minder hechte groepjes. In minder hechte groepjes zagen zij dat de interactie "voortkabbelde". In hechte groepjes zagen de docenten dat de studenten lol hadden met elkaar en dat de interactie sprankelde.

\subsubsection{Gesignaleerde knelpunten in de interactie tussen studenten}

Knelpunten zoals gesignaleerd in de docentinterviews en in het onderzoekerslogboek

Uit de interviews met zeven e-learning docenten en uit het onderzoekerslogboek kwamen vier knelpunten in de studentinteractie naar voren die hieronder puntsgewijs besproken worden. De volgorde waarmee de knelpunten worden besproken, wordt bepaald door de frequentie waarmee zij genoemd werden in de docentinterviews en in het logboek. Er wordt gestart met het knelpunt dat het vaakst genoemd werd. De interviews betroffen het eerste e-learning jaar. In het logboek werden ook gegevens over het tweede e-learning jaar verzameld.

\section{Ontevredenheid over de samenstelling van de groepjes}

Uit het onderzoekerslogboek blijkt dat in het eerste e-learning jaar door studenten regelmatig ontevredenheid werd uitgedrukt over de samenstelling van de 
groepjes. Deze problemen kwamen in het tweede e-learning jaar vrijwel niet meer voor. In het eerste jaar stelden de docenten de groepjes samen. Sommige studenten waren niet tevreden over deze samenstelling. $\mathrm{Zij}$ vonden het niet prettig om met elkaar samen te werken. Zij vroegen de e-learning docenten via telefoon of mail om wisselingen in de samenstelling van de groepjes. Dergelijke situaties ontstonden al in de eerste moduleperiode. Een zeer beperkt aantal studenten ondervond in verschillende groepjes problemen om aan te haken.

Studenten die in een fijn groepje zaten, vonden het niet prettig als de groepssamenstelling wisselde voor de volgende module. Dit leidde tot weerstand en een vermindering van de bijdrages. Deze studenten gaven aan dat ze het vervelend vonden om in een groepje te werken waarin zij de mensen niet goed kenden. De belangrijkste problemen op dit vlak speelden in moduleperiode vier waarin de groepjes door het e-learning team heel anders waren samengesteld dan in de voorgaande periodes. Meerdere studenten gaven aan dit onprettig te vinden. Het werken met onbekenden vergde gewenning. Zij gaven de voorkeur aan een stabiele samenstelling van de groepjes, zelfs als de groepssamenstelling niet ideaal was.

De e-learning docenten, die deze berichten ontvingen van studenten, vonden het moeilijk om de goede mensen bij elkaar te krijgen in de groepjes. Zij hadden bovendien problemen op het vlak van de omvang van de groepjes. Groepjes die te klein waren, genereerden te weinig interactie, groepjes die te groot waren produceerden te veel berichten. Groepjes werden te klein als studenten uitvielen door persoonlijke omstandigheden. Dit kwam regelmatig voor. Kleine groepjes van drie of vier studenten bleken kwetsbaar in dit opzicht. In deze groepjes kwam het in zulke situaties voor dat twee studenten heel intensief met elkaar aan de slag gingen, waarbij soms ook de leerdiscussie en de sociale uitwisseling door elkaar gingen lopen. Studenten die tijdelijk afgehaakt waren, vonden het moeilijk om in zulke situaties weer aan te haken. Een aantal keren vond herindeling van groepjes plaats tijdens de modules. Als er te veel volledig inactieve studenten in een groepje zaten, werden de actieve studenten bij andere groepjes ingedeeld. De inactieve studenten kwamen samen in één groepje.

Hele grote groepen bleken ook niet te werken. Eenmaal is geprobeerd om te werken met een groep van tien studenten. Het lukte noch de studenten, noch de docent om overzicht te houden over het aantal berichten dat binnenkwam. Deze groep is uiteindelijk in tweeën gesplitst. 


\section{Ontsporen van de communicatie}

In Blackboard ontstonden in het eerste jaar een aantal situaties waarbij in de asynchrone uitwisseling flink gemopperd werd door studenten. Dit ging meestal over zaken als onduidelijke opdrachten, werkdruk en problemen met software. In de eerste twee modules gebeurde dit met regelmaat in de algemene discussieruimte waar alle studenten dit konden lezen. Ook in de leerdiscussies in de kleine groepjes ontspoorde de communicatie soms. De docenten gaven aan dat ergernis online veel moeilijker te reguleren was dan in de gewone klassikale setting. Gemopper kwam zwart op wit heftiger over omdat het bleef staan en er te veel tijd overheen ging voordat er op gereageerd werd. Een schriftelijke reactie kon bovendien riskant zijn omdat het probleem er ook door verergerd kon worden. Er werd een concreet voorbeeld genoemd van blokvorming. De docent kon in dat geval moeilijk invloed uitoefenen op de groepsmening die al ontstaan was over een bepaald onderwerp. Ontsporingen in de communicatie kwamen soms heftig over op docenten, en leidden ook tot irritatie bij medestudenten die in dergelijke gevallen via de mail om hulp vroegen bij de docenten. Dit soort ontsporingen werd door de docenten als ongewenst beschouwd omdat het de e-learning omgeving minder prettig en minder veilig maakte voor zowel studenten als docenten.

\section{Gebrek aan evenwicht in timing en uitgebreidheid van de bijdrages}

Er ontstonden irritaties tussen studenten die respectievelijk veel en snel of weinig en laat bijdroegen. Studenten die weinig en laat bijdroegen, hadden er last van dat ze geen ruimte ervoeren om deel te nemen. De andere studenten maakten meteen te uitgebreide bijdrages die erg goed onderbouwd waren. Deze bijdrages hadden meer het karakter van een ingeleverde opdracht dan van een discussiebijdrage. Dit type bijdrages maakte het andere studenten soms heel moeilijk om nog met goede bijdrages te komen. Studenten die veel bijdrages leverden, hadden er last van dat ze naar hun gevoel de kar steeds moesten trekken en dat ze te weinig respons kregen om de discussie te kunnen voortzetten.

\section{Leeslast}

In moduleperiode 1 werd de leeslast te groot doordat er te veel opdrachten waren per week. Ook de vele lange bijdrages verhoogden de leeslast. Bondig formuleren bleek moeilijk voor studenten. Sommige groepen waren extreem actief. Ze produceerden wel honderd berichten per discussielijn en deden veel meer werk dan nodig. Soms kwam dit doordat een opdracht onduidelijk was voor studenten. Als niet precies duidelijk was wat er verwacht werd, kon de discussie te lang voortduren en te veel kanten uitgaan. Problemen met schriftelijk formuleren en 
spelling verhoogden in een aantal gevallen ook de leeslast. Eén student stoorde zich hier echt aan en vroeg het e-learning team om hier richtlijnen voor op te stellen.

\section{Knelpunten zoals gesignaleerd in de berichten van studenten}

De knelpunten ten aanzien van de studentinteractie zijn eveneens geïnventariseerd in de asynchrone discussiebijdrages van de vijf random geselecteerde studenten in periode 1 en 7 . Daaruit kwamen vrijwel dezelfde thema's naar voren. Ter illustratie zijn citaten uit de studentbijdrages toegevoegd. Drie van de vier thema's speelden niet meer in moduleperiode 7. Alleen thema 2: misverstanden in de communicatie, speelde in beide periodes.

\section{Ontevredenheid over de samenstelling van de groepjes}

De samenstelling van de groepjes vormde een probleem voor sommige studenten in periode 1. De studenten reageerden in Blackboard op twee soorten problemen: een gebrekkige aansluiting van het werkritme en de soms scheve verhouding tussen de vertegenwoordigde beroepsgroepen (leerkrachten en logopedisten) in de groepjes.

Het lijkt me inderdaad wel prettig om bij het indelen van de groepjes bij de volgende module rekening te houden met ieders werkritme. Ik wacht deze week wel even de eerste aanzet van de discussie van een ander af. Ik wil voorkomen om mensen onder druk te zetten.

Ik zit in mijn groepje als RTer/leerkracht met drie logopedisten en las van de week ergens op ... Blackboard dat er een logopedist in een groepje zat met drie leerkrachten. Vandaar.

\section{Misverstanden in de communicatie}

Er ontstonden in moduleperiodes 1 en 7 soms misverstanden in de asynchrone interactie. Dit leek te maken te hebben met de beperkingen van asynchrone communicatie: de afstand en het ontbreken van non-verbale cues. De studenten losten deze situaties doorgaans zelf op door te expliciteren wat zij bedoeld hadden.

Uit het volgende schrijven van jou: "Nogmaals: (student $\mathrm{x}$ ) heeft manipulatie genoemd. Dit is niet mijn woordkeus geweest", krijg ik de indruk dat je je aangevallen voelt. Dit is zeker niet mijn bedoeling geweest. Ik vind manipulatie een negatieve lading hebben, vandaar dat ik heb proberen uit te leggen hoe ik er tegen aan kijk. En zoals je schrijft denk ik dat we uiteindelijk hetzelfde bedoelen. Ik ben echter wel benieuwd of je aan kunt geven wanneer jij een discussie onnatuurlijk en onprettig vind. Bij de term beleefd communiceren denk ik aan netetiquette, het lijkt me dat dat het streven is binnen elke communicatie. 
Je reactie kwam helemaal niet vervelend bij me over (student $\mathrm{x}$ ). Bij mij speelde hetzelfde als wat jij aangeeft: je hebt me aan het denken gezet. Prima toch?!! Wellicht was mijn antwoord wat te stellig of enigszins verdedigend. Excuses als dit zo overgekomen is! Maar mijn antwoord was puur gericht op je (duidelijke en kritische) opmerkingen. (...................) Blijf kritisch a.u.b......!!! We leren op deze manier van elkaar en met elkaar. We zijn bezig met doelmatig communiceren en het geven van opbouwende feedback (Wiertzema, 2003).

\section{Gebrek aan evenwicht in timing en uitgebreidheid van de bijdrages}

De inhoudsanalyse van de berichten in periode 1 laat zien dat twee studenten die zelf veel bijdroegen (studenten $C$ en E), meermaals aangaven er last van te hebben dat de discussie regelmatig stil kwam te liggen doordat andere studenten niet tijdig reageerden.

Ook deze week maak ik het mee, dat ik eigenlijk al twee dagen wacht op reacties van mijn groepje. Ik kan nu niet verder met mijn discussies.

De discussie ligt even helemaal stil. Vandaar dat ik maar individueel aan het zoeken ben naar verdieping en extra informatie. Dit wil ik wel erg graag met jullie delen en reacties en toevoegingen zijn van harte welkom!

Hiermee in verband staan opmerkingen die drie van de vijf studenten in periode 1 maakten met betrekking tot individuele aansprakelijkheid. Niet alleen konden zij door anderen niet verder met de discussie, maar ook vreesden zij in dit verband voor hun eigen individuele studieresultaat. $\mathrm{Zij}$ voelden hun individuele aansprakelijkheid in het gedrang komen door de wijze van studeren waarin het collectieve proces een centrale rol had. Met hun berichten probeerden zij anderen aan te sporen tot studieactiviteit in Blackboard.

Het vervelende van het afhankelijk zijn van elkaars reacties is, dat ik tot en met vrijdag al $181 / 2$ uur in mijn studie had gestoken. Ook heb ik dus al vooruit gewerkt. Maar omdat ik niet met mezelf een discussie kan voeren, heb ik de zondagmiddag moeten uittrekken om te reageren op eventuele ingebrachte discussies dit weekend.

Ik heb met mijn reactie nu ook het gevoel dat ik jullie aanval. Toch moet ik dit wel kwijt, want ik vind het geen prettige manier van studeren op deze manier. Terwijl ik eigenlijk enorm enthousiast ben!

...Ik zal nu gaan kijken naar de discussielijnen. In het uiterste geval ga ik toch maar met mezelf discussiëren, want ik heb geen zin in een vervangende opdracht.

De studenten maakten in periode 1 in veel gevallen geen discussiebijdrages maar min of meer volledige opdrachten. Daardoor bleef er weinig inhoudelijke ruimte 
voor andere studenten over om te reageren en ontstonden er herhalingen. In onderstaande citaten reflecteerden zij op deze situatie, zij merkten dat deze werkwijze nadelen had voor het voeren van een discussie en voor hun leerproces.

Ik vind het vaak makkelijker mijn eigen stukje te schrijven, dan een productieve discussie te voeren. Maar dit laatste is wel leerzaam merk ik.

Wij starten al met "megagrote" bijdragen en komen dan al heel snel op hetzelfde idee/ dezelfde mening uit

\section{Leeslast}

De studenten hadden in moduleperiode 1 problemen met de grote aantallen berichten. Deze zorgden voor veel leeswerk. De studenten gaven in deze periode bovendien aan dat zij de discussielijnen onoverzichtelijk vonden. De discussielijnen gingen alle kanten op en misten goede titels. De studenten waren bovendien geneigd om apart te reageren op iedere medestudent in het groepje. Hierdoor ontstonden steeds nieuwe discussies binnen de discussie. Het eindresultaat was onprettig leesbaar, inhoudelijk gefragmenteerd en bevatte herhalingen. In veel gevallen voegden de studenten hun bijdrages toe aan hun bericht in de vorm van bijlagen. Dit vertraagde het lezen.

ik merk dat ik veel tijd kwijt ben met het lezen van ieders berichten. Ik heb ook de neiging om op iedereen te reageren. Dit is echter nauwelijks te doen merk ik.

Ik vind de discussies erg onoverzichtelijk worden, wie reageert op wie, waar staat het in de discussielijn.

\subsubsection{Samenvatting bruikbaarheid}

Nagegaan werd of de interactiekenmerken bruikbaar waren voor de e-learning opleiding. Op meerdere manieren bleek dat deze kenmerken inderdaad bruikbaar waren: de studenten produceerden veel berichten, er waren veel berichten met cognitieve inhoud en zowel de studenten als de docenten ervoeren de asynchrone discussies als bevorderlijk voor het leerproces. Het starten met asynchrone discussies bleek echter niet eenvoudig voor studenten. $\mathrm{Zij}$ waren geneigd uitvoerige individuele opdrachten af te leveren in plaats van discussiebijdrages. De leeslast liep erg op door de grote berichten, de veelheid van de berichten, de bijlagen bij berichten en de slechte organisatie van discussielijnen. De deelname was bij de aanvang nogal eens erg onevenwichtig: sommige studenten droegen 
heel veel bij en andere heel weinig. Hierdoor zagen sommige studenten hun individuele aansprakelijkheid in het gedrang komen. De beschreven problemen in periode 1 werden op één na niet meer teruggevonden in periode 7 . Eén probleem kwam in beide periodes zo nu en dan voor: studenten die elkaar verkeerd begrepen. Dit leidde niet tot onoverkomelijke problemen omdat studenten de situatie op losten door schriftelijk verheldering te geven.

Ook sociale verbondenheid bleek een bruikbaar kenmerk. De docenten bevestigden dat de studenten behoefte hadden aan persoonlijke uitwisseling en onderlinge bemoediging en steun. Ook verliep de asynchrone interactie met meer enthousiasme als studenten het goed met elkaar konden vinden. In een aantal moduleperiodes van cohort 1 vonden de studenten e-learning niet voldoende sociaal en ontstond er onvoldoende onderlinge verbondenheid. In cohort 1 bleek bij de kwalitatieve analyse bovendien dat het percentage sociale berichten vrij laag was. Ook leidden ontsporingen in de communicatie tot irritatie bij studenten en docenten. In periode 4 waren er duidelijk problemen op het vlak van de sociale interactie. De studenten gaven aan dat dit kwam doordat zij door de e-learning docenten waren ingedeeld in nieuwe groepjes met een hele andere samenstelling. De studenten vonden dit zeer onprettig. Zij gaven aan stabiliteit in de groepssamenstelling zeer op prijs te stellen omdat een nieuw groepje veel gewenning vergt. Na periode 4 herstelde de sociale verbondenheid zich. In het tweede e-learning cohort werden sociale interactie en verbondenheid in voldoende mate gerealiseerd. Deze studenten verschilden in dit opzicht niet van de reguliere studenten.

\subsection{WAARDERING VOOR DE SAMENWERKING}

Het gaat hier om de vraag hoe tevreden de studenten waren over de onderlinge samenwerking. In de rapportage over de waardering voor de samenwerking tussen studenten wordt ingegaan op twee onderwerpen:

- Waardering voor de samenwerking met medestudenten (5.2.1)

- Verbanden met de waardering voor de samenwerking met medestudenten (5.2.2) Tenslotte volgt een samenvatting ten aanzien van de onderzoeksvraag naar de waardering voor de samenwerking met medestudenten zoals die vorm kreeg binnen e-learning. 


\subsubsection{Waardering voor de samenwerking met medestudenten}

Rapportcijfer voor de samenwerking

Samenwerking tussen studenten vormde een belangrijk kenmerk van de ontworpen leeromgeving. Om na te gaan hoe tevreden studenten hierover waren werd hen gevraagd om een rapportcijfer toe te kennen aan de samenwerking met hun medestudenten. In tabel 5.14 worden gemiddeldes en standaarddeviaties van deze waardering, uitgedrukt in een rapportcijfer ( 1 tot en met 10$)$, per periode weergegeven. Ter vergelijking zijn de scores toegevoegd van de studenten van het reguliere cohort leerproblemen 2007-2008.

Tabel 5.14 Tevredenheid over de samenwerking met medestudenten

\begin{tabular}{lccccccccc}
\hline & \multicolumn{3}{c}{ Cohort 1 e-learning } & \multicolumn{3}{c}{ Cohort 1 regulier } & \multicolumn{3}{c}{ Cohort 2 e-learning } \\
periode & $N$ & $X$ & $S D$ & $N$ & $X$ & $S D$ & $N$ & $X$ & $S D$ \\
\hline 1 & 22 & 7,4 & 1,10 & & & & & & \\
2 & 26 & 7,8 & 1,02 & 20 & 7,7 & 1,18 & & & \\
3 & 22 & 7,5 & 1,54 & 7 & 7,1 & 1,57 & & & \\
4 & 16 & 6,0 & 1,37 & 16 & 7,6 & 1,59 & & & \\
6 & 19 & 7,6 & 1,30 & & & & 23 & 7,8 & 1,34 \\
7 & 13 & 7,7 & 1,25 & & & & 11 & 7,6 & 1,12 \\
\hline
\end{tabular}

In de meeste gevallen waren de gemiddelde rapportcijfers voor samenwerking met medestudenten hoog, $\geq 7,5$. In periodes 2 en 3 lagen de cijfers van e-learners en reguliere studenten dicht bij elkaar. In periode 4 is er een scherpe daling zichtbaar bij e-learning cohort 1. Het cijfer voor samenwerking met medestudenten herstelde zich weer in jaar 2 van dit cohort. Om na te gaan of de gevonden verschillen tussen de moduleperiodes van de twee e-learning cohorten significant waren, werd voor beide cohorten variantie analyse toegepast voor herhaalde metingen. Voor cohort 1 werd dit gedaan over alle zes meetmomenten. Omdat $\varepsilon=0,4$ is gebruik gemaakt van de Greenhouse-Geisser correctie. De analyse resulteerde in een significant verschil tussen de cijfers voor samenwerking in deze zes meetmomenten, $F(2,0 ; 9,9)=5,7, p<0,05, \eta_{p}{ }^{2}=0,53$. De gevonden verschillen tussen de opeenvolgende moduleperiodes worden weergegeven in tabel 5.15.

Tabel 5.15 Cohort 1: verschillen in tevredenheid over de samenwerking

\begin{tabular}{lccc}
\hline Vergeleken moduleperiodes & $\boldsymbol{F}$ & $\boldsymbol{p}$ & Effectgrootte $\boldsymbol{\eta}_{\boldsymbol{p}}{ }^{2}$ \\
\hline 1 versus 2 & 0,17 & 0,70 & 0,03 \\
2 versus 3 & 0,63 & 0,47 & 0,11 \\
3 versus 4 & 10,71 & $0,02^{*}$ & 0,68 \\
4 versus 6 & 5,60 & 0,06 & 0,53 \\
6 versus 7 & 0,67 & 0,58 & 0,07 \\
\hline
\end{tabular}

Noot: ${ }^{*} p<0,05,{ }^{* *} p<0,01,{ }^{* * *} p<0,001$. 
Opvallend zijn de scherpe daling tussen periode 3 en 4 en het herstel in periode 6 . Voor cohort 2 werden in de variantie analyse voor herhaalde metingen geen significante verschillen gevonden. In het e-learning ontwerp werd meer nadruk gelegd op samenwerking dan in de reguliere studie, maar ook tijdens de reguliere lessen spelen samenwerkingsopdrachten een belangrijke rol. De reguliere studenten kozen zowel in als buiten de lessen zelf met wie zij wilden samenwerken. In reguliere lessen kennen de studenten elkaar op een andere, meer directe, manier dan online. Dit zou er toe kunnen leiden dat reguliere studenten enthousiaster reageren op de samenwerking dan e-learners. Vergelijkingen tussen e-learning cohort 1 en het reguliere cohort 1 zijn gemaakt met de $t$-toets voor onafhankelijke steekproeven. Er bleken geen significante verschillen voor de modules in periode 2 en 3 . De $t$-toets voor onafhankelijke steekproeven gaf wel een significant verschil aan tussen het e-learning cohort en het reguliere cohort in periode $4 t=-3,11, d f=30, p=<0,01, r=0,49$. Dit verschil leek niet samen te hangen met de vraag of studenten regulier of via e-learning studeerden, maar eerder met de specifieke problemen die optraden bij de e-learners: de door de docenten opnieuw samengestelde groepjes met onbekende mensen er in.

\subsubsection{Verbanden met het cijfer voor de waardering voor de samenwerking}

Er is nagegaan welke van de in dit hoofdstuk besproken variabelen verband houden met de waardering van de studenten voor de samenwerking. Met Pearson's $r$ is per moduleperiode de correlatie bepaald tussen de deze variabelen enerzijds en het cijfer voor de samenwerking anderzijds. In tabel 5.16 is de spreiding van Pearson's $r$ weergegeven over de moduleperiodes.

Tabel 5.16 Verbanden met de waardering voor de samenwerking

\begin{tabular}{ll}
\hline Gebruikte (sub)schalen en maten & Pearson's $r$ (spreiding) \\
\hline $\begin{array}{l}\text { Kenmerk 1: } \\
\text { Samenwerkend leren via asynchrone schriftelijke discussies }\end{array}$ & \\
Leerzaamheid van de discussies & $0,58^{* *}-0,77^{* * *}$ \\
Leerzaamheid van de discussiebijdragen van de medestudenten & $0,72^{* * *}-0,77^{* * *}$ \\
Leerzaamheid van de samenwerkingsopdrachten & $0,50^{*}-0,75^{* * *}$ \\
Invloed op het begrip van de literatuur & $0,16-0,44^{*}$ \\
Steun voor het leerproces & $0,50^{*}-0,76^{* * *}$ \\
Kenmerk 2: & \\
Sociale interactie & \\
Verbondenheid & $0,53^{* *}-0,82^{* * *}$ \\
'Sociaal' , subschaal van Woord en Ervaring & $0,45^{*}-0,91^{* * *}$ \\
\hline
\end{tabular}

Noot: ${ }^{*} p<0,05,{ }^{* *} p<0,01,{ }^{* * *} p<0,001$. 
Uit de tabel blijkt dat de waardering van studenten voor de samenwerking verband houdt met zowel de sociale als de cognitieve aspecten van de interactie. Er is één cognitieve variabele waarvoor dit minder duidelijk blijkt: de invloed van de discussies op het begrip van de literatuur. Over het geheel genomen bevestigen de uitkomsten in deze tabel het belang van zowel de cognitieve als de sociale aspecten (kenmerken 1 en 2) binnen de online samenwerking tussen studenten.

\subsubsection{Samenvatting waardering}

De onderzoeksvraag was of de studenten de samenwerking met medestudenten waardeerden. De studenten bleken deze samenwerking in de meeste moduleperiodes hoog te waarderen. In die waardering speelden zowel sociale verbondenheid als leerzaamheid een rol. De waardering voor de samenwerking tussen e-learners bleek kwetsbaar. De waardering was laag in periode vier, dit werd veroorzaakt doordat de docenten de samenstelling van de groepjes sterk wijzigden. De waardering voor de samenwerking herstelde zich weer toen de elearning studenten hun eigen groepjes mochten kiezen.

\subsection{AANPASSINGEN AAN HET ONTWERP}

In paragraaf 5.3.1. wordt weergegeven welke aanpassingen het e-learning team toepaste tijdens of na moduleperiode 1 en of er daarna verbeteringen optraden. Het was niet mogelijk om te bepalen of de betreffende verbetering daadwerkelijk het gevolg was van de specifieke aanpassingen. In een aantal gevallen kunnen ook verbeteringen zijn opgetreden doordat de studenten gewend raakten aan elearning. Een aantal zaken liepen in cohort 2 vanaf het begin beter en stabieler dan in cohort 1 . Dit betrof de volgende onderwerpen: de aantallen bijdrages, de sociale interactie en de samenstelling van de groepjes. Naar ontsporingen van de netetiquette werd in cohort 2 geen onderzoek gedaan. De subjectieve indruk was dat er minder ontsporingen optraden dan in cohort 1. In paragraaf 5.3.2. worden enkele aanpassingen genoemd die nog niet geïmplementeerd waren in de eerste twee jaar van het e-learning project maar die wel zinvol lijken op grond van de bevindingen in paragraaf 5.1 en 5.2.

\subsubsection{Aanpassingen tijdens/na moduleperiode 1}

In tabel 5.17 is op basis van het onderzoekerslogboek weergegeven welke aanpassingen het e-learning team doorvoerde gedurende het eerste e-learning 
jaar. Deze aanpassingen werden op verschillende manieren gecommuniceerd naar de studenten uit het eerste cohort en naar nieuwe studenten. Naar de studenten van het eerste cohort werd vaak gecommuniceerd via de mededelingen in Blackboard, via de mail en via handleidingen die in Blackboard geplaatst werden. De aanpassingen werden daarnaast opgenomen in de training van nieuwe studenten tijdens de startbijeenkomst en op Blackboard. Daartoe werd voor Blackboard een thema unit ontwikkeld rondom het thema 'starten met elearning'. Deze unit is ingebouwd in de eerste Blackboard module en is beschikbaar sinds de start van cohort 2 . Het e-learning team streeft ernaar om de eerste module twee weken voor aanvang van de studie open te stellen. Op deze wijze kunnen nieuwe studenten zich goed oriënteren op wat de e-learning studie van hen vraagt. Na twee weken volgt dan de startdag waar studenten met elkaar kennismaken zodat zij enige informatie over elkaar hebben op grond waarvan zij de groepjes kunnen samenstellen. Ook kunnen zij vragen stellen naar aanleiding van hetgeen zij aangetroffen hebben in Blackboard. Om een goede start te kunnen maken met online discussiëren, wordt er gewerkt met goede en slechte voorbeelden waar studenten hun mening over mogen geven.

Tabel 5.17 Aanpassingen door het e-learning team in en buiten Blackboard (BB)

\begin{tabular}{|c|c|c|c|}
\hline Aanpassingen & Medium & $\begin{array}{c}\text { Tijdens/na } \\
\text { module- } \\
\text { periode }\end{array}$ & $\begin{array}{l}\text { Verbetering } \\
\text { in periode } 7\end{array}$ \\
\hline \multicolumn{4}{|l|}{ Leeslast } \\
\hline $\begin{array}{l}\text { Normen voor lengte bericht: } \\
\text { 100-300 woorden } \\
\text { Criteria met betrekking tot } \\
\text { spelling en formulering } \\
\text { Regel: geen attachments bij } \\
\text { discussiebijdrages } \\
\text { Regel: passende titel maken } \\
\text { voor bericht in discussielijn }\end{array}$ & $\begin{array}{l}\text { Handleiding online } \\
\text { discussiëren (BB) } \\
\text { Handleiding netetiquette (BB) }\end{array}$ & 1 & ja \\
\hline $\begin{array}{l}\text { Terugbrengen van het aantal e- } \\
\text { learning opdrachten naar } \\
\text { maximaal } 1 \text { discussie- of } \\
\text { samenwerkingsopdracht per } \\
\text { week }\end{array}$ & $\begin{array}{l}\text { Lijst met e-learningopdrachten } \\
\text { (BB) }\end{array}$ & 1 & \\
\hline $\begin{array}{l}\text { Scheiden van cognitieve } \\
\text { berichten en sociale berichten in } \\
\text { de groepjes }\end{array}$ & $\begin{array}{l}\text { Handleiding online } \\
\text { discussiëren (BB) } \\
\text { Aparte café ruimte binnen de } \\
\text { groepjes (BB) }\end{array}$ & 2 & \\
\hline
\end{tabular}


Tabel 5.17 Aanpassingen door het e-learning team in en buiten Blackboard (BB) (Continued)

\begin{tabular}{|c|c|c|c|}
\hline Aanpassingen & Medium & $\begin{array}{l}\text { Tijdens/na } \\
\text { module- } \\
\text { periode }\end{array}$ & $\begin{array}{l}\text { Verbetering } \\
\text { in periode } 7\end{array}$ \\
\hline \multicolumn{4}{|c|}{ Kwaliteit en timing van de bijdrages } \\
\hline $\begin{array}{l}\text { Verduidelijking verschil tussen } \\
\text { opdracht en discussiebijdrage }\end{array}$ & $\begin{array}{l}\text { Handleiding online } \\
\text { discussiëren (BB) } \\
\text { Mededelingen } \\
\text { Startdag: training }\end{array}$ & 1 & \multirow[t]{3}{*}{ ja } \\
\hline $\begin{array}{l}\text { Uitbreiding van de criteria en } \\
\text { rubrics voor de kwaliteit van de } \\
\text { discussie }\end{array}$ & $\begin{array}{l}\text { Handleiding online } \\
\text { discussiëren (BB) } \\
\text { Startdag: training }\end{array}$ & 1 & \\
\hline $\begin{array}{l}\text { Individuele feedback door de } \\
\text { docenten op de wijze van } \\
\text { discussiëren op grond van de } \\
\text { criteria en rubrics }\end{array}$ & Mail & 1 & \\
\hline $\begin{array}{l}\text { Veranderen van de groeps- } \\
\text { samenstelling tijdens lopende } \\
\text { module naar aanleiding van } \\
\text { inactiviteit van studenten }\end{array}$ & $\begin{array}{l}\text { Groepjes in BB } \\
\text { Mail }\end{array}$ & 1 & \\
\hline \multicolumn{4}{|c|}{$\begin{array}{l}\text { Problemen met de samenstelling van de groepjes, verbondenheid, perceptie van sociaal } \\
\text { gehalte, onderlinge steun voor het leerproces }\end{array}$} \\
\hline $\begin{array}{l}\text { Studenten stellen zelf hun } \\
\text { groepjes samen }\end{array}$ & $\begin{array}{l}\text { Sign up (digitale inschrijving } \\
\text { op BB) }\end{array}$ & 4 & ja \\
\hline $\begin{array}{l}\text { Benadrukken van het belang van } \\
\text { sociale uitwisseling voor nieuwe } \\
\text { e-learners }\end{array}$ & $\begin{array}{l}\text { Startdag } \\
\text { Thema unit 'starten met e- } \\
\text { learning' }\end{array}$ & 4 & \\
\hline \multicolumn{4}{|l|}{ Ontsporen van de communicatie } \\
\hline Richtlijnen voor netetiquette & $\begin{array}{l}\text { Handleiding netetiquette } \\
\text { Startdag } \\
\text { Thema unit 'starten met e- } \\
\text { learning' }\end{array}$ & 1 & \multirow[t]{3}{*}{ ja } \\
\hline $\begin{array}{l}\text { Bewaking van de netetiquette } \\
\text { door de docent, waar nodig } \\
\text { worden berichten verwijderd }\end{array}$ & $\begin{array}{l}\text { Mail } \\
\text { Discussieruimte BB }\end{array}$ & 1 & \\
\hline $\begin{array}{l}\text { Communicatie voorschrift: bij } \\
\text { irritatie gevoelens belafspraak } \\
\text { maken, digitaal geen irritatie } \\
\text { uiten. }\end{array}$ & $\begin{array}{l}\text { Handleiding netetiquette } \\
\text { Startdag } \\
\text { Thema unit 'starten met e- } \\
\text { learning' }\end{array}$ & 1 & \\
\hline
\end{tabular}

\subsubsection{Alsnog door te voeren aanpassingen}

In de doorgevoerde aanpassingen (5.3.1) is veel aandacht besteed aan de problemen die te maken hadden met de leeslast door te lange berichten en bestandsbijlagen. Minder aandacht is besteed aan het probleem van te veel 
bijdragen'. Aanvankelijk zag het e-learning team dit niet echt als een probleem, men was eerder bezorgd over de studenten die te weinig bijdroegen. Studenten die (veel) te veel bijdragen leveren in de beginfase van de studie verhoogden echter niet alleen de leeslast, maar belemmerden ook anderen om bij te dragen. Het lijkt verstandig om in de handleidingen en trainingen op te nemen dat drie bijdrages per discussie zowel het minimum als het maximum is. In het vierde jaar van de e-learning implementatie is hier ervaring mee opgedaan met een groepje van zeven en een groepje van acht nieuwe studenten. De ervaringen in de eerste module zijn positief; alle studenten leverden drie bijdrages per discussie. De discussie bleef overzichtelijk en er werd niet geklaagd over leeslast.

Een tweede aanpassing die doorgevoerd zou kunnen worden is een verduidelijking van de verwachtingen en mogelijkheden van sociaal gedrag binnen e-learning. In een aantal groepjes in cohort 1 bleef de uitwisseling vaak oppervlakkig. In groepjes waar meer gedeeld werd over het dagelijks leven en over emotionele gebeurtenissen daarin leek meer verbondenheid te ontstaan. Het lijkt zinvol om de studenten duidelijk te maken dat het belangrijk is om binnen elearning op dezelfde manier met dit type communicatie om te gaan als binnen de fysieke opleiding. Zaken die je zou vertellen als je elkaar fysiek zou ontmoeten, vertel je elkaar ook digitaal. In dat digitaal 'vertellen' kunnen soms ook foto's van belangrijke momenten een rol spelen. 


\section{HOOFDSTUK 6 \\ Resultaten implementatiefase: E-learning structuur}

\section{INLEIDING}

De e-learning structuur betreft de wijze waarop de opleiding gepland en georganiseerd is. In het ontwerp (zie hoofdstuk 3) zijn de volgende kenmerken van het cluster e-learning structuur beschreven:

- Strakke planning (kenmerk 3).

- Spreiding studielast (kenmerk 4).

- Helder geformuleerde leerdoelen en verwachtingen (kenmerk 5).

E-learning studenten hechten sterk aan tijdsonafhankelijk leren (o.m. Anderson, 2005; Arbaugh, 2000). Hoewel de tijdsonafhankelijkheid van de studie er door vermindert, werd in het huidige ontwerp besloten om een sterke structuur aan te brengen met opdrachten en deadlines. De belangrijkste doelen van deze structuur waren het mogelijk maken van interactie en het optimaliseren van het studierendement. Ook de structuurkenmerken 4 en 5 werden in het ontwerp opgenomen met het oog op deze doelen. In de pilotmodules (zie hoofdstuk 4) bleek dat de strakke planning realiseerbaar was met de studenten en dat deze wijze van plannen van belang was voor de interactie en voor het op tijd kunnen voltooien van de modules. De spreiding van de studielast bleek niet altijd even gemakkelijk te realiseren en de helderheid van de verwachtingen liet soms te wensen over voor studenten, met name ten aanzien van de eindopdracht.

Op basis van het uitgevoerde onderzoek (zie paragraaf 2.4 voor de opzet daarvan) komt in dit hoofdstuk eerst aan de orde hoe bruikbaar de ontwerpkenmerken zijn gebleken in de implementatiefase (6.1). Vervolgens komt aan de orde hoe studenten en docenten de aangebrachte structuur waarderen en met welke variabelen dit samenhangt (6.2). In de slotparagraaf (6.3) wordt beschreven welke 
aanpassingen er aan het ontwerp nodig bleken. De centrale onderzoeksvragen voor dit hoofdstuk zijn:

- Zijn de ontwerpkenmerken met betrekking tot de structuur bruikbaar binnen de opleiding?

- Hoe waarderen de studenten de organisatie van de e-learning modules?

- Met welke ontwerpkenmerken hangt deze waardering samen?

\subsection{BRUIKBAARHEID VAN DE STRUCTUUR KENMERKEN}

De bruikbaarheid van de structuur kenmerken betreft zowel de realiseerbaarheid als de zin van deze kenmerken in het kader van de volledige e-learning opleiding. De bruikbaarheid van de structuur kenmerken voor de e-learning opleiding wordt besproken aan de hand van de volgende onderwerpen:

- De ondersteunende rol van strakke planning (kenmerk 3 in paragraaf 6.1.1);

- Strakke planning in relatie tot samenwerking (kenmerk 3 in paragraaf 6.1.2);

- Spreiding van de studielast en ervaren werkdruk (kenmerk 4 in paragraaf 6.1.3);

- Duidelijkheid van leerdoelen en verwachtingen (kenmerk 5 in paragraaf 6.1.4);

- Ervaren chaos en organisatielast voor studenten (kenmerken 3,4,5 in paragraaf 6.1.5).

\subsubsection{De ondersteunende rol van strakke planning}

Ondersteuning door strakke planning

Nagegaan werd of de studenten de aangebrachte structuur van opdrachten en deadlines als ondersteunend ervoeren voor hun eigen planning en voor de tijdige afronding van de modules. Hiertoe is gebruik gemaakt van de schaal 'Ondersteuning door planning' uit de vragenlijst 'Organisatie van de e-learning'. De items zijn als volgt gescoord: $1=$ helemaal oneens, $2=$ oneens, $3=$ neutraal, $4=$ eens, 5=helemaal eens. In tabel 6.1 zijn de gemiddeldes $(X)$ en de standaarddeviaties $(S D)$ weergegeven voor de twee e-learning cohorten in de moduleperiodes waarna deze schaal werd afgenomen. 
Tabel 6.1 Gemiddeldes (X) en standaarddeviaties (SD) voor 'ondersteuning door planning'

\begin{tabular}{lcccccc}
\hline & \multicolumn{3}{c}{ Cohort 1 e-learning } & \multicolumn{3}{c}{ Cohort 2 e-learning } \\
Periode & $N$ & $X$ & $S D$ & $N$ & $X$ & $S D$ \\
\hline 2 & 23 & 3,9 & 0,73 & - & - & - \\
6 & 19 & 4,1 & 0,78 & 23 & 4,3 & 0,57 \\
7 & 13 & 4,0 & 0,84 & 11 & 4,0 & 0,75 \\
\hline
\end{tabular}

In de tabel is zichtbaar dat de scores in alle gevallen rond de 4 lagen. De studenten bevestigden hiermee dat zij ondersteuning hebben ervaren door de strakke planning. Voor beide cohorten bleken bij de variantieanalyse voor herhaalde metingen geen significante verschillen tussen de moduleperiodes. Uit de $t$-toets voor onafhankelijke steekproeven bleken geen significante verschillen tussen de twee cohorten in periodes 6 en 7 .

Binnen de termijn inleveren van de eindopdracht

Het op tijd inleveren van de eindopdrachten van de modules werd als indicator gezien voor het realiseren van de structuur en voor de mate van ondersteuning die studenten ondervonden van het rooster met de deadlines. Voor alle elearning studenten is in de periodes 1 tot en met 7 nagegaan of zij hun eindopdracht al dan niet inleverden binnen de daarvoor gestelde tijd. In tabel 6.2 is zichtbaar hoeveel studenten actief deelnamen en hoeveel procent van deze studenten de eindopdracht van de module op tijd inleverden, te laat inleverden of helemaal niet inleverden. Soms namen studenten wel deel aan de module terwijl zij er een vrijstelling voor hadden. Zij rondden de module niet af. Dit is zichtbaar gemaakt in de kolom 'vrijstelling'.

Tabel 6.2 Tijdig inleveren van de eindopdracht van de module

\begin{tabular}{|c|c|c|c|c|c|c|c|c|c|c|}
\hline \multirow[b]{2}{*}{ Periode } & \multicolumn{5}{|c|}{ Cohort 1 e-learning } & \multicolumn{5}{|c|}{ Cohort 2 e-learning } \\
\hline & $\mathrm{N}$ & $\begin{array}{c}\% \text { op } \\
\text { tijd }\end{array}$ & $\begin{array}{l}\% \text { te } \\
\text { laat }\end{array}$ & $\begin{array}{c}\% \\
\text { niet }\end{array}$ & $\begin{array}{l}\% \text { vrij- } \\
\text { stelling }\end{array}$ & $\mathrm{N}$ & $\begin{array}{c}\% \text { op } \\
\text { tijd }\end{array}$ & $\begin{array}{l}\% \text { te } \\
\text { laat }\end{array}$ & $\begin{array}{c}\% \\
\text { niet }\end{array}$ & $\begin{array}{c}\% \text { vrijs- } \\
\text { telling }\end{array}$ \\
\hline 1 & 39 & 66,7 & 5,1 & 28,2 & & & & & & \\
\hline 2 & 30 & 70 & 13,3 & 10 & 6,7 & & & & & \\
\hline 3 & 31 & 74,2 & 6,5 & 16,1 & 3,2 & & & & & \\
\hline 4 & 26 & 88 & 0 & 12 & 3,7 & & & & & \\
\hline 5 & 24 & 70,8 & 25,0 & 4,2 & & 38 & 47,4 & 26,3 & 26,3 & \\
\hline 6 & 22 & 68,2 & 27,3 & 4,5 & & 27 & 92,6 & 0 & 7,4 & \\
\hline 7 & 20 & 90 & 10 & 0 & & 25 & 64 & 32 & 4 & \\
\hline
\end{tabular}


Deze cijfers bevestigen de aangebrachte structuur. Een ruime meerderheid leverde de eindopdracht op tijd in. Het lijkt erop dat de aangebrachte structuur (roosters en deadlines) inderdaad het op tijd inleveren van eindopdrachten bevordert en daarmee de kans vergroot dat studenten ook daadwerkelijk zouden afstuderen. Opvallend zijn de hoge percentages 'niet inleveren' in periode 1 van cohort 1 en periode 5 van cohort 2 . In beide gevallen betrof dit de eerste module van de opleiding. De betreffende studenten konden of wilden niet mee in het studieritme en het studietempo. Ook het niveau en de inhoud van de studie kunnen uiteraard een rol gespeeld hebben. Het niet inleveren van de eindopdracht van de eerste moduleperiode bleek synoniem aan uitvallen (zie ook hoofdstuk 9). Opvallend is dat alle studenten uit cohort 1 in periode 7 hun werkstuk inleverden, en verreweg de meeste studenten op tijd. Deze studenten waren dicht bij hun afstuderen.

\subsubsection{Strakke planning in relatie tot samenwerking}

De samenwerking in de modules werd gestuurd door de verplichte opdrachten en deadlines. De mate waarin de studenten binnen hun groepje en binnen de gestelde tijd deelnamen aan deze opdrachten bepaalde in hoeverre sprake kon zijn van samenwerking. Dit is onderzocht door te kijken hoe de vijf voor het kwalitatieve onderzoek geselecteerde studenten bijdroegen aan de discussie en of zij opdrachten op tijd inleverden.

\section{Aantallen discussiebijdragen binnen de tijd}

De studenten werden binnen het ontwerp verplicht om minimaal drie cognitieve bijdrages per discussieopdracht te leveren binnen een gestelde termijn. De vraag was of studenten daadwerkelijk uitvoering gaven aan deze structuur. In tabel 6.3 wordt per discussieopdracht weergegeven hoeveel cognitieve bijdragen de vijf random geselecteerde studenten leverden en hoeveel van deze studenten voldeden aan het minimum van drie cognitieve bijdrages binnen de termijn. De vet gedrukte cijfers geven aan dat een student bij de betreffende discussie voldeed aan deze minimum eisen. 


\begin{tabular}{|c|c|c|c|c|c|c|c|}
\hline \multirow{2}{*}{$\begin{array}{l}\text { Discussie- } \\
\text { opdrachten }\end{array}$} & \multicolumn{5}{|c|}{$\begin{array}{l}\text { Aantal cognitieve discussiebijdragen } \\
\text { per student, binnen de tijd }\end{array}$} & \multirow[t]{2}{*}{$\begin{array}{c}\begin{array}{c}\text { Totaal } \\
\text { aantal } \\
\text { bijdrages } \\
\text { per } \\
\text { discussie }\end{array} \\
\text { Totaal }\end{array}$} & \multirow[t]{2}{*}{$\begin{array}{c}\text { Aantal } \\
\text { studenten dat } \\
\text { voldeed aan de } \\
\text { gestelde } \\
\text { minimum } \\
\text { eisen } \\
\end{array}$} \\
\hline & $A$ & $B$ & $C$ & $D$ & $E$ & & \\
\hline Moduleperiode 1 & & & & & & & $\mathrm{~N}=5$ \\
\hline 1.2 & 5 & 1 & 8 & 1 & 2 & 17 & 2 \\
\hline 1.3 & 2 & 1 & 16 & 3 & 0 & 22 & 2 \\
\hline 1.6 & 5 & 3 & 5 & 2 & 3 & 18 & 4 \\
\hline 2.2 & 1 & 2 & 6 & 4 & 3 & 16 & 3 \\
\hline 2.3 & 1 & 2 & 5 & 1 & 3 & 12 & 2 \\
\hline 3.2 & 3 & 2 & 6 & 2 & 5 & 18 & 3 \\
\hline 3.3 & 5 & 1 & 7 & 4 & 4 & 21 & 4 \\
\hline 4.1 & 7 & 4 & 18 & 5 & 4 & 38 & 5 \\
\hline 6.1 & 2 & 0 & 11 & 4 & 3 & 20 & 3 \\
\hline Moduleperiode 7 & $\mathrm{~A}$ & B & $\mathrm{C}$ & $\mathrm{D}$ & & & $\mathrm{N}=4$ \\
\hline 1.3 & 2 & 3 & 4 & 7 & & 16 & 3 \\
\hline 2.1 & 4 & 5 & 8 & 2 & & 19 & 3 \\
\hline 3.2 & 3 & 4 & 4 & 4 & & 15 & 4 \\
\hline 4.1 & 6 & 5 & 9 & 8 & & 28 & 4 \\
\hline 5.2 & 1 & 2 & 5 & 2 & & 10 & 1 \\
\hline 6.1 & 3 & 5 & 3 & 3 & & 14 & 4 \\
\hline
\end{tabular}

In moduleperiode $1 \mathrm{kwam}$ de deelname aan de discussies moeizaam op gang. In de eerste twee discussies voldeden drie van de vijf studenten niet aan de eisen. Student $C$ voldeed in alle discussies aan de eisen maar leverde bij sommige opdrachten extreem veel bijdrages. In moduleperiode 7 was de deelname aan de discussies stabieler en evenwichtiger. De verschillen in aantallen bijdrages van studenten waren kleiner dan in moduleperiode 1. Alleen discussieopdracht 5.2 leverde duidelijk problemen op. Zowel in periode 1 als in periode 7 was duidelijk dat het rooster en de deadlines ervoor zorgden dat er discussies konden plaatsvinden. In de kolom met het totaal aantal bijdrages per discussie is zichtbaar dat alle geplande discussies daadwerkelijk plaatsvonden met een substantieel aantal bijdrages van de studenten.

\section{Aantallen overige e-learning opdrachten binnen de tijd}

In tabel 6.4 wordt zichtbaar gemaakt in hoeverre de vijf random geselecteerde studenten in de twee modules voldeden aan de deadlines die er waren voor de andere soorten opdrachten: samenwerkingsopdrachten, video-opdrachten, 
feedback opdrachten en de eindopdracht. De deelopdrachten van de eindopdracht zijn buiten beschouwing gelaten. Gehaalde deadlines worden gemarkeerd met een $x$. Niet gehaalde deadlines worden aangegeven met de hoeveelheid opgelopen vertraging.

Tabel 6.4 Gerealiseerde deadlines voor de overige opdrachten in de module

\begin{tabular}{|c|c|c|c|c|c|}
\hline Opdracht & $\begin{array}{c}\text { Student } \\
\text { A }\end{array}$ & $\begin{array}{l}\text { Student } \\
\text { B }\end{array}$ & $\begin{array}{l}\text { Student } \\
\text { C }\end{array}$ & $\begin{array}{c}\text { Student } \\
\text { D }\end{array}$ & $\begin{array}{c}\text { Student } \\
\text { E }\end{array}$ \\
\hline \multicolumn{6}{|l|}{ Moduleperiode 1} \\
\hline $\begin{array}{l}\text { 1.4 Samenwerkings- } \\
\text { opdracht }\end{array}$ & $x$ & $x$ & $x$ & $x$ & $x$ \\
\hline 1.5 Video opname & $\begin{array}{c}5 \text { dagen } \\
\text { vertraging }\end{array}$ & $x$ & $x$ & $x$ & $x$ \\
\hline $\begin{array}{l}\text { 2.1 Samenwerkings- } \\
\text { opdracht }\end{array}$ & $\mathrm{x}$ & $x$ & $x$ & $x$ & $x$ \\
\hline $\begin{array}{l}\text { 3.1 Samenwerkings- } \\
\text { opdracht }\end{array}$ & $x$ & $x$ & $x$ & $x$ & $x$ \\
\hline 4.2 Feedback opdracht & $x$ & $x$ & $x$ & $x$ & $x$ \\
\hline 8.2 Eindopdracht & $x$ & $\begin{array}{c}2 \text { maanden } \\
\text { uitstel }\end{array}$ & $x$ & $x$ & $x$ \\
\hline \multicolumn{6}{|l|}{ Moduleperiode 7} \\
\hline 3.1 Feedbackopdracht & $x$ & $x$ & $x$ & $x$ & \\
\hline $\begin{array}{l}\text { 4.2 Samenwerkings- } \\
\text { opdracht }\end{array}$ & $x$ & $x$ & $x$ & $x$ & \\
\hline 5.1 Video opname & $\begin{array}{c}1 \text { week } \\
\text { vertraging }\end{array}$ & $x$ & $\begin{array}{c}1 \text { week } \\
\text { vertraging }\end{array}$ & $x$ & \\
\hline 7.2 Feedback opdracht & $\mathrm{x}$ & $x$ & $\mathrm{x}$ & $x$ & \\
\hline 8.2 Eindopdracht & $x$ & $x$ & $x$ & $x$ & \\
\hline
\end{tabular}

Uit tabel 6.4 blijkt dat bijna alle deadlines voor de opdrachten gehaald zijn. Er ontstond drie maal vertraging bij het uploaden van een video-opname (Opdracht 1.5 in moduleperiode 1 en opdracht 5.1 in moduleperiode 7). De eindopdracht is in op één na alle gevallen voor de deadline ingeleverd. De student met uitstel voor de eindopdracht leverde de opdracht uiteindelijk binnen de uitsteltermijn in. Het uitstel was aangevraagd op grond van privé omstandigheden. Het rooster met de opdrachtenstructuur leidde ertoe dat deze studenten allen actief en doorgaans tijdig participeerden in de verschillende samenwerkingsopdrachten.

\subsubsection{Spreiding van de studielast en ervaren werkdruk}

In de e-learning modules is gestreefd naar een goede spreiding van de studielast. De bedoeling was dat een evenwichtige werkdruk zou leiden tot evenwichtig 
studietempo. Er werd naar gestreefd om zowel piekbelastingen als periodes van zeer lage belasting vermijden. Een te hoge werkdruk vergt veel zelfdiscipline van studenten en kan leiden tot acute problemen met hun belastbaarheid. Periodes van zeer lage belasting kunnen het moeilijk maken om daarna de draad van de studie weer op te pakken.

\section{Evenwichtige verdeling van studiebelasting}

Om na te gaan of de studenten vonden dat er voldoende spreiding was van de studielast in de modules is gebruik gemaakt van een item uit de vragenlijst 'Organisatie van de e-learning'. Dit item was als volgt geformuleerd: 'de studiebelasting was evenwichtig verdeeld over de module'. De studenten scoorden dit item op een 5-puntsschaal ( $1=$ helemaal oneens, $2=$ oneens, $3=$ neutraal, $4=$ =ens, $5=$ helemaal eens). De schaal werd afgenomen in moduleperiodes 2,6 en 7 . In tabel 6.5 zijn de percentages 'ja' weergegeven. Deze bestaan uit de scores 4 'eens' en 5 'helemaal eens'. Bovendien zijn de gemiddeldes $(X)$ en standaarddeviaties $(S D)$ weergegeven voor de cohorten 1 en 2.

Tabel 6.5 Evenwichtige spreiding van de studielast

\begin{tabular}{lcccccccc}
\hline & \multicolumn{3}{c}{ Cohort 1 e-learning } & \multicolumn{5}{c}{ Cohort 2 e-learning } \\
\cline { 2 - 9 } Periode & $N$ & $\begin{array}{c}\text { Percentage } \\
\text { ' } j a^{\prime}\end{array}$ & $X$ & $S D$ & $N$ & 'ja' & $X$ & $S D$ \\
\hline 2 & 23 & $35 \%$ & 3,0 & 0,95 & - & & - & 0,89 \\
6 & 19 & $47 \%$ & 3,3 & 1,20 & 23 & $65 \%$ & 3,7 & 1,19 \\
7 & 13 & $54 \%$ & 3,4 & 1,12 & 11 & $55 \%$ & 3,3 & 19 \\
\hline
\end{tabular}

Uit de tabel blijkt dat in periode 2 zeer weinig studenten vonden dat de studielast evenwichtig verdeeld was over de module. In de meeste periodes gaven studenten gemiddeld een neutrale reactie op deze vraag (rond de drie). Dit betekent dat de evenwichtige verdeling van de studielast niet overtuigend werd gerealiseerd. Een uitzondering vormde moduleperiode 6 in cohort 2, waar een score dicht bij de 4 gerealiseerd werd. Dit betekent dat deze studenten bevestigden dat de studielast in periode 6 evenwichtig verdeeld was.

Er is in de tabel een positieve ontwikkeling zichtbaar van jaar 1 (periode 2) naar jaar 2 (periodes 6 en 7). In het tweede jaar waren er procentueel meer studenten die bevestigden dat de studielast evenwichtig verdeeld was. Bij de variantieanalyse voor herhaalde metingen in cohort 1 bleken de verschillen tussen de moduleperiodes echter niet significant. Ditzelfde gold voor de moduleperiodes van cohort 2. Met de $t$-toets voor onafhankelijke steekproeven werden ook geen significante verschillen gevonden tussen de cohorten 1 en 2 in periodes 6 en 7 . 


\section{Ervaren werkdruk}

Met behulp van de schaal 'werkdruk en begrip' is nagegaan of studenten de werkdruk als realistisch ervoeren en als niet belemmerend voor hun begrip van de leerstof. De schaal bevatte vier items. Een voorbeeld item is: 'Ik had doorgaans genoeg tijd om de aangeboden stof te begrijpen'. De items werden gescoord op een 5 -puntsschaal $(1=$ helemaal oneens, $2=$ oneens, $3=$ neutraal, $4=$ =ens, $5=$ helemaal eens). In tabel 6.6 zijn gemiddeldes $(X)$ en standaarddeviaties $(S D)$ op deze schaal weergegeven voor beide cohorten.

Tabel 6.6 Werkdruk en begrip

\begin{tabular}{lcccccc}
\hline \multirow{2}{*}{ Periode } & \multicolumn{3}{c}{ Cohort 1 e-learning } & \multicolumn{3}{c}{ Cohort 2 e-learning } \\
\cline { 2 - 7 } & $N$ & $X$ & $S D$ & $N$ & $X$ & $S D$ \\
2 & 23 & 3,0 & 0,81 & - & - & - \\
6 & 19 & 3,4 & 0,94 & 23 & 3,5 & 0,64 \\
7 & 13 & 3,6 & 0,81 & 11 & 3,3 & 0,77 \\
\hline
\end{tabular}

Gemiddeld reageerden de studenten neutraal tot neutraal positief op het onderwerp werkdruk en begrip. Dit betekent dat de gemiddelde student op dit vlak geen uitgesproken problemen had. De studenten in cohort 1 werden in de loop van de modules iets positiever over dit onderwerp. Als er al problemen waren, verminderden deze in de loop van de moduleperiodes. Dit wordt bevestigd door de variantieanalyse voor herhaalde metingen. Uit de analyse bleek dat de verschillen tussen de moduleperiodes significant waren, $F(2 ; 16)=4,66, p<0,05$, $\eta_{p}{ }^{2}=0,37$. Met behulp van toetsing van de contrasten is er een vergelijking gemaakt tussen de verschillende moduleperiodes. In tabel 6.7 worden $F$ waardes, $p$ waardes en effectgroottes weergegeven voor de verschillen tussen de moduleperiodes.

Tabel 6.7 Cohort 1: verschillen in werkdruk tussen moduleperiodes

\begin{tabular}{lccc}
\hline $\begin{array}{l}\text { Vergeleken } \\
\text { moduleperiodes }\end{array}$ & $\boldsymbol{F}$ & $\boldsymbol{p}$ & $\begin{array}{c}\text { Effectgrootte } \\
{ }^{2}\end{array}$ \\
\hline 2 versus 6 & 2,0 & 0,195 & 0,20 \\
6 versus 7 & 4,2 & 0,073 & 0,35 \\
2 versus 7 & 7,2 & $0,028^{*}$ & 0,47 \\
\hline
\end{tabular}

Noot: $\quad{ }^{*} p<0,05$.

Er bleek alleen een significant verschil te bestaan tussen de periodes 2 en 7, in het voordeel van periode 7 . In periode 7 werd de werkdruk als realistischer en minder belemmerend ervaren dan in periode 2. In tabel 6.6 is zichtbaar dat er ook een verschil leek te zijn tussen de twee modules van cohort 2 . Bij de 
variantieanalyse voor herhaalde metingen bleek dit verschil niet significant. De $t$ toets voor onafhankelijke steekproeven liet ook geen significante verschillen zien tussen de cohorten 1 en 2 in moduleperiodes 6 en 7.

\section{Tijdsdruk en stress}

In de schaal 'Tijdsdruk en stress' gaven de studenten reactie op de volgende woorden: tijdrovend, overspoeld, onzekerheid, roept spanning op. De studenten konden als volgt reageren op deze woorden: $1=$ Nee!, 2=Nee, 3=Soms, 4=Ja, 5=Ja! Hoe hoger de score, hoe meer tijdsdruk studenten ervoeren. In tabel 6.8 zijn gemiddeldes $(X)$ en standaarddeviaties $(S D)$ op deze schaal weergegeven voor beide cohorten. Waar mogelijk zijn ter vergelijking de scores van het reguliere cohort opgenomen.

Tabel 6.8 Schaal tijdsdruk en stress van de vragenlijst Woord en Ervaring

\begin{tabular}{lccccccccc}
\hline & \multicolumn{4}{c}{ Cohort 1 e-learning } & \multicolumn{3}{c}{ Cohort 1 regulier } & \multicolumn{3}{c}{ Cohort 2 e-learning } \\
Periode & $N$ & $X$ & $S D$ & $N$ & $X$ & $S D$ & $N$ & $X$ & $S D$ \\
\cline { 1 - 9 } & 36 & 3,5 & 0,89 & 33 & 3,6 & 0,65 & & & \\
4 & 23 & 3,2 & 0,70 & & & & & & \\
5 & 21 & 3,5 & 0,93 & 231 & 3,1 & 0,76 & 28 & 3,3 & 0,67 \\
\hline
\end{tabular}

In alle gevallen wordt gemiddeld iets boven de 3 gescoord. Dit betekent dat zowel de e-learners als de reguliere studenten soms tijdsdruk en stress ervoeren door de studie. Dit is in principe een normale situatie die bij e-learning niet erger lijkt te zijn dan in de reguliere studie. De hoogste score is voor de reguliere studenten $(3,6$ in periode 1). Het eerste cohort e-learners scoorde eveneens vrij hoog in de periodes 1 en 5 . Met de $t$ - toets voor onafhankelijke steekproeven is nagegaan of er een significant verschil was tussen cohort 1 e-learning en cohort 1 regulier in moduleperiode 1. Dit bleek niet het geval. Met behulp van variantie analyse is nagegaan of er een significant verschil was tussen de drie cohorten in periode 5, ook dit bleek niet het geval. Met behulp van variantie analyse voor herhaalde metingen bleek dat de verschillen tussen de drie periodes van cohort 1 wel significant waren, $F\left(2 ; 36=3,30, p<0,05, \eta_{p}{ }^{2}=0,16\right)$. Correctie bleek niet nodig. Uit toetsing van contrasten tussen de opeenvolgende modules bleek alleen het verschil tussen periodes 4 en 5 significant te zijn, $p<0,01, \eta_{p}{ }^{2}=0,39$. Dit is in lijn met de gegevens in tabel 6.2 waaruit blijkt dat de studenten in periode 5 meer moeite hadden met het op tijd inleveren van de eindopdracht dan in periode 4 . 


\section{Uitzonderingen op het tijdpad van de module}

Door studie-, privé- en werkomstandigheden kwam het voor dat studenten aangaven dat zij overbelast raakten. Docenten konden deze studenten tegemoet komen door ad hoc uitzonderingen te maken op de gestelde deadlines. In het instrument 'Begeleiding door de docent' was het volgende item op genomen: "Toen dat nodig was bood de docent alternatieven voor het vaste tijdpad van de module". Dit item werd gescoord op de volgende schaal: nee- gaat wel - ja - niet van toepassing. De resultaten op dit item zijn zichtbaar in tabel 6.9. In de tabel zijn de percentages ja, gaat wel en nee weergegeven.

Tabel 6.9 Uitzonderingen op rooster / deadlines

\begin{tabular}{|c|c|c|c|c|c|c|c|c|}
\hline \multirow[b]{2}{*}{ Periode } & \multicolumn{4}{|c|}{ Cohort 1 e-learning } & \multicolumn{4}{|c|}{ Cohort 2 e-learning } \\
\hline & $N$ & $\%$ ja & $\begin{array}{c}\% \text { gaat } \\
\text { wel }\end{array}$ & $\begin{array}{c}\% \\
\text { nee }\end{array}$ & $N$ & $\%$ ja & $\begin{array}{c}\% \text { gaat } \\
\text { wel }\end{array}$ & $\begin{array}{l}\% \\
\text { nee }\end{array}$ \\
\hline 1 & 22 & 41 & 5 & 5 & & & & \\
\hline 2 & 26 & 19 & 8 & 4 & & & & \\
\hline 3 & 22 & 18 & 0 & 0 & & & & \\
\hline 4 & 16 & 31 & 0 & 0 & & & & \\
\hline 6 & 19 & 42 & 5 & 0 & 23 & 17 & 4 & 0 \\
\hline
\end{tabular}

In moduleperiodes 1,4 en 6 werden in cohort 1 het vaakst uitzonderingen gemaakt op de deadlines. In de overige modules werd minder beroep gedaan op uitzonderingen in het tijdpad. In een klein aantal gevallen gaven studenten aan dat de docent geen uitzondering verleende (\% nee), toen het wel nodig was. Dit speelde alleen in de beginfase (periodes 1 en 2). Later waren studenten en docenten wellicht meer gewend geraakt aan de mogelijkheid om een uitzondering te vragen of te verlenen.

\section{Berichten van studenten over studiebelasting}

In periode 1 waren er 12 berichten die er op wezen dat de vijf voor het kwalitatief onderzoek geselecteerde studenten de studiebelasting in moduleperiode 1 als zwaar ervoeren. De combinatie van werk, studie en gezin werd als moeilijk ervaren. De studenten hadden het gevoel dat zij door de studie te weinig vrije tijd overhielden. Er werd 's avonds, 's nachts en in het weekend gewerkt. Eén van de studenten gaf aan dat haar studiebelasting groter was dan 20 uur per week omdat het lezen van de literatuur haar al bijna 20 uur per week kostte. Een andere student kwam gemiddeld op 18 uur effectieve studietijd en gaf aan dat de ervaren belasting veel hoger was door allerlei beginners perikelen zoals wennen aan Blackboard, bibliotheekbezoek en het regelen van de videocamera en de opnames. 
Het uploaden van een bewerkt videofragment kostte vier van de vijf studenten zeer veel tijd doordat zij hier nog geen handigheid mee hadden.

Ik vind het erg pittig, maar dit komt waarschijnlijk mede door het volgen van deze opleiding naast een fulltime baan en gezin. Dat wist ik echter van tevoren. De twintig uur per week zijn naar mijn idee onvoldoende. Die ben je al bijna kwijt aan de literatuur. (...)

Ook hier wordt het nachtwerk, zoals altijd, de laatste twee weken.

In de eerste moduleperiode maakten studenten zich soms zorgen over de vraag wat er moest gebeuren als zij door onvoorziene privé- of werkomstandigheden tijdelijk zouden uitvallen, zij zagen geen duidelijke oplossingen voor die situatie.

Het volgen van deze studie vraagt een strakke tijdsplanning. Ook voor je eigen groepje is het belangrijk dat je zoveel mogelijk mee discussieert en "aanwezig" bent. Maar wat nu als je (onverhoopt) ziek wordt en enkele dagen niet met de cursus bezig kunt zijn? Je zit aan deadlines, groepsleden zijn afhankelijk van je?(.... ..) Ook kan het zijn dat je soms vanwege drukte op school (............) minder inbreng kunt geven. Hoe daarmee om te gaan? Ik begin ondertussen meer inzicht te krijgen in de studie: de werkwijze/de samenwerking etc. Maar ik heb ook het gevoel dat tijdelijke uitval door ziekte/andere omstandigheden totaal niet mogelijk is binnen dit stramien. Dit geeft mij een onrustig gevoel. Kan ik hier wat uitleg en duidelijkheid over krijgen?

In periode 7 waren er geen opmerkingen meer over de studielast, wel was er soms sprake van overmacht. De studieplanning kwam dan in het nauw door privé- of werkomstandigheden. De studenten communiceerden met elkaar en met de docent om gezamenlijk tot een oplossing te komen. Waar nodig verleende de docent een week uitstel. Naast het strakke rooster met opdrachten bleek het regelmatig nodig om uitzonderingen te maken in gevallen van overmacht.

Hoi meiden (en docent $\mathrm{x}$ ): Door een heftig weekend, een vergadering die gisteren uitliep (23.30 uur thuis) en een mega administratieve klus (...........) ben ik vanavond niet aan studeren (en reageren) toegekomen. Ik kom vanavond, (want het is inmiddels na twaalven) echt langs (en dat is geen 1 april-grap).

Hoi (docent x): Mijn leerling komt deze week niet (afmelding), dat zou betekenen dat ik begin volgende week de video "pas" kan opnemen. Is dat een probleem?

\section{Studiebelasting bekeken door de ogen van docenten}

Alle docenten wezen in de interviews op de moeite die studenten hadden met de combinatie werk, gezin en baan. In het bijzonder werd de combinatie met een fulltime baan als problematisch gezien. De docenten gaven aan dat het van groot 
belang was dat studenten van te voren een realistische verwachting hadden van de studielast en hun studie uren goed planden in overleg met gezin en werk. Studenten die kozen om echt mee te gaan in het stramien van het rooster en de deadlines waren volgens de docenten lekker aan het studeren. Studenten die de studiebelasting onderschat hadden, kwamen vrijwel meteen in de problemen. Zij liepen achterstanden op die moeilijk in te halen waren. Voor alle studenten konden problemen met het studieritme ontstaan als er onverwachte persoonlijke problemen optraden zoals ziekte of een sterfgeval. In het logboek werd geregistreerd dat één van de docenten concludeerde dat cohort 2 minder moeite had om mee te gaan in de regelmaat van het rooster doordat deze studenten zich van te voren beter op de studie hadden kunnen oriënteren. Er waren uitgebreidere intakes gedaan en de studenten hadden voorafgaand aan de startzaterdag al toegang tot de eerste e-learning module, zodat zij zich goed konden oriënteren op de wijze van studeren.

Uit de interviews en uit het logboek blijkt dat er in de eerste moduleperiode van cohort 1 te veel discussie- en samenwerkingsopdrachten waren. Een aantal studenten beklaagde zich over de studielast en soms waren er te weinig bijdrages aan bepaalde opdrachten. De docenten reageerden hier na onderling overleg op met een vermindering van het aantal opdrachten. Soms hadden zij de indruk dat de studielast hierdoor te laag werd en dat niet alle opmerkingen over de studielast terecht waren.

In het rooster was voorzien in vakantiespreiding omdat met studenten uit heel Nederland gewerkt werd. Binnen groepjes liepen de vakanties vaak niet gelijk op. Hierdoor ontstond een probleem met de synchronisatie van bijdrages. $\mathrm{Na}$ de vakantie bleek het voor sommige studenten bovendien moeilijk om weer in het gestage e-learning studieritme te komen.

\subsubsection{Duidelijkheid van leerdoelen en verwachtingen}

Op basis van ontwerpkenmerk 3 bestond de intentie om voor studenten de leerdoelen en de verwachtingen helder te formuleren. Om na te gaan of de studenten inderdaad voldoende duidelijkheid ervoeren werd de subschaal 'Duidelijkheid' gebruikt in de vragenlijst 'organisatie van de e-learning'. In tabel 6.10 zijn de resultaten $(X$ en $S D$ ) zichtbaar van deze schaal die gescoord werd met 1 =helemaal oneens, $2=$ oneens, $3=$ neutraal, $4=$ eens, $5=$ helemaal eens. 
Tabel 6.10 Duidelijkheid

\begin{tabular}{lcccccc}
\hline & \multicolumn{3}{c}{ Cohort 1 e-learning } & \multicolumn{3}{c}{ Cohort 2 e-learning } \\
Periode & $N$ & $X$ & $S D$ & $N$ & $X$ & $S D$ \\
\hline 2 & 23 & 3,9 & 0,69 & - & - & - \\
6 & 19 & 4,1 & 0,70 & 23 & 3,9 & 0,51 \\
7 & 13 & 3,8 & 0,57 & 11 & 3,8 & 0,69 \\
\hline
\end{tabular}

De gemiddelde scores van de studenten waren dicht in de buurt van de 4: eens. Dit reflecteert de gewenste situatie. Er waren geen significante verschillen tussen de periodes (variantie analyse voor herhaalde metingen) en ook niet tussen de twee cohorten ( $t$-toets voor onafhankelijke steekproeven).

In e-learning is het uitermate belangrijk dat opdrachten helder geformuleerd zijn. Studenten kunnen niet gemakkelijk opheldering vragen in de les en het is gevaarlijk voor het moreel als studenten op afstand onzeker raken. Het gemiddelde in de buurt van 4 op de schaal duidelijkheid lijkt positief. Deze schaal gaat echter niet alleen over de duidelijkheid van de opdrachten, maar ook over de duidelijkheid van de leerdoelen en andere informatie in Blackboard. Het gevonden gemiddelde camoufleert mogelijk een aantal studenten waarvoor de opdrachtformulering helemaal niet duidelijk is. Om hier meer zicht op te krijgen is gekeken naar één van de items in de schaal. Dit betreft het item over de duidelijkheid van de instructies bij de opdrachten. In tabel 6.11 zijn de gemiddeldes $(X)$ en de standaarddeviaties $(S D)$ voor dit item zijn weergegeven.

Tabel 6.11 Duidelijkheid van de e-learning opdrachten

\begin{tabular}{lcccccc}
\hline & \multicolumn{3}{c}{ Cohort 1 e-learning } & \multicolumn{3}{c}{ Cohort 2 e-learning } \\
Periode & $N$ & $X$ & $S D$ & $N$ & $X$ & $S D$ \\
\hline 2 & 23 & 3,4 & 1,08 & - & - & - \\
6 & 19 & 3,7 & 0,89 & 23 & 3,2 & 0,98 \\
7 & 13 & 3,2 & 1,14 & 11 & 3,1 & 0,94 \\
\hline
\end{tabular}

Uit de tabel blijkt dat de duidelijkheid van de opdrachtformuleringen te wensen over liet. Gemiddeld werd in de buurt van 3 gescoord, hetgeen betekent dat de studenten de opdrachten soms duidelijk genoeg vonden. Een aanzienlijk aantal studenten (tussen 11 en 31\%) vond de opdrachten onvoldoende duidelijk. Het uitgangspunt van heldere formulering is voor de opdrachten onvoldoende gerealiseerd. Uit de $t$-toets voor onafhankelijke steekproeven bleken geen verschillen tussen cohort 1 en 2 in periodes 6 en 7. Bij de variantieanalyse voor herhaalde metingen bleken geen significante verschillen tussen de 
moduleperiodes, noch voor cohort 1, noch voor cohort 2 . Kennelijk is de duidelijkheid van de opdrachten een hardnekkig onderwerp. Het lukte het elearning team niet om in de loop van de tijd structureel verbetering te brengen in de duidelijkheid van de opdrachtformulering.

\section{Berichten over de duidelijkheid van de opdrachten}

In periode 1 stelden de vijf voor het kwalitatief onderzoek geselecteerde studenten veel vragen over de opdrachten en de eisen die daaraan gesteld werden. Het uitgangspunt van een heldere formulering van leerdoelen en verwachtingen bleek niet makkelijk te verwezenlijken. De studenten vonden vele onduidelijkheden in de opdrachten en waren onzeker over de verwachtingen en eisen van de e-learning docenten.

Op de planning staat verplichte en keuzeliteratuur. Als je dit allemaal leest kom je boven de uren voor de module uit. In de beoordeling staat echter verantwoorde literatuur. Betekent dit dat alleen de literatuur meetelt waarvan je een mindmap o.i.d. maakt ?!

Het is me even niet helemaal duidelijk - moeten we voor opdracht 1.2. in elkaars portfolio kijken en vergelijken hoe we het artikel hebben verwerkt?? En hier weer commentaar op geven door middel van de discussielijnen?

Een aantal problemen kwamen voort uit het niet tijdig lezen van de eindopdracht.

Voor mijn opdrachten had ik het in Arial 10, regelafstand 1; nu moet het in Arial 12, regelafstand 1,5 . Hoe heb jij de opzet dan? En bij de literatuur moet alles wat je gelezen hebt genoemd worden met APA-richtlijnen.

In periode 7 waren er nog steeds veel onduidelijkheden ten aanzien van de opdrachten, hoewel in absolute zin veel minder dan in periode 1 Daarbij speelde een rol dat de module in periode 7 , net als die in periode 1 , voor het eerst draaide. In periode 7 werd een gedeelte van de onduidelijkheden veroorzaakt door fouten in de module. Dergelijke fouten bleken zeer gemakkelijk te ontstaan tijdens het ontwikkelproces. Sommige van deze fouten kwamen voort uit de overname van elementen uit de reguliere leeromgeving waarbij vergeten werd bepaalde zinnen weg te halen of aan te passen voor e-learning. Verder waren een aantal e-learning opdrachten onduidelijk en hadden de studenten problemen met aspecten van de eindopdracht. Overigens werd deze zelfde eindopdracht ook in de reguliere opleiding gebruikt. 
Opdracht 5.2 vind ik erg onduidelijk. De bijhorende casus is te lezen, maar er wordt tevens bij vermeld dat er een filmpje van $5 \mathrm{~min}$ bij hoort. ????? Wie snapt dit????

In het werken aan de eindopdracht loop ik vast in hoofdstuk 2 met de leervraag en de analyse hiervan. Het analyseren leidt bij mij bijna automatisch tot herhaling van in overige hoofdstukken genoemde zaken, zoals uitdiepen met literatuurverwijzingen en dergelijke. Kan iemand mij op de goede weg helpen? In mijn portfolio plaats ik mijn eerste hoofdstukken in concept versie.

Uit de vele vragen die door studenten gesteld zijn, blijkt dat zij willen weten wat er precies verwacht wordt met betrekking tot de (eind)opdrachten. De studenten stelden geen vragen over de leerdoelen. Deze waren wellicht voldoende duidelijk of de studenten waren er minder in geïnteresseerd.

\section{Interviews met docenten en onderzoekerslogboek}

Twee docenten gaven in de interviews spontaan aan dat zij de duidelijkheid van de opdrachten van groot belang vonden, en dat dit nog voor verbetering vatbaar was. Eén van hen specificeerde dat de e-learning opdrachten heel duidelijk en concreet moeten zijn en niet te open. Het moet volkomen helder zijn welk resultaat van de studenten verwacht wordt. Zij gaf aan dat veel studenten onzeker leken over de vraag of ze het masterniveau wel aankonden. Het was haar indruk dat het grote verlangen van studenten naar zekerheid en duidelijkheid over de opdrachten daarmee samenhing.

Twee van de in het logboek geregistreerde incidenten rondom de duidelijkheid van opdrachten bevestigen dat het van belang is om de verwachtingen rondom de eindopdracht zeer concreet te formuleren. In beide gevallen hadden de studenten er veel bezwaar tegen dat er geen exacte richtlijnen waren voor de inhoud en de vormgeving van de eindopdracht. Uit het logboek blijken nog drie andere incidenten met betrekking tot onduidelijke opdrachtformulering. De studenten raakten daardoor in de war en in één geval de docent ook.

\subsubsection{Ervaren chaos en organisatielast voor studenten}

\section{Ervaren chaos}

Een onevenwichtige verdeling van de studielast, een hoge werkdruk en onduidelijkheden zouden er aan kunnen bijdragen dat de studenten chaos ervaren. Dit is tegengesteld aan wat met het ontwerp beoogd wordt. In de schaal 'Chaos' van het instrument Woord en Ervaring is hiernaar gevraagd. De items werden gescoord op een 5-puntsschaal: 1=Nee!, 2=Nee, 3=Soms, 4=Ja, 5=Ja! Deze 
schaal is na periode 1 en na periode 4 afgenomen bij cohort 1 . Na periode 1 werd de schaal eveneens afgenomen bij de reguliere studenten van het profiel Leerproblemen. Na periode 5 is de schaal afgenomen bij cohort 1 en 2 e-learning en bij alle ingeschreven reguliere studenten van Windesheim OSO. In tabel 6.12 zijn gemiddeldes $(X)$ en standaarddeviaties $(S D)$ weergegeven.

Tabel 6.12 Ervaren chaos

\begin{tabular}{|c|c|c|c|c|c|c|c|c|c|}
\hline \multirow[b]{2}{*}{ Periode } & \multicolumn{3}{|c|}{ Cohort 1 e-learning } & \multicolumn{3}{|c|}{ Reguliere studenten } & \multicolumn{3}{|c|}{ Cohort 2 e-learning } \\
\hline & $N$ & $X$ & $S D$ & $N$ & $X$ & $S D$ & $N$ & $X(S D)$ & $S D$ \\
\hline 1 & 37 & 2,6 & 0,74 & 33 & 2,8 & 0,79 & & & \\
\hline 4 & 25 & 2,4 & 0,78 & & & & & & \\
\hline 5 & 21 & 2,7 & 0,86 & 231 & 2,4 & 0,73 & 27 & 2,4 & 0,71 \\
\hline
\end{tabular}

De ervaren chaos lag tussen 2,4 en 2,8 voor alle metingen. Dit betekent dat er gemiddeld niet of soms chaos gevoeld werd. De situatie is vergelijkbaar voor elearners en reguliere studenten. Om na te gaan of er in periode 1 significante verschillen waren tussen cohort 1 e-learning en de reguliere studenten werd de $t$ toets voor onafhankelijke steekproeven uitgevoerd. De verschillen bleken niet significant. Met behulp van variantieanalyse (Anova) werd nagegaan of de verschillen tussen de drie groepen in periode 5 significant waren. Er bleken geen significante verschillen tussen de drie groepen. Variantieanalyse voor herhaalde metingen werd uitgevoerd voor periode 1,4 en 5 van cohort 1. Er werden geen significante verschillen gevonden.

\section{Organisatorische berichten in de leeromgeving}

Het was de bedoeling om de studenten op organisatorisch vlak zo veel mogelijk houvast en helderheid te bieden en hen daardoor te ontlasten. Op deze wijze zouden zij hun tijd aan cognitieve en sociale activiteiten kunnen besteden. Om na te gaan hoeveel inspanningen studenten toch nog leverden op organisatorisch vlak werd de inhoud van de boodschappen van de vijf daarvoor random geselecteerde studenten in de periodes 1 en 7 gecodeerd in drie categorieën: cognitief, sociaal en organisatorisch. Ieder van de drie codes kon per bericht maximaal één keer worden toegekend. Per bericht konden maximaal drie verschillende codes toegekend worden. In tabel 6.13 is per moduleperiode en per student het aantal organisatorische codes weergegeven. Ter vergelijking zijn ook de aantallen cognitieve- en sociale codes weergegeven. 
Tabel 6.13 Inhoud van de berichten in periode 1 en 7

\begin{tabular}{lccccc}
\hline Periode & Student & $\begin{array}{c}\text { Aantal } \\
\text { berichten }\end{array}$ & $\begin{array}{c}\text { Aantal } \\
\text { organisato- } \\
\text { rische codes }\end{array}$ & $\begin{array}{c}\text { Aantal } \\
\text { cognitieve } \\
\text { codes }\end{array}$ & $\begin{array}{c}\text { Aantal } \\
\text { sociale } \\
\text { codes }\end{array}$ \\
\hline Periode 1 & A & 211 & 113 & 74 & 43 \\
& B & 69 & 31 & 37 & 8 \\
& C & 290 & 126 & 138 & 48 \\
Periode 7 & D & 98 & 43 & 53 & 11 \\
& E & 227 & 123 & 63 & 77 \\
& A & 61 & 36 & 25 & 9 \\
& B & 68 & 27 & 42 & 4 \\
& C & 58 & 10 & 49 & 6 \\
\hline
\end{tabular}

Noot: *Student E had een vrijstelling voor periode 7.

Uit tabel 6.13 blijkt dat er in periode 1 verhoudingsgewijs veel organisatorische berichten waren van studenten. In absolute zin nam het aantal organisatorische berichten per student sterk af van periode 1 naar periode 7 . In periode 1 waren dit gemiddeld 87 berichten per student, in periode 7 waren het er nog 27. In beide periodes waren er studenten waaraan meer organisatorische codes werden toegekend dan cognitieve. Het aantal organisatorische berichten was in alle gevallen hoger dan het aantal sociale berichten. Sommige soorten organisatorische berichten leken noodzakelijk voor deze wijze van studeren terwijl andere berichten leken te duiden op energieverlies aan onduidelijkheden en problemen. De verwachting was dat dit type energieverlies zou afnemen tussen periode 1 en periode 7 omdat de studenten in periode 7 meer gewend zouden zijn aan e-learning.

Om na te gaan hoe de inhoud van de organisatorische berichten zich ontwikkelde tussen periode 1 en 7 is open codering toegepast op de boodschappen die vielen in de organisatorische categorie. De codes werden geclusterd tot vijf soorten organisatorische onderwerpen: samenwerking, onduidelijkheden, onderhandelen, techniek en ondersteunen van medestudenten. De componenten van deze clusters worden weergegeven in tabel 6.14. 
Tabel 6.14 Soorten organisatorische berichten

\begin{tabular}{|c|c|}
\hline Clusters & Componenten \\
\hline Samenwerking & $\begin{array}{l}\text { Organiseren van de samenwerking: hoe, wie, wat, wanneer + } \\
\text { expliciteren en verduidelijken van de eigen (in)activiteit } \\
\text { Vragen om peer feedback } \\
\text { Bedanken voor peer feedback en voor aspecten van de } \\
\text { samenwerking }\end{array}$ \\
\hline Onduidelijkheden & $\begin{array}{l}\text { Onduidelijkheden in het rooster } \\
\text { Onduidelijkheden beoordeling } \\
\text { Onduidelijkheden in de (eind)opdrachten }\end{array}$ \\
\hline Onderhandelen & $\begin{array}{l}\text { Onderhandelen over het rooster } \\
\text { Onderhandelen over de inhoud van de (eind)opdracht }\end{array}$ \\
\hline Techniek & $\begin{array}{l}\text { Technische vragen, opmerkingen en problemen } \\
\text { Onduidelijkheid enrollment }\end{array}$ \\
\hline $\begin{array}{l}\text { Praktisch ondersteunen } \\
\text { van medestudenten }\end{array}$ & $\begin{array}{l}\text { Helpen met techniek } \\
\text { Aanbevelen studiematerialen } \\
\text { Helpen met vindplaats in Blackboard/ op internet } \\
\text { Helpen met het begrijpen van de (eind)opdracht }\end{array}$ \\
\hline
\end{tabular}

In tabel 6.15 wordt weergegeven hoe vaak deze clusters voorkwamen in de berichten van studenten. Minder gewenste berichten waren de berichten over onduidelijkheden en de berichten over techniek. Deze berichten duiden op energieverlies dat wellicht voorkomen had kunnen worden.

Tabel 6.15 Soorten organisatorische codes

\begin{tabular}{|c|c|c|}
\hline $\begin{array}{l}\text { Soorten organisatorische } \\
\text { codes }\end{array}$ & $\begin{array}{l}\text { Moduleperiode } 1: \\
476 \text { codes* } \\
\text { ( } 5 \text { studenten) }\end{array}$ & $\begin{array}{c}\text { Moduleperiode } 7: \\
115 \text { codes* } \\
\text { (4 studenten) }\end{array}$ \\
\hline Samenwerking organiseren & $55 \%$ & $50 \%$ \\
\hline Onduidelijkheden & $12 \%$ & $14 \%$ \\
\hline Onderhandelen & $1 \%$ & $1 \%$ \\
\hline Techniek & $21 \%$ & $22 \%$ \\
\hline $\begin{array}{l}\text { Praktisch ondersteunen van } \\
\text { medestudenten }\end{array}$ & $11 \%$ & $13 \%$ \\
\hline Totaal & $100 \%$ & $100 \%$ \\
\hline
\end{tabular}

Noot: * Aan één organisatorisch bericht konden meerdere organisatorische codes toegekend worden, daardoor zijn de aantallen iets hoger dan de totalen in tabel 6.13.

De procentuele verdeling over de verschillende soorten organisatorische boodschappen bleek vrij stabiel tussen periode 1 en 7 . Minstens de helft van de organisatorische codes in beide modules betrof het organiseren van de samenwerking. Het gezamenlijk uitvoeren van de geformuleerde opdrachten vroeg 
meer organisatie van de studenten dan verwacht. In beide modules bleek sprake van energieverlies op grond van onduidelijkheden en technische vragen en problemen.

\subsubsection{Samenvatting bruikbaarheid}

Onderzocht werd of de structuurkenmerken bruikbaar waren voor de e-learning opleiding. Gemiddeld bevestigden de studenten dat zij de opdrachten en deadlines als ondersteunend ervoeren voor hun eigen studieplanning. Voor veel studenten in cohort 1 bleek het aan het begin van de studie moeilijk om goed mee te gaan in het studieritme. Hierdoor verliep de samenwerking niet altijd gemakkelijk (zie ook hoofdstuk 5). Later in de studie leken de studenten beter mee te gaan in het voorgeschreven studieritme. Meer studenten leverden hun opdracht op tijd in. Een onverwacht probleem in het rooster werd gevormd door de vakanties en de vakantiespreiding over de verschillende regio's van Nederland. Op verzoek van de studenten werd vakantiespreiding mogelijk gemaakt. Lastig was dat de opdrachten na de vakantie moeilijk weer op gang kwamen doordat sommige studenten moeite hadden het studieritme weer op te pakken.

Het evenwichtig spreiden van de studielast bleek niet eenvoudig te realiseren. De studenten hadden er last van als de studielast te hoog was. De ervaren werkdruk belemmerde het begrip van de stof voor een deel van de studenten. De ervaren werkdruk werd in de beginfase verzwaard door het te veel aan opdrachten, door het wennen aan e-learning en door het wennen aan de combinatie werk, studie en gezin. Dit viel een aantal e-learning studenten des te zwaarder omdat zij bij de aanvang van de studie de studiebelasting onderschat hadden. E-learning studenten die de juiste inschatting hadden gemaakt bij aanvang en de zaken goed geregeld hadden thuis en op het werk, konden meteen regelmatig meedoen. Gezien de extra complicaties bij het starten met e-learning was het enigszins onverwacht dat de ervaren tijdsdruk in periode 2 niet significant verschilde tussen e-learners en reguliere studenten. In de loop van de studie namen de problemen op het vlak van werkdruk bij e-learners iets af, maar er bleven altijd acute persoonlijke situaties voorkomen waardoor uitzonderingen nodig waren op het rooster en de deadlines. De balans tussen studie, thuis en werk bleef kwetsbaar.

De studenten ervoeren over het algemeen de informatie in Blackboard als voldoende duidelijk. Een uitzondering hierop werd gevormd door de formulering van de opdrachten en de daaraan gestelde eisen. Helder geformuleerde opdrachten en eisen bleken van groot belang voor studenten. Zij 
wilden graag weten welk resultaat verwacht werd. De duidelijkheid van de opdrachten en de daaraan gestelde eisen liet helaas voor een substantieel aantal studenten te wensen over. De studenten schreven veel berichten waarin zij om opheldering vroegen aan elkaar en aan de docenten. Dit betekende verlies van studietijd die ook aan cognitieve en sociale uitwisseling besteed had kunnen worden. De problemen rondom de duidelijkheid van de opdrachten bleven bestaan in de loop van de studie. Het lukte niet om dit in positieve zin te beïnvloeden. De stabiliteit van het probleem en de verschillen tussen de studenten onderling doen vermoeden dat persoonsgebonden kenmerken een rol zouden kunnen spelen in de perceptie van duidelijkheid. Zo gaf één van de docenten aan in het interview dat studenten meer behoefte hadden aan duidelijkheid naarmate zij onzekerder waren over de vraag of zij het masterniveau aan konden.

\subsection{WAARDERING VOOR DE ORGANISATIE}

Het gaat hier om de vraag hoe tevreden de studenten waren over de organisatie van de e-learning module. Daarbij is er van uit gegaan dat de perceptie van de kwaliteit van de organisatie samen zou hangen met de realisatie van het ontwerpcluster 'Structuur' (ontwerpkenmerken 3,4 en 5) binnen de opleiding. Twee onderwerpen worden besproken:

- waardering voor de organisatie van de e-learning module (6.2.1);

- verbanden met het cijfer voor de waardering van de organisatie (6.2.2)

Tenslotte worden de bevindingen ten aanzien van de onderzoeksvraag naar de waardering voor de organisatie samengevat.

\subsubsection{Waardering voor de organisatie van de e-learning}

Rapportcijfer voor de organisatie van de e-learning module

Aan het einde van de vragenlijst 'organisatie van de e-learning' is de studenten in periode 6 en 7 gevraagd om de organisatie van de module met een rapportcijfer te waarderen. Hieronder (tabel 6.16) wordt per module weergegeven met welk rapportcijfer (1-10) de studenten de organisatie gemiddeld waardeerden. 
Tabel 6.16 Rapportcijfer voor organisatie

\begin{tabular}{lcccccc}
\hline & \multicolumn{2}{c}{ Cohort 1 e-learning } & \multicolumn{3}{c}{ Cohort 2 e-learning } \\
Periode & $N$ & $X$ & $S D$ & $N$ & $X$ & $S D$ \\
\hline 6 & 19 & 7,3 & 1,29 & 23 & 7,6 & 0,99 \\
7 & 13 & 7,0 & 1,00 & 11 & 7,6 & 0,92 \\
\hline
\end{tabular}

Uit de rapportcijfers voor de organisatie van de e-learning blijkt dat de studenten de organisatie van de e-learning over het geheel genomen waardeerden als ruim voldoende. Opvallend zijn de verschillen tussen cohort 1 en 2. Met behulp van de $t$-toets voor onafhankelijke steekproeven is nagegaan of deze significant waren. Dit bleek niet het geval.

Gezien het feit dat de spreiding van de studielast en de duidelijkheid van opdrachten niet zo gerealiseerd werden als oorspronkelijk bedoeld (zie 6.1.3 en 6.1.4), waren deze rapportcijfers onverwacht hoog. Mogelijk compenseerden de docenten ten dele voor de geconstateerde problemen door uitstel te verlenen (zie ook tabel 6.9) en opheldering te geven. Ook konden zij wellicht compenseren als er begripsproblemen optraden ten gevolge van werkdruk. Er werd enige bevestiging voor deze gedachte gevonden in de positieve en significante correlaties tussen het rapportcijfer voor de organisatie en het rapportcijfer voor de docent (zie ook hoofdstuk 7). Deze correlaties zijn weergegeven in tabel 6.17.

Tabel 6.17 Verband tussen rapportcijfers voor de organisatie en voor de docent

\begin{tabular}{lcccc}
\hline Periode & & $\begin{array}{c}\text { Cohort 1 e-learning } \\
\text { Pearons's } r\end{array}$ & $N$ & $\begin{array}{c}\text { Cohort 2 e-learning } \\
\text { Pearson's } r\end{array}$ \\
\hline 6 & $N$ & $0,48^{*}$ & 23 & $0,46^{*}$ \\
7 & 19 & $0,56^{*}$ & 11 & $0,65^{*}$ \\
\hline
\end{tabular}

Noot: $\quad{ }^{*} p<0,05$.

In alle gevallen werden significante verbanden gevonden tussen de waardering voor de organisatie en de waardering voor de docent. Een mogelijke verklaring voor dit verband zou kunnen zijn dat docenten een compenserende rol spelen ten aanzien van problemen op het vlak van de organisatie.

\subsubsection{Verbanden met het cijfer voor de waardering van de organisatie}

Er is nagegaan welke van de in dit hoofdstuk besproken variabelen verband houden met de waardering van de studenten voor de organisatie van de modules. Met Pearson's $r$ is per moduleperiode de correlatie bepaald tussen de deze 
variabelen enerzijds en het cijfer voor de organisatie anderzijds. Beide cohorten zijn hiertoe samengevoegd. De uitkomsten hiervan zijn weergegeven in tabel 6.18. Schalen die niet genoemd worden zijn niet afgenomen in moduleperiodes 6 en 7 .

Tabel 6.18 Verbanden met de waardering voor de organisatie

\begin{tabular}{|c|c|c|}
\hline Pearson's $r$ & $\begin{array}{c}\text { Periode } 6 \\
N=42\end{array}$ & $\begin{array}{c}\text { Periode } 7 \\
N=24\end{array}$ \\
\hline \multicolumn{3}{|l|}{ Kenmerk 4: } \\
\hline \multicolumn{3}{|c|}{ Strakke planning met verplichte opdrachten en deadlines } \\
\hline Schaal ‘Ondersteuning door planning' & $0,58^{\star * *}$ & $0,62^{* *}$ \\
\hline \multicolumn{3}{|l|}{ Kenmerk 5: } \\
\hline \multicolumn{3}{|l|}{ Spreiding studielast } \\
\hline Evenwichtige spreiding van de studielast & $0,65^{* * *}$ & $0,68^{* * *}$ \\
\hline Werkdruk en begrip & $0,57^{* * *}$ & $0,48^{*}$ \\
\hline \multicolumn{3}{|l|}{ Kenmerk 6: } \\
\hline \multicolumn{3}{|c|}{ Helder geformuleerde leerdoelen en verwachtingen } \\
\hline Schaal 'Duidelijkheid' & $0,59^{* * *}$ & $0,62^{* *}$ \\
\hline Cijfer voor de docent & $0,58^{* *}$ & $0,63^{* *}$ \\
\hline
\end{tabular}

Noot: ${ }^{*} p<0,05,{ }^{* *} p<0,01,{ }^{* * *} p<0,001$.

Uit de tabel blijkt dat de waardering van studenten voor de organisatie verband houdt met alle drie de structuur kenmerken van de e-learning opleiding. De uitkomsten in deze tabel bevestigen het belang van de drie structuur kenmerken voor de organisatie van de module. Daarnaast lijkt de docent een positieve rol te kunnen spelen in de organisatie van de module.

\subsubsection{Samenvatting waardering}

De onderzoeksvraag luidde of de studenten de organisatie van de e-learning opleiding waardeerden. Gemiddeld was de waardering van de studenten ruim voldoende. De waardering hield verband met de spreiding van de studielast, de duidelijkheid en de ervaren ondersteuning door de planning. De ruim voldoende waardering was hoger dan op grond van de overige analyses werd verwacht. De spreiding van de studielast en de duidelijkheid van de opdrachten waren niet optimaal gerealiseerd. Daar waar problemen optraden speelden docenten mogelijk een ondersteunende en compenserende rol. 


\subsection{AANPASSINGEN AAN HET ONTWERP}

In tabel 6.19 is op basis van het onderzoekerslogboek weergegeven welke aanpassingen het e-learning team doorvoerde gedurende het eerste e-learning jaar. Daarnaast is aangegeven via welk medium de wijzigingen gestalte kregen en wanneer (tijdens of na welke moduleperiode). In de laatste kolom is weergegeven of verbetering optrad.

Tabel 6.19 Aanpassingen door het e-learning team in en buiten Blackboard (BB)

\begin{tabular}{|c|c|c|c|}
\hline Aanpassingen & Medium & $\begin{array}{c}\text { Tijdens/na } \\
\text { module- } \\
\text { periode }\end{array}$ & Verbetering \\
\hline \multicolumn{4}{|c|}{$\begin{array}{l}\text { Meegaan in de structuur, werkdruk en spreiding daarvan, tijdelijke uitval door privé } \\
\text { omstandigheden }\end{array}$} \\
\hline $\begin{array}{l}\text { Verbeterde voorlichting voor } \\
\text { nieuwe studenten over de } \\
\text { studielast en de wijze van } \\
\text { studeren binnen e-learning }\end{array}$ & $\begin{array}{l}\text { Voorlichtingsbrochures } \\
\text { Website www.oso- } \\
\text { windesheim.nl } \\
\text { Voorlichtingsbijeenkomsten }\end{array}$ & 1 & \multirow[t]{2}{*}{ ja } \\
\hline $\begin{array}{l}\text { Aanscherping van de intake } \\
\text { gesprekken voor e-learners op } \\
\text { het vlak van de wijze van } \\
\text { studeren en de verwachtingen } \\
\text { omtrent studielast }\end{array}$ & Telefonische intakegesprekken & 4 & \\
\hline $\begin{array}{l}\text { Studenten krijgen eerder } \\
\text { toegang tot Blackboard: na de } \\
\text { intake, ongeveer twee weken } \\
\text { voor de startzaterdag. Zo } \\
\text { kunnen zij zich van te voren } \\
\text { uitgebreid oriënteren op de } \\
\text { wijze van studeren. }\end{array}$ & Blackboard & 4 & \\
\hline $\begin{array}{l}\text { Betere aansluiting van de } \\
\text { startzaterdag bij de vragen die } \\
\text { studenten nog hebben over de } \\
\text { wijze van studeren }\end{array}$ & Startzaterdag & 4 & \\
\hline $\begin{array}{l}\text { Vermindering van het aantal } \\
\text { discussie- en } \\
\text { samenwerkingsopdrachten } \\
\text { (zowel ad hoc als structureel): } \\
\text { maximaal één opdracht per } \\
\text { week }\end{array}$ & Opdrachtenlijst en rooster (BB) & 1 & \\
\hline $\begin{array}{l}\text { Verlengen van de periode van } \\
\text { discussie-opdrachten (van } 1 \\
\text { naar } 1,5 \text { week per discussie) }\end{array}$ & Rooster & 2 & \\
\hline
\end{tabular}


Tabel 6.19 Aanpassingen door het e-learning team in en buiten Blackboard (BB) (Continued)

\begin{tabular}{|c|c|c|c|}
\hline Aanpassingen & Medium & $\begin{array}{c}\text { Tijdens/na } \\
\text { module- } \\
\text { periode }\end{array}$ & Verbetering \\
\hline $\begin{array}{l}\text { Individuele deelopdrachten van } \\
\text { de eindopdracht: verplichte } \\
\text { deadlines worden advies } \\
\text { deadlines }\end{array}$ & Rooster & 3 & \\
\hline $\begin{array}{l}\text { Ad hoc uitstel verlenen van } \\
\text { deelopdrachten }\end{array}$ & Mail & alle & \\
\hline $\begin{array}{l}\text { Ontwerpen en vaststellen van } \\
\text { alternatieve opdrachten voor } \\
\text { als studenten door } \\
\text { omstandigheden even niet mee } \\
\text { kunnen doen aan de discussies } \\
\text { en samenwerkingsopdrachten }\end{array}$ & $\begin{array}{l}\text { Mail } \\
\text { Informatie in Blackboard } \\
\text { (ondermeer in thema unit } \\
\text { 'starten met e-learning) }\end{array}$ & 1 & \\
\hline $\begin{array}{l}\text { Vergroten van de groepjes naar } \\
5-7 \text { personen zodat tijdelijke } \\
\text { uitval niet belemmerend is voor } \\
\text { het proces in het groepje }\end{array}$ & Groepjes in Blackboard & 2 & \\
\hline \multicolumn{4}{|l|}{ Duidelijkheid } \\
\hline $\begin{array}{l}\text { F.A.Q. sectie aangemaakt en } \\
\text { gevuld }\end{array}$ & F.A.Q . knop in Blackboard & 1 & \multirow[t]{2}{*}{ Nee / soms } \\
\hline $\begin{array}{l}\text { Verbeteren van een aantal } \\
\text { technische handleidingen } \\
\text { waaronder de handleiding over } \\
\text { video's bewerken en uploaden }\end{array}$ & $\begin{array}{l}\text { Knop technische informatie } \\
\text { Blackboard }\end{array}$ & alle & \\
\hline $\begin{array}{l}\text { Aanpassen } \\
\text { opdrachtformulering }\end{array}$ & $\begin{array}{l}\text { Opdrachtenlijsten in } \\
\text { Blackboard }\end{array}$ & alle & \\
\hline $\begin{array}{l}\text { Verwijderen onduidelijke } \\
\text { opdrachten }\end{array}$ & $\begin{array}{l}\text { Opdrachtenlijsten in } \\
\text { Blackboard }\end{array}$ & alle & \\
\hline $\begin{array}{l}\text { Telefonische ondersteuning bij } \\
\text { problemen rondom de video's } \\
\text { door één van de docenten }\end{array}$ & Telefoon / skype & 1 & \\
\hline
\end{tabular}

Het meegaan in de structuur van het rooster leek gemakkelijker te verlopen in cohort 2 en er waren na moduleperiode 2 minder problemen op het vlak van de werkdruk. De spreiding van de werkdruk leek in de loop van de tijd te verbeteren. De problemen rondom bewerken en uploaden van video's en andere software verminderden nadat de handleidingen op dit vlak verbeterd en uitgebreid waren. Er bleven problemen bestaan rondom de duidelijkheid van opdrachten. 


\section{HoOFDSTUK 7 \\ Resultaten implementatiefase: Docentrol}

INLEIDING

De docentrol is in het ontwerp beschreven als een serie gedragingen en vaardigheden van de e-learning docent. Het uitgangspunt was dat scholing nodig was omdat de rol van de e-learning docent, zeker in de details van de uitwerking, verschilt van de reguliere docentrol. De volgende kenmerken vormden het uitgangspunt voor de docentrol (zie ook hoofdstuk 3):

- Zichtbare aanwezigheid, reactiesnelheid en tijd (kenmerk 6).

- Moderatie (kenmerk 7).

- Feedback (kenmerk 8).

- Organisatorische ondersteuning (kenmerk 9).

- Vraagsturing en flexibiliteit (kenmerk 10).

- Controle en activering (kenmerk 11).

- Sociale aanwezigheid (kenmerk 13).

- Scholing (kenmerk 14).

Kenmerk 12, dat van synchrone spreekuren, werd op grond van de bevindingen in de pilot (zie hoofdstuk 4) niet meer uitgevoerd binnen de volledige opleiding. In dit hoofdstuk wordt besproken hoe bruikbaar deze uitgangspunten zijn gebleken in de implementatiefase van de e-learning opleiding en hoe studenten de docentrol waardeerden. De onderzoeksvragen voor dit hoofdstuk zijn:

- Zijn de ontwerpkenmerken met betrekking tot de docentrol bruikbaar binnen de opleiding?

- Hoe waarderen de studenten de begeleiding door de docenten?

- Met welke kenmerken van de docentrol hangt deze waardering samen? 
De onderzoeksopzet is beschreven in hoofdstuk 2 (paragraaf 2.4). In paragraaf 7.1 wordt per kenmerk en per onderzoeksinstrument gerapporteerd over de bruikbaarheid van de acht ontwerpkenmerken binnen de docentrol. Aan het eind van de paragraaf volgt een samenvatting van de meer algemene tendensen. In paragraaf 7.2 wordt de waardering besproken voor de docentrol. In paragraaf 7.3 wordt weergegeven welke aanpassingen met betrekking tot de docentrol gedaan werden in het eerste implementatiejaar en welke aanpassingen nog zinvol lijken voor de toekomst.

\subsection{BRUIKBAARHEID VAN UITGANGSPUNTEN VAN DE DOCENTROL}

De bruikbaarheid van de docentrol wordt in deze paragraaf per kenmerk van de docentrol geëvalueerd. Onder bruikbaarheid wordt verstaan dat de kenmerken realiseerbaar en zinvol zijn binnen de e-learning opleiding.

\subsubsection{Zichtbare aanwezigheid, reactiesnelheid en tijd}

Het was de bedoeling dat docenten met hun geschreven bijdrages regelmatig zichtbaar aanwezig zouden zijn in Blackboard en dat zij snel zouden reageren op vragen en verzoeken om feedback. Om dit mogelijk te maken, kregen zij net zo veel tijd toegekend voor hun docentrol als in een reguliere module. Nagegaan werd of docenten in voldoende mate bijdroegen en of zij snel genoeg reageerden. Ook werd nagegaan of zij van mening waren dat zij voldoende tijd hadden gekregen om hun taak goed uit te oefenen.

\section{Aantallen berichten van docenten per groepje}

De zichtbaarheid van de docent wordt in de master SEN e-learning opleiding in belangrijke mate bepaald door de vraag hoeveel asynchrone bijdrages door de docent geleverd worden in de groepjes. In periode 1 werd van de docenten gevraagd om gedurende de acht weken van de moduleperiode vijf keer per week in te loggen en een bericht achter te laten. Dit kwam neer op een minimum van veertig berichten per groepje. De drie docenten in moduleperiode 1 werkten ieder met drie groepjes. In de latere moduleperiodes werd het ritme van de bijdrages teruggebracht tot drie keer per week ( 24 berichten per groepje) en een maximum van twee groepjes. In tabel 7.1 is weergegeven hoeveel bijdrages de docenten leverden per groepje. Per periode is weergegeven: het totaal aantal groepjes $(N)$, 
het minimum, het maximum, het gemiddelde $(X)$ en de standaarddeviatie $(S D)$. Groepjes die halverwege verdeeld werden over andere groepjes zijn buiten beschouwing gelaten.

Tabel 7.1 Aantal docentbijdrages per groepje

\begin{tabular}{lcccccccccc}
\hline & \multicolumn{4}{c}{ Cohort 1 e-learning } & \multicolumn{6}{c}{ Cohort 2 e-learning } \\
Periode & $N$ & Min. & Max. & $X$ & $S D$ & $N$ & Min. & Max. & $X$ & $S D$ \\
\hline 1 & 8 & 32 & 65 & 51,8 & 12,19 & & & & & \\
2 & 7 & 8 & 59 & 37,9 & 20,36 & & & & & \\
3 & 6 & 29 & 77 & 50,7 & 17,7 & & & & & \\
4 & 5 & 32 & 73 & 44,8 & 16,62 & & & & & \\
5 & 4 & 35 & 104 & 64,8 & 29,43 & 6 & 18 & 35 & 29,0 & 5,83 \\
6 & 4 & 50 & 102 & 74,5 & 26,35 & 6 & 25 & 38 & 31,2 & 5,49 \\
7 & 4 & 28 & 38 & 31,3 & 4,57 & 5 & 27 & 53 & 46,0 & 10,86 \\
\hline
\end{tabular}

In de tabel wordt zichtbaar dat de docenten het minimum aantal berichten gemiddeld ruim haalden. Gemiddeld waren zij goed zichtbaar aanwezig voor de studenten. Uit de weergegeven minima blijkt dat niet alle docenten in periodes 1 en 2 voldeden aan het vastgestelde minimum. Het minimum aantal bijdrages in periode twee was zelfs extreem laag. De docent in kwestie was in Blackboard onvoldoende zichtbaar voor studenten. Naast de aanwezigheid via asynchrone berichten manifesteerden de docenten hun aanwezigheid ook via de mail en de telefoon. Deze communicatiewijzen werden ingezet als er persoonlijke zaken speelden.

Aantallen berichten in de algemene discussielijn

In periodes 1 tot en met 4 van cohort 1 was er naast de discussies in de groepjes ook nog sprake van een algemene discussielijn die voor alle studenten en docenten in de module toegankelijk was. In deze discussielijn was plaats voor vragen en opmerkingen van studenten die voor iedereen van belang konden zijn. Zo werden er vaak vragen gesteld over software en over onduidelijke opdrachten. In deze algemene discussielijn konden alle docenten die in de module werkzaam waren bijdragen leveren. De algemene discussielijn werd afgeschaft na moduleperiode 4 . In tabel 7.2 is zichtbaar hoeveel verschillende modules er draaiden in de betreffende periodes, hoeveel docenten een bijdrage leverden $(N)$, en hoeveel bijdrages er in totaal door docenten geleverd werden per periode. 
Tabel 7.2 Aantal docentbijdrages in algemene discussielijn

\begin{tabular}{lccc}
\hline & & \multicolumn{3}{c}{ Cohort 1 e-learning } \\
Periode & Aantal modules & $N$ & Totaal aantal docentberichten \\
\cline { 2 - 4 } 1 & 1 & 4 & 279 \\
2 & 2 & 5 & 84 \\
3 & 2 & 4 & 17 \\
4 & 2 & 1 & 2 \\
\hline
\end{tabular}

Opvallend is het zeer grote aantal docent berichten in moduleperiode 1. Daarna nam in de opeenvolgende periodes het aantal berichten zeer sterk af.

Algemene mededelingen met betrekking tot de planning op Blackboard

Eén van de manieren waarop docenten hun aanwezigheid zichtbaar kunnen maken is door het plaatsen van algemene, voor alle studenten in de module zichtbare, mededelingen op Blackboard. Studenten zagen deze mededelingen meteen als zij Blackboard openden. Zij konden zelf geen mededelingen plaatsen. Er werd van uit gegaan dat het van belang is dat docenten regelmatig nieuwe mededelingen plaatsen. Hierdoor wordt de (asynchrone) aanwezigheid van de docent meteen zichtbaar en ziet dat de leeromgeving er niet statisch uit. In het instrument 'Begeleiding door de docent' is één item opgenomen dat specifiek verband hield met de zichtbare aanwezigheid van docenten in de mededelingen. Het betrof het volgende item: 'De docent stuurde/plaatste regelmatig mededelingen over planningszaken (rooster, opdrachten, deadlines).' Het item werd gescoord op een 3-puntsschaal: nee-gaat wel-ja. In tabel 7.3 wordt weergegeven welk percentage van de studenten met 'ja' antwoordde op dit item. De studenten vulden de betreffende vragenlijst in over hun eigen docent. Docenten verschilden in de mate waarin zij algemene mededelingen plaatsten.

Tabel 7.3 Regelmatige mededelingen plaatsen over planning

\begin{tabular}{lcccc}
\hline Periode & \multicolumn{2}{c}{ Cohort 1 e-learning } & \multicolumn{2}{c}{$\begin{array}{c}\text { Cohort 2 e-learning } \\
\% ~ j a\end{array}$} \\
\hline 1 & $N$ & 64 & & \\
2 & 22 & 38 & & \\
3 & 26 & 64 & & \\
4 & 22 & 56 & & \\
6 & 16 & 53 & 23 & 74 \\
7 & 19 & 38 & 11 & 100 \\
\hline
\end{tabular}


In cohort 1 werd dit aspect niet overtuigend gerealiseerd. Opvallend zijn de hoge percentages studenten in cohort 2 die aangeven dat dit aspect wel gerealiseerd was. Mogelijk speelde daarin een rol dat het noodzakelijker was voor docenten om algemene mededelingen te plaatsen doordat de algemene discussieruimte was afgeschaft. Deze studenten waren bovendien nog in hun eerste jaar, waardoor de noodzaak tot algemene mededelingen waarschijnlijk hoger was dan voor de tweedejaars studenten in diezelfde moduleperiodes.

\section{Reactiesnelheid op vragen}

Twee items in het instrument 'Begeleiding door de docent' hielden specifiek verband met de snelheid van reageren. Dit betrof de volgende vragen:

a. De docent reageerde doorgaans op mijn vragen binnen: (n.v.t./24 uur/1-2 dagen/3-4 dagen/5-7 dagen/ $>7$ dagen/reageert helemaal niet).

b. Ik ben tevreden over de snelheid waarmee de docent reageerde op mijn vragen ( $1=$ nee, $2=$ gaat wel, $3=$ ja).

De frequentieverdeling voor item a: de snelheid van reageren op vragen, wordt weergegeven in tabel 7.4.

Tabel 7.4 De snelheid waarmee de docent reageert op vragen

\begin{tabular}{lcccccc}
\hline Cohort & & $\mathbf{1}$ & & & $\mathbf{2}$ & \\
Moduleperiode & $\mathbf{1}$ & $\mathbf{2}$ & $\mathbf{3}$ & $\mathbf{4}$ & $\mathbf{6}$ & $\mathbf{6}$ \\
$\mathbf{N}$ & $\mathbf{2 2}$ & $\mathbf{2 5}$ & $\mathbf{2 2}$ & $\mathbf{1 6}$ & $\mathbf{1 9}$ & $\mathbf{2 3}$ \\
\hline Reageert helemaal niet & 1 & 0 & 0 & 0 & 0 & 0 \\
> 7 dagen & 1 & 0 & 0 & 0 & 0 & 0 \\
5-7 dagen & 1 & 2 & 2 & 0 & 0 & 0 \\
3-4 dagen & 4 & 4 & 2 & 4 & 4 & 2 \\
1-2 dagen & 11 & 7 & 14 & 9 & 11 & 13 \\
24 uur & 3 & 8 & 1 & 2 & 3 & 3 \\
n.v.t. & 1 & 4 & 3 & 1 & 1 & 5 \\
\hline
\end{tabular}

Uit de tabel wordt duidelijk dat de door de docenten gerealiseerde snelheid voor het antwoorden op vragen vrij hoog ligt. Verreweg de meeste reacties werden volgens de studenten gegeven binnen nul en twee dagen. In cohort 1 traden over de genoemde moduleperiodes geen significante veranderingen op in de reactiesnelheid van docenten, $\chi^{2}(4)=3,3, p>0,05$. Er bleken op grond van de MannWhitney toets geen significante verschillen te bestaan tussen beide cohorten in moduleperiode $6, z=-0,57, p>0,05$. 
Op grond van de resultaten in tabel 7.4 lijkt het aannemelijk dat de studenten tevreden waren over de reactiesnelheid van docenten. In tabel 7.5 wordt de tevredenheid over de reactiesnelheid (item b) weergegeven middels het percentage 'ja' en de gemiddeldes en standaarddeviaties voor dit item dat als volgt gescoord werd: $0=$ niet van toepassing, $1=$ nee, $2=$ gaat wel, $3=$ ja. De studenten die reageerden met 'niet van toepassing' zijn in de tabel buiten beschouwing gelaten. In de periodes 1 tot en met 6 is bovendien aangegeven of er een significante correlatie (Kendall's tau) bestaat tussen de tevredenheid over de reactiesnelheid en de door studenten gepercipieerde reactiesnelheid (item a in tabel 7.4). In periode $7 \mathrm{kon}$ dit niet berekend worden omdat item a toen niet gebruikt werd.

Tabel 7.5 Tevredenheid over reactiesnelheid van docent

\begin{tabular}{lcccccccccc}
\hline & \multicolumn{4}{c}{ Cohort 1 e-learning } & \multicolumn{5}{c}{ Cohort 2 e-learning } \\
Periode & $N$ & $\% j a$ & $X$ & $S D$ & Kendall's $\tau$ & $N$ & $\% j a$ & $X$ & $S D$ & Kendall's $\tau$ \\
\hline 1 & 22 & 64 & 2,6 & 0,67 & $0,64^{* *}$ & & & & & \\
2 & 23 & 65 & 2,5 & 0,73 & $0,46^{*}$ & & & & & \\
3 & 22 & 95 & 3,0 & 0,22 & $-0,08$ & & & & & \\
4 & 15 & 67 & 2,7 & 0,49 & $0,52^{*}$ & & & & & \\
6 & 18 & 94 & 2,9 & 0,24 & 0,36 & 18 & 83 & 2,8 & 0,38 & $0,58^{*}$ \\
7 & 13 & 46 & 2,1 & 0,95 & - & 10 & 60 & 2,5 & 0,71 & - \\
\hline
\end{tabular}

Noot: ${ }^{*} p<0,05,{ }^{* *} p<0,01,{ }^{* * *} p<0,001$.

In de meeste periodes zijn de studenten gemiddeld voldoende tot goed tevreden over de reactie snelheid van docenten. In periode zeven was cohort 1 gemiddeld onvoldoende tevreden over de reactiesnelheid van de docenten $(X<2,5)$ en er was sprake van een grote spreiding in dit oordeel.

In de meeste moduleperiodes was er een significant verband tussen de tevredenheid en de gepercipieerde reactie snelheid van docenten. Met variantieanalyse voor herhaalde metingen is nagegaan of de verschillen tussen de moduleperiodes significant waren voor cohort 1. De Greenhouse Geisser correctie werd toegepast vanwege de lage $\varepsilon(=0,39)$. Er werden geen significante verschillen gevonden, maar de power van de analyse was laag $(0,28)$ omdat maar vijf studenten in alle moduleperiodes dit item hadden ingevuld. De verschillen tussen periodes 6 en 7 van cohort 2 waren niet significant. De $t$-toets voor onafhankelijke steekproeven bracht geen significante verschillen tussen cohort 1 en 2 aan het licht in moduleperiodes 6 en 7. 
Met behulp van een kruistabel is nagegaan of er een drempelwaarde te vinden was voor de reactietermijn waarover studenten meestal tevreden waren. De studenten waren bij een reactietermijn binnen 24 uur in $95 \%$ van de gevallen tevreden. Bij een reactietermijn 1-2 dagen waren zij in $89 \%$ van de gevallen tevreden. Bij langere reactietermijnen daalde dit snel. Voor een reactietermijn van 3-4 dagen was dat nog maar $45 \%$. De conclusie luidt dat de studenten meestal tevreden bleken met een reactietermijn van 0-2 dagen.

\section{Tijdigheid van feedback}

Twee items in het instrument 'Begeleiding door de docent' hielden specifiek verband met de snelheid van reageren bij het geven van feedback. Dit betrof de volgende vragen:

a. De docent gaf doorgaans feedback op mijn ingeleverde opdrachten binnen: (n.v.t./24 uur/1-2 dagen/3-4 dagen/5-7 dagen/>7 dagen/gaf geen feedback).

b. Ik ben tevreden over de snelheid waarmee de docent feedback gaf op mijn ingeleverde opdrachten (nee, gaat wel, ja).

De frequentieverdeling voor item a: de snelheid van reageren op vragen, wordt weergegeven in tabel 7.6.

\begin{tabular}{lcccccc} 
Tabel 7.6 De snelheid waarmee de docent feedback gef \\
\hline Cohort & & & $\mathbf{1}$ & & & $\mathbf{2}$ \\
Moduleperiode & $\mathbf{1}$ & $\mathbf{2}$ & $\mathbf{3}$ & $\mathbf{4}$ & $\mathbf{6}$ & $\mathbf{6}$ \\
$\boldsymbol{N}$ & $\mathbf{2 2}$ & $\mathbf{2 5}$ & $\mathbf{2 2}$ & $\mathbf{1 3}$ & $\mathbf{1 9}$ & $\mathbf{2 3}$ \\
\hline 1: Gaf geen feedback & 2 & 3 & 1 & 0 & 0 & 1 \\
2: > 7 dagen & 6 & 4 & 0 & 0 & 0 & 2 \\
3: 5-7 dagen & 2 & 4 & 2 & 0 & 1 & 1 \\
4: 3-4 dagen & 3 & 7 & 6 & 3 & 3 & 2 \\
5: 1-2 dagen & 6 & 5 & 11 & 10 & 9 & 7 \\
6: 24 uur & 0 & 1 & 1 & 0 & 3 & 1 \\
n.v.t. & 3 & 1 & 1 & 0 & 3 & 9 \\
\hline
\end{tabular}

Uit de tabel blijkt dat de snelheid waarmee feedback gegeven wordt meestal vrij hoog ligt. De meeste feedback werd binnen 1 tot 4 dagen gegeven. Er was met name in periodes 1 en 2 een grote spreiding in de feedback termijn. In tabel 7.7 is per periode en per cohort de mediaan weergegeven voor de snelheid waarmee de docent feedback gaf. 


\begin{tabular}{lcccc} 
Tabel 7.7 & \multicolumn{5}{c}{ Feedback snelheid, middelste waardes } \\
\hline \multirow{3}{*}{ Periode } & Cohort 1 e-learning & Cohort 2 e-learning \\
& $N$ & $M d n$ & $N$ & $M d n$ \\
\hline 1 & 19 & 3 & & \\
2 & 24 & 4 & & \\
3 & 21 & 5 & & \\
4 & 13 & 5 & & \\
6 & 16 & 5 & 14 & 5 \\
\hline
\end{tabular}

Opvallend is de stijgende lijn in de tabel die stabiliseert in moduleperiode 3. Vanaf periode 3 is de middelste waarde vrij hoog; feedback werd gegeven binnen 1-2 dagen. In cohort 1 traden over de genoemde moduleperiodes significante veranderingen op in de snelheid waarmee docenten feedback gaven, $\chi^{2}(4)=16,6$, $p<0,001$. Om de verschillen tussen de moduleperiodes van cohort 1 nader te beschrijven is gebruik gemaakt van Wilcoxon tests waarbij de Bonferroni correctie is toegepast. Op grond hiervan is het criterium voor $p$ bepaald op 0,005. In moduleperiode 4 gaven de docenten significant sneller feedback $(M d n=5)$ dan in moduleperiode $1(M d n=3), z=-2,5, p<0,005, r=0,59$. Ook in moduleperiode 6 $(M d n=5)$ gaven de docenten significant sneller feedback dan in moduleperiode 1, $z=-2,6, p<0,005, r=0,55$. In moduleperiode 6 gaven de docenten bovendien significant sneller feedback dan in moduleperiode $2(M d n=4), z=-2,8, p<0,005$, $r=0,51$. Tussen de overige moduleperiodes van cohort 1 bleken geen significante verschillen. Omdat de waardes voor de beide cohorten in moduleperiode 6 gelijk waren, is er niet getoetst op verschillen tussen de cohorten.

In tabel 7.8 wordt de tevredenheid over de reactiesnelheid (item b) weergegeven met het percentage ' ja' en de gemiddeldes en standaarddeviaties voor dit item dat als volgt gescoord werd: $1=$ nee, $2=$ gaat wel, $3=$ ja. In de periodes 1 tot en met 6 is aangegeven of er een significante correlatie (Kendalls'tau) bestaat tussen de tevredenheid over de reactiesnelheid en de door studenten gepercipieerde reactiesnelheid (item a in tabel 7.6). In periode 7 kon dit niet berekend worden omdat item a hier niet gebruikt werd. 
Tabel 7.8 Tevredenheid over de snelheid waarmee de docent feedback geeft

\begin{tabular}{lcccccccccc}
\hline & \multicolumn{4}{c}{ Cohort 1 e-learning } & \multicolumn{5}{c}{ Cohort 2 e-learning } \\
Periode & $\boldsymbol{N}$ & $\%$ ja & $X$ & $S D$ & Kendall's $\tau$ & $N$ & $\%$ ja & $X$ & $S D$ & Kendall's $\tau$ \\
\hline 1 & 22 & 45 & 2,2 & 0,85 & $0,79^{* * *}$ & & & & & \\
2 & 25 & 48 & 2,2 & 0,87 & $0,69^{* * *}$ & & & & & \\
3 & 22 & 91 & 2,9 & 0,29 & $0,51^{*}$ & & & & & \\
4 & 13 & 77 & 2,8 & 0,44 & 0,13 & & & & & \\
6 & 19 & 79 & 2,7 & 0,56 & 0,23 & 23 & 57 & 2,5 & 0,67 & 0,42 \\
7 & 13 & 31 & 2,0 & 0,82 & - & 11 & 82 & 2,8 & 0,41 & - \\
\hline
\end{tabular}

Noot: ${ }^{*} \mathrm{p}<0,05,{ }^{* *} \mathrm{p}<0,01,{ }^{* * *} \mathrm{p}<0,001$.

In drie periodes (1,2 en 7) waren de studenten in cohort 1 gemiddeld matig tevreden over de snelheid van de feedback van de docent. Zij scoorden in deze periodes rond de waarde 2: gaat wel. In de overige periodes waren de studenten voldoende tevreden over de snelheid van de feedback met een score $\geq 2,5$. Variantie analyse voor herhaalde metingen liet geen significante verschillen zien tussen de moduleperiodes voor cohort 1 . De geobserveerde power van de analyse voor cohort 1 was echter laag, 0,44. De verbetering die tussen moduleperiodes 6 en 7 optrad in cohort 2 blijkt significant $F(1 ; 8)=8,0, p<0,05, \eta_{p}{ }^{2}=0,50$. Met de $t$ toets voor onafhankelijke steekproeven is nagegaan of de verschillen tussen cohort 1 en 2 significant waren. Dit was niet het geval voor periode 6, maar wel voor periode $7 t(22)=3,02, p<0,01, r=0,54$.

Het verband tussen de tevredenheid en de gerapporteerde snelheid (Kendall's tau) bleek in alle gevallen positief. In drie gevallen was er sprake van een significant verband, in de overige gevallen niet. Met behulp van een kruistabel is nagegaan of er een drempelwaarde gevonden kon worden voor de reactietermijn voor feedback waarover studenten meestal tevreden waren. De studenten waren bij een termijn binnen 24 uur in alle gevallen tevreden. Bij een duur van 1-2 dagen waren zij in 90\% van de gevallen tevreden en bij een termijn van 3-4 dagen in 79\% van de gevallen. Bij langere reactietermijnen daalde dit snel. Voor een reactietermijn van 5-7 dagen bedroeg het aantal tevreden studenten nog maar $50 \%$. We concludeerden dat de studenten meestal tevreden bleken met een reactietermijn van 0-4 dagen. Voor sommige studenten was maximaal een week ook nog acceptabel, voor anderen was dat matig acceptabel. 
Aanwezigheidsritme, reactiesnelheid en tijd bekeken door de ogen van docenten Uit de interviews blijkt dat alle docenten die lesgaven in moduleperiode 1 de taakbelasting in deze periode als te zwaar ervoeren. Als eerste oorzaak hiervoor noemden zij het aantal groepjes waarmee zij werkten. Zij werkten in deze periode met drie groepjes tegelijkertijd en gaven aan dit als te veeleisend te ervaren. Een tweede oorzaak voor de overbelasting van docenten in moduleperiode 1 bleek gelegen in het inlogritme. In periode 1 werd van docenten verwacht dat zij vijf keer per week zouden inloggen en een bijdrage zouden leveren. Dit vergde te veel van docenten.

De docenten noemden ook nog andere oorzaken voor de ervaren overbelasting in moduleperiode 1. De studenten waren onvoldoende voorbereid op de wijze van studeren binnen e-learning en erg onzeker. In verband hiermee stelden de studenten volgens de docenten extreem veel vragen over onduidelijkheden en technische problemen. Sommige individuele studenten vroegen erg veel feedback en aandacht. Zij leken de overtuiging te hebben dat e-learning een individuele wijze van studeren was. Zij stuurden veel privé mails naar docenten, wilden snel reactie en er werd veel en lang getelefoneerd. De docenten gaven aan dat zij hierdoor erg veel tijd besteedden aan de ondersteuning van studenten en relatief minder aan de moderatie van de discussies en de opdrachten.

Uit het onderzoekerslogboek blijkt dat er in de eerste module een golf van paniek ontstond onder e-learning docenten die te maken had met de ervaren werkdruk en met de gepercipieerde paniek onder de groep studenten. Naar aanleiding hiervan uitte het management zorgen over de belasting van docenten; zij gaven aan dat een hele belangrijke vraag rondom e-learning luidde hoe e-learning haalbaar gemaakt kon worden binnen de gestelde tijd zodat docenten niet over hun grenzen hoeven te gaan. Uit de docentinterviews bleek dat de belasting in termen van uren inderdaad te hoog was in moduleperiode 1. Eén docent gaf in het interview aan dat zij 110 uur besteedde aan de eerste module. Dit was twee maal zo veel als begroot. Door en rond de gezamenlijk ervaren paniek ontstond een intensieve samenwerking tussen de docenten in moduleperiode 1 . Dit kostte relatief veel tijd maar de docenten spraken hier positief over in de interviews. Zij ervoeren deze intensieve samenwerking als een duidelijke meerwaarde in de beginperiode van elearning. Uit het onderzoekerslogboek blijkt dat de paniek na de tweede moduleperiode luwde bij studenten en docenten. De paniek kwam niet terug bij de start van nieuwe e-learning docenten en ook niet bij de start van cohort 2. De 
docenten gaven in de interviews aan dat zij na moduleperiode 2 de verhouding tussen de toegekende uren en de daadwerkelijke uitvoering als realistisch ervoeren.

Een thema dat de meeste docenten aanroerden in het interview was de regelmaat waarmee ingelogd en bijgedragen moet worden. Dit bleef voor de meeste docenten een probleem, ook nadat het aantal keren inloggen per week naar beneden was bijgesteld. De regelmaat en de continue druk die daarvan uitgaat contrasteerde met de gewone manier van werken. Normale lessen geven een piekbelasting, maar daarna is er rust. E-learning daarentegen gaat acht weken lang altijd maar door. Dit vergt een langdurige toewijding van docenten waardoor het voor hen voelde alsof het werk nooit af was. In dit verband werd nogal eens de term 'e-learning moeheid' gebezigd. De docenten zouden het prettig vinden als er in een moduleperiode van acht weken meerdere modulevrije weken zouden zijn. Zeker voor parttimers, maar ook voor fulltimers paste het regelmatige inloggen vaak niet binnen de formeel afgesproken werktijden. Er trad, blijkens de interviews, overloop op naar vrije dagen, avonden, weekends en vakanties. Ook de combinatie van e-learning met een reguliere docenttaak bleek docenten soms veel moeite te kosten, vooral op momenten dat er sprake was van piekbelasting in de reguliere docenttaak. Eén van de e-learning docenten stond hierdoor zo onder druk dat zij na haar eerste e-learning module niet verder is gegaan als e-learning docent. Veelal waren docenten geneigd om vaker in te loggen dan voorgeschreven en om langer bezig te zijn met moderaties. Het woord 'verslavend' werd in dit verband gebruikt. Meerdere docenten gaven aan dat zij leerdoelen hadden op het vlak van plannen en tijdbewaking. Het kwam echter ook voor dat docenten hun tijd heel strak bewaakten en daardoor te weinig en/of te kortaf modereerden. Eén van de docenten gaf aan dat het inplannen van modereerwerk moeilijk is omdat het per keer erg verschilt wat studenten gedaan hebben. Soms heeft een docent erg weinig te doen, maar als studenten veel gedaan hebben kan een modereerklus oplopen tot drie uur werk.

In de interviews bevestigden de docenten dat studenten het belangrijk vinden dat docenten regelmatig zichtbaar zijn door een reactie te geven in Blackboard. De docenten hadden in de eerste moduleperiode samen met de projectgroep elearning besloten om het inlogritme terug te brengen tot drie keer per week. Dit werd acceptabel en zinvol gevonden. Eén van de docenten gaf in het interview aan dat zij drie keer per week veel te zwaar vond. Zij stopte na haar eerste module met het e-learning docentschap. 
Uit de interviews en uit het onderzoekerslogboek bleek ook het belang van snelle reacties op vragen en tijdige feedback. Het lukte docenten niet altijd om vragen tijdig te zien en te beantwoorden, soms ontstonden daardoor onnodige irritaties en problemen. Docenten wilden dit graag voor zijn en hechtten belang aan een tijdige reactie.

\subsubsection{Moderatie}

\section{Modereren}

Het modereren van asynchrone discussies was een nieuwe vaardigheid voor docenten. Met behulp van de schaal 'Moderatie' uit de vragenlijst 'Begeleiding door de docent' is nagegaan in hoeverre docenten succesvol modereerden in de ogen van studenten. Een voorbeeld item uit de schaal is: 'de docent gaf op vakinhoudelijk vlak richting aan onze discussies'. Er werd gescoord op een 3puntsschaal: 1=nee, 2=gaat wel, 3=ja. In tabel 7.9 worden de gemiddeldes en standaarddeviaties weergegeven per moduleperiode en per cohort.

\begin{tabular}{|c|c|c|c|c|c|c|}
\hline \multirow[b]{2}{*}{ Periode } & \multicolumn{3}{|c|}{ Cohort 1 e-learning } & \multicolumn{3}{|c|}{ Cohort 2 e-learning } \\
\hline & $N$ & $X$ & $S D^{\circ}$ & $N$ & $X$ & $S D$ \\
\hline 1 & 22 & 2,1 & 0,62 & & & \\
\hline 2 & 26 & 2,2 & 0,65 & & & \\
\hline 3 & 22 & 2,7 & 0,34 & & & \\
\hline 4 & 16 & 2,7 & 0,30 & & & \\
\hline 6 & 19 & 2,7 & 0,47 & 23 & 2,7 & 0,41 \\
\hline 7 & 13 & 2,0 & 0,77 & 11 & 2,7 & 0,49 \\
\hline
\end{tabular}

In de tabel is zichtbaar dat de kwaliteit van de moderatie moeizaam op gang kwam in de eerste twee moduleperiodes van cohort 1 . De moderatie kwaliteit in deze periodes was onvoldoende $(<2,5)$. Dit verbeterde vanaf moduleperiode 3 . In moduleperiode 7 bleek de moderatie kwaliteit weer onvoldoende. Deze module werd begeleid door twee nieuwe e-learning docenten. Met variantie analyse voor herhaalde metingen is nagegaan of de gevonden verschillen significant waren. Dit bleek niet het geval, maar de power van de analyse bleek laag $(0,41)$. In de twee moduleperiodes van cohort twee werd stabiel voldoende moderatiekwaliteit bereikt. De $t$-toets voor onafhankelijke steekproeven resulteerde in een significant verschil tussen cohort 1 en 2 in moduleperiode 7 . Cohort 2 was significant positiever over de moderatie dan cohort $1 t(22)=2,5, p<0,05, r=0,47$. 
Leerzaamheid van de discussiebijdragen van de docent

Het was de bedoeling dat de docent via zijn/haar discussiebijdragen het leerproces van de studenten stimuleerde. Onderzocht werd in hoeverre dat volgens de studenten het geval was. Hiertoe is in de vragenlijst naar de leerzaamheid van de onderdelen van de e-learning modules gevraagd om de leerzaamheid van de discussiebijdragen van docenten met een rapportcijfer (1-10) te waarderen. In tabel 7.10 worden de gemiddeldes $(X)$ en standaarddeviaties $(S D)$ gerapporteerd per moduleperiode en per cohort.

Tabel 7.10 Leerzaamheid van de discussiebijdragen van docenten

\begin{tabular}{lcccccc}
\hline & \multicolumn{3}{c}{ Cohort 1 e-learning } & \multicolumn{3}{c}{ Cohort 2 e-learning } \\
Periode & $N$ & $X$ & $S D$ & $N$ & $X$ & $S D$ \\
\hline 2 & 22 & 6,5 & 1,50 & & & \\
6 & 19 & 7,7 & 1,06 & 23 & 8,0 & 1,11 \\
7 & 13 & 6,2 & 1,88 & 11 & 7,5 & 1,21 \\
\hline
\end{tabular}

In periodes 2 en 7 van cohort 1 was de leerzaamheid van de discussiebijdragen van docenten niet overtuigend. Uit de grote spreiding blijkt bovendien dat een substantieel aantal studenten dit als onvoldoende beoordeelde. In cohort 2 en in periode 6 van cohort 1 waren de discussiebijdragen van docenten wel leerzaam voor studenten. De gemiddelde score was ruim voldoende tot goed. Uit de multivariate toetsen $(\varepsilon=0,69)$ blijkt dat de verschillen tussen de drie moduleperiodes van cohort 1 significant zijn, $V=0,64, F(2,7)=6,2, p<0,05, \eta_{p}{ }^{2}=0,64$. Cohort 2 waardeert de leerzaamheid van de discussiebijdrages van docenten in beide periodes als goed. Het verschil tussen beide periodes bleek niet significant. Met de $t$-toets voor onafhankelijke steekproeven is nagegaan of de verschillen tussen cohort 1 en 2 significant waren. Dit bleek voor beide periodes niet het geval.

\section{Moderatiekwaliteit en inhoudelijke ervaring van docenten}

Het ligt in de lijn der verwachting dat de inhoudelijke kwaliteit van de docentbijdrages beïnvloed wordt door eerder opgedane ervaring in het specifieke vakgebied. In een aantal gevallen gaven docenten in de e-learning een moduleinhoud die zij nog nooit eerder gegeven hadden en/of die buiten hun primaire vakgebied lag. In deze gevallen zijn ze beschouwd als inhoudelijk onervaren. In de meeste gevallen lag de module inhoud wel binnen hun primaire vakgebied en hadden de docenten de betreffende modules eerder onderwezen aan reguliere groepen. Deze docenten werden als ervaren beschouwd. In tabel 7.11 is weergegeven hoeveel docenten al dan niet inhoudelijk ervaren waren op het vlak 
van de module. Voor ervaren- en onervaren docenten zijn gemiddeldes en standaarddeviaties weergegeven voor de moderatieschaal (1=nee, 2=gaat wel, $3=$ ja) en voor de leerzaamheid van de discussiebijdragen (rapportcijfers 1-10).

Tabel 7.11 Moderatiekwaliteit en inhoudelijke ervarenheid van docenten

\begin{tabular}{|c|c|c|c|c|c|c|c|c|c|}
\hline \multirow[t]{2}{*}{ Meting } & \multirow[t]{2}{*}{ Periode } & $\begin{array}{l}\text { Ervaren } \\
\text { docenten }\end{array}$ & \multicolumn{3}{|c|}{ Stud. } & Onervaren & \multicolumn{3}{|c|}{ Stud. } \\
\hline & & $N$ & $N$ & $X$ & $S D$ & N & $N$ & $X$ & $S D$ \\
\hline \multirow[t]{6}{*}{ Moderatie } & 1 & 0 & - & - & - & 3 & 22 & 2,1 & 0,62 \\
\hline & 2 & 2 & 18 & 2,4 & 0,51 & 1 & 8 & 1,6 & 0,58 \\
\hline & 3 & 3 & 22 & 2,7 & 0,34 & 0 & - & - & - \\
\hline & 4 & 4 & 16 & 2,7 & 0,30 & 0 & - & - & - \\
\hline & 6 & 6 & 37 & 2,7 & 0,37 & 1 & 5 & 2,3 & 0,66 \\
\hline & 7 & 5 & 17 & 2,5 & 0,52 & 1 & 7 & 1,8 & 0,89 \\
\hline \multicolumn{10}{|c|}{$\begin{array}{l}\text { Rapportcijfer } \\
\text { leerzaamheid }\end{array}$} \\
\hline & 2 & 2 & 15 & 6,9 & 1,11 & 1 & 7 & 5,7 & 1,59 \\
\hline & 6 & 6 & 37 & 8,0 & 1,08 & 1 & 5 & 7,0 & 0,71 \\
\hline & 7 & 5 & 17 & 7,5 & 1,07 & 1 & 7 & 5,14 & 1,86 \\
\hline
\end{tabular}

In de tabel is zichtbaar dat inhoudelijk ervaren docenten in het vakgebied in alle gevallen hoger scoorden dan onervaren docenten. In de periodes 2,6 en 7 waren zowel ervaren als - onervaren docenten aan het werk. Met de $t$-toets voor onafhankelijke steekproeven is in moduleperiodes 2, 6 en 7 nagegaan of er verschillen waren tussen ervaren en onervaren docenten voor wat betreft de moderatieschaal en de leerzaamheid van de discussiebijdragen. De uitkomsten hiervan zijn weergegeven in tabel 7.12.

Tabel 7.12 Verschillen tussen inhoudelijk ervaren en-onervaren docenten

\begin{tabular}{lccccc}
\hline Meting & Periode & $d f$ & $t$ & $p$ & $r$ \\
\hline Schaal moderatie & 2 & 24 & 3,7 & $0,001^{* *}$ & 0,60 \\
& 6 & 40 & 2,5 & $0,015^{*}$ & 0,36 \\
\multirow{3}{*}{ Rapportcijfer leerzaamheid } & 7 & 22 & 2,6 & $0,016^{*}$ & 0,48 \\
& 2 & 20 & 1,8 & 0,095 & 0,37 \\
& 6 & 40 & 2,0 & 0,052 & 0,30 \\
& 7 & 7,7 & 3,1 & $0,015^{*}$ & 0,75 \\
\hline
\end{tabular}

Noot: ${ }^{*} p<0,05,{ }^{* *} p<0,01,{ }^{* * *} p<0,001$.

In tabel 7.12 wordt zichtbaar dat de inhoudelijke ervarenheid van docenten samenhangt met wijze waarop de docent modereert. De studenten antwoorden significant vaker bevestigend op de items van de moderatieschaal als de docent 
ervaring heeft in het vakgebied en met de module. Het verschil tussen de rapportcijfers voor de leerzaamheid van de discussies was in twee moduleperiodes bijna significant en in moduleperiode 7 significant.

Moderatie bekeken door de ogen van docenten

Uit de interviews wordt duidelijk dat het modereren in e-learning voor docenten fundamenteel anders is dan de reguliere lesgevende taak. Alle geïnterviewde docenten waren bij aanvang onzeker over de kwaliteit van hun moderaties, maar merkten wel dat zij hierin groeiden en dat zij zich hierin nog weer verder konden bekwamen. Eén docent zag e-learning aanvankelijk als een soort procedure, zij vergat hierdoor om een aantal elementen vorm te geven die wel aanwezig waren tijdens haar gewone lessen. Achteraf was zij zich bewust van het feit dat zij haar online aanwezigheid onvoldoende zichtbaar maakte. Ook benoemde zij dat ze geen voorbeelden gaf en weinig inhoudelijke input.

De modererende rol van de docent werd door de meeste docenten omschreven als begeleidend en volgend, in tegenstelling tot de reguliere lesgevende taak die als initiërend en leidinggevend beschouwd werd. De docenten gaven aan dat zij er naast stonden in plaats van er voor. De e-learning studenten initieerden zelf hun discussies op grond van de opdrachtenlijst. De docenten gaven aan dat zij volgden door middel van bevestiging, samenvatting, inhoudelijke bijsturing, verwijzing naar literatuur, inhoudelijke informatie, het geven van voorbeelden en het stellen van vragen. De docenten vonden het belangrijk om te interveniëren omdat de discussies anders te veel verschillende kanten uitwaaierden, te snel afgelopen waren en te oppervlakkig bleven. Deze rol bleek in module 1 en 2 meer van docenten te vragen dan in module 4 . Eén van de docenten gaf aan dat de studenten in die module voor een gedeelte zelfstandig modereerden. Een docent die in moduleperiode 2 had gewerkt gaf aan dat zij het belangrijk vond om hier in een eerder stadium al sterk op aan te sturen middels een expliciete rolverdeling voor studenten. Bevestiging van de bijdragen van studenten en inhoudelijke sturing bleven volgens de docenten ook van groot belang in de latere moduleperiodes.

De docenten gaven aan dat zij voor de moderatie taak een grote expertise met betrekking tot de module en het vakgebied als noodzakelijke voorwaarde beschouwden. Eén van de docenten gaf bovendien aan dat zij een onderzoekende houding van de docent als belangrijke voorwaarde zag. Plezier beleven aan goed kijken en vragen stellen, niet meteen antwoorden geven. Soms ook de discussie 
een tijdje durven laten lopen, en een goede afweging kunnen maken tussen al dan niet ingrijpen. De docenten gaven aan dat moderatie vaardigheden vergde op het vlak van schrijftaal en begrijpend lezen. Bondig, helder en expliciet formuleren werd als heel belangrijk gezien om te voorkomen dat het geschrevene verkeerd over kwam bij studenten. De meeste docenten herlazen en redigeerden hun berichtjes zorgvuldig voorafgaand aan de verzending. Het lezen van de berichten van de studenten vereiste in een aantal gevallen veel inferentie-vaardigheden. Docenten vonden het belangrijk om goed 'tussen de regels' te kunnen lezen en heel alert te zijn op wat studenten eigenlijk bedoelden. Sommige studenten waren, zeker in de beginfase, niet voldoende expliciet in hun berichten om te kunnen compenseren voor het gebrek aan context, mimiek en intonatie. Het gebrek aan non-verbale communicatie maakte ook dat docenten soms rapporteerden 'blind' aan het werk te zijn. Ze konden niet zien en niet voelen hoe hun woorden aankwamen.

In de eerste twee moduleperiodes beschikten de docenten over onvoldoende tijd om te modereren omdat heel veel tijd verloren ging aan het beantwoorden van organisatorische en technische vragen. Modereren bleek lastig als studenten te laat begonnen in de discussie of juist erg veel reacties plaatsten. Soms kwam het voor dat de docent te laat was om nog goed te kunnen ingrijpen in een verkeerd gedachtespoor van de studenten. Op zulke momenten vormden studenten soms een blok waar moeilijk meer doorheen te komen was. Een ander probleem dat met name in de beginfase optrad werd gevormd door concurrentie tussen studenten. Sommige studenten hadden er veel last van als anderen goede bijdrages leverden terwijl zij nog moeite hadden met de opdracht. Zij vergden dan extra veel bevestiging en ondersteuning van de docent. Eén docent gaf aan dat zij gerichter dan in reguliere lessen kon reageren op onverwachte of nieuwe onderwerpen waar studenten mee kwamen omdat ze de tijd had om er over na te denken en er iets over op te zoeken. Ze kon dieper ingaan op deze onderwerpen dan ze in een gewone les zou doen en dit leidde tot een verdieping van haar eigen kennis.

\subsubsection{Feedback}

\section{Schaal 'Feedback'}

Feedback heeft een belangrijke rol in het leerproces. Feedback steunt en stuurt de inhoudelijke leerprocessen, maar steunt en stuurt ook de specifieke e-learning vaardigheden die studenten nodig hebben. De wijze waarop feedback gegeven wordt, is van belang omdat er gemakkelijk misverstanden kunnen ontstaan door 
het ontbreken van (non)-verbale uitwisseling tussen student en docent. In het ontwerp wordt de nadruk gelegd op concrete en bemoedigende feedback. Met behulp van de schaal 'Feedback' uit de vragenlijst 'Begeleiding door de docent' is nagegaan in hoeverre de studenten tevreden waren over de gegeven feedback. Een voorbeeld item uit de schaal is: 'als de docent mij feedback gaf kon ik zien dat hij/zij mijn werk goed overdacht had'. Er werd gescoord op een 3-puntsschaal: 1=nee, 2=gaat wel, 3=ja. In tabel 7.13 worden de gemiddeldes en standaarddeviaties weergegeven per moduleperiode en per cohort.

Tabel 7.13 Feedback door docenten

\begin{tabular}{lcccccc} 
& \multicolumn{3}{c}{ Cohort 1 e-learning } & \multicolumn{3}{c}{ Cohort 2 e-learning } \\
Periode & $N$ & $X$ & $S D$ & $N$ & $X$ & $S D$ \\
\hline 1 & 22 & 2,3 & 0,63 & & & \\
2 & 26 & 2,2 & 0,86 & & & \\
3 & 22 & 2,6 & 0,62 & & & \\
4 & 16 & 2,3 & 1,15 & & & \\
6 & 19 & 2,8 & 0,32 & 23 & 2,6 & 0,60 \\
7 & 13 & 2,2 & 0,73 & 11 & 2,9 & 0,16 \\
\hline
\end{tabular}

Uit tabel 7.13 blijkt dat de studenten in cohort 1 in de meeste periodes niet voldoende tevreden waren over de gegeven feedback. Zij beoordeelden de feedback gemiddeld met 'gaat wel'. Alleen in de periodes 3 en 6 was het oordeel van de studenten positief $(\geq 2,5)$. In de twee moduleperiodes van cohort 2 was het oordeel gemiddeld ook positief. Met variantie analyse voor herhaalde metingen is voor cohort 1 nagegaan of de gevonden verschillen significant waren. Dit bleek niet het geval, de power van de analyse was laag $(0,36)$. Voor cohort 2 bleek de verbetering tussen moduleperiodes 6 en 7 niet significant. Met de $t$-toets voor onafhankelijke steekproeven is nagegaan of de verschillen tussen cohort 1 en 2 significant waren. Dit was niet het geval voor periode 6, maar wel voor periode 7 , $t(13,30)=3,29, p<0,01, r=0,67$.

\section{Leerzaamheid van de feedback}

Nagegaan werd in hoeverre de studenten van mening waren dat de feedback van docenten op de door hen ingeleverde opdrachten een positieve bijdrage leverde aan hun leerproces. Hiertoe is in de vragenlijst naar de leerzaamheid van de onderdelen van de e-learning modules gevraagd om de leerzaamheid van de feedback door docenten met een rapportcijfer (1-10) te waarderen. In tabel 7.14 worden de gemiddeldes $(X)$ en standaarddeviaties $(S D)$ gerapporteerd per moduleperiode en per cohort. 
Tabel 7.14 Leerzaamheid van feedback van docenten

\begin{tabular}{lcccccc}
\hline & \multicolumn{3}{c}{ Cohort 1 e-learning } & \multicolumn{3}{c}{ Cohort 2 e-learning } \\
Periode & $N$ & $X$ & $S D$ & $N$ & $X$ & $S D$ \\
\hline 2 & 22 & 6,4 & 2,28 & & & \\
6 & 17 & 7,7 & 1,27 & 12 & 7,6 & 1,17 \\
7 & 13 & 6,5 & 1,81 & 10 & 7,4 & 0,84 \\
\hline
\end{tabular}

In de tabel is zichtbaar dat de feedback van docenten voor cohort 1 gemiddeld onder de zeven scoorde in moduleperiodes 2 en 7 . Dit was beneden het streefniveau. De spreiding was ook te groot in deze periodes hetgeen betekent dat te veel studenten een onvoldoende gaven voor dit aspect. In cohort 2 en in moduleperiode 6 van cohort 1 waren de scores ruim voldoende tot goed. Variantie analyse voor herhaalde metingen in cohort 1 maakte duidelijk dat de verschillen tussen de drie periodes significant waren $F(2 ; 20)=5,3, p<0,05, \eta_{p}{ }^{2}=0,35$. Uit toetsing van de contrasten tussen de moduleperiodes bleek dat alleen het verschil tussen periodes 6 en 7 significant was $F(1 ; 10)=4,0, p<0,05, \eta_{p}{ }^{2}=0,51$. De verschillen tussen moduleperiodes 6 en 7 van cohort 2 bleken niet significant.

Feedback bekeken door de ogen van docenten en studenten.

Feedback is een onderwerp dat veelvuldig naar voren kwam in de docentinterviews en in het logboek. Het onderwerp feedback bleek voor de docenten binnen de e-learning opleiding problematischer dan in de reguliere opleiding. De fysieke afstand tussen docent en student speelde daarin een cruciale rol. De afstand leidde in de eerste twee moduleperiodes bij studenten tot een sterke behoefte aan feedback. De studenten vroegen met grote regelmaat om bevestiging en leken veel onzekerder dan reguliere studenten. Dit verbaasde de docenten, daar zij hadden verwacht dat e-learners juist zelfstandiger zouden zijn dan reguliere studenten.

Een weerkerend thema binnen de docentinterviews was dat het lastig is om op afstand corrigerende feedback of een negatieve beoordeling te geven terwijl dit wel van groot belang is voor het leerproces. Sommige studenten accepteerden dit type feedback niet of interpreteerden de feedback te negatief. Vanuit schrikreacties van studenten ontstonden soms digitale reacties die niet strookten met de afgesproken netetiquette. Docenten hadden het hier moeilijk mee en gaven in de interviews aan banger te zijn om e-learners een negatieve beoordeling te geven dan reguliere studenten. Met e-learners misten zij de interactie met hoor en wederhoor in een gesprek waardoor zij niet konden zien hoe de boodschap binnenkwam bij de 
student. De docenten vroegen zich af hoe zij hun feedback zowel eerlijk als tactvol konden schrijven zodat de studenten op afstand niet gekwetst zouden raken. Sommige docenten kozen er voor om corrigerende feedback telefonisch te geven in plaats van schriftelijk, maar ook via de telefoon ervoeren zij het ontbreken van nonverbale cues in de communicatie als een probleem. Door het grote verlangen naar feedback en de complexe eisen waaraan online feedback bleek te moeten voldoen, hadden de docenten er veel werk aan om hun feedback zorgvuldig te schrijven, meermaals te herlezen en te redigeren. Dit kostte naar hun mening, zeker in de eerste twee modules, te veel begeleidingstijd.

In de eerste twee modules gaven docenten vooral feedback op de wijze van online samenwerken en discussiëren en op de deelopdrachten in de portfolio's van studenten. De docenten vroegen zich af of er niet meer uren beschikbaar konden komen voor het geven van feedback, of dat feedback op een andere, meer economische manier gegeven zou kunnen worden.

In het logboek is beschreven dat er verschillende feedback systemen uitgeprobeerd werden. Bij de start werd een sterrensysteem gebruikt waarbij goede discussieberichten sterren toegekend kregen zodat zij anderen tot voorbeeld zouden kunnen zijn. Dit systeem stuitte op weerstand bij studenten. Het systeem werd door sommige studenten ervaren als concurrentieverhogend; positieve feedback voor de één bleek negatieve feedback voor de ander. Op grond hiervan werd geconcludeerd dat positieve feedback voor een individu binnen de discussielijnen niet wenselijk was. Er werd met cijfers gewerkt die individueel werden toegekend. De studenten waren daar niet enthousiast over omdat het hen te weinig handvatten gaf om tot verbetering te komen. Dit bleek uit de berichten van de vijf random geselecteerde studenten.

Ik heb nog een paar vragen. Ik zag vandaag dat er punten zijn toegekend. Waarop zijn deze gebaseerd? Ik mis eerlijk gezegd nog wel wat inhoudelijke feedback. Zo'n cijfer zegt me nog niet zo veel op deze manier. .........

Er werd daarna gestart met een meer uitgewerkt en gestandaardiseerd systeem. De studenten kregen een individuele e-mail van hun docent waarin zeven verschillende criteria voor online discussiëren van een kleur werden voorzien: roze voor een aandachtspunt, geel voor 'oké' en groen voor 'super'. Bij deze beoordeling werd ter verduidelijking een standaard document meegestuurd waarin rubrics 
werden beschreven met voorbeelden. De studenten werd verzocht om hun mening te geven over de drie verschillende feedback systemen die gebruikt werden voor de kwaliteit van online bijdrages: sterren, cijfers en kleuren. Uit de reacties bleek dat de meningen verdeeld waren over de sterren en de cijfers, maar dat de studenten het met elkaar eens waren dat zij concrete feedback wilden in tekst.

Ik sluit mij helemaal bij (student $x$ ) aan. Wel feedback, geen sterren, geen cijfers ( behalve voor eindopdracht).

groet, .....

Ik vind een combinatie wel een goede oplossing. Cijfers per opdracht, maar wel onderbouwd. Sterren voor een goede bijdrage.

Uiteindelijk werd besloten dat het kleurensysteem individueel via de mail gebruikt zou worden in gevallen waarin er duidelijke leerpunten waren. Als een groepje als geheel goed voldeed aan de gestelde eisen voor discussiebijdrages en samenwerkingsopdrachten, werd collectief positieve feedback gegeven binnen Blackboard. De docenten gaven in de interviews aan dat zij deze werkwijze prettiger vonden, maar zij ervoeren het nog altijd als veel werk. Dit leidde ertoe dat dit systeem vooral werd toegepast in de eerste moduleperiodes van cohort 1 en 2 om de studenten te leren online discussiëren, en niet meer in de latere moduleperiodes van deze cohorten. Ook werd vanaf cohort 2 een korte training online samenwerken gegeven op de startzaterdag om de noodzaak tot het geven van corrigerende feedback te verminderen.

In de interviews vertelden de docenten dat de studenten in de eerste twee moduleperiodes naast feedback op online leren ook steeds inhoudelijk feedback verwachtten op het moment dat ze een deelopdracht in hun portfolio plaatsten. De docenten waren van mening dat dit veel te veel tijd kostte en zij stelden ook dat het een risico vormde bij het beoordelen van de eindverslagen. Als het eindverslag in samenhang werd bekeken kwamen er soms andere dingen boven dan bij het beoordelen van de deelopdrachten. Dit leidde tot kritische vragen van studenten. Reguliere studenten kregen dit soort tussentijdse feedback niet waardoor er volgens de docenten ongelijkheid ontstond tussen de studentengroepen. De docenten vroegen zich af of we dit nog wel moesten doen en gaven aan dat het van groot belang was om duidelijk te maken waarop wel en waarop niet feedback gegeven zou worden. Ook waren zij van mening dat het belangrijk was om het verschil duidelijk te maken tussen feedback en beoordeling. 
Uit de interviews bleek dat docenten het moeilijk vonden om te weten te komen of ze goed les gaven in de e-learning modules. Ze waren onzeker op dit vlak. Schriftelijke reacties van studenten in de module konden immers sociaal wenselijk zijn en niet werkelijk gemeend. Er was geen non-verbale communicatie om dit uit af te leiden. De feedback kwam pas na de module doordat dan pas vragenlijsten werden uitgezet. Ontevredenheid kon daardoor te lang onzichtbaar blijven. Negatieve feedback na de module was soms volkomen onverwacht. Uit het logboek bleek dat docenten ervan schrokken als dat gebeurde.

\subsubsection{Organisatorische ondersteuning}

Ondersteuning betrof het tijdig (binnen 2 dagen) beantwoorden van vragen van studenten over zaken als onduidelijkheden in de opdrachten, in de beoordeling en in de techniek. Eerder bleek al dat studenten zeer veel van dit soort vragen stelden (zie hoofdstuk 5) en dat docenten veelal tijdig reageerden op dit soort vragen (tabel 7.4). Hieronder wordt besproken in hoeverre studenten vonden dat docenten hun vragen adequaat beantwoordden en hoe docenten dit aspect van hun docenttaak ervoeren.

\section{Adequaat beantwoorden van vragen}

De studenten in cohort 1 stelden in de eerste twee moduleperiodes extreem veel vragen aan de docenten. Met behulp van een item in de vragenlijst 'Begeleiding door docenten' werd nagegaan in hoeverre studenten van mening waren dat docenten adequaat antwoord gaven op hun vragen. Het item luidde als volgt: 'De docent gaf adequaat antwoord op mijn vragen' en werd gescoord op een 3puntsschaal: nee - gaat wel - ja. In tabel 7.15 worden weergegeven het percentage studenten dat hier ja op antwoordde, alsmede de gemiddeldes $(X)$ en de standaarddeviaties $(S D)$ voor dit item.

Tabel 7.15 Adequate antwoorden van docenten

\begin{tabular}{lcccccccc}
\hline & \multicolumn{3}{c}{ Cohort 1 e-learning } & \multicolumn{3}{c}{ Cohort 2 e-learning } \\
Periode & $N$ & $\% j a$ & $X$ & $S D$ & $N$ & $\% j a$ & $X$ & $S D$ \\
\hline 1 & 22 & 68 & 2,7 & 0,48 & & & & \\
2 & 23 & 70 & 2,6 & 0,73 & & & & \\
3 & 20 & 90 & 2,9 & 0,31 & & & & \\
4 & 15 & 80 & 2,8 & 0,41 & & & & \\
6 & 18 & 83 & 2,8 & 0,38 & 17 & 100 & 3,0 & 0,00 \\
7 & 13 & 54 & 2,2 & 0,93 & 10 & 80 & 2,8 & 0,42 \\
\hline
\end{tabular}


De tabel laat zien dat de studenten hier vanaf het begin voldoende tevreden over waren $(X \geq 2,5)$. Alleen cohort 1 was gemiddeld minder tevreden in moduleperiode 7. Er was in die periode sprake van een grote spreiding in oordelen tussen studenten. Alleen voor de verschillen met betrekking tot moduleperiode 7 is geanalyseerd of deze significant waren. Het verschil tussen periode 6 en 7 van cohort 1 is geanalyseerd met behulp van variantie analyse voor herhaalde metingen. Het verschil bleek net niet significant $F(1 ; 9)=5,0, p=0,05$, $\eta_{p}{ }^{2}=0,36$. De power van de analyse was laag $(0,51)$. Het verschil tussen beide cohorten bleek in periode 7 eveneens niet significant $t(17,6)=1,97, p=0,07, r=0,43$.

\section{De ondersteuningstaak in de ogen van docenten}

In de eerste twee moduleperiodes van cohort 1 hadden de meeste studenten erg veel steun nodig. Onduidelijkheden en doorgevoerde oplossingen en veranderingen leidden tot veel vragen, onrust en tijdverlies zoals blijkt uit het logboek en uit de interviews. De docenten vertelden in de interviews dat zij vooral bezig waren met het volgen en oplossen van problemen en minder met proactief en inhoudelijk modereerwerk. Dit hadden zij van te voren niet verwacht en het kostte hen veel tijd en energie. De docenten hadden het gevoel dat zij achter de feiten aanholden en brandjes blusten. Soms ontstond ergernis bij docenten en spraken zij over 'onzelfstandig gedrag' van studenten. Het beantwoorden van de vele vragen vergde veel van hun geduld. Uit het logboek blijkt dat zij bovendien wel eens twijfelden aan hun eigen antwoorden en daardoor soms zelf ook het spoor enigszins bijster raakten. Uit de interviews blijkt dat de docenten leerden om met de vele vragen om te gaan door te selecteren wat dringend was en wat niet. Op dringende zaken gaven zij direct reactie terwijl dit voor minder dringende zaken werd uitgesteld. Vanaf moduleperiode 3 werd rondom vragen en onduidelijkheden een procedure geïmplementeerd die maakte dat de docent niet meer alle bijdrages van studenten hoefde te checken op problemen en dat studenten werden aangespoord de problemen eerst gezamenlijk op te lossen. In de interviews werd bevestigd dat dit de werklast rondom vragen verminderde voor docenten. Zo was in moduleperiode 5 voor docenten zichtbaar dat de studenten technisch goed op dreef waren en elkaar raad gaven als er iets mis ging rondom het plaatsen van de filmpjes.

Uit het logboek blijkt dat een klein aantal studenten in het eerste cohort zich niet prettig voelde bij e-learning. Dit leidde soms tot emotionele uitbarstingen die moeilijk konden zijn voor docenten. Emoties kwamen binnen e-learning scherper en onverwachter naar voren dan in de reguliere opleiding. Docenten konden 
hevig schrikken van dergelijke uitbarstingen. Negatief geladen asynchrone bijdrages waren vaak moeilijk voor docenten (zie ook hoofdstuk 5). In de eerste twee moduleperiodes kwamen op allerlei tijdstippen negatief geladen mails en telefoontjes binnen van studenten. Dit kostte veel tijd en energie. Docenten gingen hiermee om door ondersteuning te zoeken van elkaar. Zij wisselden uit, gaven elkaar raad en vroegen elkaar om mails aan studenten te controleren om te kijken of ze goed overkwamen en geen aanleiding zouden vormen voor nog meer negatieve emoties. Uit de interviews blijkt dat de docenten in de loop van de tijd leerden om zich dit soort boodschappen minder aan te trekken. Bovendien kwam dit type boodschappen minder voor na het opstellen en doorvoeren van regels rondom netetiquette (zie ook hoofdstuk 5).

Uit het logboek blijkt dat in de eerste moduleperiode door docenten en studenten veel meer werd getelefoneerd dan oorspronkelijk verwacht. Sommige docenten gaven in de interviews aan dat zij door te telefoneren veel makkelijker contact konden maken met de studenten dan schriftelijk. Gevoelige onderwerpen waren voor hen via de telefoon makkelijker te bespreken en sneller op te lossen dan schriftelijk. Sommige studenten belden veelvuldig. De docenten gaven aan dat vooral onverwachte telefoontjes sterk drukten op hun werklast. Na periode 1 werden communicatieregels geïmplementeerd. Als er sprake was van ergernis of andere gevoelige zaken werd dat niet meer digitaal besproken maar altijd via de telefoon na het maken van een belafspraak.

\subsubsection{Vraagsturing en flexibiliteit}

Onder vraagsturing en flexibiliteit wordt verstaan dat docenten met studenten zoeken naar aanpassingen waar behoefte aan is in het kader van leerwensen en privé- of werksituatie. Hieronder worden alleen de aanpassingen besproken met betrekking tot de leerwensen (vraagsturing). Over flexibiliteit met betrekking tot het rooster naar aanleiding van onmogelijkheden in de privé- of werksituatie is al eerder gerapporteerd (zie paragraaf 6.1.3).

\section{Vraagsturing}

Studenten konden er in overleg met docenten voor zorgen dat hun leerweg aansloot bij hun eigen leerwensen. Zo konden zij overleggen over aanpassingen van de eindopdracht zodat deze beter aansloot bij hun praktijksituatie. Ook konden zij eigen casuïstiek inbrengen in de discussies. Vraagsturing vergde inhoudelijke flexibiliteit van docenten. In cohort 1 werd na de vier 
moduleperiodes de schaal 'Vraagsturing' afgenomen, deze schaal bevatte drie items. De studenten hebben op een schaal van 1-3 (nee-soms-ja) aangegeven of zij ervoeren dat er flexibiliteit was om de leerweg aan te passen aan hun eigen leerwensen. In tabel 7.16 zijn de gemiddeldes $(X)$ en standaarddeviaties $(S D)$ weergegeven voor deze schaal.

\begin{tabular}{llcc} 
Tabel 7.16 & \multicolumn{4}{l}{ Vraagsturing } \\
\hline \multirow{4}{*}{ Cohort 1 e-learning } \\
Periode & $N$ & $X$ & $S D$ \\
\hline 1 & 22 & 2,3 & 0,55 \\
2 & 26 & 2,2 & 0,61 \\
3 & 20 & 2,6 & 0,47 \\
4 & 16 & 2,3 & 0,64 \\
\hline
\end{tabular}

In de tabel is zichtbaar dat er ruimte is voor verbetering van de waardering voor vraagsturing bij studenten. Alleen in periode $3 \mathrm{kwam}$ voldoende inhoudelijke flexibiliteit tot stand $(X \geq 2,5)$. In de overige periodes lag de gemiddelde score dichter bij 'gaat wel'. Met variantie analyse voor herhaalde metingen is nagegaan of de gevonden verschillen significant waren. Dit bleek het geval $F(3 ; 21)=4,1, p$ $<0,05, \quad \eta_{p}{ }^{2}=0,37$. Uit toetsing van de contrasten tussen de opeenvolgende moduleperiodes bleek alleen het verschil tussen periodes 2 en 3 significant $F(1 ; 7)=23,3, p<0,01, \eta_{p}^{2}=0,77$.

\section{Vraagsturing door de ogen van docenten}

De geïnterviewde docenten verschilden van mening over de mogelijkheid tot vraagsturing binnen e-learning. Drie docenten gaven na moduleperiodes 1 en 2 aan dat volgens hen ad hoc aanpassingen op grond van de belangstelling van studenten niet mogelijk waren binnen e-learning omdat de module inhoud en de opdrachten door de ontwikkelaar waren vastgelegd. In reguliere modules vonden deze docenten dit aspect van vraagsturing sterker aanwezig omdat zij als docent veel meer invloed hadden op de invulling van de lessen. Deze invulling konden zij aanpassen op basis van ad hoc bevindingen in de les. Daarnaast was de studiebelasting volgens deze docenten in de eerste twee moduleperiodes zo hoog dat de studenten nauwelijks tijd hadden om stil te staan bij hun eigen leervragen. Er was volgens deze docenten overigens wel sprake van vraagsturing via literatuurkeuze en via de mogelijkheid tot aanpassing van de eindopdracht. De keuzemogelijkheden binnen de literatuur hadden volgens hen echter vaak niet het gewenste effect omdat de studenten geneigd waren om alle aangeboden literatuur te gaan lezen. De docenten pasten in een aantal gevallen de eindopdracht aan om 
deze beter aan te laten sluiten bij de praktijksituatie van de studenten. Eén docent gaf aan dat de mogelijkheid tot vraagsturing niet anders was binnen e-learning dan binnen de reguliere modules, maar dat het in beide gevallen discutabel was of er veel vraagsturing mogelijk is en of dat wenselijk is voor het leerproces van de studenten. De overige twee docenten waren na hun ervaringen in moduleperiode 4 enthousiast over de mogelijkheden tot vraagsturing binnen e-learning. Zij gaven aan dat er binnen de e-learning opdrachten voldoende flexibiliteit was voor inbreng van eigen vragen uit de praktijk en voor gerichte reacties van de docent daarop. Het kwam regelmatig voor dat studenten belangrijke en onvoorziene inhoud aandroegen en dat de docenten daarop reageerden door de nieuwe richting in de discussie aan te moedigen en door inhoudelijke informatie bij te dragen.

\subsubsection{Controle en activering}

Activering door de docent

Het was de bedoeling dat de docent de discussie- en samenwerkingsactiviteit van de studenten bewaakte om te zorgen dat de interactie de gewenste intensiteit haalde. Als een student te laat of te weinig frequent bijdrages leverde dan behoorde het tot de taak van de docent om de student via de mail of via Blackboard te stimuleren tot regelmatiger deelname. Met een item in de vragenlijst 'Begeleiding door docenten' werd nagegaan of het inderdaad voor kwam dat docenten studenten eraan herinnerden om bijdrages te leveren. Het item luidde als volgt: 'De docent stuurde/plaatste berichtjes om mij eraan te herinneren op tijd bijdrages te leveren in Blackboard' . Het item werd gescoord op een 3-puntsschaal: nee - gaat wel - ja. In tabel 7.17 wordt weergegeven welk percentage van de studenten hierop antwoordde met soms en met ja. Er werd uiteraard niet gestreefd naar een 'ja' bij zo veel mogelijk studenten. Als docenten deze actie ondernamen dan was dat immers alleen bij studenten die niet uit zichzelf in voldoende mate bijdroegen.

Tabel 7.17 Herinneren om bijdrages te leveren

\begin{tabular}{lcccc}
\hline & \multicolumn{2}{c}{ Cohort 1 e-learning } & \multicolumn{2}{c}{ Cohort 2 e-learning } \\
Periode & $N$ & \% ja en soms & en soms \\
\hline 1 & 22 & 59 & & \\
2 & 26 & 46 & & \\
3 & 21 & 67 & & \\
4 & 16 & 63 & & \\
6 & 19 & 74 & 23 & 74 \\
\hline
\end{tabular}


Opvallend zijn de zeer hoge percentages studenten die aangeven dat de docent hen er aan herinnerd heeft om op tijd bijdrages te leveren binnen Blackboard. Dit percentage neemt toe in de loop van de tijd. Kennelijk blijft het nodig om de aantallen bijdrages te controleren en studenten aan te sporen op het vlak van het leveren van bijdrages.

\section{Controle en activering in de ogen van docenten}

Blijkens de interviews en het logboek vonden docenten het vaak niet eenvoudig om studenten te activeren die te weinig deelnamen, ook vonden zij het niet altijd prettig om dit te doen. $\mathrm{Zij}$ vonden het moeilijk om de juiste stimulerende toon te treffen. Te hard aan studenten trekken werd als contraproductief ervaren. Als studenten niet reageerden nam de druk vanuit de docent uiteindelijk af. Eén docent gaf in het interview aan dat het nuttig zou zijn om een set standaard berichten te hebben die verzonden kunnen worden in dergelijke situaties. Sommige inactieve studenten reageerden niet op mail en waren ook telefonisch moeilijk bereikbaar voor de docenten. De docenten ervoeren dat het voor de medestudenten van belang is dat de docent anderen tot de orde roept als ze niet bijdragen. Er ontstond in zulke gevallen geregeld enige onrust in de groepjes. Het kwam echter ook voor dat er een student aan de aandacht van de docent ontsnapte. Controleren of iedereen genoeg deelnam werd belangrijk gevonden door de docenten, maar modereren, ondersteunen en bevestigen werden als belangrijker gezien.

\subsubsection{Sociale aanwezigheid}

\section{Docentcommunicatie}

De sociale aanwezigheid van de docent begint met respectvolle, duidelijke en persoonlijke communicatie. In de vragenlijst 'Begeleiding door de docent' is daarom de schaal 'Docentcommunicatie' opgenomen. De vier items van deze schaal werden op een 3-puntsschaal gescoord: 1=nee , 2=gaat wel, 3=ja. In tabel 7.18 zijn de gemiddeldes $(X)$ en standdaardeviaties $(S D)$ weergegeven voor deze schaal.

Tabel 7.18 Docentcommunicatie

\begin{tabular}{lcccccc}
\hline & \multicolumn{3}{c}{ Cohort 1 e-learning } & \multicolumn{3}{c}{ Cohort 2 e-learning } \\
Periode & $N$ & $X$ & $S D$ & $N$ & $X$ & $S D$ \\
\hline 1 & 22 & 2,6 & 0,55 & & & \\
2 & 23 & 2,6 & 0,51 & & & \\
3 & 20 & 2,9 & 0,18 & & & \\
4 & 15 & 2,9 & 0,23 & & & \\
6 & 18 & 2,8 & 0,43 & 17 & 3,0 & 0,13 \\
7 & 13 & 2,3 & 0,73 & 10 & 2,9 & 0,24 \\
\hline
\end{tabular}


Uit de tabel blijkt dat de docentcommunicatie in alle moduleperiodes adequaat gerealiseerd werd $(\geq 2,5)$, behalve in moduleperiode 7 voor cohort 1 . Uit variantie analyse voor herhaalde metingen over alle moduleperiodes van cohort 1 bleken geen significante verschillen tussen de moduleperiodes, maar de power van deze analyse was laag $(0,61)$. De verschillen voor de moduleperiodes van cohort 2 waren zo klein dat geen variantie analyse voor herhaalde metingen werd uitgevoerd. Met de $t$-toets voor onafhankelijke steekproeven werd nagegaan of er significante verschillen waren tussen de twee cohorten in periodes 6 en 7 . Alleen het verschil tussen cohort 1 en 2 in periode 7 bleek significant $t(20,4)=2,5, p<0,05, r=0,48$.

\section{Persoonlijk communiceren}

Om de sociale aanwezigheid van de docent vorm te laten krijgen werd de docenten voorafgaand aan hun e-learning taak duidelijk gemaakt dat het van belang was om op een persoonlijke wijze te communiceren in Blackboard. Dit was als volgt geformuleerd in de docenthandleiding: 'ontwikkel een 'online personality'; zorg dat de communicatie ook informeel en gezellig is. Stimuleer studenten daar ook in'. Eén van de items uit de schaal 'Docentcommunicatie' ging na of de studenten inderdaad ervoeren dat de communicatie van de docent persoonlijk van aard was. Dit item luidde als volgt: 'de docent communiceerde op een persoonlijke manier'. Het werd gescoord op een 3-puntsschaal 1=nee , 2=gaat wel, 3=ja. In tabel 7.19 zijn voor beide cohorten per moduleperiode de percentages nee en soms weergegeven voor dit item, hieruit wordt duidelijk hoeveel procent van de studenten de communicatie van de docent als (gedeeltelijk) onpersoonlijk ervoeren .

Tabel 7.19 Persoonlijke communicatie

\begin{tabular}{lcccccc}
\hline & \multicolumn{3}{c}{ Cohort 1 e-learning } & \multicolumn{3}{c}{ Cohort 2 e-learning } \\
Periode & $N$ & \% nee & \% soms & $N$ & \% nee & \% soms \\
\hline 1 & 22 & 14 & 9 & & & \\
2 & 26 & 12 & 38 & & & \\
3 & 22 & 0 & 0 & & & \\
4 & 16 & 6 & 6 & & & \\
6 & 19 & 0 & 21 & 23 & 0 & 4 \\
7 & 13 & 23 & 38 & 11 & 0 & 18 \\
\hline
\end{tabular}

Uit de tabel kan afgeleid worden dat de persoonlijke communicatie het minst werd gerealiseerd in moduleperiodes 1, 2 en 7 van cohort 1 . In de overige moduleperiodes werd dit aspect voldoende tot goed gerealiseerd. 
Sociale aspecten van het docentschap bezien door de ogen van docenten

Een overheersend thema in de interviews met beginnende e-learning docenten na moduleperiodes 1 en 2 was dat zij de directe interactie met studenten misten. Ze vonden het onprettig dat ze studenten niet in de ogen konden zien en geen nonverbale signalen konden waarnemen. Ze konden de sfeer in de groep niet peilen en daar niet op reageren. Ze vonden het moeilijk om al schrijvend een band op te bouwen. Er was sprake van een onevenwichtige verdeling van het directe contact omdat de docenten vooral telefoneerden met studenten die problemen ervoeren. Voor één van de docenten was het gebrek aan direct contact zo ernstig dat zij na één e-learning module afhaakte. Het lukt haar niet om uit het internetcontact personen te construeren. Ze had het gevoel dat ze de e-learning studenten helemaal niet kende en raakte niet emotioneel betrokken bij hen. Dit belemmerde haar erg bij het modereren. Zij kon niet onthouden wie wat zei en waarom. Dit leidde ertoe dat ze extreem veel werk had aan het terugzoeken van berichtjes. Het modereren in twee verschillende groepjes viel haar hierdoor erg zwaar.

Eén van de andere docenten benoemde juist dit 'kunnen construeren van personen' heel expliciet als de belangrijkste voorwaarde om e-learning docent te kunnen zijn. Zij stelde dat een e-learning docent moet kunnen voelen dat hij allemaal studenten bij zich heeft en plezier moet beleven aan de geschreven interactie met studenten. Het lukte haar om zich een voorstelling van de elearning studenten te maken door te observeren hoe ze op elkaar reageerden, hoe snel hun reacties waren, hoe hun taalgebruik was, hoe ze gebruik maakten van humor in hun berichten en hoe ze omgingen met het laten zien van hun eigen zwakheden, onzekerheden en trots. Deze docent raakte ontroerd door de online leerervaringen van haar studenten.

Je ziet de mens erachter die zich ontwikkelt, dat is wat ik leuk vind aan het werk.

De tendens die duidelijk werd uit het logboek was dat docenten na het geven van meerdere e-learning modules meer contact ervoeren met hun studenten. Zij spraken dan niet langer meer over het missen van direct contact. Soms werd zelfs aangegeven dat er meer contact was met e-learning studenten dan met reguliere studenten. De e-learning docenten benoemden in de interviews vele manieren waarop zij werkten aan het contact met hun e-learning studenten. Deze manieren leken op termijn vruchten af te werpen. De filmpjes die studenten op Blackboard moesten plaatsen werden in dit opzicht als een belangrijk middel gezien. 
Docenten konden daardoor hun studenten toch zien. Respectvol schrijven, toegankelijkheid uitstralen, humor gebruiken en ontroering en empathie uitdrukken werden in de interviews door meerdere docenten als werkwijzen genoemd. Het online gebruik van humor had volgens de docenten echter ook een keerzijde. Humorvol schrijven bleek schrijftalent te vergen en online humor werd soms verkeerd begrepen.

De docenten gebruikten een specifieke techniek die hen aangereikt was door de projectgroep e-learning. Dit betrof het samenvatten van wat studenten gezegd hadden en het daarbij noemen van hun namen. Ze bevestigden in de interviews dat deze techniek hielp om contact te krijgen. Docenten die les gaven in moduleperiodes 3 en 4 stelden dat het belangrijk was om iets van zichzelf als persoon te laten zien aan studenten, zodat studenten hen ook als persoon konden 'construeren'. Zij hadden op dit vlak begeleiding gekregen door leden van de projectgroep e-learning.

Om te zorgen dat je de student ziet achter wat ze schrijven, moet ik er voor zorgen dat die student mij ziet achter wat ik schrijf.

Iets van jezelf laten zien, geeft hele leuke reacties. Apart dat ik daar niet eerder aan gedacht had. Online persoonlijkheid creëren is belangrijk. Dat kan anders zijn dan in een gewone groep.

Eén docent vertelde in het interview dat zij expliciet de tijd nam om met iedere student een keer een asynchrone uitwisseling te hebben over een meer persoonlijk onderwerp. Zij legde de relatie naar het leerproces. Door de meer persoonlijke relatie die hier uit ontstond kon zij gemakkelijker een motiverende toon treffen in haar moderaties.

Twee docenten benoemden voordelen van het ontbreken van direct contact. Ze hadden in de reguliere opleiding soms een tijdje last van hun eerste intuïtieve oordeel over mensen. Dat speelde niet in e-learning. Eén van de docenten gaf ook aan dat zij minder last had van haar neiging tot primair verbaal reageren. Ze kon die primaire reactie nu hebben zonder dat anderen er last van hadden en vervolgens een zorgvuldige schriftelijke reactie verwoorden. Tijdens de gewone les ging er voor haar soms ook een storende invloed uit van het gedrag van de studenten terwijl hiervan geen sprake was binnen e-learning. 
Tijdens de interviews is aan de docenten gevraagd of zij zelf zouden kiezen voor e-learning als zij weer zouden gaan studeren. Drie docenten antwoordden hier positief op en voor drie was het een optie. Eén van de docenten antwoordde negatief. Als motivatie om voor e-learning te kiezen werden genoemd de intensieve samenwerking met medestudenten, de autonomie in het leerproces, de diepgang in het leerproces en voordelen met betrekking tot tijd en afstand. Opvallend was dat het ontbreken van direct contact zwaarder leek te wegen vanuit het docentperspectief dan vanuit het studentperspectief. Zelfs de docent die afhaakte als e-learning docent vond vanuit studentperspectief e-learning het overwegen waard. De docent die negatief antwoordde noemde als redenen de regelmaat van het inloggen en het missen van direct contact.

\subsubsection{Scholing voor e-learning docenten}

Voor de docenten die in de eerste twee moduleperiodes zouden gaan les geven, werd een studiedag georganiseerd vlak voor de zomervakantie waarna de elearning opleiding zou starten. Daarbij werd gebruik gemaakt van een handleiding voor e-learning docenten die door de projectgroep geschreven was. Na de vakantie was het beeld dat de studiedag niet veel had opgeleverd voor de docenten. Zij waren onzeker in hun rol als e-learning docent. Zij werden overspoeld door vragen van studenten en hadden moeite met het inhoudelijk modereren, met time management en met het uitdrukken en waarnemen van online persoonlijkheid. Het was duidelijk dat het e-learning docentschap andere vaardigheden vroeg dan gewoon lesgeven. De docenten hadden tijd nodig om zich dit eigen te maken. In de eerste moduleperiode werd hiertoe een extra sessie georganiseerd waarin geoefend werd aan de hand van geslaagde voorbeelden van eigen moderaties van docenten.

\section{Leren om e-learning docent te zijn}

In de interviews werd duidelijk hoe docenten zich verder ontwikkeld hadden in het e-learning docentschap. De projectgroep e-learning rekende het tot haar taak om de docenten uitleg, ondersteuning en feedback te geven wanneer zij dat nodig hadden. De docenten gaven aan dat zij vooral leerden door te doen en door daar feedback op te krijgen van projectgroepleden en van studenten. Het leren door te doen bleek makkelijker als de docent een module gaf die inhoudelijk bekend was. Er moest gewaakt worden voor de taakbelasting. Eén docent werkte maar met één groepje en gaf aan dat zij op die manier makkelijker kon wennen aan e-learning. De docenten waren in periode 1 daarentegen juist extreem zwaar belast. Zij werkten in 
een inhoudelijk onbekende module met drie groepjes. De docenten zagen dit niet als geschikte omstandigheden om het e-learning docentschap te leren.

'Learning by doing' kon volgens meerdere docenten versterkt worden door met een projectgroeplid samen te modereren in één of meer discussies. Ook het (gezamenlijk) bestuderen van eerder gevoerde discussies in dezelfde module werd als heel leerzaam beschouwd. De docenten vonden het belangrijk dat de projectgroep hun vragen beantwoordde als zij ergens over twijfelden. Ook het overleg met mededocenten die in dezelfde module werkten, werd als leerzaam gezien. Ad hoc uitleg over de docentrol op het moment dat zij dat nodig hadden bleek belangrijker dan de papieren reader over de docentrol. Eén van de docenten gaf in het interview openlijk aan dat zij deze reader niet gelezen had.

De meeste docenten gaven aan dat zij niet veel zagen in een cursus voorafgaand aan het e-learning docentschap. Zij dachten deze vaardigheden niet in een cursus te kunnen leren. Wel vonden zij een inwerkregeling met ondersteuning en feedback van belang voor e-learning docenten. Daarbij leek het docenten prettig om met collega's door de module heen te gaan en de eerdere discussies te lezen, voorafgaand aan het zelf geven van de module. Zo zou het mogelijk zijn om voorbeelden te zien en te oefenen in het omgaan met problemen.

\subsubsection{Samenvatting bruikbaarheid uitgangspunten docentrol}

De onderzoeksvraag luidde of de acht geformuleerde elementen van de docentrol bruikbaar waren. In grote lijnen bleken alle acht elementen bruikbaar mits de docenten voldoende tijd en ondersteuning kregen om in hun rol te groeien. Het elearning docentschap bleek lang niet eenvoudig. Voor de meeste elementen van de docentrol moesten details in de uitwerking aangepast worden omdat de uitvoering op de oorspronkelijk bedoelde wijze te veel vroeg van docenten. Voor het element feedback werd nog geen volledig bevredigende oplossing gevonden. Per element worden de bevindingen kort samengevat.

Ten aanzien van zichtbare aanwezigheid, reactiesnelheid en tijd waren forse bijstellingen nodig in het ontwerp. Het bleek te veel gevraagd van de docenten om vijf keer per week in te loggen en ook het regelmatig zichtbaar zijn in drie groepjes bleek te veel gevraagd. Het regelmatig plaatsen van mededelingen door docenten op Blackboard bleek ook te veel gevraagd. Docenten deden het soms maar konden er niet aan wennen om het met regelmaat te doen. Het tijdig 
antwoorden op vragen (binnen twee dagen) werd vrij goed gerealiseerd. De docenten vonden dit zelf ook belangrijk omdat de problemen die ten grondslag lagen aan de vraag verergerden als zij te lang wachtten met antwoorden. Als studenten feedback vroegen, gaven de docenten dit meestal binnen de acceptabele termijn van vier dagen. Alle docenten gaven aan dat de continuïteit van de belasting tijdens e-learning modules hen zwaar viel. Zij voelden dat het noodzakelijk was om hun werkzaamheden in te perken en te plannen. Docenten werkten regelmatig 's avonds of in het weekend. Parttimers werkten buiten hun afgesproken werkdagen.

Inhoudelijk modereren bleek in de eerste twee moduleperiodes moeilijk voor docenten. Dit kwam doordat zij overbelast raakten door de vele vragen op organisatorisch en technisch vlak en door de vragen om feedback. In een aantal gevallen waren zij ook zelf onvoldoende bekend met de module. Zij waren niet adequaat voorbereid op het modereerwerk. De docenten groeiden in dit aspect van hun werk door te doen en door feedback en uitleg te krijgen van de projectgroep leden. Vanuit de interviews met docenten kristalliseerde zich steeds verder uit waar de nadruk lag in het modereren. E-learning studenten bleken veel behoefte te hebben aan bevestiging en aan richtinggevende inhoudelijke input voor hun discussies. Expliciet formuleren en redigeren bleken van groot belang vanwege het gebrek aan non-verbale communicatie. Daarnaast was het in de berichten van studenten van belang om impliciete boodschappen tussen de regels door te kunnen lezen. 'Learning by doing' leidde er toe dat moderatie een bruikbaar ontwerpkenmerk werd. Dit werd zichtbaar vanaf moduleperiode 3, hoewel er daarna soms wel weer problemen optraden als nieuwe docenten werden ingezet. Dit was vooral zichtbaar in moduleperiode 7.

Met betrekking tot feedback traden er verschillende problemen op. Studenten hadden een enorme behoefte aan concrete, liefst bevestigende, feedback. Dit bleek qua tijd niet te realiseren voor docenten. Het schrijven van corrigerende feedback bleek ook moeilijk omdat studenten daar op afstand hevig van konden schrikken. Ook de docenten hadden grote behoefte aan concrete feedback van hun studenten. Zij kregen dit niet en konden na afloop van de modules soms schrikken van een onverwacht negatieve beoordeling. Het belang van feedback stond voor alle partijen buiten kijf en er werden verschillende feedbacksystemen uitgeprobeerd in overleg met de studenten. Uiteindelijk werd gekozen voor een combinatie van collectieve feedback en individuele feedback met behulp van 
rubrics. Deze oplossing was nog steeds niet overtuigend omdat deze werkwijze nog te belastend was voor de docenten.

De docenten gingen vanaf de eerste dag zeer actief om met hun ondersteunende rol. Dit viel hen in het begin wel zwaar omdat er erg veel vragen en onduidelijkheden ontstonden die op allerlei onvoorspelbare tijdstippen van de dag gecommuniceerd werden door studenten. Na periode 1 werden communicatieregels ingevoerd die dit ontwerp element beter werkbaar maakten voor docenten.

Vraagsturing leek aanvankelijk een weinig bruikbaar concept binnen e-learning. De strakke structuur van e-learningopdrachten leek zich daar weinig toe te lenen. Vraagsturing kon wel gerealiseerd worden via de literatuurkeuze en de eindopdracht. Na verloop van tijd werd duidelijk dat een aantal docenten voldoende flexibiliteit ervoeren in de discussies om onvoorziene en relevante inbreng van studenten te honoreren.

'Controle en activering' bleek een bruikbaar kenmerk. Een hoog percentage studenten werd door docenten aangespoord om bij te dragen aan de gezamenlijke e-learning opdrachten. De studenten die wel bijdroegen, bleken er belang aan te hechten dat docenten hun medestudenten aanspoorden als het nodig was. De docenten voerden deze controle met regelmaat uit en vonden het belangrijk om dit te doen, hoewel duidelijk minder belangrijk dan hun andere docenttaken. Het bleek niet eenvoudig voor docenten om studenten te activeren die te weinig deelnamen. Hun aansporingen werden soms genegeerd.

Sociale aanwezigheid bleek na verloop van tijd een zeer bruikbaar kenmerk. De docenten leerden hoe zij deze sociale aanwezigheid vorm konden geven en daardoor verdween het gemis dat zij aanvankelijk voelden ten aanzien van het directe contact met studenten.

Scholing voor e-learning docenten bleek eveneens een bruikbaar kenmerk maar moest wel heel anders ingevuld worden dan aanvankelijk gedacht was. Learning by doing en ondersteuning 'on the job' bleken belangrijker dan handleidingen en scholingsdagen. Uitleg, feedback en het samen werken in (eerdere) discussies bleken belangrijke middelen om het leerproces van beginnende e-learning docenten te faciliteren. 


\subsection{WAARDERING}

\subsubsection{Waardering voor de docentrol}

De waardering voor de docent begeleiding

De studenten werd gevraagd om de waardering voor de begeleiding door de docent in een rapportcijfer uit te drukken. In tabel 7.20 wordt de gemiddelde waardering per moduleperiode en per cohort weergegeven, alsmede de standaard deviaties. Per periode wordt bovendien aangegeven hoeveel docenten (DOC) beoordeeld werden en hoeveel studenten dit oordeel gaven $(N)$.

Tabel 7.20 Rapportcijfer voor docent begeleiding

\begin{tabular}{lcccccccc}
\hline & \multicolumn{4}{c}{ Cohort 1 e-learning } & \multicolumn{5}{c}{ Cohort 2 e-learning } \\
Periode & $D O C$ & $N$ & $X$ & $S D$ & $D O C$ & $N$ & $X$ & $S D$ \\
\hline 1 & 3 & 22 & 6,8 & 1,44 & & & & \\
2 & 3 & 26 & 6,6 & 1,88 & & & & \\
3 & 3 & 22 & 8,1 & 0,92 & & & & \\
4 & 4 & 16 & 7,6 & 1,15 & & & & \\
6 & 3 & 19 & 7,4 & 1,12 & 3 & 23 & 7,9 & 1,13 \\
7 & 2 & 13 & 6,0 & 1,78 & 3 & 11 & 8,3 & 1,01 \\
\hline
\end{tabular}

In drie periodes van cohort $1(1,2$ en 7$)$ werd beneden het minimale streefniveau voor docenten gescoord $(<7)$. In de overige periodes waren de rapportcijfers voor de docentbegeleiding in e-learning ruim voldoende tot goed. Uit de multivariate toetsen $(\varepsilon=0,44)$ blijkt dat er significante verschillen zijn tussen de periodes van cohort 1, $V=1, F(1,5)=258,5, p<0,05, \quad \eta_{p}{ }^{2}=1$. De verschillen tussen de twee moduleperiodes van cohort 2 bleken niet significant. Met de $t$-toets voor onafhankelijke steekproeven is nagegaan of de verschillen tussen de cohorten 1 en 2 significant waren voor moduleperiodes 6 en 7 . De verschillen in periode 6 bleken niet significant. De verschillen in periode 7 bleken wel significant $t(19,5)=2,3, p<0,01, r=0,46$.

Sommige docenten gaven in de loop van de tijd meerdere e-learning modules. Voor de docenten in kwestie zijn in tabel 7.21 de gemiddelde cijfers $(X)$ en standaarddeviaties $(S D)$ weergegeven voor hun eerste, tweede en eventueel derde e-learning module. Met een sterretje is aangegeven als de module buiten het directe vakgebied van de docent viel. 


\begin{tabular}{lcccccc}
\hline & \multicolumn{2}{c}{ Eerste module } & \multicolumn{2}{c}{ Tweede module } & \multicolumn{2}{c}{ Derde module } \\
& $X$ & $S D$ & $X$ & $S D$ & $X$ & $S D$ \\
\hline Docent A & 8,0 & 1,41 & $6,8^{*}$ & 0,84 & 8,4 & 0,55 \\
Docent B & $6,5^{*}$ & 2,07 & 7,6 & 1,52 & & \\
Docent C & $6,9^{*}$ & 1,35 & 7,7 & 1,80 & 8,3 & 0,52 \\
Docent D & $6,9^{*}$ & 1,17 & 7,7 & 0,64 & 7,4 & 1,24 \\
\hline
\end{tabular}

Noot: * Buiten het directe vakgebied van de docent.

Opvallend zijn de hoge standaarddeviaties in de eerste e-learning module van de docenten. De waardering voor deze vier onervaren e-learning docenten fluctueerde sterk onder studenten. In de tweede module was dit ook nog het geval bij docenten B en C. In de derde module gold dit alleen voor docent D. In de tabel is verder zichtbaar dat er over het algemeen sprake was van een stijgende tendens na de eerste module. Soms is die stijging duidelijker zichtbaar in de tweede module, soms in de derde module. Dit lijkt te betekenen dat docenten vaardiger werden door ervaring op te doen binnen e-learning. Er is interactie zichtbaar met de vraag of docenten ervaring hebben in het vakgebied en met de betreffende module. Bij de tweede module van docent $\mathrm{A}$ is zichtbaar dat het geven van een module buiten het eigen vakgebied problemen kan blijven geven als er al wel ervaring is opgedaan met het geven van een e-learning module. De laagste cijfers werden in alle gevallen toegekend voor modules buiten het primaire vakgebied van de docenten (zie ook tabellen 7.11 en 7.12).

\subsubsection{Verbanden met het cijfer voor de docent}

Er is nagegaan welke van de in dit hoofdstuk besproken interval variabelen verband houden met de waardering van de studenten voor de rol van de docent. Met Pearson's $r$ is per moduleperiode de correlatie bepaald tussen de deze variabelen enerzijds en het cijfer voor de docent anderzijds. Beide cohorten zijn hiertoe samengevoegd. De spreiding in de uitkomsten van de verschillende moduleperiodes is weergegeven in tabel 7.22. 


\begin{tabular}{|c|c|}
\hline Gebruikte schalen en items & $\begin{array}{l}\text { Pearson's } r \text { (spreiding over de } \\
\text { verschillende moduleperiodes) }\end{array}$ \\
\hline \multicolumn{2}{|l|}{ Zichtbare aanwezigheid, reactiesnelheid en tijd } \\
\hline Mededelingen planning & $0,16-0,85^{\star * *}$ \\
\hline Tevredenheid snelheid reactie op vragen & $0,18-0,61^{* *}$ \\
\hline Tevredenheid snelheid feedback & $0,21-0,78^{* * *}$ \\
\hline \multicolumn{2}{|l|}{ Moderatie } \\
\hline Moderatieschaal & $0,54^{*}-0,84^{* * *}$ \\
\hline Leerzaamheid bijdrages docent & $0,77^{* * *}-0,84^{* * *}$ \\
\hline \multicolumn{2}{|l|}{ Feedback } \\
\hline Schaal feedback & $-0,48^{*}-0,81^{* * *}$ \\
\hline Leerzaamheid feedback docent & $0,59^{* *}-0,87^{* * *}$ \\
\hline \multicolumn{2}{|l|}{ Ondersteuning } \\
\hline Adequaat beantwoorden vragen & $0,24-0,70^{* * *}$ \\
\hline \multicolumn{2}{|l|}{ Vraagsturing en flexibiliteit } \\
\hline Schaal vraagsturing & $-0,11-0,51^{*}$ \\
\hline \multicolumn{2}{|l|}{ Controle en activering } \\
\hline Herinneringen plaatsen/ sturen & $0,23-0,57^{* *}$ \\
\hline \multicolumn{2}{|l|}{ Sociale aanwezigheid } \\
\hline Docent communicatieschaal & $0,22-0,75^{* * *}$ \\
\hline Persoonlijke communicatie & $0,09-0,67^{* * *}$ \\
\hline
\end{tabular}

Noot: ${ }^{*} p<0,05,{ }^{* *} p<0,01,{ }^{* * *} p<0,001$.

Voor alle maten werden in één of meer moduleperiodes significante positieve correlaties aangetroffen. Dit vormt een bevestiging voor de ontwerpkenmerken binnen de docentrol. In drie gevallen waren de maten in alle moduleperiodes significant en positief verbonden met de waardering voor de docent. Dit betrof beide moderatiematen en de vraag naar de leerzaamheid van de feedback. Voor veel van de andere maten lijkt een plafond effect op te treden; in moduleperiodes waarin de docenten homogeen hoge rapportcijfers haalden $(3,4,6)$ waren de verbanden kleiner en soms zelfs negatief.

Voor de volgende schalen en items zijn er ondanks dit effect veel periodes waarin de correlaties positief en significant zijn: mededelingen planning, adequaat beantwoorden van vragen, de docent communicatieschaal en persoonlijke communicatie. Vraagsturing correleert maar in één geval positief en significant met de 
waardering voor de docent. In periode 1 was er een kleine negatieve relatie. Daarna nam het positieve verband met het docentcijfer steeds toe. Het leek er op dat de mogelijkheid tot vraagsturing in de loop van het eerste studiejaar in een positiever licht kwam te staan en meer ging bijdragen aan de waardering voor de docentrol.

\subsubsection{Samenvatting waardering}

De onderzoeksvraag was of de studenten de begeleiding door de e-learning docenten waardeerden. In de helft van de modules van cohort 1 bleek dit onvoldoende het geval. In deze modules werd niet de norm gehaald die ten tijde van het eerste e-learning schooljaar door het management team gehanteerd werd (rapportcijfer voor docent $\geq 7$ ). In de overige drie modules en in de twee modules van cohort 2 werd de gestelde norm wel (ruimschoots) gehaald. De docentrol in elearning bestond uit een complex van gedragingen die allen in meer of mindere mate een positief verband bleken te vertonen met de uiteindelijke waardering door de studenten. Belangrijke kenmerken daarin zijn: moderatie, leerzaamheid van feedback, mededelingen plaatsen over de planning, adequaat beantwoorden van vragen en de sociale aanwezigheid van de docent. De behoefte aan vraagsturing leek toe te nemen tussen de eerste en de vierde module. De meest consistente rol bleek weggelegd voor de kwaliteit van de moderaties en de leerzaamheid van de feedback van de docent. Deze kwaliteit werd beter gerealiseerd als de docent inhoudelijk deskundig was ten aanzien van de module.

\subsection{AANPASSINGEN AAN HET ONTWERP}

\subsubsection{Doorgevoerde aanpassingen}

In het eerste jaar werden door het e-learning team veel ingrijpende aanpassingen gedaan met betrekking tot de docentrol. Dit had zowel te maken met de belangen van docenten als met de belangen van studenten. In tabel 7.23 is op basis van het onderzoekerslogboek weergegeven welke aanpassingen het e-learning team doorvoerde. 
Tabel 7.23 Aanpassingen door het e-learning team in en buiten Blackboard (BB)

\begin{tabular}{|c|c|c|c|}
\hline Aanpassingen & Medium & $\begin{array}{l}\text { Tijdens/ } \\
\text { na } \\
\text { module- } \\
\text { periode }\end{array}$ & Verbetering \\
\hline \multicolumn{4}{|c|}{ Tijd, reactiesnelheid en aanwezigheidsritme } \\
\hline $\begin{array}{l}\text { Docent modereert drie keer per } \\
\text { week (in plaats van vijf) }\end{array}$ & Docenthandleiding (teamsite) & 1 & \multirow{4}{*}{$\begin{array}{l}\text { Ja, maar het } \\
\text { gevoel van } \\
\text { continue } \\
\text { druk door } \\
\text { de regel- } \\
\text { maat van } \\
\text { het inlog- } \\
\text { gen is wel } \\
\text { blijven } \\
\text { bestaan. }\end{array}$} \\
\hline $\begin{array}{l}\text { Docenten modereren maximaal } \\
\text { twee groepjes per module- } \\
\text { periode (in plaats van drie) }\end{array}$ & Blackboard & 1 & \\
\hline $\begin{array}{l}\text { Docenten krijgen per module } 5 \\
\text { uur meer uitvoeringstijd dan } \\
\text { voor een reguliere module }\end{array}$ & Takenplaatje docent & 2 & \\
\hline $\begin{array}{l}\text { Communicatie richtlijnen ten } \\
\text { aanzien van telefoneren met } \\
\text { docent (altijd na belafspraak) }\end{array}$ & Blackboard, e-mail, telefoon & & \\
\hline \multicolumn{4}{|l|}{ Feedback } \\
\hline $\begin{array}{l}\text { Docenten geven in de eerste } \\
\text { module, en als dat nodig is later, } \\
\text { feedback op de wijze waarop de } \\
\text { studenten online discussiëren. } \\
\text { Hiervoor werd eerst een sterren } \\
\text { systeem gebruikt en daarna een } \\
\text { systeem met cijfers. Deze cijfers } \\
\text { werden vervangen door een } \\
\text { concreter feedback systeem met } \\
\text { kleuren en veel uitleg en voor- } \\
\text { beelden. }\end{array}$ & E-mail, Blackboard & 1 & \multirow[t]{3}{*}{$\begin{array}{l}\text { Ja, enigs- } \\
\text { zins. }\end{array}$} \\
\hline $\begin{array}{l}\text { Docenten geven geen tussen- } \\
\text { tijdse feedback meer op de } \\
\text { deelopdrachten van de eind- } \\
\text { opdracht in het portfolio }\end{array}$ & Blackboard & 2 & \\
\hline $\begin{array}{l}\text { Training online samenwerken } \\
\text { op startzaterdag zodat feedback } \\
\text { op discussievaardigheden } \\
\text { minder frequent nodig is. }\end{array}$ & Startzaterdag & & \\
\hline \multicolumn{4}{|l|}{ Ondersteuning van studenten } \\
\hline $\begin{array}{l}\text { F.A.Q. is aangemaakt en wordt } \\
\text { bijgehouden om niet steeds } \\
\text { dezelfde vragen te moeten } \\
\text { beantwoorden }\end{array}$ & Blackboard & 1 & Ja \\
\hline
\end{tabular}


Tabel 7.23 Aanpassingen door het e-learning team in en buiten Blackboard (BB) (Continued)

\begin{tabular}{|c|c|c|c|}
\hline Aanpassingen & Medium & $\begin{array}{l}\text { Tijdens/ } \\
\text { na } \\
\text { module- } \\
\text { periode }\end{array}$ & Verbetering \\
\hline $\begin{array}{l}\text { Communicatie richtlijnen ten } \\
\text { aanzien van het stellen van } \\
\text { vragen aan docenten (eerst met } \\
\text { mede-studenten proberen op te } \\
\text { lossen, daarna mag een vraag } \\
\text { van algemeen belang aan de } \\
\text { docent gesteld worden via de } \\
\text { mail). }\end{array}$ & Blackboard & 3 & \\
\hline $\begin{array}{l}\text { Eén van de docenten neemt } \\
\text { structureel de technische } \\
\text { ondersteuning op zich. }\end{array}$ & Afspraak & 1 & \\
\hline $\begin{array}{l}\text { Ondersteuning van docenten } \\
\text { door intensieve samenwerking } \\
\text { in een module waarin het } \\
\text { moeilijk loopt }\end{array}$ & E-mail, telefoon, fysiek overleg & 1 & \\
\hline \multicolumn{4}{|l|}{ Scholing van docenten } \\
\hline $\begin{array}{l}\text { Scholing door uitleg en door het } \\
\text { gezamenlijk exploreren van } \\
\text { eerdere discussiebijdragen in } \\
\text { Blackboard }\end{array}$ & Fysiek overleg & 1 & \multirow{2}{*}{$\begin{array}{l}\text { Ja, maar dit } \\
\text { werd niet } \\
\text { met alle do- } \\
\text { centen in } \\
\text { voldoende } \\
\text { mate toege- } \\
\text { past waar- } \\
\text { door de } \\
\text { problemen } \\
\text { in periode } 7 \\
\text { konden } \\
\text { ontstaan }\end{array}$} \\
\hline $\begin{array}{l}\text { Ondersteuning en feedback 'on } \\
\text { the job' }\end{array}$ & Fysiek overleg & & \\
\hline
\end{tabular}

\subsubsection{Alsnog door te voeren aanpassingen}

Een gewenste aanpassing betreft de condities waaronder docenten hun eerste module geven. Bij voorkeur geven docenten hun eerste module altijd binnen hun eigen vakgebied en in een module waarmee zij bekend zijn. Het zou hun leerproces als e-learning docent ook vergemakkelijken als zij in hun eerste module maar met één groepje werken. Voor de organisatie zijn dit geen eenvoudige condities, omdat het vaak moeilijk is om het rooster rond te krijgen. Het inwerken van nieuwe docenten zou plaats moeten vinden door een beperkte hoeveelheid uitleg te geven, door gezamenlijk eerdere discussies te exploreren in de module 
die gegeven moet worden (modelling) en door ondersteuning en feedback 'on the

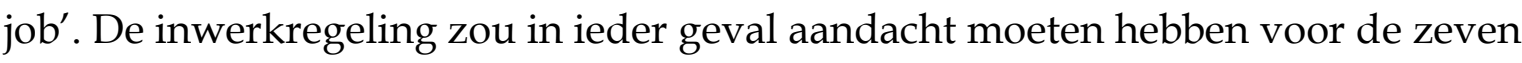
uitgangspunten van de docentrol, met speciale aandacht voor time management, communicatie regels, cognitief rijke moderatie, het schriftelijk formuleren van concrete en opbouwende feedback en de wijze waarop sociale aanwezigheid vorm kan krijgen in Blackboard.

Een tweede nog gewenste aanpassing is dat er binnen de hogeschool een faciliteit zou komen voor de technische ondersteuning van e-learners. De huidige oplossing dat een docent deze ondersteuning op zich neemt is voortgekomen uit het feit dat de helpdesk ICT van de hogeschool een smalle opdracht heeft ten aanzien van welke software ondersteund wordt. De e-learners gebruiken Blackboard en andere software die niet tot het pakket van de helpdesk behoren.

De derde gewenste aanpassing zou technisch gerealiseerd kunnen worden binnen Blackboard, en is mogelijk aanwezig in nieuwere versies. Het zou de werkdruk van docenten verlichten als een stuk van de controle van de deelname technisch en geautomatiseerd verloopt en als er in reactie op het niet deelnemen semiautomatisch (na goedkeuring door de docent) een mail verstuurd wordt naar de betreffende student.

De overige aanpassingen die nog gewenst zijn, liggen op het vlak van de online feedback. In verband met de werkdruk van docenten blijft het nodig om de mogelijkheden tot verdere efficiency in het feedback proces te exploreren. Mogelijkheden zouden kunnen zijn: sterker inzetten van peer feedback, sterker automatiseren van het feedback proces en/of het opsplitsen van het feedback proces. De laatste mogelijkheid behelst een vaste structuur waarbij in de eerste module per week op één of twee aspecten van online samenwerken feedback wordt gegeven in plaats van op alle zeven tegelijk. Om aan hun eigen behoefte aan feedback tegemoet te komen zouden docenten zouden na twee weken in hun module zeer korte en concrete vragenlijstjes kunnen uitzetten onder hun studenten. Op deze wijze zouden ze kunnen sonderen hoe studenten hun uitvoering van de docentrol ervaren. Doordat dit gebeurt bij aanvang van de module zijn bijstellingen nog mogelijk. 


\section{HoOFDSTUK 8 \\ Resultaten implementatiefase: leermaterialen}

\section{INLEIDING}

De leermaterialen spelen een belangrijke rol in de OSO e-learning opleiding. Kennis wordt in de e-learning opleiding primair overgebracht via de leermaterialen en niet door de docent. Ten aanzien van deze leermaterialen formuleerde de leiding van OSO bij de aanvang van het project het doel dat de leermaterialen aantrekkelijk moesten zijn en moesten aansluiten bij de leerwensen van studenten (zie paragraaf 3.1). Op grond hiervan werd één kenmerk geformuleerd (zie paragraaf 3.3.4):

- Rijke leeromgeving (kenmerk 15).

Vanuit de literatuurstudie werd duidelijk dat op basis van 'learning efficiency' terughoudendheid op zijn plaats was met betrekking tot het al te rijk maken van de leeromgeving met betrekking tot multi-media en lange stukken tekst. De Blackboard modules van de OSO e-learning opleiding bevatten op grond van kenmerk 15 een thematisch georganiseerde verzameling literatuur, veel leerobjecten met korte geschreven uitleg, veel links naar andere websites en een aantal multimediale leerobjecten. Uit het onderzoek tijdens de pilotfase bleek dat de studenten actief omgingen met de leermaterialen en dat zij vooral de filmpjes en de interactieve leerobjecten waardeerden. Er ontstonden in de pilotfase twijfels over het gebruik van gesproken powerpoints. Sommige studenten bleken niet bereid deze te gebruiken terwijl het maken van dit soort powerpoints veel inspanning vergde van de moduleontwikkelaars.

In dit hoofdstuk wordt besproken hoe bruikbaar het kenmerk 'rijke leeromgeving' in de implementatiefase is gebleken (8.1.) en hoe studenten de leerzaamheid van de verschillende soorten leerobjecten en van de modules als geheel waardeerden (8.2). De onderzoeksvragen voor dit hoofdstuk zijn: 
- Is het ontwerpkenmerk 'rijke leeromgeving' bruikbaar binnen de e-learning opleiding? (8.1).

- Hoe waarderen de studenten de leerzaamheid van de verschillende soorten leerobjecten? (8.2.1).

- Hoe waarderen de studenten de leerzaamheid van de modules? (8.2.2).

- Welke verbanden bestaan er tussen de leerzaamheid van specifieke soorten leerobjecten en de leerzaamheid van de modules? (8.2.3).

De bevindingen met betrekking tot bruikbaarheid en waardering in de implementatiefase worden samengevat in paragraaf 8.3. In 8.4 wordt weergegeven welke aanpassingen met betrekking tot de rijke leeromgeving gedaan werden in het eerste implementatiejaar. Om een concrete indruk te krijgen van de leeromgeving zijn screenshots toegevoegd in de bijlage.

\subsection{BRUIKBAARHEID VAN UITGANGSPUNTEN VAN DE LEERMATERIALEN}

Bruikbaarheid in de ogen van studenten

Uit het onderzoekerslogboek bleek dat de studenten in de eerste e-learning modules problemen hadden met het begrijpen van een aantal kernprincipes van de betreffende vakgebieden. Deze kernprincipes waren te impliciet gebleven in de verzameling leerobjecten. Om tot beter begrip te komen bleek er, evenals in de pilotfase, behoefte te bestaan de kernprincipes duidelijk samen te vatten.

Uit het onderzoekerslogboek bleek voorts dat sommige studenten aanvankelijk niet begrepen dat de thematische leereenheden bestonden uit meerdere leerobjecten. Zij gebruikten daardoor alleen het eerste leerobject van de leereenheid en misten de overige leerobjecten. Naar aanleiding hiervan is vanaf de start van het tweede cohort gewerkt met een leerobject dat studenten waarschuwt dat een leereenheid bestaat uit meerdere leerobjecten .

\section{Bruikbaarheid in de ogen van docenten}

In de interviews spraken de docenten over een mooie en rijke verzameling leerobjecten. Eén van de docenten bleek in de beginfase van moduleperiode 1 hetzelfde probleem te hebben gehad als sommige studenten; zij was zich er niet van bewust dat de leereenheden bestonden uit meerdere leerobjecten. Zij miste daardoor in de beginfase een belangrijk deel van de inhoud van de module. 
De clustering van de leerobjecten binnen thema's werd als positief ervaren. Deze thema's kregen binnen Blackboard vorm als leereenheden. De docenten ervoeren dat studenten intensief gebruik maakten van deze thematische leereenheden. Twee docenten die ook zelf e-learning modules ontwikkelden ervoeren een dilemma met betrekking tot de rijkdom van de leeromgeving. Zij hadden beiden plezier in het aanleggen van veel verwijzingen en een veelheid van leerobjecten maar tegelijkertijd vroegen zij zich af of dit niet tot afleiding, verwarring en keuzeproblemen zou kunnen leiden. Eén van hen noemde het risico van cognitieve belasting: het overbelast raken van het werkgeheugen door een te veel aan leerobjecten en keuzemogelijkheden. Zij gaf bovendien aan dat studenten zeker in de beginfase van hun studie niet in staat bleken om adequate keuzes te maken. Meerdere docenten gaven aan dat de leeromgeving een belangrijk deel van hun normale lesgevende taak overnam. Hiermee doelden zij op het feit dat de kennisoverdracht primair geregeld werd door de leeromgeving en niet door de docent. Eén van de docenten meende op grond hiervan dat er minder aangeboden zou moeten worden in de leeromgeving en dat er meer in reserve gehouden zou moeten houden om de docentrol meer inhoudelijk te kunnen vormgeven.

\subsection{WAARDERING}

\subsubsection{Leerzaamheid van de verschillende soorten leerobjecten}

In de verschillende Blackboardmodules is een leeromgeving gebouwd waarin kennis gepresenteerd wordt in een thematische ordening. De kennis wordt aangeboden in de vorm van artikelen en binnen thematische leereenheden die bestaan uit meerdere leerobjecten. Deze leerobjecten hebben verschillende vormen, zo zijn er bijvoorbeeld gesproken powerpoints, stukjes geschreven uitleg, links naar websites, mindmaps en filmpjes. Nagegaan werd in hoeverre de studenten deze verschillende typen leerobjecten als 'leerzaam' beschouwden, dat wil zeggen in hoeverre de studenten van mening waren dat deze verschillende soorten items een positieve bijdrage leverden aan hun leerproces.

In de vragenlijst naar de leerzaamheid van de onderdelen van de module (zie paragraaf 2.4.3) is gevraagd om de leerzaamheid van de verschillende soorten items met een rapportcijfer (1-10) te waarderen. In tabel 8.1 wordt weergegeven hoe de studenten de leerzaamheid van de verschillende soorten digitale kennisbronnen per moduleperiode waardeerden. De vragenlijst werd uitgezet na periode 2, 6 en 7 . In 
periode 6 en 7 zijn zowel cohort 1 als 2 bevraagd. Hoge waarderingen $(\geq 7,5)$ zijn vet weergegeven. Soms kwamen bepaalde soorten items niet of nauwelijks voor in een bepaalde moduleperiode, in dat geval is een streepje genoteerd.

Tabel 8.1 Leerzaamheid van soorten leerobjecten

\begin{tabular}{|c|c|c|c|c|c|c|c|c|c|c|}
\hline \multirow{3}{*}{ Moduleperiode } & \multicolumn{6}{|c|}{ Cohort 1} & \multicolumn{4}{|c|}{ Cohort 2} \\
\hline & \multicolumn{2}{|r|}{2} & \multicolumn{2}{|c|}{6} & \multicolumn{2}{|c|}{7} & \multicolumn{2}{|c|}{6} & \multicolumn{2}{|c|}{7} \\
\hline & $X$ & $S D$ & $X$ & $S D$ & $X$ & $S D$ & $X$ & $S D$ & $X$ & $S D$ \\
\hline Vakliteratuur & 7,7 & 0,96 & 7,7 & 1,10 & 6,9 & 0,95 & 8,1 & 1,01 & 7,6 & 0,92 \\
\hline Geschreven uitleg & 7,5 & 0,85 & 7,8 & 1,00 & 7,1 & 1,00 & 7,7 & 1,11 & 7,6 & 0,82 \\
\hline Interactieve vragen & 7,6 & 1,16 & & & & & 7,5 & 1,12 & 7,4 & 0,92 \\
\hline Links naar andere websites & 7,2 & 1,35 & 7,6 & 1,15 & 7,8 & 0,60 & 7,1 & 1,15 & 7,6 & 1,03 \\
\hline Gesproken powerpoints & 7,1 & 1,50 & & & & & 7,8 & 0,94 & 7,6 & 1,08 \\
\hline Powerpoints met script & 7,2 & 0,77 & & & & & 7,6 & 0,95 & 7,6 & 0,84 \\
\hline Uitgewerkte voorbeeld casussen & 7,1 & 1,51 & & & & & 7,5 & 1,30 & 6,9 & 1,05 \\
\hline Video fragmenten & 7,3 & 1,13 & 7,1 & 0,99 & 6,7 & 1,00 & 7,4 & 1,06 & 7,6 & 1.19 \\
\hline
\end{tabular}

Opvallend in tabel 8.1 is dat in periodes 6 en 7 van cohort 1 geen gebruik werd gemaakt van een aantal soorten leerobjecten. De betreffende modules werden het laatst en onder tijdsdruk ontwikkeld. Leerobjecten die moeilijk te maken waren werden toen niet meer geproduceerd.

Uit de tabel blijkt voorts dat de leerzaamheid van geschreven items, vakliteratuur en geschreven uitleg in de meeste gevallen goed gewaardeerd wordt door zowel cohort 1 als cohort 2. De interactieve vragen en de links naar andere websites werden als ruim voldoende tot goed gewaardeerd door de studenten. Naast de gesproken powerpoints werd, op grond van de bevindingen in de pilot fase, altijd al een identieke geschreven powerpoint met de uitgeschreven tekst geplaatst voor de studenten die de gesproken powerpoints niet konden of wilden gebruiken. De waardering voor de gesproken powerpoints bleek niet duidelijk te verschillen van de waardering voor de powerpoints met geschreven script, terwijl er wel meer ontwikkeltijd gemoeid was met gesproken powerpoints.

\subsubsection{Waardering voor de leerzaamheid van de module}

Rapportcijfer voor de leerzaamheid van de modules

De studenten werd gevraagd om de waardering voor de leerzaamheid van de module in een rapportcijfer uit te drukken. In tabel 8.2 wordt de gemiddelde waardering per moduleperiode en per cohort weergegeven, alsmede de standaard deviaties. 
Tabel 8.2 Rapportcijfer voor leerzaamheid van de modules

\begin{tabular}{lcccccc}
\hline & \multicolumn{3}{c}{ Cohort 1 e-learning } & \multicolumn{3}{c}{ Cohort 2 e-learning } \\
Periode & $N$ & $X$ & $S D$ & $N$ & $X$ & $S D$ \\
\hline 2 & 23 & 7,5 & 0,73 & & & \\
6 & 19 & 7,7 & 1,10 & 23 & 8,0 & 0,93 \\
7 & 13 & 7,0 & 0,91 & 11 & 7,6 & 0,69 \\
\hline
\end{tabular}

De waardering voor de leerzaamheid van de onderzochte modules stemt tot tevredenheid. In vier van de vijf gevallen werd de leerzaamheid van de module als goed gescoord $(\geq 7,5)$. Alleen cohort 1 scoorde ruim voldoende in moduleperiode 7 . Variantie analyse voor herhaalde metingen toont voor de drie periodes van cohort 1 geen significante verschillen aan. Aan de assumptie van sphericiteit was evenwel niet voldaan en de power van de analyse was zeer laag $(0,19)$. Voor de twee periodes van cohort 2 waren de verschillen eveneens niet significant. De $t$-toets voor onafhankelijke steekproeven toonde geen significante verschillen tussen cohort 1 en 2 .

\subsubsection{Verbanden met de ervaren leerzaamheid van de module}

Een andere wijze om naar het nut van de verschillende soorten digitale kennisbronnen te kijken is het berekenen van de mate van correlatie (Pearson's $r$ ) tussen de waardering voor het type kennisbron met het cijfer voor de leerzaamheid van de module als geheel. In tabel 8.3 is dit verband weergegeven voor de verschillende moduleperiodes waarin de vragenlijst is afgenomen. Als bepaalde soorten leerobjecten niet voorkwamen in de modules van cohort 1 dan zijn ze niet meegenomen in deze berekeningen.

Tabel $8.3 \quad$ Verband met cijfer voor leerzaamheid van de module

\begin{tabular}{lccc}
\hline Moduleperiode & $\mathbf{2}$ & $\mathbf{6}$ & $\mathbf{7}$ \\
\hline Geschreven uitleg & $0,61^{* *}$ & $0,74^{* * *}$ & $0,81^{* * *}$ \\
Vakliteratuur & 0,19 & $0,80^{* * *}$ & $0,75^{* * *}$ \\
Interactieve vragen & 0,04 & & \\
Video fragmenten & $0,45^{*}$ & $0,65^{* * *}$ & $0,62^{* *}$ \\
Powerpoints met script & 0,32 & & \\
Gesproken powerpoints & 0,24 & & \\
Uitgewerkte voorbeeld casussen & $0,72^{* *}$ & $0,70^{* * *}$ & \\
Links naar andere websites & $0,54^{* *}$ & $0,34^{*}$ & 0,18 \\
\hline
\end{tabular}

Noot: ${ }^{*} p<0,05,{ }^{* *} p<0,01,{ }^{* * *} p<0,001$.

In alle gevallen zijn de correlaties positief. Voor de geschreven uitleg en de video fragmenten geldt dat de correlatie met de leerzaamheid van de modules in alle periodes significant is. De interactieve vragen en de verschillende soorten 
powerpoints correleerden laag en niet significant met de leerzaamheid van de module. Kennelijk zijn deze soorten items voor studenten relatief minder belangrijk bij het geven van een algeheel oordeel over de module.

\subsection{SAMENVATTING BRUIKBAARHEID EN WAARDERING RIJKE LEEROMGEVING}

De bruikbaarheid van de leereenheden vormde in de eerste paar e-learning weken voor een klein aantal studenten en voor één van de docenten een probleem omdat zij zich niet realiseerden dat leereenheden uit meerdere leerobjecten bestaan. Hierdoor maakten zij aanvankelijk geen gebruik van de meerderheid van de leerobjecten.

De studenten maakten intensief gebruik van de leerobjecten. Soms lukte het hen niet om vanuit de leerobjecten tot begrip te komen van kernprincipes van de modules. Er was behoefte aan leerobjecten met een expliciete samenvatting van de kernprincipes. De diversiteit in leerobjecten verminderde en er kwam meer nadruk te liggen op het geven van compacte schriftelijke uitleg. Deze ontwikkeling sloot ten dele aan bij de opmerkingen van de e-learning docenten rondom cognitieve overbelasting (zie onder meer Clark, Nguyen, \& Sweller, 2006; Clark \& Mayer, 2008), maar had ook te maken met de tijdsdruk voor de docenten die de modules ontwikkelden.

De leerzaamheid van de modules was volgens de studenten in de onderzochte moduleperiodes goed en in één geval ruim voldoende. De waardering voor de leerzaamheid hing vooral samen met de waardering voor de geschreven uitleg, voor de vakliteratuur, de videofragmenten, de uitgewerkte voorbeeldcasussen en de weblinks. Er was geen duidelijke relatie met de waardering voor interactieve vragen en gesproken of geschreven powerpoints, maar dit werd maar in 1 moduleperiode met een beperkt aantal respondenten gemeten.

\subsection{AANPASSINGEN AAN HET ONTWERP}

In het eerste jaar werden door het e-learning team op zeer beperkte schaal aanpassingen gedaan met betrekking tot de leermaterialen in Blackboard. Deze aanpassingen hadden vooral te maken met de waardering van de studenten voor 
specifieke soorten leerobjecten en met efficiëntie in het bouwen van modules. Er waren in de pilotfase reeds twijfels gerezen over de waardering voor de gesproken powerpoints. De studentwaardering voor de gesproken powerpoints bleek in cohort 1 niet hoog genoeg om structureel te blijven investeren in het aanmaken er van. In tabel 8.4 is weergegeven welke aanpassingen het e-learning team doorvoerde.

Tabel 8.4 Aanpassingen door het e-learning team in Blackboard (BB)

\begin{tabular}{|c|c|c|c|}
\hline Aanpassingen & Medium & $\begin{array}{l}\text { Tijdens/na } \\
\text { module- } \\
\text { periode }\end{array}$ & Verbetering \\
\hline \multicolumn{4}{|l|}{ Rijke leeromgeving } \\
\hline $\begin{array}{l}\text { Aanmaken van leerobject dat } \\
\text { wijst op de aanwezigheid van } \\
\text { meerdere leerobjecten binnen de } \\
\text { leereenheid }\end{array}$ & Blackboard & 1 & \multirow[t]{3}{*}{$\mathrm{Ja}$} \\
\hline $\begin{array}{l}\text { De diversiteit in leerobjecten } \\
\text { nam af ten gunste van korte en } \\
\text { krachtige geschreven uitleg. }\end{array}$ & Blackboard & 3 & \\
\hline $\begin{array}{l}\text { Na moduleperiode } 3 \text { werden } \\
\text { vrijwel geen nieuwe gesproken } \\
\text { powerpoints meer aangemaakt }\end{array}$ & Blackboard & 2 & \\
\hline
\end{tabular}

In de toekomst lijkt op het vlak van learning efficiency nog verdere winst geboekt te kunnen worden. In de literatuur (Mayer \& Moreno, 2003; Clark \& Mayer, 2008) worden een aantal principes genoemd die verbeterd zouden kunnen worden in de huidige modules: dit betreft bijvoorbeeld het gebruik van het gesproken woord in combinatie met plaatjes die functioneel zijn voor het leerproces, het verwijderen van materiaal dat is toegevoegd ter motivatie maar dat niet essentieel is voor het leerproces, het toevoegen van uitgewerkte casuïstiek en interactieve training. 


\section{HoOFDSTUK 9 \\ Resultaten implementatiefase: De effecten van de OSO e-learning opleidingen}

\section{INLEIDING}

In dit hoofdstuk worden de effecten gerapporteerd van de implementatiefase van de tweejarige OSO e-learning opleiding. De resultaten van de ontworpen leeromgeving worden beschreven in het licht van de in paragraaf 1.3.1 gestelde doelen op het vlak van tevredenheid over de modules, preventie van uitval en studierendement. De doelen op het vlak van effectiviteit luidden als volgt:

- De studenttevredenheid over modules $\geq 7$.

- De uitval is niet hoger dan in de reguliere opleiding.

- Het studierendement is vergelijkbaar met de reguliere opleiding.

Het doel met betrekking tot studenttevredenheid komt overeen met het doel dat ten tijde van de start door de leiding van OSO werd gesteld voor de reguliere modules. De doelen ten aanzien van uitval en studierendement zijn gebaseerd op de eerdere ervaringen met afstandsonderwijs binnen Windesheim (zie paragraaf 1.2.2) en op literatuur over uitval en studierendement binnen e-learning. Uit deze bronnen blijkt dat de uitval en het studierendement in afstandsleren en e-learning aanleiding geven tot zorg. Als uitval en studierendement vergelijkbaar zouden zijn met de reguliere opleiding dan zou dat een forse verbetering betekenen ten opzichte van de huidige situatie in het afstandsleren van de Windesheim lerarenopleiding.

In de pilotfase bleken de studenten erg tevreden over de twee e-learning modules; in alle gevallen werden de modules gewaardeerd met het rapportcijfer 8 of hoger. Er was geen sprake van uitval en alle eindopdrachten werden op tijd ingeleverd. 
Het was niet de verwachting dat het effect in een volledige opleiding ook zo positief zou zijn. De volledige opleiding kent een langere duur (8 moduleperiodes), een hogere studiebelasting, grotere groepen en een minder intense docentbegeleiding per student.

In dit hoofdstuk wordt besproken hoe effectief de e-learning opleiding is gebleken in de implementatiefase. Eerst komt de studenttevredenheid aan de orde (9.1), en daarna de uitval en het studierendement (9.2).

De onderzoeksvragen voor dit hoofdstuk zijn:

- Hoe is de studenttevredenheid? (9.1).

- Haalt de studenttevredenheid de norm die door het management team is gesteld?

- Met welke factoren lijkt de studenttevredenheid in de e-learning vooral samen te hangen?

- Is de drop-out acceptabel? (9.2).

- Hoe groot is de drop-out na het eerste en na het tweede studiejaar?

- Hoe verhoudt deze drop-out zich tot de drop-out in de reguliere opleiding?

- Met welke factoren lijkt de drop-out vooral samen te hangen?

- Zijn de e-learning modules geschikt om competenties te verwerven op het niveau van de master SEN? (9.2).

- Hoeveel procent van de studenten studeert af als master SEN binnen de termijn van twee jaar?

- Hoeveel procent van de studenten studeert af als master SEN binnen drie en vier jaar?

- Hoe verhoudt dit zich tot de studenten in de reguliere leerroutes?

In paragraaf 9.3 worden de uitkomsten met betrekking tot deze onderzoeksvragen samengevat en in 9.4 worden de aanpassingen aan het ontwerp beschreven die plaatsvonden op basis van deze uitkomsten.

\subsection{TEVREDENHEID VAN STUDENTEN OVER DE MODULES}

Rapportcijfers voor modules

Studenttevredenheid is door het managementteam van OSO uitdrukkelijk benoemd als gewenst resultaat (paragraaf 1.3.1). Studenttevredenheid speelt een 
rol in de aantrekkingskracht van de opleiding op nieuwe lichtingen studenten en studenttevredenheid kan preventief werken ten aanzien van uitval (Levy, 2007). In tabel 9.1 is de gemiddelde tevredenheid van studenten over de modules weergegeven op grond van het rapportcijfer (1-10) dat zij toegekend hebben aan de modules. Daarnaast zijn de standaarddeviaties vermeld. Bij de aanvang van het project was het minimum te behalen doel voor de studenttevredenheid gesteld op het rapportcijfer 7 .

\begin{tabular}{lcccccc} 
Tabel 9.1 & \multicolumn{9}{l}{ Rapportcijfers voor modules } \\
\hline \multicolumn{3}{c}{ Cohort 1 e-learning } & \multicolumn{3}{l}{ Cohort 2 e-learning } \\
Periode & $N$ & $X$ & $S D$ & $N$ & $X$ & $S D$ \\
\hline 1 & 35 & 7,4 & 0,97 & & & \\
2 & 28 & 7,2 & 0,92 & & & \\
3 & 25 & 8,0 & 0,58 & & & \\
4 & 16 & 7,3 & 1,14 & & & \\
6 & 19 & 7,8 & 1,13 & 23 & 7,8 & 0,83 \\
7 & 13 & 6,7 & 1,25 & 11 & 7,6 & 0,69 \\
\hline
\end{tabular}

Uit de tabel blijkt dat slechts in één periode de doelstelling op het vlak van de tevredenheid niet werd gehaald: periode 7 van cohort 1 . In alle andere periodes werd de doelstelling ruim gehaald. Opvallend goed zijn de resultaten in periode 3 van cohort 1 en de kleine standaarddeviatie in die periode. Met behulp van variantie analyse voor herhaalde metingen is onderzocht of de verschillen tussen de verschillende periodes van cohort 1 significant zijn. Dit bleek het geval, $F(5,45)=3,5, \quad p<0,01, \quad \eta_{p}^{2}=0,28$. Uit toetsing van de contrasten tussen de opeenvolgende moduleperiodes van cohort 1 bleek het verschil tussen periodes 2 en 3 significant, $F(1 ; 9)=7,3, p<0,05, \eta_{p}{ }^{2}=0,45$. Dit gold eveneens voor het verschil tussen periodes 3 en $4, F(1 ; 9)=8,2, p<0,05, \eta_{p}{ }^{2}=0,48$ en periodes 6 en $7, F(1 ; 9)=14,4$, $p<0,05, \quad \eta_{p}^{2}=0,42$. Variantie analyse voor herhaalde metingen toont geen significante verschillen aan tussen de twee periodes van cohort 2 . Uit de $t$-toets voor onafhankelijke steekproeven bleek een significant verschil tussen cohort 1 en 2 in periode $7, t(19,2)=-2,1, p<0,05, r=0,19$. Om na te gaan of er verbanden bestaan tussen de ontwerpkenmerken en de tevredenheid over modules zijn Pearson's correlaties berekend tussen de schalen die betrekking hebben op de ontwerpkenmerken en de rapportcijfers voor de modules. Deze correlaties zijn per moduleperiode weergegeven in tabel 9.2. Niet in alle moduleperiodes zijn alle schalen gehanteerd. Lege vakken geven aan dat schalen niet afgenomen zijn. Significante correlaties zijn vet weergegeven. De moduleperiodes 1-4 betreffen alleen cohort 1, de overige moduleperiodes betreffen beide cohorten tezamen. 
Tabel 9.2 Verbanden met het rapportcijfer voor de module (cohorten 1 en 2)

\begin{tabular}{|c|c|c|c|c|c|c|}
\hline Correlatie & P1 & P2 & P3 & P4 & P6 & P7 \\
\hline \multicolumn{7}{|l|}{ Interactie tussen studenten } \\
\hline $\begin{array}{l}\text { Samenwerking met mede- } \\
\text { studenten }\end{array}$ & 0,27 & $-0,17$ & 0,33 & $0,64^{* *}$ & 0,15 & 0,02 \\
\hline Verbondenheid & 0,31 & 0,02 & 0,09 & $0,51^{*}$ & 0,13 & $-0,11$ \\
\hline Steun voor het leerproces & 0,39 & $-0,11$ & 0,14 & $0,53^{*}$ & 0,17 & $-0,04$ \\
\hline $\begin{array}{l}\text { Leerzaamheid discussies in } \\
\text { groepje }\end{array}$ & & 0,03 & & & $0,44^{* *}$ & 0,09 \\
\hline $\begin{array}{l}\text { Leerzaamheid discussiebij- } \\
\text { drages van medestudenten }\end{array}$ & & 0,03 & & & $0,37^{*}$ & \\
\hline $\begin{array}{l}\text { Leerzaamheid samenwer- } \\
\text { kingsopdrachten }\end{array}$ & & -0.13 & & & $0,35^{*}$ & 0,31 \\
\hline Woord en Ervaring: Sociaal & $-0,10$ & & & $0,54^{*}$ & & \\
\hline \multicolumn{7}{|l|}{ E-learning structuur } \\
\hline Organisatie van de module & & & & & $0,60^{* *}$ & $0,57^{* *}$ \\
\hline Ondersteuning door planning & & 0,08 & & & 0,23 & 0,30 \\
\hline Duidelijkheid & & 0,11 & & & 0,25 & 0,35 \\
\hline Spreiding studielast & & 0,15 & & & $0,35^{*}$ & 0,17 \\
\hline Woord en Ervaring: Chaos & $-0,36^{*}$ & & & $-0,22$ & & \\
\hline $\begin{array}{l}\text { Woord en Ervaring: Tijdsdruk } \\
\text { en stress }\end{array}$ & $-0,42^{*}$ & & & $-0,20$ & & \\
\hline \multicolumn{7}{|l|}{ Leermaterialen } \\
\hline $\begin{array}{l}\text { Leerzaamheid van de module } \\
\text { onderdelen }\end{array}$ & & 0,35 & & & $0,75^{* *}$ & $0,82^{* * *}$ \\
\hline Geschreven uitleg & & 0,28 & & & $0,71^{* * *}$ & $0,67^{* * *}$ \\
\hline Vakliteratuur & & 0,11 & & & $0,59^{* * *}$ & $0,74^{* * *}$ \\
\hline Interactieve vragen & & $-0,28$ & & & & \\
\hline Video fragmenten & & 0,19 & & & $0,61^{* * *}$ & $0,56^{*}$ \\
\hline Powerpoints met script & & $-0,22$ & & & & \\
\hline Gesproken powerpoints & & $-0,20$ & & & & \\
\hline Uitgewerkte voorbeeld casussen & & $-0,12$ & & & $0,65^{* * *}$ & \\
\hline Links naar andere websites & & 0,39 & & & $0,59^{* * *}$ & $-0,02$ \\
\hline \multicolumn{7}{|l|}{ Docentrol } \\
\hline Begeleiding door de docent & 0,24 & 0,18 & 0,21 & $0,61^{*}$ & $0,68^{* * *}$ & $0,66^{* * *}$ \\
\hline Moderatie & 0,14 & 0,14 & 0,02 & 0,26 & $0,45^{* *}$ & $0,70^{* * *}$ \\
\hline Feedback & 0,31 & 0,04 & $-0,32$ & $-0,32$ & 0,20 & $0,66^{* * *}$ \\
\hline Communicatie & 0,38 & 0,39 & $-0,30$ & 0,04 & 0,17 & $0,70^{* * *}$ \\
\hline Vraagsturing & 0,42 & $0,41^{*}$ & 0,04 & 0,33 & & \\
\hline Leerzaamheid feedback docent & & 0,19 & & & $0,54^{* *}$ & $0,66^{* *}$ \\
\hline $\begin{array}{l}\text { Leerzaamheid discussiebij- } \\
\text { dragen docent }\end{array}$ & & 0,42 & & & $0,63^{* * *}$ & $0,62^{* *}$ \\
\hline
\end{tabular}

Noot: ${ }^{*} p<0,05,{ }^{* *} p<0,01,{ }^{* * *} p<0,001$. 
Opvallend is dat in de moduleperiodes 1-4 van cohort 1 zeer weinig significante verbanden zichtbaar zijn. Dit kan samenhangen met het doorgaans relatief lage aantal respondenten in deze periodes. In moduleperiode 1 vertonen alleen chaos en tijdsdruk en stress een significant en omgekeerd verband met de tevredenheid over de module. Dit zou iets kunnen zeggen over een (licht) overheersende rol van deze beide percepties bij het begin van de studie van dit allereerste cohort. De modules waren aanvankelijk in organisatorisch opzicht nog onvoldoende uitgebalanceerd (zie hoofdstuk 6), en de docenten waren nog onervaren en konden daardoor mogelijk ook niet afdoende compenseren ten aanzien van de organisatie van de modules (zie hoofdstuk 7). In de moduleperiodes 6 en 7 werd studenten voor het eerst gevraagd om een oordeel over de organisatie van de module als geheel. In beide periodes blijkt een betere organisatie van de module samen te hangen met een grotere tevredenheid over de module.

In moduleperiode 4 van cohort 1 waren er problemen met de interactie tussen studenten (zie hoofdstuk 5). Opvallend is dat juist in deze periode een coherent verband zichtbaar is tussen de tevredenheid over de module en alle afgenomen sociale interactiematen. Het feit dat dit in deze moduleperiode zichtbaar is en in geen van de andere periodes zou kunnen betekenen dat er een drempelwaarde bestaat voor de waardering voor sociale aspecten van de samenwerking. Als deze aspecten te laag gewaardeerd worden ontstaat een negatieve invloed op de tevredenheid over de e-learning module als geheel.

De leerzaamheid van de leermaterialen bleek in twee van de drie bevraagde periodes verband te houden met de algehele waardering voor de module. Voor de docentrol speelde dit in vier van de zes periodes. Opvallend is de hoge correlatie op alle docentmaten in periode 7 . In deze periode waren de studenten uit cohort 1 gemiddeld niet erg tevreden over de rol van de docent.

\section{Aansluiting bij de leerwensen van studenten}

Een tweede manier om de tevredenheid te onderzoeken was de afname van de schaal 'Aansluiting bij leerwensen'. Deze schaal bevatte vier items waaronder bijvoorbeeld: 'Deze module kwam tegemoet aan mijn leerwensen' en 'Deze module stimuleerde mijn verlangen om nog meer te leren'. De items werden gescoord op een 3-puntsschaal ( $1=$ nee, $2=$ gaat wel, $3=j a)$. In tabel 9.3 zijn gemiddeldes en standaarddeviaties per moduleperiode en per cohort weergegeven. 
Tabel 9.3 Aansluiting bij leerwensen

\begin{tabular}{lcccccc}
\hline & \multicolumn{3}{c}{ Cohort 1 e-learning } & \multicolumn{3}{c}{ Cohort 2 e-learning } \\
Periode & $N$ & $X$ & $S D$ & $N$ & $X$ & $S D$ \\
\hline 1 & 22 & 2,6 & 0,44 & & & \\
2 & 26 & 2,8 & 0,39 & & & \\
3 & 20 & 2,9 & 0,17 & & & \\
4 & 16 & 2,5 & 0,41 & & & \\
6 & 19 & 2,8 & 0,35 & 23 & 2,8 & 0,37 \\
7 & 13 & 2,4 & 0,60 & 11 & 2,8 & 0,35 \\
\hline
\end{tabular}

De aansluiting bij de leerwensen is in vrijwel alle periodes adequaat gerealiseerd $(\geq 2,5)$. Alleen in periode 7 van cohort 1 werd aansluiting bij de leerwensen niet overtuigend gerealiseerd. Variantie analyse voor herhaalde metingen is voor cohort 1 niet uitgevoerd omdat slechts vijf studenten de schaal alle keren hadden ingevuld. Voor cohort 2 is deze analyse niet uitgevoerd omdat er nauwelijks verschillen waren tussen periode 6 en 7 . De $t$-toets voor onafhankelijke steekproeven toont geen significante verschillen tussen de twee cohorten in periodes 6 en 7 .

\section{Ontwerpkenmerken en aansluiting bij leerwensen}

Om na te gaan of er verbanden bestaan tussen de ontwerpkenmerken en de aansluiting bij de leerwensen zijn Pearson correlaties berekend tussen de schalen die betrekking hebben op de ontwerpkenmerken enerzijds en de schaal aansluiting bij leerwensen anderzijds. Deze correlaties zijn per moduleperiode weergegeven in tabel 9.4. De moduleperiodes 1-4 betreffen cohort 1 , in moduleperiodes 6 en 7 zijn de cohorten 1 en 2 gezamenlijk weergegeven. Niet in alle moduleperiodes zijn alle schalen gehanteerd. Lege vakken geven aan dat schalen niet afgenomen zijn. Significante correlaties zijn vet weergegeven. 
Tabel 9.4 Verbanden met leerwensen van studenten (cohorten 1 en 2)

\begin{tabular}{|c|c|c|c|c|c|c|}
\hline Pearson's $r$ & P1 & P2 & P3 & $\mathbf{P 4}$ & P6 & P7 \\
\hline \multicolumn{7}{|l|}{ Interactie tussen studenten } \\
\hline $\begin{array}{l}\text { Samenwerking met mede- } \\
\text { studenten }\end{array}$ & 0,24 & 0,07 & 0,13 & $0,60^{*}$ & 0,11 & $-0,03$ \\
\hline Verbondenheid & $0,46^{*}$ & $-0,12$ & 0,17 & 0,45 & 0,10 & $-0,05$ \\
\hline Steun voor het leerproces & 0,35 & 0,23 & 0,09 & $0,64^{* *}$ & 0,01 & $-0,09$ \\
\hline $\begin{array}{l}\text { Leerzaamheid discussies in } \\
\text { groepje }\end{array}$ & & 0,15 & & & 0,23 & $-0,03$ \\
\hline $\begin{array}{l}\text { Leerzaamheid discussiebijdrages } \\
\text { van medestudenten }\end{array}$ & & $-0,07$ & & & 0,12 & \\
\hline $\begin{array}{l}\text { Leerzaamheid samenwerkings- } \\
\text { opdrachten }\end{array}$ & & 0,00 & & & 0,14 & 0,29 \\
\hline Woord en Ervaring: Sociaal & 0,38 & & & $0,52^{*}$ & & \\
\hline \multicolumn{7}{|l|}{ E-learning structuur } \\
\hline $\begin{array}{l}\text { Rapportcijfer voor de organi- } \\
\text { satie van de module }\end{array}$ & & & & & $0,34^{*}$ & 0,34 \\
\hline $\begin{array}{l}\text { Schaal Ondersteuning door } \\
\text { planning }\end{array}$ & & $0,74^{* * *}$ & & & 0,22 & 0,29 \\
\hline Schaal Duidelijkheid & & $0,51^{*}$ & & & 0,16 & 0,26 \\
\hline Schaal Spreiding studielast & & 0,16 & & & 0,05 & 0,07 \\
\hline Woord en Ervaring: Chaos & $-0,39$ & & & $-0,18$ & & \\
\hline $\begin{array}{l}\text { Woord en Ervaring: Tijdsdruk } \\
\text { en stress }\end{array}$ & $-0,36$ & & & $-0,08$ & & \\
\hline \multicolumn{7}{|l|}{ Leermaterialen } \\
\hline $\begin{array}{l}\text { Rapportcijfer voor de leerzaam- } \\
\text { heid van de module onderdelen }\end{array}$ & & $0,44^{*}$ & & & $0,60^{* * *}$ & $0,73^{* * *}$ \\
\hline Geschreven uitleg & & 0,38 & & & $0,47^{* *}$ & $0,53^{* *}$ \\
\hline Vakliteratuur & & 0,00 & & & $0,61^{* * *}$ & $0,60^{* *}$ \\
\hline Interactieve vragen & & $-0,26$ & & & & \\
\hline Video fragmenten & & 0,04 & & & $0,39^{*}$ & $0,64^{* *}$ \\
\hline Powerpoints met script & & 0,12 & & & & \\
\hline Gesproken powerpoints & & $-0,10$ & & & & \\
\hline Uitgewerkte voorbeeld casussen & & $-0,10$ & & & 0,36 & \\
\hline Links naar andere websites & & 0,29 & & & 0,10 & $-0,11$ \\
\hline \multicolumn{7}{|l|}{ Docentrol } \\
\hline $\begin{array}{l}\text { Rapportcijfer voor de begelei- } \\
\text { ding door de docent }\end{array}$ & 0,00 & $0,44^{*}$ & 0,24 & $0,61^{*}$ & $0,37^{*}$ & $0,53^{* *}$ \\
\hline Schaal Moderatie & 0,00 & 0,27 & $0,49 *$ & 0,45 & 0,16 & $0,62^{* *}$ \\
\hline Schaal Feedback & 0,18 & 0,34 & 0,01 & $-0,12$ & 0,17 & $0,64^{* *}$ \\
\hline Schaal Communicatie & 0,21 & $0,57^{* *}$ & 0,04 & 0,42 & 0,15 & $0,65^{* *}$ \\
\hline Schaal Vraagsturing & $0,59 * *$ & $0,49^{*}$ & 0,21 & $0,74^{* *}$ & & \\
\hline Leerzaamheid feedback docent & & $0,55^{*}$ & & & 0,34 & $0,48^{*}$ \\
\hline $\begin{array}{l}\text { Leerzaamheid discussiebij- } \\
\text { dragen docent }\end{array}$ & & $0,50^{*}$ & & & $0,39 *$ & $0,47^{*}$ \\
\hline
\end{tabular}


In alle vier ontwerpclusters werden significante correlaties gevonden met de aansluiting op de leerwensen van de studenten. Voor wat betreft de interactie met medestudenten bestonden deze verbanden vooral daar waar die interactie niet naar volle tevredenheid gerealiseerd werd; periodes 1 en 4 . Als studenten minder tevreden waren over de interactie, gaven zij aan dat minder goed was voldaan aan hun leerwensen, in veel gevallen zullen zij daardoor onder de gestelde norm hebben gescoord $(\geq 2,5)$. De aansluiting bij de leerwensen houdt over de periodes het meest consistent verband met maten ten aanzien van de clusters 'docentrol' en 'leermaterialen'. Kennelijk zijn deze ontwerpclusters het belangrijkst ten aanzien van het realiseren van de leerwensen van studenten.

\section{Engagement van studenten}

Een derde manier om de tevredenheid te onderzoeken was de afname van de schaal 'Engagement' uit het instrument Woord en Ervaring. De studenten scoorden dit instrument op een 5-punts Likert schaal: 1=Nee!, 2=Nee, 3=Soms, 4=Ja, 5=Ja! In tabel 9.5 worden gemiddelde scores en standaarddeviaties weergegeven per moduleperiode en per cohort. De vragenlijst Woord en Ervaring werd afgenomen na de moduleperiodes 1, 4 en 5 .

\begin{tabular}{lcccccc} 
Tabel 9.5 & \multicolumn{2}{l}{ Engagement } \\
\hline \multirow{3}{*}{ Periode } & $N$ & $X$ & $S D$ & $N$ & $X$ & $S D$ \\
\hline 1 & 36 & 4,3 & 0,53 & & & \\
4 & 23 & 4,0 & 0,63 & & & \\
5 & 21 & 4,1 & 0,74 & 27 & 4,5 & 0,51 \\
\hline
\end{tabular}

Gemiddeld zijn de studenten positief geëngageerd $(\geq 4,0)$. Het sterkste engagement is in beide cohorten zichtbaar na hun respectievelijke eerste modules ( 1 en 5 ). Voor cohort 1 blijken uit variantie analyse voor herhaalde metingen geen significante verschillen tussen de verschillende moduleperiodes. Het verschil tussen cohort 1 en 2 in moduleperiode 5 is geanalyseerd met behulp van de $t$-toets voor onafhankelijke steekproeven. Hieruit bleek geen significant verschil tussen beide cohorten. Er werden geen verbanden met de ontwerpkenmerken berekend omdat de engagement schaal niet vaak werd afgenomen en juist in periodes waarin een aantal andere schalen niet werden afgenomen. 


\section{Computerattitude en teoredenheid}

Naast de effecten van de leeromgeving zelf kunnen er ook studentgebonden factoren zijn die de tevredenheid over e-learning modules beïnvloeden. Voor elearning kan de computerattitude van de studenten bij de aanvang van de studie een beïnvloedende factor zijn. Als studenten met een negatieve houding ten opzichte van computers aan de studie beginnen zou dat invloed kunnen uitoefenen op de tevredenheid over modules. Om na te gaan of dit inderdaad het geval is, is bij aanvang van de studie de TAC afgenomen (zie hoofdstuk 2). In moduleperiode 5 is de TAC nogmaals afgenomen, dit keer bij cohort één en twee. De TAC werd gescoord op een 5-puntsschaal: helemaal oneens - oneens neutraal - eens - helemaal eens. In tabel 9.6 zijn de resultaten van deze afnamen per subschaal uitgesplitst voor moduleperiode en voor cohort. In de tabel zijn gemiddeldes en standaarddeviaties weergegeven. De eerste twee schalen zijn positief: plezier en productiviteit. Voor deze schalen geldt: hoe hoger de score hoe beter. Voor de drie negatieve schalen: angst, vermijding en negatieve impact, geldt hoe lager de score, hoe beter.

Tabel 9.6 Computerattitude van e-learning studenten

\begin{tabular}{lccccccc}
\hline TAC subschaal & Cohort & \multicolumn{1}{c}{$\mathbf{1}$} & & \multicolumn{2}{c}{$\mathbf{2}$} \\
& Periode & $N$ & $X$ & $S D$ & $N$ & $X$ & $S D$ \\
\hline Plezier & 1 & 39 & 3,3 & 0,62 & & & \\
\multirow{3}{*}{ Productiviteit } & 5 & 23 & 3,4 & 0,57 & 27 & 3,4 & 0,35 \\
\multirow{2}{*}{ Angst } & 1 & 39 & 4,0 & 0,43 & & & \\
& 5 & 23 & 4,1 & 0,53 & 27 & 4,1 & 0,43 \\
Vermijding & 1 & 39 & 1,8 & 0,59 & & & \\
\multirow{2}{*}{ Negatieve impact } & 5 & 23 & 1,8 & 0,56 & 27 & 1,6 & 0,42 \\
& 1 & 39 & 1,6 & 0,37 & & & \\
& 5 & 23 & 1,4 & 0,33 & 27 & 1,5 & 0,29 \\
& 1 & 39 & 2,0 & 0,55 & & & \\
& 5 & 23 & 1,9 & 0,48 & 27 & 2,0 & 0,42 \\
\hline
\end{tabular}

De beide e-learning cohorten scoren gemiddeld neutraal (rond de drie) met betrekking tot plezier in het gebruiken van computers. Dit lijkt een lage score voor studenten die ervoor kiezen om via e-learning te gaan studeren. Gemiddeld scoren de studenten wel positief ten aanzien van de invloed van computers op productiviteit. Met betrekking tot de negatieve factoren angst, vermijding en negatieve impact zien we dat de studenten gemiddeld weinig of geen problemen hebben op dit vlak; er zijn geen gemiddelde scores boven de 2. Omdat er tussen de verschillende meetmomenten en tussen de cohorten slechts zeer kleine verschillen zijn is er geen nadere analyse van die verschillen uitgevoerd. 
Om na te gaan of er verbanden bestaan tussen de computerattitude van studenten en hun tevredenheid over de modules zijn Pearson's correlaties berekend. Deze zijn weergegeven in tabel 9.7. De TAC werd afgenomen in de periodes 1 en 5. In periode 1 werden de drie tevredenheids maten gebruikt. In periode 5 werd alleen de engagementsschaal afgenomen. Significante correlaties zijn vet weergegeven.

Tabel $9.7 \quad V e r b a n d e n$ tussen tevredenheid en computerattitude

\begin{tabular}{|c|c|c|c|c|c|c|c|}
\hline TAC subschaal & Periode & $\begin{array}{l}\text { hort } \\
\text { Rapport- } \\
\text { cijfer } \\
\text { module }\end{array}$ & $\begin{array}{c}\text { Leer- } \\
\text { wensen }\end{array}$ & $\begin{array}{c}\text { Engage- } \\
\text { ment }\end{array}$ & $\begin{array}{c}\text { Rapport- } \\
\text { cijfer } \\
\text { module }\end{array}$ & $\begin{array}{c}\text { Leer- } \\
\text { wensen }\end{array}$ & $\begin{array}{c}\text { Engage- } \\
\text { ment }\end{array}$ \\
\hline Plezier & 1 & $-0,02$ & $-0,17$ & $-0,16$ & & & \\
\hline & 5 & & & $-0,06$ & & & 0,14 \\
\hline Productiviteit & 1 & 0,25 & 0,41 & 0,27 & & & \\
\hline & 5 & & & $-0,30$ & & & 0,19 \\
\hline Angst & 1 & $-0,08$ & $-0,10$ & 0,04 & & & \\
\hline & 5 & & & 0,27 & & & $-0,10$ \\
\hline Vermijding & 1 & $-0,48^{* *}$ & $-0,43^{*}$ & $-0,48^{* *}$ & & & \\
\hline & 5 & & & $-0,13$ & & & $-0,12$ \\
\hline Negatieve impact & 1 & $-0,40^{*}$ & $-0,43^{*}$ & $-0,12$ & & & \\
\hline & 5 & & & 0,07 & & & $-0,36$ \\
\hline
\end{tabular}

Noot: $\quad{ }^{*} p<0,05,{ }^{* *} p<0,01,{ }^{* * *} p<0,001$.

In de meeste gevallen zijn de verbanden klein en niet significant. In cohort 1 zijn er wel significante verbanden met vermijding en negatieve impact. Hoe groter de neiging tot vermijding van computers hoe lager de tevredenheid, de aansluiting bij leerwensen en het engagement. De opvatting dat computergebruik een negatieve impact heeft op de maatschappij lijkt ook te kunnen interfereren met de tevredenheid en de aansluiting bij de leerwensen. In cohort 2 werden geen significante verbanden gevonden.

\section{Angst en tevredenheid}

Een andere meer persoonsgebonden factor die een rol zou kunnen spelen is angst die gerelateerd is aan het studeren. Deze angst kan gebonden zijn aan het studeren via de computer maar kan ook opgeroepen worden door bijvoorbeeld de online sociale situaties, door de moeilijkheidsgraad, door onduidelijkheden en door de studiebelasting. Om de angst in bredere zin te meten is gebruik gemaakt van de subschaal Angst in het instrument Woord en Ervaring. Deze schaal bevatte de volgende items: angst, bedreigend, onveilig, eenzaamheid. In tabel 9.8 zijn gemiddeldes en standaarddeviaties weergegeven voor deze subschaal die gescoord werd op een 5-punts Likert schaal: $1=$ Nee!, 2=Nee, 3=Soms, 4=Ja, 5=Ja! 
Tabel 9.8 Angst bij e-learning studenten

\begin{tabular}{lcccccc}
\hline & \multicolumn{3}{c}{ Cohort 1 e-learning } & \multicolumn{3}{c}{ Cohort 2 e-learning } \\
Periode & $N$ & $X$ & $S D$ & $N$ & $X$ & $S D$ \\
\hline 1 & 36 & 2,1 & 0,61 & & & \\
4 & 23 & 2,2 & 0,71 & & & \\
5 & 21 & 2,0 & 0,67 & 28 & 1,9 & 0,51 \\
\hline
\end{tabular}

In cohort 1 is in twee periodes gemiddeld sprake van enige angst (groter dan 2). Variantie analyse voor herhaalde metingen toont geen significante verschillen tussen de moduleperiodes van cohort 1 . Uit de $t$-toets voor onafhankelijke steekproeven blijken geen significante verschillen tussen de cohorten in moduleperiode 5 .

Om na te gaan of er verbanden bestaan tussen de angst van studenten en hun tevredenheid over de modules zijn Pearson's correlaties berekend. Deze zijn weergegeven in tabel 9.9. De angstschaal (uit de vragenlijst Woord en Ervaring, zie paragraaf 2.4.3) werd uitgezet in de periodes 1 , 4 en 5 . In de periodes 1 en 4 werden de drie tevredenheids maten gebruikt. In periode 5 werd alleen de engagementsschaal afgenomen (eveneens uit Woord en Ervaring). Significante correlaties zijn vet weergegeven.

Tabel 9.9 Verbanden tussen angst en tevredenheid

\begin{tabular}{|c|c|c|c|c|c|c|c|}
\hline \multirow[b]{2}{*}{$\begin{array}{l}\text { WE } \\
\text { subschaal }\end{array}$} & \multirow[b]{2}{*}{ Periode } & \multicolumn{2}{|c|}{ Cohort } & \multicolumn{2}{|l|}{1} & \multicolumn{2}{|c|}{2} \\
\hline & & $\begin{array}{l}\text { Rapport- } \\
\text { cijfer } \\
\text { module }\end{array}$ & $\begin{array}{c}\text { Leer- } \\
\text { wensen }\end{array}$ & $\begin{array}{c}\text { Engage- } \\
\text { ment }\end{array}$ & $\begin{array}{l}\text { Rapport- } \\
\text { cijfer } \\
\text { module }\end{array}$ & $\begin{array}{c}\text { Leer- } \\
\text { wensen }\end{array}$ & $\begin{array}{c}\text { Engage- } \\
\text { ment }\end{array}$ \\
\hline \multirow[t]{3}{*}{ Angst } & 1 & $-0,23$ & $-0,14$ & $-0,26$ & & & \\
\hline & 4 & $-0,29$ & $-0,33$ & $-0,25$ & & & \\
\hline & 5 & - & - & $-0,53^{*}$ & & & $-0,04$ \\
\hline
\end{tabular}

Noot: ${ }^{*} p<0,05,{ }^{* *} p<0,01,{ }^{* * *} p<0,001$.

De verbanden zijn in alle gevallen negatief. De correlaties zijn klein en meestal niet significant. Slechts in 1 geval is er een significant negatief verband: met de engagementscores in periode 5 van cohort 1 . Minder angst leidt tot een hoger engagement. 


\subsection{UITVAL EN STUDIERENDEMENT}

\section{Uitval}

Een belangrijk doel van het ontwerp was om de uitval van studenten niet hoger te laten zijn dan de uitval van de reguliere studenten. tabel 9.10 is de cumulatieve uitval van de e-learning en van de reguliere studenten weergegeven in procenten. Deze uitval is weergegeven over vier jaren. De reguliere studieduur bedraagt twee jaar. De aangegeven studiejaren zijn respectievelijk het eerste, tweede, en derde jaar van het betreffende cohort. Het derde jaar van het tweede cohort kon niet meer meegenomen worden in het onderzoek.

Tabel 9.10 Aantallen uitvallers (cumulatief)

\begin{tabular}{lcccc}
\hline Cohort 1 & $\begin{array}{c}\text { Gestopt in/ } \\
\text { start }\end{array}$ & $\begin{array}{c}\text { Gestopt in/ } \\
\text { \% (aantal) }\end{array}$ & $\begin{array}{c}\text { Gestopt in/ } \\
\text { na jaar 2 } \\
\text { \% (aantal) }\end{array}$ & $\begin{array}{c}\text { na jaar 3 } \\
\% \text { (antal) }\end{array}$ \\
\hline E-learning & 39 & $31(12)$ & $36(14)$ & $41(16)$ \\
$\begin{array}{l}\text { Regulier } \\
\text { Cohort 2 }\end{array}$ & 404 & $29(117)$ & $56(226)$ & $59(238)$ \\
\hline E-learning & 38 & $32(12)$ & $42(16)$ & \\
Regulier & 551 & $31(171)$ & $42(231)$ & \\
\hline
\end{tabular}

Opvallend is dat in alle cohorten de meeste studenten uitvallen in het eerste studiejaar. Alleen in het tweede jaar van het reguliere cohort 1 vallen ook nog erg veel studenten uit. In het tweede jaar van de overige cohorten is de uitval veel lager. De aantallen studenten bij de start en de aantallen uitvallers in het eerste jaar zijn vrijwel gelijk voor beide e-learning cohorten. In jaar twee van cohort 2 elearning vallen iets meer studenten uit dan in jaar 2 van cohort 1 e-learning. De uitvalspercentages in het eerste jaar van de reguliere cohorten liggen net iets lager (respectievelijk $2 \%$ en $1 \%$ ) dan de uitvalspercentages in de e-learning cohorten. In het tweede jaar is dit niet het geval. In cohort 1 regulier vallen veel meer studenten uit dan in cohort 1 e-learning. In jaar 2 zijn de cumulatieve uitvalspercentages voor cohort 2 regulier en e-learning precies gelijk.

Om na te gaan of er verbanden zichtbaar waren tussen de ontwerpkenmerken en de uitval zijn voor cohort 1 punt-biseriële correlaties berekend tussen de uitval (uitval=0, niet uitvallen=1) en de schalen die betrekking hebben op de ontwerpkenmerken. Deze correlaties zijn per moduleperiode weergegeven in tabel 9.11. Lege vakken geven aan dat schalen niet afgenomen zijn. Voor cohort 2 zijn de correlaties met de verschillende schalen niet uitgerekend omdat te weinig 
studenten die uitvielen de betreffende schalen invulden. Wel konden correlaties uitgerekend worden met de schaal Woord en Ervaring, met de TAC, met het aantal berichten en met het inleveren van het werkstuk. De meeste uitvallers uit cohort $2(10$ studenten $=26 \%)$ vielen snel uit in de eerste periode van dit cohort (periode 5), om deze reden zijn geen verbanden berekend voor periode 6 . Significante correlaties zijn vet weergegeven.

Tabel 9.11 Verbanden met al dan niet uitvallen van studenten

\begin{tabular}{|c|c|c|c|}
\hline & \multicolumn{2}{|c|}{ Cohort 1} & Cohort 2 \\
\hline Punt-biseriële correlaties & P1 & P2 & P5 \\
\hline \multicolumn{4}{|l|}{ Interactie tussen studenten } \\
\hline Samenwerking met medestudenten & 0,29 & $0,49^{*}$ & \\
\hline Verbondenheid & 0,06 & 0,12 & \\
\hline Steun voor het leerproces & 0,16 & $0,63^{* *}$ & \\
\hline Leerzaamheid discussies in groepje & & 0,31 & \\
\hline Leerzaamheid discussiebijdrages van medestudenten & & 0,06 & \\
\hline Leerzaamheid samenwerkingsopdrachten & & 0,19 & \\
\hline Woord en Ervaring: Sociaal & $0,42 * *$ & & 0,15 \\
\hline \multicolumn{4}{|l|}{ E-learning structuur } \\
\hline Ondersteuning door planning & & $0,66^{* *}$ & \\
\hline Duidelijkheid & & $0,54^{* *}$ & \\
\hline Spreiding studielast & & 0,32 & \\
\hline Woord en Ervaring: Chaos & $-0,51^{* *}$ & & $-0,18$ \\
\hline Woord en Ervaring: Tijdsdruk en stress & $-0,33^{*}$ & & $-0,29$ \\
\hline
\end{tabular}

\section{Leermaterialen}

Leerzaamheid van de module onderdelen $\quad 0,26$

Geschreven uitleg $\quad 0,02$

Vakliteratuur $\quad 0,26$

Video fragmenten $\quad 0,26$

Powerpoints met script $\quad 0,34$

$\begin{array}{ll}\text { Gesproken powerpoints } & 0,02\end{array}$

Uitgewerkte voorbeeld casussen $\quad 0,45$

Links naar andere websites $\quad 0,32$

\begin{tabular}{lcc}
\hline Docentrol & & \\
\hline Begeleiding door de docent & $-0,12$ & 0,06 \\
Moderatie & $-0,13$ & 0,05 \\
Feedback & $-0,29$ & 0,22 \\
Communicatie & $-0,16$ & $-0,01$ \\
Vraagsturing & 0,11 & 0,19 \\
Leerzaamheid feedback docent & 0,16 \\
Leerzaamheid discussiebijdragen docent & 0,00 \\
Overige aspecten & & \\
Tevredenheid over module & $-0,01$ & $-0,07$ \\
\hline
\end{tabular}


Tabel 9.11 Verbanden met al dan niet uitvallen van studenten (Continued)

\begin{tabular}{lccc}
\hline & & Cohort 1 & Cohort 2 \\
\hline TAC Plezier & $-0,28$ & & 0,05 \\
TAC Productiviteit & 0,04 & & 0,00 \\
TAC Angst & 0,04 & & 0,39 \\
TAC Vermijding & 0,02 & & $-0,05$ \\
TAC Negatieve impact & $-0,22$ & & $-0,04$ \\
WE Angst & $\mathbf{- 0 , 5 3 ^ { * * }}$ & 0,29 & $-0,37$ \\
Aansluiting leerwensen & $-0,02$ & 0,12 & $\mathbf{0 , 6 1 * *}$ \\
Aantal bijdrages & 0,18 & $\mathbf{- 0 , 4 5}^{* *}$ & $\mathbf{- 0 , 6 6 ^ { * * * }}$ \\
Moduleopdracht ingeleverd & $\mathbf{- 0 , 7 \mathbf { 1 } ^ { * * * }}$ & &
\end{tabular}

Noot: ${ }^{*} p<0,05,{ }^{* *} p<0,01,{ }^{* * *} p<0,001$.

Het inleveren van de eerste moduleopdracht vertoonde de sterkste samenhang met blijven studeren. De meeste studenten die de eerste module-opdracht op tijd inleverden ( $1=$ op tijd inleveren, $2=$ te laat, 3 = niet ingeleverd) vielen niet uit. Voorts is af te leiden dat studenten die de interactie met medestudenten en de organisatiestructuur van e-learning hoger waarderen, significant minder vaak met de studie stoppen. De leermaterialen en de docentrol lijken hierin minder een rol te spelen. Bij de overige aspecten valt de WE angstschaal op: studenten die in moduleperiode 1 hoger scoren op opleidingsgerelateerde angst, vallen vaker uit. De computerattitude (TAC schalen) houdt geen verband met de uitval. In cohort 2 blijkt een verband tussen het aantal bijdrages in moduleperiode 1 en het al dan niet uitvallen. Dit is veroorzaakt doordat een aantal studenten heel snel uitvielen tijdens de eerste moduleperiode. Hierdoor leverden zij weinig bijdrages.

\section{Studierendement}

Het doel van de e-learning opleidingen is om studenten op te leiden voor de master SEN competenties. Als indicator voor het behalen van deze competenties is het behalen van het diploma gebruikt. De gestelde eisen en de wijze van beoordeling kwamen overeen met de reguliere opleiding. Ter vergelijking zijn de resultaten opgenomen voor het reguliere cohort 2007 en 2008 Deze cijfers betreffen de reguliere studenten van alle deeltijd OSO master SEN opleidingen. Deze cijfers zijn ontleend aan cijfers die zijn geproduceerd in verband met de managementreview van de master SEN opleiding van Windesheim in 2011.

In tabel 9.12 is weergegeven hoeveel e-learning - en reguliere studenten hun diploma behaalden in de loop van de tijd. De reguliere studieduur bedroeg twee jaar. Sommige studenten studeerden met vrijstellingen en konden daardoor eerder afstuderen. De aangegeven studiejaren zijn respectievelijk het eerste, tweede, derde en vierde jaar van het betreffende cohort. In de laatste kolom is 
vermeld hoeveel procent van de studenten nog studeren in het vierde jaar van cohort 1 en in het derde jaar van cohort 2.

Tabel 9.12 Afgestudeerden (cumulatief)

\begin{tabular}{|c|c|c|c|c|c|c|}
\hline & $\begin{array}{c}N \\
\text { start }\end{array}$ & $\begin{array}{c}\text { Afgestudeerd } \\
\text { in/na jaar } 1 \\
\%\end{array}$ & $\begin{array}{c}\text { Afgestudeerd } \\
\text { in/na jaar } 2 \\
\%\end{array}$ & $\begin{array}{c}\text { Afgestudeerd } \\
\text { in/na jaar } 3 \\
\%\end{array}$ & $\begin{array}{c}\text { Afgestudeerd } \\
\text { in jaar } 4 \\
\%\end{array}$ & $\begin{array}{c}\text { Studeren } \\
\text { nog } \\
\%\end{array}$ \\
\hline 2007 & & & & & & \\
\hline $\begin{array}{l}\text { e- } \\
\text { learning }\end{array}$ & 39 & 0 & 31 & 51 & 54 & 5 \\
\hline regulier & 404 & 10 & 38 & 40 & & 1 \\
\hline 2008 & & & & & & \\
\hline $\begin{array}{l}\text { e- } \\
\text { learning }\end{array}$ & 38 & 13 & 37 & - & - & 21 \\
\hline regulier & 551 & 12 & 39 & - & - & 19 \\
\hline
\end{tabular}

De afstudeercijfers van cohort 1 e-learning na de reguliere studieduur van twee jaar zijn 7\% lager dan de afstudeercijfers van het reguliere cohort. Tegelijkertijd zijn de afstudeercijfers bij e-learning in cohort 1 na één jaar verlenging (jaar 3) $11 \%$ hoger dan die van het reguliere cohort. Uiteindelijk kunnen in dit cohort bij e-learning maximaal 59\% van de studenten afstuderen, terwijl van de reguliere studenten nog maximaal $41 \%$ kan afstuderen. De afstudeerpercentages van dit reguliere cohort liggen opvallend laag. In cohort 2 liggen de percentages voor elearning - en reguliere studenten dicht bij elkaar. De afstudeerpercentages voor elearners zijn na 2 jaar, 2\% lager dan voor reguliere studenten. Uiteindelijk kan hetzelfde percentage studenten het diploma behalen: $58 \%$.

\subsection{SAMENVATTING RESULTATEN: EFFECTEN VAN DE LEEROMGEVING}

\section{Samenvatting tevredenheid over de modules}

De eerste onderzoeksvraag ten aanzien van de tevredenheid luidde of de tevredenheid de door het managementteam gestelde norm haalde: $\geq 7$. Deze vraag werd in vrijwel alle moduleperiodes bevestigend beantwoord; de norm werd meestal ruim gehaald. Er was geen norm gesteld met betrekking tot de maximaal te tolereren spreiding, maar deze was in een aantal periodes van cohort 1 vrij groot. In moduleperiode 7 van cohort 1 werd de tevredenheids norm niet gehaald en was de standaarddeviatie ook nog eens het grootst. De gemiddelde tevredenheid van cohort 2 was goed in beide moduleperiodes waarin zij 
studeerden. Ter controle is gewerkt met twee schalen die eveneens een indicatie vormden voor de studenttevredenheid, dit waren de schalen 'aansluiting bij leerwensen' en 'engagement'. Uit de schaal aansluiting bij leerwensen bleek dat aan de leerwensen in de meeste moduleperiodes adequaat voldaan was, maar ook op deze schaal bleek dit niet het geval in periode 7 van cohort 1 . De schaal 'Engagement' uit het instrument 'Woord en ervaring' werd in drie moduleperiodes afgenomen en toonde in deze drie periodes een positief engagement met uitschieters naar boven voor de eerste modules die de studenten volgden in cohort 1 (moduleperiode 1 ) en cohort 2 (moduleperiode 5).

De tweede vraag over studenttevredenheid luidde: met welke factoren hangt de tevredenheid van de e-learning studenten samen? Hiertoe werd nagegaan of er verbanden zichtbaar waren tussen de tevredenheid over de modules enerzijds en de waardering voor de verschillende ontwerpkenmerken anderzijds. Het rapportcijfer voor de module bleek significant verband te houden met de waardering voor aspecten uit alle vier de ontwerpclusters. De gevonden significaties golden echter niet consistent doorheen alle moduleperiodes. Over meerdere periodes bleek er samenhang met aspecten uit de clusters structuur, docentrol en leermaterialen. Er bestond vooral samenhang tussen de tevredenheid en het cluster interactie tussen studenten in de periode waarin deze interactie minder goed gerealiseerd werd.

Ten aanzien van het realiseren van de leerwensen van de studenten werden de duidelijkste verbanden gevonden met de docentrol en de leermaterialen. Daarnaast werd nagegaan of er verbanden waren tussen de tevredenheidmaten enerzijds en de computerattitude en opleidingsgerelateerde angst anderzijds. In moduleperiode 1 van cohort 1 bleken studenten met een neiging tot het vermijden van computers minder tevreden over de modules. Hetzelfde gold voor studenten die de invloed van computers op de maatschappij negatief waardeerden. In één van de drie onderzochte periodes bleek een significant negatief verband tussen studiegerelateerde angst en het engagement van de studenten. Hoe meer angst zij vertoonden, hoe minder geëngageerd zij waren in de studie.

\section{Samenvatting uitval en studierendement}

Onderzocht werden de uitval en het rendement van de e-learning opleidingen. De uitval over de cohorten 2007 en 2008 was vergelijkbaar met de uitval in de reguliere cohorten, zij het dat in cohort 2007 de uitval na 2 jaar iets hoger was en de uitval na 3 jaar duidelijk lager. Kenmerken uit twee van de ontwerpclusters vertonen 
samenhang met al dan niet uitvallen: interactie met medestudenten en structuur. Studenten die de interactie met medestudenten in de eerste twee moduleperiodes hoog waardeerden vielen minder vaak uit. Studenten die de leeromgeving als goed georganiseerd en duidelijk ervoeren vallen minder vaak uit dan studenten die chaos, onduidelijkheid en te hoge werkdruk ervoeren. Deze bevindingen vertonen overeenkomsten met de bevindingen van Muilenburg en Berge (2005) die als de drie belangrijkste barrières voor online leren identificeerden:

- Een gebrek aan sociale interactie.

- Organisatorische- en docentaspecten.

- Tijd en ondersteuning om te kunnen studeren.

Het niet inleveren van eindopdrachten van de eerste modules blijkt synoniem met uitvallen. Als studenten na de eerste en tweede module hun eindopdracht inleverden bleek hun kans om alsnog uit te vallen klein. Studenten die meer studiegebonden angst vertoonden in de eerste module vielen vaker uit. Geconcludeerd kan worden dat de eerste en wellicht ook nog de tweede online module een belangrijke invloed hebben ten aanzien van de uitval. De scores met betrekking tot computerattitude bleken niet samen te hangen met al dan niet uitvallen. In het tweede cohort werd een relatie gevonden tussen uitval en het aantal bijdrages in de eerste module. Dit werd veroorzaakt doordat een aantal studenten tijdens de eerste weken stopten, waardoor zij weinig bijdragen leverden in de eerste module.

Voor wat betreft het studierendement werden de doelen vrijwel gehaald. Het bleek mogelijk om via e-learning de vereiste master SEN competenties te behalen. Het afstudeerpercentage na de reguliere studieduur van 2 jaar lag in e-learning cohort 2007 7\% lager dan het reguliere afstudeerpercentage, maar het uiteindelijke afstudeerpercentage lag duidelijk hoger (minstens 13\%). Cohort 2008 scoorde na de reguliere studieduur $2 \%$ lager dan de reguliere studie. De prognose voor dit cohort (op basis van het aantal studenten dat nog studeert) is dat de uiteindelijke afstudeerrendementen ongeveer gelijk zullen zijn voor de reguliere- en de elearning variant. 


\subsection{AANPASSINGEN AAN HET ONTWERP}

Op grond van de bevindingen rondom uitval en rendement en de verbanden met de verschillende ontwerpkenmerken werden enkele aanpassingen doorgevoerd na het tweede uitvoeringsjaar. Deze aanpassingen waren er vooral op gericht om de interactie tussen studenten zo snel mogelijk na het begin van de studie op een goed peil te krijgen en om de perceptie van chaos te voorkomen of zo kort mogelijk te laten duren. De gemaakte aanpassingen zijn weergegeven in tabel 9.13.

Tabel 9.13 Aanpassingen door het e-learning team in en buiten Blackboard (BB)

\begin{tabular}{ll}
\hline Aanpassingen & Medium \\
\hline Interactie tussen studenten & \\
\hline $\begin{array}{l}\text { Nieuw te vormen groep de hele startzaterdag } \\
\text { bij elkaar laten zijn, niet mengen met andere } \\
\text { groepen }\end{array}$ & Startzaterdag \\
\hline $\begin{array}{l}\text { Kennismakingswerkvormen op de } \\
\text { startzaterdag om de keuze voor de groepjes te } \\
\text { vergemakkelijken }\end{array}$ & \\
\hline $\begin{array}{l}\text { Uitleg over het belang van de sociale } \\
\text { component in de interactie }\end{array}$ & Startzaterdag \\
\hline Structuur & \\
\hline $\begin{array}{l}\text { Preventie van chaos in de eerste module door } \\
\text { directere bereikbaarheid van studiecoaches }\end{array}$ & Skype, mail, telefoon \\
voor vragen over opdrachten, techniek en & \\
$\begin{array}{l}\text { organisatie. De meeste studiecoaches zijn } \\
\text { inmiddels (na 3 jaar) in de eerste }\end{array}$ & \\
$\begin{array}{l}\text { moduleperiode goed bereikbaar via de chat } \\
\text { functie van skype }\end{array}$ & \\
\hline Docentrol & \\
\hline $\begin{array}{l}\text { In de eerste module worden bij voorkeur } \\
\text { ervaren e-learning docenten ingezet }\end{array}$ & Blackboard \\
\hline $\begin{array}{l}\text { Docenten en studiecoaches sturen actief aan } \\
\text { op het inleveren van de eerste module }\end{array}$ & Blackboard, mail, telefoon \\
\hline
\end{tabular}




\section{HoOfDSTUK 10 \\ Conclusies en discussie}

\section{INLEIDING}

Het OSO e-learning onderzoek ging van start met de opdracht om een e-learning opleiding tot master Special Educational Needs tot stand te brengen, uitgaande van de onderwijsdoelen en - inhouden van de reeds langer bestaande reguliere tweejarige deeltijd opleiding. Als aanpak werd gekozen voor ontwerponderzoek (zie hoofdstuk 2). Vier ontwerpclusters stonden centraal binnen dit onderzoek:

- Interactie tussen studenten.

- Structuur.

- Docentrol.

- Leermaterialen.

Deze vier ontwerpclusters werden beschreven in een aantal ontwerpkenmerken die gevalideerd zijn vanuit verschillende invalshoeken (hoofdstuk 3). Vervolgens werden deze kenmerken geconcretiseerd naar twee modules die in een pilot met studenten werden uitgeprobeerd (hoofdstuk 4). Na een aantal bijstellingen volgde de implementatiefase die onderzoeksmatig werd gevolgd (hoofdstukken 5-9). Ook tijdens de implementatiefase vonden bijstellingen plaats. De opbrengst van dit proces is kennis over de bruikbaarheid en de effectiviteit van de verschillende ontwerpkenmerken en een bruikbare elearning leeromgeving voor studenten en docenten.

In dit hoofdstuk worden de onderzoeksvragen beantwoord (paragraaf 10.1). Daarna wordt een aantal kanttekeningen geplaatst bij de onderzoeksopzet en de gehanteerde instrumenten (paragraaf 10.2). Discussie vindt plaats rondom de volgende thema's: 'leren online leren' (paragraaf 10.3), 'leren online doceren' 
(paragraaf 10.4) en 'is het de moeite waard?' (paragraaf 10.5). In de slotparagraaf (10.6) worden opbrengsten van het OSO e-learning onderzoek en mogelijke vervolgvragen besproken.

\subsection{REFLECTIE OP DE BRUIKBAARHEID EN DE EFFECTIVITEIT VAN DE ONTWERPKENMERKEN}

\subsubsection{Centrale ontwerpclusters en onderzoeksvragen}

De centrale probleemstelling luidt: welke kenmerken heeft een valide, bruikbaar en effectief e-learning ontwerp voor de opleiding tot master SEN? Op grond van een beperkte literatuurstudie werd een eerste ontwerp gemaakt voor de e-learning opleidingen. Op basis van uitgebreidere literatuurstudie, advies van experts en twee pilotmodules kristalliseerde dit ontwerp zich verder uit. De vier centrale clusters van ontwerpkenmerken waren: interactie tussen studenten, structuur, docentrol en leermaterialen. In deze paragraaf wordt de vraag beantwoord of de ontwerpclusters en - kenmerken bruikbaar en effectief waren voor het e-learning onderwijs aan master SEN studenten. Hiertoe zijn in hoofdstuk 2 de volgende onderzoeksvragen geformuleerd:

1. Bruikbaarheid

a. Zijn de verschillende ontwerpkenmerken realiseerbaar voor studenten en docenten?

b. Zijn de verschillende ontwerpkenmerken zinvol in het kader van de opleiding?

2. Waardering - tevredenheid over het ontwerpcluster

a. Hoe waarderen de studenten de clusters van ontwerpkenmerken?

b. Met welke ontwerpkenmerken hangt deze waardering samen?

3. Effectiviteit: waardering - tevredenheid over modules

a. Hoe is de studenttevredenheid over de modules?

b. Haalt de studenttevredenheid over de modules de norm die door het management team is gesteld?

4. Effectiviteit: dropout en afstuderen

a. Hoe groot is de dropout na het eerste, tweede en derde studiejaar?

b. Hoe verhoudt deze dropout zich tot de dropout in de reguliere opleiding?

c. Welke factoren hangen samen met dropout? 
d. Zijn de e-learning modules geschikt om competenties te verwerven op het niveau van de master SEN?

e. Hoeveel procent van de studenten studeert af als master SEN binnen de termijn van twee jaar? Hoeveel procent van de studenten studeert af als master SEN binnen drie en vier jaar? Hoe verhoudt dit zich tot de studenten in de reguliere leerroutes?

In de volgende paragrafen worden per ontwerpcluster de antwoorden op de onderzoeksvragen 1, 2, 3c en 4c in samenhang met elkaar besproken. Vervolgens wordt ingegaan op het effect van de leeromgeving: onderzoeksvragen 3 en 4 .

\subsubsection{Interactie tussen studenten}

Bruikbaarheid (onderzoeksvraag 1)

Met betrekking tot de interactie tussen studenten zijn twee ontwerpkenmerken beschreven: samenwerkend leren via asynchrone schriftelijke discussies en sociale interactie. Het samenwerkend leren in kleine groepen via asynchrone discussies blijkt een bruikbaar ontwerpkenmerk te zijn voor de master SEN opleiding. Studenten dragen doorgaans voldoende frequent bij aan de opdrachten en studenten en docenten zijn enthousiast over de leerzaamheid van deze werkvorm. Bij de aanvang van de pilot en bij de aanvang van jaar 1 van de implementatiefase liepen de asynchrone discussies en samenwerkingsopdrachten echter niet meteen soepel. Veel studenten dachten dat zij online een geheel uitgewerkte opdracht als bijdrage moesten inleveren en begrepen niet goed dat het schrijven van discussiebijdrages iets heel anders van hen vergde. Ook vormde het gebrek aan evenwicht in de omvang van de bijdrages een probleem; sommige studenten droegen te veel bij en anderen te weinig. Dit leidde regelmatig tot een te hoge leeslast, en soms tot het stagneren van de opdracht. De leeslast werd ook een probleem doordat er te veel opdrachten waren gepland. Er werd een aantal aanpassingen gedaan waardoor deze problemen in de loop van de tijd verminderden en verdwenen. Samengevat bestonden deze maatregelen uit: het formuleren van criteria en communicatieregels, het trainen van de vaardigheid in online discussiëren en het verminderen van het aantal opdrachten tot één per week.

Ook sociale interactie bleek een bruikbaar kenmerk, hoewel dit in de pilot en in cohort 1 kwetsbaar bleek. De hoeveelheid sociale interactie was zowel in de pilot als in cohort 1 minder dan verwacht en in cohort 1 was de sociale verbondenheid 
in de groepjes soms te laag. De laagste verbondenheid werd gemeten in de module waarin de docenten de studenten zonder overleg hadden ingedeeld in nieuwe groepjes. De studenten stelden dit niet op prijs.

Zowel studenten als docenten bleken belang te hechten aan de sociale interactie tussen studenten. Docenten brachten dit in verband met onderlinge bemoediging en steun en met enthousiaste interactie in de cognitieve discussies. Na een aantal aanpassingen werden in het tweede cohort de sociale interactie en verbondenheid in voldoende mate gerealiseerd. De belangrijkste aanpassingen die op dit vlak werden doorgevoerd waren: studenten stellen voortaan zelf hun groepjes samen, het belang van sociale uitwisseling wordt sterker benadrukt naar studenten, de sociale uitwisseling wordt een programmaonderdeel op de startdag en per groepje wordt een online café geïmplementeerd.

\section{Waardering voor de samenwerking (onderzoeksvraag 2)}

In de periodes dat er voldoende verbondenheid ervaren werd, werd de samenwerking als goed gewaardeerd. De samenwerking met medestudenten werd lager gewaardeerd (voldoende tot ruim voldoende) in de periodes dat de studenten niet of nauwelijks onderlinge verbondenheid ervoeren. In de periode waarin er problemen waren met de samenstelling van de groepjes, werd de samenwerking het laagst gewaardeerd, als net voldoende. De waardering voor de samenwerking bleek verband te houden met zowel de cognitieve als de sociale aspecten van de interactie tussen studenten. Dit maakt duidelijk dat beide ontwerpkenmerken in dit cluster van belang zijn voor de waardering van het cluster als geheel.

\section{Effect (onderzoeksvragen 3c en 4c)}

De tevredenheid over de modules als geheel bleek in de meeste moduleperiodes niet of nauwelijks verband te houden met de tevredenheid van de studenten over de samenwerking. Ten aanzien van de uitval lijken beide kenmerken uit dit ontwerpcluster een beschermende rol te spelen. De studenten die bij aanvang positief gestemd waren over de sociale interactie hadden minder kans om uit te vallen. Een hoge waardering voor de samenwerking en voor de ervaren onderlinge steun voor het leerproces hadden eveneens een beschermend effect ten aanzien van uitval. 


\subsubsection{E-learning structuur}

\section{Bruikbaarheid (onderzoeksvraag 1)}

De strakke planning met verplichte opdrachten en deadlines (kenmerk 3) bleek een bruikbaar ontwerpkenmerk voor de e-learning opleidingen. De studenten gingen meestal mee in het voorgeschreven studieritme en de meeste studenten ervoeren de strakke planning als ondersteunend voor hun eigen studieplanning. De strakke studieplanning bleek ook een belangrijke voorwaarde voor het samenwerkend leren. In het eerste implementatiejaar ging een aantal studenten niet makkelijk mee met de voorgeschreven planning. Hierdoor ontstonden problemen in de samenwerking met medestudenten. Het bleek van groot belang dat studenten met de juiste verwachtingen omtrent studiebelasting aan de studie beginnen en thuis en op het werk de zaken goed regelen zodat er echte ruimte ontstaat voor deze belasting. In alle periodes kwam het voor dat studenten tijdelijk de structuur niet konden volgen door privéomstandigheden. De balans tussen studie, thuis en werk was fragiel en leidde soms tot acute problemen op het vlak van de belastbaarheid. Op momenten dat er wat mis ging, waren er uitzonderingen nodig op het rooster en het tijdpad. Voor een aantal studenten bleek ook het oppakken van de structuur na vakanties een struikelblok te vormen.

In de periodes waarin we dit nagingen, werd een evenwichtige spreiding van de studielast over de module (kenmerk 4) niet overtuigend gerealiseerd. Het lukte maar zeer ten dele om hier in de loop van de tijd verbetering in aan te brengen. Een aantal e-learners ervoer hierdoor tijdsdruk en stress. Sommige studenten gaven aan dat de tijdsdruk een negatieve invloed had op het begrip van de leerstof.

Ten aanzien van de strakke planning en de spreiding van de studielast werd een aantal aanpassingen doorgevoerd: uitgebreide informatie geven over de planning voorafgaand aan en bij het begin van de studie, het beschrijven van mogelijke oplossingen voor het geval dat iemand tijdelijk niet mee kan in het rooster met opdrachten en deadlines, het vergroten van de groepjes zodat tijdelijke uitval het proces van samenwerking minder zou bedreigen, het verminderen van het aantal opdrachten per module en het ad hoc uitstel verlenen van deelopdrachten. De verplichte deadlines voor individuele deelopdrachten kwamen te vervallen, de deadlines voor samenwerkingsopdrachten bleven gehandhaafd maar werden iets ruimer gesteld. Er werd geen effectieve aanpassing gevonden voor het probleem dat sommige studenten hadden met het weer opstarten na vakanties. 
Het ontwerpkenmerk 'helder geformuleerde leerdoelen en verwachtingen' bleek voor studenten een uitermate belangrijk kenmerk. Zij ervoeren in het algemeen de informatie in Blackboard als voldoende duidelijk, maar de duidelijkheid van de opdrachten en de daaraan gestelde eisen liet voor een aanzienlijk aantal studenten te wensen over. Dit leidde vooral in de beginfase tot veel communicatie en tijdverlies rondom deze organisatorische zaken. Er werden continu verbeterslagen gemaakt rondom de formulering van opdrachten en eisen en toch bleef onduidelijkheid voor veel studenten een probleem. Bij de aanvang van cohort 1 waren er veel technische onduidelijkheden, deze werden duidelijk minder door het publiceren van gedetailleerde handleidingen, een lijst met 'frequently asked questions' en het bieden van ondersteuning in een telefonisch spreekuur.

Waardering voor de organisatie van de e-learning (onderzoeksvraag 2)

De waardering van de studenten voor de organisatie van de e-learning modules was gemiddeld ruim voldoende tot goed. Dit was een onverwacht positieve waardering door de problemen die speelden rondom de spreiding van de studielast en de helderheid van de verwachtingen en eisen. De waardering voor de organisatie van de modules was groter naarmate de drie structuurkenmerken (strakke planning, spreiding studielast en helderheid van verwachtingen en eisen) beter gerealiseerd waren en naarmate er meer waardering was voor de docent. Mogelijk speelden de docenten een ondersteunende en compenserende rol ten aanzien van de geconstateerde problemen.

\section{Effect (onderzoeksvragen 3c en 4c)}

In meerdere periodes werden verbanden gevonden tussen de waardering voor de organisatie enerzijds en de tevredenheid en de aansluiting bij de leerwensen anderzijds. Goede ervaringen met de module organisatie hebben een positieve invloed op de waardering voor de module. Op momenten dat de organisatie te wensen overlaat, kunnen de studenten daardoor chaos en tijdsdruk en stress ervaren. Deze ervaringen beïnvloeden de waardering voor de module in negatieve zin. Bovendien bleken deze ervaringen samen te hangen met een verhoogde kans op uitval, met name de tolerantie voor het ervaren van chaos bleek laag. Een goede, duidelijke en strakke organisatie draagt bij aan de waardering voor modules en beschermt studenten tegen uitval. 


\subsubsection{Docentrol}

\section{Bruikbaarheid (onderzoeksvraag 1)}

Er werden voor de docentrol acht ontwerpkenmerken geformuleerd: zichtbare aanwezigheid, reactiesnelheid en tijd, moderatie, feedback, organisatorische ondersteuning, vraagsturing en flexibiliteit, controle en activering, sociale aanwezigheid en scholing. Aan de synchrone spreekuren werd na de pilotfase geen uitvoering meer gegeven. In grote lijnen bleken de overige kenmerken bruikbaar, maar veel aanpassingen op details bleken nodig en docenten hadden tijd en ondersteuning nodig om in hun rol te kunnen groeien.

Snel reageren en regelmatig zichtbaar aanwezig zijn bleken van groot belang voor studenten. Helaas bleken de eisen die op dit vlak bij de aanvang van cohort 1 gesteld waren, te leiden tot overbelasting van de docenten. Na ingrijpende bijstellingen op dit vlak kwamen tijdsbesteding en tijdstoekenning met elkaar in balans. De docenten bleven wel last houden van de continuïteit van de belasting bij e-learning. Zij hoopten hier middels actieve planning van hun werkzaamheden in de toekomst minder last van te krijgen.

In het begin van de implementatiefase werd het inhoudelijk modereren onvoldoende gerealiseerd. De docenten hadden nog onvoldoende vaardigheden op dit vlak en waren bovendien te veel tijd kwijt met het beantwoorden van vragen rondom de organisatie van de e-learning. Ervaring, informatie en ondersteuning leidden ertoe dat de docenten in de loop van de tijd sterker gingen modereren, hetgeen gewaardeerd werd door de studenten.

Het krijgen van concrete en opbouwende feedback bleek heel belangrijk voor studenten. Het geven van feedback op afstand bleek risicovol en vergde een leerproces van de docenten. De enorme behoefte van studenten aan feedback overviel de docenten en tegelijkertijd ervoeren zij zelf een tekort aan feedback van studenten. Meerdere feedbacksystemen werden door de docenten uitgeprobeerd, maar er bleef bij docenten behoefte bestaan aan een eenvoudiger systeem waarmee het geven van feedback minder tijd zou kosten.

Ondersteuning ten aanzien van de organisatie bleek uiterst belangrijk voor studenten, maar er ging soms veel te veel tijd in zitten, ten koste van de inhoudelijke rol van de docent. Door het invoeren van communicatie richtlijnen, een lijst met veelgestelde vragen en structurele technische ondersteuning werd dit aspect van de docenttaak teruggebracht tot beheersbare proporties. 
Het ontwerpkenmerk vraagsturing en flexibiliteit werd niet altijd overtuigend gerealiseerd binnen de strakke structuur van de e-learning. De literatuurkeuze en de richting van de eindopdracht lieten ruimte voor vraagsturing. De ruimte voor vraagsturing binnen discussies en samenwerkingsopdrachten werd niet door alle docenten gezien en benut.

Controle van de deelname van studenten bleek belangrijk omdat er onrust in groepjes ontstond als studenten onvoldoende deelnamen. Docenten ervoeren wel dat het moeilijk was om naar de 'digitale spijbelaars' de juiste activerende toon te treffen. Controle en activering werd door de docenten als een minder belangrijk kenmerk ervaren dan de meeste andere kenmerken van hun rol.

Sociale aanwezigheid werd in het begin onvoldoende gerealiseerd, de docenten misten toen ook het fysieke contact met studenten. Naderhand leerden de docenten om hier vorm aan te geven. $\mathrm{Zij}$ raakten toen ook meer tevreden over hun online contacten met studenten.

Scholing voor e-learning docenten bleek nodig, maar de aanvankelijk gekozen vormen bleken niet zo effectief. Studiedagen en handleidingen hadden niet de verwachte opbrengst. Het ondersteunen van het handelen in de praktijk, met informatie, voorbeelden en feedback, sluit meer aan bij de leerwensen van de docenten. Zij hebben behoefte aan ondersteuning 'on the job'.

\section{Waardering voor de docentrol (onderzoeksvraag 2)}

Onervaren e-learning docenten haalden doorgaans niet de tevredenheidnorm die door het management team was gesteld $(\geq 7)$. Ervaren e-learning docenten haalden de norm meestal ruimschoots. Daarbij bleek van belang dat ze niet alleen ervaring hadden met e-learning, maar ook dat ze expert waren in het vakgebied van de module. De tevredenheid over de docent hing duidelijk en consistent samen met de kwaliteit van de moderatie door de docent. Naarmate de moderatiekwaliteit van de docent hoger was, was de waardering voor de docent ook hoger. Daarnaast bleken er ook verbanden tussen de tevredenheid over de docent en de overige ontwerpkenmerken binnen het cluster 'docentrol'. Het merendeel van deze verbanden was positief. De verbanden met feedback en vraagsturing waren soms positief, soms negatief. Voor vraagsturing was er een tendens zichtbaar van negatieve waardering voor vraagsturing bij de start van de studie naar meer waardering voor vraagsturing in de loop van de moduleperiodes. 


\section{Effect (onderzoeksvragen 3c en 4c)}

In alle moduleperiodes gold: hoe groter de waardering voor de docent, hoe groter de tevredenheid over de module. In de helft van de moduleperiodes bleek dit verband significant. In alle moduleperiodes bleken er positieve en significante verbanden tussen kenmerken van de docentrol en de aansluiting bij de leerwensen van de student. De conclusie luidt dat de docentrol belangrijk is voor de tevredenheid van studenten en voor de aansluiting op hun leerwensen.

Ten aanzien van de uitval is de invloed van de docenten echter veel minder duidelijk. De uitval van studenten hangt niet of nauwelijks samen met kenmerken uit de docentrol. De docenten hebben in de eerste modules van cohort 1 kennelijk niet of nauwelijks een beschermende rol gespeeld ten aanzien van uitval. Deze uitkomst kan te maken hebben met het feit dat de docenten in deze eerste moduleperiodes nog onervaren waren en daardoor niet veel invloed konden uitoefenen. Toekomstig onderzoek met ervaren e-learning docenten zou een betrouwbaarder beeld kunnen geven van de mogelijkheden van docenten op dit vlak. In cohort 2 was zichtbaar dat veel studenten erg snel uitvielen. Hun docenten mogen dan ervarener zijn geweest, maar het is de vraag of zij door het korte tijdsbestek waarin de uitval plaatsvond tijd en mogelijkheid hadden om een beschermende rol te spelen.

\subsubsection{Leermaterialen}

\section{Bruikbaarheid}

Met betrekking tot de leermaterialen werd uitgegaan van één ontwerpkenmerk: rijke leeromgeving. De rijke leeromgeving kreeg enthousiaste reacties van experts (zie hoofdstuk 3), studenten en docenten. Toch ontwikkelde de rijke leeromgeving zich in de loop van de tijd door van een rijke naar een meer efficiënte leeromgeving. De diversiteit in leerobjecten verminderde, waarbij vooral de soorten leerobjecten behouden werden die studenten als zeer leerzaam ervoeren en waarvan door de meeste studenten gebruik gemaakt werd. Er kwam meer nadruk te liggen op het geven van compacte schriftelijke uitleg om complexe materie inzichtelijk te maken. Door deze wijzigingen werden de keuzeproblematiek en het risico van cognitieve overbelasting bij studenten verminderd terwijl het ontwikkelproces efficiënter werd. Sommige docenten hadden er moeite mee dat hun rol als 'leverancier van kennis' in belangrijke mate werd overgenomen door de kennisbronnen en kernprincipes in Blackboard. 


\section{Waardering}

De waardering van studenten voor de leerzaamheid van de modules was in de onderzochte periodes ruim voldoende tot goed. Deze waardering hing positief samen met de waardering voor de geschreven uitleg, de literatuur, de videofragmenten, de uitgewerkte voorbeelden en de weblinks.

\section{Effect (onderzoeksvragen 3c en 4c)}

Naarmate studenten de leerzaamheid van de module positiever waarderen, zijn zij ook meer tevreden over de module als geheel. Er blijkt geen verband tussen de uitval en de leerzaamheid van de modulematerialen.

\subsubsection{De effecten van de leeromgeving}

\section{Studenttevredenheid}

De studenttevredenheid was in de meeste gevallen ruim voldoende tot goed en haalde daarmee de door het management team gestelde norm, $\geq 7$. De spreiding was in een aantal modules van cohort 1 echter te groot. De studenttevredenheid vertoonde een positief verband met de structuur, de leermaterialen en de docentrol. Een negatieve attitude ten opzichte van computers (TAC vermijding, TAC negatieve invloed) hing in cohort 1 samen met een verminderde tevredenheid over de modules.

\section{Uitval en rendement}

Het bleek mogelijk om via e-learning de vereiste master SEN competenties te behalen. Op het vlak van uitval en afstudeerrendement werden de gestelde doelen vrijwel gehaald. Uitval en rendement bleken voor beide cohorten vergelijkbaar met de betreffende reguliere cohorten. Studenten die tevreden waren over de interactie met medestudenten en over de organisatie van de e-learning (de e-learning structuur) vielen minder vaak uit. Daarnaast bleek het van groot belang dat studenten de eindopdracht van hun eerste module inleveren; dit verhoogt sterk de kans dat zij doorgaan met de studie. Studiegebonden angst in de eerste module bleek niet gunstig, het verhoogde de kans op uitval. De scores met betrekking tot computerattitude vertoonden geen verband met het al dan niet uitvallen van studenten. 


\subsection{METHODOLOGISCHE ASPECTEN}

\section{Reflectie op ontwerponderzoek binnen de onderwijspraktijk van een hogeschool}

Het huidige onderzoek is een voorbeeld van een onderzoek dat geïnitieerd werd binnen een hogeschool. Het onderzoek was zo verweven met de praktijk, dat de belangen en beperkingen van het onderwijsinstituut ook belangen en beperkingen betekenden voor het onderzoek. Een voordeel van deze situatie was dat de complexe onderwijsinnovatie direct aansloot bij de ambities van de hogeschool waardoor de onderzoeksbevindingen leidden tot daadwerkelijke en blijvende vernieuwingen in het onderwijs. De evaluaties maakten het mogelijk om fouten te identificeren en te verhelpen en tot een sterker ontwerp te komen. De belangrijkste nadelen van de sterke praktijknabijheid waren de tijdsdruk en de beperkte personele capaciteit. De onderwijsinstelling wilde het studeren via elearning relatief snel introduceren en de collega's werden in beslag genomen door reguliere onderwijstaken waardoor zij niet ingezet konden worden om de nieuwe concepten uit te proberen in een pilot fase van het onderzoek.

Complexe onderwijsvernieuwingen die raken aan de professionele normen en waarden van leraren vergen een langzame en zorgvuldige implementatie (McKenney \& Reeves, 2012). Het huidige onderzoek betreft zo'n complexe onderwijsvernieuwing. Studenten en docenten worden uit de comfortzone van het reguliere klaslokaal gehaald en met elkaar geconfronteerd in een digitale situatie die van beide kanten nieuw gedrag vergt. Om een dergelijke onderwijsvernieuwing zorgvuldig voor te bereiden kent ontwerponderzoek meerdere iteratieve cycli waarin een prototype op basis van kennis en onderzoek wordt doorontwikkeld. Vaak vloeien de cycli in elkaar over (zie bijvoorbeeld McKenney \& van den Akker, 2005). De praktische onderwijssituatie op Windesheim limiteerde echter het aantal mogelijke iteraties en leidde tot abrupte, niet vloeiende overgangen tussen de cycli in het onderzoek.

In het onderzoek was er sprake van drie cycli: de analyse, de pilot en de implementatie. De overgang van de pilot naar de implementatiefase verliep niet vloeiend. In de pilot waren een aantal problemen al wel naar voren gekomen, maar deze problemen waren door de onderzoeker vrij gemakkelijk opgelost waardoor het risico voor de eerste opleidingsmodule van cohort werd onderschat. De problemen werden sterk uitvergroot toen in moduleperiode 1 met 39 studenten gewerkt werd door meerdere onervaren e-learning docenten. De 
module waarmee gewerkt werd, had bovendien geen deel uitgemaakt van de pilot waardoor een aantal onduidelijkheden niet eerder gebleken waren en niet vooraf gecorrigeerd konden worden.

De problemen die ontstonden, werden uiteindelijk opgevangen doordat de nieuwe e-learning docenten een intensief samenwerkingsverband vormden met elkaar en met de onderzoeker. De collega's in dit team losten gezamenlijk praktische problemen op en ondersteunden elkaar bij onverwachte gebeurtenissen. Besluiten over benodigde aanpassingen werden meestal voorbereid door de onderzoeker, maar gezamenlijk afgewogen en genomen. Op deze wijze konden de nieuwe e-learning docenten in snel tempo medeeigenaarschap opbouwen van de onderwijsvernieuwing. Het aantal studenten waarmee gewerkt werd, was weliswaar veel groter dan in de pilot, maar was nog wel voldoende overzichtelijk om uiteindelijk tot oplossingen te kunnen komen. De gebeurtenissen vormen een waarschuwing tegen het prematuur opschalen van onderwijsvernieuwingen naar grotere aantallen (zie ook McKenney \& Reeves, 2012). Klein beginnen en cyclisch verbeteren alvorens op te schalen, vormt de veilige weg voor zowel studenten als docenten.

$\mathrm{Na}$ de wat abrupte start van de implementatiefase werd de hele e-learning opleiding als iteratieve cyclus geïnterpreteerd, waarbij zowel eerste als volgende uitvoeringen van specifieke modules aanleiding gaven tot verbeteringen naar aanleiding van systematisch verzamelde reacties van studenten. Op deze wijze is op basis van dit onderzoek een bruikbaar en effectief ontwerp tot stand gekomen voor e-learning onderwijs. Dit betekent tegelijkertijd dat het ontwerp nooit helemaal af zal zijn. Bij iedere vernieuwing die wordt doorgevoerd en bij iedere module die wordt toegevoegd aan de opleiding zijn iteraties nodig om de kwaliteit van het onderwijs te optimaliseren.

Ontwerponderzoek heeft de potentie om tot theorievorming, kwaliteitsverbetering in het onderwijs en zinvolle onderwijsvernieuwingen te leiden. Deze potentie wordt echter in veel gevallen nog onvoldoende gerealiseerd (McKenney \& Reeves, 2012). De vraag is hoe ontwerponderzoek kan doorontwikkelen ten einde deze potentie wel te realiseren. Vanuit het huidige onderzoek wordt in dit kader gereflecteerd op de volgende vragen:

- Welke meerwaarde heeft ontwerponderzoek voor de onderwijspraktijk binnen een hogeschool? 
- Hoe kan in ontwerponderzoek systematisch rekening gehouden worden met beperkingen binnen de onderwijspraktijk?

- Hoe kunnen zo veel mogelijk docenten een stem krijgen in het ontwerp ondanks de bestaande tijdsdruk?

\section{Meerwaarde binnen het hoger onderwijs}

De belangrijkste meerwaarde van ontwerponderzoek voor het hoger onderwijs is dat dit type onderzoek beveiligt tegen implementaties die bepaald worden door de politieke, financiële en ideologische waan van de dag. Een degelijk uitgevoerde analysefase levert een stevige theoretische, empirische en praktische basis voor de ontwerpprincipes. Niet alleen voor wat betreft het 'hoe' van het ontwerp, maar ook ten aanzien van het 'waarom'. Het is juist dat 'waarom' dat een belangrijk uitgangspunt vormt voor de adoptie door anderen (McKenney \& Reeves, 2012). Het huidige e-learning ontwerp was in financieel opzicht voor de hogeschool zeker niet het meest aantrekkelijke en voor de hand liggende ontwerp omdat het niet goedkoper was dan regulier onderwijs. Het ontwerp kreeg alleen een kans vanwege de degelijkheid van de analyse en de bevestiging van de daaruit voortvloeiende ontwerpprincipes door experts.

\section{Omgaan met beperkingen die de onderwijspraktijk oplegt aan ontwerponderzoek}

Opvallend in het huidige onderzoek is de grote behoefte van studenten en docenten aan een uitwerking die correct is tot in de kleine details, waardoor zij duidelijk weten wat er van hen verwacht wordt. Onzekerheid en handelingsverlegenheid lijken de implementatie te belemmeren en leiden tot veel vragen en tijdverlies. In natuurlijke onderwijssituatie van de master SEN bleek het hierdoor niet goed mogelijk om te werken met de onvolledig uitgewerkte prototypes die thuishoren in de cycli van ontwerponderzoek. De twee pilotmodules waren minutieus uitgewerkt voordat zij van start gingen, maar ondanks deze uitwerkingsgraad oordeelden veel studenten dat het een te groot risico was om deel te nemen aan een pilot e-learning. De conclusie voor ontwerpgericht onderzoek lijkt te moeten luiden dat praktijknabij ontwerpen de mogelijkheid tot het werken met prototypes inperkt, en een grote nadruk vergt op het adequaat realiseren van praktische details. De vertaling van theorie naar praktijk vergt invulling van veel details die ieder voor zich en in onderlinge samenhang het succes van die vertaalslag bepalen.

Het verdient de voorkeur dat onderzoekers al in de fase van het onderzoeksvoorstel rekening houden met de beperkingen die worden opgelegd 
door de onderwijsomgeving en hier systematisch compensaties voor inbouwen. In het huidige onderzoek werden ad hoc oplossingen gevonden voor een tekort aan iteraties en een moeizame overgang tussen twee van de cycli. Het is belangrijk als in ontwerponderzoek de aandacht systematisch wordt gericht op de mogelijke gevolgen van een beperkter aantal iteraties en de hobbels die dat met zich mee kan brengen in de overgang tussen de verschillende cycli. Van daaruit kan dan gezocht worden naar compensaties waar vanaf het begin van het onderzoek rekening mee wordt gehouden., zonder daarbij afbreuk te doen aan de algehele fasering van het onderzoek die de kernkwaliteit bepaalt van ontwerponderzoek (analyse prototype/pilot - implementatie). Benodigde alternatieven en compensaties kunnen gevonden te worden door het zorgvuldig integreren van bestaande kennis over het optimaliseren van implementatieprocessen in het onderwijs (zie onder meer Spillane, Reiser, \& Reimer, 2002; Thoonen, Sleegers, Oort, Peetsma, \& Geijssel, 2011). Op die manier kan duidelijk worden wat leraren binnen onderwijsorganisaties nodig hebben om op een economisch verantwoorde wijze de verschillende fasen van het ontwerponderzoek te doorlopen en te komen tot duurzame en goed uitgebalanceerde implementatie waarin altijd ruimte blijft voor verdere verbetering.

\section{Stem geven aan docenten in het ontwerp}

Om het realiteitsgehalte en de uitvoerbaarheid van onderwijsvernieuwingen te bewaken is het van groot belang om de docenten een stem te geven in het ontwerp door hen op te nemen in het ontwerpteam (McKenney \& Reeves, 2012). In het huidige onderzoek was dit aanvankelijk wel zo gepland maar lukte dit uiteindelijk niet door allerlei (niet ongebruikelijke) overmachtsituaties binnen de onderwijsinstelling. Compensatie hiervoor vond ten dele plaats doordat de onderzoeker zelf een ervaren $\mathrm{HBO}$ docent was. Hierdoor kon toch worden aangestuurd op realiteitsgehalte en uitvoerbaarheid. De combinatie van de rol van onderzoeker en docent lijkt een duidelijke meerwaarde te hebben in situaties waarin er onvoldoende ruimte beschikbaar is voor een ontwerpteam. Als de rol van onderzoeker en van praktiserend docent in één persoon geconcentreerd worden blijft echter de vraag: hoe krijgen andere docenten een stem in het ontwerp? In het huidige onderzoek gebeurde dat enerzijds door collega docenten na de pilotfase te betrekken bij het in teamverband ontwikkelen en uitvoeren van e-learning modules en anderzijds door middel van teamvergaderingen, teamscholingen en individuele interviews. 
Ontwerponderzoek kent naast het ontwerpteam ook andere instrumenten om de betrokkenheid van docenten bij de vernieuwing te vergroten. Zo lijkt het interview een onderzoeksinstrument dat positieve effecten kan hebben ten aanzien van de implementatie van de vernieuwing. In en na de interviews gaven meerdere docenten aan het heel prettig te vinden om zo uitvoerig hun mening te kunnen geven over het werken binnen e-learning. Zij voelden zich gehoord en met hun mening werd in veel gevallen wat gedaan. Een gevoel van erkend en serieus genomen worden ten aanzien van het onderwerp e-learning leek een belangrijke opbrengst van de interviews naast de beoogde onderzoeksmatige opbrengst. Het gevoel van erkenning leek te ontbreken bij het afnemen van vragenlijsten. Vragenlijsten stuitten op minder enthousiasme dan interviews, terwijl de interviews feitelijk tijdrovender waren. In ontwerponderzoek worden onderzoeksinstrumenten gebruikt tijdens pilots en tijdens de implementatie. Het lijkt vanuit de ervaringen binnen het huidige onderzoek voor de hand te liggen dat het gebruik van deze onderzoeksinstrumenten invloed kan uitoefenen op het implementatieproces. Het lijkt dan ook van belang om uitvoeriger na te gaan en te beschrijven op welke punten er een synergie bereikt kan worden tussen onderzoeksinstrumenten en implementatiestrategieën. Ook de omgekeerde vraag lijkt belangrijk: zijn er onderzoeksinstrumenten die de implementatie belemmeren en waar ligt dat aan?

\section{Reflectie op de gehanteerde vragenlijsten}

In het onderzoek werd veelvuldig gebruik gemaakt van vragenlijsten. Daarbij is waar mogelijk gebruik gemaakt van bestaande vragenlijsten. Voor het Nederlandse taalgebied bestonden geen voor dit ontwerp bruikbare vragenlijsten. De gebruikte Amerikaanse vragenlijsten (de vertaalde TAC en de Classroom Community Scale, CCS) bleken items te bevatten die niet meer actueel waren (gezien de snelle uitbreiding van het gebruik van ICT middelen) en die een culturele bias vertoonden (CCS). Uit de TAC zijn de niet meer actuele items verwijderd. Voor het Amerikaans bestond inmiddels al een geactualiseerde versie van de TAC (Christensen \& Knezek, 2009). Het was echter moeilijk om die versie te vertalen naar het Nederlands omdat er voor een aantal schalen slechts vijf items gebruikt werden. Bij een verminderde betrouwbaarheid door de vertaling zouden wellicht zo veel items weggelaten moeten worden dat geen betrouwbare schaal over zou blijven. De oudere vorm van de TAC was reeds eerder naar het Nederlands vertaald (Moonen, 2001) en er is voor gekozen om met diezelfde vertaling te werken. 
De vertaling van de CCS (Rovai, 2002a) naar het Nederlands vergde niet alleen een verandering van taal maar ook een aanpassing op cultureel vlak. De CCS leed door de vertaling verlies op het vlak van de betrouwbaarheid. Dit werd opgelost minder betrouwbare items te verwijderen. Er bleven drie betrouwbare CCS schalen over : 'steun van medestudenten voor het leerproces' ,'verbondenheid' en 'aansluiting bij de leerwensen'. De oorspronkelijke CCS kende slechts twee schalen: verbondenheid en leren.

De overige vragenlijsten zijn zelf geconstrueerd waardoor nauwkeurig kon worden aangesloten op de ontwerpkenmerken. Voor de constructie is waar mogelijk gebruik gemaakt van items uit bestaande Amerikaanse en Australische schalen (Ginns \& Ellis, 2007; Pearson \& Trinidad, 2006; Stewart, Hong \& Strudler, 2004). Om de betrouwbaarheid en de validiteit van de zelfgeconstrueerde vragenlijsten na te gaan is steeds de homogeniteit (Cronbach's alpha) berekend en werd de convergente validiteit (Pearson correlatie) bepaald tussen verschillende schalen die geacht werden hetzelfde concept te meten (zie hoofdstuk 2). Bij aanvang werd gestart met vrij lange vragenlijsten waaruit uiteindelijk betrouwbare schalen werden gedestilleerd. Dit had als nadeel dat het invullen van de vragenlijsten aanvankelijk vrij veel tijd kostte van de studenten. Dit leidde tot beperkingen in de hoeveelheid vragenlijsten die per moduleperiode afgenomen konden worden. Niet alle studenten vulden de vragenlijsten steeds in. Het totaal aantal respondenten was kleiner dat het aantal aangeschreven studenten. Dit vermindert de betrouwbaarheid van de uitkomsten en introduceert mogelijk een non- respons bias in het onderzoek. Men kan zich immers afvragen welke studenten het zijn die niet deelnemen aan de vragenlijsten. In het tweede cohort bleken vooral de uitvallers tot de non-respons te behoren. Om deze reden is besloten om in cohort 2 geen correlatie berekeningen te maken met betrekking tot de uitval van studenten. Om de geldigheid van het onderzoek te versterken is gewerkt met meerdere vormen van dataverzameling; het onderzoekerslogboek, asynchrone bijdrages van studenten, vragenlijsten en docent interviews. Triangulatie leverde doorgaans congruente gegevens op en versterkte zo de validiteit van de uitkomsten.

De kleine groepen respondenten vormden een probleem bij de keuze van de te hanteren statistische technieken. Hoewel de assumptie van normale verdeling in een aantal gevallen werd geschonden is toch de keuze gemaakt om te werken met variantie analyse voor herhaalde metingen. De variantie analyse is betrekkelijk 
robuust tegen schendingen van de normale verdeling, zeker als maar met één factor wordt gewerkt. Daar waar de assumptie van sphericiteit werd geschonden is de Greenhouse-Geisser correctie gebruikt of zijn de multivariate toetsen gerapporteerd.

\section{Reikwijdte van het onderzoek}

Er wordt in dit onderzoek gestreefd naar het ontwikkelen van kennis met betrekking tot ontwerpkenmerken voor een bruikbare en effectieve e-learning opleiding en naar het ecologisch valideren (Barab \& Squire, 2004; Gravemeijer \& Cobb, 2006) van de ontwikkelde aanpakken. De meeste van de getoetste aanpakken bleken na een aantal aanpassingen binnen onze onderwijssetting bruikbaar en effectief. Gebruikers van het huidige onderzoek kunnen op grond van de beschrijving van de onderwijssetting overeenkomsten en verschillen met hun eigen setting bepalen en op grond daarvan bepalen welke bevindingen mogelijk ook voor hun eigen setting bruikbaar zouden kunnen zijn. Daarbij is zeker ook aandacht nodig voor culturele verschillen tussen onderwijs settingen zoals bijvoorbeeld kunnen spelen tussen Nederland en Vlaanderen. Andere factoren waarmee rekening gehouden zou moeten worden zijn geslacht, niveau en inhoud van de opleiding .

\subsection{AANPASSINGEN AAN HET ONTWERP: LEREN ONLINE LEREN}

\section{Voor het eerst online leren}

Starten met online leren bleek voor studenten en docenten niet eenvoudig. Beschouwing van de aanpassingen die doorgevoerd werden binnen de diverse ontwerpclusters leert dat deze aanpassingen vaak gerelateerd waren aan wat door Arbaugh (2004) 'leren online leren' genoemd wordt. Zo bleek het belangrijk om ervoor te zorgen dat studenten met de juiste verwachtingen aan de studie begonnen, zowel op het vlak van de te verwachten studielast als met betrekking tot de wijze van studeren (paragraaf 6.3). Dit betekende dat er aanpassingen kwamen in de voorlichting, de intake en het starttraject. Daarnaast werd het aantal handleidingen uitgebreid en er werd een F.A.Q. sectie aangemaakt om meer duidelijkheid te scheppen over technische- en andere aspecten van de elearning studie. De online interactie bleek een aantal problemen op te leveren voor beginnende e-learning studenten en -docenten(paragraaf 5.1.5). Om hieraan tegemoet te komen werden criteria en regels geïmplementeerd om de leeslast te reguleren en om de kwaliteit, de timing en de netetiquette van de bijdrages te 
bevorderen. Ook bleek het van belang (zie paragraaf 7.3.1) dat de docenten de studenten in hun eerste module feedback gaven op de wijze van online discussiëren ter ondersteuning van het leerproces van de studenten op dit vlak, en ook om de onzekerheid van studenten te verminderen. Om te zorgen dat de studenten optimaal profiteerden van de leermaterialen (paragraaf 8.4) bleek het nodig om de studenten te leren navigeren door de leereenheden.

Evenals in het onderzoek van Arbaugh (2004) werd in het OSO e-learning onderzoek de tendens geconstateerd dat veel uitval vroeg plaatsvindt; in of net na de eerste online module. De ervaringen van studenten in deze eerste module zouden wel eens bepalend kunnen zijn voor hun beslissing om door te gaan of te stoppen. Hun eerste ervaringen lijken cruciaal voor de meningsvorming over elearning. Het is voor onderwijsinstellingen dan ook van groot belang om ervoor te zorgen dat de eerste ervaringen met e-learning goed zijn (Arbaugh, 2004; Levy, 2004) door startproblemen te voorkomen, te identificeren en te verhelpen. Startproblemen van e-learners worden door verschillende factoren veroorzaakt (Arbaugh, 2004). Hieronder worden besproken : de rol van de student in de online leeromgeving en het wegwijs raken in deze omgeving.

\section{De rol van de student in de online leeromgeving}

De informatie die studenten voorafgaand aan de studie verwerken over e-learning is van groot belang voor een soepele start (paragraaf 6.3). Het beginnen met elearning verloopt voor een aantal studenten niet soepel omdat zij de informatie vooraf onvoldoende gelezen hebben. Dit leidt vaak tot misvattingen over e-learning zoals bijvoorbeeld een onderschatting van de studielast (Clay, Rowland, \& Packard, 2009; Tweddell Levinsen, 2006), of een verkeerd beeld van het niveau en de wijze van studeren. Bovendien lukt het studenten niet altijd om uit de veelheid van de aanwezige informatie een duidelijk samenhangend beeld te krijgen van e-learning (zie ook Bullen, 1998; Levy, 2004). Voor een aantal studenten blijkt e-learning bij het begin dan ook een onduidelijke en verwarrende ervaring. Soms ontstaan daardoor gevoelens van angst, desoriëntatie, overbelasting en chaos (Easton, 2003; Levy, 2004). Deze gevoelens zijn niet zonder risico omdat ze blijkens het huidige onderzoek samenhangen met een verhoogde kans op uitval.

Uit het huidige onderzoek bleek dat studenten met realistische verwachtingen een prettiger start maakten met de studie doordat zij hun studieactiviteiten gepland hadden en op hun omgeving afgestemd. Op deze manier werden gevoelens van 
overbelasting voorkomen en ontstond meteen een patroon van regelmatige deelname. Dit gold echter niet voor alle studenten. Het beeld van de flexibiliteit van online studeren bracht met zich mee dat sommige studenten in cohort 1 de studiebelasting bij aanvang ernstig onderschatten (zie ook Clay et al., 2009). De studiebelasting van online studeren is echter zeker niet minder dan van de reguliere studie (Mc Cullough \& Aimard, 2006). Studenten moeten er goed op voorbereid zijn dat online studeren zelfdiscipline vergt en een goede planning en organisatie (Bozarth, Chapman, \& LaMonica, 2004; Bullen, 1998; Clay et al., 2009; Hwang \& Wang, 2004). Studenten die de benodigde zelfdiscipline missen zouden op grond van deze informatie kunnen kiezen om op een reguliere manier te gaan studeren. Dit is waarschijnlijk kansrijker voor deze studenten (Leidner \& Jarvenpaa,1995).

De e-learning student heeft een actieve rol in de omgang met kennis (zie ook Garrison et al., 2000; Levy, 2004; Pallof \& Pratt, 2001). Deze rol wordt in de OSO elearning opzet vooral gekenmerkt door het samenwerkend leren via asynchrone discussies. Voor sommige studenten uit OSO e-learning cohort 1 kwam dit vrij onverwacht. Zij dachten dat deze wijze van leren heel individueel zou zijn zonder veel interactie met medestudenten. Na de start van de studie kwamen deze verwachtingen echter niet uit. Het is van belang dat dit soort onjuiste verwachtingen voorkomen worden door voorafgaand aan de studie goede informatie te geven over alle consequenties van het online samenwerkend leren (Cramphorn, 2004; McGorry, 2002).

Samenwerkend leren kan een uitdaging kan betekenen voor volwassenen die zijn opgegroeid met kennistransmissie en een passieve studentrol. De eerdere leergewoonten in meer traditionele onderwijssituaties kunnen het samenwerkend leren belemmeren (Arbaugh, 2004; Kennedy \& Duffy, 2004; Pallof \& Pratt, 2001). Het kan voor nieuwe e-learning studenten daardoor moeilijk zijn om hun nieuwe rol op zich te nemen in de leeromgeving (Arbaugh, 2004). Dit blijkt doordat het in de beginfase vaak moeilijk is om discussies goed op gang te krijgen (zie hoofdstuk 5 en ook Levy, 2004). Veel studenten moeten echt over een drempel om actief te gaan deelnemen aan de discussies (Coppola, Hiltz, \& Rotter, 2002; Cramphorn, 2004; Grabinger, 2004; Pallof \& Pratt, 2001).

Online samenwerkend leren blijkt bovendien speciale vaardigheden te vergen die expliciet aangeleerd moeten worden ( zie hoofdstuk 5 en ook Haavind, 2006; Pallof \& Pratt, 2007). 
Deze vaardigheden hebben tot doel om een veilig, sociaal en leerzaam klimaat te scheppen voor studenten en docenten. Aan de basis van het veilig klimaat ligt de implementatie van netetiquette- en andere communicatieregels die ontworpen zijn voor de leeromgeving en die gecommuniceerd, gedemonstreerd en gehandhaafd worden door alle daarin werkzame docenten (Anderson, Rourke, Garrison, \& Archer, 2001). Daarnaast stimuleert de docent de sociale communicatie en de inhoudelijke kwaliteit van de asynchrone bijdrages.

In het OSO e-learning onderzoek bleven de sociale aspecten van de communicatie in cohort 1 achter bij de verwachtingen. Online sociale communicatie vergt speciale middelen vanwege het ontbreken van non-verbale cues (Garrison et al., 2000). Meer ervaren e-learners maken meer gebruik van informele communicatie aspecten (Arbaugh, 2004). Dit dient echter wel expliciet gestimuleerd te worden, anders blijft het percentage informele communicatie laag (Conaway, Easton \& Schmidt, 2005). Daarnaast dienen ook de cognitieve aspecten van de asynchrone communicatie expliciet gestimuleerd te worden. Niet iedere asynchrone bijdrage vormt immers een goede bijdrage aan het leerproces van studenten (Aviv, Erlich, Ravid, \& Geva, 2003; Dennen, 2008; Häkkinen \& Järvelä, 2006; Schellens \& Valcke, 2005; Vonderwell, 2003) en de kwaliteit van de bijdrages is belangrijker voor het leerproces dan de gevraagde kwantiteit (Conaway et al., 2005). Pallof en Pratt (2007) maken door middel van rubrics duidelijk aan welke eisen een goede discussiebijdrage moet voldoen. Het opnemen van een rubric in de online leeromgeving is echter niet genoeg; training, geschikte opdrachten, moderatie, feedback en beoordeling door de docent zijn nodig om leerzame en engagerende discussies tot stand te brengen. De materialen moeten precies kloppen en de acties van de docent moeten daar nauwkeurig op aansluiten (Haavind, 2006).

Het OSO e-learning ontwerp werd gedurende de looptijd van het onderzoek versterkt door op verschillende vlakken de studenten te ondersteunen bij hun nieuwe rol in de leeromgeving. In de voorlichting voorafgaand aan de opleiding ligt inmiddels de nadruk op studiebelasting, zelfsturing en samenwerkend leren via verplichte deelname aan asynchrone discussies (clusters structuur en docentrol). In de daaropvolgende intake wordt expliciet gevraagd naar het beeld dat de student van de opleiding heeft en naar de concrete bereidheid tot online samenwerken in de voorgeschreven frequentie (cluster docentrol). Op de fysieke startdag (cluster docentrol) is aandacht voor kennismaking, voor communicatierichtlijnen en netetiquette en voor het belang van online sociale 
communicatie en ondersteuning. Er wordt een toelichting gegeven op de functionele splitsing van de sociale en de cognitieve bijdragen. Daarnaast worden op de startdag de eisen voor asynchrone cognitieve bijdrages uitgedeeld. Deze worden toegelicht en er wordt mee geoefend naar aanleiding van bestaande en geanonimiseerde discussiebijdrages van oud studenten. De handleiding voor online discussiëren is aangescherpt en er zijn voorbeelden opgenomen van gewenste en ongewenste bijdrages (cluster structuur). Naast het minimum aantal discussiebijdragen is er nu ook een maximum aantal vastgesteld om te voorkomen dat studenten zich bedolven voelen onder en bedreigd door een 'lawine' van bijdrages (zie hoofdstuk 5, en ook Conrad, 2002). Docenten hebben middelen gekregen om gemakkelijker feedback te geven op de wijze van discussiëren. Dit betreft een systeem met rubrics en concrete voorbeelden. Dit systeem wordt voornamelijk gebruikt in de eerste module van een nieuw cohort. Het toepassen ervan is helaas nog steeds vrij arbeidsintensief. Een vervangend systeem zou kunnen zijn dat de vaardigheid tot online discussiëren in de eerste moduleweken stapje voor stapje opbouwen door steeds nieuwe criteria toe te voegen. In een dergelijk systeem wordt per week maar één criterium beoordeeld hetgeen de beoordeling vergemakkelijkt en versnelt. Het lijkt van belang om dan als startcriterium te kiezen dat studenten op elkaar moeten reageren en elkaar de ruimte moeten laten in de discussie om te voorkomen dat zij de discussie als 'opdracht' zien die zij individueel en excellent moeten afleveren.

\section{Wegwijs raken in de online omgeving}

Oriëntatie op de leeromgeving behelst het leren kennen en gebruiken van de structuur van de module en van de daarin beschikbare handleidingen en discussieruimtes (Levy, 2004). De meeste deelnemers in de casestudy van Levy (2004) vonden snel en makkelijk hun weg in de online leeromgeving, maar sommige studenten reageren heftig op die eerste kennismaking. Angst, desoriëntatie, cognitieve overload en concentratieproblemen traden op en sommige studenten kwamen niet tot een goede oriëntatie ondanks de zeer gestructureerde leeromgeving. Ook O'Regan (2003) geeft de frustratie weer van nieuwe e-learning studenten die eindeloos aan het zoeken zijn, in de war raken en zich verdwaald voelen in de leeromgeving.

De emotionele ervaringen waarover Levy (2004) en O'Regan (2003) rapporteren, traden eveneens op in het OSO e-learning onderzoek met een aantal studenten in het eerste cohort. $\mathrm{Zij}$ raakten gefrustreerd en angstig en vroegen erg veel 
begeleiding ten aanzien van de e-learning werkwijze en de structuur van de omgeving (zie hoofdstuk 7). Ook kwam het voor dat studenten niet alle kernstukken lazen, waardoor zij niet goed wisten wat er wanneer van hen verwacht werd.

Alle OSO e-learning modules hadden dezelfde structuur en werkwijze, en net als in het onderzoek van Arbaugh (2004) nam het gemak waarmee de e-learners de omgeving gebruikten in de loop van de tijd toe; de begeleidingsvragen op dit vlak namen af. In de literatuur over begripsprocessen op internet verklaart men dit vanuit toegenomen kennis en verbeterde geïnternaliseerde schemata (Foltz, 1996; Moore, Downing \& York, 2009). Deze toegenomen kennis en gewoontevorming verminderen de belasting van het werkgeheugen waardoor het risico van cognitieve overbelasting kleiner wordt.

Intrigerend was dat lang niet alle OSO e-learning studenten bevangen werden door angst en paniek. De verschillen tussen studenten waren groot. Dit zou kunnen samenhangen met de eerdere ervaring van studenten met vergelijkbare internet platformen. Meer ervaren studenten beschikken bij de start waarschijnlijk al over bruikbare schemata in het lange termijn geheugen waardoor zij minder belast raken door de omgeving en minder chaos ervaren door cognitieve overbelasting. Daarnaast leken studenten verschillend te reageren op dit soort ervaringen. Sommigen vochten zich zelf een weg uit het labyrint, en anderen vroegen veel ondersteuning van de docenten en/of vertoonden vermijdingsgedrag. Dit vermijdingsgedrag kan verklaren waarom sommige studenten een aantal belangrijke stukken niet lazen. Niet goed lezen van stukken kan ook samenhangen met cognitieve overbelasting. Ook een volkomen helder aangelegde structuur in de leeromgeving kan dit soort situaties niet volledig voorkomen. Het ontbreken van individuele schemata maakt ook een heldere structuur tot een doolhof.

De ervaring van angst en chaos bleek samen te hangen met het uitvallen van studenten, bovendien veroorzaakte de grote ondersteuningsbehoefte van sommige studenten een flinke werkdruk voor docenten. Hoewel enige angst en chaos vrijwel onvermijdelijk lijkt bij het leren werken met een nieuw platform is uiteraard toch geprobeerd om dit zo veel mogelijk te voorkomen. Een belangrijke maatregel die doorgevoerd werd op grond van Conrad (2002), is het eerder openstellen van de eerste module. Het lijkt zeer ongelukkig en riskant om in de 
eerste module de kennismaking met de online omgeving samen te laten vallen met de start van de studie (zie ook Conrad, 2002; Levy, 2004). Verdwaald raken en tegelijkertijd aan allerlei studieverplichtingen moeten voldoen vormen een riskante combinatie, zeker daar waar we zien dat de ervaringen in de eerste module zo cruciaal zijn voor de beslissing om door te gaan of te stoppen (Arbaugh 2004). Om deze risicovolle combinatie te voorkomen wordt de eerste elearning module twee weken voor de startzaterdag geopend voor studenten. Studenten kunnen dan twee weken rustig kijken en wennen. Er wordt bovendien de nadruk op gelegd dat de studenten een aantal belangrijke stukken printen, overzichtelijk opslaan en lezen. Op de startzaterdag kunnen zij dan hun vragen stellen en vindt er een interactieve demonstratie plaats van de digitale leeromgeving om deze vragen te beantwoorden. De schema- opbouw die dan al begonnen is kan worden versterkt door mondelinge uitwisseling. Door op deze wijze de tijd te nemen om de eerste module te verkennen krijgen de studenten de kans om correcte schemata op te bouwen zonder de hete adem van onderwijsverplichtingen in hun nek en ontstaan geen onnodige cognitieve overload, verwarring en chaos.

\subsection{LEREN ONLINE DOCEREN}

Ook voor de docenten bleek het starten met e-learning in het huidige onderzoek niet altijd gemakkelijk. Online doceren kent een leercurve en de eerste modules kunnen als extra belastend en tijdrovend ervaren worden (zie ook Berger, 1999; Conrad, 2004; Hall, 2006; Harasim, 2000; Morris, Xu, \& Finnegan, 2005; Thompson, 2004).

\section{Overbelasting bij de start}

De e-learning docenten in het huidige onderzoek gaven in de interviews blijk van overbelasting in de eerste twee moduleperiodes. Deze overbelasting kwam in belangrijke mate voort uit de door docenten niet verwachte stortvloed van organisatorische en technische vragen van studenten. Deze stortvloed van vragen viel samen met het feit dat de docenten, net als de studenten, nog moesten wennen aan de werkwijze in Blackboard en aan de daarbij behorende software. Daarnaast werd overbelasting veroorzaakt door de complexiteit van de nieuwe docentrol en doordat de docenten te veel groepjes moesten begeleiden die te veel opdrachten moesten uitvoeren. De overbelasting verergerde nog doordat 
sommige studenten geen maat hielden met de aantallen en de lengte van de asynchrone bijdrages. Er waren nog onvoldoende richtlijnen om de communicatie tussen studenten en docenten te stroomlijnen.

Daar waar studenten al cognitieve overload ervoeren, leek dit voor docenten nog erger. Er heerste dan ook een gevoel van paniek bij docenten. Zij ervoeren de werkdruk in de aanvangsfase als zeer hoog. Deze chaos en paniek bij de start van een e-learning opleiding is geen ongewoon verschijnsel. Verschillende onderzoekers constateerden deze zelfde chaos bij de start van een e-learning initiatief (Alavi, Yoo, \& Vogel, 1997; Cronjé et al., 2006; Easton, 2003). Chaos en een hoge werkdruk werken demotiverend voor docenten (Berger, 1999; Hiltz, Kim \& Shea, 2007). Het is een ongelukkige samenloop van omstandigheden als zowel studenten als docenten nieuw zijn in de leeromgeving. Beginnende studenten leunen zwaar op docenten voor de ondersteuning. Als docenten dezelfde paniek ervaren als studenten en ook de weg kwijt zijn dan wordt het voor de docenten heel zwaar. Het is niet eenvoudig om deze aanvangspaniek te voorkomen. Mogelijk was het in de eerste OSO e-learning modules beter gelopen als de nieuwe docenten eerst hadden meegedraaid in kleine pilots. Gelukkig kwamen deze chaos en paniek niet terug bij de docenten die later instroomden. Zij kwamen in een omgeving die qua werkdruk en communicatierichtlijnen beter uitgebalanceerd was en konden met hun vragen en met de problemen van studenten terecht bij meer ervaren docenten. Het bleek een voordeel om onervaren docenten te laten werken met één groepje studenten in plaats van twee, en om ze te laten werken met een module waarin ze veel inhoudelijke ervaring en expertise hadden.

\section{Online doceren: starten vanuit het reguliere docentschap}

Bij de aanvang van de implementatiefase van het OSO e-learning onderzoek waren in het ontwerp zeven kenmerken beschreven van de online docenttaak. De beschrijving van deze kenmerken bleek echter onvoldoende houvast te geven voor docenten om in de eerste moduleperiode tot een uitgebalanceerde taakuitoefening te kunnen komen. In de literatuur is weliswaar een aantal beschrijvingen van de docentrol voorhanden, maar ook deze zijn zo complex dat ze niet makkelijk na te volgen zijn (bijvoorbeeld Bender, 2003; Collison, Elbaum, Haavind, \& Tinker, 2000; Pallof \& Pratt, 2007). Er wordt vaak een veelheid van taken aangegeven en het relatieve belang van de verschillende taken komt nauwelijks aan de orde (Smits \& Voogt, 2009). Daarnaast worden de docenttaken 
meestal niet beschreven vanuit de, voor de docenten bekende, reguliere docentrol. De nadruk wordt doorgaans eerder gelegd op het 'anders' zijn van de online docenttaken dan op de overeenkomsten met de reguliere docentrol. Dit komt de herkenbaarheid voor reguliere docenten niet ten goede. Dit probleem is een mogelijke verklaring voor het gebrek aan succes van de OSO e-learning docenthandleiding en de cursus voor docenten voorafgaand aan de e-learning opleidingen in het huidige onderzoek.

De ervaring die docenten hebben opgedaan in reguliere lessen zorgt ervoor dat zij in hun reguliere lessen automatisch kunnen functioneren, zonder al te veel bewust denkwerk. Als leraren voor het eerst online gaan lesgeven vallen deze automatismen weg (Dziuban, Shea \& Arbaugh, 2005). De totaal andere, en aanvankelijk cognitief belastende, online context roept het eerder geleerde docentgedrag niet automatisch op en de meeste raadgevingen in de literatuur doen dat evenmin. Een docent kan zich hierdoor verloren en angstig voelen (Anderson et al., 2001).

Het verlies van de normale onderwijskaders en -reflexen kan er in resulteren dat het gedrag van de onervaren online docent aanvankelijk te sterk gestuurd wordt door individuele studenten die aandringen op het geven van verduidelijking en feedback. De kwaliteit van de groepsgewijze cognitieve en sociale interactie komt daardoor in het gedrang en de interactie is soms meer individueel gericht dan groepsgericht. Docenten vergeten om cognitief en sociaal gedrag te tonen dat in reguliere lessen behoort tot hun normale gedragrepertoire. Zo vergeten docenten soms bijvoorbeeld om hun inhoudelijke expertise in te brengen, voorbeelden te geven, passie uit te drukken voor hun vakgebied (zie ook Braten \& Strømsø, 2006; Morris et al., 2005) en gebruik te maken van humor (zie ook Coppola \& Hiltz, 2002). Een te veel aan individuele interactie kan ten koste gaan van de zichtbare aanwezigheid van de docent in de groep, terwijl online studenten juist meer waarde hechten aan dit laatste (Dennen, Darabi, \& Smith, 2007).

De belangrijkste overeenkomst tussen regulier en online docentschap is gelegen in de aard van de docenttaken hoewel er uiteraard verschillen zijn in de concrete uitvoering daarvan. Coppola et al. (2002) onderscheiden cognitieve, affectieve en organisatorische docenttaken die zowel in regulier als in online onderwijs vorm krijgen. De start van het online docentschap zou wellicht vergemakkelijkt kunnen worden als de nadruk aanvankelijk gelegd zou worden op de overeenkomsten 
tussen online en regulier docentschap. Het lijkt zinvol om docenten aan te moedigen om te kijken naar wat ze belangrijk vinden in hun reguliere docenttaak en van daaruit met ze te bespreken hoe zij online concreet vorm kunnen geven aan deze aspecten. Op deze wijze zouden docenten in de online omgeving meer kunnen profiteren van hun eerdere ervaringen in het reguliere onderwijs. Zij kunnen veel aspecten daarvan meenemen naar de online leeromgeving. Hun online docentschap kan dan een doorontwikkeling worden van hun bestaande docentschap.

Op het eerste gezicht lijken de uitvoeringsverschillen tussen regulier en online onderwijs vooral bepaald te worden door een verschil in de wijze van communiceren: mondeling en synchroon enerzijds en schriftelijk en asynchroon anderzijds. Deze verschillen worden de laatste jaren echter steeds kleiner. Ook de reguliere docent communiceert asynchroon met studenten via e-mail, en soms ook via asynchrone discussieruimtes (Easton, 2003). Dit betekent dat reguliere docenten in toenemende mate geoefend zijn in zaken als online feedback geven en modereren. Als e-learning docent kunnen zij deze vaardigheden verder uitbouwen hetgeen ook ten goede kan komen van het reguliere onderwijs. Daarnaast vergt het creëren van een online sociaal klimaat veel van het voorstellingsvermogen en het schriftelijke communicatie repertoire van docenten. Waar zij in de reguliere groep psychologische en sociale nabijheid kunnen creëren met verbale en non-verbale middelen, hebben zij online overwegend verbale middelen tot hun beschikking (Arbaugh, 2001; Baker, 2004), daarnaast kunnen zij gebruik maken van zaken als cartoons, foto's, muziek en smileys (Gorissen, 2006; Herring, 2004; Muirhead, 2004; Tallent-Runnels et al., 2006). Uit het huidige onderzoek blijkt dat docenten online soms vergeten de gewone verbale middelen voor sociale doelen in te zetten die zij in het reguliere klaslokaal wel gebruiken. Het gaat dan om zaken als het vertellen over zichzelf, het gebruiken van humor, het uitdrukken van gevoelens, het geven van persoonlijke voorbeelden en het laten zien van kwetsbaarheid (Baker, 2004; Gorham, 1988; Haavind, 2006, Richardson \& Swan, 2003). In platforms als Facebook spelen dit soort online activiteiten ook een belangrijke rol (Zhang, Tang, \& Leung, 2011). Het toenemende gebruik van dit soort platforms in de vrije tijd kan de vaardigheden op het vlak van online sociale vaardigheden in de nabije toekomst vergroten, waarbij overigens niet evident is dat deze vaardigheden ook generaliseren naar activiteiten in het onderwijs. 
Een tweede oorzaak van uitvoeringsverschillen is gelegen in de psychologische afstand die e-learning studenten ervaren door de fysieke en temporele afstand tussen studenten, medestudenten en docenten (Moore, 1980, 2007). Deze afstand kan resulteren in angst, gevoelens van isolement en een verminderd zelfvertrouwen (Kahl \& Cropley, 1986; Arbaugh \& Benbunan-Fich, 2007; Richardson \& Swan, 2003). Hierdoor hebben online studenten een sterke behoefte aan ondersteuning door hun docenten (Wheeler, 2009). In het huidige onderzoek bracht deze sterke ondersteuningsbehoefte van studenten bij de aanvang van de e-learning opleidingen met zich mee dat de cognitief faciliterende taken van docenten tijdelijk in het gedrang kwamen en dat de docenten zich overbelast voelden. Een spannende vraag is of online studeren in de toekomst nog steeds gevoelens van angst en isolement zal oproepen. Sociale media op internet worden immers juist op grote schaal gebruikt vanuit een behoefte aan sociale verbinding (Sheldon, Abad, \& Hinsch, 2011).

De derde oorzaak voor uitvoeringsverschillen tussen online en regulier docentschap houdt verband met het specifieke onderwijsontwerp dat in dit onderzoek beschreven en uitgevoerd is. Kenmerkend voor dit type ontwerp is dat de asynchrone door de docent gemodereerde discussie als centrale factor gezien wordt voor het leerproces van de studenten (Anderson et al., 2001; Bender, 2003; Collison et al., 2000; Hiltz, \& Goldman, 2005). De primaire rol van de docent binnen dit ontwerp is niet die van het presenteren van kennis. In plaats daarvan heeft de docent een cognitief katalyserende rol. De bedoeling van de docentinterventies is om de discussie te stimuleren, te focussen, inhoudelijk te verrijken en cognitief op een hoger niveau te tillen (Anderson et al., 2001). Deze rol sluit overigens het overdragen van kennis door de docent niet uit. Dit geschiedt echter alleen binnen de context van de discussie. Dergelijke katalyserende vaardigheden zijn uiteraard ook van groot belang in regulier onderwijs (Shelton, Lane, \& Waldhart, 1999) waar ook de nadruk gelegd wordt op de positieve effecten van activerende didactiek. De docenten in het huidige onderzoek verschilden in de mate waarin zij de katalyserende rol verwelkomden en in de mate waarin zij de kennisoverdracht misten. Ditzelfde blijkt ook uit het onderzoek van Sarker en Nicholson (2005). Een constructivistische oriëntatie lijkt voor aanstaande e-learning docenten een gunstig uitgangspunt.

Een vierde en laatste oorzaak voor uitvoeringsverschillen in het huidige onderzoek is de continuïteit van de werkbelasting die hoort bij online doceren (zie 
ook De Gagne \& Walters, 2009). Punt van discussie in de literatuur is de vraag of doceren op afstand tot een zwaardere werkbelasting leidt dan het regulier docentschap. In vragenlijsten en interviews (Coppola, et al., 2002; Hartman, Dziuban, \& Moskal, 2001; Schifter, 2000) geven docenten doorgaans aan dat zij een zwaardere werkbelasting ervaren als zij online doceren. Uit onderzoeken waarin daadwerkelijk tijd wordt gemeten komt een meer wisselend beeld naar voren dat niet in alle gevallen de perceptie van de online docenten bevestigt (Bender, Wood, \& Vredevoogd, 2004; DiBiase, 2000; Hislop,2001; Hislop \& Ellis, 2004; Visser, 2000). De onderzoeken waarin tijd gemeten wordt, zijn niet heel makkelijk met elkaar te vergelijken omdat de taken van online docenten per opleiding kunnen verschillen. Dit is onder meer afhankelijk van ontwerpelementen, ontwikkeltaken, de taken van onderwijsassistenten, de hoeveelheid online ervaring van de docent en ook van de wijze waarop ondersteuning van de e-learning studenten is georganiseerd binnen het onderwijsinstituut. Duidelijk is wel dat de eerste module die studenten volgen tot erg veel werkbelasting leidt voor docenten (Bender et al., 2004). De eerste module die docenten geven, vormt ook een zwaardere belasting. Uit het OSO e-learning onderzoek blijkt dat na de eerste module de feitelijke werkbelasting als vergelijkbaar werd beschouwd met de reguliere opleiding. Toch percipieerden de docenten het online doceren als zwaar. Dit kwam in hun ogen voornamelijk door de ervaren continuïteit van de belasting. In verschillende andere onderzoeken komt ditzelfde punt naar voren. Hislop en Ellis (2004) kwantificeren dit; uit hun onderzoek bleek dat online docenten op meer dagen actief waren. Het aantal dagen waarop activiteit geregistreerd werd, was één derde hoger dan voor reguliere docenten. Bij Thompson (2004) en Coppola et al. (2001) lezen we over de psychologische gevolgen hiervan. Deze continuiteit wordt door docenten in hun onderzoek gezien als een bron van frustratie en demotivatie. De tijd die ze anders ongehinderd konden doorbrengen met schrijven en onderzoeken werd nu onderbroken door contacten met online studenten. Dit leidt tot negatieve gevolgen voor de productiviteit. Eén docent (Coppola et al. 2001) verwoordde dat er door de noodzaak tot voortdurende online beschikbaarheid onvoldoende psychologische afstand van de studenten bestond om zich te kunnen concentreren op research en schrijfwerk. Hiltz (1994, p.260) gebruikte hiervoor de metafoor van het ouderschap: 'You are on duty all the time, and there seems to be no end to the demands on your time and energy'. 
In het huidige onderzoek kwam naar voren dat docenten dit wilden oplossen door hun online werkzaamheden duidelijk te plannen en te begrenzen. In de interviews formuleerden alle docenten voor zichzelf doelen op dit vlak. Duidelijke communicatie naar studenten over wat zij op dit punt precies kunnen verwachten, bleek ook belangrijk. Het lijkt van belang om hier aandacht aan te schenken met beginnende online docenten omdat de ervaren werkbelasting een belangrijke demotivator kan zijn voor het online doceren (Coppola et al., 2001; Hiltz et al., 2007).

Uit het huidige onderzoek blijkt dat de meeste nieuwe e-learning docenten de verschillen met het reguliere docentschap snel overbruggen. Na één module gaan de meeste docenten duidelijk beter functioneren. De leercurve voor het online docentschap is steil (Berger, 1999). Deze leercurve zou deels kunnen bestaan uit het verminderen van de aanvankelijke cognitieve overbelasting waardoor ruimte ontstaat voor de bewustwording van de overeenkomsten met de reguliere docenttaak. Ook dienen enkele aanvullende vaardigheden geleerd te worden. Daarbij bleek in het huidige onderzoek 'coaching on the job' van groot belang. Twee van de 15 docenten uit dit onderzoek vermeden na hun eerste module het online onderwijs. Sommige verschillen met regulier onderwijs waren voor hen waarschijnlijk niet gemakkelijk te overbruggen. Waarschijnlijk heeft Kearsley (2002) niet alleen voor studenten maar ook voor docenten het gelijk aan zijn kant: e-learning is niet voor iedereen. In het licht van de effecten van de razendsnelle verspreiding van online communicatieplatforms kan dat wellicht anders geformuleerd worden: e-learning is nu nog niet voor iedereen.

\subsection{IS HET DE MOEITE WAARD?}

De e-learning opleiding in het huidige onderzoek kent een complex ontwerp waarin structuur en interactie centraal staan. Dit ontwerp vormt binnen hogeschool Windesheim een antwoord op het relatief geringe afstudeerrendement van de voornamelijk op zelfstudie gerichte afstandsopleidingen. Anderson (2009) geeft aan dat docenten in het hoger onderwijs niet sympathiek staan ten opzichte van zelfstudie. De meerderheid van de Amerikaanse e-learning initiatieven volgt deze werkwijze dan ook niet meer. Het 'industriële tijdperk van afstandsleren' (Garrison, 2000) waarin opleiden vooral bestaat uit het beschikbaar stellen van leermaterialen voor zelfstudie (met 
een beperkt aantal terugkomdagen) lijkt in Nederland echter nog niet afgelopen. De korte termijn aspecten van eenvoudige organiseerbaarheid en grote flexibiliteit voor studenten lijken het gebrekkige lange termijn effect en de matige docentmotivatie te camoufleren. Een complexer ontwerp is op korte termijn minder aantrekkelijk voor onderwijsinstellingen, al is het alleen al om financiële redenen. De makers er van moeten dan ook regelmatig verdedigen waarom een dergelijke complexiteit (vergelijkbaar met die van regulier onderwijs) noodzakelijk is.

In de recente literatuur en in de praktijk van het hoger onderwijs worden drie vragen gesteld die betrekking hebben op de centrale ontwerpkenmerken van de hier beschreven e-learning opleiding.

- Perkt de aangebrachte structuur de vrijheid van studenten niet onnodig in (Anderson, Annand, \& Wark, 2005).

- Is het nodig om docenten zo intensief in te zetten of kunnen zij passiever functioneren; langs de zijlijn (Mazzolini \& Maddison, 2003).

- Heeft interactie wel een meerwaarde (Annand, 2011; Battalio, 2009; Rourke \& Kanuka, 2009).

Hieronder volgt, vanuit het kader van het huidige onderzoek en vanuit de literatuur een reflectie op deze vragen.

\section{De structuur: kan het met minder?}

De aangebrachte structuur in de OSO e-learning omgeving lijkt op het eerste gezicht niet heel aantrekkelijk voor studenten. De structuur met roosters en deadlines is strijdig met de behoefte aan tijdonafhankelijk leren van afstandsleerders die in de literatuur regelmatig genoemd wordt (zie onder meer Anderson et al., 2005). Toch blijkt uit het huidige onderzoek dat de studenten de organisatie van de e-learning waarderen en de structuur ervaren als ondersteunend voor hun leerproces. Daarnaast blijken studenten een sterke behoefte te hebben aan duidelijkheid en is hun tolerantie voor chaos laag. Studenten die chaos ervaren in cohort 1 liepen een grotere kans om af te haken. De structuur van roosters en deadlines vormt daarnaast een essentiële voorwaarde om intensieve interactie te kunnen realiseren tussen docenten en studenten, en tussen studenten onderling. De bevindingen uit het huidige onderzoek sluiten daarmee aan op de bevindingen van Swan (2002, p. 34): 'The research findings on computer-mediated communication and asynchronous online learning, both those reported in the literature and the findings reported in 
this article, are quite consistent. They suggest that three factors are consistently associated with the success of online courses. These are a clear and consistent course structure, an instructor who interacts frequently and constructively with students, and a valued and dynamic discussion.'

Het belang van strakke, duidelijke en consistente roosters met deadlines komt niet alleen voort uit de mogelijkheden die daardoor ontstaan ten aanzien van de online interactie. Het heeft te maken met het feit dat time management, zelfsturing en planningsvaardigheden als belangrijk gezien worden voor online studenten (Bozarth et al., 2004, Bullen, 1998; Clay et al., 2009). Een regelmatig studiepatroon leidt tot betere studieresultaten en het is belangrijk dat de opleiding deze zelfdiscipline stimuleert (Hwang \& Wang, 2004). Het door OSO gehanteerde rooster met deadlines bleek hiertoe een prima middel. De studenten volgden dit rooster doorgaans goed en als dat nodig bleek, werden uitzonderingen gemaakt.

De behoefte aan duidelijkheid en de intolerantie voor chaos kunnen mogelijk geïnterpreteerd worden vanuit de basisbehoeften zoals beschreven door Maslow (1987). Onvoldoende duidelijkheid kan leiden tot de ervaring van onveiligheid. Bij het starten met e-learning is enige onzekerheid inherent als studenten niet terug kunnen vallen op eerdere e-learning ervaringen. Dit wordt versterkt door de transactionele afstand tussen student en docent en door de situatie van machtsasymmetrie waarin de student zich bevindt. De student moet functioneren en leren in een voor hem relatief onbekende omgeving waarin hij geobserveerd wordt maar de observator niet kan zien (Mcalpine, 2005). De online docenten observeren daarbij ook nog eens vanuit een machtspositie omdat zij op enig moment het werk van de studenten zullen gaan beoordelen. Vanuit dit kader is het begrijpelijk dat studenten grote behoefte hebben aan duidelijkheid over hetgeen er van hen verwacht wordt. Herhaalde belevingen van chaos leiden tot een gevoel van onveiligheid, en daarmee tot een verhoogde kans op afhaken.

Hoe verhoudt zich deze behoefte aan duidelijkheid en structuur nu tot de behoefte aan vrijheid en tijdsonafhankelijk leren? Een mogelijke interpretatie is de volgende: de behoefte aan vrijheid en tijdsonafhankelijk leren komen voort uit een hedonistisch motivatiesysteem dat streeft naar gewin, gemak en genot (Collis, 1991) en dat alles op korte termijn. Een integere en duidelijke e-learning structuur daarentegen is verbonden met een gevoel van veiligheid in het platform, schept 
de mogelijkheid tot onderlinge verbondenheid en vergroot op langere termijn de mogelijkheid tot zelfrealisatie doordat het de kans op afstuderen verhoogt. Daarbij is het een onjuiste aanname om te veronderstellen dat een rooster met deadlines iedere vorm van vrijheid in het leren uitsluit. Het is niet terecht om vrijheid en structuur als twee absolute tegenpolen te zien. Autonoom leren kan juist door een adequate structuur vorm krijgen, waarbij het zeker een optie kan zijn om gevorderde studenten invloed te laten uitoefenen op die structuur (Stein, Wanstreet, Calvin, Overtoom, \& Wheaton, 2005).

\section{De docentrol: kan het met minder?}

Het huidige onderzoek bevestigt het belang van de docentrol voor e-learning studenten. Een ervaren e-learning docent die expert is in zijn vakgebied heeft een positieve invloed op de tevredenheid van studenten en op de mate waarin studenten menen dat voldaan is aan hun leerwensen.

In de literatuur (Mazzolini \& Maddison, 2003) en in de dagelijkse praktijk van een hogeschool wordt geregeld de vraag gesteld hoe omvangrijk de rol van een elearning docent moet zijn. Voor een onderwijsinstelling is de vraag naar de omvang van de docenttaken belangrijk omdat deze verband houdt met de wijze waarop docenten voorbereid moeten worden op hun taak en met de wijze waarop deze taak gefaciliteerd moet worden. Uit het OSO e-learning onderzoek wordt duidelijk dat de online docent een veelheid van taken heeft die allemaal van belang zijn voor de studenten. Naast de modererende rol, die wellicht als de kerntaak omschreven kan worden, zijn op basis van de literatuur zeven andere kenmerken van de docentrol geformuleerd. De taken die hieruit voortvloeiden bleken in alle gevallen van belang te zijn voor studenten, en leveren een serieuze taakverzwaring op ten opzichte van een zuiver modererende rol (Shea, Hayes, \& Vickers, 2010). Als hier in de facilitering van e-learning docenten niet terdege rekening mee gehouden wordt dan kan de zwaarte van de taak een demotiverende invloed krijgen (zie ook Hiltz et al., 2007). Voor OSO e-learning betekende dit dat de docenten op dezelfde wijze gefaciliteerd werden als voor de reguliere lessen. In de eerste moduleperiode van docenten bleek dit niet voldoende, later werd het haalbaar om de docenttaken binnen de toegekende tijd uit te voeren.

Ten aanzien van de modererende rol van de docent is een discussiepunt in de literatuur of het noodzakelijk is dat de docent inhoudelijke expertise heeft en inzet. Een aantal experts is de mening toegedaan dat de docent zich 
terughoudend zou moeten opstellen en dat deze relatief weinig inhoudelijke expertise nodig heeft om asynchrone discussies te begeleiden (Collison et al., 2000; Gibson, 1996; Pallof \& Pratt, 1999; Salmon, 2004). Een docent met weinig inhoudelijke expertise in het vakgebied kan voor een onderwijsinstelling om financiële redenen een aantrekkelijke optie lijken. Als weinig inhoudelijke expertise nodig is, dan kunnen ook studenten een modererende taak op zich nemen, waardoor de kosten mogelijk nog verder afnemen.

In de literatuur vinden we een aantal onderzoeken dat de mening van bovengenoemde experts lijkt te bevestigen. Moderatie door experts bleek in deze situaties weinig succesvol (Lockhorst, 2004; Oliver \& Shaw, 2003; Moonen, 2001). Bij nadere beschouwing van deze situaties bleken de experts zeer weinig kans gekregen te hebben tot moderatie. In al deze gevallen waren er problemen met onvoldoende participatie door studenten aan de discussies. Daardoor konden de betreffende discussies onmogelijk tot een goed leerproces leiden. Het ging hier steeds om gemengde vormen van leren: workshops of colleges in combinatie met asynchrone discussies. Lockhorst (2004) kwam naar aanleiding hiervan tot de conclusie dat het moeilijk is om studenten te bewegen tot online discussiëren als zij ook mogelijkheden hebben tot mondeling contact. Het feit dat asynchrone discussies moeizaam lopen in gemengde opleidingen kan niet zonder meer vertaald worden naar e-learning opleidingen waarin de studenten weinig tot geen mondeling contact hebben.

In de literatuur zijn voorbeelden van het succesvol inzetten van studenten als moderator. De Wever, Van Winckel, en Valcke (2008) lieten studenten modereren in asynchrone discussies die aanvullend waren op een geneeskundige opleiding. In deze discussies bespraken gevorderde studenten pediatrische casuïstiek. Cognitieve diepgang ontstond als één van de studenten een gespecialiseerde rol op zich nam; het was de taak van deze student om alternatieve oplossingen voor de casus te genereren. Positief effect van deze werkwijze was dat er meer interactie was op hogere cognitieve niveaus dan in discussies die door docenten gemodereerd werden en waarin eveneens een student de rol had om alternatieve oplossingen te bedenken. Mogelijk had de aanwezigheid van de docent een remmend effect, de afwezigheid van de docent leek daarentegen de autonomie en de durf van de studenten te verhogen. In het onderzoek van De Wever et al. (2008) spelen meerdere condities die de vertaling naar OSO e-learning moeilijk maken. Ten eerste betreft het hier een gemengde opleiding. Het is voorstelbaar 
dat het in een gemengde opleiding mogelijk is om studenten als moderator van asynchrone discussies te laten optreden. De expertrol is immers elders belegd: de docenten gebruiken hun (werk)colleges om studenten te helpen om tot begrip van de stof te komen. In een volledige e-learning opleiding lijkt dit minder geslaagd omdat de asynchrone discussie een geschikt platform is voor de expertrol. De expertrol krijgt daarin overigens op een andere, minder dominante wijze vorm dan in het reguliere onderwijs. Ten tweede is de moderatie uitgevoerd door gevorderde studenten die kennelijk voldoende expertise tot hun beschikking hadden om de discussie op een hoger plan te brengen. Zij hadden al veel langer gestudeerd dan de totale duur van de twee-jarige OSO e-learning opleiding. Studentmoderatoren zullen niet vanaf het begin van de studie over voldoende expertise beschikken om dit te bereiken. Ten derde is het de vraag of Nederlandse docenten de autonomie en de durf van studenten in dezelfde mate belemmeren als Vlaamse docenten. Eén van de culturele verschillen tussen Nederland en Vlaanderen lijkt immers te zijn dat Vlamingen grotere verschillen in macht accepteren dan Nederlanders (Hofstede, 1986).

Ook andere auteurs rapporteren over toename van interactie door studentmoderatie, dit maal niet zozeer in kwaliteit als wel in kwantiteit (Durrington \& Yu, 2009; Rourke \& Anderson, 2002;). De kwantiteit van de interactie is echter niet de belangrijkste maatstaf voor het slagen van asynchrone discussies (Ho \& Swan, 2007; Hrastinski, 2008; Pawan, Paulus, Yalcin \& Chang, 2003). Het zijn vooral de kwaliteit en de cognitieve diepgang van de bijdrages die van belang zijn voor het leerproces. In het onderzoek van Rourke en Anderson (2002) geven studenten aan dat zij de door studenten geleide discussies soms te vriendelijk en te weinig kritisch vonden; zij hechtten waarde aan meer uitdaging. Alleen interactie is niet genoeg, de docentrol is nodig om tot verdieping te komen (Garrison \& Cleveland-Innes, 2005).

Dit argument voor de meerwaarde van het inzetten van inhoudelijke expertise vinden we ook terug bij Anderson et al. (2001) en Wallace (2003). De docenten geven vanuit hun expertise inhoudelijke input en ondersteuning aan het leerproces en geven daarmee vorm aan een kernvoorwaarde om samenwerkend leren te doen slagen. Zonder deze hulp zal het veel studenten vaak niet lukken om in de asynchrone discussies vanuit de informatieuitwisseling te komen tot zinvolle toepassing en integratie van kennis. Een passieve rol van de docent kan in dit licht dan ook gezien worden als een onjuiste interpretatie van modellen voor sociale cognitie. Om de docentrol adequaat vorm te geven is het 
noodzakelijk dat de expert inhoudelijke kwalificaties heeft die de moduleinhouden ontstijgen (Garrison et al., 2000).

Uit het OSO e-learning onderzoek blijkt dat inhoudelijke moderatie door docenten belangrijk is voor e-learning studenten. De studenten bleken binnen de discussies behoefte te hebben aan richtinggevende inhoudelijke input en bevestiging door de docent. Hun waardering voor de docentrol hing duidelijk en consistent samen met hun waardering voor de moderatiekwaliteit van de docent. De waardering voor de moderatiekwaliteit leek samen te hangen met de inhoudelijke expertise van de docent in het vakgebied van de module. Docenten gaven aan dat moderatie nodig is om ervoor te zorgen dat e-learning discussies voldoende diepgang, duur en doelgerichtheid hebben.

Het belang van inhoudelijke moderatie door de docent in discussies tussen elearning studenten wordt ondersteund door een groot aantal eerdere onderzoeken. Een actieve en veelzijdige docentrol die gebaseerd is op inhoudelijke en pedagogische expertise is belangrijk voor studenttevredenheid en leren (Arbaugh, 2001; Baker, 2004; Bangert, 2008; Bernard et al., 2009; Dennen et al., 2007; Garrison \& Cleveland-Innes, 2005; Garrison, Cleveland-Innes, \& Fung, 2010; Kim \& Moore, 2005, Lim \& Cheah, 2010; Marks, Sibley, \& Arbaugh, 2005; Mazzolini \& Maddison, 2003; Mullen \& Tallent-Runnels, 2006; Shea, Fredericksen, Pickett, Pelz, \& Swan, 2001; Shea \& Bidjerano, 2009a; Shea \& Bidjerano, 2009b; Smits \& Voogt, 2009; Swan \& Shih, 2005) . Bernard et al. (2004) concluderen in hun metareview dat de leerresultaten van asynchrone opzetten gemiddeld even goed zijn als van regulier onderwijs. Wel zijn er grote verschillen tussen de vele verschillende asynchrone opleidingen. Om te zorgen dat asynchrone discussies leiden tot 'diep leren' en tot werkelijke bijdragen aan het leerproces, moet aan veel condities voldaan worden (Haavind, 2006). Het expliciet ontwerpen voor cognitieve diepgang via moderatie technieken is één van die belangrijke voorwaarden (Garrison \& Cleveland-Innes, 2005).

Interactie met medestudenten: een must?

In de literatuur (Annand, 2011; Rourke \& Kanuka, 2009) en in de praktijk van het hoger onderwijs wordt kritisch gekeken naar de noodzaak van samenwerkend leren (kenmerk 1) en sociale interactie (kenmerk 2) binnen e-learning opleidingen. Daarbij worden de volgende argumenten aangehaald: samenwerkend leren past niet bij de leervoorkeuren van een gedeelte van de studenten; er is te weinig 
expertise onder de deelnemende studenten om de discussies te voeren waardoor de cognitieve activiteit in de discussies te laag zou zijn; en sociale interactie speelt geen rol in de studenttevredenheid over modules. Ook wordt gesteld dat sociale interactie met medestudenten vervangen zou kunnen worden door een geïntensiveerde interactie tussen de individuele student en docent voor studenten die dat nodig hebben (Battalio, 2009).

De zorgen over de leervoorkeuren van studenten zijn begrijpelijk vanuit het belang wat door onderwijsinstituten gehecht wordt aan de aantrekkelijkheid van de opleidingen voor studenten. Als studenten een afkeer hebben van samenwerkend leren zal een dergelijk ontwerpkenmerk leiden tot weinig aanmeldingen. Wereldwijd lijkt dit overigens nauwelijks het geval omdat veel online opleidingen gestalte krijgen via samenwerkend leren. Het U.S. Department of Education (2010) concludeerde in haar meta-analyse dat online samenwerkend leren tot betere effecten leidt dan zelfstudie. Het is echter zeker waar dat bepaalde studenten samenwerkend leren minder prettig vinden (zie ook hoofdstuk 3). Dit blijkt ook uit het huidige onderzoek: studenten verschillen in hun waardering voor samenwerkend leren. De gemiddelde tendens was echter dat de samenwerking positief gewaardeerd werd. De studenten en de docenten waren bovendien tevreden over de leerzaamheid en het niveau van cognitieve activiteit in de discussies.

Als studenten voorafgaand aan de start van de online studie een negatieve houding hebben ten aanzien van samenwerkend leren dan wordt dat mogelijk veroorzaakt door eerder negatieve ervaringen met samenwerkend leren. Het goed vormgeven van samenwerkend leren vergt veel (Dillenbourg, 1999; Swan, 2002) en is waarschijnlijk lang niet altijd gelukt in de eerdere onderwijservaringen van studenten. Zo kunnen er problemen zijn ontstaan op het vlak van groeps- en individuele aansprakelijkheid, meeliften en rol- en taakverdeling. Het is voor het OSO master SEN onderwijs, met leraren als belangrijkste doelgroep, maar de vraag of er zo maar mee gegaan moet worden met een afwijzing van samenwerkend leren door studenten (Brower, 2003; Schlager \& Fusco, 2004). Samenwerkend leren heeft (mits goed vormgegeven) immers niet alleen positieve uitkomsten maar vormt ook een leerdoel op zich (zie Hawkes \& Coldeway, 2009). Voor het onderwijs lijkt het van bijzonder belang om de restanten van de 'koning in het eigen klaslokaal' te laten verdwijnen en een open feedbackcultuur tot stand te brengen. Leraren die open staan voor samenwerking en intercollegiale 
feedback hebben een voorsprong met betrekking tot het implementeren van vernieuwingen in hun onderwijs. Dit geldt onder meer voor het inzetten van constructivistische werkvormen, voor het inzetten van ict in het onderwijs en voor het inzetten van vormen van samenwerkend leren (Becker \& Riel, 2000; Tondeur, Hermans, van Braak \& Valcke, 2008).

Sociale interactie (kenmerk 2 van het ontwerp) leidt op zichzelf niet tot cognitieve diepgang en leren. Garrison, Cleveland-Innes en Fung (2010) geven aan dat het eerder een mediërende rol heeft: de sociale interactie vormt een vruchtbare bodem waarop het samenwerkend leren kan plaatsvinden. De invloed van sociale interactie op studenttevredenheid kent wisselende resultaten in de literatuur. In het onderzoek van Shea en Bidjerano (2008) wordt geen relatie gevonden tussen sociale interactie tussen studenten en de studenttevredenheid. In andere onderzoeken (Shea et al., 2001; Swan \& Shih, 2005) worden er wel positieve relaties gevonden.

In het OSO e-learning onderzoek zijn vooral positieve relaties gevonden met studenttevredenheid in een periode waarin een aantal studenten zeer ontevreden was over de sociale interactie en het samenwerkend leren. Een mogelijke verklaring voor deze verschillende bevindingen is de wijze waarop de tevredenheid bevraagd wordt bij de studenten. Afhankelijk van de formulering kan het zijn dat studenten 'tevredenheid' alleen in verband brengen met de inspanningen van de onderwijsorganisatie, zij zullen dan niet geneigd zijn om tevredenheid over hun relatie met medestudenten tot uitdrukking te brengen. Een andere verklaring zou kunnen zijn dat sociale interactie een drempelwaarde kent waarboven het geen meerwaarde meer heeft ten aanzien van de studenttevredenheid. Onder deze drempelwaarde voelt de student isolement en er niet bijhoren hetgeen de tevredenheid over de onderwijservaring sterk kan aantasten. Dit betekent dat het ontbreken van sociale interactie wel degelijk tot ernstige gevolgen kan leiden voor de opleiding. Ondersteuning voor deze gedachte kan gevonden worden in het onderzoek van Muilenburg en Berge (2005) waaruit blijkt dat een gebrek aan sociale interactie de belangrijkste barrière vormt voor online leren. In het OSO e-learning onderzoek wordt dit bevestigd. De studenten die in de eerste moduleperiode de sociale interactie laag waardeerden, hadden een grotere kans om te stoppen met de studie. Bevestiging hiervoor vinden we bij Boston et al. (2009). Op basis van 28.877 geretourneerde vragenlijsten concludeerden zij dat $18 \%$ van de variantie met betrekking tot al dan 
niet uitvallen bepaald werd door twee items over online sociale interactie. $\mathrm{Zij}$ concluderen dat sociale interactie cruciaal is voor de preventie van uitval. Binnen het OSO e-learning ontwerp is dan ook de aandacht voor dit onderwerp toegenomen. Het is van groot belang in een e-learning ontwerp om aandacht te schenken aan zowel de sociale omgang als de samenwerking. Deze twee kenmerken hebben een wederzijds versterkend effect.

\subsection{OPBRENGSTEN VAN HET ONDERZOEK EN VERVOLGVRAGEN}

Ontwerponderzoek leidt tot verbeteringen in de onderwijspraktijk. Naast kennis levert dit type onderzoek concrete producten op, en professionele ontwikkeling van de betrokkenen (zie hoofdstuk 1). Het OSO e-learning onderzoek heeft een aantal resultaten opgeleverd. Dat betreft in de eerste plaats kennis over de vier ontwerpclusters en over de tijdens de implementatie benodigde aanpassingen. Toepassing van deze vier ontwerpclusters en de aanpassingen daarop leidde tot de gewenste resultaten in termen van tevredenheid, beperking van de uitval en afstuderen. De vier ontwerpclusters die in de context van Windesheim OSO master SEN effectief bleken vertonen grote verwantschap met de principes van de community of inquiry zoals beschreven door Garrison et al. (2000) en met de Asynchronous Learning Networks van Hiltz (1994). De beschrijving van de 'community of inquiry' is in de literatuur steeds verder verfijnd en gevalideerd.

In het huidige onderzoek is opvallend dat er veel valkuilen waren in de beginfase en dat zeer veel bijstellingen nodig waren om tot een soepel lopend ontwerp te komen. De community of inquiry en de Asynchronous learning Networks zijn zinvolle theoretische uitgangspunten die zich echter niet op een vanzelfsprekende en eenvoudige manier naar de complexe praktijk van een opleiding laten vertalen. De details van de concretisering naar de praktijk hebben grote invloed op het gedrag van studenten en docenten. Een uitspraak die van toepassing lijkt voor e-learning is: 'The devil is in the detail'. Kleine details kunnen tot flinke risico's leiden.

De resultaten van het huidige onderzoek kunnen een bijdrage leveren aan verdere theorievorming over de vraag welke factoren van belang zijn met betrekking tot tevredenheid, studiesucces en beperking van uitval van e-learning studenten. In dit verband lijkt het belangrijk om tot een herwaardering te komen van het cluster 'structuur'. Structuur is het enige cluster in dit onderzoek dat systematisch 
verband vertoont met zowel studenttevredenheid als uitval. Vanuit het oogpunt van oppervlakkige, extrinsieke motivatieprocessen lijkt dit cluster niet erg aantrekkelijk voor studenten. Dit cluster zou echter een intrinsiek motiverende rol kunnen spelen die verklaard kan worden vanuit de basisbehoeften van Maslow (1987). Een goed georganiseerde module biedt veiligheid en voldoet daarmee aan een menselijke basisbehoefte. Chaos kon wel eens gevaarlijker zijn dan een strak rooster met deadlines.

Het OSO e-learning onderzoek droeg bij tot het tot stand komen van een aantal concrete onderwijsproducten. In de eerste plaats waren dat de 11 verschillende elearning modules die tijdens het onderzoek gebouwd en uitgevoerd werden. Het onderzoek vormde ook de grondslag voor de modules die daarna nog gebouwd werden voor de e-learning opleiding, die inmiddels (januari 2012) voor het vijfde jaar draait. Momenteel worden de e-learning opleidingen uitgebreid met twee opleidingen van de OSO master SEN. De samenwerking tussen LOI en Windesheim is beëindigd voor wat betreft afstandsleren en er liggen plannen om voor de voormalige LOI - Windesheim opleidingen het model van de OSO master SEN te volgen.

Binnen het OSO e-learning onderzoek werden verschillende instrumenten ontworpen. Eén van die instrumenten lijkt een rol te kunnen spelen bij het in een vroeg stadium voorspellen van uitval. Het lijkt zinvol dit nader te onderzoeken met nieuwe cohorten e-learners, en wellicht ook met reguliere studenten. Delen van de andere vragenlijsten uit het onderzoek hebben de oorspronkelijke master SEN studentevaluatie vervangen en worden vier keer per jaar uitgezet bij zowel e-learners als reguliere studenten.

De uitkomsten van het OSO e-learning onderzoek bieden houvast op het vlak van aanpassingen die gedaan kunnen worden om de risico's voor studenten te verkleinen, vooral bij het begin van de studie. Er is minder duidelijkheid over de vraag hoe docenten adequaat voorbereid kunnen worden zodat zij niet in de valkuilen hoeven trappen van het beginnend e-learning docentschap. Naar aanleiding van de resultaten van het huidige onderzoek is een e-learning module gebouwd waarin docenten worden voorbereid op hun online docentschap. Deze e-learning module kent dezelfde werkwijze als de modules voor studenten. De inhoud betreft: de start van de studie, het bouwen van een module, de organisatie van de module, de interactie tussen studenten en de docentrol. Het zou 
interessant zijn om te onderzoeken of docenten door deze module te volgen minder moeite hebben bij hun start als e-learning docent dan de docenten in het huidige onderzoek.

In het licht van de plannen voor het uitbreiden van de e-learning opleidingen liggen er voor de nabije toekomst vervolgvragen op het vlak van de vermindering van de werkbelasting van docenten: het lijkt belangrijk om na te gaan of bepaalde taakaspecten ten dele kunnen worden geautomatiseerd (controle en feedback) en of studenten een grotere rol kunnen krijgen in feedback en moderatie zonder dat de opbrengst van de discussies vermindert. Het is lang niet uitgesloten dat er hele andere soorten effectief ontwerp zouden kunnen bestaan. Bovendien zullen toekomstige technische mogelijkheden tot nieuwe pedagogische mogelijkheden leiden en nieuwe vragen opwerpen. 


\section{REFERENTIES}

Akker, J. van den (1999). Principles and methods of development research. In J. van den Akker, R. Branch, K. Gustafson, N. Nieveen, \& T. Plomp (Eds.), Design approaches and tools in education and training (pp. 1-15). Dordrecht: Kluwer Academic Publishers.

Akker, J. van den (2003). Curriculum perspectives: An introduction. In J. van den Akker, W. Kuiper, \& U. Hameyer (Eds.), Curriculum landscapes and trends (pp. 1-10). Dordrecht: Kluwer Academic Publishers.

Akker, J. van den, Gravemeijer, K., McKenney, S., \& Nieveen, N. (Eds.). (2006). Educational design research. London: Routledge.

Alavi, M., Yoo, Y., \& Vogel, D. R. (1997). Using information technology to add value to management education. Academy of Management Journal, 40(6), 1310-1333.

Anderson, T. (2003). Getting the mix right again: An updated and theoretical rationale for interaction. International Review of Research in Open and Distance Learning, 4(2), 1-14.

Anderson, T. (2005). Distance learning-Social software's killer ap. Paper presented at the $17^{\text {th }}$ Biennial Conference of the Open and Distance Learning. Retrieved from www.odlaa.org

Anderson, T. (2009). A rose by any other name: Still distance education - a response to DR Garrison-" Implications of online and blended learning for the conceptual development and practice of distance education". Journal of Distance Education, 23(3), 111-116.

Anderson, T., Annand, D., \& Wark, N. (2005). The search for learning community in learner paced distance education: Or, 'Having your cake and eating it, too!' Australasian Journal of Educational Technology, 21(2), 222-241.

Anderson, T., Rourke, L., Garrison, D. R., \& Archer, W. (2001). Assessing teaching presence in a computer conferencing context. Journal of Asynchronous Learning Networks, 5(2), 1-17.

Annand, D. (2011). Social presence within the community of inquiry framework. International Review of Research in Open and Distance Learning, 12(5), 38-54.

Aragon, S. R. (2003). Creating social presence in online environments. New Directions for Adult and Continuing Education, 100, 57-68.

Arbaugh, J. B. (2000). Virtual classroom characteristics and student satisfaction with internetbased MBA courses. Journal of Management Education, 24(1), 32-54.

Arbaugh, J. B. (2001). How instructor immediacy behaviors affect student satisfaction and learning in web-based courses. Business Communication Quarterly, 64(4), 42-54.

Arbaugh, J. B. (2004). Learning to learn online: A study of perceptual changes between multiple online course experiences. Internet and Higher Education, 7(3), 169-182. 
Arbaugh, J. B. (2005). Is there an optimal design for on-line MBA courses? Academy of Management Learning and Education, 4(2), 135-149.

Arbaugh, J. B., \& Benbunan-Fich, R. (2006). An investigation of epistemological and social dimensions of teaching in online learning environments. Academy of Management Learning and Education, 5(4), 435-447.

Arbaugh, J. B., \& Benbunan-Fich, R. (2007). The importance of participant interaction in online environments. Decision Support Systems, 43(3), 853-865.

Arbaugh, J. B., \& Hiltz, S. R. (2005). Improving quantitative research on ALN effectiveness. In S. R. Hiltz, \& R. Goldman (Eds.), Learning together online. Research on asynchronous learning networks. (pp. 81-102). Mahwah, NJ: Lawrence Erlbaum Associates.

Aviv, R., Erlich, Z., Ravid, G., \& Geva, A. (2003). Network analysis of knowledge construction in asynchronous learning networks. Journal of Asynchronous Learning Networks, 7(3), 1-23.

Baddeley, A. D. (1999). Essentials of human memory. Hove: Psychology Press.

Baker, J. D. (2004). An investigation of relationships among instructor immediacy and affective and cognitive learning in the online classroom. Internet and Higher Education, $7(1), 1-13$.

Bangert, A. W. (2004). The seven principles of good practice: A framework for evaluating online teaching. The Internet and Higher Education, 7(3), 217-232.

Bangert, A. (2008). The influence of social presence and teaching presence on the quality of online critical inquiry. Journal of Computing in Higher Education, 20(1), 34-61.

Barab, S. A., Kling, R., \& Gray, J. H. (2004). Introduction. Designing for virtual communities in the service of learning. In S. A. Barab, R. Kling, \& J. H. Gray (Eds.), Designing for virtual communities in the service of learning (pp. 3-15). Cambridge: Cambridge University Press.

Barab, S., \& Squire, K. (2004). Design-based research: Putting a stake in the ground. Journal of the Learning Sciences, 13(1), 1-14.

Battalio, J. (2009). Interaction online: a reevaluation. In A. Orellana, \& M. Simonson (Eds.), The perfect online course. Best practices for designing and teaching (pp. 443-462). Charlotte, NC: Information Age Publishing.

Becker, H. J., \& Riel, M. M. (2000). Teacher professional engagement and constructivist-compatible computer use. Irvine, CA: Center for Research on Technology and Organizations.

Benbunan-Fich, R., \& Hiltz, S. R. (2003). Mediators of the effectiveness of online courses. IEEE Transactions on Professional Communication, 46(4), 298-312.

Bender, T. (2003). Discussion based online teaching to enhance student learning. Theory, practice and assessment. Sterling: Stylus Publishing.

Bender, D. M., Wood, D., \& Vredevoogd, J. D. (2004). Teaching time: Distance education versus classroom instruction. The American Journal of Distance Education, 18(2), 103-114.

Berger, N. S. (1999). Pioneering experiences in distance learning: Lessons learned. Journal of Management Education, 23(6), 684-690.

Bernard, R. M., Abrami, P. C., Borokhovski, E., Wade, C. A., Tamim, R. M., Surkes, M. A., et al. (2009). A meta-analysis of three types of interaction treatments in distance education. Review of Educational Research, 79(3), 1243-1289.

Bernard, R. M., Abrami, P. C., Lou, Y., Borokhovski, E., Wade, A., Wozney, L., et al. (2004). How does distance education compare with classroom instruction? A meta-analysis of the empirical literature. Review of Educational Research, 74(3), 379-439. 
Bernard, R. M., \& Lundgren-Cayrol, K. (2001). Computer conferencing: An environment for collaborative project-based learning in distance education. Educational Research and Evaluation, 7(2), 241-261.

Beuchot, A., \& Bullen, M. (2005). Interaction and interpersonality in online discussion forums. Distance Education, 26(1), 67-87.

Bishop, A. (2002). Come into my parlour said the spider to the fly: Critical reflections on webbased education from a student's perspective. Distance Education, 23(2), 231-236.

Blignaut, S., \& Trollip, S. R. (2003). Developing a taxonomy of faculty participation in asynchronous learning environments - An exploratory investigation. Computers $\mathcal{E}$ Education, 41(2), 149-172.

Bolhuis, E., Schoot, H., Smits, A. E. H., \& Valstar, J. (2003). Raamplan implementatie van elearning op Windesheim Educatief 2003-2007. Zwolle: Hogeschool Windesheim.

Boston, W., Díaz, S. R., Gibson, A. M., Ice, P., Richardson, J., \& Swan, K. (2009). An exploration of the relationship between indicators of the community of inquiry framework and retention in online programs. Journal of Asynchronous Learning Networks, 13(3), 67-83.

Bouhnik, D., \& Marcus, T. (2006). Interaction in distance-learning courses. Journal of the American Society for Information Science and Technology, 57(3), 299-305.

Bozarth, J., Chapman, D. D., \& LaMonica, L. (2004). Preparing for distance learning: Designing an online student orientation course. Educational Technology \& Society, 7(1), 87106.

Brace-Govan, J. (2003). A method to track discussion forum activity: The moderators' assessment matrix. Internet and Higher Education, 6(4), 303-325.

Braten, I., \& Strømsø, H. I. (2006). Epistemological beliefs, interest, and gender as predictors of Internet-based learning activities. Computers in Human Behavior, 22(6), 1027-1042.

Brost, B. D., \& Bradley, K. A. (2006). Student compliance with assigned reading: A case study. Journal of Scholarship of Teaching and Learning, 6(2), 101-111.

Brower, H. H. (2003). On emulating classroom discussion in a distance-delivered OBHR course: Creating an on-line community. Academy of Management Learning and Education, 2(1), 22-36.

Bruner, J. (1990). Acts of meaning. Harvard: Harvard University Press.

Bullen, M. (1998). Participation and critical thinking in online university distance education. Journal of Distance Education, 13(2), 1-32.

Burke, L. A. (2005). Transitioning to online course offerings: Tactical and strategic considerations. Journal of Interactive Online Learning, 4(2), 94-107.

Burnett, C. (2003). Learning to chat: Tutor participation in synchronous online chat. Teaching in Higher Education, 8(2), 247-261.

Busch, F., \& Mayer, T. B. (2002). Der Online-Coach. Wie Trainer virtuelles Lernen optimal fördern können. Basel: Beltz Verlag.

Carr-Chellman, A., \& Duchastel, P. (2000). The ideal online course. British Journal of Educational Technology, 31(3), 229-241.

Chickering, A. W., \& Gamson, Z. F. (1987). Seven principles for good practice in undergraduate education. AAHE Bulletin, 39(7), 3-7.

Christensen, R. W., \& Knezek, G. A. (2009). Construct validity for the teachers' attitudes toward computers questionnaire. Journal of Computing in Teacher Education, 25(4), 143-155. 
Christophel, D. M. (1990). The relationships among teacher immediacy behaviors, student motivation, and learning. Communication Education, 39(4), 323-340.

Clark, R., \& Mayer, R.E. (2008). E-Learning and the science of instruction. Proven guidelines for consumers and designers of multimedia learning. San Francisco: Pfeiffer.

Clark, R., Nguyen, F., \& Sweller, J. (2006). Efficiency in learning. Evidence-based guidelines to manage cognitive load. San Francisco: Pfeiffer.

Clay, M. N., Rowland, S., \& Packard, A. (2009). Improving undergraduate online retention through gated advisement and redundant communication. Journal of College Student Retention: Research, Theory and Practice, 10(1), 93-102.

Clouse, S. F., \& Evans, G. E. (2003). Graduate business students performance with synchronous and asynchronous interaction e-learning methods. Decision Sciences Journal of Innovative Education, 1(2), 181-202.

Cluitmans, J. J., Dekkers, M. A. F., \& Oeffelt, T. van (2002). Aan de slag met competenties: Competentiegericht leren in $\mathrm{HBO}$ en $\mathrm{MBO}$. Nuenen: Onderwijsadviesbureau Dekkers.

Cobb, P., Confrey, J., diSessa, A., Lehrer, R., \& Schauble, L. (2003). Design experiments in educational research. Educational Researcher, 32(1), 9-13.

Cohen, E. G. (1994). Restructuring the classroom: Conditions for productive small groups. Review of Educational Research, 64(1), 1-35.

Cohen, L., Manion, L., \& Morrison, K. (2007). Research methods in education. London: Routledge.

Cohen, M. S., \& Ellis, T. J. (2004). Validating a criteria set for an online learning environment. Paper presented at the ASEE/IEEE Frontiers in Education Conference, Savannah, GA.

Collins, M. (1992). Flaming: The relationship between social context cues and uninhibited verbal behavior in computer-mediated communication. Retrieved from http://www.mediensprache.net/archiv/pubs/2842.htm

Collis, B. A. (1991). The evaluation of electronic books. Educational \& Training Technology International, 28(4), 355-363.

Collis, B., de Boer, W., \& Slotman, K. (2001). Feedback for web based assignments. Journal of Computer Assisted Learning, 17(3), 306-313.

Collis, B., \& Gervedink Nijhuis, G. (2000). The instructor as manager: Time and task. The Internet and Higher Education, 3(1-2), 75-97.

Collison, G., Elbaum, B., Haavind, S., \& Tinker, R. (2000). Facilitating online learning. Effective strategies for moderators. Madison: Atwood Publishing.

Conaway, R. N., Easton, S. S., \& Schmidt, W. V. (2005). Strategies for enhancing student interaction and immediacy in online courses. Business Communication Quarterly, 68(1), 2325.

Conrad, D. (2002). Engagement, excitement, anxiety, and fear: Learners' experiences of starting an online course. American Journal of Distance Education, 16(4), 205-226.

Conrad, D. (2004). University instructors' reflections on their first online teaching experiences. Journal of Asynchronous Learning Networks, 8(2), 31-44.

Conrad, D. (2005). Building and maintaining community in cohort-based online learning. Journal of Distance Education, 20(1), 1-20.

Coppola, N. W., Hiltz, S. R., \& Rotter, N. G. (2002). Becoming a virtual professor: Pedagogical roles and asynchronous learning networks. Journal of Management Information Systems, 18(4), 169-189. 
Cramphorn, C. (2004). An evaluation of formal and underlying factors influencing student participation within e-learning web discussion forums. In S. Banks, P. Goodyear, C. Jones, V. Lally, D. McConnel, \& C. Steeples (Eds.), Proceedings of the Fourth International Conference on Networked Learning 2004 (pp.417-423). Lancaster: Lancaster University.

Cronjé, J. C., Adendorff, D. E., Meyer, S. M., \& Van Ryneveld, L. (2006). Surviving the shipwreck: What makes online students stay online and learn? Educational Technology and Society, 9(4), 185-193.

Davidson-Shivers, G. V., Muilenburg, L. Y., \& Tanner, E. J. (2001). How do students participate in synchronous and asynchronous online discussions? Journal of Educational Computing Research, 25(4), 351-366.

Dawson, S. (2006). A study of the relationship between student communication interaction and sense of community. Internet and Higher Education, 9(3), 153-162.

Dawson, S. (2008). A study of the relationship between student social networks and sense of community. Educational Technology and Society, 11(3), 224-238.

De Gagne, J. C., \& Walters, K. (2009). Online teaching experience: A qualitative metasynthesis (QMS). MERLOT Journal of Online Learning and Teaching, 5(4), 577-589. Retrieved from http://jolt.merlot.org/vol5no4/abstracts.htm

De Wever, B., Van Winckel, M., \& Valcke, M. (2008). Discussing patient management online: The impact of roles on knowledge construction for students interning at the paediatric ward. Advances in Health Sciences Education, 13(1), 25-42.

Dede, C. (2004). If design-based research is the answer, what is the question? A commentary on Collins, Joseph, and Bielaczyc; diSessa and Cobb; and Fishman, Marx, Blumenthal, Krajcik, and Soloway in the JLS special issue on design-based research. The Journal of the Learning Sciences, 13(1), 105-114.

Delfino, M., \& Manca, S. (2007). The expression of social presence through the use of figurative language in a web-based learning environment. Computers in Human Behavior, 23(5), 2190-2211.

Dennen, V. P. (2005). From message posting to learning dialogues: Factors affecting learner participation in asynchronous discussion. Distance Education, 26(1), 127-148.

Dennen, V. P. (2008). Looking for evidence of learning: Assessment and analysis methods for online discourse. Computers in Human Behavior, 24(2), 205-219.

Dennen, V. P., Darabi, A. A., \& Smith, L. J. (2007). Instructor-learner interaction in online courses: The relative perceived importance of particular instructor actions on performance and satisfaction. Distance Education, 28(1), 65-79.

DePaolo, C. A., \& Sherwood, A. L. (2006). Instructional uses of web-based survey software. The Journal of Educators Online, 3(1), 1-19. Retrieved from http://www.thejeo.com/Archives/Volume3Number1/DePaoloFinal.pdf

DiBiase, D. (2000). Is distance teaching more work or less work? American Journal of Distance Education, 14(3), 6-20.

Dillenbourg, P. (1999). Introduction: What do you mean by 'collaborative learning'? In P. Dillenbourg (Ed.), Collaborative learning: Cognitive and computational approaches (pp. 1-19). Amsterdam: Pergamon.

Doyle, W., \& Ponder, G. A. (1977). The practicality ethic in teacher decision-making. Interchange, 8(3), 1-12. 
Duemer, L., Fontenot, D., Gumfory, K., Kallus, M., Larsen, J. A., Schafer, S., et al. (2002). The use of online synchronous discussion groups to enhance community formation and professional identity development. The Journal of Interactive Online Learning, 1(2), 1-12. Retrieved from http://www.ncolr.org/jiol/issues/pdf/1.2.4.pdf

Duffy, T. M., \& Kirkley, J. R. (2004a). Introduction: Theory and practice in distance education. In T. M. Duffy, \& J. R. Kirkley (Eds.), Learner-centered theory and practice in distance education (pp. 3-15). Mahwah, NJ: Lawrence Erlbaum Associates.

Duffy, T. M., \& Kirkley, J. R. (Eds.). (2004b). Learner-centered theory and practice in distance education. Cases from higher education. Mahwah, NJ: Lawrence Erlbaum Associates.

Dunlap, J. C. (2005). Workload reduction in online courses: Getting some shuteye. Performance Improvement, 44(5), 18-25.

Dziuban, C., Shea, P., \& Arbaugh, J. (2005). Faculty roles and satisfaction in asynchronous learning networks. In S. R. Hiltz, \& R. Goldman (Eds.), Learning together online: Research on asynchronous learning networks (pp. 169-190). Mahwah, NJ: Lawrence Erlbaum Associates.

Easton, S. S. (2003). Clarifying the instructor's role in online distance learning. Communication Education, 52(2), 87-105.

Elbeck, M., \& Mandernach, B. J. (2009). Journals for computer-mediated learning: Publications of value for the online educator. International Review of Research in Open and Distance Learning, 10(3), 1-19. Retrieved from http://www.irrodl.org/index.php/irrodl/article/view/676/1295

Faber, A., \& Mazlish, E. (1996). How to talk so kids can learn. At home and in school. London: Piccadilly Press.

Fenby, F. (2006). Examining dissatisfaction with an online doctoral program (Doctoral dissertation, Dallas Theological Seminary). Retrieved from

http://learnshapes.brinkster.net/af-\%20\%205.pdf

Field, A. (2009). Discovering statistics using SPSS. London: Sage Publications.

Fink, A., \& Kosecoff, J. (2008). How to conduct surveys: A step-by-step guide. Thousand Oaks, CA: Sage Publications.

Finlay, W., Desmet, C., \& Evans, L. (2004). Is it the technology or the teacher? A comparison of online and traditional English composition classes. Journal of Educational Computing Research, 31(2), 163-180.

Foltz, P. W. (1996). Comprehension, coherence, and strategies in hypertext and linear text. In J.-F. Rouet, J. J. Levonen, A. Dillon \& R. J. Spiro (Eds.), Hypertext and cognition (pp. 109136). Hillsdale, NJ: Lawrence Erlbaum Associates.

Garrison, D. R. (2000). Theoretical challenges for distance education in the $21^{\text {st }}$ century: A shift from structural to transactional issues. International Review of Research in Open and Distance Learning, 1(1). Retrieved from htttp://www.irrodl.org/index.php/irrodl/article/viewFile/2/22

Garrison, D. R. (2006). Online collaboration principles. Journal of Asynchronous Learning Networks, 10(1), 25-34.

Garrison, D. R., \& Anderson, T. (2003). E-learning in the 21st century: A framework for research and practice. London: Routledge.

Garrison, D. R., Anderson, T., \& Archer, W. (2000). Critical inquiry in a text-based environment: Computer conferencing in higher education. The Internet and Higher Education, 2(2-3), 87-105. 
Garrison, D. R., Anderson, T., \& Archer, W. (2001). Critical thinking, cognitive presence, and computer conferencing in distance education. American Journal of Distance Education, 15(1), 7-24.

Garrison, D. R., \& Cleveland-Innes, M. (2005). Facilitating cognitive presence in online learning: Interaction is not enough. American Journal of Distance Education, 19(3), 133-148.

Garrison, D. R., Cleveland-Innes, M., \& Fung, T. S. (2010). Exploring causal relationships among teaching, cognitive and social presence: Student perceptions of the community of inquiry framework. The Internet and Higher Education, 13(1-2), 31-36.

Garrison, D. R., Cleveland-Innes, M., Koole, M., \& Kappelman, J. (2006). Revisiting methodological issues in transcript analysis: Negotiated coding and reliability. Internet and Higher Education, 9(1), 1-8.

Gibbons, H. S., \& Wentworth, G. P. (2001). Andrological and pedagogical training differences for online instructors. Online Journal of Distance Learning Administration, 4(3). Retrieved from http:// www.westga.edu/ distance/ojdla/fall43/gibbons_wentworth43.html

Gibson, C. C. (1996). Toward emerging technologies and distributed learning: Challenges and change. American Journal of Distance Education, 10(2), 47-49.

Ginns, P., \& Ellis, R. (2007). Quality in blended learning: Exploring the relationships between on-line and face-to-face teaching and learning. Internet and Higher Education, 10(1), 53-64.

Ginott, H., Ginott, A., \& Goddard, H. $(1965,2003)$. Between parent and child. New York: Three Rivers Press.

Gokhale, A. A. (1995). Collaborative learning enhances critical thinking. Journal of Technology Education, 7(1), 22-30.

Gorham, J. (1988). The relationship between verbal teacher immediacy behaviors and student learning. Communication Education, 37(1), 40-53.

Gorissen, P. (2006). Social software in het onderwijs. Eindhoven: Fontys.

Grabinger, S. (2004). Design lessons for social education. In T. M. Duffy, \& J. R. Kirkley (Eds.), Learner-centered theory and practice in distance education: Cases from higher education (pp. 4960). Mahwah, NJ: Lawrence Erlbaum Associates.

Graham, C., Cagiltay, K., Craner, J., Lim, B.-R., \& Duffy, T. M. (2000). Teaching in a web based distance learning environment: An evaluation summary based on four courses. Bloomington: Indiana University.

Gravemeijer, K., \& Cobb, P. (2006). Design research from a learning design perspective. In J. van den Akker, K. Gravemeijer, S. McKenney, \& N. Nieveen (Eds.), Educational design research (pp. 17-51). London: Routledge.

Gunawardena, C. N., Lowe, C. A., \& Anderson, T. (1997). Analysis of a global online debate and the development of an interaction analysis model for examining social construction of knowledge in computer conferencing. Journal of Educational Computing Research, 17(4), 397-431.

Gunawardena, C. N., \& Zittle, F. J. (1997). Social presence as a predictor of satisfaction within a computer-mediated conferencing environment. American Journal of Distance Education, 11(3), 8-26.

Gunn, C. (2006). Engaging learners through continuous online assessment. In D. Hung, \& M. S. Khine (Eds.), Engaged learning with emerging technologies (pp. 255-273). Dordrecht: Springer. 
Haavind, S. (2006). Tapping online dialogue for learning: A grounded theory approach to identifying key heuristics that promote collaborative dialogue among secondary online learners. Doctoral dissertation. Harvard University.

Hacker, D. J., \& Niederhauser, D. S. (2000). Promoting deep and durable learning in the online classroom. New Directions for Teaching \& Learning in the Online Classroom, 84, 53-63.

Häkkinen, P., \& Järvelä, S. (2006). Sharing and constructing perspectives in web-based conferencing. Computers $\mathcal{E}$ Education, 47(4), 433-447.

Hall, R. (2006). Delivering what students say they want on-line: Towards academic participation in the enfrachisement of e-learners? The Electronic Journal of E-learning, 4(1), 25-32. Retrieved from www.ejel.org

Hammond, M. (2005). A review of recent papers on online discussion in teaching and learning in higher education. Journal of Asynchronous Learning Networks, 9(3), 9-23.

Hara, N., \& Kling, R. (2000). Student distress in a web-based distance education course. Information, Communication \& Society, 3(4), 557-579.

Harasim, L. (1990). Online education: An environment for collaboration and intellectual amplification. In L. Harasim (Ed.), Online education. Perspectives on a new environment (pp. 39-64). New York: Praeger.

Harasim, L. (1990). Online education: Perspectives on a new environment. New York: Praeger.

Harasim, L. (2000). Shift happens: Online education as a new paradigm in learning. Internet and Higher Education, 3(1-2), 41-61.

Harinck, F., Smits, A., \& Bruggen, B. van der (2005). Opleidings- en toetskader. Master Special Educational Needs. Zwolle: OSO Windesheim.

Hartman, J., Dziuban, C., \& Moskal, P. (2001). Faculty satisfaction in ALNs: A dependent or independent variable? In J. Bourne (Ed.), Online education. Learning effectiveness and faculty satisfaction. (Vol. 1, pp. 155-179). Needham: The Sloan Consortium.

Hawisher, G. E., \& Pemberton, M. A. (1997). Writing across the curriculum encounters asynchronous learning networks or WAC meets up with ALN. Journal of Asynchronous Learning Networks, 1(1), 52-72.

Hawkes, M., \& Coldeway, D. O. (2009). An analysis of team vs. faculty-based online course development: Implications for instructional design. In A. Orellana, T. L. Hudgins, \& M. Simonson (Eds.), The perfect online course. Best practices for designing and teaching (pp. 249264). Charlotte, NC: Information Age Publishing.

Haythornthwaite, C., Kazmer, M. M., Robins, J., \& Shoemaker, S. (2000). Community development among distance learners: Temporal and technological dimensions. Journal of Computer Mediated Communication, 6(1).

Heckman, R., \& Annabi, H. (2005). A content analytic comparison of learning processes in online and face-to-face case study discussions. Journal of Computer-Mediated Communication, 10(2).

Herring, S. C. (2004). Computer-mediated discourse. In D. Schiffrin, D. Tannen, \& H. E. Hamilton (Eds.), Handbook of discourse analysis (pp. 612-634). Oxford: Blackwell.

Hewitt, J. (2005). Toward an understanding of how threads die in asynchronous computer conferences. Journal of the Learning Sciences, 14(4), 567-589.

Hiltz, S. R. (1994). The virtual classroom: Learning without limits via computer networks. Norwood, NJ: Ablex Publishing Corporation. 
Hiltz, S. R., \& Goldman, R. (Eds.). (2005a). Learning together online. Mahwah, NJ: Lawrence Erlbaum Associates.

Hiltz, S. R., \& Goldman, R. (2005b). What are asynchronous learning networks? In S. R. Hiltz, \& R. Goldman (Eds.), Learning together online. Research on asynchronous learning networks (pp. 3-18). Mahwah, NJ: Lawrence Erlbaum Associates.

Hiltz, S. R., Kim, E., \& Shea, P. (2007). Faculty motivators and de-motivators for teaching online: Results of focus group interviews at one university. Paper presented at the Proceedings of the Annual Hawaii International Conference on System Sciences, Big Island, HI.

Hiltz, S. R., \& Wellman, B. (1997). Asynchronous learning networks as a virtual classroom. Communications of the ACM, 40(9), 44-49.

Hislop, G. W. (2001). Does teaching online take more time? Proceedings of the 31 ${ }^{\text {st }}$ ASEE/IEEE Frontiers in Education Conference (Vol. 1, pp. TIF-23-27): IEEE.

Hislop, G. W., \& Ellis, H. J. C. (2004). A study of faculty effort in online teaching. Internet and Higher Education, 7(1), 15-31.

Ho, C. H., \& Swan, K. (2007). Evaluating online conversation in an asynchronous learning environment: An application of Grice's cooperative principle. Internet and Higher Education, 10(1), 3-14.

Hofstede, G. (1986). Cultural differences in teaching and learning. International Journal of Intercultural Relations, 10(3), 301-320.

Hostetter, C., \& Busch, M. (2006). Measuring up online: The relationship between social presence and student learning satisfaction. Journal of Scholarship of Teaching and Learning, 6(2), 1-12.

Hrastinski, S. (2008). What is online learner participation? A literature review. Computers $\mathcal{E}$ Education, 51(4), 1755-1765.

Hwang, W. Y., \& Wang, C. Y. (2004). A study of learning time patterns in asynchronous learning environments. Journal of Computer Assisted Learning, 20(4), 292-304.

Islas, J. R. L. (2004). Collaborative learning at Monterrey Tech-Virtual University. In T. M. Duffy, \& J. R. Kirkley (Eds.), Learner-centered theory and practice in distance education (pp. 297-319). Mahwah, NJ: Lawrence Erlbaum Associates.

Jeong, A. C. (2003). The sequential analysis of group interaction and critical thinking in online threaded discussions. American Journal of Distance Education, 17, 25-43.

Jeong, A. C. (2006). The effects of conversational language on group interaction and group performance in computer-supported collaborative argumentation. Instructional Science, 34(5), 367-397.

Johnson, G. M. (2006). Synchronous and asynchronous text-based CMC in educational contexts: A review of recent research. TechTrends, 50(4), 46-53.

Johnson, G. M., \& Howell, A. J. (2005). Attitude toward instructional technology following required versus optional WebCT usage. Journal of Technology and Teacher Education, 13(4), 643.

Jonassen, D., Davidson, M., Collins, M., Campbell, J., \& Haag, B. B. (1995). Constructivism and computer-mediated communication in distance education. The American Journal of Distance Education, 9(2), 7-26.

Jonassen, D. H., \& Kwon, H. (2001). Communication patterns in computer mediated versus face-to-face group problem solving. Educational Technology Research and Development, $49(1), 35-51$. 
Jonassen, D. H., Lee, C. B., Yang, C. C., \& Laffey, J. (2005). The collaboration principle in multimedia learning. In R. E. Mayer (Ed.), The Cambridge handbook of multimedia learning (pp. 247-270). Cambridge: Cambridge University Press.

Kahl, T. N., \& Cropley, A. J. (1986). Face-to-face versus distance learning: Psychological consequences and practical implications. Distance Education, 7(1), 38-48.

Kearsley, G. (2002). Is online learning for everybody? Educational Technology, 42(1), 41-44. Kennedy, D., \& Duffy, T. (2004). Collaboration-a key principle in distance education. Open Learning: The Journal of Open, Distance and E-Learning, 19(2), 203-211.

Kiesler, S., Siegel, J., \& McGuire, T. W. (1984). Social psychological aspects of computermediated communication. American Psychologist, 39(10), 1123-1134.

Kim, K. S., \& Moore, J. L. (2005). Web-based learning: Factors affecting students' satisfaction and learning experience. First Monday, 10(11), 115-131.

King, F. B. (2002). A virtual student: Not an ordinary Joe. The Internet and Higher Education, $5(2), 157-166$.

Kirschner, P. A., \& Paas, F. (2001). Web-enhanced higher education: A tower of Babel. Computers in Human Behavior, 17(4), 347-353.

Kirschner, P., Strijbos, J. W., Kreijns, K., \& Beers, P. J. (2004). Designing electronic collaborative learning environments. Educational Technology Research and Development, 52(3), 47-66.

Knezek, G., Christensen, R., \& Miyashita, K. (2000). Instruments for assessing attitudes toward information technology. Denton: Institute for the Integration of Technology into Teaching and Learning, University of North Texas.

Kosak, L., Manning, D., Dobson, E., Rogerson, L., Cotnam, S., Colaric, S., \& McFadden, C. (2004). Prepared to teach online? Perspectives of faculty in the University of North Carolina System. Online Journal of Distance Learning Administration, 7(3). Retrieved from http://www.westga.edu/ distance/ojdla/fall73/kosak73.html

Kreijns, K. (2004). Sociable CSCL environments. Social affordances, sociability, and social presence Doctoral thesis. Heerlen, the Netherlands: Open Universiteit. Retrieved from http://dspace.learningnetworks.org/bitstream/1820/1030/1/Dissertation \%20Kreijns\%2 02004.pdf

Kreijns, K., Kirschner, P. A., \& Jochems, W. (2002). The sociability of computer-supported collaborative learning environments. Educational Technology and Society, 5(1), 8-22.

Kreijns, K., Kirschner, P. A., \& Jochems, W. (2003). Identifying the pitfalls for social interaction in computer-supported collaborative learning environments: A review of the research. Computers in Human Behavior, 19(3), 335-353.

Langer, J., \& Applebee, A. (1987). How writing shapes thinking: A study of teaching and learning. Urbana, Il: National Council of Teachers of English.

Leidner, D. E., \& Jarvenpaa, S. L. (1995). The use of information technology to enhance management school education: A theoretical view. MIS Quarterly: Management Information Systems, 19(3), 265-291.

Levy, P. (2004). Developmental processes in networked learning: Orientation. Paper presented at the Conference on Networked Learning, Lancaster.

Levy, Y. (2007). Comparing dropouts and persistence in e-learning courses. Computers $\mathcal{E}$ Education, 48(2), 185-204.

Lim, C. P., \& Cheah, P. T. (2003). The role of the tutor in asynchronous discussion boards: A case study of a pre-service teacher course. Educational Media International, 40(1-2), 33-48. 
Locke, E. A., \& Latham, G. P. (2002). Building a practically useful theory of goal setting and task motivation: A 35-year odyssey. American Psychologist, 57(9), 705-717.

Lockhorst, D. (2004). Design principles for a CSCL environment in teacher training. Doctoral thesis. Utrecht, Nederland: Universiteit Utrecht. Retrieved from http://igiturarchive.library.uu.nl/dissertations/2008-0807-201244/lockhorst $\% 20$ -

\%20design \%20principles\%20for\%20a \%20 cscl\%20environment $\% 20 \mathrm{in} \% 20$ teacher $\% 20$ traini $\underline{\text { ng.pdf }}$

Lou, Y., Abrami, P. C., \& D'Apollonia, S. (2001). Small group and individual learning with technology: A meta-analysis. Review of Educational Research, 71(3), 449-521.

Ludwig-Hardman, S., \& Dunlap, J. C. (2003). Learner support services for online students: Scaffolding for success. International Review of Research in Open and Distance Learning, 4(1). Retrieved from http://www.irrodl.org/index.php/irrodl/article/view/131/211Hardman

Mandernach, B. J., Gonzales, R., \& Garrett, A. L. (2006). An examination of online instructor presence via threaded discussion participation. Journal of Online Learning and Teaching, 2(4), 248-260.

Mariola, E., \& Manley, J. (2002). Teaching finance concepts in a distance learning environment--A personal note. Journal of Education for Business, 77(3), 177-180.

Marks, R. B., Sibley, S. D., \& Arbaugh, J. (2005). A structural equation model of predictors for effective online learning. Journal of Management Education, 29(4), 531-563.

Marshall, S. (2006). E-learning maturity model, version 2.2. Wellington: Victoria University of Wellington.

Martens, R., Bastiaens, T., \& Gulikers, J. (2002). Leren met computergebaseerde authentieke taken: Motivatie, gedrag en resultaten van studenten. Pedagogische Studiën, 79(6), 469-481.

Maslow, A. (1987). Motivation and personality (3rd ed). New York: Harper \& Row.

Mayer, R. E. (1989). Systematic thinking fostered by illustrations in scientific text. Journal of Educational Psychology, 81(2), 240-246.

Mayer, R. E. (2001). Multimedia learning. Cambridge, UK: Cambridge University Press.

Mayer, R. E., Bove, W., Bryman, A., Mars, R., \& Tapangco, L. (1996). When less is more: Meaningful learning from visual and verbal summaries of science textbook lessons. Journal of Educational Psychology, 88(1), 64-73.

Mayer, R. E., \& Moreno, R. (2003). Nine ways to reduce cognitive load in multimedia learning. Educational Psychologist, 38(1), 43-52.

Mazzolini, M., \& Maddison, S. (2003). Sage, guide or ghost? The effect of instructor intervention on student participation in online discussion forums. Computers $\mathcal{E}$ Education, $40(3), 237-253$.

Mc Cullough, C., \& Aimard, V. (2006). E-Learning in Europe: How do trainers, teachers and learners rate e-learning. Paris: Cedefop.

Mcalpine, M. (2005). E-portfolios and digital identity: Some issues for discussion. E-Learning and Digital Media, 2(4), 378-387.

McGorry, S. Y. (2003). Measuring quality in online programs. Internet and Higher Education, 6(2), 159-177. 
McKenney, S., \& van den Akker, J. (2005). Computer-based support for curriculum designers: A case of developmental research. Educational Technology Research \& Development, 53(2), 41-66.

McKenney, S., Nieveen, N., \& van den Akker, J. (2006). Design research from a curriculum perspective. In J. van den Akker, K. Gravemeijer, S. McKenney, \& N. Nieveen (Eds.), Educational design research (pp. 67-90). London: Routledge.

McKenney, S., \& Reeves, T. C. (2012). Conducting educational design research. London: Routledge.

McLinden, M., McCall, S., Hinton, D., \& Weston, A. (2006). Participation in online problembased learning: Insights from postgraduate teachers studying through open and distance education. Distance Education, 27(3), 331-353.

Mebus, L. (red.), Smits, A. E. H., Moesker, G., Versloot, A., Van der Molen, J., Scholtens, T., \& Ter Halle, I. (2008). Afstandsleren, een kunst apart. Een inventarisatie van afstandsleren op de hogeschool Windesheim. Zwolle: Hogeschool Windesheim.

Meyer, K. A. (2003). Face-to-face versus threaded discussions: The role of time and higherorder thinking. Journal of Asynchronous Learning Networks, 7(3), 55-65.

Miles, M. B., \& Huberman, A. M. (1999). Qualitative data analysis. London: Sage.

Milstead, J. A., \& Nelson, R. (1998). Preparation for an online asynchronous university doctoral course lessons learned. Computers in Nursing, 16(5), 247-258.

Moonen, B. (2001). Teacher learning in inservice networks on internet use in secondary education Unpublished doctoral dissertation. Enschede, The Netherlands: University of Twente.

Moore, J. L., Downing, R. E., \& York, D. L. (2009). Organizing instructional content for webbased content: Does a single model exist? In A. Orellana, T. L. Hudgins, \& M. Simonson (Eds.), The perfect online course. Best practices for designing and teaching (pp. 341-358). Charlotte, NC: Information Age Publishing.

Moore, M. G. (1980). Independent study. In R. D. Boyd, \& J. W. Apps (Eds.), Redefining the discipline of adult education. San Francisco: Jossey-Bass.

Moore, M. G. (1989). Editorial: Three types of interaction. American Journal of Distance Education, 3(2), 1-7.

Moore, M. G. (1993). Theory of transactional distance. In D. Keegan (Ed.), Theoretical principles of distance education. London: Routledge.

Moore, M. G. (2007). The theory of transactional distance. In M. G. Moore (Ed.), Handbook of distance education (pp. 89-108). Mahwah, NJ: Lawrence Erlbaum Associates.

Morris, L. V., Finnegan, C., \& Wu, S. S. (2005). Tracking student behavior, persistence, and achievement in online courses. Internet and Higher Education, 8(3), 221-231.

Morris, L. V., Xu, H., \& Finnegan, C. L. (2005). Roles of faculty in teaching asynchronous undergraduate courses. Journal of Asynchronous Learning Networks, 9(1), 65-82.

Muilenburg, L. Y., \& Berge, Z. L. (2005). Students barriers to online learning: A factor analytic study. Distance Education, 26(1), 29-48.

Muirhead, B. (2004). Encouraging creativity in student online work. International Journal of Instructional Technology and Distance Learning, 1(12), 51-56.

Muirhead, B., \& Betz, M. (2002). Faculty training at an online university. USDLA Journal, 16(1). Retrieved from http://www.usdla.org/html/journal/JAN02_Issue/article04.html 
Mullen, G. E., \& Tallent-Runnels, M. K. (2006). Student outcomes and perceptions of instructors' demands and support in online and traditional classrooms. The Internet and Higher Education, 9(4), 257-266.

Murphy, K. L., \& Collins, M. P. (1997). Development of communication conventions in instructional electronic chats. Journal of Distance Education, 12(1), 177-200. Retrieved from http://www.jofde.ca/index.php/jde/article/view/269

Nieveen, N. (1999). Prototyping to reach product quality. In J. van den Akker, R. M. Branch, K. Gustafson, N. Nieveen, \& T. Plomp (Eds.), Design approaches and tools in education and training (pp. 125-136). Dordrecht: Kluwer Academic Publisher.

Nieveen, N. (2009). Formative evaluation in educational design research. In T. Plomp, \& N. Nieveen (Eds.), An introduction to educational design research (pp. 89-101). Enschede: SLO.

Nulden, U. (1999). Thematic modules in an asynchronous learning network: A Scandinavian perspective on the design of introductory courses. Group Decision and Negotiation, 8(5), 391-408.

NVAO. (2003). Accreditatiekader bestaande opleidingen hoger onderwijs. Retrieved 25-102006, from http://www.jointquality.org/content/descriptors/AccreditatiekadersDDNLpage21.pdf

Oblinger, D. G., \& Maruyama, M. K. (1996). Distributed learning, CAUSE Professional Paper Series \#14. Retrieved from http:// net.educause.edu/ir/library/pdf/PUB3014.pdf

Oliver, R., \& Omari, A. (2001). Student responses to collaborating and learning in a web based environment. Journal of Computer Assisted Learning, 17(1), 34-47.

Oliver, M., \& Shaw, G. P. (2003). Asynchronous discussion in support of medical education. Journal of Asynchronous Learning Networks, 7(1), 56-67.

O'Regan, K. (2003). Emotion and e-learning. Journal of Asynchronous Learning Networks, 7(3), 78-92.

OSO Windesheim. (2005). Deelproject digitalisering en e-learning 2005-2006. Zwolle: Hogeschool Windesheim.

O'Sullivan, P. B., Hunt, S. K., \& Lippert, L. R. (2004). Mediated immediacy: A language of affiliation in a technological age. Journal of Language and Social Psychology, 23(4), 464-490.

Pallof, R. M., \& Pratt, K. (1999). Building learning communities in cyberspace: Effective strategies for the online classroom. San Francisco: Jossey-Bass.

Palloff, R. M., \& Pratt, K. (2001). Lessons from the cyberspace classroom. San Francisco: JosseyBass.

Pallof, R. M., \& Pratt, K. (2003). The virtual student. San Francisco: Jossey-Bass.

Pallof, R. M., \& Pratt, K. (2007). Building online learning communities. Effective strategies for the virtual classroom. San Francisco: Jossey-Bass.

Parkinson, M. G., \& Ekachai, D. (2002). The Socratic method in the introductory PR course: An alternative pedagogy. Public Relations Review, 28(2), 167-174.

Pawan, F., Paulus, T. M., Yalcin, S., \& Chang, C. F. (2003). Online learning: Patterns of engagement and interaction among in-service teachers. Language Learning $\mathcal{E}$ Technology, 7(3), 119-140. 
Pearson, J., \& Trinidad, S. (2006). Evaluating e-learning environments in initial teacher education programmes using the online learning environment survey (OLES). Paper presented the ACEC: Australian Computers in Education Conference 2006, Cairns, Queensland. Retrieved from

http://acce.edu.au/sites/acce.edu.au/files/archived_papers/conf_P_345_ACEC2006Pe arsonTrinidad.doc

Phipps, R., \& Merisotis, J. (2000). Quality on the line: Benchmarks for success in internet-based distance education. Washington: The Institute for Higher Education Policy.

Piaget, J., \& Inhelder, B. (1969, 2000). The psychology of the child. New York: Basic Books.

Picciano, A. G. (2002). Beyond student perceptions: Issues of interaction, presence, and performance in an online course. Journal of Asynchronous Learning Networks, 6(1), 21-40.

Plomp, T. (2009). Educational design research: An introduction. In J. van den Akker, B. Bannan, A. E. Kelly, N. Nieveen, \& T. Plomp (Eds.), An introduction to educational design research. Proceedings of the seminar conducted at the East China Normal University (pp. 9-35). Enschede: SLO.

Polin, L. (2004). Learning in dialogue with a practicing community. In T. M. Duffy, \& J. R. Kirkley (Eds.), Learner-centered theory and practice in distance education. Cases from higher education. (pp. 17-48). Mahwah, NJ: Lawrence Erlbaum Associates.

Reeve, J., \& Jang, H. (2006). What teachers say and do to support students' autonomy during a learning activity. Journal of educational psychology, 98(1), 209-218.

Reis, H. T., Sheldon, K. M., Gable, S. L., Roscoe, J., \& Ryan, R. M. (2000). Daily well-being: The role of autonomy, competence, and relatedness. Personality and Social Psychology Bulletin, 26(4), 419.

Richardson, J. C., \& Swan, K. (2003). Examining social presence in online courses in relation to students perceived learning and satisfaction. Journal of Asynchronous Learning Networks, $7(1), 68-88$.

Richey, R. C., \& Klein, J. D. (2007). Design and development research: Methods, strategies and issues. London: Lawrence Erlbaum Associates.

Rogers, E. M. (1995). Diffusion of innovation (4th ed.). New York: Free Press.

Rosenberg, M. J. (2006). Beyond e-learning: Approaches and technologies to enhance organizational knowledge, learning, and performance. San Francisco: Pfeiffer \& Co.

Rossman, M. H. (1999). Successful online teaching using an asynchronous learner discussion forum. Journal of Asynchronous Learning Networks, 3(2), 91-97.

Rourke, L., \& Anderson, B. (2002). Using peer teaching to lead online discussions. Journal of Interactive Media in Education, 7(1), 112-120.

Rourke, L., Anderson, T., Garrison, D. R., \& Archer, W. (2001). Assessing social presence in asynchronous text-based computer conferencing. Journal of Distance Education, 14(2), 50-71.

Rourke, L., \& Kanuka, H. (2009). Learning in communities of inquiry: A review of the literature. Journal of Distance Education, 23(1), 19-48.

Rovai, A. P. (2002a). Development of an instrument to measure classroom community. Internet and Higher Education, 5(3), 197-211.

Rovai, A. P. (2002b). Sense of community, perceived cognitive learning, and persistence in asynchronous learning networks. Internet and Higher Education, 5(4), 319-332. 
Rovai, A. P. (2002c). Sense of community, perceived cognitive learning, and persistence in asynchronous learning networks. Internet and Higher Education, 5(4), 319-332.

Rovai, A. P., \& Jordan, H. M. (2004). Blended learning and sense of community: A comparative analysis with traditional and fully online graduate courses. International Review of Research in Open and Distance Learning, 5(2), 1-13. Retrieved from http://www.irrodl.org/index.php/irrodl/article/view/192/795

Russo, T., \& Benson, S. (2005). Learning with invisible others: Perceptions of online presence and their relationship to cognitive and affective learning. Educational Technology $\mathcal{E}$ Society, 8(1), 54-62.

Salmon, G. (2004). E-moderating: The key to teaching and learning online. London: Taylor and Francis.

Sarker, S., \& Nicholson, J. (2005). Exploring the myths about online education in information systems. Informing Science: International Journal of an Emerging Transdiscipline, 8, 55-73.

Savery, J. R. (2005). Be vocal: Characteristics of successful online instructors. Journal of Interactive Online Learning, 4(2), 141-152.

Schellens, T., \& Valcke, M. (2005). Collaborative learning in asynchronous discussion groups: What about the impact on cognitive processing? Computers in Human Behavior, 21(6), 957-975.

Schellens, T., \& Valcke, M. (2006). Fostering knowledge construction in university students through asynchronous discussion groups. Computers $\mathcal{E}$ Education, 46(4), 349-370.

Schifter, C. C. (2000). Faculty participation in asynchronous learning networks: A case study of motivating and inhibiting factors. Journal of Asynchronous Learning Networks, 4(1), 15-22.

Schlager, M. S., \& Fusco, J. (2004). Teacher professional development, technology, and communities of practice: Are we putting the cart before the horse? In S. A. Barab, R. Kling, \& J. H. Gray (Eds.), Designing for virtual communities in the service of learning (pp. 120-153). Cambridge: Cambridge University Press.

Schunk, D. H. (2008). Learning theories: An educational perspective (5 $5^{\text {th }}$ ed.). Upper Saddle River, NJ: Merril Prentice Hall.

Schweber, C., Kelley, K. B., \& Orr, G. J. (1998). Training, and retaining, faculty for online courses: Challenges and strategies. Proceedings of the Annual Conference on Distance Teaching \& Learning (pp. 347-352). Madison, WI.

Shavelson, R. J., Phillips, D. C., Towne, L., \& Feuer, M. J. (2003). On the science of education design studies. Educational Researcher, 32(1), 25-28.

Shea, P., \& Bidjerano, T. (2008). Measures of quality in online education: An investigation of the community of inquiry model and the net generation. Journal of Educational Computing Research, 39(4), 339-361.

Shea, P., \& Bidjerano, T. (2009a). Community of inquiry as a theoretical framework to foster. Computers \& Education, 52(3), 543-553.

Shea, P., \& Bidjerano, T. (2009b). Cognitive presence and online learner engagement: A cluster analysis of the community of inquiry framework. Journal of Computing in Higher Education, 21(3), 199-217.

Shea, P., Fredericksen, E., Pickett, A. Pelz, W. \& Swan, K. (2001). Measures of learning effectiveness in the Suny Learning Network. In J. Bourne, \& J. Moore (Eds.), Online Education: Proceedings of the 2000 Sloan Summer Workshop on Asynchronous Learning Networks, Volume 3. Needham, MA: Sloan-C Press. 
Shea, P., Hayes, S., \& Vickers, J. (2010). Online instructional effort measured through the lens of teaching presence in the community of inquiry framework: A re-examination of measures and approach. International Review of Research in Open and Distance Learning, 11(3), 127-154.

Shea, P., Sau Li, C., \& Pickett, A. (2006). A study of teaching presence and student sense of learning community in fully online and web-enhanced college courses. Internet and Higher Education, 9(3), 175-190.

Sheldon, K. M., Abad, N., \& Hinsch, C. (2011). A two-process view of Facebook use and relatedness need-satisfaction: Disconnection drives use, and connection rewards it. Psychology of Popular Media Culture, 1, 2-15.

Shelton, M. W., Lane, D. R., \& Waldhart, E. S. (1999). A review and assessment of national educational trends in communication instruction. Communication Education, 48(3), 228237.

Slavin, R. E. (1994). Student teams-achievement divisions. In S. Sharan (Ed.), Handbook of cooperative learning methods (pp. 3-19). London: Greenwood Press.

Smits, A. E. H. (2005) E-learning in de nabije toekomst bij Windesheim OSO. Zwolle: Hogeschool Windesheim

Smits, A. E. H., \& Logtenberg, H. (2005). Uitgangsprincipes e-learning. Zwolle: Windesheim OSO master SEN.

Smits, A. E. H., \& Voogt, J. M. (2009). Elements of online teacher behaviour that lead to student satisfaction. Paper presented at the ICDE 2009. Retrieved from http://www.ou.nl/Docs/Campagnes/ICDE2009/Papers/Final_paper_335smits.pdf

Song, L., Singleton, E. S., Hill, J. R., \& Koh, M. H. (2004). Improving online learning: Student perceptions of useful and challenging characteristics. The Internet and Higher Education, 7(1), 59-70.

Spillane, J. P., Reiser, B. J., \& Reimer, T. (2002). Policy implementation and cognition: Reframing and refocusing implementation research. Review of Educational Research, 72(3), 387-431.

Sproull, L., \& Kiesler, S. (1986). Reducing social context cues: electronic mail in organizational communication. Management Science, 32(11), 1492-1512.

Stahl, G., Koschmann, T., \& Suthers, D. (2006). Computer-supported collaborative learning: An historical perspective. In R. K. Sawyer (Ed.), Cambridge handbook of the learning sciences (pp. 409-426). Cambridge, UK: Cambridge University Press.

Stake, R. E. (1995). The art of case study research. Thousand Oaks, CA: Sage Publications.

Stein, D. S., Wanstreet, C. E., Calvin, J., Overtoom, C., \& Wheaton, J. E. (2005). Bridging the transactional distance gap in online learning environments. The American Journal of Distance Education, 19(2), 105-118.

Stewart, I., Hong, E., \& Strudler, N. (2004). Development and validation of an instrument for student evaluation of the quality of web-based instruction. The American Journal of Distance Education, 18(3), 131-150.

Su, B., Bonk, C. J., Magjuka, R. J., Liu, X., \& Lee, S. (2005). The importance of interaction in web-based education: A program-level case study of online MBA courses. Journal of Interactive Online Learning, 4(1), 1-19.

Sudman, S., \& Bradburn, N. M. (1982). Asking questions? San Francisco: Jossey-Bass.

Swan, K. (2001). Virtual interaction: Design factors affecting student satisfaction and perceived learning in asynchronous online courses. Distance Education, 22(2), 306-331. 
Swan, K. (2002). Building learning communities in online courses: The importance of interaction. Education Communication and Information, 2(1), 23-49.

Swan, K., Shea, P., Fredericksen, E., Pickett, A., Pelz, W., \& Maher, G. (2000). Building knowledge building communities: Consistency, contact and communication in the virtual classroom. Journal of Educational Computing Research, 23(4), 359-383.

Swan, K., \& Shih, L. F. (2005). On the nature and development of social presence in online course discussions. Journal of Asynchronous Learning Networks, 9(3), 115-136.

Tallent-Runnels, M. K., Thomas, J. A., Lan, W. Y., Cooper, S., Ahern, T. C., Shaw, S. M., \& Liu, X. (2006). Teaching courses online: A review of the research. Review of Educational Research, 76(1), 93-135.

Thompson, M. M. (2004). Faculty self-study research project: Examining the online workload. Journal of Asynchronous Learning Networks, 8(3), 84-88.

Thoonen, E. E. J., Sleegers, P. J. C., Oort, F. J., Peetsma, T. T. D., \& Geijsel, F. P. (2011). How to improve teaching practices. Educational Administration Quarterly, 47(3), 496-536.

Tinto, V. (1997). Classrooms as communities: Exploring the educational character of student persistence. The Journal of Higher Education, 68(6), 599-623.

Tisdell, E. J., Strohschen, G. I. E., Carver, M. L., Corrigan, P., Nash, J., Nelson, M., ... O'Connor, M. (2004). Cohort learning online in graduate higher education: Constructing knowledge in cyber community. Educational Technology and Society, 7(1), 115-127.

Tondeur, J., Hermans, R., Van Braak, J., \& Valcke, M. (2008). Exploring the link between teachers' educational belief profiles and different types of computer use in the classroom. Computers in Human Behavior, 24(6), 2541-2553.

$\mathrm{Tu}, \mathrm{C} . \mathrm{H} .$, \& McIsaac, M. (2002). The relationship of social presence and interaction in online classes. The American Journal of Distance Education, 16(3), 131-150.

Tweddell Levinsen, K. (2006). Collaborative on-line teaching: The inevitable path to deep learning and knowledge sharing? The Electronic Journal of E-learning, 4(1), 41-48. Retrieved from http:// www.ejel.org/volume-4/v4-i1/levinsen-karin-tweddell.pdf

U.S. Department of education (2010). Evaluation of evidence-based practices in online learning. A meta-analysis and review of online learning studies. Washington, DC: U.S. Department of Education.

Visser, J. A. (2000). Faculty work in developing and teaching web-based distance courses: A case study of time and effort. American Journal of Distance Education, 14(3), 21-32.

Volery, T., \& Lord, D. (2000). Critical success factors in online education. International Journal of Educational Management, 14(5), 216-223.

Vonderwell, S. (2003). An examination of asynchronous communication experiences and perspectives of students in an online course: A case study. Internet and Higher Education, $6(1), 77-90$.

Voogt, J., Almekinders, M., van den Akker, J., \& Moonen, B. (2005). A 'blended' in-service arrangement for classroom technology integration: Impacts on teachers and students. Computers in Human Behavior, 21(3), 523-539.

Vrasidas, C., \& McIsaac, M. S. (1999). Factors influencing interaction in an online course. American Journal of Distance Education, 13(3), 22-36.

Vygotsky, L. S. (1961). Thought and language. Cambridge, MA: MIT Press.

Vygotsky, L. S. (1978). Mind in society. The development of higher psychological processes. Cambridge, MA: Harvard University Press. 
Wallace, R. (2003). Online learning in higher education: A review of research on interactions among teachers and students. Education, Communication and Information, 3(2), 241-280.

Wang, F., \& Hannafin, M. J. (2005). Design-based research and technology-enhanced learning environments. Educational Technology Research and Development, 53(4), 5-23.

Wen, M. L., Tsai, C. C., Lin, H. M., \& Chuang, S. C. (2004). Cognitive-metacognitive and content-technical aspects of constructivist Internet-based learning environments: A LISREL analysis. Computers $\mathcal{E}$ Education, 43(3), 237-248.

Wheeler, S. (2009). Learner support needs in online problem-based learning. In A. Orellana, T. Hudgins, \& M. Simonson (Eds.), The perfect online course. Best practices for designing and teaching (pp. 475-486). Charlotte, NC: Information Age Publishing.

Wilson, G., \& Stacey, E. (2003). Online interaction impacts on learning: Teaching the teachers to teach online. In G. Crisp, D. Thiele, I. Scholten, S. Baker, \& J. Baron (Eds.), Interact, integrate, impact: Proceedings of the 20th annual conference of the Australasian Society for Computers in Learning in Tertiary Education (ASCILITE) (pp. 541-551). Adelaide: ASCILITE.

Windesheim. (2003). Instellingsplan: Windesheim op streek. Zwolle: Hogeschool Windesheim.

Wise, A., Chang, J., Duffy, T., \& Del Valle, R. (2005). The effects of teacher social presence on student satisfaction, engagement, and learning. Journal of Educational Computing Research, 31(3), 247-271.

WOSO. (2004). Bekwaam en speciaal, generiek compententieprofiel speciale onderwijszorg. Apeldoorn: Garant.

Yacci, M. (2000). Interactivity demystified: A structural definition for distance education and intelligent CBT. Educational Technology, 40(4), 5-16.

Zhang, K. (2004). Effects of peer-controlled or externally structured and moderated online collaboration on group problem solving processes and related individual attitudes in wellstructured and ill-structured small group problem solving in a hybrid course. Doctoral dissertation. Pennsylvania State University. Retrieved from https://etda.libraries.psu.edu/paper/6275

Zhang, Y., Tang, L. S. T., \& Leung, L. (2011). Gratifications, collective self-esteem, online emotional openness, and traitlike communication apprehension as predictors of Facebook uses. Cyberpsychology, Behavior, and Social Networking. Retrieved from http://www.liebertonline.com/doi/pdf/10.1089/cyber.2010.0042

Zimmerman, B. J. (2000). Self-efficacy: An essential motive to learn. Contemporary Educational Psychology, 25(1), 82-91. 


\section{ENGLISH SUMMARY \\ Design and implementation of the master Special Educational Needs through e-learning}

\section{PURPOSE OF THE STUDY AND PROBLEM STATEMENT}

Dutch colleges and universities are increasingly working with e-learning or planning to do so in the near future. In many cases they are seeking ecologically valid design principles. Currently Dutch higher education lacks clear and complete sets of valid e-learning design principles. The current research seeks to contribute to building such a set of design principles for e-learning within the context of Dutch higher education. The study took place within the Windesheim master Special Educatonal Needs (SEN).

In 2005 the management team of the Windesheim master SEN commissioned to design and produce four master SEN courses via e-learning. These four master SEN courses had existed for some time in the form of face to face courses. The face to face courses were to constitute the basis of the e-learning courses. The assignment from the management team contained short-term goals in terms of numbers of enrollments, student satisfaction and academic success for the elearning courses. Within the Windesheim institute there was no prior experience with e-learning. The conversion of the four face to face courses to e-learning courses therefore constituted a major challenge. A small e-learning team was formed. Near the end of 2005 a rough draft of the e-learning design was delivered, based on a limited review of the literature. In response to the rough draft, questions were raised about relevance, usefulness and effectiveness.

In response to these questions the research that is the subject of the dissertation was initiated. The purpose of the study was to validate and to refine the rough draft of the 
e-learning design, and to support, to augment and to evaluate the implementation. The problem statement in this study was as follows: Which principles constitute a valid, useful and effective e-learning design for master SEN courses?

\section{RESEARCH QUESTIONS AND METHOD}

The problem statement in the study resulted in the following research questions:

1. What is a suitable design for the master SEN e-learning courses?

2. Do the design principles turn out to be usable in the setting of the Windesheim master SEN?

3. Do the design principles lead to effective master SEN courses?

The study was designed according to the principles of design research. This type of research is ideally suited to answer the kinds of questions that arose in reaction to the rough draft of the e-learning design. In design research there is a close relationship between theory and practice and a cyclic interaction between design, implementation and evaluation. The present study consisted of three phases: the analysis phase, the pilot phase and implementation phase. The analysis phase took 1,5 years. The pilot phase lasted six months. The implementation phase covered a period of almost two years, in which two cohorts of students were followed. Data collection was rich, several methods were used: interviews, surveys, field notes, document analysis and quantitative and qualitative analysis of contributions in Blackboard.

\section{RESULTS}

\section{Design of the e-learning courses}

The first research question was central to the analysis phase of the study: What is a promising design for the master SEN e-learning courses? This research question was answered on the basis of contextual analysis, literature review and expert interviews. This resulted in a grounded description of four clusters of design principles for e-learning: the interaction among students, the structure, the instructor's role, and the course materials. Within these four clusters a total of 15 design principles were identified and described for the e-learning courses. In 
order to obtain a more concrete impression of the e-learning courses, a general overview of the design is given below.

E-learning in the master SEN takes place in small groups and under a tight schedule in purpose-built e-learning modules. These modules are arranged in a fixed way to promote clarity and predictability. Each school year four modules are taught. Each module lasts for 8 weeks. All modules are moderated by an online instructor. The modules offer weekly themes that consist of literature and multimedia learning objects.

Student interaction in the Blackboard modules is both cognitive and social. The cognitive interaction is guided by clearly articulated collaboration and discussion assignments that take place under a tight schedule in Blackboard group discussion boards. The assignments are mandatory, the goal is to rehearse, apply and/or construct knowledge. Social interaction among students is seen as a precondition for collaboration and mutual support during the course. Social interaction among students is initiated and stimulated during a one-day oncampus session at the start of the course.

After this face-to-face session online social activities and the 'café area' in Blackboard serve to stimulate online social behavior.

The instructor moderates the cognitive discussions in Blackboard with a fixed frequency per week. The input from the instructor in the cognitive discussions consists of professional expertise, moderation and concrete feedback. Online teacher immediacy is considered important in teacher-student contact. In addition, the instructor monitors student activity in Blackboard and activates students via e-mail when necessary. The instructor responds timely (within 2 working days) to questions from students and negotiates exceptions for individual students when needed. A synchronous virtual office hour is scheduled weekly via Breeze. E-learning instructors and face to face instructors are allotted equal amounts of time for their teaching tasks. Before the start of the e-learning courses the instructors received training and a manual describing the various aspects of recommended instructor behavior.

The three e-learning experts who were interviewed during the study, confirmed the design in general, although one of the experts reacted negatively to 
asynchronous discussions and to collaborative learning. The strong confirmation from the other two experts (one of them was very experienced) was important to convince the management of the Windesheim master SEN of the feasibility of the current design. The three e-learning experts contributed a number of nuances to the design with respect to the formulation of assignments and the complexity of the instructor's role. The experts questioned the usefulness of the weekly synchronous office hours.

Usability of the four design clusters

\section{Design cluster 'interaction among students'}

In this cluster two design principles were described:

- Collaborative learning through asynchronous discussion.

- Social interaction.

Collaborative learning through asynchronous discussion proved to be a usable design principle for the Windesheim master SEN. The students contributed to the discussion assignments in a satisfactory way. The student scores on perceived learning from the discussions were high and the instructors confirmed the learning effect. However, in the beginning of the course it took time for students to learn how to contribute to asynchronous discussions. Initially a number of students produced very extensive contributions which led to a very high reading load for all participants. Discussion assignments sometimes stagnated due to the fact that some students contributed too much and others too little. A number of adjustments were made so that these problems decreased and disappeared in the course of time.

Social interaction turned out to be usable but also vulnerable as a design principle. In the pilot modules as well as in the first cohort, social interaction occurred less frequently than expected. Connectedness scored too low in several modules of cohort 1 . The lowest score for connectedness was found in the module where the students were assigned to new groups by the instructors without prior consultation. The students did not appreciate this.

Both the students and the e-learning instructors valued social interaction among students. The instructors associated social interaction between students with mutual encouragement and support, and with a more enthusiastic interaction in 
cognitive discussions. After some modifications, connectedness and social interaction were sufficiently realized in the second cohort.

We examined whether the students appreciated the design cluster 'interaction between students'. To this end, the students were asked to rate the overall collaboration with fellow students. In the module with the group composition problems (caused by the instructors), the overall collaboration was rated the lowest. The overall appreciation for collaboration was positively associated with both design principles in the cluster: collaborative learning through asynchronous discussion and social interaction. Higher scores for perceived learning in asynchronous discussions were associated with higher appreciation for the overall collaboration. Higher scores for social connectedness were also associated with higher scores for collaboration.

\section{Design cluster 'e-learning structure'}

In this cluster three design principles were described:

- Tight schedule.

- Balanced workload.

- Clearly defined goals and expectations.

The tight schedule with compulsory assignments and deadlines proved a useful design principle for the master SEN e-learning courses. In most cases the students adhered to the prescribed study rhythm. Most students experienced the tight schedule as supportive for their own planning. Furthermore the tight schedule proved to be an important precondition for collaborative learning. During the first year of implementation, some students were not comfortable with the prescribed schedule. Problems ensued in the collaboration with fellow students. It turned out to be very important that students embarked on the course with realistic expectations and corresponding arrangements at home and at work. Students who made proper arrangements before starting the course, had (almost) no problems following the schedule. Temporary problems with the schedule arose every now and then, due to private circumstances. When necessary, the instructors agreed on exceptions to the required schedule in such cases. For some students picking up on the rhythm of the schedule proved difficult after holidays.

A balanced workload in the e-learning modules proved important but also difficult to realize. Over time no clear improvement was measured in the 
workload balance, despite attempts that were made to this end. As a result of this a number of e-learners experienced stress and / or comprehension problems.

Clearly defined goals and expectations turned out to be very important to students. In general the students confirmed that the information in Blackboard was sufficiently clear. However the clarity of the assignments and the associated requirements often met with discontent. At the start of cohort 1 , this resulted in communication overload and loss of time around these organizational matters. Despite continuous improvements, unclear tasks and requirements remained a problem for some students.

The students overall appreciation of the design cluster 'e-learning structure' was examined. To this end, the students were asked to rate their appreciation for the organization of the modules. On average the students rated the module organization as more than adequate. This was a more positive evaluation than expected, given the problems with two of the design principles. The appreciation for the organization of the modules was positively related to all three design principles in the cluster. In addition to that a relation to the appreciation for the instructor was found. The online instructors played a supportive and compensatory role with regard to the problems that were identified.

\section{Design cluster 'instructors role'}

Initially nine design principles were described for the role of the online instructor.

- Time and attendance schedule.

- Moderation.

- Feedback.

- Support and advice.

- Flexibility and content adjustments.

- Control and activation.

- Synchronous office hours.

- Social presence.

- Training.

The synchronous office hours were terminated due to the negative expert opinions on the subject and the experiences in the pilot phase. The usability of this principle proved insufficient during this phase. The other design principles proved useful, but many adjustments were made in the details of the 
implementation. Apart from the adjustments, the online instructors needed time and support to grow in their complex roles.

Timely reactions and regular visible presence of the instructor proved to be of great importance to students. Unfortunately, the requirements in this area caused a very high workload for the instructors at the start of cohort 1. After major revisions in this area, time use and time allocation reached an acceptable balance for the online instructors. The tasks of e-learning instructors proved to be of a more continuous nature than the tasks of face-to-face instructors. Through active planning, instructors tried to come to terms with this feature of e-learning.

In the beginning of the implementation phase, the instructors had little moderating skills as well as little time to moderate due to the many organizational questions of students that needed to be answered. Over time the number of organizational questions decreased and the instructors' moderating skills improved.

Specific and constructive feedback was highly valued by students. Providing feedback from a distance proved to be difficult and time consuming for online instructors. They tested several feedback systems, but the need for a less time consuming feedback system remained.

Support on organizational matters proved to be extremely important for students. At the start of cohort 1 too much time was spent on this aspect of the instructor's tasks at the expense of other, more substantive, aspects. Communication guidelines, technical guides and a list of frequently asked questions reduced this aspect of the instructor role to manageable proportions.

Flexibility and adjustment of the content were not always realized in a convincing way. The literature, the assignments and the discussions left room for adjustment to the individual student's needs, but not all instructors were equally aware of these opportunities.

Monitoring of student participation was important because problems arose in groups when some of the group members participated too little. The instructors experienced that it was difficult to find the right tone to activate the less active students. They considered 'control and activation' as less important than the other aspects of their instructor role. 
Social presence proved to be a usable principle. The instructors learned how to express themselves online. While they initially reported missing the face to face contact with students, they were very content about the online contacts later on. Training for e-learning teachers appeared to be important, but the forms that were chosen had disappointing results. The manual and the workshop did not lead to the expected results. The instructors needed support on the job, examples and direct and concrete feedback on their work with students.

The students' appreciation of the design cluster 'instructor role' was examined. To this end, the students were asked to rate their appreciation for the instructor in each of the modules. In most cases inexperienced online instructors did not reach the standard that was set by the management team. Experienced e-learning instructors scored above the standard. It is important to note that the experienced instructors not only had experience with e-learning, but that they were also experts in the subject of the module. Satisfaction with the instructor was positively and consistently associated with the instructor's moderation quality. Associations with the other design principles were also identified. Most associations were positive. The associations with feedback and with flexibility were sometimes positive, sometimes negative. For flexibility there was a negative association at the start of the study, in the course of time this progressed to a positive association.

\section{Design cluster 'course materials'}

One design principle was described for this cluster:

- Rich learning environment

The rich learning environment of the e-learning modules elicited enthusiastic reactions from the experts, students and online instructors. Nevertheless the rich learning environment developed after some time into a more efficient learning environment. The diversity of the learning objects decreased in the newer modules. After some time module builders primarily built the sorts of learning objects that were considered to be most instructive by the students. This resulted in an emphasis on providing compact written explanations to enhance understanding of complex issues. The enhanced efficiency of the learning environment reduced cognitive load for students as well as the complexity of building modules for instructors. 
The student's appreciation for the design cluster 'course materials' was examined. To this end, the students were asked to rate the overall learning effect of the course materials. The students confirmed a positive learning effect. Their appreciation of the overall learning effect showed positive associations with their appreciation of the learning effect of written explanations, literature, video fragments, worked examples and web links.

\section{Effects of the e-learning master SEN}

\section{Student satisfaction}

In most cases student satisfaction reached the standard that was set by the management team. However, in a number of cohort 1 modules, student satisfaction varied largely. Student satisfaction was associated with the appreciation for the structure, the course materials and the instructor role. In cohort 1 a negative attitude toward computers was associated with lower student satisfaction.

\section{Attrition and academic success}

Attrition and academic success were comparable with the face to face cohort. This was consistent with the targets of the management team. Students who were satisfied with e-learning structure and student interaction dropped out less often. Study-related anxiety in the first module was not favourable; anxious students dropped out often. Computer attitude showed no relation to drop out and failure.

\section{REFLECTIONS}

Design research in the context of higher education

The present study is an example of a study initiated within an institute of higher education. The interests and limitations of the institute also meant interests and constraints for the research.

An advantage of this situation was that the complex educational innovation directly matched the ambitions of the institute so that the research findings could lead to real and lasting innovations.

Disadvantages of the central role of the institute, were time constraints and limited availability of staff. The practical teaching situation within the 
Windesheim master SEN limited the number of possible iterations and resulted in abrupt transitions between the cycles in the study. It is important that researchers take into account the constraints imposed by the educational environment. It is advisable to draft compensations for the constraints of the situation as early as the research proposal.

Design research protects against implementations that are determined by the political, financial and ideological fads. A well conducted analysis phase provides a solid theoretical, empirical and practical basis for design principles. From a financial management point of view the current e-learning design was certainly not the most attractive and obvious design because it was not cheaper than regular education. The design was granted a chance because of the thoroughness of the analysis and confirmation of the resulting design principles by experts.

\section{Learning to learn online}

Consideration of the many adjustments that were made to details in the implementation, shows that these changes were often intended to teach students to learn online. The trend was identified that students drop out early, in or just after the first online module. It turned out to be of high importance to prevent, identify and remedy problems in the early stages of the course.

\section{Learning to teach online}

The current study confirms that most new e-learning instructors quickly overcome the differences with regular teaching. After one module, most online instructors showed improvement in terms of student satisfaction. Only a very limited number of instructors dropped out after their first online module. However, for most instructors, starting to teach via e-learning was not easy. In the beginning their workload was too high because they had to adjust to the process while supporting students who had to adjust to e-learning as well. Their new role was complex, there was a large amount of written communication and in the first module they had to supervise too many groups that worked on too many assignments. At the start of the implementation phase the instructors lacked guidance to balance their complex online tasks. The online course required not only new teaching behavior, but also aspects of regular teaching skills. The latter did not automatically transfer to the online context. The start of online teaching might be facilitated by an emphasis on the similarities between online and regular teaching. Obviously the differences also merit attention. Important differences are 
the emphasis on asynchronous written communication, the psychological distance between students and lecturers, moderation of the discussions and continuity of the workload.

\section{Is it worth the trouble?}

The e-learning course in this study has a complex design to which structure and interaction are central. Such a design is demanding in terms of the organization and deployment of instructors. The complexity of the design can be unattractive for educational institutions, even if only for financial reasons. Educational designers are forced to defend why such a complexity (similar to that of regular education), is necessary. In the recent literature and practice of higher education three questions arise that relate to the central design principles of the described online course.

- Does the structure provided in the online course unnecessarily constrain the freedom of students?

- Is active involvement of instructors necessary or can they operate more passively on the side?

- Is interaction between students really necessary?

Regarding the first question the following is concluded: the students appreciate the organization of e-learning as a supporting structure for their learning. In addition, students appear to have a strong need for clarity and a low tolerance for chaos. Chaos increases the likelihood of dropping out. Schedules and deadlines also proved to be an essential condition for interaction to take place. Support for these conclusions is found in the literature.

At first glance, schedules and deadlines do not seem very attractive to students. One may wonder how the need for clarity and structure relates to the need for time independent learning that is often reported in the e-learning literature. One possible interpretation is the following: the need for time independent learning without obligations stems from a hedonistic motivation system that strives for short term gain, convenience and enjoyment. A clear e-learning structure, on the other hand, supports students' own planning, creates the necessary and safe conditions for interaction, and enhances the possibility for self-realization in terms of academic success and graduation. 
Based on this study and on review of the literature it is concluded that it is wise to assign an active role to online instructors. An experienced e-learning instructor, who is expert in his field, has a positive impact on student satisfaction and on the extent to which students believe that their learning needs are met.

The answer to the third question is that interaction with fellow students in elearning is indeed an added value. Doubts on this matter usually arise from the following statements: collaborative learning does not suit the learning preferences of some students, there is too little expertise among the participating students to make the asynchronous collaboration worthwhile; and social interaction plays no role in student satisfaction.

For some students in the master SEN study collaborative learning was not the preferred study method. However, on average the students participating in the study clearly appreciated the collaboration. An important question is whether educational institutions should give in when students refuse to collaborate. Collaborative learning (if well designed) does not only produce positive learning results but also forms a learning goal in itself for students. Education in the 21st century does not merely require students to collaborate, collaboration is also required from teachers and other professionals in education.

In this study, both students and instructors were satisfied with the levels of cognitive activity and perceived learning in the asynchronous discussions offered in the SEN e-learning program. The social interaction provided the fertile soil on which collaborative learning could flourish. A threshold value for social interaction seems to exist, above which it no longer contributes to student satisfaction. Below that threshold, the satisfaction with the educational experience as a whole, however, seems affected in this study. Students who were dissatisfied with the social interaction in their first module, often dropped out. The current study and the results of the literature review confirm the importance of social interaction between online students.

\section{OUTPUT AND PROSPECTS}

Design research leads to improvements in teaching practice. Knowledge is produced, as well as products and professional development of those involved. The 
master SEN e-learning study produced a number of results. First of all, it yielded knowledge of the four design clusters and of the implementation adjustments that proved necessary. The application of the design clusters and the adjustments led to the desired results in terms of satisfaction, retention and graduation.

The results of the study may give rise to further theorizing about factors that play a role in the satisfaction, retention and academic success of e-learning students. A reappraisal of the role of the design cluster 'structure' seems warranted. Structure is the only cluster in this study that is systematically associated with both student satisfaction and retention. From a superficial (external) motivation point of view this cluster does not seem very attractive to students. However, this cluster may well play an intrinsically motivating role that can be explained from the basic needs pyramid as described by Maslow. A well organized e-learning course provides safety and thereby satisfies a basic human need. Chaos may be far more dangerous than tight schedules with deadlines.

The study contributed to the creation of several products for educational practice. Significant outputs of the study were the 11 different modules that featured in the study as well as all consecutively developed modules for the e-learning initiative that is now (February 2012) in its fifth year of implementation. In addition to the modules an instrument was developed that may predict attrition at an early stage of the study. It would be useful to further investigate this with new cohorts of students. A number of the instruments used for this research are currently used on a regular basis for both the e-learning and the face to face courses.

Another result of the study is the professional development of the instructors involved in e-learning. Based on the results of the present study an e-learning module was built to prepare instructors for their online tasks.

For the near future the study yields follow-up questions with respect to the workload of online instructors. It seems important to determine whether certain job aspects may partly be automated and whether students can play a more important role in feedback and moderation without reducing the cognitive output of the discussions.

The outcomes of the master SEN study do certainly not preclude the existence of other types of effective e-learning design. Both current and future technological developments will lead to new educational opportunities, and will raise new design questions. 


\section{BiJLAGEN}


Bijlage A Nederlandse vertaling van de Teachers Attitude Toward Computers (TAC) Vragenlijst (Knezek, Christensen, \& Miyashita, 2000; Moonen, 2001)

\section{Docent attitude computer vragenlijst}

Wij verzoeken je deze vragenlijst naar waarheid in te vullen. Klik het antwoord aan dat het meeste op jou van toepassing is. Kies 1 antwoord per vraag.

Bij de beantwoording heb je de volgende mogelijkheden:

\section{helemaal oneens}

oneens

neutraal

eens

helemaal eens

Je gegevens

Je naam is: *

Studeer je via e-learning of volg je lessen op de hogeschool? *

C Via e-learning

C Volg lessen op de hogeschool

\section{Factor 1 (Plezier)}

Ik denk dat het nuttig en stimulerend is om met computers te werken.*

$C$ Helemaal oneens $C$ Oneens $C$ Neutraal $C$ Eens $C$ Helemaal eens Ik vind leren over en omgaan met computers interessant *

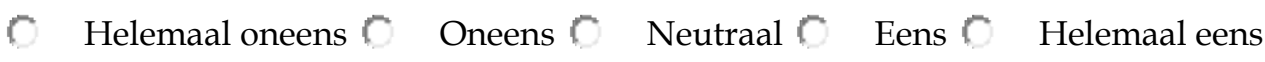

Het is leuk uit te zoeken hoe computers werken. *

$C$ Helemaal oneens $C$ Oneens $C$ Neutraal $C$ Eens $C$ Helemaal eens

Ik vind computers heel interessant. *

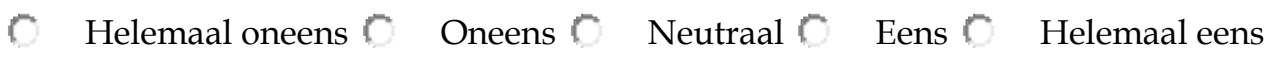
Ik verheug me erop om in mijn werk een computer te gebruiken. *

$C$ Helemaal oneens $C$ Oneens $C$ Neutraal $C$ Eens $C$ Helemaal eens Kennis maken met de verschillende typen computergebruik is best interessant *

$C$ Helemaal oneens $C$ Oneens $C$ Neutraal $C$ Eens $C$ Helemaal eens De mogelijkheid om problemen met computers op te lossen trekt me niet aan. *

$C$ Helemaal oneens $C$ Oneens $C$ Neutraal $C$ Eens $C$ Helemaal eens Computers zijn saai. *

$C$ Helemaal oneens $C$ Oneens $C$ Neutraal $C$ Eens $C$ Helemaal eens Ik wil computerlessen volgen. *

$C$ Helemaal oneens $C$ Oneens $C$ Neutraal $C$ Eens $C$ Helemaal eens

Ik vind het plezierig iets met de computer te doen. * 


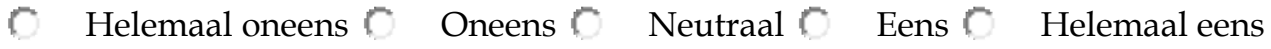

Als het mogelijk is, zal ik cursussen volgen die mij leren nog beter met computers om te gaan. *

$C$ Helemaal oneens $C$ Oneens $C$ Neutraal $C$ Eens $C$ Helemaal eens

Ik zou de computer graag meer gebruiken. *

$C$ Helemaal oneens $C$ Oneens $C$ Neutraal $C$ Eens $C$ Helemaal eens

Ik lees graag over computers. *

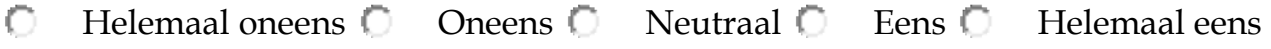

Ik zal zo weinig mogelijk de computer gebruiken bij mijn werk. *

$C$ Helemaal oneens $C$ Oneens $C$ Neutraal $C$ Eens $C$ Helemaal eens

Ik praat graag met anderen over computers. *

$C$ Helemaal oneens $C$ Oneens $C$ Neutraal $C$ Eens $C$ Helemaal eens

\section{Factor 2 (Angst)}

Ik voel me onprettig als ik er aan denk de computer te moeten gebruiken. *

$C$ Helemaal oneens $C$ Oneens $C$ Neutraal $C$ Eens $C$ Helemaal eens

Computers zorgen ervoor dat ik me niet op mijn gemak voel. *

$C$ Helemaal oneens $C$ Oneens $C$ Neutraal $C$ Eens $C$ Helemaal eens

Werken met computers maakt me erg nerveus. *

$C$ Helemaal oneens $C$ Oneens $C$ Neutraal $C$ Eens $C$ Helemaal eens

Computers zorgen ervoor dat ik me ongemakkelijk en verward voel. *

$C$ Helemaal oneens $C$ Oneens $C$ Neutraal $C$ Eens $C$ Helemaal eens

Ik heb veel zelfvertrouwen in het omgaan met computers. *

$C$ Helemaal oneens $C$ Oneens $C$ Neutraal $C$ Eens $C$ Helemaal eens

Ik durf een computer niet te gebruiken omdat ik bang ben fouten te maken die ik niet kan herstellen. *

$C$ Helemaal oneens $C$ Oneens $C$ Neutraal $C$ Eens $C$ Helemaal eens

Ik ben terughoudend over het gebruik van computers. *

$C$ Helemaal oneens $C$ Oneens $C$ Neutraal $C$ Eens $C$ Helemaal eens

Computers zijn verwarrend. *

$C$ Helemaal oneens $C$ Oneens $C$ Neutraal $C$ Eens $C$ Helemaal eens

Ik vermijd computers te gebruiken, want ik ben er niet vertrouwd mee en ze intimideren me enigszins. *

Helemaal oneens $C$ Oneens $C$ Neutraal $C$ Eens $C$ Helemaal eens

Ik voel me hulpeloos wanneer mij gevraagd wordt een nieuwe taak op de computer uit te voeren. *

$C$ Helemaal oneens $C$ Oneens $C$ Neutraal $C$ Eens $C$ Helemaal eens

Computers beangstigen me soms. *

$C$ Helemaal oneens $C$ Oneens $C$ Neutraal $C$ Eens $C$ Helemaal eens

Ik voel me incompetent wanneer anderen over computers praten. *

Helemaal oneens $C$ Oneens $C$ Neutraal $C$ Eens $C$ Helemaal eens

Ik vind dat computers erg makkelijk in het gebruik zijn. *

Helemaal oneens $C$ Oneens $C$ Neutraal $C$ Eens $C$ Helemaal eens 
Ik heb niet het gevoel controle te hebben over wat ik doe als ik een computer gebruik. *

$C$ Helemaal oneens $C$ Oneens $C$ Neutraal $C$ Eens $C$ Helemaal eens

Ik voel me op mijn gemak wanneer een gesprek over computers gaat. *

$C$ Helemaal oneens $C$ Oneens $C$ Neutraal $C$ Eens $C$ Helemaal eens

\section{Factor 3 (Vermijding)}

Eigenlijk zou ik de computer het liefst uit huis doen. *

$C$ Helemaal oneens $C$ Oneens $C$ Neutraal $C$ Eens $C$ Helemaal eens

Leren over computers is tijdverspilling. *

$C$ Helemaal oneens $C$ Oneens $C$ Neutraal $C$ Eens $C$ Helemaal eens

Ik heb geen flauw idee hoe ik in mijn carrière computers kan gebruiken. *

$\checkmark$ Helemaal oneens $C$ Oneens $C$ Neutraal $C$ Eens $C$ Helemaal eens

Ik zal waarschijnlijk wel nooit iets over computers weten. *

$C$ Helemaal oneens $C$ Oneens $C$ Neutraal $C$ Eens $C$ Helemaal eens

Ik zie mijzelf niet als iemand die regelmatig iets met computers zal doen. *

$C$ Helemaal oneens $C$ Oneens $C$ Neutraal $C$ Eens $C$ Helemaal eens

Er zijn niet veel mensen die computers kunnen gebruiken. *

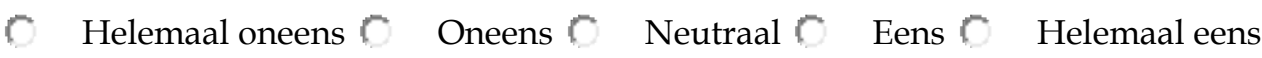

Het leren bedienen van een computer is zoals het leren van iets nieuws - hoe meer ervaring je hebt, des te beter je er in wordt. *

$\checkmark$ Helemaal oneens $C$ Oneens $C$ Neutraal $C$ Eens $C$ Helemaal eens

Het is een waardevolle vaardigheid als je weet hoe je computers moet gebruiken. *

Helemaal oneens $C$ Oneens $C$ Neutraal $C$ Eens $C$ Helemaal eens

Ik denk dat ik het moeilijk zou vinden een computercursus te volgen. *

$C$ Helemaal oneens $C$ Oneens $C$ Neutraal $C$ Eens $C$ Helemaal eens

Ik zou nooit een baan accepteren waarbij ik met computers zou moeten werken. *

Helemaal oneens $C$ Oneens $C$ Neutraal $C$ Eens $C$ Helemaal eens

Als ik de kans had, zou ik graag leren over en met computers. *

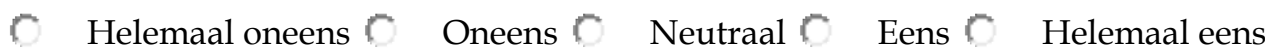

Je moet hoogbegaafd zijn om met computers te werken. *

$C$ Helemaal oneens $\mathbb{C}$ Oneens $C$ Neutraal $C$ Eens $C$ Helemaal eens

\section{Factor 4 (Negatieve impact op de maatschappij)}

Computers veranderen de wereld te snel *

Helemaal oneens $C$ Oneens $C$ Neutraal $C$ Eens $C$ Helemaal eens

Ik ben bang dat als ik computers ga gebruiken, ik daarvan afhankelijk zal worden en mijn denkvermogen zal verminderen. *

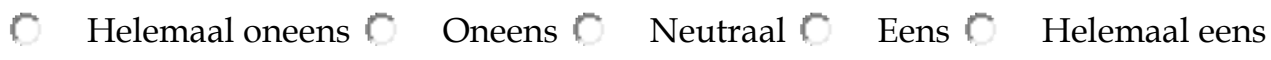

Computers maken de maatschappij onpersoonlijk door iedereen als een nummer te behandelen. *

Helemaal oneens $C$ Oneens $C$ Neutraal $C$ Eens $C$ Helemaal eens

Ons land is te veel van computers afhankelijk. * 


\section{Helemaal oneens $C$ Oneens $C$ Neutraal $C$ Eens $C$ Helemaal eens}

Computers isoleren mensen door normale sociale contacten tussen gebruikers te verhinderen. *

$C$ Helemaal oneens $C$ Oneens $C$ Neutraal $C$ Eens $C$ Helemaal eens

Door het gebruik van computers in het onderwijs vermindert bijna altijd de persoonlijke aandacht voor studenten. *

1 Helemaal oneens $C$ Oneens $C$ Neutraal $C$ Eens $C$ Helemaal eens Computers hebben het potentiële gevaar ons leven over te nemen. *

$C$ Helemaal oneens $C$ Oneens $C$ Neutraal $C$ Eens $C$ Helemaal eens

Werken met computers zorgt ervoor dat ik me geïsoleerd voel van andere mensen. *

$\checkmark$ Helemaal oneens $C$ Oneens $C$ Neutraal $C$ Eens $C$ Helemaal eens

Ik vind het niet leuk met apparaten te werken die slimmer zijn dan ik. *

$C$ Helemaal oneens $C$ Oneens $C$ Neutraal $C$ Eens $C$ Helemaal eens

Het gebruik van een computer remt mijn creativiteit. *

$C$ Helemaal oneens $C$ Oneens $C$ Neutraal $C$ Eens $C$ Helemaal eens

Werken met computers betekent geïsoleerd werken, zonder contact met anderen. *

Helemaal oneens $C$ Oneens $C$ Neutraal $\mathbb{C}$ Eens $C$ Helemaal eens

\section{Factor 5 (Productiviteit)}

Computers verhogen mijn productiviteit. *

Helemaal oneens $C$ Oneens $C$ Neutraal $C$ Eens $C$ Helemaal eens

Ervaring met computers is een voordeel in mijn werk. *

$C$ Helemaal oneens $C$ Oneens $C$ Neutraal $C$ Eens $C$ Helemaal eens

Computers kunnen mij tijd besparen. *

$C$ Helemaal oneens $C$ Oneens $C$ Neutraal $C$ Eens $C$ Helemaal eens

Ik zal computers nodig hebben voor mijn toekomstige werk. *

$C$ Helemaal oneens $C$ Oneens $C$ Neutraal $C$ Eens $C$ Helemaal eens

Ervaring met computers zal me helpen een baan te houden. *

$C$ Helemaal oneens $C$ Oneens $C$ Neutraal $C$ Eens $C$ Helemaal eens

Computers kunnen me helpen mijn werk te organiseren. *

Helemaal oneens $C$ Oneens $C$ Neutraal $C$ Eens $C$ Helemaal eens

Ervaring met computers zal mijn carrière mogelijkheden vergroten. *

$C$ Helemaal oneens $C$ Oneens $C$ Neutraal $C$ Eens $C$ Helemaal eens

De computer kan mij helpen een beter inzicht in financiële zaken te krijgen. *

Helemaal oneens $C$ Oneens $C$ Neutraal $C$ Eens $C$ Helemaal eens

Computers vormen een belangrijk onderdeel van mijn leven. *

$C$ Helemaal oneens $C$ Oneens $C$ Neutraal $C$ Eens $C$ Helemaal eens

Computers kunnen mijn creativiteit stimuleren. *

$C$ Helemaal oneens $C$ Oneens $C$ Neutraal $C$ Eens $C$ Helemaal eens Ervaring met computers vergroot de kans op een goede baan. *

$C$ Helemaal oneens $C$ Oneens $C$ Neutraal $C$ Eens $C$ Helemaal eens 
Computers kunnen me helpen dingen makkelijker te leren. *

$C$ Helemaal oneens $C$ Oneens $C$ Neutraal $C$ Eens $C$ Helemaal eens

Computers helpen leerlingen hun schrijfvaardigheid te verbeteren. *

$C$ Helemaal oneens $C$ Oneens $C$ Neutraal $C$ Eens $C$ Helemaal eens

In de opleiding van leraren zouden onderwijskundige toepassingen van computers aan de orde moeten komen. *

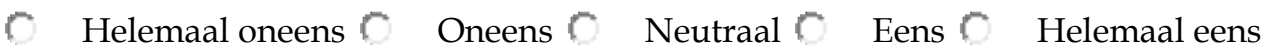

Computers motiveren leerlingen. *

$\therefore$ Helemaal oneens $C$ Oneens $C$ Neutraal $C$ Eens $C$ Helemaal eens

De originele versie van de TAC die gebruikt is, is te vinden via www.tcet.unt.edu. De Nederlandse vertaling gebeurde in eerste instantie door Bert Moonen in het kader van zijn proefschrift 'Teacher learning in inservice networks on internet use in secondary education'. Anneke Smits maakte enkele kleine aanpassingen hierop.

* $=$ Input is required 
Bijlage B Woord en Ervaring

Vragenlijst woord en ervaring

Naam *

Module: *

Module periode *

Geef aan of de volgende woorden passen bij jouw ervaringen in de afgelopen e-learning module:

Boeiend *

$C$ nee! $C$ nee $C$ soms $C$ ja $C$ ja!

Sociaal *

$C$ nee! $\mathbb{C}$ nee $C$ soms $C$ ja $\mathbb{C}$ ja!

Inspirerend *

$C$ nee! $C$ nee $C$ soms $C$ ja $C$ ja!

Tijdrovend *

$C$ nee! $C$ nee $C$ soms $C$ ja $C$ ja!

Chaotisch *

$C$ nee! $C$ nee $C$ soms $C$ ja $C$ ja!

Enthousiast *

$C$ nee! $C$ nee $C$ soms $C$ ja $C$ ja!

Efficiënt *

$C$ nee! $\mathrm{C}$ nee $\mathrm{C}$ soms $\mathrm{C}$ ja $\mathrm{C}$ ja!

Irritant *

$C$ nee! $\mathrm{C}$ nee $\mathrm{C}$ soms $\mathrm{C}$ ja $\mathrm{C}$ ja!

Onveilig *

$C$ nee! $C$ nee $C$ soms $C$ ja $C$ ja!

Roept spanning op *

$C$ nee! $C$ nee $C$ soms $C$ ja $C$ ja!

Gevoel van verbondenheid *

$C$ nee! $C$ nee $C$ soms $C$ ja $C$ ja!

Persoonlijk *

$C$ nee! $C$ nee $C$ soms $C$ ja $C$ ja! 
Gezellig *

$C$ nee! $\mathrm{C}$ nee $\mathrm{C}$ soms $\mathrm{C}$ ja $\mathrm{C}$ ja!

Eenzaamheid *

$C$ nee! $C$ nee $C$ soms $C$ ja $C$ ja!

Onzekerheid *

$C$ nee! $C$ nee $C$ soms $C$ ja $C$ ja!

Ongezellig *

$C$ nee! $C$ nee $C$ soms $C$ ja $C$ ja!

Angst *

$C$ nee! $C$ nee $C$ soms $C$ ja $C$ ja!

Overspoeld *

$C$ nee! $\mathrm{C}$ nee $\mathrm{C}$ soms $\mathrm{C}$ ja $\mathrm{C}$ ja!

Bedreigend *

$C$ nee! $\mathbb{C}$ nee $\mathrm{C}$ soms $\mathrm{C}$ ja $\mathrm{C}$ ja!

Maakt nieuwsgierig *

$C$ nee! $\bigcirc$ nee $C$ soms $C$ ja $C$ ja!

Stimulerend *

$C$ nee! $C$ nee $C$ soms $C$ ja $C$ ja!

Verwarrend *

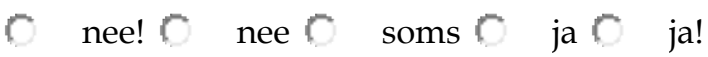

Subschalen Woord en Ervaring

\begin{tabular}{|l|l|}
\hline Titel schaal & Items \\
\hline Engagement & stimulerend, inspirerend, boeiend, maakt nieuwsgierig, enthousiast \\
\hline Sociaal & gezellig, verbondenheid, sociaal, persoonlijk, ongezellig \\
\hline Tijdsdruk en stress & tijdrovend, onzekerheid, overspoeld, roept spanning op \\
\hline Chaos & chaotisch, efficiënt, irritant, verwarrend \\
\hline Angst & onveilig, bedreigend, angst, eenzaamheid \\
\hline
\end{tabular}




\section{Bijlage C Vraagsturing}

\section{Schaal Vraagsturing}

1. In deze module was er ruimte om mijn eigen praktijkproblemen in te brengen. *

$C$ nee $C$ gaat wel $C$ ja

2. Als ik dat wilde was er ruimte om te leren buiten de gebaande modulepaden. *

$C$ nee $C$ gaatwel $C$ ja

3. Ik kon de eindopdracht zo uitvoeren dat hij goed aansloot op mijn eigen leerwensen *

$C$ nee $C$ gaat wel $C$ ja 
Bijlage D Samenwerking met medestudenten (Rovai, 2002a)

\section{Schaal Verbondenheid}

1. Ik voelde me verbonden met de anderen in mijn groepje *

$C$ nee $C$ gaatwel $C$ ja

2. In ons groepje heerste een echt groepsgevoel. *

$C$ nee $C$ gaatwel $C$ ja

3. Mijn contact met medestudenten werd gestimuleerd doordat de uitwisseling ook persoonlijk van aard was. *

$C$ nee $C$ gaat wel $O$ ja

4. Ik heb mijn medestudenten goed leren kennen. *

$C$ nee $C$ gaatwel $C$ ja

\section{Schaal Steun voor het leerproces}

1. Ik heb mijn medestudenten als behulpzaam ervaren *

$C$ nee $C$ gaat wel $C$ ja

2. Ik kreeg op tijd feedback van groepsgenoten. *

$C$ nee $C$ soms $C$ ja

3. Mijn medestudenten hebben mijn leerproces positief beïnvloed. *

$C$ nee $C$ gaatwel $C$ ja

\section{Schaal Aansluiting bij leerwensen}

1. Ik denk deze module maar een matig leerproces op gang bracht. *

$C$ nee $C$ gaatwel $C$ ja

2. Er waren in deze module veel mogelijkheden tot leren. *

$C$ nee $C$ gaatwel $C$ ja

3. Deze module kwam tegemoet aan mijn leerwensen. *

$C$ nee $C$ gaatwel $C$ ja

4. Deze module stimuleerde mijn verlangen om nog meer te leren. *

$C$ nee $C$ gaatwel $C$ ja 


\section{Bijlage E Begeleiding door de docent}

\section{Schaal Moderatie}

1. De docent gaf op vakinhoudelijk vlak richting aan onze verplichte discussies *

$C$ nee $C$ gaatwel $C$ ja

2. De bijdragen van de docent aan de verplichte discussies stimuleerden mij om nieuwe bijdrages te leveren. *

$C$ nee $C$ gaat wel $\mathbb{C}$ ja

3. De discussiebijdragen van de docent waren inspirerend *

$C$ nee $C$ gaat wel $\mathbb{C}$ ja

4. Ik heb steun ervaren van de docent bij mijn leerproces *

$C$ nee $\mathrm{C}$ gaat wel $\mathrm{C}$ ja

\section{Schaal Feedback}

1. Ik ben tevreden over de snelheid waarmee de docent feedback gaf op mijn ingeleverde opdrachten *

$C$ nee $\mathrm{C}$ gaat wel $\mathrm{C}$ ja

2. De feedback van de docent was helder geformuleerd *

$C$ nee $C$ gaat wel $\mathbb{C}$ ja

3. Als de docent mij feedback gaf kon ik zien dat hij/zij mijn werk goed overdacht had. *

$C$ nee $C$ gaat wel $C$ ja

\section{Schaal Docentcommunicatie}

1. De docent communiceerde op een duidelijke manier. *

$C$ nee $C$ gaat wel $C$ ja

2. De docent communiceerde op een persoonlijke manier. *

$C$ nee $C$ gaatwel $C$ ja

3. Ik heb me wel eens beledigd of gekwetst gevoeld door de docent. *

$C$ nee $C$ gaat wel $C$ ja

4. De docent gaf adequaat antwoord op mijn vragen. *

$C$ nee $C$ gaatwel $C$ ja 
Bijlage F Leerzaamheid van de onderdelen van de module

Leerzaamheid van onderdelen in deze e-learning module

Beoordeel met een rapportcijfer van 1-10 de leerzaamheid van onderstaande elementen uit de module.

n.v.t. $=$ niet van toepassing $(=$ komt niet voor in de module $)$.

De vakliteratuur *

De video's die bij het cursusmateriaal hoorden *

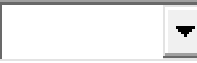

De gesproken powerpoints *

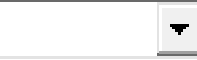

De gewone powerpoints met geschreven ondersteunende tekst. *

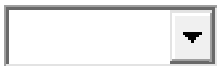

De geschreven uitleg over een aantal onderwerpen (bij de thema-units) *

De interactieve vraag/vragen (waarbij je een antwoord krijgt als je op een knopje klikt) *

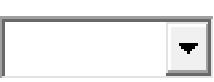

De uitgewerkte voorbeeld casus(sen) *

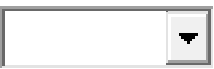

De links naar informatie op andere internetsite *

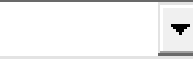

De discussies binnen je groepje *

De discussiebijdragen van medestudenten in je groepje *

De discussiebijdragen van je docent *

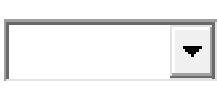

De samenwerkingsopdrachten binnen je groepje *

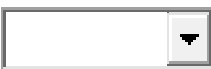

De feedback van de docent op jouw ingeleverde opdrachten * 
Welk rapportcijfer (1-10) geef je over het geheel genomen aan de leerzaamheid van de onderdelen uit de e-learning module?* 
Bijlage G Organisatie van de e-learning

Schaal Ondersteuning door planning

De deadlines in de module ondersteunden mijn eigen time-management *

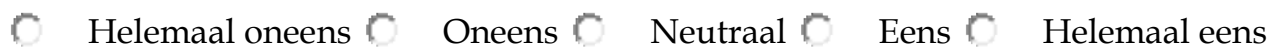

Het strakke tijdpad stimuleerde me om de module op tijd af te ronden *

$C$ Helemaal oneens $C$ Oneens $C$ Neutraal $C$ Eens $C$ Helemaal eens

De deadlines en het tijdpad voor de opdrachten waren duidelijk *

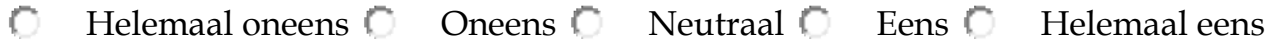

\section{Schaal Duidelijkheid}

Ik kan in Blackboard gemakkelijk informatie vinden over de cursusorganisatie (rooster, eindopdracht, e-learningopdrachten, beoordelingscriteria, leerdoelen) *

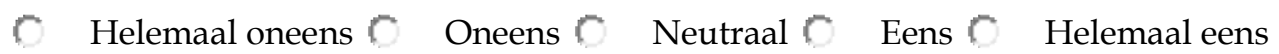

De instructies met betrekking tot het uitvoeren van de opdrachten waren verwarrend *

$C$ Helemaal oneens $C$ Oneens $C$ Neutraal $C$ Eens $C$ Helemaal eens

De e-learning opdrachten pasten bij de geformuleerde leerdoelen. *

$C$ Helemaal oneens $C$ Oneens $C$ Neutraal $C$ Eens $C$ Helemaal eens

De leerdoelen in de module waren me duidelijk *

$C$ Helemaal oneens $C$ Oneens $C$ Neutraal $C$ Eens $C$ Helemaal eens

Schaal Werkdruk en begrip

Door de hoge werkdruk in de module kon ik niet alle stof begrijpen *

Helemaal oneens $C$ Oneens $C$ Neutraal $C$ Eens $C$ Helemaal eens

De studiebelasting was evenwichtig verdeeld over de module *

$C$ Helemaal oneens $\mathbb{C}$ Oneens $\mathbb{C}$ Neutraal $\mathbb{C}$ Eens $\mathbb{C}$ Helemaal eens

De werkdruk in deze module was te hoog *

$C$ Helemaal oneens $C$ Oneens $C$ Neutraal $C$ Eens $C$ Helemaal eens

Ik had doorgaans genoeg tijd om de aangeboden stof te begrijpen *

$C$ Helemaal oneens $\mathbb{C}$ Oneens $C$ Neutraal $C$ Eens $C$ Helemaal eens 
Bijlage H Standaard OSO evaluatie formulier (2007-2009)

Naam *

Naam docent(en) *

Ik geef aan deze module het

rapportcijfer *

Ik heb aan deze module, voorbereiding, bijeenkomsten en werkstuk ongeveer besteed *

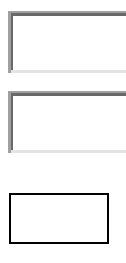

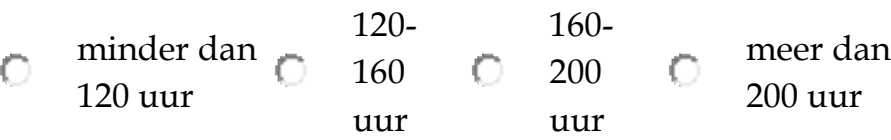

Geef je mening over de volgende stellingen:

$++=$ helemaal mee eens

$+=$ grotendeels mee eens

- = grotendeels niet mee eens

-- = helemaal niet mee eens

$\mathrm{nvt}=$ niet van toepassing

\section{Module}

Het geleerde in deze module levert een meerwaarde op voor mijn werk *

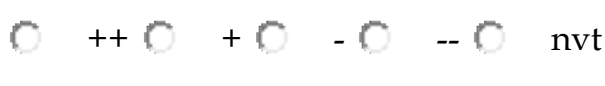

De literatuur draagt bij aan een beter begrip van mijn werk. *

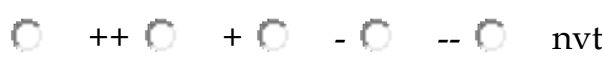

\section{Eindopdracht}

In de eindopdracht is geformuleerd aan welke criteria het beroepsproduct $C++C+C-C-C$ nvt moet voldoen. *

De e-learningopdrachten en de cursusmaterialen

De e-learningopdrachten en de cursusmaterialen droegen bij aan het ontwikkelen van mijn competenties

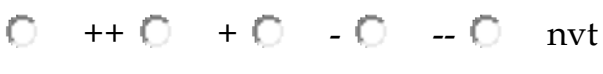
(inhoud en niveau) *

De module kenmerkte zich door activerende werkvormen. *

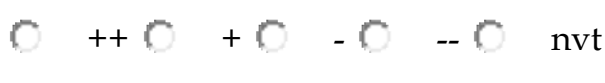

\section{Materiaal}

De modulematerialen zijn relevant voor het afronden van de module. *

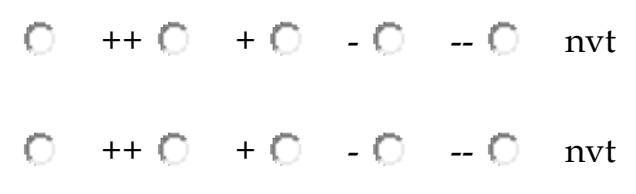

Het gebruik van Blackboard was functioneel in deze module *

\section{ICT}

ICT gebruik heeft bijgedragen aan internationalisering van mijn kennis *

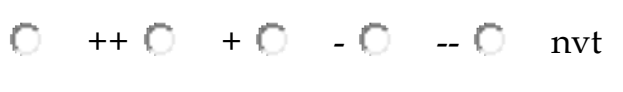

\section{Docent}


De docent ondersteunde mij bij het ontwikkelen van een onderzoekende $C++C+C-C-C$ nvt houding. *

* = Invoer verplicht 


\section{Bijlage I Onderwerpen voor de semigestructureerde expert interviews}

1. Kunt $\mathrm{u}$ iets vertellen over $\mathrm{uw}$ achtergrond, en een paar essentiële uitgangspunten noemen voor e-learning?
a. Achtergrond
b. Essentiële uitgangspunten

2. Wat vindt $\mathrm{u}$ van de gekozen uitgangspunten; hoe belangrijk vindt $\mathrm{u}$ die?

a. Hoge mate van structuur (studenten tegelijk met dezelfde leerstof bezig, rooster, deadlines)
i. Strakke tijdsplanning
ii. In relatie tot behoefte aan indeling eigen studietijd

b. Snelle feedback (docent, peers)
c. Centrale rol asynchrone interactie ( discussionboard opdrachten verplicht, wordt beoordeeld)

d. Online presentie: breeze / chat
i. Welke ervaringen daarmee
ii. Zinvol om dat iedere module te doen?
iii. Welke ervaringen met msn? Stimuleren bij studenten?
e. Samenwerkingsopdrachten
f. Groepsgrootte
g. Kerntaken module docent bij e-learning

3. Uw reactie en suggesties m.b.t. de werkende e-learning module

4. Heeft $\mathrm{u}$ waarschuwingen m.b.t. programmatuur, hardware (ondersteuning)?

5. Suggesties m.b.t. literatuur, good practice, conferenties. 


\section{Bijlage J Onderwerpen voor de semigestructureerde interviews met pilot studenten}

Hoe heb je het leren via e-learning ervaren?

Heb je verschillen ervaren in vergelijking met gewoon leren / gewone modules? Zo ja, wat waren voor jou de belangrijkste verschillen?

Heb je verschillen ervaren tussen de twee e-learning modules? Zo ja, wat waren voor jou de belangrijkste verschillen?

Zie je voordelen aan het studeren via e-learning? Zo ja welke?

Zie je nadelen aan het studeren via e-learning? Zo ja welke?

Hecht je belang aan interactie met medestudenten in de e-learning omgeving? Zo ja, waarom? Zo nee, waarom niet? Zo ja: naar welke vormen van interactie gaat je voorkeur uit? Hoe heb je de interactie met medestudenten ervaren?

Hoe heb je de discussies ervaren? Hoe denk je over het verplicht zijn en de beoordeling van discussies?

Hoe heb je de samenwerkingsopdrachten ervaren? Hoe denk je over het verplicht zijn en de beoordeling van discussies?

Hoe heb je de leermaterialen in het platform ervaren?

Hoe heb je de planning ervaren zoals die werd aangebracht door de opdrachten lijst en het rooster?

Hoe denk je over de rol van de docent in de e-learning omgeving? Wat vind je belangrijk dat de docent doet, wat minder belangrijk?

Heb je technische problemen ondervonden, zo ja welke? Heb je technische ondersteuning gekregen toen dat nodig was?

Welke tips heb je voor toekomstige e-learning modules? 


\section{Bijlage K Onderwerpen voor de semigestructureerde interviews met docenten}

\section{Algemene reactie op e-learning}

Heb je verschillen ervaren in vergelijking met het geven van gewone modules? Zo ja, wat waren voor jou de belangrijkste verschillen?

Zie je voordelen aan het doceren via e-learning? Zo ja welke?

Zie je nadelen aan het doceren via e-learning? Zo ja welke?

Zou je weer e-learning docent willen zijn? Waarom?

Als je zelf (weer) zou gaan studeren zou je dan kiezen voor e-learning? Waarom?

Wat heb je gemerkt dat studenten belangrijk vinden in de e-learning?

\section{Ontwerpaspecten}

Hoe vond je de Blackboard module om mee te werken?

Hecht je belang aan interactie tussen studenten in de e-learning omgeving? Zo ja, waarom? Zo nee, waarom niet? Zo ja: naar welke vormen van interactie gaat je voorkeur uit? Zijn er vormen van interactie die je minder geschikt vond, zo ja waarom?

Hoe heb je de discussies tussen studenten ervaren? Hoe denk je over het verplicht zijn en de beoordeling van discussies? Aan welke eisen moet volgens jou een goede discussieopdracht voldoen?

Hoe heb je de samenwerkingsopdrachten ervaren? Hoe denk je over het verplicht zijn en de beoordeling van samenwerkingsopdrachten? Aan welke eisen moet volgens jou een goede samenwerkingsopdracht voldoen?

Hoe heb je de leermaterialen in het platform ervaren?

Hoe heb je de planning ervaren zoals die werd aangebracht door de opdrachten lijst en het rooster?

Gegeven het onderwijsconcept van OSO Windeheim:

- Is er voldoende ruimte voor vraagsturing?

- Heeft de module een master niveau?

\section{Docentrol}

Wat is volgens jou de rol van de docent in de e-learning omgeving? Wat vind je belangrijk dat de docent doet, wat minder belangrijk? Vind je dat er een verschil is in de rol van de docent in gewone en e-learning modules?

Hecht je belang aan interactie tussen student en docent bij e-learning? Zo ja, waarom? Zo nee, waarom niet? Zo ja: naar welke vormen van interactie gaat je voorkeur uit? Zijn er vormen van interactie die je minder geschikt vond, zo ja waarom? 
Hecht je belang aan samenwerking tussen docenten bij e-learning? Zo ja, waarom? Zo nee, waarom niet? Zo ja: aan welke vormen van samenwerking en interactie denk je?

Wat vind jij belangrijke vaardigheden voor een e-learning docent?

Hoe functioneer jij m.b.t. die vaardigheden? Ben je in de afgelopen periode gegroeid in je rol als elearning docent? Hoe dan? Welke leerdoelen zie je nog voor jezelf als e-learning docent? Wat heb je nodig om dat te kunnen bereiken?

Wat is er volgens jou nodig om een goede e-learning docent te kunnen worden?

Wat zijn jouw belangrijkste tips voor toekomstige e-learning docenten?

Hoe ervaar je de mentale belasting m.b.t. e-learning docentschap? Ervaar je 'e-learning moeheid?' Welke onderdelen ervaar je als belastend in de module? Heb je suggesties?

\section{Leren en gedrag van studenten}

Is het voor de meeste studenten volgens jou mogelijk om via de module de beoogde master SEN competenties te behalen?

Voor welke studenten lijkt het moeilijk? Waarom?

Heb je problemen ervaren met (het gedrag van) studenten? Met welke? Wat voor problemen?

Heb je bij jezelf ontwikkeling gemerkt in het omgaan daarmee?

\section{Tijdsbesteding}

Hoe schat je je tijdsbesteding in m.b.t. e-learning docentschap in de afgelopen module?

\section{Randvoorwaarden}

Wat zou er kunnen verbeteren in de organisatie waardoor die tijdsbesteding zou kunnen verminderen? Hoe zou de organisatie de juiste ondersteuning kunnen bieden voor e-learning / wat heb je nodig vanuit de organisatie?

Heb je technische problemen ondervonden, zo ja welke? Heb je technische ondersteuning gekregen toen dat nodig was?

Tips

Welke tips heb je voor toekomstige e-learning modules? 


\begin{tabular}{|l|l|l|}
\hline Opdracht & $\begin{array}{l}\text { Gebruik onderstande korte casussen en bespreek met elkaar in welk stadium } \\
\text { van de leesontwikkeling volgens Ehri de leerlingen zich bevinden. Bepreek } \\
\text { bovendien hoe jullie het lezen / de leesproblemen in zouden schatten vanuit } \\
\text { connectionistische modellen van de leesontwikkeling. Onderbouw jullie } \\
\text { uitspraken. Reageer op minstens 2 andere bijdrages. } \\
\text { Casussen: } \\
\text { Casus 1: } \\
\text { Bjorn zit in groep 3. Het is begin december en hij leest een boekje van Sinterklaas. } \\
\text { Het boekje bevat alleen woorden met mkm-structuur. Bjorn leest geen fouten, } \\
\text { maar hij spelt alles. } \\
\text { Casus 2 } \\
\text { Elsa zit in groep 5. Ze leest hardop een boekje op AVI 5 niveau. Hoorbaar is dat } \\
\text { zij verschillende woorden in een keer kan lezen. Vooral langere woorden moet ze } \\
\text { eerst in stukken verdelen, daarna kan ze die pas lezen. Dat doet ze echter niet } \\
\text { altijd. Wat verder opvalt is dat ze vaak niet precies leest wat er staat, maar een } \\
\text { invulling maakt op basis van wat ze denkt dat er staat. Ze heeft erg veel moeite } \\
\text { met spelling. }\end{array}$ \\
\hline Knop groepen: in je eigen groep: in de discussieruimte \\
\hline Waar & \begin{tabular}{l} 
Start midden week 1- slot eind week 2 \\
\hline We criteria voor discussieopdrachten worden gehanteerd (zie \\
cursusinformatie/toetsen en beoordelen)
\end{tabular} \\
\hline Criteria & \\
\hline
\end{tabular}




\begin{tabular}{|l|l|l|}
\hline Discussie & 3.2 \\
\hline Opdracht & $\begin{array}{l}\text { Maak gebruik van onderstaande casussen. Bespreek met elkaar welke } \\
\text { Connect begeleidingsvorm jullie zouden kiezen. Beargumenteer jullie keuze } \\
\text { gezamenlijk en onderbouw de keuze met behulp van literatuur. } \\
\text { Casussen: } \\
\text { Casus 1: } \\
\text { Sven zit in groep 3. Het is begin februari en hij leest een Leesleeuwboekje } \\
\text { waarin de /ie/ veel voorkomt. Het boekje bevat woorden met mkm en } \\
\text { mmkm- en mkmm-structuur. Sven heeft moeite met het onderscheid tussen } \\
\text { de ie en de ei, de b en de d en aarzelt veelvuldig tussen de a en de aa. De } \\
\text { overige letters beheerst hij wel op een grafementoets. Hij heeft moeite om } \\
\text { clusters te ontcijferen. Sven maakt gebruik van de context om de woorden } \\
\text { waar hij moeite mee heeft te lezen. Hij leest relatief veel fouten. Hij haalt een } \\
\text { E score op de DMT (kaarten 1 en 2) doordat hij veel fouten leest. Hij haalt } \\
\text { AVI M3 niet omdat hij ook daar in te veel fouten maakt. } \\
\text { Casus 2: } \\
\text { Carolien zit in groep 3. Het is april. Ze kent alle letters vlot. Ze leest } \\
\text { langzaam en spelt nog veel woorden, ook mkm woorden. Ze herkent } \\
\text { sommige woorden direct maar als diezelfde woorden op een ander moment } \\
\text { weer worden gelezen, worden ze soms niet herkend. Het lezen kost } \\
\text { zichtbaar moeite en er worden in de loop van een tekstje ook steeds meer } \\
\text { fouten gelezen. Ze begint dan radend te lezen. De geraden woorden passen } \\
\text { wel logisch binnen de tekst. }\end{array}$ \\
\hline Knop groepen: in je eigen groep: in de discussieruimte \\
\hline Waar & $\begin{array}{l}\text { Midden week 3 - eind week 4 } \\
\text { De criteria voor discussieopdrachten worden gehanteerd } \\
\text { cursusinformatie/toetsen en beoordelen) }\end{array}$ \\
\hline
\end{tabular}




\section{Bijlage M Screenshots van de leeromgeving}

\begin{tabular}{|c|c|c|}
\hline Windesheim & 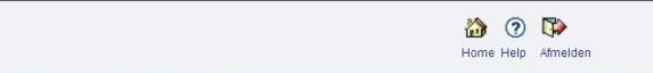 & \\
\hline \multicolumn{3}{|c|}{ Mjn instituut Cursussen Projects Readers FAQ } \\
\hline \multirow{2}{*}{$\begin{array}{l}\text { Mededelingen } \\
\text { Cursusinformatie } \\
\text { Cursusmaterialen } \\
\text { Docenten } \\
\text { Groepen } \\
\text { Hier inschrijven } \\
\text { FAQ }\end{array}$} & (8) Cursusinformatie & BEWERKWEERGAVE \\
\hline & \& Inleiding & \\
\hline (1) Configuratiescherm & $\$$ Rooster & \\
\hline \multirow[t]{5}{*}{$\begin{array}{l}\text { (9) Vernieuwen } \\
\text { (9i) Detailweergave }\end{array}$} & Toetsing en beoordeling & \\
\hline & Kennisbronnen & \\
\hline & \$echnische gegevens & \\
\hline & $\otimes$ Algemene informatie & \\
\hline & Wat vind je in de Blackboard projectmodule Studie-informatie Ma & \\
\hline
\end{tabular}

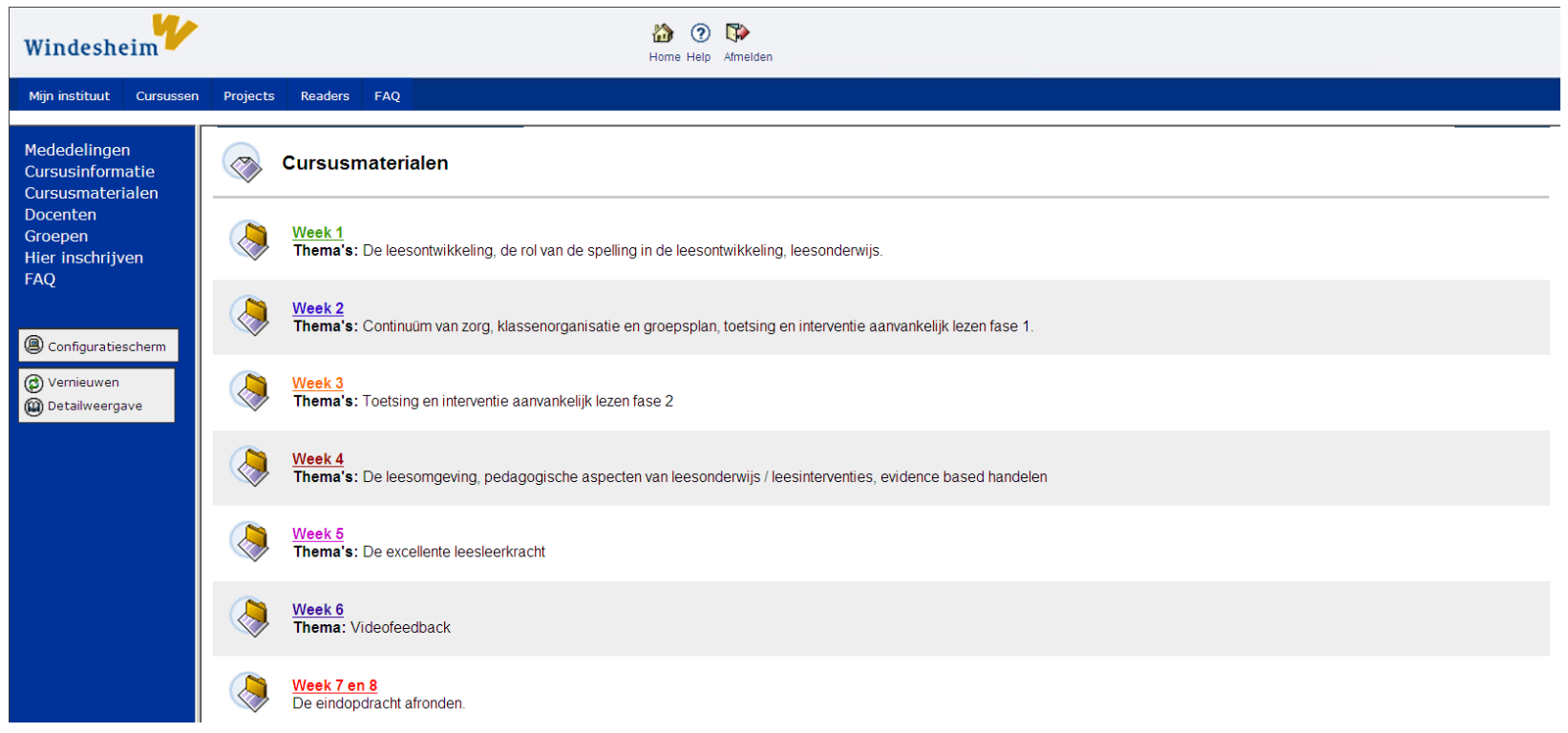




\title{
$\nabla_{\text {Toetsing }}$
}

\author{
2. Alle verplichte e-learningopdrachten (inclusief de deelopdrachten van de toetsopdracht \\ 3. Informatie over de discussieopdrachten \\ Richtlinen voor het geven van feedback
}

1. Deze module wordt beoordeeld aan de hand van de toetsopdracht

Waar mogelijk wordt in de loop van de module via de e-learningopdrachten toegewerkt naar deze toetsopdracht. Let op dat je de toetsopdracht zorgvuldig bestudeert bij

het masterniveau uit zich onder meer in het bondig kunnen overdragen van het geleerde.

Copy paste is een probleem dat steeds grotere proporties aanneemt. Als je er niet alert op bent bestaat het risico dat je zelf in die fout vervalt Zorg daarom voor betreft. De opleiding controleert via Ephorus (cursusmaterialen $>$ week $8>0$ opdrachten week $8>$ inleveren eindopdracht) op copy paste en accepteert je werkstuk niet als daar tekst in over genomen is van anderen zonder correcte verwijzing. Grotere stukken overgenomen tekst worden niet geaccepteerd.

2. De e-learningopdrachten zijn verplicht waar mogelijk zijn het deelopdrachten voor de toetsopdracht

3. De discussieopdrachten spelen een bijzondere rol in iedere e-learning module. In het hierboven gelinkte document worden doelen en eisen uitvoerig toegelicht. Laat je bij de discussies ondersteunen door het document critical thinking questions en door Macknight (2000) Feedback m.bt discussie- en samenwerkingsopdrachten wordt door de docent groepsgewis gegeven in de discussieruimte in je groep indien nodig krijg je een individuele mall omje te wilzen op een specifiek aandachts- of verbeterpunt Op de bijdragen inje portfolio kunje twee keer feedbackviagen aan de docent. Denk eraan datje deze viagen specifiek en concreet maakt. dus bijvoorbeeld niet. ik wil graag feedback op mijn handelingsplan, maar. zou je willen reageren op mijn tweede hypothese, is deze genoeg afgebakend. De feedbackverzoeken kun je indienen t/m het

4. In je opdrachten en in de toetsopdracht wordt gevraagd hetgeen je beweert of vindt te onderbouwen. De kwaliteit van je onderbouwing geeft het masterniveau weer. In bovenstaand document vind je richtlijnen voor onderbouwen op masterniveau

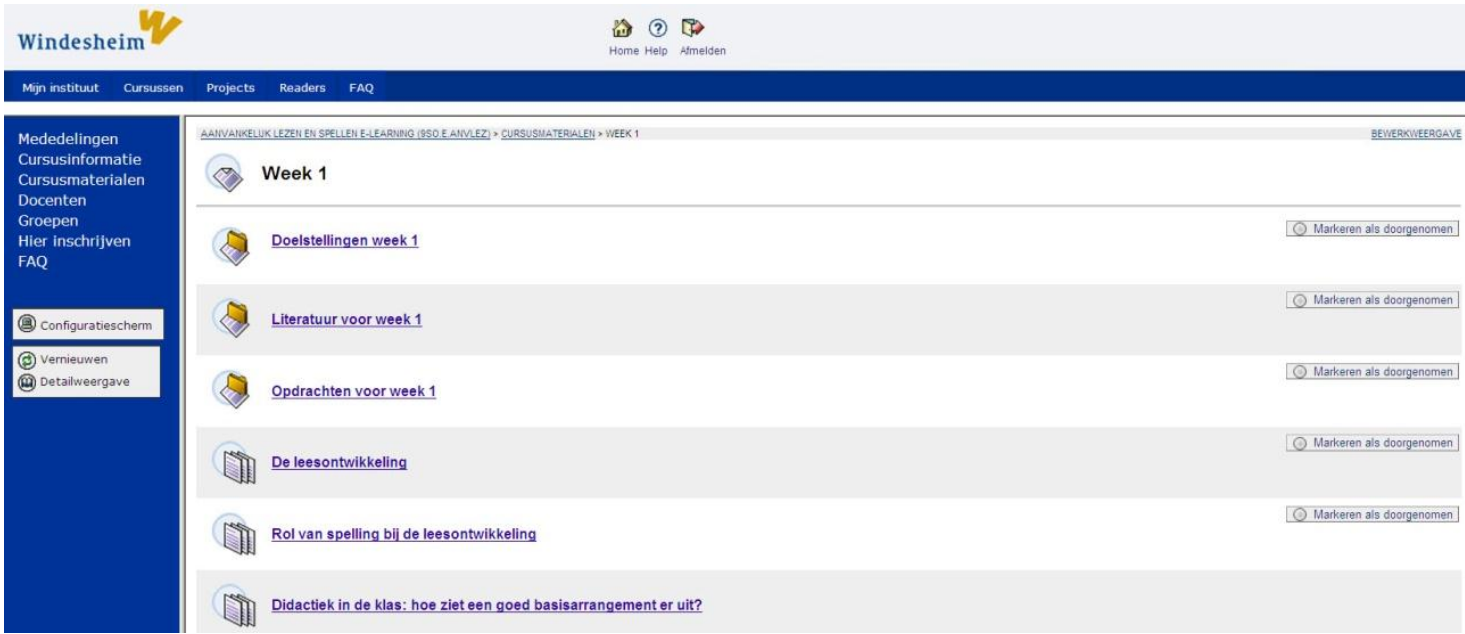


